Florida International University FIU Digital Commons

6-13-2007

\title{
I had a different way of governing : the evangelical presidential style of Jimmy Carter and his mission for middle east peace
}

D. Jason Berggren

Florida International University

DOI: $10.25148 /$ etd.FI14051111

Follow this and additional works at: https://digitalcommons.fiu.edu/etd

Part of the American Politics Commons

\section{Recommended Citation}

Berggren, D. Jason, "I had a different way of governing : the evangelical presidential style of Jimmy Carter and his mission for middle east peace" (2007). FIU Electronic Theses and Dissertations. 1624.

https://digitalcommons.fiu.edu/etd/1624 
FLORIDA INTERNATIONAL UNIVERSITY

Miami, Florida

"I HAD A DIFFERENT WAY OF GOVERNING":

THE EVANGELICAL PRESIDENTIAL STYLE OF JIMMY CARTER

AND HIS MISSION FOR MIDDLE EAST PEACE

A dissertation submitted in partial fulfillment of the

requirements for the degree of

DOCTOR OF PHILOSOPHY

in

POLITICAL SCIENCE

by

D. Jason Berggren 
To: Interim Dean Mark Szuchman

College of Arts and Sciences

This dissertation, written by D. Jason Berggren, and entitled "I Had A Different Way of Governing": The Evangelical Presidential Style of Jimmy Carter and His Mission for Middle East Peace, having been approved in respect to style and intellectual content, is referred to you for judgment.

We have read this dissertation and recommend that it be approved.

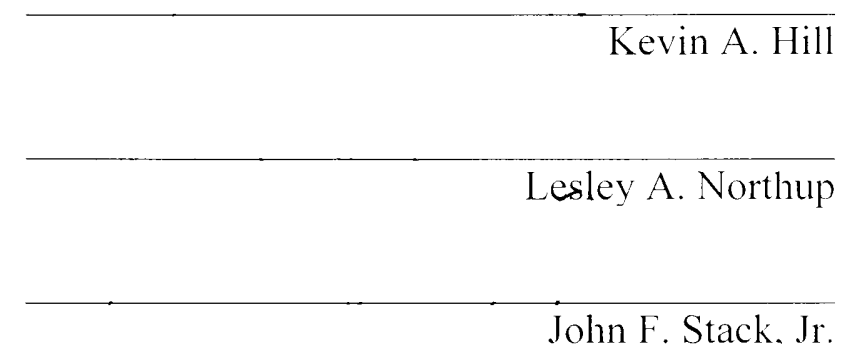

Nicol C. Rae, Major Professor

Date of Defense: June 13, 2007

The dissertation of D. Jason Berggren is approved.

Interim Dean Mark Szuchman

College of Arts and Sciences

Dean George Walker

University Graduate School

Florida International University, 2007 


\section{DEDICATION}

I dedicate this dissertation to my children, Joshua and Eva, my parents, Loren and Phyllis Berggren, and my in-laws, Harvey and Joan Levine. Without their love, encouragement, and patience, the completion of this project would not have been possible. But most of all, I am especially indebted to Bonnie, my loving wife these past eleven years. She has been my rock of support, love, understanding, patience, and faith. I thank and love her so much. 


\section{ACKNOWLEDGMENTS}

I wish to thank all my committee members, Lesley A. Northup (especially for her editorial work), John F. Stack, Jr., and Kevin A. Hill, for their service and encouragement on this project and throughout my years at Florida International University. I also express my thanks to the staff at the Jimmy Carter Library for their assistance and expertise.

I express special thanks to my committee chair and major professor, Nicol C. Rae. Four years ago, this project began as a research paper in his presidency seminar. Since then, Dr. Rae has read and corrected many drafts, pointed out various sources to consult, and helped me clarify the idea of the evangelical presidential style. Additionally, during this time, we collaborated on two conference papers, a journal article, and a book chapter. I thank him for his insights, his constructive criticisms and challenges, his patience, his availability, and his friendship. He has been a true mentor. I could not have had a better advisor.

Funding for this project was made possible by the Florida International University Dissertation Year Fellowship. 


\section{ABSTRACT OF THE DISSERTATION \\ "I HAD A DIFFERENT WAY OF GOVERNING":}

THE EVANGELICAL PRESIDENTIAL STYLE OF JIMMY CARTER AND HIS MISSION FOR MIDDLE EAST PEACE by
D. Jason Berggren

Florida International University, 2007

Miami, Florida

Professor Nicol C. Rae, Major Professor

President Jimmy Carter once said, "I had a different way of governing." In attempting to explain what he meant by this, Carter has been variously described as a political amateur, a trustee, a non-political politician, an "active-positive" president, and a forerunner of the 1990s' New Democrats. It is argued here, however, that mere secular descriptions and categories such as these do not adequately capture the essence of Carter's brand of politics and his understanding of the presidency.

Rejecting Richard Neustadt's prescriptions for effective presidential leadership, Carter thought political bargaining and compromise were "dirty" and "sinful." $\mathrm{He}$ deemed the ways of Washington as "evil," and considered many, if not most, career politicians immoral. While he fully supported the institutional separation of church and state, politics for Carter was about "doing right," telling the truth, and making the United States and the world "a better demonstration of what Christ is." Like two earlier Democrats, William Jennings Bryan and Woodrow Wilson, Carter understood politics 
as an alternative form of Christian ministry and service. In this regard, Carter was a presidential exception.

Carter's evangelical faith gave his politics meaning, skill, vision, and a framework for communication. Using Fred Greenstein's categories of presidential leadership, Carter's faith provided him with "emotional intelligence", too. However, Carter's evangelical style provoked many of his contemporaries, including many of his fellow Democrats. To his critics at home and abroad, Carter was often accused of being arrogant, stubborn, naïve, and ultimately a political failure. But as evinced by his indispensable role in negotiating peace between Israel and Egypt, his leadership style also provided him some remarkable achievements.

The research here is based on a thorough examination of President Carter's many writings, his public papers, interviews, and opinion pieces. Written accounts from former Carter administration officials and from Israeli and Egyptian participants at Camp David are also used. This project is largely descriptive, qualitative in approach, but quantitative data are used when appropriate and as supplements. 
CHAPTER

PREFACE

INTRODUCTION: The Promise of an Evangelical-Styled Presidency

I. The Religion Gap in the Presidential Literature of Jimmy Carter

II. The Origins of the Evangelical Presidential Style:

The Leadership Alternative of William Jennings Bryan and

Woodrow Wilson

III. Features of the Evangelical Presidential Style:

Presidential Communication, Skill, Vision, and Emotional Control

IV. "I Had a Different Way of Governing":

The Living Faith of President Carter

V. The "Real" Carter Doctrine:

Foreign Policy Guidelines from the Sermon on the Mount

VI. "Blessed Are the Peacemakers"

Carter's Mission and Vision for Middle East Peace

VII. Israel, the Arabs, and the Middle East in Presidential Memory:

Carter in Comparative Perspective

VIII. CONCLUSION: "More Missionary Than Politician" 


\section{LIST OF TABLES}

TABLE

PAGE

1.1 1996 Scholarly Assessments of Modern Presidents

1.22000 Scholarly Assessments of Modern Presidents

1.32005 Scholarly Assessments of Modern Presidents

1.4 Public Assessments of Modern Presidents, 2004-2006

1.5 Most Appearances in Gallup's "Top 10 Most Admired Man” List, 1948-2006

1.6 Public Favorability Assessments of Living Former Presidents, 2007

I.7 Carter: A Religious Person, 1976-I980

1.8 Carter: A Man of High Moral Principles, 1976-1980

1.9 Gallup's Personality Profile of President Carter, 1978-1980

1.10 Carter and His Contemporaries: Religion Person or Not Particularly Religious

1.11 Carter and His Contemporaries: Man of High Moral Principles or Not Particularly Moral

2.1 Carter's Southern and Northeastern Electoral Strength Compared

2.2 National and Regional Electoral Strength of American Presidents, 1896-2004

3.1 George W. Bush as "Honest and Trustworthy," 1999-2005

3.2 Bill Clinton as "Honest and Trustworthy," 1992-200 I

4.1 1999-2000 Historian Assessments of Modern Presidential Relations with Congress

4.2 Democratic Presidents and Democratic-controlled Congresses 251

5.1 Carter in Comparative Perspective on War and Peace 303 
6.1 Meetings with Foreign Leaders During Carter's First 100 Days 333

6.2 Timeline of Key Events in the Middle East Peace Process, 1977-1981 428 


\section{LIST OF FIGURES}

FIGURE

PAGE

4.1 President Carter's Weekly Church Attendance Rate, 1977-1981 192

4.2 President Carter's Major Addresses by Topic 231

4.3 U.S. Presidents and Executive Orders, 1953-2001 252

6.1 Approval of President Carter's Handling of Foreign Policy, 1977-1979 415

6.2 Jewish Vote for Democratic Presidential Candidates, 1916-2004 418

7.1 Relevance of Religion: Can Answer All or Most of Today's Problems or Is Largely Old-Fashioned and Out of Date

7.2 Viewing Israel and the Middle East: Religiously Significant or Not? 442

7.3 Religious Beliefs Biggest Influence on Middle East Views (\% Yes) 444

7.4 Land of Israel Given By God to the Jewish People (\% Yes) 445

7.5 Modern State of Israel as a Fulfillment of Bible Prophecy (\% Yes) 446 
I had a different way of governing...I was a Southerner, a born-again Christian, a Baptist, a newcomer.

I am a Christian. I'm the most important thing in my life is Jesus Christ.

I have considered myself in full-time Christian service every day I have been governor.

I'm running for President because I'm a deeply religious person.

I'm a father and I'm a Christian; I'm a businessman and I'm a Christian; I'm a farmer and I'm a Christian; I'm a politician and I'm a Christian. The most important thing in my life beyond all else is Jesus Christ.

Christ has set the standard I am to attain as his representative. I try to pattern my life after his life.

The standards of government should exemplify the highest attributes of mankind, and not the lowest common denominator. There is no legitimate reason for different standards in our home, our office, our church, or our government. In every component of life we should continually strive for perfection as commanded by God.

We ought to make our own societal structure a better demonstration of what Christ is.

I don't think I would ever take on the same frame of mind that Nixon or Johnson did-lying, cheating, and distorting the truth...I think my religious beliefs alone would prevent that from happening to me. I have that confidence. 
The Oval Office is a powerful pulpit...I serve Christ. I also serve America. And I have never found in my own life any incompatibility between these two responsibilities for service.

We should live our lives as though Christ were coming this afternoon.

I feel like I have one life to live. I feel that God wants me to do the best I can with it.

Religious faith has always been at the core of my existence.

Despite what I consider to be a constitutional and biblical requirement for the separation of church and state, I must acknowledge that my own religious beliefs have been inextricably entwined with the political principles I have adopted.

Personal experience underlies my conviction that religion can be significant for peacemaking. The negotiations between Menachem Begin, Anwar el-Sadat, and myself at Camp David in 1978 were greatly influenced by our religious backgrounds. This was evident in the fact that a joint appeal for prayer preceded our discussions at Camp David and that each of us worshiped separately throughout our stay together. But the role of religion was perhaps greater than is commonly recognized or easily quantified. Begin and Sadat were deeply religious men. Their religious beliefs shaped their personalities, historical perspectives, and political convictions. If the talks at Camp David engaged statesman in the search for a political settlement, in the final analysis they also involved religiously committed men. Each of the principals at Camp David recognized peace to be both a gift from God and a preeminent human obligation. As the mediator of the talks, I am convinced that to have overlooked the importance of religion for both Sadat and Begin would have resulted in a failure to understand these two men. Such a failure could have had a pervasive and incalculable impact. 


\section{Preface}

Nearly nine months before he would declare his candidacy for president, in remarks made before a prayer breakfast gathering in March 1974, Jimmy Carter explained that his role as governor was one of providing and offering the citizens of Georgia "sustenance," "help," "fairness and equity," and "spiritual and moral guidance and inspiration." He said he saw no incompatibility between being a good governor and a good Christian. "I'm a father and I love my children, and I'm a Christian. I'm a businessman, and I'm a Christian. I'm a politician, and I'm a Christian." ${ }^{2}$ When there was an incompatibility, he said, it is when politicians substituted their personal ambitions and desires for the "hand of God." "There is a potential continuing conflict that exists in all of us, because most of us are not willing to relinquish our preeminent hunger for worldly prestige, possessions, recognition, influence, social prominence and wealth in order to grasp without any reticence a hand of God." But for him, he explained, "the most important thing in my life is Jesus Christ."

Governor Carter closed his remarks with a prayer. He asked God to provide those in attendance with "the permanent presence of the Holy Spirit," "to accept the standards of perfection and excellence in our Christian life," and to "particularly bless those who have been entrusted by their citizens to set examples of honesty and integrity,

\footnotetext{
' Jimmy Carter, "Remarks at the Leadership Prayer Breakfast in Orlando, Florida," March 27, 1974, in Jessyca Russell Gaver, The Faith of Jimmy Carter (New York: Manor Books, 1977), p. 30.

2 Ibid., p. 31; "Interview with Kim Watson of the Baptist Home Mission," April 1974, in The Faith of Jimmy Carter, p. 38.
} 
of compassion and understanding, of truthfulness and love."” "Honesty and integrity," "compassion and understanding," "truthfulness and love"-all of these would soon become the central themes of a presidential campaign, a presidency, and postpresidential missions through the Carter Center. To these principles, Carter pledged "to exemplify in every moment" of his life and public career the "attitudes and actions of Christianity."4

\footnotetext{
'Ibid., p. 37.

${ }^{4}$ Carter, "Interview with Jim Newton, editor of the World Mission Journal," 1976, in The Faith of Jimmy Carter, p. 27.
} 


\section{INTRODUCTION:}

\section{The Promise of an Evangelical-Styled Presidency}

"I have one life to live. I feel that God wants me to do the best I can with it." -----Jimmy Carter

It was the spring of 1976, the bicentennial year of the country and the first presidential election after the Vietnam War and the Watergate scandal that brought down the presidency of Richard Nixon. After tremendous gains in the 1974 midterm elections and with a seemingly vulnerable Republican in the White House, Gerald Ford, Democrats were exceedingly hopeful about their prospects for taking back the presidency.

With voters looking for something new, someone who promised a return to morality, former Georgia governor Jimmy Carter in stunning fashion rolled up victories in the opening contests of Iowa and New Hampshire. He then won in Vermont, the Midwestern states of Illinois, Wisconsin, and Indiana, and Pennsylvania and D.C. in the East. He secured wins over George Wallace in his native South, winning in Florida, North Carolina, and Georgia. Against better known, more established and experienced national party figures, Carter was quickly emerging as the unexpected frontrunner for the Democratic Party presidential nomination. His only primary loss by the beginning of May was in Massachusetts, where he came in fourth. At this point, Bill Moyers, a former press secretary to Lyndon Johnson, sat down to interview the increasingly probable, though still largely unknown, Democratic nominee. 
"What drives you?" asked Moyers. After a brief pause, Governor Carter said, "I feel like I have one life to live. I feel that God wants me to do the best I can with it. And that's quite often my prayer. Let me live my life so that it will be meaningful." In a follow-up question, Moyers pressed the Democratic frontrunner, "How do you know God's will?" "Well," Carter responded, "I pray frequently. And not continually, but many times a day. When I have a sense of peace and just self-assurance-I don't know where it comes from - that what I'm doing is the right thing, I assume, maybe in an unwarranted way, that that's doing God's will."

Later in the interview, Moyers said, "People say to me, 'Jimmy Carter appears to be so full of certainty and conviction.' Do you ever have any doubts? About yourself, about God, about life?" "I can't think of any," Carter offered. Explaining that he was obviously not omniscient by any means, did not have all the answers to life's questions or to all the political problems of the day, and frequently had "many doubts about the best way to answer a question or how to alleviate a concern," Carter said he was certain about God, his faith, and his purpose in life. ${ }^{2}$

A good president, Carter told Moyers, is one who tells "the truth always. I see no reason for the President to lie." And, if anyone who serves in his cabinet or administration lies, "They'll be gone the next day." The job entails, according to Carter, establishing justice at home and abroad, between the races, in the tax code, and

\footnotetext{
' Jimmy Carter, "Interview with Bill Moyers of the Public Broadcasting Service," May 6, 1976, in Conversations with Carter, edited by Don Richardson (Boulder, CO: Lynne Rienner Publishers, 1998), p. 9; see also "Interview with the National Religious Broadcasters in Indianapolis, Indiana, October 14, 1976, in Wesley Pippert, The Spiritual Journey of Jimmy Carter: In His Own Words (New York: Macmillan Publishing Company, 1978), p. 92.

${ }^{2}$ Carter, "Interview with Bill Moyers of the Public Broadcasting Service," May 6, 1976, in Conversations with Carter, pp. 10-11.
} 
in the criminal system. "It's not a crusade," he was on, he insisted. These are just "common sense" things a president should and must do. Unfortunately, he believed, at the moment, this was not a just society. In foreign policy, unlike his immediate predecessors, Carter promised if he were the president there would be no more military adventures in foreign lands, like Vietnam and Korea. Using military power abroad is unnecessary "to show we're strong. We are strong.,"

Carter admitted to Moyers that he had at least one "very legitimate source of criticism." "I'm not a good compromiser." Once he has taken a position on something, he explained when he was governor of Georgia, it was very difficult to "compromise away the things I believed in." In another interview, later that fall, he pledged that if he was elected president he would work on this. "I learned a lot as Governor, and I think that's one of the things that I did learn"-- "when to compromise and when not to compromise," "continuing consultations and sharing of ideas."

While Carter explained to Moyers that he "never asked God to let me be President" or that God "ordained him to take a dominant position," his rise to the pinnacle of American political power was rather miraculous. " $\mathrm{He}$ 'd pulled off a miracle," said Carter biographer Betty Glad. "In the fall of 1975, he was barely visible

\footnotetext{
3 Ibid., pp. 12-13.

${ }^{4}$ Ibid., p. 15.

${ }^{5}$ Carter, "Interview with the Editors of U.S. News \& World Report," September 13, 1976, in Conversations with Carter, p. 31.

${ }^{6}$ Carter, "Interview with Bill Moyers," p. 16.
} 
as a candidate, six months later he has the Democratic presidential nomination, now that is a miracle."

What would be the Carter legacy? What mark did he hope to leave behind? "When I go out of office," Carter said, "if I'm elected, at the end of four years or eight years, I hope people will say, 'You know, Jimmy Carter made a lot of mistakes, but he never told me a lie.", Just a little over two weeks before he took the oath of office as the $39^{\text {th }}$ President of the United States, Carter told U.S. News and World Report on January 3, 1977, what he ultimately hoped to accomplish and his presidency would be remembered for:

I'd like to go out of office with people being able to say that I always told the truth. I'd like to continue to play a leading role in the search for an enhancement of human rights. I'd like to do everything I can as President to ensure world peace. ${ }^{9}$

In doing these tasks, he hoped his style would not come off as preachy or overly religious. "I don't mean to preach to other countries." But the very fact that he raised the potential preacher problem suggests he recognized even before his inaugural his propensity for such a tendency.

Not for legislation passed, not for wars won, not for building a new party regime would a Carter presidency strive. Telling the truth, playing a lead role in advancing human rights, and working for peace-these Carter hoped, before he even took the oath

\footnotetext{
${ }^{7}$ Betty Glad, Transcript Part Two, American Experience: Jimmy Carter, narrated by Linda Hunt, directed by Adriana Bosch (WGBH Educational Foundation, 2002), (accessed September 18, 2006).

${ }^{8}$ Carter, "Interview with Bill Moyers of the Public Broadcasting Service," May 6, 1976, The Presidential Campaign 1976: Jimmy Carter (Washington, DC: United States Government Printing Office, 1978), p. 171.

${ }^{9}$ Carter, "Interview with Murray Gart, Hugh Sidey, Stanley Cloud, and Bonnie Angelo of U.S. New's \& World Report," January 3, 1977, in Conversations with Carter, p. 67.
} 
of office, would be the features of his presidency for which he would be remembered. His cousin, Hugh Carter, Sr., wrote after Carter's first year in the White House that, in the end. "the only list he wants to be on is that of the ten best presidents or ten most faithful followers of the Lord." "That's the real Jimmy," cousin Hugh concluded. Though told by his mother, "Miss Lillian," to knock off "that stuff about never telling a lie and being a Christian and how he loves his wife more than the day he met her." Carter's performance and style on the campaign trail retained "the flavor of a devotional, to God, love, morality, hard work."

Carter's religious faith was more than an interesting or curious part of his background. his upbringing in the South. or something he privately did only on Sundays. His faith was more central to Carter the man, the candidate, the president than is commonly acknowledged or discussed in the literature about him and his presidency. For Carter, his faith was politically consequential. Though he thought it would be "inappropriate" to say that his politics could be wholly ascribed to his "religious convictions," that he did not "look on the Presidency as a pastorate" or "with religious connotations," and that he considered "sacrilegious" caricatures of him as a Jesus-type figure or slogans that read, "J.C. Can Save America." the Democratic nominee claimed that "my life has been shaped in the church.".12

\footnotetext{
${ }^{10}$ Hugh Carter and Frances Spatz Leighton. Cousin Beedie and Cousin Hot: My Life with the Carter Family in Plains, Georgia (Englewood Cliffs. NJ: Prentice-Hall, 1978), p. 181.

"Peter Goldman and Eleanor Clift, "Carter on the Rise," Newsweek, March 8, 1976, p. 26.

${ }^{12}$ Carter, "Interview with Bill Moyers of the Public Broadcasting Service," May 6. 1976. The Presidential Campaign 1976, p. 179; "Interview with Jim Castelli of the National Catholic News Service." August 9, 1976, The Presidential Campaign 1976. pp. 458, 461.
} 
I try to utilize my own religious beliefs as a constant guide in making my decisions as a private or public citizen.

My deep commitment as a Christian, and my knowledge of the example of the life of Christ, and the observations of my own religious training of the attitude of Christ toward other human beings has been obviously an example that I followed.

Charles O. Jones was right Carter was not an enigma. He was a "moralizer" from beginning to end. ${ }^{13}$ From the day he formally declared his candidacy on December 12, 1974, Carter ran for president on a promise not to lie, not to mislead, not to avoid the tough, controversial issues, and not to betray the trust of the American people. He said he would be different from day one of the campaign. Right out of the gate, the former Georgia governor promised a government of love, compassion, and a restoration of "the basic integrity of our nation." "There is a standard," he said, "of what's right and what's fair and what's open and what's honest." ${ }^{14}$ For Carter, these were the values of a "benevolent conservatism.",15

"I'd like to see," Carter wrote in a letter to old friends and supporters a little over a week before his formal announcement, "this country return to the high standards and ideals on which it was founded." Americans, he said, "have lost faith" in their government and are "troubled by the dishonesty of public officials." He believed that by offering "bold, competent, honest leadership" the country could be reborn. "We are

\footnotetext{
${ }^{13}$ Charles O. Jones, The Trusteeship Presidency: Jimmy Carter and the United States Congress (Baton Rouge, LA: Louisiana State University Press, 1988), pp. 207, 217.

${ }^{14}$ Carter, "Remarks at a Campaign Rally in the Civic Center in Atlanta, Georgia," December 12, 1974. The Presidential Campaign 1976, pp. 11-12.

${ }^{15}$ Carter, "Remarks at the National Press Club in Washington, DC," February 9, 1973, The Presidential Campaign 1976, p. 39.

${ }^{16}$ Carter, "Letter to Friends," December 4, 1974, The Presidential Campaign 1976, pp. 1-2.
} 
ready for a time of healing... a time of cleansing and rededication." ${ }^{17}$ And the same principles that must guide the country at home must guide it abroad. "Courage, compassion, integrity, and dedication to basic human rights and freedoms" must be the standard established by the United States "within the community of nations." endure "changing times," whether at home or abroad, the country must reach out and grasp for "unchanging principles," understanding that the source for "moral imperative" is "ancient" and "personal". 19 This is the president's responsibility, and among national politicians, it is his alone. "There is only one person in this nation who can speak with a clear voice, who can set a standard of morals, decency, and openness. ${ }^{20}$ In short, as described by Newsweek in early March 1976, Carter was a candidate who spoke "unabashedly of returning the Golden Rule to public life.,"21

Candidate Carter said politics was not "a matter of liberal or conservative," but "the art of doing what is right." 22 This, Carter would later state a week into his presidency, is precisely what the clergy teach us: "to hold firm to what is right—against

\footnotetext{
${ }^{17}$ Carter, "Remarks at a Town Hall Forum in Los Angeles, California," August 23, 1976, The Presidential Campaign 1976, p. 510.

${ }^{18}$ Carter, "Formal Announcement as a President Candidate at the National Press Club in Washington, DC," December 12, 1974, The Presidential Campaign 1976, p. 3.

${ }^{19}$ Carter, "Remarks to the American Bar Association in Atlanta, Georgia," August 11, 1976, The Presidential Campaign 1976, pp. 491, 494.

20 “"Jimmy Carter's Code of Ethics' position paper," March 1, 1976, The Presidential Campaign 1976, p. 92; Carter, "Interview with Bill Moyers of the Public Broadcasting Service," May 6, 1976, The Presidential Campaign 1976, p. 175.

${ }^{21}$ Goldman and Clift, "Carter on the Rise," p. 25.

22 Carter, "Remarks at a Town Hall Forum in Los Angeles, California," August 23, 1976, The Presidential Campaign 1976, p. 504.
} 
what is wrong." 23 And being president, Carter said, is not about being "First Boss," but being "First Servant." "I'm no better than any of you."24 Quoting Jesus, Carter said "Whosoever would be chief among you, let him be His servant."25 Not even two weeks into Carter`s presidency, even Pope Paul VI was praising "the strong religious underpinnings" of the new administration. ${ }^{26}$

Carter also promised that his foreign policy would be different. He believed that the United States must promote moral principles in international affairs that were "absolute." 27 As at home, Carter believed that leadership abroad should be based on honesty and truthfulness, not "military might or political pressure or economic power." "We cannot impose democracy...by force"; "we cannot buy friends.,"29 Foreign policy "must once again reflect the basic ideals of our people and our nation,"

\footnotetext{
${ }^{23}$ Carter, "Proclamation of International Clergy Week," January 28, 1977, Public Papers of the Presidents, Jimmy Carter, 1977, Book I (Washington, DC: United States Government Printing Office), p. 33.

${ }^{24}$ Carter, "Remarks and Question-and-Answer Session with Employees of the Department of Health, Education, and Welfare," February 16, 1977, Public Papers of the Presidents, Book I, p. 167; see also "Remarks and Question-and-Answer Session with Employees of the Department of Agriculture," February 16, 1977, Public Papers of the Presidents, Book I, p. 175.

${ }^{25}$ Carter, "Remarks at the Annual National Prayer Breakfast," January 27, 1977, in Public Papers of the Presidents, Book 1, p. 25.

${ }^{26}$ Walter F. Mondale, "Remarks Upon Return from Trip to Europe and Japan," February 1, 1977, Public Papers of the Presidents, Book I, p. 58.

${ }^{27}$ Carter, Transcript Part One, American Experience: Jimmy Carter.

${ }^{28}$ Carter, "Remarks at Florida State University in Tallahassee, Florida," September 28, 1975, in $A$ Government As Good As Its People (1977; reprint, Fayetteville, Ark., 1996), 48; "Remarks at the Chicago Council on Foreign Relations," March 15, 1976, The Presidential Campaign 1976, p. 112.

${ }^{29}$ Carter, "Remarks at the American Chamber of Commerce in Tokyo, Japan," May 28, 1975, The Presidential Campaign 1976, p. 67.
} 
designating "human rights and humanitarian concerns" as "our vital interest" and modeling for the world rightness, fairness, decency, honesty, and truthfulness. ${ }^{30}$

During the second presidential debate with President Gerald Ford, the focus of which was foreign policy, Carter explained that "the strength of our country" was rooted in "its moral integrity," not its military power. ${ }^{31}$ "That's where our strength lies." Of course, he believed that "militarily we are as strong as any nation on earth." But that was not what is of fundamental importance. He said, U.S. foreign policy should be committed to "human rights" and to "our principles that don't change," not "supporting dictatorships" or rhetorical "bombast and threats." In this area, "we are weak and the rest of the world knows it." Strength is "derived from doing what's right—caring for the poor, providing food, becoming the breadbasket of the world instead of the arms merchant of the world." "In those respects," Carter said, "we're not strong." The problem at the time as he saw it was that for too many years the United States had become in the eyes of the world "a warmonger," "a liar," and "an intervener in the internal affairs of other countries." 32

If the country followed his course, Carter believed that the United States could once again become "a beacon for nations who search for peace and who search for freedom, who search for individual liberty, who search for basic human rights." This is the country's "quiet strength based on the integrity of our people, the vision of the

\footnotetext{
${ }^{30}$ Ibid., p. 70.

${ }^{31}$ Carter, "Remarks during the Second Presidential Debate with President Gerald Ford, San Francisco, California," October 6, 1976, moderated by Pauline Frederick of National Public Radio, The Commission on Presidential Debates, http://www.debates.org.

${ }^{32}$ Carter, "Remarks at Johns Hopkins University in Baltimore, Maryland," April 2, 1975, The Presidential Campaign 1976, p. 58.
} 
Constitution, an innate strong will and purpose that God's given us in the greatest nation on earth." 33

Jimmy Carter, in many respects, was an unusual president. He was an evangelical president who had what will be defined here as an "evangelical" style of governing. ${ }^{34}$ Carter did not so much have a political ideology as a moral one, said former speechwriter Hendrik Hertzberg. ${ }^{35}$ It was this, he continued, that "guided him" in politics and focus on certain issue priorities. This, as the above discussion makes clear, was all there before he took the oath of office and made clear in the beginning weeks of his presidency. This view of himself, how he intended to behave, what he intend to do is precisely who he was and what kind of president he would be before and after the votes were counted. It was not a style only seen during election time.

The evangelical political, presidential style, which has antecedents in the style of William Jennings Bryan and Woodrow Wilson, often collides with the Richard Neustadt-Max Weber prescriptions for effective political, presidential leadership.

Sociologist Max Weber recognized long ago that politicians who claimed to be fundamentally motivated by religious faith existed. He described a religiously motivated politician as one "who seeks the salvation of the soul, of his own and others" through politics. This type of politician, however, Weber recommended, "should not seek it along the avenue of politics." ${ }^{36}$ Politics, he said, was "made with the head, not

\footnotetext{
${ }^{33}$ Carter, "Remarks during the Second Presidential Debate with President Gerald Ford."

${ }^{34}$ D. Jason Berggren and Nicol C. Rae, "Jimmy Carter and George W. Bush: Faith, Foreign Policy, and an Evangelical Presidential Style," Presidential Studies Quarterly 36.4 (December 2006): 606-632.

${ }^{35}$ Hendrik Hertzberg, Transcript Part One, American Experience: Jimmy Carter.
} 
with other parts of the body or soul." Richard Neustadt said, "the Presidency is a place for men of politics," men who can get things done with and through others. ${ }^{37}$ Because presidents cannot command or compel other players in the political process to act. effective presidential leadership rests upon the capacity and willingness to persuade and bargain. Presidents should be lovers of politics and the conventional workings of the process. But Carter did not like politics as such; he was frequently adverse to compromise and it sorely hurt his relations with his fellow Democrats who controlled the Congress. Carter's preference for being right and doing good more than occasionally outweighed political considerations and costs. As described before his election, Carter had "a certain Mr. Cleanly rigidity at politics," a reputation he has had throughout his long public career. ${ }^{38}$

In his classic primer on politics, All Politics is Local and Other Rules of the Game, House Speaker Tip O'Neill said that compromise and patience are among the key ingredients in successful political leadership. To get things done, majorities have to be built, discussions held, and deals struck. ${ }^{39}$ But Carter believed that politics was a legitimate form of Christian ministry and service; politics was a compatible art to formal religious vocations of doing right and being good. As we will see, he incorporated his faith into his politics. It influenced his views toward and with

\footnotetext{
${ }^{36}$ Max Weber, "Politics as a Vocation," in From Max Weber: Essays in Sociology, ed. H.H. Gerth and C. Wright Mills (New York: Oxford University Press, 1946), pp. 126, 115.

${ }^{37}$ Richard E. Neustadt, Presidential Power and the Modern Presidents: The Politics of Leadership from Roosevelt to Reagan (New York: The Free Press, 1990), p. 152.

${ }^{38}$ Goldman and Clift, "Carter on the Rise," p. 29.

${ }^{39}$ Tip O’Neill with Gary Hymel, All Politics is Local and Other Rules of the Game (Holbrook, MA: Bob Adams, Inc., 1994), pp. 92, 95.
} 
Congress, domestic policies, such as energy, and his foreign policy, particularly his understanding of what constitutes a superpower in the world and his pursuit of peace in the Middle East. It was a style that brought him defeats and failures all too well noted in the literature of his presidency. However, what is often missed is that the evangelical style of leadership brought him tremendous successes, too. It got him elected, which in itself is no small feat. Then, his success at Camp David was an achievement unequaled by his immediate successors in a region where American presidents have enjoyed few, if any, memorable successes. This study takes a look at this different kind of president, putting his failures and successes in the context of what he and those who knew him best said was most important to him: his evangelical faith.

\section{The Promise of a Faith-Based Presidency in the United States}

"One cannot understand America if one does not have an awareness and appreciation of the religious underpinnings of our society."

"In no other country outside the Islamic world is religion such a central aspect of politics as it is in the United States."

Writing in the $19^{\text {th }}$ century, Alexis de Tocqueville said this about the United

States: "There is no country in the world where the Christian religion retains a greater influence over the souls of men than in America." ${ }^{.22}$ In the $20^{\text {th }}$ century, Sidney Mead went so far as to say the United States was still a country "with the soul of a church."

\footnotetext{
${ }^{40}$ George Gallup, Jr. and D. Michael Lindsay, Surveying the Religious Landscape: Trends in U.S. Beliefs (Harrisburg, PA: Morehouse Publishing, 1999), p. 1.

${ }^{41}$ Frances Cairncross, "The God Gulf," Index on Censorship 33, no. 4 (October 2004): 17.

${ }^{42}$ Quoted by Seymour Martin Lipset, American Exceptionalism: A Double-Edged Sword (New York: W.W. Norton \& Company, 1996), p. 62.
} 
Samuel Huntington explained that one of the crucial differences between the United States and Europe was that European states rationalized, secularized, and centralized political authority much more completely and thoroughly than the United States. ${ }^{44}$ In other words, Europe has had the more "modern" political arrangement, while the United States preserved a more "medieval," traditional, decentralized, "Tudor" form of government. Elsewhere, Huntington observed that the United States was a country in which fits of moralist politics, or "creedal passion" are periodically experienced, and this usually occurs after a major religious revival. ${ }^{45}$ The United States was a place where politics was not simply a contest between alternative policy views, but often cast into plays of moral passion. As Seymour Martin Lipset wrote, "Americans are utopian moralists who press hard to institutionalize virtue, to destroy evil people, and [to] eliminate wicked institutions and practices... They tend to view social and political dramas as morality plays, as battles between God and the Devil, so that compromise is virtually unthinkable." ${ }^{46}$ Whether at home or abroad, a strong sense of divine mission flavored the style and content of American politics. At the beginning of the $21^{\text {st }}$ century, the Pew Research Center reported that "Americans overwhelmingly consider the U.S. a Christian nation," and, unlike other major Western countries, the United States continues to stand alone "in its embrace of religion." 47

\footnotetext{
${ }^{43}$ Sidney E. Mead, The Nation with the Soul of a Church (Macon, GA: Mercer University Press, 1985).

${ }^{44}$ Samuel P. Huntington, "Political Modernization: America vs. Europe," chap. in Political Order in Changing Societies (New Haven, CT: Yale University Press, 1968), pp. 93-139.

${ }^{45}$ Samuel P. Huntington, American Politics: The Promise of Disharmony (Cambridge, MA: The Belknap Press of Harvard University Press, 1981), pp. 160-166.

${ }^{46}$ Lipset, American Exceptionalism, p. 63.
} 
Historically, unlike Europe, religion in America has been Arminian,

voluntaristic, biblicist, antiestablishmentarian, anti-hierarchical, millennial, populist. and heavily influenced by revivalistic sectarian groups, such as the Baptists, Methodists, Disciples of Christ, Holiness movements, and Pentecostals. ${ }^{48}$ Religion in America has additionally tended towards anti-intellectualism, a suspicion of higher learning and rationalist thought. ${ }^{49}$

The revolutionary heritage of the United States is even different. H. Richard Niebuhr observed that the United States began as country when an "awakening to God" coincided "with its awakening to national self-consciousness." ${ }^{50}$ One of the fundamental differences, too, between the spirit of the American Revolution and the French, Mexican, Russian, Chinese, or Cuban revolutions is that the American Revolution was not an anticlerical, antireligious, iconoclastic revolution. ${ }^{51}$ Unlike the religious establishments in Europe or Latin America, religion in America has been populist and even "revolutionary."

\footnotetext{
47 "Many Americans Uneasy with Mix of Religion and Politics," Pew Research Center Report, August 24, 2006, p. 5; "U.S. Stands Alone in Its Embrace of Religion," The Pew Global Attitudes Project, December 2002.

${ }^{48}$ Lipset, American Exceptionalism, pp. 60-67; Lipset, The First New Nation: The United States in Historical and Comparative Perspective (Garden City, NY: Anchor Books, 1967), pp. 159-192; Lipset, Continental Divide: The Values and Institutions of the United States and Canada (New York: Routledge, 1990), pp. 74-89.

${ }^{49}$ Richard Hofstadter, Anti-Intellectualism in American Life (New York: Vintage Books, 1963); George M. Marsden, Fundamentalism and American Culture: The Shaping of Twentieth-Century Evangelicalism. 1870-1925 (New York: Oxford University Press, 1980).

${ }^{50}$ H. Richard Niebuhr, The Kingdom of God in America (Middletown, CT: Wesleyan University Press, 1988), p. 126.

${ }^{51}$ Sydney E. Ahlstrom, A Religious History of the American People (New Haven, CT: Yale University Press, 1972), p. 382.

${ }^{52}$ Louis Hartz, The Liberal Tradition in America (Orlando, FL: Harcourt Brace \& Company, 1991), p. 41.
} 
supported the revolution itself and provided some of its ablest publicists. ${ }^{.53}$ As David Chidester noted. one of the most frequently heard revolutionary slogans colonial ministers and politicians hurled against continued British rule was "No King but King Jesus. ${ }^{\circ 4}$ Therefore, the anticlerical, irreligious character of the French. Mexican. Russian, Chinese, and Cuban revolutions never became a part of the American revolutionary fervor. Nor. once the 1787 Constitution was drafted, did the new Republic harbor a "grudge against religion," blame clerics "for siding with oppressive rulers," or hunt them "down for execution." 55 Instead, it was an experiment that blended the assumptions and aspirations of rationalists and pietists. Lockeans and Calvinists. ${ }^{56}$ "The United States was both secular and religious from the start." ${ }^{57}$ And this has been true, too, of its politics.

Most Americans, as borne out in the pages of American history, have believed. while firmly embracing the institutional separation of church and state. "religion has an important role to play in the public realm."

53 Robert N. Bellah. Richard Madsen. William M. Sullivan, Ann Swidler. and Steven M. Tipton. The Good Society (New York: Vintage Books, 1992), p. 180. See also Winthrop S. Hudson. Religion in America (New York: Macmillan Publishing Company. 1987). pp. 92-96: Michael Corbett and Julia Mitchell Corbett, Politics and Religion in the United States (New York: Garland Publishing. Inc.. 1999). pp. 59-60, 106-107.

${ }^{5+}$ David Chidester, Patterns of Power: Religion and Politics in American Culture (Englewood Cliffs. NJ: Prentice- Hall. Inc., 1988), p. 60.

${ }_{55}$ R. Laurence Moore. Touchdown Jesus: The Mixing of Sacred and Secular in American Histor? (Louisville. KY: Westminster/John Knox Press. 2003), p. 6.

${ }^{56}$ Corbett and Corbett. Politics and Religion in the United States, pp. 55-70.

${ }^{57}$ Raymond F. Bulman, "MMyth of Origin,' Civil Religion and Presidential Politics." Journal of Church and State 33.3 (Summer 1991): 527.

${ }^{58}$ Robert N. Bellah. Richard Madsen. William M. Sullivan. Ann Swidler. and Steven M. Tipton. Huhits of the Heart: Individualism and Commitment in American Life (New York: Vintage Books, 1992). p. 219. 
Religion has always played an important part in American politics. The founders of the Republic drew on religious values and rhetoric in forming the new nation. Churches were active on both sides in the controversy over slavery and the Civil War that it produced. Religious groups were significant participants in campaigns for such diverse causes as prohibition of the sale of liquor, defense of the gold standard in the 1890s, enactment of women's suffrage, reform of the national economy under the New Deal, and passage of civil rights legislation in the 1960s. Perhaps most important, religion was the source of the so-called Protestant ethic, which has helped shape both the goals and the behavioral standards of American political life. ${ }^{59}$

Much of the religious variance between the United States and Europe was produced by waves of religious immigrants who sought to escape religious persecution in Europe. Thus, it is not surprising that American Christians are different from European Christians. As John Kingdon explained, "American values are connected to the kinds of people who came here... systematically and fundamentally different from those who stayed behind in the old countries." ${ }^{60}$ Given this and its persistence across time, historian Garry Wills went so far as to question whether the United States is even an enlightened country anymore: "Can a people that believes more fervently in the Virgin Birth than in evolution still be called an Enlightened nation?"61

This brings us to the following questions: "Is a faith-based presidency conceivable?" "Would the American people elect a religiously motivated president?" "If a faith-based presidency is conceivable and if the American people would elect a religiously motivated president, what would such a presidency look like?" "What kind of person would such a president be?" These questions underlie the premise of this

\footnotetext{
${ }^{59}$ A. James Reichley, "Religion and the Future of American Politics," Political Science Quarterly 101.1 (I986): 23

${ }^{60}$ John W. Kingdon, America the Unusual (New York: Worth Publishers, Inc., 1999), p. 58.

${ }^{61}$ Garry Wills, "The Day the Enlightenment Went Out," New York Times, November 4, 2004.
} 
project. Those who disagree with or remain skeptical about the possibility of a faithbased presidency may do so for three fundamental reasons.

First, such critics may contend that religion is merely epiphenomenal; it is just the product or projection of economic, political, or social factors. ${ }^{62}$ They may claim that religion is simply a passive, dependent variable with little or no dynamic, transformational capacity of its own. They may view religion, as Sigmund Freud did, as an illusion, a human wish or fantasy. ${ }^{63}$

Second, critics may argue that though religion has been historically important it is no longer. ${ }^{64}$ Religion, they may claim, is increasingly becoming outmoded and replaced by more purely secular, rational perspectives. As such, it is futile to study religion as an important independent variable in modern politics and in modern presidencies.

Third, critics may take an instrumentalist view. They may argue that religion is worthy of study, but it is worthy mostly if it is more properly understood as a tool used by politicians to keep voters from focusing on the real issues in order to avoid offering real solutions to real problems, or to deviously mask their true political intentions, or to cynically "divide and conquer" an electorate in order to obtain the sufficient number of votes to win office.

\footnotetext{
${ }^{62}$ Kenneth D. Wald and Clyde Wilcox, "Getting Religion: Has Political Science Rediscovered the Faith Factor?" American Political Science Review 100.4 (November 2006): 525.

${ }^{63}$ Sigmund Freud, The Future of an Illusion, translated and edited by James Strachey, introduction by Peter Gay (New York: W.W. Norton and Company, 1989).

${ }^{64}$ Wald and Wilcox, "Getting Religion: Has Political Science Rediscovered the Faith Factor?", p. 526.
} 
There is certainly merit to such perspectives. But they are just thatperspectives. They are, as William Paden noted, "interpretative frames." ${ }^{65}$ Religion can be, and is, shaped by other phenomena. It is true that in some places, Western Europe for example, traditional religious faith and worship are certainly fading. ${ }^{66}$ And yes, there are and have been politicians who may manipulate religion for personal political advantage. But that is not the whole story of religion and politics.

Religion can, and often does, have "a voice of its own." 67 It can be "an alternative way of seeing and experiencing the same cosmos," bringing with it its "own set of pictures to bear in interpreting... facts about the world. ${ }^{, 68}$ Large majorities of Americans vote their faith and like their politicians to be religious. "The truth," wrote Stephen Carter, "is that tens of millions of Americans rely on their religious traditions for the moral knowledge that tells them how to conduct their lives, including their political lives." 69

More than two-thirds of Americans (64\%) have said their religion is an important factor affecting their vote and more than seventy percent (72\%) said presidents should have strong religious beliefs. ${ }^{70}$ Though Americans are divided over

\footnotetext{
${ }^{65}$ William E. Paden, Interpreting the Sacred: Ways of Viewing Religion (Boston, MA: Beacon Press, 1992), pp. 1-14.

${ }^{66}$ Ronald Inglehart, Modernization and Postmodernization: Cultural, Economic, and Political Change in 43 Societies (Princeton, NJ: Princeton University Press, 1997).

${ }^{67}$ Paden, Interpreting the Sacred, p. 87.

${ }^{68}$ Ninian Smart, Worldviews: Crosscultural Explorations of Human Beliefs (New York: Charles Scribner's Sons, 1983), p. 163.

${ }^{69}$ Stephen L. Carter, The Culture of Disbelief: How American Law and Politics Trivialize Religious Devotion (New York: Basic Books, 1993), p. 67.
} 
whether churches should get actively involved in politics, with a slight majority in Pew polls from 1996-2006 consistently saying they should; in 2003, a plurality of Americans (41\%) believed politicians expressed their faith "too little." "71 Another twenty-nine percent said politicians expressed it in the "right amount"; only twenty-one percent of Americans thought politicians expressed their faith "too much." Americans also thought it is "proper" for the media to ask presidential candidates about their religious faith $(57 \%$ to $39 \%)$, and nearly fifty percent (46\%) said they could not vote for an atheist running for president.

Politicians have many motives. ${ }^{72}$ As Richard Fenno observed, all politicians are "goal seekers." 73 Some politicians may be motivated by material incentives, like financial gain, patronage and the distribution of public goods. Others may be motivated by desires for power and influence, holding office and winning reelection. Others may want to continue a family legacy or feel it part of their civic duty. Some may calculate that the benefits, actual and expected, of political activity outweigh the costs of noninvolvement. Some may get involved in politics for solidarity or social purposes. And others may be motivated by purposive goals - the advancement of certain ideas

\footnotetext{
${ }^{70}$ Albert L. Winseman, "Bringing Faith into the Voting Booth: Part I," The Gallup News Service, December 9, 2003; "GOP, the Religion-Friendly Party," The Pew Research Center, August 24, 2004.

71 "Many Americans Uneasy with Mix of Religion and Politics," Pew Research Center Report, August 24, 2006, p. 27; "Religion and Politics: Contention and Consensus," The Pew Research Center, July 24. 2003.

${ }^{72}$ David R. Mayhew, Congress: The Electoral Connection (New Haven, CT: Yale University Press, 1974), pp. 5-6; Richard F. Fenno, Jr., Home Style: House Members and Their Districts (Boston, MA: Little, Brown and Company, 1978); Marjorie Randon Hershey, Party Politics in America (New York: Longman, 2005), pp. 83-90; Andre Blais, To Vote or Not to Vote: The Merits and Limits of Rational Choice Theory (Pittsburgh, PA: University of Pittsburgh Press, 2000).

${ }^{73}$ Richard F. Fenno, Jr., Congress at the Grassroots: Representational Change in the South, 1970-1998 (Chapel Hill, NC: The University of North Carolina Press, 2000), p. 5.
} 
and policies. Like other politicians, presidents, too, have varying leadership and

managerial styles, abilities, personality traits, and attitudes toward public service and about the nature of the office they hold. ${ }^{74}$

If scholars generally recognize and accept that politicians, including presidents, have many and mixed motives for public service and policymaking, there is no logical or theoretical reason why one's religious faith may not be counted among the manifold motives. This is especially so in a country long recognized as and empirically shown in comparative studies to be "a godly nation." 75

Evidence exists that religion is indeed a source of political motivation.

Members of Congress, Republican and Democrat, conservative and liberal, often claim that their religious faith influences their voting behavior. ${ }^{76}$ The religious composition of districts also seems to have an influence on how members vote. ${ }^{77}$ Religious beliefs and frequent church attendance have been shown to have a major influence on a person's decision to run for office. ${ }^{78}$

\footnotetext{
${ }^{74}$ James David Barber, The Presidential Character: Predicting Performance in the White House (Upper Saddle River, NJ: Prentice-Hall, 1992); Fred 1. Greenstein, The Presidential Difference: Leadership Style from FDR to Clinton (Princeton, NJ: Princeton University Press, 2000); John P. Burke, The Institutional Presidency: Organizing and Managing the White House from FDR to Clinton (Baltimore, MD: The Johns Hopkins University Press, 2000); Steven J. Rubenzer and Thomas R. Faschingbauer, Personality, Character, and Leadership in the White House: Psychologists Assess the Presidents (Washington, DC: Brassey's lnc., 2004).

75 Jay Tolson, "The Faith of Our Fathers," U.S. News and World Report, June 28-July 5, 2004, p. 54; "U.S. Stands Alone in 1ts Embrace of Religion," The Pew Global Attitudes Project, December 2002.

${ }^{76}$ Peter L. Benson and Dorothy L. Williams, Religion on Capitol Hill: Myths and Realities (New York: Harper and Row, 1982), pp. 140-167; James L. Guth, "The Confessional Congress: Religion and Legislative Behavior," paper presented at the 2005 annual meeting of the Southern Political Science Association.

${ }^{77}$ John C. Green and James L. Guth, "Religion, Representatives, and Roll Calls," Legislative Studies Quarterly 16.4 (November 1991): 571-584.
} 
Places of worship in the United States, too, have long been places for learning

civic and political virtues, developing civic and political skill and experience, and inspiring civic and political activism. They have been the heart of American associational life; they have been places where social movements and political campaigns have been born. In his widely acclaimed book, Bowling Alone, Robert Putnam described the important role American churches have had at the most basic level in initiating and nurturing the political life of the country:

Churches provide an important incubator for civic skills, civic norms, community interests, and civic recruitment. Religiously active men and women learn to give speeches, run meetings, manage disagreements, and bear administrative responsibility. They also befriend others who are in turn likely to recruit them into other forms of community activity. In part for these reasons, churchgoers are substantially more likely [than other Americans] to be involved in secular organizations, to vote and participate politically in other ways, and to have deeper informal social connections. ${ }^{79}$

Religion has also been a major factor in dividing the parties and many religious groups have long had distinct party loyalties and ideological tendencies. ${ }^{80}$ For presidents, religion can be a key component in a candidate's psychological profile.

\footnotetext{
${ }^{78}$ Melissa Deckman, "Religion Makes the Difference: Why Christian Right Candidates Run for School Board," Review of Religious Research 42.4 (2001): 349-371.

${ }^{79}$ Robert D. Putnam, Bowling Alone: The Collapse and Revival of American Community (New York: Simon and Schuster, 2000), p. 66. See also Kenneth D. Wald, Dennis E. Owen, and Samuel S. Hill, Jr., "Churches as Political Comnunities," American Political Science Review 82.2 (June 1988): 531-548; Kenneth D. Wald, Dennis E. Owen, and Samuel S. Hill, Jr., "Political Cohesion in Churches," Journal of Politics 52.1 (February 1990): 197-215; Robert Huckfeldt, Eric Plutzer, and John Sprague, "Alternative Contexts of Political Behavior: Churches, Neighborhoods, and Individuals," The Journal of Politics 55.2 (May 1993): 365-381; Eric M. Uslaner, "Religion and Civic Engagement in Canada and the United States," Journal for the Scientific Study of Religion 41.2 (2002): 239-254.

${ }^{80}$ Laura R. Olson and John C. Green, "The Religion Gap," PS: Political Science and Politics 39.3 (July 2006): 455-459; Alan Abramowitz and Kyle Saunders, "Why Can't We All Just Get Along? The Reality of a Polarized America," The Forum 3.2 (2005), Article 1; Morris P. Fiorina with Samuel J. Abrams and Jeremy C. Pope, Culture War? The Myth of a Polarized America (New York: Longman, 2005), pp. 96103; A James Reichley, The Life of the Parties (Lanham, MD: Rowman and Littlefield Publishers, 2000): Mark A. Noll, ed., Religion and American Politics: From the Colonial Period to the 1980s (New York:
} 
Religious upbringing and moral behavior, for instance, can shape the leadership style, worldview, and character of future presidents. ${ }^{81}$

It is argued here that religion was politically important for the thirty-ninth President. Not merely in his upbringing in the Carter family or the context of the American South, while important, Jimmy Carter had a religiously inspired presidency. with a distinctly evangelical style. Admittedly, this may be difficult to measure, but as this project will document, evidence of Carter's faith-in-action is abundant.

Faith-based American presidencies, or presidents with religious styles, are not only conceivable, they have existed and may again, often "following corrupt administrations or times." ${ }^{\circ 2}$ In particular, the central claim here is that President Jimmy Carter was not just religious, he was a religious president. He was a president who boldly claimed that "the most important thing in my life is Jesus Christ..$"{ }^{-83}$ that Christ is "an avenue to God, an example, a guide, and a source of reassurance, strength, and wisdom, ${ }^{8+}$ and that Christians in the world, whatever their profession, have a

\footnotetext{
Oxford University Press, 1990); Robert Booth Fowler, Allen D. Hertzke, and Laura R. Olson, Religion and Politics in America: Faith, Culture, and Strategic Choices (Boulder, CO: Westview Press, 1999).

${ }^{81}$ See Barber, The Presidential Character for various background descriptions of American presidents and Marvin Olasky, The American Leadership Tradition: The Invevitable Impact of a Leader's Faith on a Nation's Destiny, (Wheaton, IL: Crossway Books, 1999) for a case of how religion and sexual ethics influences presidential behavior and policy.

${ }^{82}$ Derek H. Davis, "Thoughts on the Separation of Church and State under the Administration of President George W. Bush," Journal of Church and State 45.2 (Spring 2003): 234: Jeff Walz, "Religion and the American Presidency," in In God We Trust? Religion and American Political Life, edited by Corwin E. Smidt (Grand Rapids, MI: Baker Book House Company, 2001), p. 194.

${ }^{83}$ David Kucharsky, The Man from Plains: The Mind and Spirit of Jimmy Carter (New York: Harper and Row Publishers, 1976), p. 67.

${ }^{84}$ Carter, Living Faith (New York: Random House, Inc., 1998), p. 230.
} 
responsibility to "serve God with boldness." $"$ While as a Southern Baptist he affirmed the separation of church and state, Carter was driven by the sense that he has but "one life to live" and feels that "God wants me to do the best I can with it." 86 And if he did his best and could convince the Congress to act on his agenda, "together, as the Bible says, we can move mountains.", 87

The purpose here is not to claim that religion was the only thing that mattered to or influenced President Carter. In The Virtues of Aging, Carter explained that each person "is a complex human being," having multiple identities. He noted that over the course of his life he has variously introduced himself "as a submariner, farmer, warehouseman, state senator, governor, or even president...I might have added where 1 lived." In his post-presidency, Carter has said that he might have described himself as "a professor, author, fly fisherman, or woodworker," and that he could also "add American, southerner, Christian, married, or grandfather." matter and has been central to his public identity.

He has consistently claimed that his religion did matter as a public figure, but this has been largely ignored in previous studies. But more importantly, it is claimed here that Carter, in effect, presented a leadership alternative to the prevailing Weber-

\footnotetext{
${ }^{85}$ Carter, Sources of Strength: Meditations on Scripture for a Living Faith (New York: Three Rivers Press, 1997), p. 241.

${ }^{86}$ Carter, "Interview with Editors and Reporters of the Washington Star," August 5, 1976, The Presidential Campaign 1976, p. 452; "Interview with Jim Castelli of the National Catholic News Service," August 9, 1976, The Presidential Campaign 1976, p. 453; Kucharsky, The Man from Plains: The Mind and Spirit of Jimmy Carter, p. 80.

${ }^{87}$ Carter, "State of the Union Address," January 19, 1978, in Public Papers of the Presidents, Book I, p. 98.

${ }^{88}$ Carter, The Virtues of Aging (New York: The Ballantine Group, 1998), pp. 89-90.
} 
Neustadt model. Instead of being motivated by politics first and protecting his reputation with key presidential audiences, Carter was motivated by his faith, often justified his policy and involvement in religious terms, and forged religious ties with the leaders involved, particularly Egyptian President Anwar Sadat. Politics was a form of Christian ministry, a means to a moral end.

Many scholars have examined the influence of religion on voting behavior and political attitudes. But fewer have explored the role of faith in the behavior and attitudes of presidents. Carter did not come to Washington to persuade and bargain. He came to the nation's capitol to do good. In the Weberian sense, Carter was a president who lived "for" politics and railed against professional, career politicians, regardless of party, who lived "off" politics. ${ }^{89}$ He did not come as the head of the Democratic Party. He claimed to be his own man and owed no one in politics anything. He claimed to come in the name of God and in the name of the American people. As the Democratic nominee, he made it clear that if Congress, even a Democratic Congress, stood in his way, he would unhesitatingly "go directly to the American people" when he felt "I'm right. $" 90$

And he would feel this rightness often. For Jimmy Carter, Christ was the figure worthy of imitation, not only personally, but politically. He promised not to lie, but to tell the truth. He promised a government of love and policies with transcendent purpose. He believed that his faith was not merely a private affirmation or church-

\footnotetext{
${ }^{89}$ Weber, "Politics as a Vocation," p. 84.

${ }^{90}$ Carter, "Interview with Congressional Quarterly," August 24, 1976, The Presidential Campaign 1976, p. 553.
} 
confined activity, but a public expression, a public act, a means of moving toward God. ${ }^{91}$ If religion can be defined as "activities and beliefs directed toward that which is perceived to be of sacred value and transforming power," Carter saw his religious principles, including orthodoxy (right belief) and orthopraxis (right action), containing the political potential to be America-reforming and world-transforming. ${ }^{92}$ He found that the teachings, ethics, and virtues from one of the great "wisdom traditions" had political relevance in the modern world. ${ }^{93}$

Though many may find this troubling and subverting of their strict separationist, secular, and rational sensibilities, they should not be surprised at such a reality in a country known for its traditional religious character. As Carter said, "I'm not unique. There are a lot of people in this country who have the same religious faith. ${ }^{94}$ Within the United States, traditional, evangelical religion is particularly salient in the South, where Carter comes from, and in the Midwest. It is in this American context that a faith-based, religiously inspired presidency, an evangelical presidency, such as Carter's. is possible. It is in this cultural milieu, a uniquely American milieu, that a Carter candidacy had appeal. And given this character of the United States, from time to time. such candidacies and presidencies may be come again. A religious people may be

\footnotetext{
${ }^{91}$ Theologian Paul Tillich, a Carter favorite, defined religion as a "function of the human mind," "the futile attempt of man to reach God." Unlike revelation, "religion moves from man to God." Biblical Religion and the Search for Ultimate Reality (Chicago, IL: University of Chicago Press, 1955), p. 2.

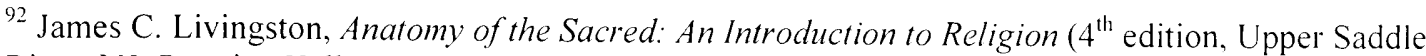
River, NJ: Prentice-Hall, 200I), p. 11; Lawrence S. Cunningham and John Kelsay, The Sacred Quest: An Invitation to the Study of Religion ( $3^{\text {rd }}$ edition, Upper Saddle River, NJ: Prentice-Hall, 2002), pp. 13-17.

${ }^{93}$ Huston Smith, The World's Religions: Our Great Wisdom Traditions (revised edition, New York: HarperCollins Publishers, 1991), pp. 386-389.

${ }^{94}$ Carter, "Interview with Robert Scheer," Playboy, November, p. 66.
} 
expected to elect religious presidents who govern with a religious style, who often speak in religious terms, who prioritize issues based on religious principles. ${ }^{95}$ Jimmy Carter was such a president.

\section{Organization of the Project}

The research here is based on a thorough examination of President Carter's many writings, his public papers, interviews, and opinion pieces. Since Carter has had a long post-presidency and has been a prolific writer, more than most presidents who write perhaps little more than their presidential memoirs, one is likely to get a better and deeper understanding of the man and his views than many other presidents. ${ }^{96}$ In addition, this research has used written accounts from former Carter administration officials, from other international officials, from participants at Camp David, and from other scholarly works. This project is largely descriptive, qualitative in approach, but quantitative data are used when appropriate and as supplements to the text.

Chapter 1 examines the key themes in the scholarly literature on the Carter presidency. Though polling data shows that he was consistently considered by the American people to be more religious and moral than his contemporaries, the general tendency among presidential scholars has been to either overlook entirely or treat only marginally the importance of Carter's evangelical faith to his politics and presidential style. There is an ostensible "religion gap." In many, if not most, Carter studies, his

\footnotetext{
${ }^{95}$ Davis, "Thoughts on the Separation of Church and State under the Administration of President George
W. Bush," p. 234.

${ }^{96}$ Doug Gross, "Carter, Mondale Surpass Adams, Jefferson," Associated Press, May 23, 2006.
} 
successes and failures are presented and examined from an exclusively secular standpoint.

In chapters 2 and 3, I lay out what precisely constitutes an evangelical political/ presidential style. Here it is argued that the model of leadership Carter pursued was not new, but rather an approximate replay of the style offered by William Jennings Bryan and Woodrow Wilson, two early twentieth-century, religiously-motivated Democratic leaders. Rejecting conventional leadership norms and practices, Bryan, Wilson, and Carter shared a distaste for politics as usual and were contemptuous of the give-andtake of political necessities and niceties. Political compromise and bargaining were commonly an anathema to them. Instead, all three proudly mixed their religion and their politics.

Following Fred Greenstein's categories of presidential leadership, the faith of Bryan, Wilson, and Carter gave their politics meaning, skill, vision, and a framework for communication. It gave them emotional intelligence, too. But this style provoked many of their contemporaries. To their critics at home and abroad, these men were often seen as and accused of being arrogant, stubborn, naïve, and ultimately political failures. Bryan lost three general elections. Wanting a return to political normalcy, the public handed Wilson's party a landslide defeat in 1920. In 1980, Carter suffered a devastating loss to Reagan.

In chapter 4, several features of the evangelical style outlined in chapters 2 and 3 are applied to Carter. This chapter describes his evangelical faith and his views on the integration of religion and politics. It documents how he viewed the 1976 election and his general view of politics. The chapter also looks at two domestic cases where 
Carter's alternative style was demonstrably put to work: his energy policy, which he called "the moral equivalent of war," and what may be termed his "religious contempt" for Congress. Here the reader finds the main features of Carter's understanding of politics, his presidential style, and his role as president.

Chapter 5 turns to foreign affairs. Though frequently criticized for lacking vision and lacking priorities, Carter had a foreign policy vision, including his vision for the country's role in the world, guidelines to be followed, a view on the use of force, and a focus on the promotion of human rights and finding peace in the Middle East. This vision, it is argued, was largely inspired by Biblical principles, specifically the New Testament teachings of Jesus found in the his famous "Sermon on the Mount."

In chapter 6, Carter's efforts to find peace in the Middle East are discussed and explored. While not denying the security and strategic factors involved, it is argued here that he viewed his role as partner and mediator in the Camp David peace process as a faith-inspired project. His faith provided him with a vision, a sense of mission, and the emotional intelligence to succeed. This chapter also notes some limitations of Carter's style. Still, Camp David may be even the most illustrative case in the history of the American presidency where a president's use of and reliance on faith led to the achievement of a major foreign policy objective.

In chapter 7, using presidential memoirs, Carter's views of the Middle East, specifically toward Israel, are compared with three of his immediate predecessors (Johnson, Nixon, and Ford) and three of his immediate successors (Reagan, Bush, and Clinton). The purpose here is to explore to what extent Carter is different from his fellow presidents. Though every president since 1948 has claimed to be pro-lsrael, 
their reasons for supporting the Jewish state and finding peace in the region may stem from a variety of factors. It is shown here that Carter, unlike most others, views Israel, the Israeli-Arab conflict, and the Middle East region through a religious, evangelical lens. This is a trait generally absent in the writings of Carter's presidential contemporaries.

In this project, the reader will find that Carter's evangelical leadership style has many pitfalls. In the worm's eye view of history, evangelical-styled presidents like Carter are likely to be considered average-to-below-average presidents. Their penchant for certainty and confidence alienates and offends many who perceive them as amateurish, arrogant, and naïve about politics and the ways of the world. They are seen as dreamers and silly-hearts. They force perhaps unnecessary situations that drive a serious wedge between members of their own party or between the parties. They are more likely to be dividers than uniters. ${ }^{97}$ However, what cannot be denied is that evangelical presidents, like Carter, are consequential and may even score extraordinary achievements that otherwise would elude more secular-minded and styled presidents. Evangelical presidents are not merely active presidents. They are ambitious, risk-takers who often gamble on big projects as Carter was in his pursuit of Mideast peace.

Prudence is hardly a word that comes to mind in describing this subset of presidents. Though they risk big defeats, perhaps great blunders, the payoff for such gambles may

\footnotetext{
${ }^{97}$ Gary C. Jacobson, A Divider, Not a Uniter: George W. Bush and the American People (New York: Longman, 2006); Jacobson, "The Polls: Polarized Opinion in the States: Partisan Differences in Approval Ratings of Governors, Senators, and George W. Bush," Presidential Studies Quarterly 36.4 (December 2006): 732-757.
} 
be ones for the ages. ${ }^{98}$ In the bird's eye view of history, their standing and esteem, like Wilson's, may rise.

These presidents may change the political discourse, and their successors may adopt parts of their style. For more than a quarter century, Jimmy Carter made it safe for future candidates to run as evangelicals and to discuss their faith publicly and explain how it might be politically relevant. He made it safe for candidates and presidents to assert that prayer sustains them and that they consult a higher power. Perhaps even, as in the case of Clinton, successors to an evangelical president may try to emulate the evangelical style and strategy for Middle East peace.

${ }^{98}$ Carter described President George W. Bush's Iraq War policy as "one of the greatest blunders that American presidents have ever made." "Interview with Wolf Blitzer," CNN's The Situation Room, November 28, 2006. 


\section{The Religion Gap in the Presidential Literature of Jimmy Carter}

"The most important thing in my life is Jesus Christ.".

In presidential studies, presidential behavior is typically defined or explained in terms of political attitude, psychology, bargaining skills, managerial style, or behavior constrained in and by political time. But what about a president's personal religious faith? As a society that is comparatively more religious than most advanced democracies and has a rich tradition of mixing religion with politics, we should expect, from time to time, religiously motivated presidents. ${ }^{2}$ This may be especially true if that president hails from the South, the most religious region in a religious country, and who establishes an electoral base there. ${ }^{3}$ We, therefore, should expect that presidents will

\footnotetext{
${ }^{1}$ David Kucharsky, The Man from Plains: The Mind and Spirit of Jimmy Carter (New York: Harper and Row Publishers, 1976), p. 67; Jimmy Carter, "Interview with Kim Watson of the Baptist Home Mission," April 1974, in Jessyca Russell Gaver, The Faith of Jimmy Carter (New York: Manor Books, 1977), p. 39; "Interview with World Religious News," 1976, in The Faith of Jimmy Carter, p. 14; "Interview with Jim Newton, editor of the World Mission Journal," 1976, in The Faith of Jimmy Carter, p. 27.

2 Seymour Martin Lipest, "Religion and American Values," in The First New Nation: The United States in Historical and Comparative Perspective (Garden City, NY: Anchor Books, 1967), pp. 159-192; Seymour Martin Lipset, American Exceptionalism: A Double-Edged Sword (New York: W.W. Norton and Company, 1996), pp. 60-67; Michael Corbett and Julia Mitchell Corbett, Politics and Religion in the United States (New York: Garland Publishing, 1999); James A. Morone, Hellfire Nation: The Politics of Sin in American History (New Haven, CT: Yale University Press, 2003); R. Laurence Moore, Touchdown Jesus: The Mixing of Sacred and Secular in American History (Louisville, KY: Westminster John Knox Press, 2003); Robert D. Putnam, "Religious Participation," chap. in Bowling Alone: The Collapse and Revival of American Community (New York: Simon and Schuster, 2000), pp. 65-79; Pippa Norris and Ronald Inglehart, Sacred and Secular: Religion and Politics Worldwide (New York: Cambridge University Press, 2004).

${ }^{3}$ D. Jason Berggren and Nicol C. Rae, "The American South: The 'Bible Belt' of America (and the Western World?)," paper presented at the 2006 Annual Meeting of the Southern Political Science Association in Atlanta, Georgia.
} 
not always conceive of politics or justify their actions in exclusively secular terms; some may even struggle with separating their religious views and their politics. In other words, they may have difficulty with playing by the typical rules of the political game, such as bargaining.

Some presidents may believe their faith has political consequences and will have their actions and policies guided and informed by their personal religious principles. A president's religious faith might be an important source of authority and may, at least occasionally, influence their behavior and decision-making, particularly in issue areas they designate as moral/religious. Connecticut Senator Joseph Lieberman, the 2000 Democratic vice-presidential nominee, once explained that some politicians, including himself, have minds that are "faith-based." Similarly, Jimmy Carter was a president with a "faith-based" view of politics, the office of president, and his role in the world.

As this chapter shows, presidential scholars, however, have rarely or only marginally examined the religious dimension of the Carter presidency. Those that have may have focused exclusively on one dimension of his peculiar leadership style. For instance, in her 2006 study, Colleen Shogan briefly examined Carter's moral rhetoric as part of a wider study of the moral rhetoric of presidents in their annual and inaugural addresses. But in most cases, Carter's faith is taken as a given and perhaps not worthy of much comment or examination. It is assumed it matters somewhere in the background or it is implicitly judged inconsequential. When examining his successes and failures, the Carter presidency is merely presented in secular terms and categories,

\footnotetext{
${ }^{4}$ Joseph I. Lieberman, "Interview with Tim Russert," NBC's Meet the Press, March 27, 2005.
} 
in ways he did not understand, or, more accurately, simply refused to adopt. It is the view taken here and in the following chapters that the man and his politics and the lessons of his presidency are more completely understood when his religious faith is explored and examined. It is a crucial part of who he is, who he lives. and a key motivation for his political activities. Other presidents who exhibit similar religious tendencies and leadership styles. such as Woodrow Wilson and George W. Bush. may be examined from this angle and may be thought of as part of the same family of American presidents. a subclass of politicians who share a strong religious faith, believe it is politically relevant. and consciously allow it to guide their behaviors and influence decisions. For these presidents, accounts that either ignore their faith or include mere passing references to it are missing an important dimension to their presidencies. It is important in analyzing the presidency to capture the essence of the person who was president.

\section{Ratings of President Carter}

"Was it the times? Was it the man? I don't know. Probably all of them."

Though his stock rose for some scholars in the $1990 \mathrm{~s},{ }^{6}$ the consensus about the Carter presidency among presidential scholars is that Jimmy Carter, while a good and decent man, was largely incompetent and a political neophyte. and that his presidency

\footnotetext{
"Haynes Johnson, "Discussion Among Panelists." in Jimm. Carter: Foreign Policl. and PostPresidential Years. ed. Herbert D. Rosenbaum and Alexej Ugrinsky (Westport, CT: Greenwood Press. 1994). p. 397.

${ }^{6}$ Otis White. "Time heals old wounds: Carter makes comeback," St. Petersburg Times. December 25. 1991. 1A. 22A.
} 
was at best "average." Many have gone further and characterized it as "below

average." Morris Fiorina has suggested that there is an "emotional antagonism" among scholars toward Carter. ${ }^{8}$ Erwin Hargrove concurs. Carter "became the scapegoat for all the unresolved national and international problems. Everybody-politicians, the public, interest groups and media-piled on him." It has also been noted that many of Carter's post-presidential activities have received at best only lukewarm support from the Washington establishment. ${ }^{10}$

In presidential polls, Carter has not fared well. In the first major poll of scholars and journalists after he left the White House (I982 Chicago Tribune poll), Carter was ranked next to last of all presidents and last of all Democrats since World War II. Only Richard Nixon fared worse. ${ }^{11}$ In a I985 analysis, Michael Krukones found that Carter often failed to accomplish his basic objectives. He had a greater percentage of unfulfilled promises than any other modern Democratic president and "his success rate

\footnotetext{
${ }^{7}$ Jack E. Holmes and Robert E. Elder, Jr., "Our Best and Worst Presidents: Some Possible Reasons for Perceived Performance," Presidential Studies Quarterly 19, no. 3 (1989): 529-557; Gary W. Reichard, "Early Returns: Assessing Jimmy Carter," Presidential Studies Quarterly 20, no. 3 (1990): 603-620; J.M. Sanchez, "Awaiting Rehabilitation: The Carter Presidency in Political Science Textbooks," Presidential Studies Quarterly 27, no. 2 (1997): 284-296. In contrast, First Lady Rosalynn Carter is often ranked among the best first ladies. For instance, according to the 2003 Siena Research lnstitute, Mrs. Carter was ranked sixth. See John B. Roberts II, Rating the First Ladies: The Women Who Influenced the Presidency (New York: Citadel Press Books, 2003).

${ }^{8}$ Morris P. Fiorina, Congress: Keystone of the Washington Establishment (New Haven, CT: Yale University Press, 1989), p. 162n.

${ }^{9}$ Erwin C. Hargrove, Jimmy Carter as President: Leadership and the Politics of the Public Good (Baton Rouge, LA: Louisiana State University Press, 1988), p. 188. See also Mark J. Rozell, The Press and the Carter Presidency (Boulder, CO: Westview Press, 1989).

${ }^{10}$ Charles William Maynes, "Diplomacy wins Carter no respect," St. Petersburg Times, January 1, 1995.

${ }^{11}$ Cited in Patrick J. Kenney and Tom W. Rice, "The Contextual Determinants of Presidential Greatness," Presidential Studies Quarterly 18, no. 1 (1988): 161-169.
} 
on major campaign pledges... was only $28.6 \%$ which places him at the bottom of the list on major campaign promises fulfilled by Presidents since Wilson." 12

A decade later, according to the I996 Schlesinger Poll, a survey of thirty-two presidential scholars, a plurality of fifteen scholars gave Carter a "below average" rating, twelve ranked him as an "average" president, two a "failure," and only one as "near great."13 Table 1.1 shows the overall assessment scores for modern presidents.

\section{Table 1.1 1996 Scholarly Assessments of Modern Presidents}

$\begin{array}{lll}\text { President } & \text { Rating } & \text { Score } \\ \text { Franklin Roosevelt (D) } & \text { Great } & 3.97 \\ \text { Harry Truman (D) } & \text { Near Great } & 3.10 \\ \text { Dwight Eisenhower (R) } & \text { High Average } & 2.34 \\ \text { John Kennedy (D) } & \text { High Average } & 2.29 \\ \text { Lyndon Johnson (D) } & \text { High Average } & 2.21 \\ \text { Bill Clinton (D) } & \text { Average } & 1.58 \\ \text { George Bush (R) } & \text { Average } & 1.45 \\ \text { Ronald Reagan (R) } & \text { Average } & 1.42 \\ \text { Jimmy Carter (D) } & \text { Average } & \mathbf{1 . 3 7} \\ \text { Gerald Ford (R) } & \text { Average } & 1.00 \\ \text { Richard Nixon (R) } & \text { Failure } & -21\end{array}$

* Scores based on values assigned to each category: Great $=4$, Near Great $=3$, Average $=2$, Below Average $=1$; Failure $=-2$. Total scores then divided by the number of scholarly assessments for each president.

Source: 1996 Schlesinger Poll.

\footnotetext{
${ }^{12}$ Michael G. Krukones, "The Campaign Promises of Jimmy Carter: Accomplishments and Failures," Presidential Studies Quarterly 15, no. 1 (1985): 136-144.

${ }^{13}$ Arthur M. Schlesinger, Jr., "Rating the Presidents: Washington to Clinton," in The Presidenc1: Classic and Contemporary Readings, Jeffrey Cohen and David Nice, eds. (New York: McGraw-Hill, 2003), pp. 89-100.
} 
Of the eleven modern presidents, not surprisingly, Franklin Roosevelt was considered the greatest. Harry Truman was considered "near great," and three presidents (Eisenhower, Kennedy, and Johnson) were considered higher than average. Along with presidents Clinton, Bush, Reagan, and Ford, Carter was just average. Though charged by conservatives for having a liberal bias, Carter ranked below three of the aforementioned "average" presidents in this poll. ${ }^{14}$ Overall, he was only ranked higher than Republican presidents Gerald Ford and Richard Nixon and he ranked last among all modern Democratic presidents.

To correct the perceived liberal bias in the Schlesinger poll, a 2000 poll of seventy-eight, "ideologically balanced" historians, political scientists, and law professors reevaluated the standing of presidents. In this poll, Carter was given an overall rating of "below average," and among all presidents, Carter was rated as the tenth worst modern president overall and the worst modern Democratic president. ${ }^{15}$ Only President Richard Nixon ranked lower. Table 1.2 shows these results.

Five years later, this poll was conducted again, and Carter fell to the bottom among modern presidents, surpassed this time by even Nixon (Table 1.3). ${ }^{16}$

\footnotetext{
${ }^{14}$ Alvin S. Felzenberg, “'There You Go Again': Liberal Historians and the New York Times Deny Ronald Reagan His Due," Policy Review (March-April 1997).

15 James Lindgren, "Appendix I: Methodology of Rankings," in Presidential Leadership: Rating the Best and the Worst in the White House, eds. James Taranto and Leonard Leo (New York: Wall Street Jourmal Book/Free Press, 2004), pp. 249-269.

${ }^{16}$ James Taranto, "How's He Doing? Bush is 'average,' but far from ordinary," Wall Street Journal, September 12, 2005.
} 
Table 1.2 2000 Scholarly Assessments of Modern Presidents

President

Franklin Roosevelt (D)

Harry Truman (D)

Ronald Reagan (R)

Dwight Eisenhower (R)

Lyndon Johnson (D)

John Kennedy (D)

George Bush (R)

Bill Clinton (D)

Gerald Ford (R)

Jimmy Carter (D)

Richard Nixon (R) $\underline{\text { Rating }}$

Great

Near Great

Near Great

Near Great

Above Average

Above Average

Average

Average

Below Average

Below Average

Below Average $\underline{\text { Score }}$

4.67

3.95

3.81

3.71

3.21

3.17

2.92

2.77

2.59

2.47

2.22

* Scores based on a standard 5-point scale, with highly superior (great) $=5$ to well below average (failure) $=1$. Total scores then divided by the number of scholarly assessments for each president.

Source: 2000 Federalist Society/Wall Street Journal Survey

\section{Table 1.3 2005 Scholarly Assessments of Modern Presidents}

$\begin{array}{lll}\text { President } & \text { Rating } & \underline{\text { Score }} \\ \text { Franklin Roosevelt (D) } & \text { Great } & 4.41 \\ \text { Ronald Reagan (R) } & \text { Near Great } & 4.03 \\ \text { Harry Truman (D) } & \text { Near Great } & 3.95 \\ \text { Dwight Eisenhower (R) } & \text { Near Great } & 3.67 \\ \text { John Kennedy (D) } & \text { Above Average } & 3.25 \\ \text { Lyndon Johnson (D) } & \text { Average } & 3.05 \\ \text { George W. Bush (R) } & \text { Average } & 3.01 \\ \text { George H.W. Bush (R) } & \text { Average } & 2.95 \\ \text { Bill Clinton (D) } & \text { Average } & 2.93 \\ \text { Gerald Ford (R) } & \text { Below Average } & 2.61 \\ \text { Richard Nixon (R) } & \text { Below Average } & 2.40 \\ \text { Jimmy Carter (D) } & \text { Below Average } & \mathbf{2 . 2 4}\end{array}$

\footnotetext{
* Scores based on a standard 5-point scale, with highly superior (great) $=5$ to well below average (failure $)=1$. Total scores then divided by the number of scholarly assessments for each president.

Source: 2005 Federalist Society/Wall Street Journal Survey
} 
Interestingly, however, the American people do not share the negative consensus among presidential scholars about the Carter years, and Carter's negatives have been declining over the years. Certainly, the American people do not consider him among the greatest presidents. Among modern presidents, those since Franklin Roosevelt, only $2 \%$ in 2007 said he was the greatest. ${ }^{17}$ Still, Carter's percentage was the same given to Dwight Eisenhower and George W. Bush and one-percent more than Gerald Ford and George H.W. Bush.

According to a 2006 Gallup poll, for instance, thirty-eight percent of Americans rated the Carter presidency as "average," ten percent lower than in 2004. ${ }^{18}$ An equal percentage (38\%) judged him as an "outstanding/above average" president, an elevenpoint increase in two years. Only twenty-two percent judged him as "below average/poor." Employing the same calculation method as used in the Schlesinger poll, Table 1.4 shows that Carter's overall rating is higher than six other modern presidents, and among Democratic presidents, he is even rated higher than Presidents Clinton and Johnson.

Americans also admire Jimmy Carter. Since 1948, Carter ranks fourth all-time in the number of appearances in Gallup's annual "Top 10 Most Admired Man" list. Carter has appeared in the list 25 times; only the evangelist Billy Graham (50),

\footnotetext{
${ }^{17}$ Lydia Saad, "Lincoln Resumes Position as Americans' Top-Rated President," Gallup Poll News Service, February 19, 2007.

${ }^{18}$ Lydia Saad, "Majority Predicts History Will Judge Bush Harshly," Gallup Poll News Service, December 13, 2006; Jeffrey M. Jones, "Roosevelt, Kennedy Most Positively Rated Recent Presidents," Gallup Poll News Service, June 11, 2004.
} 
President Reagan (31), and Pope John Paul II (27) have had more appearances (Table

1.5). ${ }^{19}$ Of those who have appeared in the top list at least ten times and still living,

Carter ranks only behind Graham.

Table 1.4 Public Assessments of Modern Presidents, 2004-2006

$\begin{array}{lll}\text { President } & \text { Rating } & \underline{\text { Score }} \\ \text { John Kennedy (D) } & \text { Above Average } & 3.00^{*} \\ \text { Franklin Roosevelt (D) } & \text { Above Average } & 3.00^{*} \\ \text { Ronald Reagan (R) } & \text { Above Average } & 2.59 \\ \text { Gerald Ford (R) } & \text { Average } & 1.97 \\ \text { Jimmy Carter (D) } & \text { Average } & 1.94 \\ \text { George H.W. Bush (R) } & \text { Average } & 1.94 \\ \text { Bill Clinton (D) } & \text { Average } & 1.89 \\ \text { Lyndon Johnson (D) } & \text { Average } & 1.76^{*} \\ \text { George W. Bush (R) } & \text { Below Average } & 1.18 \\ \text { Richard Nixon (R) } & \text { Below Average } & 1.05^{*}\end{array}$

* Scores based on values assigned to each category: Great $/$ Outstanding $=4$, Near Great $/$ Above Average $=$ 3 , Average $=2$, Below Average $=1 ;$ Poor $/$ Failure $=-2$. Total scores then divided by the combined percentages of respondents that held an opinion for each president.

* Neither Harry Truman nor Dwight Eisenhower were included in these two polls.

Source: *Based 2004 Gallup Poll only; others based on 2004 and 2006 polls combined.

According to a 2007 Gallup poll, in spite of the controversy sparked by his 2006 book, Palestine: Peace Not Apartheid, Carter received higher favorable ratings than either George H.W. Bush or Bill Clinton, the two other living presidents. ${ }^{20}$ Table 1.6 shows that $69 \%$ of Americans surveyed had a favorable view of Carter compared with

\footnotetext{
${ }^{19}$ Joseph Carroll, "George W. Bush Is Most Admired Man in 2004," Gallup Poll News Service, December 29, 2004; Jeffrey M. Jones, "Bush, Hillary Most Admired, Again," Gallup Poll News Service, December 28, 2005; Jeffrey M. Jones, "George W. Bush, Hillary Clinton Most Admired Again," Gallup Poll News Service, December 29, 2006.

${ }^{20}$ Joseph Carroll, "Little Impact of Jimmy Carter's Book on the Middle East," Gallup Poll News Service, February 14, 2007.
} 
$63 \%$ for Clinton and $62 \%$ for Bush. What is of particular interest is that Carter was also the only one of the three that had favorable majorities among self-identified Republicans, Democrats, and Independents, and among self-identified conservative, moderates, and liberals; his reputation, to a greater extent, transcended partisan and ideological bounds. In contrast, Bush and Clinton were overwhelming given favorable ratings from their respective co-partisans and majority approval from Independents and moderates.

Table 1.5 Appearances in Gallup's “Top 10 Most Admired Man” List, 1948-2006

$\begin{array}{ll}\text { Billy Graham } & 50 \\ \text { Ronald Reagan } & 31 \\ \text { Pope John Paul II } & 27 \\ \text { Jimmy Carter } & \mathbf{2 5} \\ \text { Dwight Eisenhower } & 21 \\ \text { Richard Nixon } & 21 \\ \text { Harry Truman } & 20 \\ \text { Edward Kennedy } & 18 \\ \text { Winston Churchill } & 17 \\ \text { George H.W. Bush } & 17 \\ \text { Douglas MacArthur } & 15 \\ \text { Bill Clinton } & 15 \\ \text { Nelson Mandela } & 15 \\ \text { Colin Powell } & 15 \\ \text { Henry Kissinger } & 12 \\ \text { Pope Paul VI } & 12 \\ \text { Adlai Stevenson } & 11 \\ \text { Albert Schweitzer } & 11 \\ \text { Jesse Jackson } & 11 \\ \text { Herbert Hoover } & 10 \\ \text { Pope Pius XII } & 10\end{array}$

*Survey responses were unprompted.

Italic indicates still living.

Source: Gallup Organization 
Table 1.6 Public Favorability Assessments of Living Former Presidents, 2007

$\begin{array}{lccc}\text { All } & \% \text { Favorable } & & \\ \text { Jimmy Carter (D) } & 69 \% & & \\ \text { Bill Clinton (D) } & 63 \% & & \\ \text { George H.W. Bush (R) } & 62 \% & & \text { Dem } \\ \text { Party } & \text { Rep } & \text { Ind } & 81 \% \\ \text { Jimmy Carter (D) } & 56 \% & 68 \% & 42 \% \\ \text { George H.W. Bush (R) } & 90 \% & 61 \% & 89 \% \\ \text { Bill Clinton (D) } & 30 \% & 64 \% & \text { Lib } \\ \text { Ideology } & \text { Con } & \text { Mod } & 80 \% \\ \text { Jimmy Carter (D) } & 59 \% & 72 \% & 42 \% \\ \text { George H.W. Bush (R) } & 75 \% & 62 \% & 86 \% \\ \text { Bill Clinton (D) } & 42 \% & 70 \% & \end{array}$

Source: Gallup Organization, February 9-11, 2007.

In all probability, Carter's post-presidential work has improved his standing with the American people over the years. ${ }^{21}$ Images of the former president in overalls swinging a hammer or monitoring elections in nascent democracies rather than playing golf or fishing have likely changed perceptions of the man from Plains who used to be president. One cannot help but admire a man who does good deeds, who is a prolific writer, and who keeps himself busy with many interests. Like Thomas Jefferson and Abraham Lincoln, it has been argued that Carter is a "philosophe" president, "an extraordinary renaissance man. ${ }^{, 22} \mathrm{He}$ is intensely curious about the world; he is a man

\footnotetext{
${ }^{21}$ Douglas A. Lonnstrom and Thomas O. Kelly II, "Rating the Presidents: A Tracking Study," Presidential Studies Quarterly 33.3 (September 2003): 631-632.

${ }^{22}$ Steven J. Rubenzer and Thomas R. Faschingbauer, Personality, Character, and Leadership in the White House: Psychologists Assess the Presidents (Washington, DC: Brassey's Inc., 2004), pp. 206-234; Larry King, "Interview with Jimmy Carter," CNN's Larry King Live, December 9, 2004.
} 
of ideas, a writer of more than twenty books, including poetry, a war novel, and a children's book. As he notes,

In the past, I have written about history, political science, religion, the technique of negotiation, outdoor experiences, a novel about the Revolutionary War, a book of poetry, and a presidential memoir-all fairly serious subjects. ${ }^{23}$

He also paints and makes wood furniture.

\section{Carter's Assessment of the Carter Presidency}

All presidents want history to judge their presidencies a success. Carter is no exception. Carter says it does not bother him that in the public's mind he is the best expresident ever or that he used his presidential experience to improve his postpresidential reputation. ${ }^{24}$ President Carter is proud of his presidency, and in hindsight, he believes that events have borne out he was on the right track. In comparison with his immediate predecessors and successors, Carter seems to take the view that history will be eventually revisit and reassess his presidency:

We kept the peace, we kept our country safe, we promoted human rights around the world, we normalized relations with China, we had nuclear agreements with the Soviet Union, we brought peace to Israel and Egypt. I feel comfortable about my Administration. ${ }^{25}$

When you look back on, you know, normal relations with China and doubling the size of our national park system and the Panama Canal treaties and the Middle East peace process and so forth, there's a great sense of gratification. ${ }^{26}$

\footnotetext{
${ }^{23}$ Carter, Sharing Good Times (New York: Simon and Schuster, 2004), p. xi.

${ }^{24}$ Randall Balmer, Encyclopedia of Evangelicalism (Louisville, KY: Westminster John Knox Press, 2002), p. 115.

${ }^{25}$ Carter, "Interview with Massimo Calabresi," Time, December 8, 2003, p. 8.

${ }^{26}$ Carter, "Interview with Larry King," CNN's Larry King Live, November 15, 2002.
} 
His wife Rosalynn is especially sensitive to charges that her husband's

presidency was a failed or below-average presidency. "I think he was a really good president." ${ }^{27}$ For the former first lady, her husband was a leader, one who was willing to take on tough problems and persist in spite of opposition.

The things he did were controversial, like an energy program that nobody wanted, he had to take people screaming and kicking together. I think a leader can lead people easily where they want to go, but I think it takes a real leader to lead them where they don't want to go, which is what he did.

Expectedly, former Carter officials also defend the Carter record. In his exit interview from the White House, press secretary Jody Powell said,

History is going to be very kind to this President, to this administration... there will be a much finer appreciation for just the specific accomplishments, the things that he did that were important changes for the better... the value of those things will become more apparent. ${ }^{28}$

Domestic policy advisor Stuart Eizenstat agreed that Carter's term "was full of accomplishments," though "largely unreported or unrecognized by the public," in areas of education, energy policy, child welfare, deregulation, and government reorganization. ${ }^{29}$ In foreign policy, national security advisor Zbigniew Brzezinski said, "One of the things that history is going to give Carter for is that his policies had, in fact, a lot of substance." 30

\footnotetext{
${ }^{27}$ Rosalynn Carter, "Interview with Larry King."

${ }^{28}$ Jody Powell, "Exit interview with David Alsobrook, Presidential Papers Staff," December 2, 1980, Jimmy Carter Library and Museum, Oral History Transcripts, http:/www.jimmycarterlibrary.gov/library/oral.phtml.

${ }^{29}$ Stuart Eizenstat, "Exit interview with Emily Soapes, Presidential Papers Staff," January 10, 1981, Jimmy Carter Library and Museum, Oral History Transcripts.

${ }^{30}$ Zbigniew Brzezinski, "Exit interview with Marie Allen, Presidential Papers Staff," February 20, 1981. Jimmy Carter Library and Museum, Oral History Transcripts.
} 
Powell has further said that even if Carter had never become president, "He'd still be doing things. His reach would be shorter and his resources less, but he'd be trying to make a piece of the world better and to lighten the load of others." ${ }^{\text {'1 }}$ Former Carter speechwriter Hendrik Hertzberg explained that Carter's post-presidential effort “doesn't retrospectively make [him] a better president," but it does reveal that Carter's humanitarian reputation in office was justified, his character "turned out to be very, very real." ${ }^{32}$ The character qualities Carter insiders, such as White House counsel Lloyd Cutler, found most compelling were "his sincerity, his decency, his compassion., 33

\section{Scholarly and Political Assessments of President Carter}

In contrast to the public's increasingly positive evaluations of President Carter and those of Carter and administration officials, scholarly assessments and textbook descriptions are almost uniformly negative towards the thirty-ninth president. ${ }^{34}$ Some even charge that Carter's post-presidential activities stem not from genuinely altruistic motives, but from a nefarious desire "to resurrect his reputation" and find "vindication

\footnotetext{
${ }^{31}$ Michael J. Brooks, "Carter Collectors Hear Former Press Secretary Jody Powell," The Political Bandwagon (December 2003): 4.

${ }^{32}$ Hertzberg quoted in transcript of American Experience: Jimmy Carter, 2000. Transcript available online at http://www.pbs.org/wgbh/amex/carter; Hendrik Hertzberg, "Jimmy Carter, 1977-1981," in Character Above All: Ten Presidents from FDR to George Bush, ed. Robert A. Wilson (New York: Simon and Schuster, 1995), pp. 175-176.

${ }^{33}$ Lloyd Cutler, "Exit Interview with Marie Allen, Presidential Papers Staff," March 2, 1981, Jimmy Carter Library and Museum, Oral History Transcripts.

${ }^{34}$ Journalist Bernard Goldberg, for instance, ranked Jimmy Carter sixth in his "top 100" list of Americans who are "screwing up" the country. See 100 People Who Are Screwing Up America (New York:

HarperCollins, 2005), pp. 282-285.
} 
for himself and his principles." 35 But why is there an "emotional antagonism" among scholars toward Carter, as Morris Fiorina once suggested? Why have Carter observers said that as president he was seemingly impotent, irrelevant, invisible, hopelessly ineffective, and making the presidency more an imperiled than imperial institution? Late in Carter's term, Richard Neustadt wondered if the presidency was still possible. ${ }^{36}$ Austin Ranney added that, "Perhaps the most remarkable thing about the Carter administration is that it existed at all., ${ }^{, 37}$

Since Carter left the White House in 1981, two general explanations have been offered: blaming the man and blaming the hour. For those who blame the man, it is said Carter was too much of an outsider, too ordinary, too amateurish, too inexperienced in the ways of Washington to be an effective president. It has also been said that Carter neither effectively managed the inner workings of the White House nor cultivated effective ties with Congress. It has been suggested, too, that because Carter was too technical, too wonkish, too immersed in the details of governing, he failed to prioritize policies and to communicate administration goals. ${ }^{38}$ In short, he failed to govern. But the common theme that runs through the Carter presidency literature is that President

\footnotetext{
${ }^{35}$ Joshua Muravchik, "James Earl Carter, Jr.," in Presidential Leadership, p. 192; Steven F. Hayward, The Real Jimmy Carter: How Our Worst Ex-President Undermines American Foreign Policy, Coddles Dictators, and Created the Party of Clinton and Kerry (Washington, DC: Regnery Publishing Inc., 2004), p. 228.

${ }^{36}$ Richard E. Neustadt, Presidential Power and the Modern Presidents: The Politics of Leadership from Roosevelt to Reagan (New York: The Free Press, 1990), p. 230.

${ }^{37}$ Quoted in Larry Berman, "Presidents as Leaders: Carter and Reagan," chap. in The New American Presidency (Boston, MA: Little, Brown and Company, 1987), p. 309.

${ }^{38}$ These were among the earliest criticisms of Carter and much of the literature on Carter is a rehash of criticisms made during Carter's first year in office. On the charge of doing to much, see "Remarks and Question-and-Answer Session with a Group of Editors and News Directors," October 14, 1977, Public Papers of the Presidents, Jimmy Carter, 1977, Book II (Washington, DC: United States Government Printing Office, 1981), pp. 1808-1809.
} 
Carter simply did not know what he was doing; he was in over his head and he had no sense of direction. Carter "was simply the wrong person for the job." 39

Others have argued that Carter was a prisoner of political time; he became president at an inopportune time to be successful. ${ }^{40}$ No Democrat, the argument goes, could have been expected to govern well at a time of declining parties, declining trust in democratic governance, seismic changes in Congress and the international system, paradoxical popular expectations of the presidency, and declining popular support for New Deal liberalism. Carter did as well as possible in a rapidly changing political and electoral environment. In short, "Carter was a victim of political circumstance."

\section{Blaming the Man}

Journalist Elizabeth Drew said Jimmy Carter's problem was that he tried to govern as he ran-as an outsider. "His top people had no experience in Washington. And they were sort of contemptuous of Washington. Well it's one thing to sort of run against Washington, but you have to live there and you have to govern there, and you have to work hard with the people who are there." ${ }^{42}$ Leslie Gahl wrote, "Carter was naïve in thinking that he could campaign against the very government that he was expected to head." 43

\footnotetext{
${ }^{39}$ William F. Mullen, "Perceptions of Carter's Legislative Successes and Failures: Views from the Hill and the Liaison Staff," Presidential Studies Quarterly 12.4 (December 1982): 530.

${ }^{40}$ Stephen Skowronek, The Politics Presidents Make: Leadership from John Adams to Bill Clinton (Cambridge, MA: Harvard University Press, 1997).

${ }^{41}$ Gary L. Rose, "The Lesson of the Carter Presidency," chap. in The American Presidency Under Siege (Albany, NY: State University of New York Press, 1997), p. 72.

${ }^{42}$ Elizabeth Drew quoted in transcript of American Experience: Jimmy Carter, 2000, http://www.pbs.org/wgbh/amex/carter/filmmore/pt.html.
} 
Press secretary Powell largely concurred. He believed that too many

Washington insiders said something like, "Here come these folks riding in here that didn't really pay their dues. They're not us. They're not our kind of folks." ${ }^{+4}$ Charles O. Jones agreed as well with the view that Carter's outsider status contributed to his failures, namely in his relations with Congress. ${ }^{45}$ So did Ulrich Haynes, Jr., U.S. Ambassador to Algeria (1977-1981), who wrote, that "with his previous political experience limited to the governorship of Georgia, Carter came to Washington without an instant network of personal foreign and domestic policy experts to advise him on the running of the country and the handling of international relations. ${ }^{, 46}$

Similarly, according to Neustadt, one of Jimmy Carter's fundamental problems was "Jimmy-who-ness." 47 He was too alienated from "the Washingtonians," a man without party, commitments, a record. ${ }^{48}$ Citizen Carter, the outsider, was too much a novice to be an effective president. By electing Carter, the American people had put an amateur in the White House. ${ }^{49}$ He tried to be above politics, and he was compulsively mired in detail and micro-management. ${ }^{50}$ Further, because of his outsider status, said

\footnotetext{
${ }^{43}$ Leslie L. Gahl, "Moral Courage: The Essence of Leadership," Presidential Studies Quarterly 14, no. 1 (1984): 44.

${ }^{44}$ Jody Powell quoted in transcript of American Experience: Jimmy Carter, 2000.

${ }^{45}$ Charles O. Jones, "Keeping Faith and Losing Congress: The Carter Experience in Washington,"

Presidential Studies Quarterly 14, no. 3 (1984): 437-445.

${ }^{46}$ Ulrich Haynes, Jr., email correspondence with the author, October 2, 2006.

${ }^{47}$ Neustadt, Presidential Power and the Modern Presidents, p. 239.

${ }^{48}$ Ibid., p. 237.

${ }^{49}$ Ibid., p. 151.
} 
Neustadt, Carter lacked the star-like "personal style to stir a national audience, and he distanced himself from experienced Beltway insiders who could have guided him, preferring instead "Georgians all." ${ }^{51}$ Consequently, Carter "barely kept from sinking out of sight," and "Jimmy-who?" was quickly followed by "Who cares?".52

Maybe Carter's problem was that he was too ordinary to be president; he tried to "demythologize" the office, failing to appreciate the power of presidential symbolism and ceremony. ${ }^{53}$ Among the first things Carter did as president was to sell off the presidential yacht, ban the playing of "Hail to the Chief," abolish limousine service for White House staff, and carry his own luggage. Henry Kissinger explained that the American people did not "want a president who wears a sweater. They want someone who is a little more majestic." ${ }^{54}$ After President Reagan`s passing, one journalist said that one of the main differences between Reagan's success and Carter's failure was that Carter's was a "dour presidency," not an optimistic, cheerful one like Reagan's, partly because "he confused the trappings of the office with the abuse of power."

\footnotetext{
${ }^{50}$ Robert Strong, however, did not find evidence that "Carter gave inordinate time and attention to the trivia of White House management." He calls antedotes, such as Carter immersing himself in tennis court scheduling, "ludicrous." Working in the World: Jimmy Carter and the Making of American Foreign Policy (Baton Rouge, LA: Louisiana State University Press, 2000), 8-9n10.

${ }^{51}$ Neustadt, Presidential Power and the Modern Presidents, 238, 242, 249, 260, 276, 290.

52 Ibid., 238, 260.

${ }^{53}$ Michael A. Genovese, The Presidential Dilemma: Leadership in the American System (New York: HarperCollins, 1995), p. 11; Sidney Milkis and Michael Nelson, The American Presidency: Origins and Development, 1776-2002 (Washington, DC: Congressional Quarterly Press, 2003), pp. 340-341: Richard V. Pierard and Robert D. Linder, "Jimmy Carter and that Old-Time (Civil) Religion." in Civil Religion and the Presidency (Grand Rapids, Ml: Zondervan Publishing House, 1988). 231-256.

${ }^{54}$ Douglas Brinkley, The Unfinished Presidency: Jimmy Carter's Journey Beyond the White House (New York: Penguin Putnam Inc., 1998), p. 27.

${ }^{55}$ Philip Gailey, "Political civility would be a proper tribute," St. Petershurg Times. June 13, 2004, 3P.
} 
Continuing, this journalist wrote, "most Americans don't want a commoner-in-chief but a president who conducts himself in a style befitting the nation's highest office." Carter lacked a "cosmopolitan approach" to governing, said former Illinois Congressman and 1980 Independent presidential candidate John B. Anderson. "He did not seem to grow with the job. ${ }^{, 56}$

But that is what Americans wanted in 1976, says former Carter speechwriter Hendrik Hertzberg. "Jimmy Carter was exactly what the American people always say they want: above politics, determined to do the right thing regardless of the political consequences, a simple person who doesn't lie, a modest man, not somebody with a lot of imperial pretenses. That's what people say they want. And that's what they got with Jimmy Carter." 57

Maybe presidents need a little mystique, pretense, pomp and circumstance to guard their prestige and reputation. Maybe presidents need to remember that they are not only heads of the government, but also heads of State. In addition to what Alexis de Tocqueville called the "almost royal prerogatives" of the presidency," that American presidents "are Tudor kings," possessing both substantive power and a crown. ${ }^{59}$ But it is also an office of myth and symbol, and the president, upon taking the oath of office, becomes a totemic figure, the chief-king of the country, "the living

\footnotetext{
${ }^{56}$ John B. Anderson, email correspondence with author via Janet Corso, Faculty Coordinator at Nova Southeastern University Law Center, September 26, 2006.

${ }^{57}$ Hendrik Hertzberg quoted in transcript of American Experience: Jimmy Carter, 2000.

${ }^{58}$ Alexis De Tocqueville, Democracy in America, edited and abridged by Richard D. Heffner (New York: Penguin Books, 1984), p. 80;

${ }^{59}$ Huntington, Political Order in Changing Societies, p. II 5.
} 
embodiment of the nation," and "the defender of the faith." 60 He must not only be gifted in Neustadian political skills, but "the president must also seem presidential," exude character, and be a moral exemplar publicly and privately. ${ }^{61}$ Thus, it may be justifiably argued that Carter suffered from some of the paradoxical popular expectations of modern presidents: "We want our presidents to be like us, but better than us... king and commoner." 62

Maybe Carter's problem stemmed from his organizational, managerial style, namely "his tendency to micromanage," immersing himself in policy details. ${ }^{63}$ Phillip Henderson described his presidency as a "policy wonk," technocratic presidency. ${ }^{64}$

In seeking to separate himself from the staff-oriented, hierarchical Nixon-Ford administrations, Carter, according to John Burke, sought "a more decentralized," collegial White House that included staff and the cabinet secretaries. ${ }^{65}$ However, Carter

\footnotetext{
${ }^{60}$ Forrest McDonald, The American Presidency: An Intellectual History (Lawrence, KS: University of Kansas Press, 1994), p. 425; see also Thomas E. Cronin, "The Symbolic and Shamanistic Functions of the American Presidency," The Political Chronicle 1.2 (September 1989): 8-13; Robert N. Bellah, "Civil Religion in America," in Religion in America, ed. George C. Bedell, Leo Sandon, Jr., and Charles T. Wellborn (New York: Macmillan Publishing Company, 1982), p. 24-32; James David Fairbanks, "The Religious Dimensions of Presidential Leadership: The Case of Dwight Eisenhower," Presidential Studies Quarterly 12, no. 2 (Spring 1982): 260-267.

${ }^{61}$ McDonald, The American Presidency, p. 425; Richard A. Posner, "Morality, Private and Public," chap. in An Affair of State: The Investigation, Impeachment, and Trial of President Clinton (Cambridge, MA: Harvard University Press, 1999), pp. I33-169; James P. Pfiffner, The Character Factor: How We Judge America's Presidents (College Station, TX: Texas A\&M University Press, 2004).

${ }^{62}$ Thomas E. Cronin and Michael A. Genovese, The Paradoxes of the American Presidency (New York: Oxford University Press, 1998), pp. 6-7.

${ }^{63}$ Rubenzer and Faschingbauer, Personality, Character, and Leadership in the White House, p. 233.

${ }^{64}$ Phillip G. Henderson, "Technocratic Leadership: The Policy Wonk Presidencies of Jimmy Carter and Bill Clinton," in The Presidency Then and Now, ed. Phillip G. Henderson (Lanham, MD: Rowman \& Littlefield Publishers, 2000), pp. 219-247.

${ }^{65}$ John P. Burke, The Institutional Presidency: Organizing and Managing the White House from FDR to Clinton (Baltimore, MD: The Johns Hopkins University Press, 2000), p. 117.
} 
was to be the central player in this arrangement. He would "play an active role as the hub of his collegial spokes and wheels." ${ }^{.66}$ Carter even did without a formal chief of staff for the first half of his presidency. Burke called this arrangement "centralized collegiality." ${ }^{67}$ The key problems with this model is that it burdened the president too much in terms of time, attention, and energy, and it required an interpersonal character that Carter lacked. ${ }^{68}$ In short, Carter was too involved in the petty and mundane activities of the White House Office and the institutional presidency better left to staff and other subordinates. Carter shouldered too much of the burden of being president, too much of the institutional presidency, and too much of the country's problems.

\section{Blaming the Hour}

Perhaps Carter's problem was contextual; his failed presidency was the product of his time--political time. ${ }^{69}$ It has been argued that Carter became president at a time of declining trust in government and respect for authority, declining parties and civic engagement. Carter, like every president since Nixon, was hamstrung by a general suspicion of presidential power and motive and had to confront an emboldened Congress and media determined not to be deceived or bullied by another president; these presidents governed under the shadow of Watergate. ${ }^{70}$ "Carter," said Crotty and

\footnotetext{
${ }^{66}$ Ibid., p. 118.

${ }^{67}$ Ibid., p. 118-119.

${ }^{68}$ Ibid., p. 119.

${ }^{69}$ Skowronek, The Politics Presidents Make.

${ }^{70}$ Bob Woodward, Shadow: Five Presidents and the Legacy of Watergate (New York: Simon and Schuster, 1999).
} 
Jacobson, "had the singular misfortune to assume the presidency at a time when it had been seriously damaged by the actions of his recent predecessors."

The 1970s was also a time of the rise of candidate-centered campaigns and the plebicitary presidency. ${ }^{72}$ Combined with changes in the party system, the nomination process, technology, and the professionalization of campaigns, politically unknown, illprepared, yet momentarily popular outsiders, such as Carter, were able to emerge out of nowhere. The post-1968 nomination process encouraged an outsider candidate to run against Washington, to run against party, and to rely almost solely on his own skills and organization, yet once in power "the outsider cannot govern" effectively. ${ }^{73}$ Carter had no ties to the national party or the established ideological wings of the party, and he was not emblematic of any so-called special interests tied to the party, such as organized labor. $^{74}$ And he became the party nominee on his own, taking advantage of the expanded primary and caucus nominating process, winning early and often. More than any of his presidential contemporaries, he was the quintessential "antiestablishment

\footnotetext{
${ }^{71}$ William J. Crotty and Gary C. Jacobson, American Parties in Decline (Boston, MA: Little, Brown and Company, 1980), p. 226.

${ }^{72}$ Samuel P. Huntington, "The United States," in The Crisis of Democracy, ed. Michael Crozier, Samuel P. Huntington, and Joji Watanuki (New York: New York University Press, 1975), pp. 59-118; Anthony King, "Distrust of Government: Explaining American Exceptionalism," in Disaffected Democracies: What's Troubling the Trilateral Countries?, ed. Susan J. Pharr and Robert D. Putnam (Princeton, NJ: Princeton University Press, 2000), pp. 74-98; Samuel Kernell, Going Public: New Strategies of Presidential Leadership (Washington, DC: Congressional Quartlerly Press, 1997); David Menefee-Libey, The Triumph of Campaign-Centered Politics (New York: Chatham House Publishers, 2000); Theodore J. Lowi, The Personal President: Power Invested, Promise Unfulfilled (Ithaca, NY: Cornell University Press, 1985).

${ }^{73}$ Rose, "The Lesson of the Carter Presidency," p. 78.

${ }^{74}$ Kucharsky, The Man from Plains: The Mind and Spirit of Jimmy Carter, p. 98.
} 
figure." 75 He was what Sidney Milkis called one of the first "independent entrepreneurs," "an anti-party outsider," and his presidency "marked the culmination of the institutional separation between the presidency and party." 76 And, Milkis notes, Carter made no solid efforts to court and cultivate party ties. In fact, Carter and his top aides from Georgia viewed the national Democratic Party as part of "the Washington establishment they had pledged to ignore, ${ }^{, 77}$ and he had decided he would handle recalcitrant members of Congress like he handled the Georgia legislature. ${ }^{78}$

In essence, then, Carter was a president who only carried a party label at election time; he was more or less a partyless president. Thus, it may be argued that party still matters and Carter's lack of partisanship contributed to his failings. The party could move on without him, its domestic policies could remain popular and the party could continue to at least hold on in the Congress. ${ }^{79}$

But Carter's outsider problem was compounded by the fact that of all the socalled outsider presidents he was only a one-term governor with no national reputation and he hailed from a region long since banished from presidential politics for its role in rebellion and racism. Jimmy Carter was the lone Democrat elected president, the lone Southern Democrat nominated, and the lone Democrat to win the South from 1968 to

\footnotetext{
${ }^{75}$ Doug Wead, George Bush: Man of Integrity (Eugene, OR: Harvest House Publishers, 1988), p. 50.

${ }^{76}$ Sidney M. Milkis, The President and the Parties: The Transformation of the American Party System Since the New Deal (New York: Oxford University Press, 1993), pp. 257-258.

${ }^{77}$ Larry J. Sabato and Bruce Larson, The Party's Just Begun: Shaping Political Parties for America's Future. (New York: Longman, 2002), p. 53.

${ }^{78}$ Kernell, Going Public, p. 45.

${ }^{79}$ Martin P. Wattenberg, The Decline of American Political Parties, 1952-1996 (Cambridge, MA: Harvard University Press, 1998), pp. 69-70.
} 
$1988{ }^{80}$ In fact, Carter was the first Deep South president since Zachary Taylor was elected in 1848 . His win marked the return of the South, "the prodigal son," to national prominence. $^{81}$

For more than a century, Deep South politicians were effectively barred from serious presidential consideration, given the South's attempt to secede and the regional reality of racial segregation. As such, it may be that several core constituencies within the Democratic Party viewed him with suspicion, if not contempt, for who he was and where he was from. ${ }^{82}$ It is possible that Carter was simply out of step, like many white southerners in the 1970s, with much of a party that had become more secular, less Southern, and less conservative. As Sabato and Larson put it, Carter was another Southern politician "without a partisan home. ${ }^{183}$

Hargrove, along with many others, has suggested that Carter was simply ahead of his time, the first what would later be called centrist, a "new Democrat" who sought "a new synthesis of liberalism and conservatism in both policy and politics."

\footnotetext{
${ }^{80}$ Nicol Rae, Southern Democrats (New York: Oxford University Press, 1994), p. 57.

${ }^{81}$ Harry S. Dent, The Prodigal South Returns to Power (New York: John Wiley and Sons, 1978).

${ }^{82}$ David D. Lee, "The Politics of Less: The Trials of Herbert Hoover and Jimmy Carter," Presidential Studies Quarterly 13 (1983): 306.

${ }^{83}$ Sabato and Larson, The Party's Just Begun, p. 145.

${ }^{84}$ Hargrove, Jimmy Carter as President, pp. 192-193; Erwin C. Hargrove and Michael Nelson, Presidents, Politics, and Policy (New York: Alfred A. Knopf, 1984), p. 116; Milkis and Nelson, The American Presidency, p. 343; Augustus B. Cochran 1I1, Democracy Heading South: National Politics in the Shadow of Dixie (Lawrence, KS: University Press of Kansas, 2001), pp. 107, 113; William E. Leuchtenburg, "Jimmy Carter and the Post-New Deal Presidency," in The Carter Presidency: Policy Choices in the Post-New Deal Era, eds. Gary M. Fink and Hugh Davis Graham (Lawrence, KS: University Press of Kansas, 1998), pp. 7-28; John B. Judis and Ruy Teixeira, The Emerging Democratic Majority (New York: Scribner, 2002), pp. 120-121; John A. Farrell, Tip O'Neill and the Democratic Century (Boston, MA: Little, Brown and Company, 2001), 445; Iwan Morgan, "Jimmy Carter, Bill Clinton, and the New Democratic Economics," The Historical Journal 47.4 (2004): 1015-1039.
} 
According to Hargrove, Carter's difficulty stemmed from being "a victim of bad luck." a transitional president elected at a time when the country was in a liminal state between the end of New Deal liberalism and the rise of New Right, Reagan Republicanism. ${ }^{85}$ Though Hargrove believed Carter was often skillful, achieved some great successes, and did the best anyone could expect in these political conditions, he was nevertheless still "too conservative" for Democrats and still "too liberal" for Republicans. Early on in his presidency, for example, Carter was accused by fellow Democrat, South Dakota Senator George McGovern, of promoting economic policies that were "hard to differentiate" from Gerald Ford and the Republicans. Though he tried to brush off the extent to which he had engendered opposition within his party, Carter admitted that "some liberals... are very difficult to please." 86

Akin to Hargrove's analysis, Byron Shafer explained that Carter was an accidental president, "the aberrant product of the accumulation of peculiar political circumstances - the Watergate crisis, the Nixon resignation, the Ford pardon." Carter's problem was that he came into office during a particular electoral order that began in 1968, when "the presidency should be Republican; the House should be Democratic; and the Senate should be capturable by either political party, while retaining an intrinsic Democratic bias." ${ }^{\prime 87}$ Consequently, Carter's problems lay in that he was not nationalistic enough in foreign affairs nor as traditional on cultural issues as Republican

\footnotetext{
${ }^{85}$ Hargrove, Jimmy Carter as President, pp. 192; Genovese, The Presidential Dilemma, p. 68.

${ }^{86}$ Carter, "The President's News Conference," May 12, 1977, Public Papers of the Presidents, Book I, pp. 861, 864-865.

${ }^{87}$ Byron E. Shafer, "The Notion of an Electoral Order," in The End of Realignment?: Interpreting American Electoral Eras, ed. Byron E. Shafer (Madison, WI: The University of Wisconsin Press, 1991), p. 51 .
} 
presidents, and not liberal enough or committed enough to the "welfare and service liberalism" that prevailed in Democratic congresses. ${ }^{88}$ There is truth here. Carter was an aberration: he was an exceptional Democrat who won in an exceptional election year. $^{89}$

In The Politics Presidents Make. Stephen Skowronek takes up the concept of political time. He argued that Carter`s essential problem was that he came to the White House at a time of political disjunction--that is, a time in which his party`s orthodox or prevailing policies. in this case the New Deal welfare state, were at odds with wider public sentiment. ${ }^{90}$ Presidents like Carter are therefore in a catch-22. If they embark upon a new course they alienate their party`s electoral base and congressional party: if they do not, they alienate the wider electorate that wants change. What these presidents lack is "the authority to repudiate," and without this authority these presidents become symbolic of all that is wrong with the country, the "malaise" and the "crisis of confidence. ${ }^{.91}$ As such. Carter's presidency has more in common with the presidencies of John Adams. John Quincy Adams, Franklin Pierce. James Buchanan. and Herbert Hoover: They were presidencies of crisis management.

\footnotetext{
${ }^{88}$ lbid.. 52-53.

${ }^{89}$ Rae. Southern Democrats. pp. 55-57.

${ }^{90}$ Skowronek. The Politics Presidents Make, pp. 39-41, 361-406: "Presidential Leadership in Political Time," in The Presidency and the Political System, ed. Michael Nelson (Washington. DC: CQ Press. 2003), pp. 138-150.

${ }^{91}$ Skowronek. The Politics Presidents Make, p. 27.
} 
Finally, Richard Rose has argued that Carter's central problem was that he was the first post-modern president. ${ }^{92}$ That is, in a world that is evermore interdependent and where the lines between domestic and international issues are blurred, Carter was the first president whose success at home was dependent upon international events and dramatically affected by them.

Was the Time Ungovernable?

William Mullen said that "if the president is the 'right man,' structure and circumstances can be overcome." 93 Burton Kaufman made a similar observation: "I am not convinced that the nation was as ungovernable as some of Carter's defenders contend." Carter's "was a mediocre presidency and... much of the reason for this was his own doing." ${ }^{94}$ Certainly, there were major leadership, committee, and rule changes on Capitol Hill, a desire in Congress to reassert its authority after Vietnam and Watergate and growing partisanship and polarization between the congressional parties; these changes were already underway in the 1970s. ${ }^{95}$

\footnotetext{
${ }_{92}$ Richard Rose, The Postmodern President: George Bush Meets the World, (Chatham, NJ: Chatham House Publishers, 1991), p. 26.

${ }^{93}$ Mullen, "Carter's Legislative Successes and Failures," p. 530.

${ }^{94}$ Burton I. Kaufman, The Presidency of James Earl Carter, Jr. (Lawrence, KS: University of Kansas Press, 1993), pp. 3, 210.

${ }^{95}$ David W. Rohde, Parties and Leaders in the Postreform House (Chicago, IL: University of Chicago Press, 1991); Barbara Sinclair, Legislators, Leaders, and Lawmaking: The U.S. House of Representatives in the Postreform Era (Baltimore, MD: The Johns Hopkins University Press, 1995); Barbara Sinclair, Unorthodox Lawmaking: New Legislative Processes in the U.S. Congress (Washington, DC: Congressional Quarterly Press, 2000); Christopher J. Deering and Steven S. Smith, Committees in Congress (Washington, DC: Congressional Quarterly Press, 1997).
} 
But suppose any of the other leading Democratic figures. Hubert Humphrey. Edward Kennedy. Morris Udall. Henry Jackson. Birch Bayh. or Frank Church. had won the party s nomination and the presidency in 1976. Would these Democrats have had the number of problems Carter had with Democratic congresses? Would these presidents have been as hampered by internal congressional developments? Would their party unity scores have been as low as Carter"s? Would these men have shown contempt for congressional norms and practices as Carter did? Would these men have vigorously pursued resolution of the Panama Canal issue. boldly brought human rights back into U.S. foreign policy and immersed themselves in Middle East peace efforts? Fiorina. for one. suggests not. He observed that Carter`s rivals would more likely have preserved the status quo. preferring to satisfy the electoral base of the Democratic Party by creating more federal programs. In contrast. Carter promised to shake up the Washington establishment. irrespective of whether Democrats ran that establishment. and reorient U.S. foreign policy. irrespective of whether European allies grimaced. Moreover. all were members of Congress or. in Humphrey"s case. a former member and a former vice president. At the very least all of these men were quite familiar with the ways of the Hill. Besides. Udall. for instance. was Speaker O'Neill's choice for president in $1976 .{ }^{96}$

Ronald Reagan. Bill Clinton. and George W. Bush were outside-the-Beltway presidents. too. But. it is improbable that Reagan would have had the sort of trouble

\footnotetext{
${ }^{96}$ John A. Farrell. Tip O Weill and the Democratic Century. (Boston. MA: Little. Brown and Company. 2001). 444 .
} 
Carter had if he had a Republican-controlled Congress for all eight years. In fact, it has been noted that unlike Carter, Reagan actually "demonstrated that he could work with Washingtonians. ${ }^{97}$ Clinton's serious problems with Congress did not fully develop until after the Republicans took control in 1994. By one measure, Clinton did not veto a single bill in his first two years when Democrats controlled Congress. Though a "New Democrat" reformer, Clinton, unlike Carter, worked to prevent a liberal Democratic challenge to his presidency. Here, he succeeded where Carter failed-Clinton ran unopposed for renomination in $1996 .{ }^{98}$ George W. Bush had Republican-controlled congresses for six years and did not have Carter-like problems. In his first term, for instance, Bush, too, did not veto even one bill; it was not until midway through his fifth year that he vetoed his first. In contrast, after four years, with Democrats fully in charge of Washington, Carter vetoed 31 bills. ${ }^{99}$ This suggests that Carter did not get along with congressional Democrats and they did not with him. In fact, Speaker O’Neill even noted that he had better working relations with Reagan, also a former governor without Washington experience, than he did with Carter. ${ }^{100}$

\footnotetext{
${ }^{97}$ Larry Berman, "Presidents as Leaders: Carter and Reagan," chapter in The New American Presidency' (Boston, MA: Little, Brown and Company, 1987), p. 310

98 Joe Klein, The Natural: The Misunderstood Presidency of Bill Clinton (New York: Broadway Books, 2002), pp. 53-54.

${ }^{99}$ Lyn Ragsdale, Vital Statistics on the Presidency: Washington to Clinton (Washington, DC: Congressional Quarterly Press, 1998), p. 402.

${ }^{100}$ O'Neill, Man of the House: The Life and Political Memoirs of Speaker Tip O'Neill (New York: Random House, 1987), pp. 302, 308.
} 
Those who claim that national context matters more in understanding the Carter presidency must also consider Carter's political style in Georgia. Was Carter a different kind of politician in Atlanta than in Washington? If so, the explanatory power of context increases. If not, if there is continuity between Carter's gubernatorial and presidential politics, then other compelling factors may be at work.

Throughout his career, Carter saw himself as an outsider, taking unpopular stances and fighting entrenched politicians. ${ }^{101}$ While attending a naval school in Connecticut, Carter recalled that he was "a firmly committed, and somewhat lonely, Democrat" and that during the 1948 election he and Rosalynn were the only couple for Harry Truman. ${ }^{102}$ When Carter was a Sumter County school board member, he took unpopular stances on reforming education. ${ }^{103}$

On race issues, Carter was an outsider, too. ${ }^{104}$ When invited to join the White Citizens' Council, Carter asserts that he was the only white adult male in Plains to decline. When the Plains Baptist Church voted to exclude blacks from regular worship. Carter and his family took the unpopular, lonely public stand in opposition. In Turning Point, he recalls that on one occasion a sign that read "Coons and Carters Go Together" was posted at the Carter warehouse. ${ }^{105}$

\footnotetext{
${ }^{101}$ Mazlish and Diamond, Jimmy Carter: A Character Portrait, p. 77.

${ }^{102}$ Carter, Turning Point: A Candidate, A State, and a Nation Come of Age (New York: Times Books, 1992), p. 55.

${ }^{103}$ Carter, Why Not the Best?, p. 88; Turning Point, pp. 57-59.

${ }^{104}$ Carter, Why Not the Best?, pp. 72-75.

${ }^{105}$ Carter, Turning Point, p. 59.
} 
When Carter ran for the Georgia State senate in 1962, he ran and ultimately won as a reform-minded outsider against the corrupt power of the county courthouse elites and Democratic party insiders. In Turning Point, Carter said the 1962 senate race boiled down to an insider-vs.-outsider contest: "the basic issue between me and Homer Moore was whether the conservative political establishment would be preserved against a total newcomer to politics." 106 Continuing, Carter wrote that those principally opposed to him were "public officials who had more confidence that Homer would be compatible with the existing political system," whereas he developed a reputation "as an activist and relatively independent in making decisions." 107 In Why Not the Best?, Carter explained that he "began to realize how vulnerable our political system was to an accumulation of unchallenged power" and how "honest and courageous people could be quieted." ${ }^{108}$ He noted that his supporters tended to be "mostly young" and "newcomers," that "state party officials proved to be aloof or downright hostile" to his legal challenges to voting irregularities and fraud, and that the local newspapers deemed him "a politically naïve sorehead and a poor loser" when the initial counting showed that he lost. ${ }^{109}$ He concluded that the lesson of his 1962 campaign was that the good people of southwest Georgia would be "willing to stand up and be counted on the side of decency and of honest politics and government" if they had a hardworking, good and

\footnotetext{
${ }^{106}$ Ibid., p. 72.

${ }^{107}$ Ibid.

${ }^{108}$ Carter, Why Not the Best?, p. 96.

${ }^{109}$ Ibid., pp. 89-91.
} 
decent man to lead them. ${ }^{110}$ Later, when he ran for governor in 1966 and 1970. Carter said, "I was a newcomer, filled with a sense that it was my destiny to "save the state of Georgia and the public school system.".111

Jack Bass and Walter DeVries noted that when Carter was governor of Georgia he had troubled relations with the Atlanta news media and the state legislature.

According to one legislator, Governor Carter tended to do too many things at once and thought he could "give the orders" to the legislature and "everything falls into line."112 James Cook described Carter's relations with the Democratic-controlled Georgia legislature as "controversial, aggressive, and combative." $" 13$ Cook wrote that Carter constantly engaged in "verbal warfare" with former governor Lester Maddox and had "conflicts with others." As a result of Carter's poor relations with the Georgia legislature, "Carter was not a popular governor" and Georgia historians ranked his effectiveness as average. According to a piece in U.S. New's and World Report, Carter's "relationship with [state] legislators was stormy from the beginning, and he pushed through most of his ideas only by weathering one showdown after another" and "by going over the heads of the legislature to appeal directly to voters."

\footnotetext{
${ }^{110}$ Ibid., p. 96.

${ }^{\prime \prime}$ Carter, Sharing Good Times, p. 45.

112 Jack Bass and Walter DeVries, "Georgia," chap. in The Transformation of Southern Politics: Social Change and Political Consequence Since 1945 (New York: Basic Books, 1977), pp. 145-146.

113 James F. Cook, "James Earl Carter, Jr.: From Plains to the Presidency," in The Governors of Georgia. 1754-1995 (Macon, GA: Mercer University Press, 1995), pp. 289-297.

114 "What Carter Would Do as President," U.S. New's \& World Report, July 26, 1976, 19
} 
Kaufman described Carter's gubernatorial leadership style similarly. "At times," he wrote, "Carter was his own worst enemy, committing many of the same strategic and tactical mistakes he would make as president." To illustrate, Governor Carter "unnecessarily antagonized powerful state officials by attempting to turn the battle over reorganization into a morality play, in which he was the guardian of the public welfare and his opponents were tools of special interest groups." Carter "compounded his mistake by resisting efforts at compromise and coalition building. 115

Longtime Carter friend and advisor Peter G. Bourne described Governor Carter as one who despised "traditional backslapping, trading favors, and massaging egos." 116 He further notes an occasion when Carter's friend, Georgia state senator Ford Spinks, suggested that he needed to spend more personal time with state legislators. Carter angrily snapped, "Ford, I want to tell you that as long as I'm governor of this state, don't ever tell me again what I ought to do and what I ought not to do with the legislature." Throughout his four years, "Carter's unwillingness to wheel and deal was a source of great frustration to both his friends and his enemies." "117 Carter would take the same view of legislatures with him to Washington, said Bourne. ${ }^{118}$

Gary Fink described Governor Carter as having a "fundamental abhorrence to the uniquely American practice of legislative logrolling," an "unorthodox legislative style," a "reputation for stubbornness and obstinacy," and an "obdurate resistance to

\footnotetext{
${ }^{115}$ Kaufman, The Presidency of James Earl Carter, Jr., p. 10.

${ }^{116}$ Bourne, Jimmy Carter: A Comprehensive Biography from Plains to Postpresidency, p. 206.

${ }^{117}$ Ibid., p. 216.

${ }^{118}$ Ibid., pp. 370-371.
} 
the endemic political trade-offs so common (and perhaps necessary) in the American political system."119 This approach, Fink continued, "provoked his volatile relationship with the more traditional politicians in the Georgia Assembly," and Georgia Democrats "considered him out-of-touch with political reality" and "insensitive to their constituency interests." 120 In 1972, the editors of the Atlanta Constitution wrote, "Gov. Carter is not one for the smoke filled rooms, the hearty slap on the back and fervent friendships formed instantaneously."121 Bruce Mazlish and Edwin Diamond observed that if "governors must work with others to achieve goals; Governor Carter's record in this regard contains few successes. He wouldn't horse-trade" and "his critics said this showed he was overly proud and stiff-necked."122 As he would find years later in his relations with Congress, Carter had difficulty in making legislative friends. ${ }^{123}$

Such tendencies were evident years earlier when he served in the Georgia State Senate. According to Mazlish and Diamond, state senator Carter "did not banter with his fellow senators or make small talk that greases committee work and other legislative relations." 124 In return, not surprisingly, he had few friends at the state capitol and had virtually no support from them in his bids for governor. Time magazine reported that

\footnotetext{
${ }^{119}$ Gary M. Fink, Prelude to the Presidency: The Political Character and Legislative Leadership Style of Governor Jimmy Carter (Westport, CT: Greenwood Press, 1980), p. 166-167: Sam Hopkins, "Carter characterized as being 'marginally effective governor'," Atlanta Journal-Constitution, November 2. 1985, B5.

${ }^{120}$ Fink, Prelude to the Presidency, pp. 166, 169.

${ }^{121}$ Ibid., p. 164.

${ }^{122}$ Bruce Mazlish and Edwin Diamond, Jimmy Carter: A Character Portrait (New York: Simon and Schuster, 1979), p. 205.

${ }^{123}$ Fink, Prelude to the Presidency, p. 169; Johnson, "Discussion among Panelists," in Jimm. Carter: Foreign Policy and Post-Presidential Years, pp. 397-398.
} 
State Senator Carter "disliked the tussle and compromise" of legislative service. Seeing "himself more of an executive" than a legislator, he decided to run for governor. ${ }^{125}$ This was simply the Carter style.

\section{Carter's Foreign Policy Style}

Those who claim national context is the best explanation for Carter's failures. his outsider status, and his troubled dealings with Congress do not account for his strained relations with European allies or his penchant for unilateralism abroad. Several scholars and critics from the right and left note that Carter's foreign policy style, like his domestic policy style, was often alienating, arrogant, and unilateral. ${ }^{126}$ Former Secretary of State Kissinger, for instance, remarked,

The Carter administration has managed the extraordinary feat of having, at one and the same time, the worst relations with our allies, the worst relations with our adversaries. ${ }^{127}$

Rejecting the religious moralism of Carter's foreign policy, historian Arthur

Schlesinger, Jr. (by the way, a supporter of the 1980 Kennedy challenge) even suggested that before Carter judged the human rights policies of other countries, the "born-again President might have remembered Matthew 7:2-3: 'And why beholdest

${ }^{124}$ Mazlish and Diamond, Jimmy Carter: A Charucuer Portrait, p. 145.

125 "Jimmy Carter: Not Just Peanuts," Time, March 8, 1976, 17.

${ }^{126}$ Brinkley, The Unfinished Presidency, p. 20; Margarita Mathiopoulos, "The American President Seen Through German Eyes--Continuity and Change from the Adenauer to the Kohl Era," Presidential Studies Quarterly 15, no. 4 (Fall 1985): 673-706; Friedbert Pflüger, "Human Rights Unbound: Carter's Human Rights Policy Reassessed," Presidential Studies Quarterly 19, no. 4 (Fall 1989): 707; Karl Helicher, "The Response of the Soviet Government and Press to Carter's Human Rights Policies," Presidential Studies Quarterly 13, no. 2 (Spring 1983): 296-304.

${ }^{127}$ Quoted in William A. DeGregorio, The Complete Book of U.S. Presidents: From George IIashingtom to George W. Bush (New York: Barnes and Noble Books, 2004), p. 630. 
thou the mote that is in thy brother's eye, but considerest not the beam that is in thine own eye?", 128

Carter's Post-Presidential Style

Carter seems to be the same old Carter in his post-presidential style. It did not matter to him whether a Republican or a Democrat occupied the White House. Carter would be Carter. He openly worked against President George H.W. Bush's policies leading up to the 1991 Gulf War. In an uncharacteristic manner for former presidents, Carter even personally wrote to UN Security Council members to vote against the United States. Bush's National Security Advisor. Brent Scowcroft, had this to say about Carter's actions:

It was an unbelievable letter, asking the other members of the council to vote against his own country... he also lobbied the President's foreign colleagues. It seemed to me that if there was ever a violation of the Logan Act prohibiting diplomacy by private citizens, this was it. President Bush was furious at this interference in the conduct of his foreign policy and the deliberate attempt to undermine it. ${ }^{129}$

Carter also had strained relations with President Clinton, the only other

Democratic president since the 1960s, due to his blunt personal criticisms and his repeated unilateral interference in foreign affairs. ${ }^{130}$ Carter also repeatedly violated the norm of ex-presidents staying out of policy debates and refraining from criticisms of

\footnotetext{
${ }^{128}$ Arthur Schlesinger, Jr., "Human Rights and the American Tradition," Foreign Affairs 57.3 (1979): 517.

129 George Bush and Brent Scowcroft, A World Transformed (New York: Alfred A. Knopf, 1998), pp. 413-414.

${ }^{130}$ Brinkley, The Unifinished Presidency. pp. 368-387.
} 
sitting presidents, publishing several op-ed articles criticizing the foreign policy of George W. Bush. ${ }^{131}$

There is a pattern here; there is a thematic continuity. Whether in Plains, Georgia Senate District 14, Atlanta, or Washington, Carter ran against the powers that be. He ran as an outsider, he ran against power. He promised a politics of decency and honesty. In his view, wrote Mazlish and Diamond, "he cast himself... as the lone and public-spirited David against the Goliaths of entrenched political power."

If such assessments of Carter's leadership style in Georgia are accurate, the best explanations for his successes and failures as president are probably not merely found in national contextual explanations or in political time. While context may partially explain his electoral appeal and success in 1976, and while unexpected events may have forced Carter to make some strategic changes and forced some organizational adjustments within the administration, he still could have won reelection in $1980 .^{133}$ According to Gallup, Reagan's support surged only after the 1980 debate with Carter: prior to that, the two were either in a dead heat or Carter held a small lead. ${ }^{134}$ In fact, in the last Gallup poll before the debate, Carter led Reagan by eight points, 47\%-39\%.

It seems clear that any account of the man, his politics, his presidency, his successes and failures should at least describe and explain Carter's leadership style and

\footnotetext{
${ }^{131}$ Carter, "The Troubling Face of America," Washington Post, September 5, 2002; "Just War-or a Just War?" New York Times, March 9, 2003.

${ }^{132}$ Mazlish and Diamond, Jimmy Carter: A Character Portrait, p. 140.

${ }^{133}$ William W. Newmann, "The Structures of National Security Decision Making: Leadership. Institutions, and Politics in the Carter, Reagan, and G.H.W. Bush Years," Presidential Studies Quarter/y 34, no. 2 (June 2003): 272-306.

134 "Debate Sparked Reagan Surge in Final Week," Gallup Opinion Index (December 1980): 10-11.
} 
issue priorities across time, whether in Atlanta or Washington, whether as state senator, governor, president, or former president, whether his core constituents were Georgia Democrats, congressional Democrats, or foreign leaders. It should include some account of the strong religious faith of the man from Plains, Georgia, who became president.

\section{The Religion Gap in Carter Studies}

"President Carter is above all a man of faith." 135 --Ronald Reagan

"My belief in Christ is so important in my life, that it's unshakable."136 --Jimmy Carter

Contrary to conventional wisdom, Republican presidents and presidential candidates do not, and have not historically, possessed a monopoly on religion. ${ }^{137}$ Though they may have been unsuccessful in conveying this to many Americans, Democratic presidents and presidential candidates have also claimed to be inspired and motivated by their religious faith and have often grounded policy initiatives and decisions in religious, moral principles. ${ }^{138}$ This was certainly true of Democratic president Jimmy Carter. Though religion is not the only source of Carter's identity and

\footnotetext{
${ }^{135}$ Ronald Reagan, "Remarks at the Dedication Ceremony for the Jimmy Carter Library in Atlanta, Georgia," October 1, 1986, http://www.reagan.utexas.edu/achives/speeches/1986/100186a.htm.

${ }^{136}$ Carter, "Interview with Barbara Reynolds of USA Today," May 12, 1986, in Conversations with Carter, edited by Don Richardson (Boulder, CO: Lynne Rienner Publishers, 1998), p. 275.

137 Jim Wallis, God's Politics: Why the Right Gets It Wrong and the Left Doesn't Get It (New York: HarperCollins Publishers, 2005).

${ }^{158}$ Paul Kengor, "God and Democrats," chap. in God and George W. Bush: A Spiritual Life (New York: Regan Books, 2004), pp. 173-196.
} 
style, it is one that clearly defines him and one he and those who knew him best frequently highlight. ${ }^{139}$ As one scholar put it, "Some of us are motivated by secular and humanist traditions, while others find strength in their religious beliefs. Carter will tell you that his commitment springs from his faith in God."140

According to Gallup polling data, Carter consistently had the reputation of being a religious person; it was the highest personality trait assigned to him, and he was viewed as being significantly more religious than any other major political contemporary. ${ }^{141}$ Carter was also widely viewed as "a man of high moral principles." Given this widespread perception, it is surprising how little Carter's faith and his moral standing have been explored in presidential literature. This chapter reveals a gap between public perceptions of Carter and academic ones. It shows that Americans have long viewed Carter in religious terms, while presidential scholars, though they typically make reference to some religious or moral dimension to Carter and his presidential style, tend to ignore or minimize the political significance of his faith.

\section{Carter's Religious Public Perception}

Few studies have explored and examined the religious rhetoric of presidents. One 2004 study, for instance, did find that Republican presidents (Reagan, Bush 41, and

\footnotetext{
${ }^{139}$ Carter, The Virtues of Aging (New York: The Ballantine Publishing Group, 1998), pp. 89-90.

${ }^{140}$ Gregory Paul Domin, Jimmy Carter, Public Opinion, and the Search for Values, 1977-1981 (Macon, GA: Mercer University Press, 2003), p. 99.

141 "Carter Praised for Personal Qualities," The Gallup Opinion Index (December 1980), pp. 56-57. Fifteen years later, Gallup found that Americans gave Carter the highest moral character rating of any modern president. See Domin, Jimmy Carter, Public Opinion, and the Search for V'alues, 1977-1981, p. 91.
} 
Bush 43) used religious rhetoric more than Democratic presidents (Carter and Clinton). ${ }^{142}$ However, the speech occasions examined were confined to "speeches given on regular ritual occasions by all presidents," such as inaugural and State of the Union addresses. Those are indeed useful and important speeches to explore, but they are, as the author acknowledged, ritual, "civil religious" occasions. But there are obviously other measures that may be employed to uncover the religious character and style of presidents. Though Adam Kradel may be right that Republican presidents more frequently use religious rhetoric than Democratic presidents, no other president in modern times has exceeded Jimmy Carter in the public's perception as the most religious and most moral.

Table 1.7 shows, from a low of $85 \%$ to a high of $94 \%$, that the American public widely and consistently perceived Carter as a religious person. In aggregate four years of his presidency, $88 \%$ of Americans viewed him as religious. Carter was also considered "a man of high moral principles" (Table 1.8). On this measure, in those four years, more than $86 \%$ of Americans viewed him as moral.

Religion was also Carter's number one personality trait. Of the seventeen personality-leadership qualities assessed by Gallup (Table 1.9), more Americans consistently agreed that the descriptive "a religious person" more appropriately applied to Carter than any other. The second most cited trait was that Carter was "a man of high moral principles." What stands out about these two qualities is that they were consistently the top qualities positively associated with Carter throughout his term.

\footnotetext{
${ }^{142}$ Adam Kradel, "God on Our Side: The Religious Rhetoric of Recent U.S. Presidents," paper presented at the Annual Meeting of the American Political Science Association, September 2004, Chicago, Illinois.
} 
Table 1.7 Carter: A Religious Person, 1976-1980

\begin{tabular}{lcccl}
$\begin{array}{l}\text { \%-A Religious } \\
\text { Person (N) }\end{array}$ & \multicolumn{2}{c}{$\begin{array}{l}\text { \%-Not Particularly } \\
\text { Religious (N) }\end{array}$} & Survey Dates \\
\cline { 3 - 5 } $88 \%$ & $(961)$ & $12 \%$ & $(130)$ & September 21, 1976 \\
$94 \%$ & $(1194)$ & $6 \%$ & $(79)$ & February 15, 1977 \\
$89 \%$ & $(2160)$ & $11 \%$ & $(262)$ & September 27, 1977 \\
$87 \%$ & $(2255)$ & $13 \%$ & $(345)$ & July 18, 1978 \\
$87 \%$ & $(2164)$ & $13 \%$ & $(311)$ & January 16, 1979 \\
$85 \%$ & $(2205)$ & $15 \%$ & $(378)$ & July 10, 1979 \\
$93 \%$ & $(2180)$ & $7 \%$ & $(154)$ & January 2, 1980 \\
$87 \%$ & $(2142)$ & $13 \%$ & $(311)$ & June 24, 1980 \\
$87 \%$ & $(2311)$ & $13 \%$ & $(360)$ & September 9, 1980 \\
\hline $88.3 \%(17572)$ & $11.7 \%(2330)$ & 4-Year Total
\end{tabular}

Source: Gallup Brain; Non-responses were excluded here.

Table 1.8 Carter: A Man of High Moral Principles, 1976-1980

\%-Man of High $\quad \%$-Not Particularly

Moral Principles (N) Moral (N)

$\begin{array}{lccc}84 \% & (895) & 16 \% & (175) \\ 93 \% & (1132) & 7 \% & (85) \\ 89 \% & (2130) & 11 \% & (267) \\ 86 \% & (2222) & 14 \% & (370) \\ 86 \% & (2131) & 14 \% & (348) \\ 83 \% & (2131) & 17 \% & (445) \\ 93 \% & (2183) & 7 \% & (177) \\ 85 \% & (2056) & 15 \% & (361) \\ 83 \% & (2235) & 17 \% & (443)\end{array}$

$86.5 \%(17115) \quad 13.5 \%(2661) \quad 4-Y e a r$ Total $\underline{\text { Survey Dates }}$

September 21, 1976

February 15,1977

September 27, 1977

July 18,1978

January 16, 1979

July 10,1979

January 2, 1980

June 24, 1980

September 9, 1980

Source: Gallup Brain; Non-responses were excluded here. 
The qualities on which Carter fared the worst were in the areas of leadership and

political skill. For example, an average of only $37 \%$ believed he "offers imaginative, innovative solutions to national problems," $36 \%$ thought he was "decisive, sure of himself," $32 \%$ thought he possessed "strong leadership qualities," and 28\% said, "You know where he stands on the issues."

Table 1.9 Gallup's Personality Profile of President Carter, 1978-1980

\begin{tabular}{lccccccc}
\hline Highest Positive Qualities & Avg & $9-80$ & $6-80$ & $1-80$ & $7-79$ & $1-79$ & $7-78$ \\
A Religious Person & $80 \%$ & $82 \%$ & $78 \%$ & $78 \%$ & $79 \%$ & $82 \%$ & $81 \%$ \\
A Man of High Moral Principles & $78 \%$ & $79 \%$ & $75 \%$ & $78 \%$ & $76 \%$ & $80 \%$ & $80 \%$ \\
Takes Moderate, Middle Positions & $74 \%$ & $76 \%$ & $70 \%$ & $77 \%$ & $72 \%$ & $73 \%$ & $73 \%$ \\
A Likeable Person & $71 \%$ & NA & $68 \%$ & $71 \%$ & $69 \%$ & $73 \%$ & $76 \%$ \\
Bright, Intelligent & $70 \%$ & $70 \%$ & $62 \%$ & $71 \%$ & $69 \%$ & $73 \%$ & $74 \%$ \\
Would Display Good Judgment in a Crisis & $64 \%$ & $51 \%$ & $62 \%$ & $74 \%$ & $68 \%$ & $65 \%$ & $63 \%$ \\
Sympathetic to Problems of the Poor & $58 \%$ & $64 \%$ & $55 \%$ & $58 \%$ & $54 \%$ & $53 \%$ & $63 \%$ \\
Says What He Believes Even if Unpopular & $57 \%$ & $54 \%$ & $53 \%$ & $57 \%$ & $59 \%$ & $57 \%$ & $59 \%$
\end{tabular}

Highest Negative Qualities

Puts Country's Interest Ahead of Politics $\quad 49 \% \quad$ NA $\quad 46 \% \quad 58 \% \quad 45 \% \quad 49 \% \quad 49 \%$

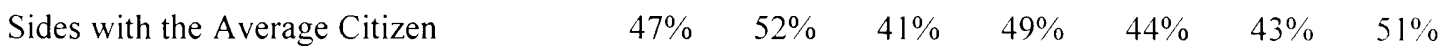

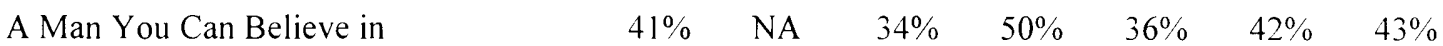

Offers Imaginative Solutions to Problems $\quad 37 \% \quad 34 \% \quad 30 \% \quad 41 \% \quad 35 \% \quad 40 \% \quad 42 \%$

Decisive, Sure of Himself $\quad 36 \% \quad 35 \% \quad 28 \% \quad 39 \% \quad 33 \% \quad 43 \% \quad 38 \%$

Has Strong Leadership Qualities $\quad 32 \% \quad 29 \% \quad 26 \% \quad 34 \% \quad 27 \% \quad 38 \% \quad 36 \%$

A Person of Exceptional Abilities $\quad 29 \% \quad$ NA $\quad 24 \% \quad 29 \% \quad 26 \% \quad 34 \% \quad 32 \%$

You Know Where He Stands on Issues $\quad 28 \% \quad 31 \% \quad 23 \% \quad 33 \% \quad 23 \% \quad 29 \% \quad 28 \%$

$\begin{array}{llllll}\text { Has Program to Move Country } & 26 \% & 25 \% & 21 \% & 31 \% & 19 \%\end{array} \quad 29 \% \quad 29 \%$

Source: Gallup Opinion Index (December 1980); Figures here include non-responses. 
Through the 1980s, Carter continued to be perceived as the most religious and most moral of his political contemporaries. Tables 1.10 and 1.11 show that Carter not only possessed the highest popular ratings, but also near unanimous identification with being religious and moral. In September 1976, 88\% of Americans considered Carter "a religious person," compared with 54\% who considered President Ford religious. In 1979-1980, Carter was also considered significantly more religious than Senator Edward Kennedy (85\%-62\%, 93\%-61\%), Governor Ronald Reagan (87\%-37\%, 87\%$40 \%$ ), and Independent candidate John Anderson (87\%-44\%, 87\%-46\%). In the next presidential election cycle (1983-1984), though majorities considered both men religious, neither President Reagan nor Carter's Vice President Walter Mondale even came close to Carter's religious standing.

All too often, though, the religion of President Carter and its political consequences has been ignored or marginalized in the scholarly literature of his presidency. Despite his being described as the most moralistic major-party presidential nominee since William Jennings Bryan and "widely considered to have been the most religious U.S. president of the $20^{\text {th }}$ century, ${ }^{\prime 43}$ presidential scholars have tended to either entirely ignore Carter's faith or note it so briefly that it appears unimportant, or that he neatly separated it from his politics.

${ }^{143}$ Encyclopedia of American Religion and Politics, eds. Paul Djupe and Laura Olson (New York: Facts on File, Inc., 2003) p. 76. 
Table 1.10 Jimmy Carter and His Presidential Contemporaries: Religion Person or Not Particularly Religious

Presidential

Candidates

Jimmy Carter

Gerald Ford

Jimmy Carter

Edward Kennedy

Jimmy Carter

Edward Kennedy

Jimmy Carter

Ronald Reagan

John Anderson

Jimmy Carter

Ronald Reagan

John Anderson

Ronald Reagan

Ronald Reagan

Walter Mondale

Ronald Reagan

Walter Mondale
A Religious

Person

$\% \quad \mathrm{~N} \quad \% \quad \mathrm{~N}$

$88 \%(961) \quad 12 \%(130)$

$54 \%$ (537) $46 \%(454)$

$85 \%(2205) \quad 15 \%(378)$

$62 \%(1555) \quad 38 \%(956)$

$93 \%(2180) \quad 7 \% \quad(154)$

$61 \%(1134) \quad 39 \%(734)$

$87 \%(2142) \quad 13 \%(311)$

$37 \%(772) \quad 63 \%(1329)$

$44 \%(694) \quad 56 \%(874)$

$87 \%(2311) \quad 13 \%(360)$

$40 \%(978) \quad 60 \%(1468)$

$46 \%(880) \quad 54 \%(1044)$

$59 \%(1355) \quad 41 \%(948)$

$66 \%(1146) \quad 34 \%(601)$

$64 \%(892) \quad 36 \%(497)$

$62 \%(1403) \quad 38 \%(849)$

$57 \%(1160) \quad 43 \% \quad(887)$
Survey Date

September 21, 1976

July 10,1979

August 7, 1979

January 2. 1980

June 24, 1980

September 9, 1980

May 14-17. 1982

August 12-15, 1983

August 10-12. 1984

George H.W. Bush^ 50\%(270) 50\%(268) October 7-9, 1987

Source: Gallup Brain. Non-responses were excluded here. A-Bush had the highest non-response rate. More than $67 \%$ (1102) did not know enough to answer this question. In contrast. in 1980. Reagan had non-response rates of $23 \%$ and $13 \%$ and John Anderson had $43 \%$ and $32 \%$. 
Table 1.11 Jimmy Carter and His Presidential Contemporaries:

Man of High Moral Principles or Not Particularly Moral

Presidential

Candidates

Jimmy Carter

Gerald Ford

Jimmy Carter

Edward Kennedy

Jimmy Carter

Edward Kennedy

Jimmy Carter

Ronald Reagan

John Anderson

Jimmy Carter

Ronald Reagan

John Anderson

Ronald Reagan

Ronald Reagan

Walter Mondale

Ronald Reagan

Walter Mondale

Ronald Reagan

Walter Mondale
Man of High

Moral Principles

$\begin{array}{llll}\% & \mathrm{~N} & \% & \mathrm{~N}\end{array}$

$84 \%(895) \quad 16 \% \quad(175)$

$80 \% \quad(854) \quad 20 \% \quad(209)$

$83 \%(2131) \quad 17 \% \quad(445)$

$51 \%(1268) \quad 49 \%(1230)$

$93 \%(2183) \quad 7 \% \quad(177)$

$50 \%(921) \quad 50 \%(929)$

$85 \%(2056) \quad 15 \%(361)$

$73 \%(1632) \quad 27 \%(597)$

$74 \%(1234) \quad 26 \%$ (442)

$83 \%(2235) \quad 17 \%(443)$

$70 \%(1778) \quad 30 \%(757)$

$73 \%(1482) \quad 27 \%(547)$

$77 \%(1835) \quad 23 \%(558)$

$73 \%(1342) \quad 27 \%(508)$

$80 \%(1316) \quad 20 \% \quad(337)$

$80 \%(1844) \quad 20 \%(461)$

$86 \%(1670) \quad 14 \%(267)$

$79 \%(1838) \quad 21 \%(485)$

$78 \%(1686) \quad 22 \%(489)$ $\underline{\text { Survey Date }}$

September 21, 1976

July 10,1979

August 7, 1979

January 2, 1980

June 24, 1980

September 9, 1980

May 14-17, 1982

August 12-15, 1983

January 27-30, 1984

August 10-12, 1984

Source: Gallup Brain; Non-responses were excluded here. 
Such omissions and marginalizations in the Carter literature may be partially due to a prevailing "secular prejudice" in academia that includes what some have called the "myth of secularism"- "the separability of church and state" and "the false assumptions of pure politics and pure religion." 144 As such, the tendency is to treat Carter's devout faith as a mere "oddity" or some Freudian illusion that has no more than a "psychical origin" in human nature or early childhood. ${ }^{145}$ In much the same way as the national media tended to treat it when Carter ran for president in 1976, some scholars find it a curious part of his background and his upbringing in the South that was largely inconsequential politically and had no meaningful influence on his presidency. It may be acknowledged, but there has been an apparent rush to move beyond it without much documentation, thought, analysis, or reflection.

\section{References to Carter's Faith in the Literature}

Though many presidential scholars have ignored Carter's faith entirely, others have at least mentioned it, if only in passing, if sometimes indirectly. A sample of those references are cited here.

In his history of the Democratic Party, Jules Witcover described Carter as a candidate who succeeded in casting himself as a "centrist," "an outsider to the political

\footnotetext{
${ }^{144}$ Daniel Walker Howe, "Religion and Politics in the Antebellum North," in Religion and American Politics: From the Colonial Period to the 1980s, ed. Mark A. Noll (New York: Oxford University Press, 1990), p. 125; M.A. Muqtedar Khan, "The Myth of Secularism," in One Electorate Under God?' A Dialogue on Religion and American Politics, eds. E.J. Dionne, Jr., Jean Bethke Elshtain, and Kayla M. Drogosz (Washington, DC: Brookings Institution Press, 2004), p. 134.

${ }^{145}$ A. James Reichley, Faith in Politics (Washington, DC: Brookings Institution Press, 2002), p. 2; Sigmund Freud, The Future of an Illusion, translated and edited by James Strachey (New York: W.W. Norton and Company, 1989).
} 
evils of Washington," and a "pious straight shooter."146 But Witcover did not tell us what "pious straight shooter" means. Did it simply mean that Carter would tell the truth? Was that all his faith required politically? Did it distinguish him from other Democrats? Here Witcover is silent.

John Burke admitted that Carter's religion probably influenced his predilection for a collegial model: "Carter's emphasis on collegiality had its roots in his training as an engineer and in his moral and religious values." Burke, however, did not mention the religion factor again or elaborate on it. ${ }^{147}$ In The American Presidency, Forrest McDonald offered this passing description: "Carter was an engineer who had a Wilsonian faith in reason and in his own rightness," and who had an "amateurish, rationalist approach" to presidential politics. ${ }^{148}$ Richard Rose observed, "Jimmy Carter entered office with the simple belief that policy choices were between doing what was right or wrong."149 James MacGregor Burns said Carter created a presidential image of "humble plainness, stubborn integrity infused with Baptist piety." Still, though a "devout Baptist," Carter was guided more by "a higher faith in rationality."150

\footnotetext{
146 Jules Witcover, Party of the People: A History of the Democrats (New York: Random House, 2003), p. 595.

${ }^{147}$ Burke, The Institutional Presidency, p. 118. Peter Bourne also noted that Carter's preference for a collegial model may have had a religious source. He wrote, "The Baptist church had no hierarchy, with each congregation being autonomous and the preacher being supported by a group of deacons. There was, of course, the obvious parallel of Christ and his disciples." Peter G. Bourne, Jimmy Carter: A Comprehensive Biography from Plains to Postpresidency (New York: Scribner, 1997), p. 360.

${ }^{148}$ McDonald, The American Presidency, p. 371.

${ }^{149}$ Rose, The Postmodern President, p. 7.

150 James MacGregor Burns, "The Carter-Clinton Connection," chap. in Running Alone: Presidential Leadership-JFK to Bush II (New York: Basic Books, 2006), pp. 119-129.
} 
Though they focused on Carter's independent presidential style. Kunhardt et al. also described Carter in moral terms. They wrote that he established a political career around "strict honesty and idealism," and that "his basic decency" has been quite evident in his post-presidential life as "an energetic humanitarian" and "an international trouble-shooter." 151 They also quote him as saying that his religious faith was crucial to handling his job as president: "I did the best I could. And with my self-confidence and my religious faith I accommodated disappointments and really enjoyed being president."

Douglas Brinkley described Carter as "a Bible-spouting peanut farmer" and "a seemingly sincere born-again Christian." In a single reference, he says Carter's human rights campaign and foreign policy were rooted in his belief that "we should live our lives as though Christ were coming this afternoon." 152 Elsewhere, he said Carter possessed a "Christian engineer's approach to problem-solving," a "moralistic approach to conflict resolution," and his diplomatic style involved a "Baptist-missionary sensibility and honest-broker integrity." 153

In a post-presidential biography, Rod Troester suggested that Carter may be the best ex-president the country has ever had because he brought "a unique quality" to that role. Part of the reason may be that his post-presidential activities are grounded in and

\footnotetext{
${ }^{151}$ Kunhardt et al, The American President, p. 158-159.

152 Douglas Brinkley, "Jimmy Carter," in To the Best of My Ability": The American Presidents, ed. James M. McPherson (New York: DK Publishing, 2004), p. 282, 284-285.

${ }^{153}$ Douglas Brinkley, “Jimmy Carter's Modest Quest for Global Peace," Foreign Affairs 74.6 (November/December 1995): 92, 95.
} 
guided by a religious sense of mission. ${ }^{154}$ He believes peacemaking and the alleviation of world suffering are religious obligations; he believes "anyone can be redeemed," including dictators and tyrants.

Charles Jones, too, noted that Carter was "a born-again Christian who worked hard at doing what he defined as 'right'," but he did not explain how Carter's faith mattered politically. He argued that Carter was "a missionary president," a "moralizer" who was determined to do "the right thing" because it was "the right thing to do," and that he had a "holier-than-thou" attitude towards Congress. ${ }^{155}$ However, according to Jones, this apparently was not the consequence of faith. Instead, Jones found the source of his unusual, anti-political politics in his outsider status and his reformist agenda. For Jones, Carter was a "trustee" president, a president who thought and acted more for the national interest than for local interests; a president who chose the "right" courses of action over expedient, electorally gainful ones. ${ }^{156}$ For Jones, trusteeship is what Carter meant by having "a different way of governing." Interestingly, Jones often describes Carter in religious terms, yet his explanations avoid religion. He also left unclear what "the right" is for Carter and why Carter is motivated toward "doing what's right." Has "doing right" been for Carter, for instance, a matter of efficiency, a practical costsaving, time-saving innovation? Or, was "doing right" a matter of seeking righteousness, a moral condition, a virtue? Was politics simply, for Carter, to

\footnotetext{
${ }^{154}$ Rod Troester, Jimmy Carter as Peacemaker: A Post-Presidential Biography (Westport, CT: Praeger Publishers, 1996), pp. 170-173.

155 Jones, "Keeping Faith and Losing Congress," 438; The Trusteeship Presidency: Jimmy. Carter and the United States Congress (Baton Rouge, LA: Louisiana State University Press, 1988), p. 217.

${ }^{156}$ Jones, The Trusteeship Presidency, pp. 1-9.
} 
paraphrase Harold Lasswell, a better, fairer way of delivering who gets what, when, and how? Or, did Carter view politics as a form of lay ministry, a means "to establish justice in a sinful world"? ${ }^{157}$ Though the two views are not incompatible, the validity of Jones' trusteeship model would be enhanced if it were grounded in Carter's faith-based worldview, if it linked Carter's personal religious/ moral qualities to his leadership style and political skill.

Two works on presidential character devoted more space to Carter's faith, but they too were brief and indirect. In The Presidential Character, James David Barber did note the influence of religion on Carter's life. ${ }^{158}$ What is less clear is how Carter's religion impacted his presidential campaign, presidential behavior, and presidential priorities. After briefly describing Carter's spiritual development and predicting that it would have an influence on his presidential style, Barber did not examine its influence again. The religious dimension of Carter is inexplicably abandoned or submerged in the text. If one reads only the pages Barber devoted to Carter's presidential years, the role of religion is mysteriously missing, compared with the predictions Barber made as to what a Carter presidency would mean. ${ }^{159}$ The only whiff of it we get is that Carter had a "preacher problem," a tendency to sermonize to the American people in his presidential rhetoric." 160

\footnotetext{
${ }^{157}$ Robert Shogan, Promises to Keep: Carter's First 100 Days (New York: Thomas Y. Crowell Company, 1977), p. 41.

${ }^{158}$ James David Barber, The Presidential Character: Predicting Performance in the White House (Upper Saddle River, NJ: Prentice Hall, 1992), pp. 424-428.

${ }^{159}$ Ibid., pp. 430-433.

${ }^{160}$ Ibid., p. 445.
} 
In The Presidential Difference, Fred Greenstein admitted, "Carter stands alone among modern presidents in the centrality of religious principles to his political leadership and, indeed, his very being."161 Having said that, Greenstein goes on to other matters. Carter's religion is only briefly mentioned over the next several pages. For instance, Greenstein states that "Carter's deficiencies as a political operator appear to have been...plainly bound up in his identities as a Christian and an engineer. Rather than viewing compromise as the essence of politics, he seems to have perceived it as a readiness to do what one knows is wrong." ${ }^{162}$ However, in Greenstein's account, there is not a specific word about Carter's faith or how it may have provided him with a vision of what could be in foreign policy. Instead, one finds only vague or marginal references to "his human rights policy" being a reflection of "his own lofty ideals"163 and that his desire to play the peacemaker in the Middle East was "spurred by the knowledge that it was the Holy Land." "64

Edwin C. Hargrove explained that Carter's "politics of the public good" had many sources: childhood and early adult role models, his early experiences in politics, and early success as a farmer and businessman. In addition to these sources noted by Hargrove, but again not given much attention after the initial acknowledgment, was Carter's faith. "Carter," Hargrove wrote, "also drew on southern religious traditions in his style of leadership. His religious faith was central to his life. Faith shaped his

\footnotetext{
${ }^{16]}$ Greenstein, The Presidential Difference, pp. 128-129.

${ }^{162}$ Ibid., p. 141.

${ }^{163}$ Ibid., p. 142.

${ }^{164}$ Ibid., p. 137.
} 
understanding of himself and others, his beliefs about political purposes in government and his style of authority. ${ }^{165}$

While Hargrove acknowledged that religion was important for Carter, like Barber and Greenstein, he did not further explore the religious dimension. Even in the area of foreign policy, particularly Carter's preoccupation with human rights and the Camp David accords, the possible religious roots of Carter's foreign policy were not addressed. Hargrove saw Carter having more "an idealistic, 'Wilsonian' world view which valued peace and human rights." 166 Hargrove had earlier in the book described Carter as a "New Testament Christian," a Christian who "practiced humility, charity, forgiveness and tolerance as political virtues. He did not see the world as inherently evil and sought peace through understanding rather than confrontation." ${ }^{167}$ If this is so, it would be legitimate to further explore this dimension of Carter and how it influenced his policies.

These references show that many scholars do acknowledge the importance of Carter's faith and concede that it may have had political consequence. However, those concessions did not lead to further exploration and explanation.

\section{Carter's Unhidden Faith}

What does Carter himself claim? As will be shown in the chapters that follow. Carter has not hidden his faith. He readily admits in his many post-presidential

\footnotetext{
${ }^{165}$ Hargrove, Jimmy Carter as President, pp. 7-8.

${ }^{166}$ Ibid., p. 111.

${ }^{167}$ Ibid., p. 8.
} 
publications the profound effect of religion upon his life and his politics. He has written two books, Living Faith and Sources of Strength, where his religious faith was the central focus. Using select Sunday School lessons he has taught over the years, Carter explained what his Christian faith means to him and what the teachings of Jesus should mean for other Christians. He has written another book, Our Endangered Values, where he discussed the negative aspects of political religion (i.e., the politics of the Religious Right). In 2007, Simon and Schuster published a two- volume set of Carter's Sunday school lessons.

Carter's memoirs were entitled Keeping Faith. He also discussed religion at length in a book on the Middle East conflict, The Blood of Abraham. He wrote about his favorite Christmases in Christmas in Plains, in three other books, Carter included chapters on sharing his faith with others and learning about the reality of $\sin$ in the world. ${ }^{168}$ He wrote the foreword to Religion, the Missing Dimension of Statecraft, a book on the positive role religion and religious persons can have in international affairs and how religion can be a useful source of conflict resolution. ${ }^{169}$ He participated in a book tribute to the life and career of evangelist Billy Graham. ${ }^{170}$

In The Virtues of Aging, though he tried to keep "biblical references to a minimum" this time, he could not resist in his advice to older Americans to remember

\footnotetext{
${ }^{168}$ Carter, "Learning About Sin," in An Hour Before Daylight: Memories of Rural Boyhood (New York: Simon and Schuster, 2001), pp. 207-230; "Religion," in Christmas in Plains (New York: Simon and Schuster, 2001), pp. 39-47; "Sharing My Faith," in Sharing Good Times, pp. $45-47$.

${ }^{169}$ Carter, "Foreword," in Religion, The Missing Dimension of Statecraft, ed. Douglas Johnston and Cynthia Sampson (New York: Oxford University Press, 1994), pp. vii-viii.

${ }^{170}$ Billy Graham: A Tribute from Friends, compiled by Vernon McLellan (Colorado Springs, CO: Warner Books, 2002), p. 33.
} 
the Apostle Paul's focus on Christian love and hold firm to "things we cannot see." like "patience, kindness, truthfulness, hope, endurance, and generosity."171 And finally, he has written several articles and has given several interviews about his faith over the years. including the Christian responsibility to forgive, to remember the poor, to not judge or "demonize" others, to work for human rights, to emulate the example of the "Prince of Peace." On matters of crime and punishment, he believes that for too many Americans "the Old Testament standard of 'an eye for an eye' is not harsh enough."172 The Middle East, in particular, has been a subject of focus in his writings. In contrast. with the lone exception of George W. Bush`s I 999 campaign autobiography, A Charge to Keep. a title inspired by a Methodist hymn with the same title, no other modern president has written books and articles on religion or books and articles with religious themes or titles. Carter is not merely a prolific writer. What is interesting is the subject matter he frequently chooses to discuss - his faith, values, human rights, the alleviation of suffering, disease. and world poverty, and Middle East peace (See Appendix I).

Former administration officials note the importance of Carter's faith. too. Jody Powell. for instance, is convinced that Carter's faith contributed to the difficulties he had with the national press corps. ${ }^{173}$ He wrote that they could not accept Carter because he did not fit the typical presidential mold. He was Southern, devoutly religious, and very smart:

\footnotetext{
${ }^{171}$ Carter, The I'irtues of Aging, pp. 131-132.

${ }^{172}$ Carter, "Regaining Our Trust in Justice," Atlanta Journal-Constitution, November 20. 1995.

${ }^{173}$ Jody Powell, The Other Side of the Story' (New York: William Morrow and Company, 1984). pp. 206207.
} 
For most journalists, Carter was different-not only from most politicians and Presidents they had covered, but from them. He was a small-town Southern Baptist with a set of values and beliefs that made many of them decidedly uncomfortable.

As an example of this, Powell quoted one journalist's view of Carter in 1976:

This guy Carter may win the nomination and he may even make the best President of the bunch, but he is a redneck, Baptist, Bible thumper and I don't like it one damn bit.

Powell even added that the press seemed to prefer "politicians who lie, cheat, and steal than one who prays - particularly if he prays in private and with conviction." Carter was unlike the media stereotype of Southern politicians, he reflected.

Not only did he practice as well as preach his religion, he did not tell racist jokes, even in private, and he did not drink large quantities of bourbon and pat strange women on the fanny.

In this study, a different perspective is offered. It will be argued that Carter's personal religious faith played a significant role in his presidency; it shaped his leadership style and influenced his agenda-setting and decision-making. Carter's faith was also a fundamental source of his successes and a source of personal strength. It also contributed to difficulties in office. ${ }^{174}$ For those who did not share his view, it could be difficult to work with him.

\footnotetext{
${ }^{174}$ About his presidential failings, biographer Betty Glad once said, "I certainly wouldn't say his religion was the major explanatory factor in his political failings." See Glad, "Discussion Among Panelists," in Jimmy Carter: Foreign Policy and Post-Presidential Years, p. 399. Glad has also said, "Whatever the changes in his relationship to God and in his own inner feelings, Carter's religious experiences seem to have worked no dramatic alteration of the external man." Because Carter remained in politics and had the charisma he had prior to his born-again experiences, religion was not the source of his politics and political ambition. However, she does note, "If anything, Carter's political drive was stronger after his born again experiences." Later, Glad does concede that "Carter's political views rest on a simplistic moralism," "he advocated purity for all government officials," his human rights policy was "based on a missionary assumption that we must not permit violations of the American Bill of Rights in the world at large and that it is our duty to take the lead," he believed "placing one's [political] interests first is a vice," and "his religion provides moral vision." See Glad, Jimmy Carter: In Search of the Great White House (New York: W.W. Norton and Company, 1980), pp. 118-119, 477-480.
} 
For Carter, religion matters and he, like William Jennings Bryan and Woodrow Wilson, had a religious, evangelical style. Religion was not only a key part of his presidential style and a source of his political ambition, policy objectives, and postpresidential work; it defined his presidency and life work in unmistakable moral terms. Throughout his career. he was a politician who claimed having a voice with certain "moral authority" and influence. ${ }^{175}$ Marshall Frady explained, Carter's political style included a "sort of Southern schoolteacher"s morality and earnestness." ${ }^{176}$ Many others. too, through the years have sought his advice and his support for moral causes not only because he was the president of the United States, but a president with a national and international reputation as a moral leader and peacemaker.

Measuring religion. the depth and breath of one's personal faith, however. is not simple. ${ }^{177}$ As Carter himself once said. the impact of religion is not "commonly recognized or easily quantified" and "its great rewards cannot be measured in ordinary terms. ${ }^{178}$ The reason for this. he has argued, is that Christians are obligated to seek after "the things you cannot see." the things that are truly important and permanent. And these things "you cannot see are the principles of Jesus Christ." $" 179$

\footnotetext{
${ }^{1 " 5}$ Carter, "Interview with Charles Trumbull." Encrclopedia Britannica. June 26. 2003. http: "www.britannica.com.

${ }^{176}$ Marshall Frady, "Interview with Ray Suarez," PBS Newshour, October 11, 2002. http: "www pbs.org newshour bb international july-dec()2 nobel 10-11.html.

${ }^{177}$ David Brooks, "How Niebuhr Helps Us Kick the Secularist Habit: A Six-Step Program." in One Electorate Under God? A Dialogue on Religion and American Politics, eds. E.J. Dionne. Jr.. Jean Bethke Elshtain. and Kayla M. Drogosz (Washington. DC: Brookings Institution Press. 2004), p. 70.

${ }^{178}$ Carter. "Foreword." to Religion. The Missing Dimension of Statecraft. p. vii; Talking Peace. p. xiv.

${ }^{179}$ Carter. "Interview with Elizabeth Sams," Beliefnet, March 27, 2007. http: "www beliefnet.com/story 214 story 21478.html.
} 
Be that as it may, much evidence indicates that religion was an important influence on the 1976 campaign, on Carter's politics, on his presidential behavior, and on his policy priorities. Importantly, he admits, and often details, in his postpresidential publications the profound, holistic effect of religion on his life and his politics. Many of those who served with him often make similar claims. It is a common mistake to downplay, discard or discount its importance or simply take it as a given. 


\section{The Origins of the Evangelical Presidential Style: The Leadership Alternative of William Jennings Bryan and Woodrow Wilson}

"You are the most real Christian I know."1

--Secretary of the Interior Franklin Lane to William Jennings Bryan upon his resignation as Secretary of State

"He [Woodrow Wilson] thinks he is another Jesus Christ come upon the earth to reform men. $"$ ?

--French President Georges Clemenceau

"I really think that at first the idealistic President [Wilson] regarded himself as a missionary whose function it was to rescue the poor European heathen from their age-long worship of false and fiery gods. He was apt to address us in that vein."

--British Prime Minister David Lloyd George

"I have a rare background... I have been President of the United States of America and I'm a dedicated evangelical Christian who believes in the traditional values that were inculcated in me by own father."

--Jimny Carter

\footnotetext{
${ }^{1}$ Lawrence W. Levine. Defender of the Faith: William Jennings Bryan, the Last Decade, 1915-1925 (New York: Oxford University Press. 1965), p. 17.

2William A. DeGregorio. The Complete Books of U.S. Presidents: From George Wishington to George II. Bush (New York: Barnes and Nobles Books, 2004). p. 427.

${ }^{3}$ Herbert Hoover, The Ordeal of Woodrow W'ilson (Washington, DC: Woodrow Wilson Center Press. Baltimore, MD: Johns Hopkins University Press, 1992; originally published in 1958), p. 254.

${ }^{4}$ Carter, "Interview with Rich Cline." Evangelical Alliance of the United Kingdom. November-December 2006. http: "Www.eauk.org resources idea NovDec2006 the-power-of-unity
} 
Shortly after his involuntary departure from the White House, Jimmy Carter explained to a group of presidential scholars in 1982 that as president he had "a different way of governing" than his predecessors. ${ }^{5}$ What did he mean by "a different way of governing"? He did not elaborate on that occasion precisely what he meant. All Carter mentioned was that he was "a southerner, a born-again Christian, a Baptist, a newcomer." He additionally noted that he "didn't have any obligations to the people in Washington for my election." Taken together, Carter hints that there was something about his regional background, his religious faith, and his outsider status that distinguished his presidential style, his "way of governing" from other presidents, and. potentially, his policy priorities as well.

In the first part of this chapter, it is argued that it is the religious dimension of the Carter that fundamentally shaped his "way of governing," distinguishing him from most other American presidents of the twentieth-century. While the Southern dimension and his outsider status are certainly of interest and consequence in their own right, Carter's faith and his understanding of the relationship of faith and politics in many respects encompassed these features. ${ }^{6}$ However, Carter was not the first major American politician to offer this different governing style.

In the second part of this chapter, it is shown that Carter's style was not sui generic. Rather, it is argued his style had precedents-precedents in the late nineteenth-

\footnotetext{
${ }^{5}$ Jimmy Carter, "Interview with Charles O. Jones, H. Clifton McCleskey, Kenneth W. Thompson, James Sterling Young, Richard Neustadt, David B. Truman, Richard F. Fenno, Jr., and Edwin C. Hargrove in Plains, Georgia," November 29, 1982. Transcript available at the Miller Center Foundation, http:/www.millercenter.virginia.edu/index.php/scripps/digitalarchive/oralhistories/detail/3260.

${ }^{6}$ I explored the "Southern" dimension in "More Proud Being Southern: Jimmy Carter and Southern Identity," a paper presented at the 2006 Citadel Symposium on Southern Politics in Charleston, South Carolina.
} 
century, early twentieth-century politics of fellow Democrats William Jennings Bryan

and Woodrow Wilson. Therefore, the Carter case may not be dismissed as a mere

political aberration. Instead, we may rightly claim that there exists in American politics an authentic, though alternative, form of governing that may be witnessed from time to time and examined as a theoretical model. Though this style has its roots in the Democratic Party, the case of George W. Bush shows that it cannot be reduced to a partisan form of governing. ${ }^{7}$ Still, the Democratic origins of the model are of interest in their own way.

\section{A Southern Electoral Base}

Carter's religious, specifically "born-again" evangelical, faith is partially a product of his Southern upbringing. To a greater degree than other Americans, Southerners are known for their religious intensity, orthodoxy, and willingness to claim being evangelical. ${ }^{8}$ Furthermore, part of what made him an outsider to Washington, to the media, and to many national Democrats was his evangelical religion.

In the 1896 election, explained A. James Reichley, Democratic nominee William Jennings Bryan's open appeal to the country's rural voters and "mass of evangelical Protestants" made "many normally Democratic working-class voters in the

\footnotetext{
${ }^{7}$ D. Jason Berggren and Nicol C. Rae, "Jimmy Carter and George W. Bush: Faith, Foreign Policy, and an Evangelical Presidential Style,” Presidential Studies Quarterly 36.4 (December 2006): 606-632.

${ }^{8}$ D. Jason Berggren and Nicol C. Rae, "The American South: The 'Bible Belt' of America (and the Western World?)," paper presented at the 2006 Annual Meeting of the Southern Political Science Association in Atlanta, Georgia; Linda Lyons, "Religiosity Compass Points South," Gallup Poll New's Service, January 14, 2003; John C. Green, Lyman A. Kellstedt, Corwin E. Smidt, and James L. Guth, "The South of the South: Religion and the New Electoral Order," in The New Politics of the Old South An Introduction to Southern Politics, eds. Charles S. Bullock and Mark J. Rozell (Lanham, MD: Rowman and Littlefield Publishers, 1998), 261-276.
} 
major cities of the Northeast and around the Great Lakes" uneasy and suspicious of the former two-term Nebraska congressman." His "evangelical style and emphasis on Protestant moral values," Reichley added, were particularly "jarring to the sensibilities of many working-class Catholics." Eighty years later, many Democrats were perplexed by Jimmy Carter's claims of being "born-again." Like Bryan, It was wondered whether Carter, a devout Southern evangelical, could successfully appeal to Northern ethnic Catholics and Jews. ${ }^{10}$ As one commentator explained, Carter was not merely a political outsider, but a "sociocultural" one, even to fellow Democrats. He was "a southern, born-again Baptist who wore his religion on his sleeve." $" 11$ In fact, two other commentators noted, Carter was being described at the time as " "the most unabashed moralist' candidate for the presidency since William Jennings Bryan," an "overtly evangelical politician" whose "religious beliefs were central to his political identity" and electoral appeal. $^{12}$

For these reasons, it may explain why Carter was able to establish a Southern electoral base in 1976 (127-20) and why, even with Watergate and the Nixon pardon. he

\footnotetext{
${ }^{9}$ A. James Reichley, The Life of the Parties: A History of American Political Parties (Lanham, MD: Rowman \& Littlefield Publishers, 2000), pp. 144-146. See also James L. Sundquist, Dynamics of the Party System: Alignment and Realignment of Political Parties in the United States (rev. edition; Washington, DC: The Brookings Institution, 1983), pp. 167-169.

${ }^{10}$ Timothy A. Byrnes, Catholic Bishops in American Politics (Princeton, NJ: Princeton University Press, 1991), p. 70; Albert J. Menendez, Evangelicals at the Ballot Box (Amherst, NY: Prometheus Books, 1996), pp. 128-142. In 1980, in fact, Carter received the lowest Catholic and Jewish support for a Democrat since the 1920. Seymour Martin Lipset and Earl Raab, Jews and the New American Scene (Cambridge, MA: Harvard University Press, 1995), p. 16; Robert Booth Fowler, Allen D. Hertzke, and Laura R. Olson, Religion and Politics in America: Faith, Culture, and Strategic Choices (Boulder, CO: Westview Press, 1999), pp. 108-111.

"Maurice M. Eisenstein, "Religion in the 1976 Presidential Election," in Encyclopedia of American Religion and Politics, eds. Paul Djupe and Laura Olson (New York: Facts on File, Inc., 2003), p. 366.
} 
still lost the rest of the country to President Gerald Ford (220-170). In fact. as Table 2.1

shows. Carter's largest popular votes gains from George McGovern`s performance four years earlier were largely in the South and his gains in the Northeast. except for the border states of Maryland and Delaware, were all below the national average $(+12.56 \%)$. Indeed. most of his gains in the Northeast were in the single-digits. with Massachusetts haring the smallest gain $(+1.91 \%)$.

\section{Table 2.1 Carter's Southern and Northeastern Electoral Strength Compared (states ranked by \% Carter Gain)}

\begin{tabular}{|c|c|c|c|c|c|c|c|}
\hline Southern State & $\underline{1972}$ & $\underline{1976}$ & 0 Carter Gain & Northeast State & 1972 & $\underline{1976}$ & $0_{0}$ Carter Gain \\
\hline Georgia & 24.65 & 66.74 & $\div+2.09$ & Marylland & 37.36 & 53.04 & -15.68 \\
\hline Arkansas & 30.71 & 64.94 & -34.23 & Delaware & 39.18 & 51.98 & -12.80 \\
\hline Alabama & 25.54 & 55.73 & +30.19 & Pennsylvania & 39.13 & 50.40 & -11.27 \\
\hline Mississippi & 19.63 & 49.56 & +29.93 & New Jersey & 36.77 & 47.92 & -11.15 \\
\hline South Carolina & 27.92 & 56.17 & +28.25 & New York & 41.21 & 51.95 & -10.74 \\
\hline North Carolina & 28.89 & 55.27 & +26.38 & Maine & 38.48 & 48.07 & -9.59 \\
\hline Tennessee & 29.75 & 55.94 & +26.19 & New Hampshire & 34.86 & 43.47 & -8.61 \\
\hline Oklahoma & 24.00 & 48.75 & +24.75 & Rhode lsland & 46.81 & 55.36 & -8.55 \\
\hline Florida & 27.80 & 51.93 & +24.13 & Connecticut & 40.13 & 46.90 & -6.77 \\
\hline Louisiana & 28.35 & 51.73 & +23.38 & Vermont & 36.47 & 43.14 & -6.67 \\
\hline Kentucky & 34.77 & 52.75 & -17.98 & $\mathrm{DC}$ & 78.10 & 81.63 & $-\quad 3.53$ \\
\hline Texas & 33.24 & 51.14 & +17.90 & Massachusetts & 54.20 & 56.11 & -1.91 \\
\hline Virginia & 30.12 & 47.96 & -17.84 & & & & \\
\hline
\end{tabular}

Source: Election Data from Dave Leip`s Atlas of U.S. Presidential Elections. http: www uselectionatlas.org.

Table 2.2 shows that Carter"s electoral base was different from most post-1896 presidents. Since then. most presidential winners (15) have won both the North and South. That is, they were national winners. The second most common type are Northern sectional winners (9). presidents who win the North. but lose the South.

\footnotetext{
12 Robert E. Dewhirst. "James Earl Carter." in Enciclopedia of .tmerican Religion and Politics. p. 76: Alvin O. Turner, "James Earl "Jimmy" Carter." in Enclclopedia of Religion in tmericun Politic's. eds. Jeffrey D. Schultz. John G. West. Jr.. and Ian Maclean (Phoenix. AZ: Oryx Press. 1999). p. 43.
} 
However, their margin of victory in the North was sufficient for winning the presidency

despite little or no Southern electoral vote support. The third type is Southern sectional winners, presidents who win with solid or near solid Southern support and win enough

\section{Table 2.2 National and Regional Electoral Strength of American Presidents, 1896-2004 (ranked by \% Southern within each category)}

Presidents and

Electoral Category

Southern Sectional (4)
Southern

Winner

GW BUSH (163-0)

GW BUSH (168-0)

WILSON (149-0)

CARTER (127-20)
Non-Southern

Winner
George W. Bush (R) $2004 \quad 58.74$

Woodrow Wilson (D) $\quad 1916 \quad 53.79$

Jimmy Carter (D)

National (15)

$\begin{array}{lll}\text { George Bush (R) } & 1988 & 36.38 \\ \text { Harry Truman (D) } & 1948 & 35.97 \\ \text { Franklin Roosevelt (D) } & 1944 & 34.26 \\ \text { Woodrow Wilson (D) } & 1912 & 34.25 \\ \text { Franklin Roosevelt (D) } & 1940 & 32.52 \\ \text { Franklin Roosevelt (D) } & 1932 & 30.93 \\ \text { Ronald Reagan (R) } & 1984 & 29.52 \\ \text { Richard Nixon (R) } & 1972 & 28.08 \\ \text { Franklin Roosevelt (D) } & 1936 & 27.92 \\ \text { Ronald Reagan (R) } & 1980 & 27.61 \\ \text { John Kennedy (D) } & 1960 & 26.73 \\ \text { Richard Nixon (R) } & 1968 & 24.58 \\ \text { Lyndon Johnson (D) } & 1964 & 20.16 \\ \text { Herbert Hoover (R) } & 1928 & 19.14 \\ \text { Dwight Eisenhower (R) } & 1956 & 18.60\end{array}$

Northern Sectional (9)

Bush $(155-0)$
Truman $\left(109-39^{*}\right)$
Roosevelt $(148-0)$
Wilson $(149-0)$
Roosevelt $(146-0)$
Roosevelt $(146-0)$
Reagan $(155-0)$
Nixon $\left(146-1^{*}\right)$
Roosevelt $(146-0)$
Reagan $(135-12)$
Kennedy $\left(81-50^{*}\right)$
Nixon $\left(74-71^{*}\right)$
Johnson $(98-47)$
Hoover $(85-64)$
Eisenhower $\left(85-61^{*}\right)$

Bush (271-112)

Truman (194-189)

Roosevelt (284-99)

Wilson (286-96*)

Roosevelt (303-82)

Roosevelt (326-59)

Reagan (370-13)

Nixon (374-17)

Roosevelt (377-8)

Reagan (354-37)

Kennedy (222-169)

Nixon $(227-166)$

Johnson (388-5)

Hoover (359-23)

Eisenhower (372-13)

$\begin{array}{lrrll}\text { Bill Clinton (D) } & 1996 & 15.57 & \text { Dole (104-59) } & \text { Clinton (320-55) } \\ \text { Dwight Eisenhower (R) } & 1952 & 14.71 & \text { Stevenson (81-65) } & \text { Eisenhower (377-8) } \\ \text { Bill Clinton (D) } & 1992 & 12.70 & \text { Bush (116-47) } & \text { Clinton (323-52) } \\ \text { Warren Harding (R) } & 1920 & 5.44 & \text { Cox (127-22) } & \text { Harding (382-0) } \\ \text { William McKinley (R) } & 1896 & 4.43 & \text { Bryan }(113-12) & \text { McKinley (259-63) } \\ \text { Calvin Coolidge (R) } & 1924 & 3.40 & \text { Davis (136-13) } & \text { Coolidge (369-13*) } \\ \text { William H. Taft (R) } & 1908 & 0.00 & \text { Bryan (140-0) } & \text { Taft (321-22) } \\ \text { William McKinley (R) } & 1900 & 0.00 & \text { Bryan (125-0) } & \text { McKinley (292-30) } \\ \text { Theodore Roosevelt (R) } & 1904 & 0.00 & \text { Parker (133-0) } & \text { Roosevelt (336-7) }\end{array}$

*includes votes for minor party candidates and "protest" votes 
Northern electoral votes to win the presidency. Put differently, these are presidents who win the South, but actually lose the North. Comparatively, these are presidents who have the highest percentage of their electoral votes coming from the Southern region.

The import for this project is that Carter is found in a subclass of electoral winners and it is a subclass that antedates the 1976 election. Of all presidential winners since the 1896 realignment. Jimmy Carter is in an electoral class that includes only Woodrow Wilson and George W. Bush. Together these three presidents belong in the Southern sectional class, presidents who were either native-born Southerners or resided most of their life there. They are presidents who won the South, but lost the rest of the country. These are presidents who unashamedly speak in moral, religious terms and believe that the mixing of politics and religion is proper. And, their greatest appeal at the time of their election was in the more religious, evangelical parts of the country, while they tended to lose the more secular, non-evangelical parts. Given this electoral reality, it should not be surprising that evangelical-styled presidents tend to be Southern. have a Southern electoral base, and, given the South`s smaller size, have smaller electoral victories. They were cultural-political dividers before they governed, and the divisions only grew during their terms.

\section{Carter's Religious Exceptionalism Among Modern Presidents}

The degree and frequency to which Jimmy Carter sought to apply his faith as president makes him stand apart from other post-FDR presidents. "Carter made a convincing case that Christians had an obligation to participate in politics, thus challenging the notion that Christians should not mix their religious beliefs with 
politics." Recognizing that Carter brought different qualities to the office and different expectations, social and political scientists since Carter have been asking about bornagain experiences in surveys. The Carter era, too, marked "a watershed in the growth of scholarly literature in the area of religion and politics.",13

Many subsequent presidential candidates did not miss the Carter "born-again" precedent either. Many candidates since have also felt the need to claim that they too were born-again evangelicals, campaign for evangelical votes, and talk more openly about their faith and how it may affect their decision-making. In 1980, for instance, all three major presidential candidates (Carter, Reagan, and Anderson) "all claimed to have had a born-again experience." But it was Carter that inaugurated the presidential alternative in contemporary times. With the arrival of Jimmy Carter, said Richard Hutcheson, "the gentlemen's agreement" of presidents' separating their religion and politics "was consigned to the dust heap of history."

While he may not have explained what he meant by a "different way of governing" during that 1982 interview and denies that he was unique, Jimmy Carter has left a long paper trail, as will be documented more fully in later chapters, that provide a better and more thorough understanding of his presidential style and the foundational principles of his politics. ${ }^{15}$ Jimmy Carter was, as one writer explained, an "American

\footnotetext{
${ }^{13}$ Eisenstein, "Religion in the 1976 Presidential Election," p. 366. Eisenstein noted that "since 1980, a born-again question has been included in the American National Election Study's Presidential Election surveys. There was no such question in 1976."

${ }^{14}$ Richard G. Hutcheson, Jr., God in the White House: How Religion Has Changed the Modern Presidency (New York: Collier Books, 1988), p. 34.

${ }^{15}$ When asked if he was religiously unique, he said he was not. "I think almost every Baptist Christian with whom 1 grew up as a child and even the Methodists and the Lutherans and others who lived around
} 
moralist," a president "obviously propelled by powerful moral passions," "a moral leader." and a key source of his moralism is "his evangelical Christian faith." 16

Father Robert F. Drinan, a Jesuit priest and a Massachusetts Democratic congressman who served for ten years (1971-1981). characterized Carter as "the most religious president in U.S. history," "a man with a deep sense of the personal presence of God in his life." and "a devout Evangelical." ${ }^{17}$ To the dismay and consternation of foreign policy realists, Drinan wrote. Carter had "an unapologetically moralistic approach to conflict resolution" and he made the promotion of human rights "the soul of U.S. foreign policy. ${ }^{\prime 18}$ He noted as well that former Secretary of State Henry Kissinger even called Carter "a missionary man. ${ }^{19}$ Ambler Moss. Jr., who assisted in negotiating the 1978 Panama Canal Treaties and who would later serve as the U.S. Ambassador to Panama (1978-1982). had this to say. "President Carter was certainly motivated by his personal sense of Christianity. above all in a moral and ethical sense." "I believe." Ambassador Moss added. "that faith was a motivating factor in his decisions." He was

my hometown considered themselves to be born again." "Interview with Jonathan Serrie." Fox Vews Special Report with Brit Hume. December 26, 2005.

${ }^{16}$ Kenneth E. Morris. Jimmy Carter: American Moralist (Athens. GA: University of Georgia Press. 1996). pp. 7-8.

1" Father Robert F. Drinan. "Reflections on Nobel Laureate Jimmy Carter." National Catholic Repurler. October 25. 2002: "Jimmy Carter"s book reflects the man of faith 1 knew." National Catholic Reporter. December 16, 2005.

${ }^{18}$ Drinan, "Carter's work touches many lives worldwide," National Catholic Reporter. December 15. 1995: Drinan. "Reflections on Nobel Laureate Jimmy Carter," National Catholic Reporter. October 25. 2002.

19 Drinan, "Carter's work touches many lives worldwide." Vational Catholic Reporter. December 15.
1995. 1995. 
guided by a strong "sense of right and wrong" and "his moral values led him to be a non-realist (in the international relations theory sense). ${ }^{, 20}$

Throughout his public career, Carter believed that political activity was, as he entitled his 1996 spiritual autobiography, part of a "living faith." 21 Religion and politics are very much related. Politics can a form of ministry, a legitimate means of applying Christian values in the world. "For a Christian," Carter wrote, "the life and teachings of Jesus offer a sound moral foundation that includes all the basic elements that should guide us.",22 "Our faith," he continued, "can provide enough courage to apply these biblical lessons to our daily lives."23

Perhaps, it may even be claimed, Jimmy Carter was "the most religious U.S. president of the $20^{\text {th }}$ century." 24 Certainly, good cases can be made that other presidents were at least as religious and also applied their faith during their presidencies.

However, with the probable exception of George W. Bush, few, if any, can match Carter's combination of personal religiosity and public faith. ${ }^{25}$ In contributions to three reference books, Paul Djuje and Laura Olson's Encyclopedia of American Religion and Politics, Randall Balmer's Encyclopedia of Evangelicalism, and Jeffrey D. Schultze, et. al.'s Encyclopedia of Religion in American Politics, this point becomes evident.

\footnotetext{
${ }^{20}$ Ambler H. Moss, Jr., email correspondence with the author, September 27, 2006.

${ }^{21}$ Carter, Living Faith (New York: Times Books, 1998, originally published in 1996).

22 Ibid., p. 9.

${ }^{23}$ Ibid., p. 14.

${ }^{24}$ Dewhirst, "James Earl Carter," p. 76.

${ }^{25}$ Berggren and Rae, "Jimmy Carter and George W. Bush," 606-632; Paul Kengor, God and George W Bush: A Spiritual Life (New York: Regan Books, 2004).
} 
Among all modern, post-Depression presidents, no president, except George W. Bush, has walked and talked faith quite like Carter.

Carter stands out as the only president since the 1930s to be judged to exhibit a style, appeal, and agenda with a specific religious nature. In the reference books, some had no individual entries in any of the three collections (Johnson, Ford, and Bush, Sr.). Some were noted for their specific appeal to various religious constituencies (Roosevelt, Kennedy, Reagan). Some were included for their personal faith, but not necessarily for any significant public displays of it (Truman). Some were mentioned for their general promotion of religion in society, or civil religion (Eisenhower). Some were paradoxically known for their religious faith and their serious moral failings (Nixon, Clinton). However, no president was described as combining the personal, electoral, or public religious dimension to any where near the degree as the $39^{\text {th }}$ president. Before, during, and after his presidency, Carter has retained his religious image. undisputed religious credentials, and his efforts to apply his faith in the world.

Franklin Roosevelt and Harry Truman

Except noting that he was "not overtly religious" in his youth and that his election in 1932 "was seen as a realignment of Roman Catholics, Jews," there is nothing in Franklin Roosevelt's entry in Djupe and Olson's work that illuminates his faith or whether it had political implications. ${ }^{26}$ One has to question why it was even included in the collection. Roosevelt did not have an entry in the other two reference works.

\footnotetext{
${ }^{26}$ Robert W. Smith, "Franklin Delano Roosevelt," in Encyclopedia of American Religion and Politic:s, pp. 392-393.
} 
Though "he possessed a strong belief in God" and "as his presidency wore on. he increasingly turned to the language of faith" to describe the Cold War, Harry Truman was described as an "erratic churchgoer." His wife Bess and his daughter often went to church while he stayed back at the White House. ${ }^{27}$ Like Roosevelt, Truman does not have an entry in the other two works.

\section{Dwight Eisenhower}

For most of his life, despite had deep religious familial roots, Dwight Eisenhower was without formal ties to any religious denomination until he was president. ${ }^{28}$ Eisenhower is remembered for making major contributions to the ritualistic role of religion in the public square, such as starting the tradition of the annual National Prayer Breakfasts. ${ }^{29}$ In addition, it was under his watch that the words "under God" were added to the Pledge of Allegiance and "In God We Trust" became the national motto. ${ }^{30}$ But beyond these symbolic gestures, there is no evidence that Eisenhower applied his faith to his politics. Typifying the common tendency of American presidents to embrace and exhibit little more than public ceremonial faith, President Dwight Eisenhower once said that although he considered religion and faith in God important for understanding America, he did not care which religion it was. ${ }^{31}$

\footnotetext{
${ }^{27}$ Ryan Barilleaux, "Harry S. Truman," in Encyclopedia of American Religion and Politics, p. 444.

${ }^{28}$ Hutcheson, God in the White House, pp. 50-51; Ryan Barilleaux, "Dwight D. Eisenhower," in Encyclopedia of American Religion and Politics, p. 147-148.

${ }^{29}$ Barilleaux, "Dwight D. Eisenhower," in Encyclopedia of American Religion and Politics, pp. 147-148.

${ }^{30}$ Ibid.; William Binning, "Dwight D.Eisenhower," Encyclopedia of Religion in American Politic:s, p. 87

${ }^{31}$ Hutcheson, God in the White House, p. 2.
} 
Eisenhower served in the priestly role of protecting and promoting what Robert Bellah called the American civil religion - a public form of civic faith in the country that coexists more formal and orthodox religious beliefs. ${ }^{32}$ In short. Bellah said, this civil religion may be called "the American Way of Life"- -"a genuine apprehension of universal and transcendent religious reality as seen in or... as revealed through the experience of the American people." If Eisenhower did allow his faith to guide his politics, he had a "hidden" way of doing so akin to his more general presidential style that Fred Greenstein called the "hidden-hand presidency." 33

John F. Kennedy

President John Kennedy is remembered for being "a descendent of Irish Catholics" and making history as "the first Roman Catholic elected president of the United States. ${ }^{3+}$ Electorally, it is noted. "his Catholicism helped him in the industrial east where large numbers of Catholics lived. ${ }^{.35}$ To blunt questions about his Catholicism. John Kennedy tried to assure voters his faith would be politically inconsequential. In fact, judges Richard Hutcheson. Kennedy went further than any other president to keep his faith and his politics separate. ${ }^{36}$ He affirmed that the church-

\footnotetext{
${ }^{32}$ Robert N. Bellah, "Civil Religion in America." Daedalus 96.1 (Winter 1967).

Fred I. Greenstein, The Hidden-Hand Presidency: Eisenhower as Leader (New York: Basic Books, 1982).

it Robert W. Smith. "John Fitzgerald Kennedy." in Enclyclopedia of American Religion and Politic's. pp. 240-24l: William V. Moore, "John Fitzgerald Kennedy," in Encliclopedia of Religion in tmerican Politics, p. 137.

${ }^{35}$ Moore, "John Fitzgerald Kennedy," in Ençclopedia of Religion in American Politics. p. 137.

${ }^{36}$ Hutcheson. God in the White House. pp. 52-55.
} 
state separation was absolute, and said that neither Catholic clerics nor his personal

Catholicism would influence his presidential actions. In his entry, William V. Moore wrote, as president, "Kennedy created a public-personal barrier and firmly placed his Catholic ideology in the realm of the private." 37

\section{Lyndon Johnson}

There were no individual entries for Lyndon Johnson in these three works, nor was religion's role in the 1964 election specifically remembered. However, at least as a campaigner, President Johnson, who belonged to the Disciples of Christ, did make repeated use of Biblical passages. As the country struggled with issues of race, Kennedy's assassination, and the Republicans with a perceived fringe nominee, Barry Goldwater, Johnson campaigned on a theme of national unity and bipartisanship. In this, he asked his fellow Americans, regardless of race, religion, or region, to remember "We are all God's children, and the true morality of private life is the true morality of a free society: the Golden Rule, do unto to others as you would them do unto you." 38 One scholar, at least, was convinced that Johnson's Christian faith strongly influenced his commitment to civil rights for blacks, Great Society programs, and even "his stubborn stand in Vietnam."39

\footnotetext{
${ }^{37}$ Moore, "John Fitzgerald Kennedy," in Encyclopedia of Religion in American Politics, p. 137.

${ }^{38}$ Lyndon B. Johnson, "Remarks at the Mormon Tabernacle in Salt Lake City, Utah," October 29, 1964. Public Papers of the Presidents, Book II, (Washington, DC: United States Government Printing Office, 1965), p. 1515. From September to October 1964, the author counts at least 19 other occasions where President Johnson cited the Golden Rule.

${ }^{39}$ Monroe Billington, "Lyndon B. Johnson: The Religion of a Politician," Presidential Studies Quarterly. 17.3 (Summer 1987): 519-530.
} 
Still, Johnson's faith is not what is remembered or even best describes a career long tied to Washington politics. Fred Greenstein, for instance, observed that the center of Johnson's life was "the primacy of politics." ${ }^{40}$ He was a career, effective, and powerful politician. Over the course of his career, he adeptly and shrewdly shifted from New Deal liberalism to racial conservatism and then to the center as political circumstances changed or as he set his sights on higher offices. Johnson had been the youngest Senate Majority Leader and then Vice President. Johnson, Greenstein noted. had a reputation, a well-justified, for being "a legislative wizard," transforming the usually slow, deliberative Senate into "a productive law-making body." He was, as Robert Caro put it, "master of the Senate."

\section{Richard Nixon}

The Quaker-raised Richard Nixon was a self-proclaimed evangelical, had close ties with evangelist Billy Graham, spoke of defending the values of the "silent majority," and frequently used religious rhetoric. ${ }^{42}$ However, Nixon did not seem to advance any so-called "faith-based" policies or claim his policies were rooted in his Christian faith. "Nixon's approach to politics was strategic, not religious or moralistic." ${ }^{43}$ Much of his religious story tends to focus on his youth and the faith of

\footnotetext{
${ }^{40}$ Fred I. Greenstein, The Presidential Difference: Leadership Sytle from FDR to Clinton (Princeton. NJ: Princeton University Press, 2000). pp. 74-89.

${ }^{41}$ Robert A. Caro, Master of the Senate: The Years of Lyndon Johnson (New York: Alfred A. Knopf, 2002).

${ }^{+2}$ William Binning, "Richard Nixon," in Encyclopedia of Religion in American Politics, pp. 174-175.

${ }^{43}$ Robert Booth Fowler, Allen D. Hertzke, and Laura R. Olson, Religion and Politics in America: Faith. Culture, and Strategic Choices (Boulder. CO: Westview Press. 1999), p. 117.
} 
his mother. ${ }^{44}$ Furthermore, in light of Watergate and revelations from the Nixon tapes (e.g., his penchant for profanity), Nixon may have been publicly religious, but seemingly not privately. ${ }^{45}$

Gerald Ford and George H.W. Bush

Gerald Ford and George H.W. Bush were self-proclaimed evangelicals, too, but neither one were comfortable publicly sharing their essentially private faith. In God in the White House, Richard Hutcheson provides a nice comparison between the different approaches of Ford and Carter. He wrote,

Mr. Ford draws a sharp distinction between his religion, which he regards as a private matter, and his public responsibilities. He has been a faithful believer and churchgoer all his life, and there are many evidences of the depth and authenticity of his faith. Little is said about religion, however, in his memoirs, A Time to Heal. This is in sharp contrast to the memoirs and autobiographical writings of President Carter, who writes of his religion frequently and freely. ${ }^{46}$

Ford believed, "one's religious convictions and dedication are personal" and said he "never tried to mix my religion and politics." $"$ In this regard, Hutcheson explained, Ford fit the more "classic pattern" of presidents not mixing their faith and politics, of viewing public displays of faith as improper and "discomfiting."

\footnotetext{
${ }^{44}$ Veronica Donahue DiConti, "Richard M. Nixon," in Encyclopedia of American Religion and Politics, pp. 309-310.

${ }^{45}$ Randall Balmer, Encyclopedia of Evangelicalism (Louisville, KY: Westminster John Knox Press, 2002), p. 476.

${ }^{46}$ Hutcheson, God in the White House, p. 96.

${ }^{47}$ Ibid.
} 
Carter, in contrast, represented an uncommon alternative. In his race with

Carter, a long-time Ford associate suggested Ford discuss his faith. He explained.

unlike Carter, Ford's problem was nobody knew he was a Christian. ${ }^{48}$

In an interview designed to rally evangelical voters to his 1988 campaign for the presidency by showing that he had "a spiritual side." George H.W. Bush confessed that he had not "always found it easy to discuss [religion] in public. since my faith has been a very personal thing to me." ${ }^{,+9}$ When it came to knowing what God expects believers to do in the public square, he wrote, "I'm not sure what God wants of us."

To use Bill Clinton`s words. George H.W. Bush can be counted among "the frozen chosen. ${ }^{.51}$ That is. Bush. like other Northern mainline Protestant politicians (particularly Episcopalians). often had a difficult time explaining or sharing his religious faith publicly. He once said that he simply was not made way: it was contrary to his nature. ${ }^{52}$ His faith was just too personal. Robert Booth Fowler et al. provides this

\footnotetext{
${ }^{+8}$ Nancy Gibbs and Michael Duffy. "The Other Born-Again President?” Time, January 2, 2007.

${ }^{49}$ George H.W. Bush, interview with Doug Wead. George Bush: Man of Integrity (Eugene. OR: Harvest
} House Publishers. 1988), p. 33. As further evidence of his reluctance to discuss his faith, in his autobiography, Bush only had two references to his faith. One reference was about his Episcopalian upbringing. his family's weekly church attendance. and his parent's practice of reading a Bible lesson daily at the breakfast table. The second reference was a note about his reliance on prayer and how his faith sustained him and Barbara when their daughter Robin died. See George Bush with Victor Gold. Looking Forward: An Autobiography. (New York: Doubleday, 1987), pp. 27.69.

${ }_{50}^{50}$ George H.W. Bush. All the Best, George Bush: My Life in Letters and Other Iritings (New York: Lisa Drew Book/Scribner, 1999). p. 319.

${ }^{51}$ Bill Clinton. "Remarks at the Funeral Service for Coretta Scott King in Lithonia. Georgia." February 7. 2006.

$\$ 2$ George H.W. Bush, "Remarks at the Billy Graham Library Dedication in Charlotte, North Carolina," May 31, 2007. 
excellent description of President Bush's religious perspective and his seeming separation of faith and politics.

Bush is a mainline Protestant, an Episcopalian, and, although he is a religious man, he is uncomfortable with pietistic politics. The evangelical world of public witnessing, of stories of sin and redemption, of calls for moral renewal, are as alien to Bush as they are to most mainline Protestants. As one of his own evangelical aides confirmed, Bush did not like talking about faith. His Episcopalian sensibility meant that one should not wear one's religion on one's sleeve. $^{53}$

Probably because of this discomfort, Fowler et al. continued, "It was never clear how much Bush's political actions derived from his religious beliefs. Nor were the political implications, if any, of his religious beliefs clear." Compare this to Fowler et al.'s description of Carter.

A born-again Southern Baptist, a Sunday school teacher, and by all accounts a devout man, Carter's faith mattered to him, and he appears to have drawn close conscious links between his faith and his politics...Jimmy Carter's political endeavors [the Camp David Accords, his human rights advocacy, his environmental politics as "biblical stewardship of God's creation"] are closely connected to his understanding of Christian faith. ${ }^{54}$

Because of his discomfort with expressing his faith publicly, the first President Bush employed his son George W. as his personal liaison to the evangelical community because the son was much better than the father at talking about the faith of the evangelical world. ${ }^{55}$ It may be telling as well that neither Ford nor the first President Bush (nor Lyndon Johnson) has a biographical entry in the Djupe and Olson, Schultz,

\footnotetext{
${ }^{53}$ Fowler et al., Religion and Politics in America, p. 120.

${ }^{54}$ Ibid., p. 118.

${ }^{55}$ David Aikman, A Man of Faith: The Spiritual Journey of George W. Bush (Nashville, TN: W Publishing Group, 2004), pp. 80-84.
} 
et.al., and Balmer reference books. Carter appears in all three, and the entries consistently noted Carter's private and public Christian faith.

\section{Ronald Reagan}

President Ronald Reagan, too, identified himself as an evangelical, was very popular with evangelical voters and the new Christian Right movement of the 1980s, and worked closely with Pope John Paul II to de-legitimize the Soviet Union's "evil empire." ${ }^{56}$ But again unlike Carter, Reagan was not a regular churchgoer, was divorced, came up from Hollywood, and he was not especially Biblically literate. Moreover, his biography lacks the evangelical, born-again character of personal faith, church involvement, doubt, failure, repentance, and rededication that one finds with Carter (and George W. Bush). ${ }^{57}$ His faith, according to Jeff Walz, was "opaque and ambiguous." ${ }^{58}$ Similarly, Randall Balmer explained, while Reagan had the electoral and political support of evangelicals, "his own religious commitments remained rather tepid. ${ }^{59}$ As president, Reagan did not forge personal international bonds based on shared religious faith and personal witness (Pope John Paul II the possible exception). His religious rhetoric tended to be blandly theocentric or God-centered, and although his positions on moral issues, such as abortion and school prayer, conformed with the

\footnotetext{
${ }^{56}$ J. David Woodward, "Ronald Reagan," in Encyclopedia of American Religion and Politics, pp. $353-$ 354; Marsha Richards, "Ronald Reagan," in Encyclopedia of Religion in American Politics, p. 207.

${ }^{57}$ Fowler et al., Religion and Politics in America, p. 119; Jeff Walz, "Religion and the American Presidency," in In God We Trust? Religion and American Political Life, edited by Corwin E. Smidt (Grand Rapids, MI: Baker Book House Company, 2001), pp. 198-199.

${ }^{58}$ Walz, "Religion and the American Presidency," in In God We Trust?, pp. 196.

${ }^{59}$ Balmer, Encyclopedia of Evangelicalism, p. 476.
} 
views of many evangelicals, the Reagan administration did not make those issues a priority. $^{60}$

\section{Bill Clinton}

Like Reagan, President Bill Clinton knew the evangelical talk quite well and, as candidate and president, he even "drew on religious themes," such as his vision of a "New Covenant" with the American people. ${ }^{61}$ Clinton, furthermore, is known for his ability to move religious audiences, particularly black Christians. As the Reverend Joseph Lowery, a civil rights leader from Atlanta, Georgia, explained,

The boy can preach...He and I became friends because he loved preaching. He can preach, but he also knows how to go to a black church and just melt into the woodwork. He becomes an invisible white man. He becomes a black man in the pews. ${ }^{62}$

Clinton is quite comfortable addressing church congregations and attended church regularly. He is familiar with the Bible and church hymns and sought counsel from his pastor in Little Rock, W.O. Vaught, on various social issues. Following Carter, he also said he had a born-again experience. But like Nixon, there seems to be a disconnect between the public and private Clinton. As Bert Rockman wrote,

A politician, like any of us, has a public side and a personal side, and the two do not always coincide. Nixon's public face was sanctimony; his private one vulgarity and prejudice... The sobriquet 'Slick Willie' for Clinton was to the

\footnotetext{
${ }^{60}$ Steve Bruce, The Rise and Fall of the New Christian Right: Conservative Protestant Politics in America, 1978-1988 (Oxford, UK: Clarendon Paperbacks, 1990), pp. 134-137; Matthew C. Moen, The Transformation of the Christian Right (Tuscaloosa, AL: University of Alabama Press, 1992), p. 94.

${ }^{61}$ James L. Guth, "William Jefferson Clinton," in Encyclopedia of American Religion and Politics, p. 107; Fowler et al., Religion and Politics in America, pp. 120-121.

${ }^{62}$ Lowery's remarks in DeWayne Wickham, Bill Clinton and Black America (New York: Ballantine Books, 2002), p. 26.
} 
Republicans what 'Tricky Dickie' for Nixon was to the Democrats-an expression of their confidence that the individual in question, regardless of any number of rebirths and apologies was, at bottom. an incorrigible cad. ${ }^{63}$

The sexual and financial scandals during the Clinton years and impeachment undermined his "moral/religious" credentials with the American public. They liked Clinton the president. but not necessarily Clinton the man.

The point here is not to suggest that modern presidents, other than Carter. were not religious. The degree of one's faith is ultimately beyond the scope of academic analysis. The human heart. including that of presidents, cannot fully be known. But what seems clear is that no president since Franklin Rooserelt except Carter (and perhaps George W. Bush) has simultaneously built a reputation for being personally and publicly religious, who made it clear that his faith would be politically consequential. and who inspired successors to embrace evangelicalism. specifically "the inflections of a white southern Evangelicalism. ${ }^{* 64}$

While Kennedy broke the glass ceiling for Catholics and greatly reduced public mistrust of Catholic politicians, he did so by largely downplaying his Catholicism. Additionally, he left no so-called "Catholic" legacy; more than four decades later. no other Catholics have been elected president. While there have been a number of Catholic vice-presidential candidates (William Miller, Edmund Muskie. Tom Eagleton. Sargent Shriver, and Geraldine Ferraro). no Catholic still has ever served as vice president. In contrast. Carter had an immediate and lasting impact.

\footnotetext{
${ }^{63}$ Bert A. Rockman. "Cutting With the Grain: 1s There a Clinton Leadership Legacy." in The Clinton Legacy, eds. Colin Campbell and Bert A. Rockman (New York: Chatham House Publishers. 2000). p. 284.

${ }^{64}$ E.J. Dionne, "'The Real America,' Redefined." Washington Post. December 19. 2006. A29.
} 
In response to Carter, President Ford, in 1976, also claimed he was an evangelical. In 1980, all three major presidential candidates ran as evangelicals. And since Carter, Presidents Reagan, Bush Sr., Clinton, and George W. Bush claimed to be evangelicals. Vice presidents Dan Quayle and Al Gore emphasized their evangelicalism, too. In 1988, two Christian ministers, Pat Robertson and Jesse Jackson, respectively sought the Republican and Democratic presidential nominations and did better than several more established politicians. If 1976 was "the year of the evangelicals," what may be said of the presidency and the pursuit of the presidency from Carter to George W. Bush? It may not be an exaggeration to assert that there has been a "Carter effect"- the evangelization of the presidency, to a greater or lesser degree, for more than a quarter-century. ${ }^{65}$

Like Carter, many presidents were raised in religious homes, were privately devout, could effectively appeal to various religious communities at election time, or knew the language of faith. However, they lacked the whole religious package of Carter: private devotion and public witness, a changed personal life and a desire to morally clean up Washington, an understanding of politics as a form of Christian ministry and calling. Unlike most other presidents, Carter's religious faith and his determination to politically apply religious principles is a crucial part of telling his presidential story or narrative. ${ }^{66}$

\footnotetext{
${ }^{65}$ Andrew R. Flint and Joy Porter, "Jimmy Carter: The Re-Emergence of Faith-Based Politics and the Abortion Rights Issue," Presidential Studies Quarterly 35.I (March 2005): 28-51.

${ }^{66}$ Evan Cornog, The Power and the Story: How the Crafted Presidential Narrative Has Determined Political Success from George Washington to George W. Bush (New York: Penguin Press, 2004).
} 
Later, it will be shown that Carter established faith-based, fellowship bonds with international leaders, namely Egyptian President Anwar Sadat, and he had a faith-based and inspired foreign policy. Principles from the Sermon on the Mount, in particular, formed the heart of Carter's foreign policy and his faith was a major factor in his pursuit for peace in the Middle East. Unlike other presidents, who in their own words, viewed the region in almost wholly secular terms, Carter viewed the region through a religious lens. To a greater degree than other presidents, religious faith figures large in the presidential and public life narrative of Carter. While his faith-based political style may have contributed to political problems at home, particularly with the liberal wing of the Democratic Party, the case of Camp David illustrates that in certain circumstances Carter's "different way of governing" could be successful.

\section{"The Presidency is a Place for Men of Politics"}

There are many things presidents cannot control—let alone even anticipate. It is certainly true, as Stephen Skowronek explained, that each president is not "equally at liberty to be," as Woodrow Wilson once said, "'as big a man as he can"” and "differences among leaders" are not "simply matters of character and skill." ${ }^{67}$ Even so, it is hard to escape the fact that the American presidency has, at any given moment, an occupancy of one. There is a compelling and acute sense that who that occupant is matters and whether if it is this person or that person "can have profound

\footnotetext{
${ }^{67}$ Stephen Skowronek, The Politics Presidents Make: Leadership from John Adams to Bill Clinton (Cambridge, MA: Harvard University Press, 1997), p. xvi.
} 
repercussions." ${ }^{68}$ It is difficult to escape the fact, in Thomas Jefferson's words, that it is the president, to a greater or lesser degree, who steers the vessel of statecraft. ${ }^{69}$ Though there are many things that lie beyond a president's control, he is not helpless. His character matters. ${ }^{70}$ His organizational ability and management style matter. ${ }^{71}$ His combined abilities to communicate, offer a clear vision, work with other politicians, and control his emotions matter. ${ }^{72}$ His understanding of the public's expectations of the office matters. ${ }^{73}$ His "strategic skill" and "tactical capacity" matter. ${ }^{74}$ In short, "individual presidents can make a difference." 75 There is much that they can control. Because of this, presidents are rightly held accountable for the things they can control and how they react to things they cannot. Whether presidents and their supporters like it or not, "we rate him from the moment he takes office" and "we are quite right to do

${ }^{68}$ Fred I. Greenstein, The Presidential Difference: Leadership Sytle from FDR to Clinton (Princeton, NJ: Princeton University Press, 2000), p. 2.

${ }^{69}$ Forrest McDonald, The American Presidency: An Intellectual History (Lawrence, KS: University Press of Kansas, 1994), p. 259.

${ }^{70}$ James David Barber, The Presidential Character: Predicting Performance in the White House (Saddle River, NJ: Prentice Hall, 1992).

${ }^{71}$ John P. Burke, The Institutional Presidency: Organizing and Managing the White House from FDR to Clinton (Baltimore, MD: The Johns Hopkins University Press, 2000).

${ }^{72}$ Greenstein, The Presidential Difference, pp. 5-6.

${ }^{73}$ Stephen J. Wayne, "Great Expectations: What People Want From Presidents," in Rethinking the Presidency, ed. Thomas E. Cronin (Boston, MA: Little, Brown and Company, 1982), pp. 185-199.

${ }^{74}$ Erwin C. Hargrove and Michael Nelson define "strategic skill" as "the ability to formulate coherent policy goals that match the historical situation" and "tactical capacity" as the ability "to construct coalitions of power holders to secure agreement on particular questions." See Presidents, Politics, and Policy (New York: Alfred A. Knopf, 1984), pp. 87-91.

${ }^{75}$ Ibid., p. 87. 
so. ${ }^{76}$ Even in death, presidents cannot escape or find reprieve in assessments of their individual leadership and performance. This is not to say that presidents can be a Superman always "able to leap tall separations of power in a single bound" or to add to the already inflated and impossible expectations and standards of presidential success. ${ }^{77}$ But presidents can and do vary in their effectiveness - their ability to make "the most of what you have to work with." 78

In Presidential Power and the Modern Presidents, considered a modern classic on the do's and don'ts of presidential leadership, Richard Neustadt described how modern presidents could make their constitutional powers work for them, "how to be on top in fact as well as name."79 He said modern presidents need to be activists and experienced, and possess a healthy passion for politics. ${ }^{80}$ "The Presidency is a place for men of politics," in fact, "extraordinary politicians."

In the American political system of "separated institutions sharing powers." presidents cannot command. ${ }^{82}$ A president may say "do this, do that," but "nothing will happen." ${ }^{83}$ A president must, therefore, take and make his case before his five core

\footnotetext{
${ }^{76}$ Richard E. Neustadt, Presidential Power and the Modern Presidents: The Politics of Leadership firom Roosevelt to Reagan (New York: The Free Press, 1990), p. 3.

${ }^{77}$ Michael A. Genovese, The Presidential Dilemma (New York: HarperCollins Publishers, 1995), p. 8: Theodore J. Lowi, The Personal President: Power Invested, Promise Unfulfilled (Ithaca, NY: Cornell University Press, 1985).

${ }^{78}$ Hargrove and Nelson, Presidents, Politics, and Policy, p. 90.

${ }^{79}$ Neustadt, Presidential Power and the Modern Presidents, $\mathrm{p} . \mathrm{xx}$.

${ }^{80}$ Ibid., pp. 151-152.

${ }^{81}$ Ibid., pp. 152-153.

${ }^{82}$ Ibid., p. 29.
} 
constituencies: the bureaucracy, the Congress, his party, the American people, and international leaders. ${ }^{84}$

Presidents cannot avoid politics; they must embrace it. Since presidents cannot command, they must be political, know and work with their respective audiences, and learn and develop the art of political compromise. The bottom line is they must exercise "the power to persuade" and "the power to persuade is the power to bargain. Even earlier, during Wilson's presidency, Max Weber, in his essay "Politics as a Vocation," warned of politicians who placed their personal morals above politics. ${ }^{86}$ This class of politicians he deemed irresponsible. "It is in the nature of officials of high moral standing to be poor politicians," indeed, "irresponsible politicians." ${ }^{87}$ Their poor performance, he explained, was due to their adherence to moral absolutes, what he variously and interchangeably called "the ethic of the Sermon on the Mount," "the absolute ethic of the gospel," or "the ethic of ultimate ends." $" 88$

These politicians, who tend to strive to be "saintly in everything," invariably fail because they fail to recognize the "ethical paradoxes" and the "ethical irrationality of the world." ${ }^{89}$ They fail to realize, as the early Christians did, that to enter politics, a

\footnotetext{
${ }^{83}$ Ibid., p. 24.

${ }^{84}$ Ibid., p. 8.

${ }^{85}$ Ibid., pp. 11, 32

${ }^{86}$ Max Weber, "Politics as a Vocation," in From Max Weber: Essays in Sociology, eds. H.H. Gerth and

C. Wright Mills (New York: Oxford University Press, 1958 paperback edition), pp. 77-128.

${ }^{87}$ Ibid., p. 95.

${ }^{88}$ Ibid., pp. 119-I20.

${ }^{89}$ Ibid., pp. 119, 122, 125.
} 
world "governed by demons," that one "contracts with diabolical powers." 90 In their attempt to apply otherworldly ethical standards to human, this-worldly situations, these politicians typically fail to think through the full consequences of their morally-driven acts. Unfortunately, however, Weber believed that religious politicians are usually satisfied in saying something like: "the Christian does rightly and leaves the results with the Lord," and they take solace in the mere fact that their actions are noble, rightly intended. ${ }^{91}$ The great danger is that politicians who speak of "love" may risk the bodies of others to save their own souls or blame others for negative policy results.

The accession to the presidency of politicians of a very different disposition Woodrow Wilson, Jimmy Carter, and George W. Bush - indicates that Neustadt's desired attributes are certainly not essential to attaining the office. Periodically. political circumstances in the United States appear to call for chief executives who are "amateur" political outsiders and "men of faith" who pursue "the ethic of the Sermon on the Mount," "the absolute ethic of the gospel" or "the ethic of ultimate ends." These are also the presidents who demonstrate what is termed here as an evangelical style of presidential leadership. This style as we will see in this study of Carter stands in stark contrast to the political professionalism valued by Neustadt and his followers.

Of course, Neustadt believed such leaders were bound to fail as presidents because they failed to comprehend both the institutional limitations on presidential power and the diminishing utility of moral exhortation in achieving presidential goals in a pluralistic political system of multiple independent interests. Weber strongly

\footnotetext{
${ }^{90}$ Ibid., p. 123.

${ }^{91}$ Ibid., p. 120.
} 
prescribed two rules of thumb for politicians: 1) "politics is made with the head, not with other parts of the body or soul", and 2) "whoever wants to engage in politics at all...has to realize... ethical paradoxes," namely good means can and often does produce evil results and evil means can and often does produce good results. ${ }^{92}$ The responsible politician, he claimed, must pursue the mundane, yet necessary, activities of compromise, bargaining, logrolling, pork spending, patronage, burden-sharing, and the occasional use of force. They must have control over their passion and emotions, what he called the "firm taming of the soul," have "a feeling of responsibility," and "a sense of proportion." ${ }^{93}$ If one cannot accept these realistic maxims of responsible leadership, Weber recommended that he pursue nonpolitical vocations. "He who seeks the salvation of the soul, of his own and others, should not seek it along the avenue of politics." 94 Because when they do, these politicians only seek to ensure that "the flame" of their "pure intentions is not quelched," choosing objectives that may not have tangible results, that may not have any realistic conclusion, only goals that have "exemplary value," rekindling "the flame ever anew." "A5 "Anyone who fails to see this," Weber contended, "is, indeed, a political infant," an "amateur" in Neustadt's words. ${ }^{96}$

\footnotetext{
92 Ibid., pp. 115, 125.

${ }^{93}$ Ibid., p. 115.

${ }^{94}$ Ibid., p. 126.

${ }^{95}$ Ibid., p. I21.

${ }^{96}$ Ibid., p. 123.
} 
Weber's concerns admittedly do not appear to apply to most American presidents. All presidents may, and often do, offer vague, largely non-controversial acknowledgements of God and some transcendent purpose for the country. ${ }^{97}$ Michael Gerson, chief speechwriter for George W. Bush and originator of many of Bush's own religious references, for instance, explained that among the key categories of presidential religious rhetoric are offering "comfort in grief and mourning.." acknowledging the "historic influence of faith on our country," making "literary allusions to hymns and scripture," and identifying the role of Providence. ${ }^{98}$ In other words, the religious rhetoric of presidents is essentially civic-oriented. The content is theologically fuzzy, nonsectarian, and largely non-offensive (at least on the home front). It is a speech that embraces "neither the religion of a particular church, not at the other extreme, a fully articulated religion that competes with existing denominations." ${ }^{.99}$ It is a speech that aims "to harmonize" peoples from various religious backgrounds.

Protestant and Catholic, Christian and non-Christian.

Beyond the occasional, ceremonial, religious rhetoric, presidential and presidential aspirants, out of respect for the church-state principle of separation and the country's religious pluralism, tend to keep their personal faith separate from their politics, avoid sectarian religious language (e.g., invoking the name of Jesus Christ). or

\footnotetext{
${ }^{97}$ Thomas E. Cronin, "The Symbolic and Shamanistic Functions of the American Presidency," The Political Chronicle 1.2 (1989): 8-13; A. James Reichley, Faith in Politics (Washington, DC: Brookings Institution Press, 2002), p. 5.

${ }^{98}$ Michael Gerson, "Religion, Rhetoric and the Presidency: A Conversation with Michael Gerson." The Pew Forum on Religion and Public Life, December 6, 2004. http: pew forum.org events.

${ }^{99}$ Kenneth D. Wald, Religion and Politics in the United States (New York: St. Martin's Press. 1987). p. 49.
} 
claim that their faith is too personal to discuss publicly. ${ }^{100}$ Another concern or obstacle to faith-based politics is that since presidents inhabit "the high stakes world of realpolitik, the 'religious niceties' of their faith often give way to Machiavellian calculations." "Presidents are, after all, very much political animals, and they are in the business of making political judgments and calculations."

\section{Forerunners of the Evangelical Presidential Style: Bryan and Wilson}

Compared to most modern presidents, Carter's governing style was unique. It must be clarified, however, that his "evangelical" presidential style was not sui generic. Carter was not the first national political leader or president ever to employ this style. What may be said is that Carter belongs to a subset of presidents and would-be presidents who typically deviated from the customary rhetorical and behaviorial expectations of political leadership. What Carter actually did as president was to resurrect an alternative form of leadership from the late nineteenth-early twentieth century and apply it to the present. It may be said that he was the first "modern," postFDR president to use it, but not necessarily the last.

In several respects, the leadership style of George W. Bush is strikingly similar to Carter's. ${ }^{102}$ But even among Carter's successors who did not fully adopt his alternative style, Reagan, Bush, Sr., and Clinton did minimally claim to be evangelicals,

\footnotetext{
${ }^{100}$ Hutcheson, God in the White House, p. 2; Charles W. Dunn, "The Theological Dimensions of Presidential Leadership: A Classification Model," Presidential Studies Quarterly 14.1 (1984): 61-72.

${ }^{101}$ Fowler et al., Religion and Politics in America, p. 116.

102 Berggren and Rae, "Jimmy Carter and George W. Bush," 606-632.
} 
used evangelical language, and courted evangelical voters. ${ }^{103}$ After Carter, being an evangelical became politically fashionable for presidents and presidential aspirants. In this respect, it may be said that Carter evangelized the presidency.

To understand Carter and his style, a discussion of his political kindred spirits is worthwhile. What Carter offered was not entirely foreign to the American scene. though it may be in the presidential literature. To ground our understanding of Carter before we move ahead, we look here to two major personalities, both of whom were Democrats and with ancestral or residential roots in the South, in the late nineteenth and early twentieth century: William Jennings Bryan and Woodrow Wilson. For readers familiar with Carter, the similarities among Bryan, Wilson, and Carter (and George W. Bush) should be readily apparent. For those not as familiar, it is recommended to keep the brief points about Bryan and Wilson in mind. This is a study of Carter, but it is also study about an alternative form of presidential leadership.

\section{William Jennings Bryan}

"By George, [Bryan] would make the greatest Baptist preacher on earth." ---Theodore Roosevelt

William Jennings Bryan may be the first major politician and major party presidential candidate who possessed what will be defined here as an "evangelical" style. Perhaps, had Bryan been elected president in one of his three bids, he would be

\footnotetext{
${ }^{103}$ Hutcheson, God in the White House, pp. ix, 212-213, 245.

${ }^{10+}$ Quoted in Doug Linder, "William Jennings Bryan (1860-1925),"

http:/www.law.umkc.edu/faculty/projects/ftrials/scopes/bryanw.htm (accessed October 18. 2006).
} 
the first counterexample to prevailing presidential norms and expectations. Still, he is pertinent to this project.

Bryan not only helped form the modern Democratic Party and contributed to its move toward the promotion of economic social justice, but ultimately, as various biographers have described him, he was a "defender of the faith," a promoter of "righteous" causes, and "a godly hero."105 Beginning with his famous 1896 "Cross of Gold" speech, his political style stood out as distinctly "revivalist."

Bryan, as we will see with Carter, viewed politics as an alternative means of Christian service, "the cornerstone of social relations."107 The "Great Commoner" from Nebraska, three-time Democratic presidential nominee (1896, 1900, and 1908), and later Wilson's first Secretary of State (1913-1915) believed that "politics should be a moral enterprise and that religion should purify the political world." His religious speech was not for ceremonial purpose or to justify the status quo. He was no civic priest. Instead, he believed "the duty of a true Christian was to transform a nation." 108 Bryanism was a mix of "Jefferson and Jesus," a "synthesis of evangelical Protestantism and republicanism," a merging of "crusading with governing." 109 Cherny concluded his study of Bryan this way,

\footnotetext{
${ }^{105}$ Robert W. Cherny, A Righteous Cause: The Life of William Jennings Bryan (Norman, OK: University of Oklahoma Press, 1994), p. viii; Michael Kazin, A Godly Hero: The Life of William Jennings Bryan (New York: Alfred A. Knopf, 2006), p. xix; Levine, Defender of the Faith: William Jennings Bryan. the Last Decade, 1915-1925.

${ }^{106}$ Nicol C. Rae, Southern Democrats (New York: Oxford University Press, 1994), p. 11.

${ }^{107}$ Cherny, A Righteous Cause, p. 195.

${ }^{108}$ Kazin, A Godly Hero, p. xx.

${ }^{109}$ lbid., pp. xiv, 219.
} 
As an evangelical Protestant, his concepts of Christian duty and service and his belief in perfection led him to seek to rescue people from industrial oppression and from immorality. As a public figure, he found Christian love more compelling than logic. ${ }^{110}$

Bryan was personally devout, too. He frequently read his Bible and went to church. His teetotaling revealed his pietism, and he had a reputation for "sincerity, honesty, geniality, and wholesomeness."111

Bryan campaigned like an evangelist, as well. He was the first major party candidate to actually campaign for the presidency. He broke the precedent of past candidates "by taking his case directly to the people." "12 Like the evangelist who travels the country in search of souls to save, Bryan traveled the country using whatever modern means available in search of votes. Like the evangelist, his voice was his instrument. Like followers of a successful evangelist, Bryan's supporters were intensely devoted to him, particularly in the South. His followers were often called Bryanites and the South was said to be "the most thoroughly Bryanized region in the country."113 At a personal level, former Georgia Governor and Senator Zell Miller, for instance, noted that his mother, Birdie Bryan, "took pride that we may have been related to the old Democratic warhorse, William Jennings Bryan. It doesn't matter that we're not." 114

\footnotetext{
${ }^{110}$ Cherny, A Righteous Cause, p. 204.

${ }^{111}$ lbid., p. 203.

${ }^{112}$ Ibid., pp. 66, 71 .

${ }^{113}$ Quoted in Dewey W. Grantham, Southern Progressivism: The Reconciliation of Progress and Tradition (Knoxville, TN: University of Tennessee Press, 1983), p. 353.

${ }^{11+}$ Zell Miller, A National Party No More: The Conscience of a Conservative Democrat (Atlanta, GA:
} Stroud \& Hall Publishers, 2003), p. 21. 
Bryan, like Carter, believed that the model and message of Jesus had power and relevancy in the modern world, especially in international affairs. He offered what was termed a "new gospel for the nations." 115 With the "Prince of Peace" as the model, he believed that states in the international system should be one based on peace and brotherhood. He often said, "the Gospel of the Prince of Peace gives us the only hope the world has." 116 He rejected the conventional notion that the standards for individual morality and public morality were different. As reminder of one's Christian duty to work for peace, he widely distributed a "plowshare paperweight," a powerful image of peace from the Book of Isaiah. ${ }^{117}$ As Carter too would use the Sermon on the Mount as a guide for his foreign policy, Bryan argued, "We Americans should make the Sermon on the Mount real in the law of nations." "118

Bryan biographer Robert Cherny records that Bryan was widely viewed as "the nation's leading defender of evangelical Protestant values," as evinced by his lead role in the 1925 Scopes Monkey Trial and his support for the prohibition of alcohol. ${ }^{19}$ Cherny noted as well that many contemporaries viewed him as having "an apostolic zeal," as being "the greatest moral force of his day," "never did unworthy or mean things," and he tried "always to do the right as he saw it." 120

\footnotetext{
${ }^{115}$ Kazin, A Godly Hero, p. 228.

${ }^{116}$ Cherny, A Righteous Cause, p. 136.

${ }^{117}$ Ibid., p. 155.

${ }^{118}$ Kazin, A Godly Hero, p. 244.

${ }^{119}$ Cherny, A Righteous Cause, p. 183.

${ }^{120}$ Ibid., p. 184.
} 
Win or lose, regardless of political consequence, Bryan believed that "I must continue to fight the battles of the people, for what I think is right and just." ${ }^{121}$ And if necessary. Bryan said, he would fight "single-handed and alone. I care naught whether I am ever elected to an office or not." Instead, Bryan saw his mission as being "the instrument for spreading the truth, and he counted his success more by converts to his cause than by offices he won." 122

With this unothrodox view of politics, Bryan found compromise difficult. More directly, Kazin said, Bryan "abhorred compromise." ${ }^{123}$ He would rather lose an election. which he did three times, or resign from office, as he did in 1915 as Secretary of State, than sacrifice Christian principle. Because he had a "habit of clothing almost every issue in Biblical metaphors." Bryan found it hard to bargain and reevaluate decisions. ${ }^{124}$ "Once committed," Cherny says, "he held doggedly to a cause long after other politicians moved on to other concerns." His commitment to free silver long after the issue faded from the national agenda is but one example. What mattered more to him than winning was fighting "with courage for principle." 125 This, according to Cherny, "set him apart from most other politicians." 126 Kazin concurred. "Once he

\footnotetext{
${ }^{121}$ Ibid., p. 47.

122 Ibid., p. 189.

${ }^{123}$ Kazin, A Godly Hero. p. 304.

${ }^{124}$ Cherny, A Righteous Cause, pp. 202-203.

${ }^{125}$ Ibid., p. 188.

${ }^{126}$ Ibid., p. 202.
} 
framed a question in stark moral terms, no retreat was possible." ${ }^{\prime 27}$ As such he concluded, Bryan was "a better prophet" than politician or diplomat. ${ }^{128}$

\section{Woodrow Wilson}

"Christ came into the world to save others, not to save himself; and no man is a true Christian who does not think constantly of how he can lift his brother, how he can assist a friend, how he can enlighten mankind, how he can make virtue the rule of conduct in the circle in which he lives." 129

---Woodrow Wilson (1914)

Presidential observers have long recognized that Woodrow Wilson offered an alternative, perhaps unique, form of presidential leadership and style. His style was uncharacteristically and unmistakably religious. Though he was a college professor, a college president, a former president of the American Political Science Association, Wilson's temperament has been characterized as "essentially theological not intellectual." ${ }^{\prime 30}$ His particular brand of governing stands out so among presidents that it even bears his name--"Wilsonian."

According to Richard Hutcheson, there was one exception to the normal relationship between a personal faith and presidential politics in the pre-New Deal era

\footnotetext{
${ }^{127}$ Kazin, A Godly Hero, p. 239.

${ }^{128}$ Ibid., p. 234.

${ }^{129}$ Woodrow Wilson, “Address at the Young Men's Christian Association's Celebration in Pittsburgh, Pennsylvania," October 24, 1914, The American Presidency Project, http:/www.presidency.ucsb.edu/ws.

${ }^{130}$ Quoted in Michael Elliott, "The Trouble with Saving the World," Time, December 30, 2002-January 6. 2003, p. 108.
} 
and that was Woodrow Wilson. ${ }^{131}$ "He was a special case." Hutcheson explained. His -importance lay in his uniqueness - as the most overtly religious of the pre-modern presidents and the one whose personal religion had the most effect on his approach to public policy." Unlike his predecessors and immediate successors. Hutcheson continued. "only Woodrow Wilson allowed deep personal religious commitment to become evident in presidential policymaking."

In an earlier study, Robert Alley, too, noted that "Wilson came to the White House as the most Christian of Presidents" and he "saw most political decisions in moralistic terms."132 Similarly, Kenneth Woodward remarked, "Woodrow Wilson... was one of the few presidents of whom it could be said that to know his religious pedigree was to know the man." ${ }^{133}$ Biographer Louis Auchincloss said Wilson was "passionate in his relationship with God." ${ }^{134}$ Forrest McDonald described Wilson"s image of himself as something a "little short of messianic" and who had a tendency to view every political issue "in terms of a great moral crusade." ${ }^{35}$ Richard Gamble said Wilson offered a "gospel of service" and pictured himself as "an international Good

\footnotetext{
${ }^{131}$ Hutcheson, God in the White House, pp. 33, 55.

1:2 Robert S. Alley, So Help Me God: Religion and the Presidencl; Wilson to Nixon (Richmond. VA: John Knox Press, 1972), pp. 33, 35.

133 Kenneth L. Woodward. "Gospel on the Potomac." Newsweek, March 10. 2003, p. 29.

${ }^{134}$ Louis Auchincloss, Transcript Part Two. American Experience: Woodrow Wilson. narrated by Linda Hunt, directed and produced by Carl Byker and Mitch Wilson (WGBH Educational Foundation. 2001). http:/www.pbs.org/wgbh/amex/wilson/filmmore/fm trans2.html. (accessed September 18. 2006).
}

${ }^{135}$ McDonald, The American Presidency: An Intellectual History, p. 359-360. 
Samaritan with all the world for a neighbor."136 Wilson had a "rigid, self-exacting personality," said Robert Dallek, "whose uncompromising adherence to principles barred agreement on some of his most important political goals."137 James David Barber explained that Wilson was not merely an "active" president, but that he was a president who "quite openly identified his cause with God's cause." 38 He saw himself as God's instrument on earth to see through that "God's will would triumph." And, journalist Chris Wallace said, Wilson was a president on a "mission from God.",139

Wilson viewed politics and America's mission in the world as a form of ministry, "the vindication of right, of human right." 140 With "no selfish ends to serve," "no conquest, no dominion," and "no material compensation for the sacrifices we shall freely make," Wilson saw it as his fundamental presidential responsibility, whether at home or abroad, to govern according to the "principles of right and of fair play" and to "share with all free peoples" America's religious and political values. Indeed, Wilson believed, "America was created to unite mankind"; it is a "special example" for the rest of the world. ${ }^{141}$

\footnotetext{
${ }^{136}$ Richard M. Gamble, "Savior Nation: Woodrow Wilson and the Gospel of Service," Humanitas 14.1 (2001): 10 .

${ }^{137}$ Robert Dallek, "Woodrow Wilson, Politician," The Wilson Quarterly (Autumn 1991): 106.

${ }^{138}$ Barber, The Presidential Character, pp. 52-53.

${ }^{139}$ Chris Wallace, "Mission from God: Woodrow Wilson and the League of Nations," in Character: Profiles in Presidential Courage (New York: Rugged Land, 2004), p. 165.

${ }^{140}$ Dallek, "Woodrow Wilson, Politician," The Wilson Quarterly; Wilson, "War Message to Congress." April 2, 1917.

${ }^{1+1}$ Woodrow Wilson, "Address to Naturalized Citizens at Convention Hall in Philadelphia, Pennsylvania," May 10, 1915, The American Presidency Project, http://www.presidency.ucsb.edu ws.
} 
American involvement and success in World War I for Wilson was a crusade and American soldiers were "crusaders." $1+2$ He did not send them abroad "to prove the might of the United States." No, he said, they were sent "to prove the might of justice and right" and lead the very "redemption of the world." In fact, it was "nothing less than liberation and salvation of the world"; it was a "transcendent achievement."

This, for Wilson, is the essence of politics-a commitment to "public service shot through with principle and honor" and filled with "profound impulses of sympathy which connect him with the rest of mankind. ${ }^{-1+3}$ Politics is the pursuit of justice. rectifying the wrong. and alleviating suffering. ${ }^{1+4}$ "Not niggardly or selfish." it is the sharing of things Americans enjoy, "human liberty and the rights of man... with the whole world." 145 True presidential leadership. Wilson believed. is not about popularity. it is showing that "you are not afraid of anybody except God and his final verdict." This vision was not mere war-time rhetoric. He sounded themes of changing the world before American entry into the war and before the war in Europe even began.

In 1909. before he was president, before he was elected governor of New Jersey, he told an audience at the University of North Carolina, how he wished and hope for "some great orator" to rise above petty self-interest and selfishness and instead "make

\footnotetext{
$1+2$ Woodrow Wilson, "Remarks in Support of the League of Nations in Pueblo. Colorado." September 25, 1919. The American Presidency Project, http: www.presidency.ucsb.edu ws.

${ }^{143}$ Woodrow Wilson, "Address at Congress Hall in Philadelphia. Pennsylvania." October 25. 1913. The American Presidency Project, http: /www.presidency.ucsb.edu ws.

${ }^{1+4}$ Woodrow Wilson, "First Inaugural Address," March 4, 1913. The American Presidency Project. http. www presidency ucsb.edu/ws.
} 
men drunk with this spirit of self-sacrifice" in the United States and throughout the world. ${ }^{146}$ In short, on this occasion, Wilson pleaded for a politics not of "material advantage," but a politics that "seeks those things which are of the spirit." It is far better for a nation to be poor, but with "purified purpose," than to be a "rich nation in the wrong" that "destroys the fair work that God has permitted and man has wrought."147

In his First Inaugural Address, Wilson stated that the duty of his administration was to transform a "government too often debauched and made an instrument of evil" by past administrations. It was his duty "to cleanse, to reconsider, to restore, to correct the evil without impairing the good, to purify and humanize every process of our common life." $" 148$

Later in his first year as president, Wilson reiterated these themes before another Southern audience. "It is a very perilous thing to determine the foreign policy of a nation in terms of national material interest." "It is not only fair to those whom you are dealing," Wilson added, "it is degrading as regards [to] your own actions." It would be far better for the United States to be "a poor nation that was free than to be a rich nation that ceased to be in love with liberty." What guides him and ought to guide his country, Wilson concluded, are moral principles. "Morality and not expediency is the thing that

\footnotetext{
${ }^{145}$ Woodrow Wilson, "Remarks at Independence Hall in Philadelphia, Pennsylvania," July 4, 1914, The American Presidency Project, http://www.presidency.ucsb.edu/ws.

${ }^{146}$ Woodrow Wilson, "Remarks on Robert E. Lee at the University of North Carolina in Chapel Hill, North Carolina," January 19, 1909, later published as Robert E. Lee: An Interpretation (Chapel Hill, NC: University of North Carolina Press, 1924), pp. 41-42.

${ }^{147}$ Ibid., p. 39.

${ }^{148}$ Wilson, "First Inaugural Address," March 4, 1913.
} 
must guide us and that we will never condone iniquity because it is most convenient to do so." 149

Months before the United States would enter the war in April 1917. Wilson. speaking before the U.S. Senate in January, said that the country, whether it participated in the war or not, had a tremendous, unprecedented role to play. ${ }^{150}$ Its task was nothing less than to "show mankind the way to liberty," by working to promote the post-war formation of "a League of Peace." For Wilson, "a community of power" must replace traditional notions of "a balance of power" as the central organizing principle in international affairs. ${ }^{151}$ In this, he believed himself proven right by the Great War, which had "now forever discredited," "the great game... of the balance of power."152 In his 1919 campaign for the League, Wilson told crowds of his intentions were nothing less than to revolutionize international law "by putting morals into it."

Wilson turns Weber's warning upside down. Politics is as much of the heart as of the head. Politics is a means of doing good, promoting morality, reflecting "the spirit of righteousness," and the striving for "the perfectibility of human life." ${ }^{15+}$ Otherwise,

\footnotetext{
${ }^{149}$ Woodrow Wilson, "Remarks to the Southern Commercial Congress in Mobile, Alabama," October 27. 1913, The American Presidency Project, http:/www.presidency.ucsb.edu/ws.

${ }^{150}$ Wilson, "Remarks to the U.S. Senate," January 22, 1917, The American Presidency Project, http://www.presidency.ucsb.edu/ws.

${ }^{151}$ Wilson, "Remarks to the U.S. Senate," January 22, 1917; Wilson, "Second Inaugural Address," March 5, 1917, The American Presidency Project, http://www.presidency.ucsb.edu'ws.

${ }^{152}$ Wilson, "Address to Congress," February 11, 1918, The American Presidency Project, http:/www.presidency.ucsb.edu/ws.
}

${ }^{153}$ Wilson, "Remarks in Support of the League of Nations in Pueblo, Colorado," September 25, 1919. The American Presidency Project, http://www.presidency.ucsb.edu/ws.

${ }^{154}$ Wilson, "Remarks Before the American Bar Association," October 20, 1914, The American Presidency Project, http:/www.presidency.ucsb.edu/ws. 
'no man ought to go into politics." ${ }^{155}$ Parties that forget this, Wilson averred, would soon be turned out of office by the people. This, Wilson believed, is what happened to the Republicans. They were "put out of power because of failure, practical failure and moral failure" because they "served special interests" and thought of profit first. ${ }^{156}$

Perhaps, Wilson's greatest legacy was in the area of foreign policy; it is here that he "casts an especially long shadow." "157 As one writer asserted, "Wilson left a powerful legacy of internationalism and idealism." ${ }^{58}$ While he may not have been the first American president to make "the promotion of American ideals at the center of American foreign policy," this ambition "is most closely associated with him." He offered, what Stephen Skowronek called, a "novel approach" to international politics. ${ }^{159}$ When the term "Wilsonian" is used in the literature it is commonly associated with the frequent use of religious or moralistic rhetoric, a view of politics as a religious calling, idealism, a de facto propensity for unilateralism, an uncompromising posture. and a personalistic style that included efforts to personally convert or actively bring others to democracy, human rights, and peace. Wilson, wrote James Chace, "became

\footnotetext{
${ }^{155}$ Wilson, "Address at Congress Hall in Philadelphia, Pennsylvania," October 25, 1913, The American Presidency Project, http://www.presidency.ucsb.edu/ws.

${ }^{156}$ Wilson, "Speech of Acceptance of the 1916 Democratic Party Nomination," September 2, 1916. The American Presidency Project, http://www.presidency.ucsb.edu/ws.

${ }^{157}$ Elizabeth Edwards Spalding, "True Believers," The Wilson Quarterly (Spring 2006): 40.

${ }^{158}$ Max Boot, "Thomas Woodrow Wilson," in Presidential Leadership: Rating the Best and the Worst in the White House, ed. James Taranto and Leonard Leo (New York: Wall Street Journal Books, 2004). p. 139.

${ }^{159}$ Stephen Skowronek, The Politics Presidents Make: Leadership from John Adams to Bill Clinton (Cambridge, MA: Harvard University Press, 1997), p. 457.
} 
the very personification of the democratic mission." ${ }^{160}$ Describing the Wilsonian mission, Hutcheson said, Wilson had "a sacred mission to share the blessings of freedom and democracy... He saw affairs of state in biblically based moralistic terms." ${ }^{161}$ Cherny said, because Wilson "attached moral dimensions" to whether the United States would recognize a government or not. "missionary diplomacy" might be a good description of his foreign policy. ${ }^{162}$

George Marsden explained, Wilson offered a "secularized postmillennial vision of the American mission-to make the world safe for democracy. "163 Many churches. too, interpreted Wilson's proposed League of Nations as "in effect, an attempt to apply Christian principles to the dealings of nations with one another." Juliette George said. "It is no exaggeration to say that Wilson was aflame with something akin to a religious zeal to "save mankind." There was "a missionary ardor" to his personality." 165

According to Brands, referring to Wilson's Fourteen Points. European leaders sensed the essence of Wilson's style, too. Paraphrasing French President Georges

\footnotetext{
160 James Chace, "Imperial America and the Common 1nterest," World Policy Journal (Spring 2002): 1-9.

${ }^{161}$ Hutcheson, God in the White House, p. 46.

${ }^{162}$ Cherny, A Righteous Cause, p. 143.

${ }^{163}$ George M. Marsden. "Afterword: Religion, Politics, and the Search for an American Consensus." in Religion and American Politics: From the Colonial Period to the 1980s, ed. Mark A. Noll (New York: Oxford University Press, 1990), p. 386.

${ }^{164}$ Quote found in Robert T. Handy, A Christian America: Protestant Hopes and Historical Realities (New York: Oxford University Press, 1984), pp. 160-161.

${ }^{165}$ Alexander L. George and Juliette L. George. Woodrow Wilson and Colonel House: A Personalit. Study (New York: Dover Publications, 1964), p. 198.
} 
Clemenceau, Brands notes, "God gave men ten commandments and they broke every one; now Wilson wanted to impose fourteen."166

Perhaps, one of his successors, Herbert Hoover best summarized and captured the nature of Wilson's foreign policy style and vision. ${ }^{167}$ He described Wilson as a man of "deep convictions," "staunch morals," having a mind that "ran to "moral principles," and was "the personification of the heritage of idealism of the American people," who "brought spiritual concepts to the peace table." Wilson was "a born crusader." Against the advice of his staff, Wilson's active presence at Versailles and his campaign for the League of Nations at home, Hoover believed, were illustrative of his style.

Fundamentally, Hoover said, Wilson's foreign policy could described as "evangelistic idealism," a "gospel of peace for mankind."168 Wilson, said Hoover, sought a new world order where there would be no more empires, no more balance-of- power relations, no more secrecy, no more war. Describing his reception in Europe, Hoover wrote, "It was the star of Bethlehem rising again." 169

He was received everywhere with almost religious fervor by immense outpourings of people. The ovations were greater than had ever come before mortal man. His eloquent development of his basis of peace, with its 'independence of peoples,' 'self-determination,' 'no annexations,' 'justice.' 'right,' a 'new order,' 'freedom of mankind' and a 'lasting peace,' had stirred hope among the masses everywhere in the world. To them, no such man of moral and political power and no such evangel of peace had appeared since

Christ preached the Sermon of the Mount. Everywhere men believed that a new era had come to mankind.

\footnotetext{
${ }^{166}$ H.W. Brands, Woodrow Wilson (New York: Times Books, 2003), p. 90.

${ }^{167}$ Hoover, The Ordeal of Woodrow Wilson, p. xxvii.

${ }^{168}$ Ibid., pp. xxv, 78.

${ }^{169}$ Ibid., pp. 68-69.
} 
Forrest McDonald made this observation, "When Wilson went to Europe after the war tens of millions of people cheered him, and women and children stewed flowers in his path as if he represented the Second Coming."

But Wilson's religious style and messianic visions had a negative side as well. He bluntly told Democratic party officials after his election in 1912, "I owe you nothing." Democratic victory, but a victory made possible by God alone. It was his destiny, he believed, to be president, to be God's instrument. ${ }^{172}$

In this sense, a particularly Calvinist sense, Wilson understood his "election." "God ordained that I should be the next president of the United States."173 "Neither you," he told members of the Democratic National Committee, "nor any other mortal could have prevented that!" For those who did not "match his intellect or share his mission," Wilson, said Kazin, "had to hide his scorn."

According to Barber, Wilson's faith was centered on three axioms: ${ }^{175}$

1) "God judges man by standards of perfection"

2) "life is a constant struggle of good against evil"

3) "there is no room for compromise in that struggle"

\footnotetext{
${ }^{170}$ McDonald, The American Presidency, p. 439.

${ }^{171}$ Steven J. Rubenzer and Thomas R. Faschingbauer, Personality, Character, and Leadership in the White House: Psychologists Assess the Presidents (Washington, DC: Brassey’s Inc.. 2004), p. 129.

172 Walter LaFeber, Transcript Part Two, American Experience: Woodrow Wilson, narrated by Linda Hunt, directed and produced by Carl Byker and Mitch Wilson (WGBH Educational Foundation, 2001). http:/www.pbs.org/wgbh/amex/wilson/filmmore/fm trans2.html, (accessed September 18, 2006).

${ }^{173}$ Rubenzer and Faschingbauer, Personality, Character, and Leadership in the White House, p. 129.

${ }^{174}$ Kazin, A Godly Hero, p. 217.
} 
Wilson, Barber added, was raised in a home environment where "religious principles were beyond debate... where faith meant the prohibition of doubt." 176

As previously mentioned, Weber warned of the politician who thinks it matters more to do "rightly and leaves the results with the Lord," taking comfort in actions having "exemplary value." 177 Wilson could not have better fit the type of politician that concerned Weber. In early adulthood, for instance, Wilson made the following statement: "Leave consequences to God, but do right. Be genuine, real, sincere, true. by right, Godlike." 178 On another occasion, in an essay titled "Christ's Army," that he contributed to a Presbyterian publication, again quoted by Barber, Wilson wrote that in the world "there is no middle course, no neutrality. Each and every one must enlist either with the followers of Christ or those of Satan."

As one who aimed to establish righteousness in the world and as one who saw his election coming from God, not surprisingly, when faced with opposition, Wilson had trouble compromising. He often had an "unwillingness to tolerate opposition." "I am not the kind that considers compromises when I once take my position." Brands observed, whereas "mere mortals wrestled with doubt and confusion," Wilson, full of

\footnotetext{
${ }^{175}$ Barber, The Presidential Character, p. 93.

${ }^{176}$ Ibid., p. 99.

${ }^{177}$ Weber, "Politics as a Vocation," p. 120.

${ }^{178}$ Barber, The Presidential Character, p. 99.

${ }^{179}$ Ibid.

${ }^{180}$ Sidney M. Milkis and Michael Nelson, "Woodrow Wilson and the Defense of Popular Leadership," chapter in The American Presidency: Origins and Development, 1776-2002 (Washington, DC:

Congressional Quarterly Press, 2003), p. 244.
} 
confidence, believed he had "a direct line to heaven." ${ }^{81}$ He exhibited "a certitude his rivals found infuriating." Because he thought God was on his side. Wilson was "afforded...a moral serenity few could match." Regardless of political consequences. Wilson plainly declared, "I want to do right, whether popular or not."182 The words Auchincloss used to describe Wilson were: "stiff, idealistic, hated to compromise. hated small talk." 183

Sidney Milkis and Michael Nelson characterized Wilson's foreign policy as one based "more on altruism and less on narrow considerations of the national interest." and his style as an admixture of "stubbornness and idealism." ${ }^{18+}$ Another described Wilson's speeches of containing "a strong sniff of sanctimony."185 Barber. too. classified Wilson as exhibiting "negative" qualities, namely his rigidity and "the impulse to lash out freely at his enemies." ${ }^{186}$ Max Boot said Wilson could be "pigheaded." 187 In their psychological assessments of Wilson, Rubenzer and Faschingbauer found that Wilson could often be "disagreeable," lacking in modesty. uncooperative, "often thought himself superior to those around him.," tended to blame

\footnotetext{
${ }^{181}$ Brands, Woodrow Wilson, p. 25.

182 lbid., p. 79.

${ }^{183}$ Auchincloss, Transcript Part Two, American Experience: Woodrow Wilson, narrated by Linda Hunt. directed and produced by Carl Byker and Mitch Wilson (WGBH Educational Foundation. 2001). http:/www.pbs.org/wgbh/amex/wilson/filmmore/fm trans2.html. (accessed September 18. 2006)

${ }^{184}$ Milkis and Nelson. The American Presidency; pp. 239, 241.

${ }^{185}$ Boot, "Thomas Woodrow Wilson," p. 136.

${ }^{186}$ Barber. The Presidential Character, p. 56.

${ }^{187}$ Boot, "Thomas Woodrow Wilson," p. 139.
} 
others for his problems, and could be "bullheaded, obstinate, and stubborn."188

Additionally, they found, Wilson took opposition and criticism personally; he was "markedly thin-skinned and sensitive to insults or slights."

\section{Towards an Evangelical Presidential Style}

If these assessments of Bryan and Wilson, both positive and negative, are right. it may be argued that Bryan was the first major party presidential candidate and Wilson was the first modern president to offer and point toward an alternative leadership model and style to the predominant Neustadian/Weberian paradigm. They appear to have originated an approach to governing that will be characterized in this study as the "evangelical" presidential style. The attributes of such a style are directly at odds with aptitude for politics and political professionalism characteristic of Neustadt's model for modern presidents. Indeed, if Bryan and Wilson are used as archtypical examples, the evangelical style can be distinguished by its disdain for "politics as usual" and day-today political bargaining. In their analysis of his involvement at Versailles, George and George said Wilson viewed the political concerns of the other Allied powers as "immorality incarnate" and viewed their leaders as "a cynical and evil crew." 189 Hoover, too, observed that Wilson was inclined to view political bargaining as beneath him, was "impatient with honest and proper argument with his conclusions," and that he took questions and concerns about his policies as "personal criticism.",190

\footnotetext{
${ }^{188}$ Rubenzer and Faschingbauer, Personality, Character, and Leadership in the White House, pp. 129. 131.

${ }^{189}$ George and George, Woodrow Wilson and Colonel House, pp. 201-202.
} 
Though he disagreed with critics" charges that he could be "obstinate" and had a tendency for issuing "little sermonettes," Hoover did acknowledge that Wilson frequently encountered "unfriendly and cynical attitudes," especially from European leaders. ${ }^{191}$ In the starkest of terms, Hoover conceded that Wilson's style. ideals. and difficulty with bargaining provoked a "collision of civilizations" between the Old World of Europe and the New World of America. ${ }^{192}$ "From my own experience." Hoover explained, "I was convinced that Mr. Wilson's New World idealism would clash seriously with the Old World concepts of the Allied statesmen." 193

Where Neustadt, following Weber, has little use for religious faith or moralism in conducting the presidency, the evangelical, "Bryan-Wilsonian" style is characterized by open and frequent professions of religious faith and moralizing rhetoric. a tendency to view politics as a religious calling or vocation, having a evangelical sense of mission to remake the world, and resistance, if not hostility, to political bargaining and compromise. Being right and doing right may be seen as more important regardless of political costs and the political, electoral divisions that may occur as result.

As a consequence of their contempt for political bargaining, evangelical presidents find compromise difficult, and are more inclined to try to short-circuit the Washington political process and make direct appeals to the public, with whom such presidents are particularly inclined to claim a special relationship. Bryan revolutionized

\footnotetext{
${ }^{190}$ Hoover, The Ordeal of Woodrow Wilson, pp. xxvii. 76.

${ }^{191}$ Ibid., pp. xxvii, 253-254. Forrest McDonald documented that the American press identified Wilson's proclivity for lecturing. McDonald, The American Presidency, p. 437.

${ }^{192}$ Hoover, The Ordeal of Woodrow Wilson, pp. 72, 76, 81.

${ }^{193}$ Ibid., p. 61.
} 
political campaigning by actively courting voters across the country. Wilson certainly attempted to do this by holding public press conferences and in his tireless on-the-road campaign for the League of Nations. In the modern era, evangelical presidents can be assisted in this regard by the evolution of modern travel - rail, air, and interstate highway - and mass communications media - radio and television - that reduce the costs of what Samuel Kernell called "going public."194 Furthermore, evangelical presidents could benefit from the legitimacy accorded to the notion of a presidential election "mandate" in contemporary American political culture, no matter how slender the president's margin of victory. Due to these developments it is now probably easier to conduct an evangelical-style presidency or campaign than it was for Bryan and Wilson in the pre-radio, pre-television era.

It is claimed in this project that Jimmy Carter was an "evangelical" president. He had a style and a view of politics reminiscent of Bryan and Wilson that collided with the Neustadt/Weber prescriptions for effective political leadership.

Of modern twentieth-century, post-FDR presidents, it has been frequently claimed that Wilson is most akin to Jimmy Carter. According to Rubenzer and Faschingbauer, Wilson "stands out among all presidents by his combination of idealism and occasional but absolute inflexibility. The only modern president with any similarity to him is Jimmy Carter." ${ }^{195}$ Others have pointed out their similarities as well. ${ }^{196}$ Here are some examples:

\footnotetext{
${ }^{194}$ Samuel Kernell, Going Public: New Strategies of Presidential Leadership (Washington, DC: Congressional Quarterly Press, 1997).

${ }^{195}$ Rubenzer and Faschingbauer, Personality, Character, and Leadership in the White House, p. 135.
} 
- Carter was "the first true outsider-having no previous experience in Washingtonto be elected since Woodrow Wilson." 197

- When preparing for his inaugural address, Carter studied Wilson's "most closely while preparing his own."

- "Reviewing past inaugural addresses, Carter was impressed that President Wilson had called for national repentance." 199

- "Certainly Carter was the most theologically literate president since Woodrow Wilson." ${ }^{200}$

- "There are certain parallels between Wilson and Carter that permit of a highly instructive comparison... Both leaders were progressive southerners and devout Christians who believed in the gospel of service and considered political office a form of ministry. $" 201$

- "In terms reminiscent of Woodrow Wilson, [Carter] spoke of a new world order based on mutual cooperation, stability, justice, and peace." $" 202$

- "Carter became the first American president since Woodrow Wilson to try actively to reform repressive regimes in other nations.",203

${ }^{196}$ One writer even said that the presidential couples most alike were the Carters and the Wilsons. Referring to the inseparable closeness between Jimmy and Rosalynn Carter, Kari Marton wrote. "Not since Edith and Woodrow Wilson had there been a couple this close in the White House." Kari Marton. "Rosalynn and Jimmy Carter: Virtue Unrewarded," chap. in Hidden Pover: Presidential Marriages That Shaped Our History (New York: Anchor Books Edition, 2002), p. 215.

${ }^{197}$ Erwin C. Hargrove, Jimmy Carter as President: Leadership and the Politics of the Public Good (Baton Rouge, LA: Louisiana State University Press, 1988), p. xv; James Sterling Young. "The Perspective of the First Lady," in The Carter Presidency: Fourteen Intimate Perspectives of Jimm. Carter, Portraits of American Presidents, Vol. V1Il, edited by Kenneth W. Thompson (Lanham, MD: University Press of America, 1990), p. 227.

${ }^{198}$ Dan F. Hahn, "The Rhetoric of Jimmy Carter, 1976-1980," Presidential Studies Quarterly 14.2 (Spring 1984): 270.

${ }^{199}$ Peter G. Bourne, Jimmy Carter: A Comprehensive Biography from Plains to Postpresidency (New York: Scribner, 1997), p. 365.

${ }^{200}$ Hutcheson, God in the White House, p. 109.

${ }^{201}$ Burton I. Kaufman. The Presidency of James Earl Carter, Jr. (Lawrence, KS: University Press of Kansas. 1993), p. 35.

${ }^{202}$ Ibid., p. 38. 
- "Like Woodrow Wilson, [Carter] saw the United States as a beacon for the ideals of democracy and human rights."204

- "Carter was an engineer who had a Wilsonian faith in reason and in his own rightness." 205

If candidate Bryan and Presidents Wilson and Carter (to which George W. Bush may be added as well) share an approach to governing distinctive from other twentiethcentury presidents and would-be presidents, it is highly suggestive that there may be a subset of intensely religious presidents who seek to apply their faith politically, who tend to "sermonize," and who have a comparatively harder time in being secular professional politicians-participating in the give-and-take of politics and recognizing the limited malleability of the world. Indeed, these presidents may never fully assimilate to the secular political world; they may never want to, become NeustadianWeberian presidents.

As shown above, Bryan and Wilson had difficulties with compromising. Bryan preferred to resign his position as Secretary of State than support actions that could lead to a war he judged immoral. Wilson preferred to see his proposals for peace in Europe and U.S. entry in the League of Nations fail rather than support amendments to such proposals with which would have easily passed the Senate with wide bipartisan support. Wilson believed such changes would have betrayed everything for which he fought.

Similarly, throughout his public career, whether as governor, presidential candidate, president, or ex-president, Carter admitted that he never had the stomach for

\footnotetext{
${ }^{203}$ Douglas Brinkley, The Unfinished Presidency: Jimmy Carter's Joumey Beyond the White House (New York: Penguin Putnam Inc., 1998), p. 19.

${ }^{204}$ Hargrove, Jimmy Carter as President, p. 168.
} 
"politics as usual" whether in international or domestic affairs; he did not love politics.

Vice President Walter Mondale once said, "Carter thought politics was sinful. The worst thing you could say to Carter if you wanted to do something was that it was politically the best thing to do. $" 206$

William Jennings Bryan, Woodrow Wilson, and Jimmy Carter did not love politics in the way presidential scholars, like Neustadt, have recommended. They often displayed contempt for the give-and-take necessities and niceties of politics. Political compromise and bargaining were difficult for them. These were leaders who liked to claim that nobody owned them and they did not politically owe anyone else..$^{207}$ Furthermore, unlike most other presidents and presidential candidates, they did not separate their religion and their politics. To the contrary, their religion gave their politics meaning, skill, vision. It gave them a sense of emotional calm in the rough-andtumble world of politics. To critics, particularly among European allies, these men were arrogant and naïve.

To use Barber's description, Bryan, Wilson, and Carter were "active-positive" presidents or national political leaders who actively and confidently pursued policies they deemed moral. As Wilson explained, the true Christian is one who does not "stand still." The true Christian is one who aims to advance "Christian principle upon the

\footnotetext{
${ }^{205}$ McDonald, The American Presidency: An Intellectual History, p. 371.

${ }^{206}$ Lewis L. Gould. The Modern American Presidency (Lawrence, KS: University Press of Kansas. 2003), p. 182.

207 Dallek, "Woodrow Wilson, Politician," The Wilson Quarterly; Wallace, "Mission from God: Woodrow Wilson and the League of Nations," in Character, p. 172.
} 
strongholds of evil and of wrong in the world."208 For Bryan, Wilson, and Carter, politics was not fundamentally about the efficient and equitable distribution of goods and services, though they certainly wanted to make government better and more responsive. It was not the art of the possible, though sometimes they may have had to settle for it. For all three, politics was a means of Christian service, a legitimate vocation in the religious sense. It was the art of obtaining the impossible. It was about establishing a domestic and international political order on the Christian principles of love, peace, and justice.

\footnotetext{
${ }^{208}$ Wilson, "Address at the Young Men's Christian Association's Celebration in Pittsburgh, Pennsylvania," October 24, 1914.
} 


\section{Features of the Evangelical Presidential Style: Presidential Communication, Skill, Vision, and Emotional Control}

"I'm an evangelical and my definition of evangelical is someone who accepts Jesus Christ as savior and who's willing to spread the news about the advantages of worshipping Christ, and who makes an attempt to demonstrate [that] in their own activities the character of Christ."1

--Jimmy Carter

"We didn't know what [evangelicalism] meant until Jimmy Carter was elected president and he began to talk."2

--Billy Graham

Being Christ-centered, having a missionary impulse, and evincing a commitment to pious living are among the defining traits President Carter associated with being an evangelical Christian. Evangelicalism is a theological understanding. says Carter, which rests upon the premise that "we are saved by the grace of God through our faith in Jesus Christ." It is a faith-based obligation that includes reaching out "to others to spread the word about Jesus." And in one's own life and activities,

\footnotetext{
* This chapter includes excerpts from and expands upon content found in D. Jason Berggren and Nicol C. Rae. "Jimmy Carter and George W. Bush: Faith. Foreign Policy, and an Evangelical Presidential Sty.le." Presidential Studies Quarterly 36.4 (December 2006): 606-632.

' Jimmy Carter, "Interview with Rich Cline," Evangelical Alliance of the United Kingdom, NovemberDecember 2006, http://www eauk.org/resources/idea/NovDec2006/the-power-of-unity.

2 Billy Graham, Living in God's Love: The New York Crusade (New York: G.P. Putnam's Sons, 2005). pp. 45-46.
} 
Carter explains, Christ's presence should be evident through the application of "basic Christian principles."3

In this chapter, evangelicalism is defined. But for the purposes here, knowing who is an evangelical or what evangelicalism is insufficient. What is of ultimate interest is not just religion, but politics, specifically defining and understanding the basic features of an alternative form of presidential leadership.

It is argued here that being or claiming to be an evangelical is not enough to constitute an "evangelical" presidency. It is perhaps a necessary condition, but insufficient alone. The Bible says, "no one can see the kingdom of God unless he is born again." ${ }^{, 4}$ For religious, salvific purposes, claiming to be a "born again" evangelical may not only be necessary, but more importantly, sufficient. But in political terms, having an evangelical style of leadership must be demonstrable. A president's evangelical claim, as will be illustrated by the case of Bill Clinton, is not the same as possessing an evangelical form of governance.

Using features of religious evangelicalism as identified by leading evangelical figures and scholars of evangelicalism, prominent aspects of the evangelical political style are identified in this chapter. To bridge the gap between the religious and political worlds, Fred Greenstein's six markers of presidential leadership are especially helpful: public communication, organizational capacity, political skill, political vision, cognitive style, and emotional intelligence. ${ }^{5}$ This chapter identifies four basic features of the

\footnotetext{
${ }^{3}$ Carter, "Interview with Rich Cline," November-December 2006.

${ }^{4}$ Quoted in Graham, Living in God's Love, p. 43.
} 
evangelical style and pairs them with commensurate features found in Greenstein's

work. These include the frequent use of religious/evangelical rhetoric and methods and public communication, the evangelical sense of mission and political vision, evangelical personalism and political skill, and the certainty and calmness of evangelical faith and emotional intelligence. This combination offers more than a presidential trusteeship, the "doing what's right, not political," but an alternative way of being president, informed by evangelical faith principles and tendencies, including doing what he thinks Christ wants. ${ }^{6}$ In subsequent chapters, these four features become readily evident in the life, politics, presidency, and post-presidency of Jimmy Carter.

\section{What is Evangelicalism?}

Evangelicalism is not only a religious movement, it has long been a fact of American political and cultural life. Randall Balmer described evangelicalism as "quintessentially a North American phenomenon." It is "the most influential religious

\footnotetext{
${ }^{5}$ Fred I. Greenstein, The Presidential Difference: Leadership Style from FDR to Clinton (Princeton, NJ: Princeton University Press, 2000), pp. 5-6, 194-200; "George W. Bush and the Ghosts of Presidents Past," PS: Political Science and Politics 34.1 (March 2001): 77-80; "The Changing Leadership of George W. Bush: A Pre- and Post-9/11 Comparison," The Forum 1.1 (2002), Article 6; "George W. Bush and the Politics of Agenda Control," chap. in The Presidential Difference: Leadership Style from FDR to George W. Bush (2 ${ }^{\text {nd }}$ edition, Princeton, NJ: Princeton University Press, 2004), pp. 190-210; "The Person of the President, Leadership, and Greatness," in The Executive Branch, edited by Joel D. Aberbach and Mark A. Peterson, Institutions of American Democracy series (New York: Oxford University Press, 2005), pp. 218-240; "Presidential Difference in the Early Republic: The Highly Disparate Leadership Styles of Washington, Adams, and Jefferson," Presidential Studies Quarterly 36.3 (2006): 373-390.

${ }^{6}$ Charles O. Jones argued that Carter had a "different style of politics"- "doing what's right, not what's political." He saw his role as a trustee, a leader who seeks to "separate electoral politics from policy making" in order to do what is in the best interest of the national whole, than what is purely best for reelection or benefit to party. This type of leader is national-focused, not parochial. This leader values independence over partisanship, and he prefers comprehensive policy outcomes to incrementalism or cosmetic change. Thus, Jones wrote, "the president as chief executive," in Carter's mind, is "to perform as a trustee rather than a constituency-bound, election-oriented delegate." Jones, The Trusteeship Presidency: Jimmy Carter and the United States Congress (Baton Rouge, LA: Louisiana State University Press, 1988), pp. 1-9.
} 
and social movement in American history," and it is "deeply imbedded in American

life." It is a distinctly American religious tradition, he continued, that has "folk appeal" and has a strong "grassroots character." Perhaps, evangelicalism is the religious version of American political, democratic populism.

American evangelicalism is fundamentally a religious tradition that has little in common with Christian religious patterns and practices in much of the world. For instance, there is "nothing comparable to the American religious right," evangelical Protestantism, and politically influential evangelists such as Billy Graham, Pat Robertson, and Jerry Falwell, in Europe. ${ }^{9}$

Historically, of all the major religious traditions in the United States, said Doug Koopman, "Evangelical Protestant Christianity has been the most politically active." William McLoughlin said that "the story of American Evangelicalism" has been for the most part "the story of America." II In fact, McLouglin not only asserted that evangelicalism has been one of the key distinguishing features of religion in the United

\footnotetext{
${ }^{7}$ Randall Balmer, Encyclopedia of Evangelicalism (Louisville, KY: Westminster John Knox Press, 2002), pp. vii, 204, 207.

${ }^{8}$ Randall Balmer, Mine Eyes Have Seen the Glory: A Journey into the Evangelical Subculture in America (New York: Oxford University Press, 1989), p. 227.

${ }^{9}$ Steven Muller, "Time to Kill---Employment in Europe," National Interest (Summer 1997); Peter L. Berger, "Religion and the West," National Interest (Summer 2005); Grace Davie, "Believing Without Belonging: Just How Secular is Europe?" The Pew Forum on Religion and Public Life, December 5, 2005, Key West, Florida, Event Transcript, http://pewforum.org/events (accessed March 16, 2006), 10 , 18, 30; Karsten D. Voigt, "Religion is the wild card in transatlantic relations," EU Observer, June 16, 2006, http://euobserver.com/7/21839.

${ }^{10}$ Doug Koopman, "Religion and American Political Parties," in In God We Trust? Religion and American Political Life, edited by Corwin E. Smidt (Grand Rapids, MI: Baker Book House Company, 2001), p. 142.

${ }^{11}$ William G. McLoughlin, The American Evangelicals, 1800-1900: An Anthology (New York: Harper \& Row, 1968), p. 1.
} 
States, it was additionally the essential religious-cultural force that "made Americans the most religious people in the [Western] world, molded them into a unified. pietisticperfectionist nation, and spurred them on to those heights of social reform. missionary endeavor, and imperialistic expansionism."

To explore what might constitute an evangelical style of leadership. we first must examine what evangelicalism is. While the term is familiar to many, it is not necessarily easy to define. Politically or religiously, evangelical Christians are not monolithic in opinion or practice. ${ }^{12}$ Although, as Carl Henry explained, the Bible may provide evangelicals certain political "principles," it does not provide either a "blueprint for a universal evangelical political order" or does it "commit itself to particular parties or programs of social reform.",13

Jimmy Carter made this argument as well. For example. when asked about evangelical support for Governor Ronald Reagan in the 1980 election. he said, "It think it would be a mistake...to assume that evangelical Christians [are] any more homogenous in the their political preferences than...other groups in our Nation. ${ }^{.14}$ The mistake some make, he added, is when some claim, such as the Jerry Falwell and the Moral Majority, that the Bible answers every political question, contains a solution to

\footnotetext{
${ }^{12}$ Ronald H. Nash, Evangelicals in America: Who They Are, What They Believe (Nashville. TN: Abingdon Press, 1987), p. 16; Stuart Rothenberg. "Evangelicals Are Politically Diverse." in Piety and Politics: Evangelicals and Fundamentalists Confront the World, eds. Richard John Neuhaus and Michael Cromartie (Washington. DC: Ethics and Public Policy Center, 1987). pp. $321-326$.

${ }^{13}$ Carl Henry, Carl Henry at His Best: A Lifetime of Quotable Thoughts. edited by Steve Halliday and Al Janssen (Portland, OR: Multnomah Press, 1989), pp. 92-93.

${ }^{14}$ Carter, "Remarks and Question-and-Answer Session at a Town Meeting in Pittsburgh. Pennsylvania." October 29, 1980, Public Papers of the Presidents, Book III. (Washington. DC: United States Government Printing Office, 1981), pp. 2505-2506.
} 
every problem, provides a specific political agenda to advance, and define political tests "for religious fellowship." "I have never found anything in the Bible, in the Old or New Testament," he argued, "that specifies whether or not we should have a Department of Education in the Federal Government or whether you should have a B-1 bomber or the air-launched cruise missiles - or whether we should share with Panama, the rest of this century, operation of the Panama Canal or whether we should be able to guard it in the next century as has been worked out." The Bible, he explained, is not "some sort of mystical guidebook" for politics; it does not "give us quick and simple answers to every problem of a nation or personal life." Rather, through prayer and frequent study, one can "find new insights and new inspirations" in the text as he had done as president. ${ }^{15}$ "Like the children of Israel, we cannot always know where the road will lead." Still, "God does give us guidance, but he does not provide roadmaps with a sure and certain destination." 16

Balmer described evangelicalism as having an "unwieldy nature," characterized by "breadth and diversity," "a patchwork quilt."17 There are many prominent personalities and various subcultures, many kinds of evangelicals and evangelicalisms. Ronald Nash observed, evangelicalism is often "not one big happy family." 18 Mark Noll explained that religious "evangelicalism has always been diverse, flexible,

\footnotetext{
${ }^{15}$ Carter, "Remarks at the Annual Convention of the National Religious Broadcasters," January 21, 1980, Public Papers of the Presidents, Book I, p. 181.

${ }^{16}$ Carter, "Remarks at the Annual Convention of the National Religious Broadcasters," January 21, 1980 , Public Papers of the Presidents, Book I, p. 182.

${ }^{17}$ Balmer, Mine Eyes Have Seen the Glory, pp. xii, 229.

${ }^{18}$ Nash, Evangelicals in America, p. 27.
} 
adaptable, and multiform." ${ }^{\text {19 }}$ Elsewhere. he added, "There are only three things to keep in mind when looking at evangelicals in general. They are diverse. They are diverse. They are diverse." 20 Politically, Wendy Murray Zoba remarked, "One thing is clear: evangelicals do not vote as a bloc. ${ }^{21}$

Evangelicals may be Democrats like William Jennings Bryan, Bill Clinton. and Al Gore, Republicans like former senators Mark Hatfield, Dan Quayle, and John Ashcroft, or even an Independent like John Anderson. As such, evangelicalism, argued Alister McGrath, is "notoriously difficult to give a precise definition." 22 David Wells rhetorically asked, "What, then, is the essence of being evangelical today?" His answer, "Well, that all depends." 23

Though they are most likely to be Baptist or Methodist, evangelicals can be found within nearly every Protestant denomination in the United States. There are evangelical denominations and there is also a general "evangelical" spirit that is transdenominational. There are many prominent personalities and various subcultures, many

\footnotetext{
${ }^{19}$ Mark Noll, "Understanding American Evangelicals," Lecture delivered at the Ethics and Public Policy Center, Washington, DC, December 8, 2003, transcript available at the Ethics and Public Policy Center website. http. www eppc.org publications pubID.1943 pub_detail.asp.

${ }^{20}$ Mark A. Noll, "Foreword," to Southern Baptists and American Evangelicals: The Conversation Continues, ed. David S. Dockery (Nashville, TN: Broadman \& Holman Publishers, 1993), p. xiii.

${ }^{21}$ Wendy Murray Zoba, The Beliefnet Guide to Evangelical Christianity' (New York: Three Leaves Press, 2005), p. 99.

22 Alister McGrath, Evangelicalism and the Future of Christianity. (Downers Grove. IL: InterVarsity Press, 1995), p. 53.

${ }^{23}$ David Wells, "On Being Evangelical: Some Theological Differences and Similarities," in Evangelicalism: Comparative Studies of Popular Protestantism in North America, the British Isles, and Beyond. 1700-1990, eds, Mark A. Noll, David W. Bebbington, and George A. Rawlyk (New York: Oxford University Press, 1994), p. 407.
} 
kinds of evangelicals and evangelicalisms. Given this incredible variety, some have proposed to even discard "evangelical" and "evangelicalism" as useful concepts. ${ }^{24}$

Still, most scholars seem to agree that in spite of its radical internal diversity, there is a "family resemblance" among evangelicals, a "unity despite diversity." 25 There are, said George Marsden, "common heritages, common tendencies, an identity, and an organic character" that broadly unifies evangelicals. ${ }^{26}$ According to both qualitative and quantitative studies, ${ }^{27}$ the commonly cited "hallmarks of evangelicalism" and spiritual affirmations are as follows:

1) PROTESTANT

- Evangelicalism is a broad, transdenominational, multifacted movement within world Christianity that can be traced back to the $16^{\text {th }}$ century Protestant Reformation and its separation from the Roman Catholic Church.

\footnotetext{
${ }^{24}$ Donald W. Dayton, "Some Doubts about the Usefulness of the Category 'Evangelical'," in The Variety' of American Evangelicalism, eds. Donald W. Dayton and Robert K. Johnston (Downers Grove, IL: InterVarsity Press, 1991), pp. 245-251.

${ }^{25}$ Robert K. Johnston, "American Evangelicalism: An Extended Family," in The Variety of American Evangelicalism, pp. 252-272; George Marsden, "The Evangelical Denomination," in Piety and Politics: Evangelicals and Fundamentalists Confront the World, pp. 55-68.

${ }^{26}$ Marsden, “The Evangelical Denomination," p. 60.

${ }^{27}$ Noll, "Understanding American Evangelicals"; McGrath, Evangelicalism and the Future of Christianity, pp. 53-87; Zoba, The Beliefnet Guide to Evangelical Christianity, pp. 4-5: Donald G. Bloesch, The Evangelical Resurgence (Grand Rapids, MI: William B. Eerdmans Publishing Company. 1973), pp. 48-79; "The Christianity Today-Gallup Poll: An Overview," Christianity Today, December 21 , 1979, 12-15; James Davison Hunter, American Evangelicalism: Conservative Religion and the Quandary of Modernity (New Brunswick, NJ: Rutgers University Press, 1983); Billy Graham, A Biblical Standard for Evangelists (Minneapolis, MN: World Wide Publications, 1984); Lyman A. Kellstedt, "The Meaning and Measurement of Evangelicalism: Problems and Prospects," in Religion and Political Behavior in the United States, eds. Ted G. Jelen (New York: Praeger Publishers, 1989), pp. 3-22; George M. Marsden. "Contemporary American Evangelicalism," in Southern Baptists \& American Evangelicals, pp. 28-29; Anna Greenberg and Jennifer Berktold, "Evangelicals in America." Washington, DC: Greenberg, Quinlan, Rosner Research Inc. Prepared for Religion and Ethics Newsweekly, 2004.
} 
- It is "an American brand of Protestant Christianity" prominently found in the American South and the Midwest. ${ }^{28}$

2) "BORN AGAIN"

- Claiming to be "born-again" is typically an evangelical self-identification.

- It is a claim to have had a personal conversion experience or encounter with God.

- To be saved, as evangelist Billy Graham often says, "You must be born again., ${ }^{29}$

\section{3) SOLA FIDEI}

- Evangelicals consistently claim salvation is obtained through Christ by faith alone.

- A key scriptural proof-text for evangelicals is Ephesians 2:8: "For by grace you have been saved through faith..."

\section{4) SOLA SCRIPTURA}

- Evangelicals view the Bible as the sole authority for faith and morals.

- In explaining or defending the faith to others, evangelicals without apology often make their points beginning with the words, "The Bible says..."

- To a greater extent than Catholics or mainline Protestants, $62 \%$ of white evangelicals view the Bible as the "literal word of God." By stark contrast, only $17 \%$ of white mainline Protestants and $18 \%$ of white Catholics hold this view. ${ }^{31}$

\footnotetext{
${ }^{28}$ Mark Noll, "Interview with Judy Valente," Religious \& Ethics Newsweekly, April 16. 2004, Episode no. 733 , http:/www.pbs.org/wnet/religionandethics/week 733 /interview.html.

${ }^{29}$ Graham, Living in God's Love, p. 37.

${ }^{30}$ Billy Graham, A Biblical Standard for Evangelists (Minneapolis, MN: World Wide Publications, 1984), p. 36.

31 "Many Americans Uneasy with Mix of Religion and Politics," Pew Research Center Report, August 24, 2006, p. 19, http:/people-press.org/reports.
} 


\section{5) CHRISTOCENTRICISM}

- Evangelicals emphasize the centrality of Jesus Christ in faith discourse and the personal experience of salvation.

- "The Person of Jesus Christ...is the central figure of our evangelistic message, 32

6) PERSONALISM

- Evangelicals stress the direct experience with God through Christ.

- They place a greater focus on individual religious experience, one-on-one encounters.

- There is a tendency among evangelicals to refer to fellow believers as "brothers and sisters" and often relate to them on an informal, familial, or fraternal basis.

\section{7) PIETISM}

- Pietism is a quest for personal holy living, including frequent prayer, Bible reading, church attendance and, may be even, abstinence from alcohol and tobacco.

- "We acknowledge our obligation, as servants of God, to lead lives of holiness and moral purity, knowing that we exemplify Christ to the church and to the world"33

- "The Gospel," explained Billy Graham, "must be communicated not only by our lips but our lives." 34

- "A life of regular and faithful prayer and Bible study is essential to our personal spiritual growth, and to our power for ministry." 35

\footnotetext{
${ }^{32}$ Graham, A Biblical Standard for Evangelists, p. 11.

${ }^{33}$ Ibid., p. 73.

${ }^{34}$ Ibid.

${ }^{35}$ Ibid., p. 81.
} 


\section{8) EVANGELISM}

- Evangelicals are filled with a sense of urgent mission, which includes the active conversion of others and reforming a lost world. ${ }^{36}$

- Graham wrote, "evangelists are activists." "Traveling, meeting new people, organizing, and preaching" define the busy life of God's preachers. ${ }^{37}$

- Evangelism is "winning the world for Christ" or increasing the glory of God in the world, what Weber called "activity in majorem gloriam Dei". 38

- "We respond to God's call to the biblical ministry of the evangelist, and accept our solemn responsibility to preach the Word to all peoples as God gives opportunity." 39

- "We affirm our commitment to the Great Commission of our Lord, and we declare our willingness to go anywhere, do anything, and sacrifice anything God requires of us in the fulfillment of that Commission."

By these measures, as will be shown in more detail throughout the coming chapters, Jimmy Carter is not only a Protestant, but a Southern Baptist, a self-identified born-again evangelical who was raised in a Christian home in the South where "being born again is just like breathing." ${ }^{41}$ Like other evangelicals, he fully affirms and frequently proclaims the centrality of Christ in his faith. "Christians are, by definition.

\footnotetext{
${ }^{36}$ Noll, "Interview with Judy Valente," April 16, 2004.

${ }^{37}$ Graham, A Biblical Standard for Evangelists, p. 81.

${ }^{38}$ See Weber, The Protestant Ethic and the Spirit of Capitalism (New York: Charles Scribner's Sons, 1958), p. 108.

${ }^{39}$ Graham, A Biblical Standard for Evangelists, p. 31.

${ }^{40}$ Ibid., p. 23.

${ }^{41}$ Carter, "Interview with Jonathan Serrie," Fox News' Special Report with Brit Hume, December 26. 2005.
} 
"little Christs'." Jesus as possible and to emulate him as fully as we can." And it is the duty of every evangelical Christian to relate "their experience with Christ and others in hopes that the other person will accept Christ as savior." ${ }^{43}$

Carter has written that it is through faith in Christ our sins are removed, that through Christ we can receive the blessings of God, that through Christ's example we know how to live in the world, and through his teachings, particularly the Sermon on the Mount, humans have "the avenue - the only avenue--to personal peace and peace in our world."44 In short, "the simple but profound fact," explains Carter, "is that our lives can be changed - beginning now — by professing our faith in Jesus Christ. ${ }^{.45}$ The essence of the Christian message, what evangelist Billy Graham calls "the Gospel in a nutshell" and what every evangelical knows by heart, Carter says is found in John $3: 16^{46}$

Carter affirms and cites the scriptural supports for the doctrine of sola fidei, "We cannot save ourselves. Only God can save us, through our faith." ${ }^{.47}$ Like "the Hebrew

\footnotetext{
${ }^{42}$ Carter, Sources of Strength: Meditations on Scripture for a Living Faith (New York: Three Rivers Press, 1997), p. 8.

${ }^{43}$ Carter, "Interview with Jonathan Serrie," December 26, 2005.

${ }^{44}$ Carter, Sources of Strength, pp. 4-6, 100.

${ }^{45}$ Ibid., p. 7.

${ }^{46}$ Ibid., pp. 83, 104; "Interview with Elizabeth Sams," Beliefnet, March 27, 2007, http://www.beliefnet.com/story/214/story 21478.html. John 3:16 says, "For God so loved the world that he gave his only Son, so that everyone who believes in him may not perish but may have eternal life" (New Revised Standard Version).

${ }^{47}$ Ibid., p. 5; see also "Remarks at the Funeral Service for President Gerald R. Ford at Grace Episcopal Church in Grand Rapids, Michigan," January 3, 2007, "Interview with Elizabeth Sams," Beliefnet, March 27, 2007, http://www.beliefnet.com/story/214/story 21478.htmll.
} 
patriarch Abraham" who "did not earn his righteousness before God." Christians, Carter says, are saved according to what the Apostle Paul wrote. "for by grace are you saved through faith."

Carter holds a high view of the Bible's authority. It is not merely a human document. It is not merely to be read as a work of history or literature. It is "the Holy Word of God." ${ }^{+8}$ He begins his book. Sources of Strength, with this question, "Why Should We Read the Bible?"+9 Citing 2 Timothy 3:16-17, Carter provides the classic evangelical scriptural proof: " All scripture is inspired by God. and profitable for teaching, for reproof, for correction, for training in righteousness." Within its pages and through prayer and meditation, Carter says the Bible reveals how one can learn of God's "love, grace, and forgiveness." to do "God"s will." be "more like Christ." improve "our behavior." and "strive for a transcendent life." ${ }^{50}$ Wrote Kati Marton, Carter views "the Bible as his manual for living." in the existence of the devil, he replied in characteristic evangelical fashion: "I believe there is a devil, or spirit of evil, in competition with the spirit of Christ. The reason 1 believe it is that it's said repeatedly in the Bible. including from the lips of Jesus himself.",52

\footnotetext{
${ }^{48}$ Ibid. p. xv.

${ }^{49}$ Ibid.. p. xiii.

${ }^{50}$ Ibid., p. xvi.

${ }^{51}$ Kati Marton, "Rosalynn and Jimmy Carter: Virtue Unrewarded," chapter in Hidden Power. Presidential Marriages That Shaped Our History (New York: Anchor Books editon, 2002), p. 219.

\$2 Carter. "Interview with Lisa Miller." March 21, 2007, Newsweek. http., www.msnbc.msn.com.
} 
Such views, however, do not necessarily lead a president to adopt an "evangelical" presidential style. Such views are perhaps necessary, but not sufficient alone. Be that as it may, one would be hard pressed to find a president like Carter who so publicly shared his faith, explored its contours, and meditated on its meanings and implications. Carter is not just a believer, he has been a missionary, a Sunday school teacher, and a lay teacher to the wider world. Given this and his role as president of the United States, Carter believes that he has a unique "voice" that warrants speaking out publicly (preaching?) on matters of faith and morals and their implications for politics. ${ }^{53}$ Indeed, Carter's books Sources of Strength and Living Faith may be the only works by a president that have been classified as "inspiration/religion," and that one is likely to encounter in both evangelical Christian and secular bookstores.

\section{Religious Evangelicalism: Necessary, Not Sufficient}

We now turn to explaining the features of an evangelical presidential style. The common traits associated with religious evangelicalism noted above provide markers with which to identify and define this alternative leadership style, and, as just discussed, Carter clearly counts himself a religious evangelical and holds conventional evangelical principles of faith. ${ }^{54}$ Using these markers previously identified and as shown with Carter, at the most basic level, an "evangelical" president is most likely to be a Protestant who claims publicly to be an evangelical or "born-again" Christian. Part of

\footnotetext{
${ }^{53}$ Carter, "Interview with Rich Cline," November-December 2006.

${ }^{54}$ Gary Scott Smith, "Jimmy Carter: First Servant of the Nation," chapter in Faith and the Presidency: From George Washington to George W. Bush (New York: Oxford University Press, 2006), pp. 295-296.
} 
what Evan Cornog called the presidential narrative or story, "evangelical" presidents will also likely have a narrative or story that tells of moments of crises, times of religious backsliding and lukewarm behavior, and perhaps immoral activities. ${ }^{55}$ Then, they experience a spiritual rebirth. a rededication to the faith of their youth. Being and becoming "born-again" emerges as a key part of their story.

In their personal life, like Carter, these presidents are likely to be devout and lead generally moral lives. Practicing their faith is part of their daily regimen. They pray frequently, read and studying the Bible, are frequent churchgoers, and may have even held church positions as Sunday school teachers or deacons. They probably lead pious lives-abstaining from or temperantly using such worldly pleasures as alcohol (or at least hard liquor) and tobacco. Colin Campbell and Bert Rockman observed, one thing that can certainly be said of Carter is that his personal "character was never in doubt. ${ }^{, 56}$

At this point, however, these traits may have little or no impact on a president's leadership style. A president can possess all these attributes and yet not be an "evangelical" president as understood here. It is well-known fact that evangelicals for a long time tended to separate their religion and politics or abstain from politics altogether. To use H. Richard Niebuhr's categories, many evangelicals either embraced the "Christ and culture in paradox" perspective where religion and politics should be

\footnotetext{
${ }^{55}$ See Evan Cornog, The Power and the Story: How the Crafted Presidential Narrative Has Determined Political Success from George Washington to George W. Bush (New York: Penguin Press, 2004).

${ }^{56}$ Colin Campbell and Bert A. Rockman, "Introduction," in The Clinton Legacl, eds. Colin Campbell and Bert A. Rockman (New York: Chatham House Publishers. 2000), p. xii.
} 
separate or they took the more radical "Christ against culture" view entirely shunning political involvement. ${ }^{57}$

Obviously, "evangelical" presidents embrace neither of these views. By definition, they are obviously active in the political world and necessarily believe their faith has political consequence. To use George W. Bush's words, the evangelical president sees himself as one full of "will" and "determination" and lacking the luxury of having the historian's sense of pause and reflection. Rather, the evangelical president views himself as "the guy making history," one "willing to lead and make the tough calls." 58

Since the evangelical resurgence in the 1970s, interestingly coinciding with the unexpected rise of Carter, evangelicals have reentered the political world seeking to reapply their faith in the world. Since Carter, evangelicals, once isolated and objects of scorn and ridicule, obtained a new respectability. "Suddenly," with Carter's success, wrote James Davison Hunter, “it was acceptable, even socially [perhaps politically] desirable, to become a born-again Christian — an Evangelical." ${ }^{\circ 0}$ When asked in a 2004

${ }^{57}$ H. Richard Niebuhr, Christ and Culture (New York: Harper and Row Publishers, 1951), pp. 45, 171172.

${ }^{58}$ George W. Bush, "Interview with Nancy Gibbs and John Dickerson," Time, September 6, 2004, pp. 40, 43.

${ }^{59}$ By generating "an outpouring of derision" across the country, after the 1925 Scopes Monkey Trial, many evangelicals went into political and religious retreat for several decades. See George M. Marsden. Fundamentalism and American Culture: The Shaping of Twentieth-Century Evangelicalism, 1870-1925 (New York: Oxford University Press, 1980), pp. 184-195.

${ }^{60}$ James Davison Hunter, "The Evangelical Worldview Since 1890," in Piety and Politics: Evangelicals and Fundamentalists Confront the World, p. 50. 
interview, "Why do you think evangelicals have become so much more prominent in recent years than they were 50 years ago?", historian Mark Noll said.

I think it's possible to suggest that evangelical Christians have become more prominent in public space over the last 30 to 40 years because of signal events, turning points, as it were. Certainly, the presidency of Jimmy Carter was important.

Here was a Southern Baptist who said that he was born again and tried to live by his faith. This was nothing new in the South and in many parts of the rest of the country, but it was new for a public speaker [especially a president] to talk like this. $^{61}$

Put differently, Carter legitimized mass evangelical political participation and political service and made possible anew, at least theoretically, even if not clearly defined or codified, the concept of an evangelical brand and style of politics-and perhaps style of presidential leadership.

Evangelical presidents are politicians who exhibit a distinct political style. But unlike the "Christ and culture in paradox" model and mutually antagonistic "Christ against culture" model, evangelical-styled presidents are likely to see Jesus as a sort of religious-cultural hero, "his life and teachings are regarded as the greatest human achievement" and "he confirms what is best in the past, and guides the process of civilization to its proper goal. ${ }^{.62}$ That is, Jesus is seen as someone who is to be imitated in one's personal and political lives. For the evangelical president, there is a close. though not perfect or coterminous, relationship or correlation between "Christianity and Western civilization" or "between Jesus" teachings [or the teachings about him] and

\footnotetext{
${ }^{61}$ Noll, "Interview with Judy Valente," April 16, 2004.

${ }^{62}$ Niebuhr. Christ and Culture, p. 41.
} 
democratic institutions." 63 They are, thus, left with no sense of any "great tension between church and world." 64 In this regard, they may be of Niebuhr's "Christ of culture" type. To briefly illustrate this, Carter often said he saw no incompatibility between the teachings and expectations of Christian faith and the values and ideals of the American political tradition, or at least an idealized form of it. "I serve Christ. I also serve America. And I have never found in my own life any incompatibility between these two responsibilities for service. ${ }^{, 65}$

Be that as it may, the "Christ of culture" type is judged an insufficient descriptor of Carter and the "evangelical" presidential form. While certainly Carter as an "evangelical" president saw a great deal of compatibility between the fine ideals of the faith and society, it is still incomplete and perhaps ultimately even unbridgeable. As with the mainstream of historic Christianity that rejected wholesale abandonment of the world and the complete idolization of the world, Carter neither conformed to the "Christ against culture" nor the "Christ of culture" forms.

Presidents who best fit the "evangelical" form, like Carter, are normally elected during times when the wider society has lost confidence in itself, when there have been major instances of corruption or scandal, when political leaders seem distant and despondent. In such times, many voters are looking for reform, something new, a return to the traditional values of decency and honesty. In such times, "outsiders", political or

\footnotetext{
${ }^{63}$ Ibid., p. 41.

${ }^{64}$ Ibid., p. 83.

${ }^{65}$ Carter, "Remarks at the Annual Convention of the National Religious Broadcasters," January 21, 1980 , Public Papers of the Presidents, Book I, p. 182; "Interview with Leaders Magazine," April 1985, in Conversations with Carter, edited by Don Richardson (Boulder, CO: Lynne Rienner Publishers, 1998), 267; see also Living Faith (New York: Times Books, 1998; originally published in 1996), p. 132.
} 
socio-cultural outsiders, may have great and particular appeal. In light of this, an "evangelical" president offers more than a reaffirmation of "politics as usual" or "Christ of culture" type. This president offers either a restoration of lost principles or the implementation of principles previously untried, principles from the "Christ above culture" type. Carter, for instance, promised both a restoration and rejuvenation of American principles and believed there existed an "untapped reservoir of innate strength." As he explained in his first debate with President Ford, Carter said, We need to restore the faith and the trust of the American people in their own government. In addition to that, we've suffered because we haven't had leadership in this administration... We've lost the vision of what our country can and ought to be. This is not the America that we've known in the past. It's not the America that we have to have in the future. I don't claim to know all the answers. But I've got confidence in my country.

I believe we can bind our wounds. I believe that we can work together. And I believe that if we can tap the tremendous untapped reservoir of innate strength in this country, that we can once again have a government as good as our people. ${ }^{66}$

Or more specifically, such as in foreign policy, Carter asserted that the goal is "trying to find the ideal of Christ: peace on earth." 67

Nevertheless, the religious features of evangelicalism are foundational for adopting an evangelical presidential style. Before a president can lead with an evangelical style or form of leadership, one must model those traits or behaviors in their own lives. In other words, by modeling those traits in their personal lives, such

\footnotetext{
${ }^{66}$ Carter, "Remarks During First Presidential Debate with President Gerald Ford in Philadelphia, Pennsylvania," September 23, 1976, moderated by Edwin Newman, the Commission on Presidential Debates, http://www.debates.org.

${ }^{67}$ Carter, "Remarks at the Annual Convention of the National Religious Broadcasters," January 21, 1980, Public Papers of the Presidents, Book I, p. 181.
} 
presidents can cultivate the trust and legitimacy to lead in this particular, peculiar fashion. Private devotion, according to evangelicals, is the foundation and source of "our power to ministry." It is, says Billy Graham, especially so "in the life of an evangelist." ${ }^{\prime 68}$

Survey data can be useful here to determine if such presidents (or presidential candidates) have indeed established that impression. Polls, such as Gallup, often ask registered or likely voters if the president (or a specific presidential candidate) is "honest and trustworthy," "has strong moral character," "provides good moral leadership," and "confident will set a good moral example." Answers to such questions can give presidential observers clues if a president has successfully created a moral image or not. Those that have this image, along with the requisite evangelical credentials, could be strong candidates for being classified as having an evangelical form of leadership or ones who are attempting to implement such a presidency.

George W. Bush is a good example. Through two national campaigns and throughout his first term, despite a highly partisan environment, a solid majority of Gallup survey respondents consistently identified President Bush as "honest and trustworthy" (Table 3.1). Combining this image with his solid evangelical credentials, Bush was a plausible candidate for pursuing this alternative presidential style.

\footnotetext{
${ }^{68}$ Graham, A Biblical Standard for Evangelists, p. 81.
} 
Table 3.1 George W. Bush as "Honest and Trustworthy," 1999-2005

\begin{tabular}{ll} 
\%-Yes & Gallup Survey Dates \\
\hline 56.09 & January 14-16.2005 \\
56.66 & February 16-17.2004 \\
59.16 & November 14-16.2003 \\
65.07 & June 27-29.2003 \\
73.08 & April 5-6, 2003 \\
69.66 & January 10-12, 2003 \\
69.31 & July 26-28, 2002 \\
76.72 & April 29 to May 1.2002 \\
65.98 & July 10-11.2001 \\
67.00 & April 20-22.2001 \\
63.73 & February 9-11.2001 \\
58.06 & October 16-22,2000 \\
63.63 & March 10-12,2000 \\
62.07 & September 10-14, 1999
\end{tabular}

Source: Gallup Organization

Clinton: An Evangelical Without An Evangelical Style

President Bill Clinton is a good counterexample to consider here. He was a Protestant (Southern Baptist) and a self-identified evangelical. Clinton knows his Bible and the favorite hymns of the evangelical world. He goes to church, and after his 1980 reelection bid for governor, he claims to have had a "born-again" experience. However. Bill Clinton, even if he aimed to do so, was an unlikely candidate to provide an evangelical-styled presidency. His image as a consummate politician and his reputation as an adulterer overshadowed his evangelical, religious credentials. Table 3.2 shows, in contrast to George W. Bush, with the exception of his first year, a solid majority of Americans consistently did not think Bill Clinton was honest. Later events. such as the Monica Lewinsky scandal and impeachment, only served to confirm what many, if not most, Americans believed about Clinton's personal life and character since the 1992 
presidential primaries. He managed "to demonstrate without much doubt that his word was worthless, that lying came easy to him, and that his behavior and lack of control toward women left him a perpetual adolescent." ${ }^{, 69}$ Clinton recognized this gap. In his memoirs, My Life, he wrote, "Whether I'm a good man is, of course, for God to judge. 1 know that I am not as good as my strongest supporters believe or as I hope to become. nor as bad as my harshest critics assert.",70

Though an evangelical, Bill Clinton's presidential reputation is closer to Neustadt's ideal president than one who offered the sort of alternative leadership model described here. Clinton loved politics, and, as Joe Klein described him, he was simply a political natural and governed with a seemingly "value-free pragmatism.."71 Friend and foe alike respected his political prowess, communicative abilities, ability to win elections, and his ability to make astonishing political comebacks. Clinton, Fred Greenstein judged, was a president "political to the core," "political in every fiber of his being," and "notable for his intelligence, energy, and exceptional articulateness." 72 Though he lacked self-discipline, Greenstein continued, he shown remarkable "resiliency and coolness under pressure that enabled him to extricate himself from many of his predicaments." Moreover, he showed too that he could still retain high public approval for his job performance even while his character ratings were low. In

\footnotetext{
${ }^{69}$ Campbell and Rockman, "Introduction," The Clinton Legacy, p. xii.

${ }^{70}$ Bill Clinton, My Life (New York: Alfred A. Knopf, 2004), p. 3.

${ }^{71}$ Joe Klein, The Natural: The Misunderstood Presidency of Bill Clinton (New York: Broadway Books. 2002), p. 32.

${ }^{72}$ Greenstein, The Presidential Difference, p. 174; "The Person of the President, Leadership, and Greatness," p. 222.
} 
Greenstein's assessment, Clinton will "likely to be remembered as a politically talented underachiever." ${ }^{, 73}$ Translation, Clinton was a stillborn Neustadian president. The point here with Clinton is to briefly illustrate that a self-identified evangelical president does not necessarily have or can be expected to have an evangelical leadership style. Again. personal evangelicalism is perhaps necessary, which Clinton had, but insufficient alone.

\section{Table 3.2 Bill Clinton as "Honest and Trustworthy," 1992-2001}

I'm going to read off some personal characteristics and qualities. As I read each one, please tell me whether you think it applies or doesn't apply to Bill Clinton... Honest and trustworthy?

\begin{tabular}{|c|c|}
\hline$\%$-Yes & Gallup Survey Dates \\
\hline 35.89 & January 5-7, 2001 \\
\hline 21.37 & July 14-16, 2000 \\
\hline 32.21 & February $12-13,1999$ \\
\hline 30.62 & August 21-23, 1998 \\
\hline 34.31 & August $10-11,1998$ \\
\hline 43.84 & May 8-10, 1998 \\
\hline 33.09 & March 20-22. 1998 \\
\hline 43.69 & January 30 to February 1,1998 \\
\hline 45.98 & December 18-21, 1997 \\
\hline 50.66 & October 27-29, 1997 \\
\hline 50.86 & September 25-28, 1997 \\
\hline 53.14 & September 6-7, 1997 \\
\hline 44.19 & March 24-26, 1997 \\
\hline 49.12 & February 24-26, 1997 \\
\hline 59.49 & January 10-13, 1997 \\
\hline 45.35 & October $25-27,1996$ \\
\hline 46.31 & October 7-13, 1996 \\
\hline 44.84 & August 5-7, 1996 \\
\hline 45.75 & June $18-19,1996$ \\
\hline 44.94 & March 15-17, 1996 \\
\hline 40.05 & January $12-15,1996$ \\
\hline 46.12 & February $3-5,1995$ \\
\hline 43.81 & December 2-5, 1994 \\
\hline 38.68 & July $15-17,1994$ \\
\hline 48.58 & June 3-6, 1994 \\
\hline
\end{tabular}

\footnotetext{
${ }^{73}$ Greenstein, The Presidential Difference, p. 188.
} 
^-combines "strongly applies" and "somewhat applies" responses

\#--question used here was, "Do you see Clinton as... Dishonest or honest?"

*--question used here was, "Does... personally honest... apply to... Bill Clinton?

Source: Gallup Organization

\section{Features of an Evangelical Presidential Style}

Returning to the markers of evangelicalism, it is proposed here that among the features of an evangelical presidential style are: a public communication style with frequent rhetorical use of biblical and moral language, a personalistic style that fosters political skill, such as in diplomacy, an evangelistic sense of mission that functions as a political vision, and personal strength or emotional intelligence derived from and sustained by the calmness of prayer and certainty of faith. 
"We, as God's Ambassadors, are called to sound the warning, to make judgment clear, to call all sinners to repentance, to announce God's grace, to direct them to Calvary and the God-man on the cross, to point to the empty tomb, to shout the good news from the housetops, to show the way to peace with God and peace between men and nations." ${ }^{, 74}$

--Billy Graham

To use Howard Fineman"s words, an evangelical president speaks "the Biblical and political language" of the evangelical world. ${ }^{75}$ Their religious rhetoric reveals a certain political "compass." ${ }^{, 76}$ Randall Balmer defined evangelism as "the process of spreading the Gospel, the "good news' of salvation through Jesus Christ." ${ }^{.77}$ It is "something that evangelicals take seriously as part of their mandate from the Scriptures." That mandate is known as the Great Commission. Evangelists, then, are itinerant Christian ministers who feel compelled by Jesus" call to bring the "good news" to "the whole creation," making "disciples of all nations." They are, as Billy Graham explained, "God's ambassadors." 78

Technically, Balmer said, "every Christian who engages in evangelism would be considered an evangelist." ${ }^{79}$ However, more commonly, it is applied "to professional preachers, such as Dwight L. Moody or Billy Sunday or Billy Graham"--evangelists

\footnotetext{
${ }^{74}$ Graham, A Biblical Standard for Evangelists, p. 28.

${ }^{75}$ Howard Fineman, "Apocalyptic Politics," Newsweek, May 24, 2004, p. 55.

${ }^{76}$ Paul Kengor, "God \& W. at 1600 Penn.," National Review, March 5, 2003.

${ }^{77}$ Balmer, Encyclopedia of Evangelicalism, p. 207.

${ }^{78}$ Russ Busby, Billy Graham: God's Ambassador (San Diego, CA: W Publishing Group, 1999).

${ }^{79}$ Balmer, Encyclopedia of Evangelicalism, p. 207.
} 
who made evangelism "a full-time vocation." To put it differently, evangelists, using

Samuel Kernell's description of the increasingly common "strategic choice" of presidents to bypass formal political institutions to bring their case directly to the people, are voices of the church known for "going public" to "preach the word.", 80

Like modern presidents, evangelists have long used modern advances in technology, such as radio, television, direct mail, and air and rail travel, to reach more and more people. Though they may be promoting the "old-time religion," their methods are quite modern, they are quite innovative and dynamic. ${ }^{81}$ As Quentin Schultze observed, "evangelicalism has shaped the American system of mass communication" and "were often at the forefront of developing and using new media technologies, from the printing press to communications satellites." 82 In fact, he continues, "American media are distinctly evangelistic enterprises hoping to attract new "converts." If Schultze's assessment has merit, then, many of the strategies presidents use to reach the public may be described as "evangelistic." Arguably, it may be said that the "going public" strategies of modern presidents discussed by Kernell began as an initiative of the evangelical style of presidential politics beginning with William Jennings Bryan.

\footnotetext{
${ }^{80}$ Samuel Kernell, Going Public: New Strategies of Presidential Leadership (Washington, DC: Congressional Quarterly Press, 1997), p. ix; Graham, A Biblical Standard for Evangelists, p. 31.

${ }^{81}$ Martin E. Marty and R. Scott Appleby, The Glory and the Power: The Fundamentalist Challenge to the Modern World (Boston, MA: Beacon Press, 1992), pp. 18, 30-32; Bruce R. Lawrence, Defenders of God: The Fundamentalist Revolt Against the Modern Age (San Francisco, CA: Harper \& Row, 1989), p. 1; Noll, "Interview with Judy Valente," April 16, 2004.

${ }^{82}$ Quentin J. Schultze, "Introduction," to American Evangelicals and the Mass Media (Grand Rapids, MI: Academie Books, 1990), p. 13. See also Steve Bruce, Pray TV: Televangelism in America (London. UK: Routledge, 1990).
} 
As seen in the last chapter, the political style of William Jennings Bryan's was evangelistic. Indeed, one author described him as a "political evangelist." 83 Lawrence Levine described the Nebraska politician as an "evangelical crusader" full of "indefatigable energy and zeal." ${ }^{\prime 84}$ With his religious, evangelical-laded message, Bryan revolutionized presidential campaigns with his evangelistic style to directly take his message by crisscrossing the country to the people. ${ }^{85}$ He was a political innovator, using the conveniences of modern life to enhance his electoral appeal. Bryan's approach radically differed from the stay-at-home, front-porch strategy of others. "Bryan's herculean speaking tours," wrote Richard Ellis and Mark Dedrick, "marked a giant step in the direction of the modern candidate-centered campaign." His campaign was "precedent shattering," 86 Another wrote, "Bryan was the first "modern' presidential candidate in terms of aggressively selling himself." ${ }^{87}$ He was the "father of the "stump speech', perfected the art of whistlestopping." According to one estimate, "Bryan traveled farther (18,000 miles by train), saw more people (five million in twenty-seven states) and gave more speeches (600, or ten to twenty a day) than any

\footnotetext{
${ }^{83}$ Paolo E. Coletta, William Jennings Bryan: Political Evangelist, 1860-1908 (Lincoln, NE: University of Nebraska Press, 1964).

${ }^{84}$ Lawrence W. Levine, Defender of the Faith: William Jennings Bryan, the Last Decade, 1915-1925 (New York: Oxford University Press, 1965), pp. 21-23.

${ }^{85}$ Paul F. Boller, Jr., Presidential Campaigns (New York: Oxford University Press, 1996), pp. 169-170.

${ }^{86}$ Richard J. Ellis and Mark Dedrick, "The Rise of the Rhetorical Candidate," in The Presidency. Then and Now, ed. Phillip G. Henderson (Lanham, MD: Rowman \& Littlefield Publishers, 2000), p. 194.

${ }^{87}$ Eileen Shields-West, The World Almanac of Presidential Campaigns (New York: World Almanac, 1992), p. 127.
} 
presidential candidate before him." "On a scale never before attempted, Bryan decided to take his message directly to the people." ${ }^{\prime 89}$ With his newspaper, The Commoner, Bryan had a readership that reached into "tens of thousands of homes." Woodrow Wilson displayed this tendency too. As Jeffrey Tulis explained, Wilson was the originator of "the rhetorical presidency," a perspective that sees the president as the center of energetic government and as chief spokesperson of the people. $^{91}$ As will be seen with Carter in the next chapter, Wilson came to view the "separation of powers" as "the central defect of American politics." 92 1t inhibited the president's capacity to act on behalf of or express the will of the people. Rather than viewing the authority of presidential leadership from the Constitution, Wilson believed it was derived "directly from the people." 93 As if the national electorate was a Baptist polity writ large, the president, like the pastor, is elected by and serves at the pleasure of popular sentiment. He is granted the authority to lead, to act independently, to decipher majority opinion, and to teach and inform. And when confronted by opposition or delay from other centers of power (e.g., legislatures), the governor or president can take his case directly before the people and appeal for their direct support. To succeed, the

\footnotetext{
${ }^{88}$ Ibid., p. 125.

${ }^{89}$ Ibid., p. 129.

${ }^{90}$ Levine, Defender of the Faith, p. 23.

91 Jeffrey K. Tulis, "The Two Constitutional Presidencies," in The Presidency and the Political System, ed. Michael Nelson (Washington, DC: CQ Press, 2003), p. 92.

92 Ibid., p. 93.

${ }^{93}$ Ibid., pp. 101, 98.
} 
governor or president needs great oratory and the ability to simplify complex problems and solutions.

Whether in Trenton or Washington. Wilson did this. As governor of New Jersey, after the state legislature initially refused to advance his reforms, Wilson took his case to the people of the Garden State. Chris Wallace wrote, "If the career politicians refused to bend to his will, [Wilson] would take his case on the road." ${ }^{94}$ As president, against the recommendations of his advisors, Wilson took his case for the Fourteen Points directly to the leaders and people of Europe, making him the first sitting president to visit the continent, the first to personally take the cause of America (God?) to the world. ${ }^{95}$ Later, Wilson's campaign across the United States for the League of Nations is yet another example of this evangelical trait. Though he had to cut his travels halfway through due to illness and fatigue. Wilson`s whirlwind tour planned to cover 10,000 miles. ${ }^{96}$ It may be said, then, that the evangelistic style and method of Bryan and Wilson are the originators of what Kernell calls the "going public" strategy.

Obviously, having a penchant for evangelism does not guarantee effective or inspiring communication. One cannot choose to have the natural gifts of oratory (though they can be coached and can practice it). ${ }^{97}$ Bryan and Wilson were great

\footnotetext{
${ }^{94}$ Wallace, "Mission from God: Woodrow Wilson and the League of Nations," in Character, p. 172.

${ }^{95}$ Ibid., pp. 173-174.

${ }^{96}$ Transcript Part Two, American Experience: Hoodrow Wilson, narrated by Linda Hunt. directed and produced by Carl Byker and Mitch Wilson (WGBH Educational Foundation. 2001), http:/www.pbs.org/wgbh/amex/wilson/filmmore/fm_trans2.html, (accessed September 18, 2006).

${ }^{97}$ Greenstein, The Presidential Difference, p. 195. Carter, however, detested being coached and practicing his speeches. In his exit interview, speechwriter James Fallows explained that he did know "of any case in which he has accepted coaching." Carter "just hates to use texts and hates to practice to improve his delivery." His preference is to talk extemporaneously. "Whenever he can get away with it.
} 
orators. In Wilson's case, James David Barber said, "the core of Woodrow Wilson's presidential style was rhetoric." 98 Though he tried, Carter was not a great communicator. Nonetheless, hints of Carter evangelistic style are found in Greenstein.

Fred Greenstein observed that Carter "began well" with his unprecedented inaugural walk and during his "cardigan sweater phase." 99 He also noted that a Time magazine writer said at the time that Carter was "winning converts by the millions with his revivalist, meet-the-masses approach to the presidency."

For his part, as if he were before his Sunday school class, Carter was at his best in small groups. ${ }^{100}$ He was everything he was not before large audiences, wrote William Quandt, "less skillful," "his delivery was wooden, the rhetoric was stilted, and he often seemed uncomfortable."101 Before small groups, said United Nations Ambassador Donald McHenry (1979-1981), Carter was "a great communicator," "a very impressive, communicative figure," but "double the size of [the] room and he would be a disaster."102 Based on interviews with communications staffers, Mark Rozell reported that in "addresses to smaller, more familiar groups," such as before

he prefers to have us [his staff] just give him talking points rather than a text." Fallows, "Exit Interview with Lee Johnson, Presidential Papers Staff," November 14, 1978. Transcript available at Jimmy Carter Library and Museum, Oral History Transcripts, http://www.jimmycarterlibrary.gov/library/oral.phtml.

${ }^{98}$ James David Barber, The Presidential Character: Predicting Performance in the White House (Upper Saddle River, NJ: Prentice Hall, 1992), p. 48.

${ }^{99}$ Greenstein, The Presidential Difference, p. 140.

${ }^{100}$ Barber, The Presidential Character, p. 445; Walter Mondale, "The Perspective of the Vice President," in The Carter Presidency: Fourteen Intimate Perspectives of Jimmy Carter, Portraits of American Presidents, Vol. VIII, edited by Kenneth W. Thompson (Lanham, MD: University Press of America, 1990), p. 240.

${ }^{101}$ William B. Quandt, Camp David: Peacemaking and Politics (Washington, DC: The Brookings Institution, 1986), p. 31 . 
African-American groups, Carter "required little preparation" and he felt "a genuine sense of empathy with the audience." 103 He hated to act or produce fake emotions. "Carter's finest speeches," staffers said. "were ones in which he related on a personal level to individual members of the audience."

Because a president is an effective and inspiring "public communicator" like Franklin Roosevelt or Ronald Reagan, this trait does not qualify him as an "evangelist" as understood here. Evangelistic communication is a coterminous characteristic with the other features of the evangelical style. Though Carter, for instance, was not a great orator, on issues that mattered to him, he presented them in biblical or moral terms, such as energy, human rights, or peace in the Middle East. Whether he did it well or not is inconsequential. The fact is the $39^{\text {th }}$ president did resort to frequent national addresses with a tone that commonly came across as sermons, such as his inaugural address and his so-called "malaise" speech of July 1979. Roosevelt and Reagan, in contrast, were not said to have a preacher-problem, but Carter, like Wilson, was. ${ }^{104}$ Evangelistic public communication is a descriptive trait of the evangelical style, but not necessarily an effective one. As Dan Hahn explained, "just as he talked his way into the White House from 1972-1976, once there he talked himself out of it." ${ }^{\text {105 }}$ Still, evangelical presidents will evangelize. They will try to make their case to the people, and make it

\footnotetext{
${ }^{102}$ Donald McHenry, "The Carter Presidency and the United Nations," in The Carter Presidency: Fourteen Intimate Perspectives of Jimmy. Carter, Portraits, p. 167.

${ }^{103}$ Mark J. Rozell, "President Carter and the Press: Perspectives from White House Communications Advisers," Political Science Quarterly 105.3 (Autumn 1990): 425.

${ }^{104}$ See Barber. The Presidential Character, p. 445; MacMillan, Paris 1919. p. 39: Dan F. Hahn. "The Rhetoric of Jimmy Carter, 1976-1980," Presidential Studies Quarterly 14.2 (Spring 1984): 265-288.

${ }^{105}$ Hahn, "The Rhetoric of Jimmy Carter, 1976-1980," p. 285.
} 
often in moral terms and with scriptural reference. But going further than Tulis, the evangelical politician, the evangelical president, does not solely rest his case on popular authority, but on higher authorities. ${ }^{106}$

\section{Evangelical Mission and Political Vision}

"My relationship with God through Christ gives me meaning and direction."107 ---George W. Bush

Having a sense of mission is a defining characteristic of evangelicalism. It may be said that this sense of evangelistic mission is a key element of an evangelical style of governing.

The evangelical president views the country and the world more in terms of what they ought to be than what they presently are or have been. They are ruled more by idealism than realism. Following Greenstein, it may be fair to claim that the evangelical president possesses a "political vision." And, following James David Barber's typology, they are likely to be "active" leaders. ${ }^{108}$ But unlike other "active," regime-creating, politically visionary presidents, the evangelical president presents his

\footnotetext{
${ }^{106}$ As an example of this, British Prime Minister Tony Blair admitted in 2006 that he prayed about his decision to go to war in Iraq and that his Iraq war policy was not merely a matter of judgment for voters. Perhaps most importantly, as a believer, he claimed, historic judgment is not made by the voters alone, but "made by God as well." See "Blair "prayed to God' over Iraq," BBC News, March 4, 2006; "PM attacked on Iraq 'God' remarks," $B B C$ News, March 4, 2006; Michael White, "God will judge me, PM tells Parkinson," The Guardian, March 4, 2006. Similarly, German Chancellor Gerhard Schroeder was troubled by President George W. Bush's reliance on his faith in God. "Again and again in our private talks," said Chancellor Schroeder, "it became clear how God-fearing this President was and how ruled he was by what he saw as a Higher Power." Quoted in Roger Boyes, The (London) Times, October 23, 2006.

${ }^{107}$ George W. Bush, Transcript, PBS Frontline: The Jesus Factor, narrated by Will Lyman, written, produced, and directed by Raney Aronson (WGBH Educational Foundation, 2004), http:/www.pbs.org/wgbh/pages/frontline/shows/jesus/etc/script.html, (accessed May 25, 2004).
} 
vision in unmistakable religious, moral terms. In fact, there is a strong temptation for observers to call this kind of president a "crusader" or "Wilsonian." For instance, one critic of George W. Bush's foreign policy and fellow Republican. Senator Chuck Hagel of Nebraska said, "You cannot have a foreign policy based on divine mission. We tried that in the Middle Ages, that's what the Crusades were about."

President Carter has often been criticized for having not put forth a compelling political vision. He took on too many issues, lacked focus, and failed to prioritize. It is true that he did not necessarily provide a clear linkage between and among the many issues he undertook and policy proposals he pushed. Carter speechwriter James Fallows wrote that his former boss held "no large view of the relations between" parts of his agenda. ${ }^{110}$ For Carter staffers whose job it was to communicate the direction of the administration the absence of issue linkage was problematic and frustrating. But Carter did have a strong sense of mission and, as will be seen in chapters 5 and 6 , he had a foreign policy vision, particularly with regards to the Middle East, inspired by guidelines from the Bible. Rather than offering a comprehensive, systematically presented political vision as a legitimate theologian might offer. Carter was perhaps more like the Good Samaritan. Unlike his priestly predecessors that walked by an injured man on the road, this unknown, unidentified, yet heroic, Biblical figure was guided by a simple sense of mission, the love of God and neighbor, to help others in

\footnotetext{
${ }^{1118}$ Barber, The Presidential Character, p. 9.

${ }^{109}$ Quoted in Dimitri K. Simes, "End the Crusade," National Interest 87 (January/February 2007): 5.

$11($ James Fallows, "The Passionless Presidency: The Trouble with the Jimmy Carter Administration." Atlantic Monthly (May 1979), 42.
} 
need in a random, unstructured, unanticipated way. In his own way, Carter, the onetime dark-horse candidate who became president, explained that he took on many difficult issues, intentionally left by his predecessors, because they were the right things to do, even if "they've cost us politically." 111

\section{Evangelical Personalism and Political Skill}

"Tony [Blair] is a man of strong faith. You know, the key to my relationship with Tony is he tells the truth, and he tells you what he thinks and when he says he's going to do something, he's going to do it. I trust him." 112

---George W. Bush

Presidents exhibiting an evangelical style are likely to have a personalistic approach in their relations with others. That is, as the quote above illustrates, they are likely to publicly proclaim their intimacy with God and may seek out others who share their intense religious faith. In some way, they may claim they that have been "called" into public service and they may seek out others who share their faith outlook and intensity. Though this "tactic" is not always successful, if not in most cases, it is still the primary means an evangelical-styled president uses to build trust and forge close personal ties with fellow world leaders.

Later in this study, evidence will be provided showing such a relationship between Carter and Egyptian President Anwar Sadat. Other evidence will show that

\footnotetext{
${ }^{111}$ Carter, "Remarks at a State Democratic Party Reception in Columbus, Ohio," September 23, 1978. Public Papers of the Presidents, Book II, p. 1623.

112 George W. Bush, "Interview with Sir David Frost of BBC News," November 17, 2003. The White House, http://whitehouse.gov/news/releases/2003/11/20031117-1.html.
} 
Carter did try to use his faith to forge closer ties with other leaders as well. Though other presidential studies do not consider this dimension, it is argued here that the personalism inherent in the evangelical style can contribute to effective presidential negotiation particularly when in Greenstein"s terms "it is harassed to a vision of public policy." $" 113$

\section{The Calmness and Certainty of Evangelical Faith and Emotional Intelligence}

"When God tells a man to speak he cannot stop to count those who stand with him. He must speak even though he cries in the wilderness; he must stand up even if he has to stand alone."114

---William Jennings Bryan

"Die happy because you believe that you tried to serve your country by not selling your soul." 115

---Woodrow Wilson

"I take great comfort in my faith...[it] helps deal with the stress and the burden that you carry. .116

---George W. Bush

Evangelicals may be described as Christians of certainty. They are certain the

Bible is the Word of God, Christ died for their sins, and that they have the "blessed assurance" of a heavenly reward. One could expect then that evangelical-styled

\footnotetext{
${ }^{113}$ Greenstein. The Presidential Difference, pp. 5-6.

${ }^{114}$ Levine, Defender of the Faith, p. 3.

${ }^{115}$ Wilson, "Remarks at Independence Hall in Philadelphia, Pennsylvania," July 4. 1914. The American Presidency Project, http://www.presidency.ucsb.edu/ws.

${ }^{116}$ G.W. Bush, "Interview with Diane Salvatore," Ladies ' Home Journal (August 2004): 103.
} 
presidents will exhibit certainty and calm in policy areas they view in religious or moral terms. This was true of Bryan, Wilson, and Carter.

Though critics are likely to charge this class of political leaders with arrogance, naiveté, simplemindedness, and the unnecessary alienation of would-be allies at home and abroad for their "rigid" adherence to a policy course chosen on moral grounds, their evangelical faith provided these presidents with the personal confidence and equanimity to make bold decisions and endure frequent, bitter criticisms. Though presidents often pray during times of crisis and war, prayer for the evangelical president is more routine; they seek emotional support from a higher power frequently, if not daily. ${ }^{117}$ This dimension of the evangelical style fits nicely with what Greenstein called "emotional intelligence"- - "the president's ability to manage his emotions and turn them to constructive purpose."118 Among the five other qualities he considered important for effective presidential leadership, Greenstein considered "emotional intelligence" as an absolutely essential presidential attribute, in fact, it may be the most important. "Beware the presidential contender who lacks emotional intelligence. In its absence all else may turn to ashes." 119

The Calm and Certainty of Bryan and Wilson

William Jennings Bryan once said, "Only the man of faith can be courageous." That is, says biographer Robert Cherny, Bryan could maintain a sense of calm and

\footnotetext{
${ }^{117}$ Evan Thomas and Andrew Romano, "In God They Trust," Newsweek, May 7, 2007. pp. 35-36.

${ }^{118}$ Greenstein, The Presidential Difference, p. 6.

${ }^{119}$ Ibid., p. 200.
} 
certainty in the face of strong opposition and repeated disappointed because Bryan as "a Christian gained inner peace through prayer and through assurance of immortality. Inner peace produced courage." 120

Contrary to most Bryan biographers who argued that the Bryan of the 1920s was fundamentally different from the Bryan of earlier years, Lawrence Levine asserted that Bryan was largely the same throughout his career. "The Bryan of the 1920's was essentially the Bryan of the 1890 's: older in years but no less vigorous, no less optimistic, no less certain."121 That, Levine concluded, was his problem-"he was incapable of change in a world that demanded it."122 Additionally, Levine continued, Bryan "lacked any introspective quality; he never questioned his own actions, he never sought to know his deepest motives, he never agonized..."123

Biographer Louis Auchincloss found a similar tendency in Wilson. He noted that after losing the Treaty vote in the Senate, President Wilson "reached for a Bible and had this verse from Saint Paul's Epistle to the Corinthians read to him: 'We are troubled on every side but not distressed. We are perplexed but not in despair.' Then he commented: 'If I were not a Christian, I think I should go mad, but my faith in God holds me to the belief that He is in some way working out His own plans." 124 In the

\footnotetext{
${ }^{120}$ Robert W. Cherny, A Righteous Cause: The Life of William Jennings Bryan (Norman, OK: University of Oklahoma Press, 1994), p. 188.

${ }^{121}$ Levine, Defender of the Faith, p. vii.

${ }^{122}$ Ibid., p. viii.

${ }^{123}$ Ibid., p. ix.

${ }^{124}$ Louis Auchincloss, Woodrow Wilson (New York: Viking-Penguin Group, 2000), p. 118.
} 
end, regardless of how his contemporaries or history would judge him, Wilson took solace in the fact that he "tried to serve God." 25 Remarking on his failure to get the U.S. Senate to approve his proposal for the League of Nations, Wilson said the people just were not ready. Had it passed, the League would have been merely his own "personal triumph." "God knew," he said. "God knew what to do better than I did."126

\section{Emotional Intelligence or Arrogance}

Historian Margaret MacMillan noted that Woodrow Wilson's critics frequently charged him with being "a good hater," "stubborn," possessing "a dangerous egotism," lacking "the slightest conception that he can ever be wrong," of being "intolerant of differences," and characterizing his opponents as "not just wrong but wicked." 127 French President Georges Clemenceau remarked that "talking to Wilson is something like talking to Jesus Christ!" 128

Similarly, wrote Neustadt, Carter despised "politics as usual," did not want an administration where advisors and staffers "rise and fall by virtue of Machiavellianism." and did not like to be coached and handled by staff. ${ }^{129}$ He thought politics as it was

\footnotetext{
${ }^{125}$ Kendrick A. Clements, Woodrow Wilson: World Statesman (Chicago, IL: Ivan R. Dee, 1999), p. 224.

${ }^{126}$ Wilson, Transcript Part Two, American Experience: Woodrow Wilson, narrated by Linda Hunt, directed and produced by Carl Byker and Mitch Wilson (WGBH Educational Foundation, 2001), http://www.pbs.org/wgbh/amex/wilson/filmmore/fm trans2.html, (accessed September 18, 2006).

${ }^{127}$ Margaret MacMillan, Paris 1919: Six Months that Changed the World (American edition; New York: Random House, 2003), pp. 5, 7.

${ }^{128}$ Ibid., pp. 18, 33.

${ }^{129}$ Neustadt, Presidential Power and the Modern Presidents, p. 152. Carter speechwriter Jim Fallows said that Carter hated to practice his speech delivery, hated to use prepared texts, hated to practice before debates. In time, Fallows noted, Carter did learn that he could not do all the speechwriting and editing
} 
commonly conducted was dirty, "almost ignoble." and he often got angry when staffers suggested he at least try to see things from the political perspectives of members of Congress. ${ }^{130}$ Haynes Johnson observed that "Carter, over and over in conversations and interviews. would say. 'It was not my nature to do this. it was not my nature to do that. ${ }^{\cdots 131}$ He freely admitted in his campaign autobiography that one of his faults is his uncompromising tendency: "I don't know how to compromise on any principle I believe is right... maybe this is a time, on matters of principles, for an absence of compromise."132 In the first year of his presidency, he again said, "I'm not naturally inclined to overcompromise.".133

This was one of Carter's main criticisms of President Ford. He said Ford lacked "boldness or aggressiveness." His problem, Carter believed, was that he spent too many years in Congress before he became president where bargaining and politicking are the norm. "I think he is a typical product of a lifetime in the Congress. where everything is handled incrementally and through compromise. ${ }^{-134}$

himself and that he could not simply speak plainly and extemporaneously, but that was not his preferred style. "He lived most of his political life without any speechwriters... [and] he feels much more comfortable extemporizing rather than reading from a text." James Fallows. "Exit interview with Lee Johnson, Presidential Papers Staff." November 14, 1978, Jimmy Carter Library and Museum, Oral History Transcripts.

1 \$30 Johnson. "Discussion Among Panelists," in Jimmy. Carter: Foreign Policy' and Post-Presidential Years, p. 396.

131 Johnson, "Questions and Answers," in Jimmy. Carter: Foreign Policy and Post-Presidential Years. p. 401 .

${ }^{132}$ Carter, Why Not the Best? (New York: Bantam Books, 1976). p. 161.

$13:$ Carter, "Remarks and Question-and-Answer Session by Telephone with Members of the American Society of Newspaper Editors," May 3, 1977, Public Papers of the Presidents, Book 1. p. 791; "Interview with Tom Brokaw of NBC News. Bob Schieffer of CBS New', Robert MacNeil of PBS Newshour. and Barbara Walters of ABC News." December 28. 1977. Public Papers of the Presidents, Book 11. p. 2202. 
Like Wilson, Carter had the expected "emotional intelligence" of an evangelical president, both positively and negatively. Barber believed that successful presidents inevitably had a positive view of themselves and the presidency. In his initial assessment of Carter, he believed that his faith would have a positive influence. ${ }^{135}$ In particular, Barber cited Carter's born-again experience as a key moment in his life that signified "a letting go, an inner surrender of pride." Barber believed that Carter's renewal of faith made him a better man, a more confident politician, and in turn would make him a "positive" president.

Though Greenstein only emphasized the negative aspects, such as Carter's ostensible rigid personality and his reluctance to take account and care of political realities and responsibilities, Carter, like Bryan and Wilson, believed it was more important to be right than popular and often said he enjoyed being president. $\mathrm{He}$ believed that while he never was certain if his decisions as president were necessarily the right ones he believed his evangelical faith nonetheless provided him "a greater level of assurance and equanimity."136

Instead of being emotionally overwrought and feeling terribly burdened by the office, Carter said his faith was "a stabilizing factor."137 "God gave me a character and

\footnotetext{
${ }^{134}$ Carter, "Remarks at a News Conference in Little Rock, Arkansas," April 11, 1975, in A Government As Good As Its People, pp. 44-45.

${ }^{135}$ Barber, The Presidential Character, p. 432.

${ }^{136}$ Carter, Living Faith, p. 105.

${ }^{137}$ Carter, "Remarks and Question-and-Answer Session at a Town Hall Meeting with New Hampshire High School Students," February 18, 1978, Public Papers of the Presidents, Book 1. p. 370.
} 
a temperament that doesn't cause me to lose control of myself."138 As president, he said that although "I still fall far short of what God expects of me," he received comfort and strength from God and the Bible. "I look to the Bible as a source for guidance and pray for God's guidance."139 Faith in God and inspiration from the Bible evidently helped him have a positive attitude toward being president and his presidential duties.

1 feel at ease with the job. I ve enjoyed it. I roll easily with the punches of criticism, whether I think it's deserved or not deserved...I m doing the best I can with difficult problems. ${ }^{1+0}$

Carter asserted that the presence of God in his life, the living model of Christ, and his daily routine of worship and prayer with his wife Rosalynn sustained and refreshed him during the low moments of his presidency.

I seek divine guidance when I make a difficult decision as President and also am supported, of course, by a common purpose which binds Christians together in a belief in the human dignity of mankind and in the search for worldwide peace. $^{1+1}$

To me, God is real. To me, the relationship with God is a very personal thing. God is ever-present in my life-sustains me when I am weak, gives me guidance when I turn to him, and provides for me as a Christian through the life of Christ. a perfect example to emulate in my experiences with other human beings. $\mathrm{My}$ wife and I worship together every night, and often during the day I turn to God in a quiet and personal way. ${ }^{142}$

\footnotetext{
${ }^{138}$ Carter, "Remarks and a Question-and-Answer Session with Editors and Broadcasters of Harte-Hanks Communications," April 23, 1980, Public Papers of the Presidents, Book I, p. 766.

${ }^{139}$ Carter, "Remarks and a Question-and-Answer Session at a Town Meeting in Elk City, Oklahoma," March 24. 1979, in Public Papers of the Presidents, Book 1. p. 473.

${ }^{140}$ Carter. "The President's News Conference," April 11, 1978, Public Papers of the Presidents, Book I. pp. $728-729$.

141 ."The President's News Conference Held in Warsaw, Poland," December 30, 1977, in Public Papers of the Presidents of the United States. Book II. p. 2207.

142 Carter, "Remarks at the $26^{\text {th }}$ National Prayer Breakfast." February 2, 1978, Public Papers of the Presidents, Book I, p. 263.
} 
I am a believer in Jesus Christ and a born-again Christian. I do worship regularly. I spend a lot of my own time in prayer. Every evening, my wife and I have religious services together, one of the last things we do each day. And we never miss under any circumstances. ${ }^{143}$

Carter often confessed as president his moral limitations, too. He acknowledged he was a sinner and that he made mistakes. "As a Christian," he explained, "I recognize that I am sinful, that I fall short of the expectations of God and my fellow human beings. And as a politician, I know that there are many times when I or either or my associates have disappointed the American people."144 Still, critics often charged Carter with holier-than-thou arrogance. ${ }^{145}$

To deal with the special burdens of the presidency, he said he "prayed more during those four years than at any other time" in his life, feeling the need to have "a sense of God's presence" around him in job that could be lonely and stressing. ${ }^{146} \mathrm{He}$ said that he found his faith "very beneficial" as president. In the ebbs and flows of political life, he said it provided him something "that never changes." ${ }^{477}$ Frequently turning to prayer as president, Carter said he daily sought "God's guidance."

${ }^{143}$ Carter, "Remarks and a Question-and-Answer Session at a Town Meeting in Elk City, Oklahoma," March 24, 1979, in Public Papers of the Presidents of the United States, Book I, pp. 472-473; "Remarks During a Telephone Call-Out Program on National Public Radio," October 13, 1979, in Public Papers of the Presidents of the United States, Book II, p. 1887.

${ }^{144}$ Carter, "Remarks and Question-and-Answer Session with a Group of Editors and News Directors," July 28, 1978, in Public Papers of the Presidents of the United States, Book I, p. 1355.

${ }^{145}$ Leo P. Ribuffo, "God and Jimmy Carter," in Transforming Faith: The Sacred and the Secular in Modern American History, eds. M.L. Bradbury and James B. Gilbert (New York: Greenwood Press, 1989), p. 154.

${ }^{146}$ Carter, Living Faith, p. 97.

${ }^{147}$ Carter, "Remarks and Question-and-Answer Session at a Town Hall Meeting with New Hampshire High School Students," February 18, 1978, Public Papers of the Presidents, Book 1, p. 370. 
Despite his crushing defeat in 1980. Carter confidently reinserted himself into public life and political debate throughout his post-presidential years, taking on both Republican and Democratic presidents and American allies and enemies. ${ }^{1+8}$ While defeat could have caused the emotionally insecure to retreat permanently into private life, Carter did not. He remained a public figure. often presently himself as a national and international authority on political and religious matters of the day.

There was a rich life, may be even richer, to be had after political defeat. In Everything to Gain, a book co-authored with his wife, Carter explained that "a sense of joy and peace" was still to be had provided he first and foremost took upon "a spirit of submission to God's will," pursuing worthy goals "as measured by God." ${ }^{1+9}$ In fact, as he began thinking about establishing the Carter Center, he came to believe not long after leaving the White House, that without the confines of elected office, "We may even be able to do more than if we had won the election in $1980 !^{* 150}$

I now turn to describing and discussing the faith of President Jimmy Carter and the operation of his evangelical leadership style.

\footnotetext{
${ }^{148}$ Greenstein. "George W. Bush and the Ghosts of Presidents Past," p.80; "The Person of the President. Leadership. and Greatness," p. 221.

${ }^{149}$ Carter, Everything to Gain: Making the Most of the Rest of Your Life (Fayetteville. AR: University of Arkansas Press, 1995; originally published in 1987). p. 169.

${ }^{150}$ Ibid., p. 27.
} 


\section{"I Had a Different Way of Governing": The Living Faith of President Carter}

"I had a different way of governing...I was a Southerner, a born-again Christian, a Baptist, a newcomer."1

"There's no doubt that my faith did affect my decisions.",

As he ran on a promise to be good, honest, and decent, the religious style of Jimmy Carter and his wholesome image were a key part of his electoral appeal in 1976. Many of his supporters, such as Martin Luther King, Sr., believed "the Lord has sent Jimmy Carter to...bring America back." ${ }^{3}$ Those promises and hopes did not end with the campaign. He consciously allowed his faith to guide his presidential behavior, set his priorities, and inspire his post-presidential life. This chapter shows that religion was not simply part of his election appeal or important to Carter personally and privately, it was central and fundamental to his politics and his presidency.

Jimmy Carter did not separate his faith from politics; he applied it. Carter understood politics as "an extension of the gospel, problem solving combined with

\footnotetext{
* Versions of this chapter were presented on April 30, 2004 at The Symposium on Religion and Politics, the Henry Institute, Calvin College, Grand Rapids, Michigan and published in the Journal of Church and State 47.1 (Winter 2005): 43-61, and The Keynoter: Journal of the American Political Items Collectors (Fall/Winter 2004): 24-25.

${ }^{1}$ Quoted in Erwin C. Hargrove, Jimmy Carter as President: Leadership and the Politics of the Public Good (Baton Rouge, LA: Louisiana State University Press, 1988), p. 15; Fred I. Greenstein, The Presidential Difference: Leadership Style from FDR to Clinton (Princeton, NJ: Princeton University Press, 2000), p. 128.

2 Jimmy Carter, "Interview with Bob Abernathy," Religion and Ethics Newsweekly, October 29, 1999, http://www.pbs.org/wnet/religionandethics/week309/cover.html.
} 
Christian charity." $\mathrm{He}$ was, as former Carter speechwriter Hendrik Hertzberg put it, a president who had a style of leadership that "was and is religious more than political in nature. He was and is a moral leader more than a political leader." ${ }^{5}$ And that is what concerned some in 1976: Carter was serious about his faith; it was not empty rhetoric. As one wrote, "It was the very sincerity of his religious beliefs that troubled people.", This chapter describes and discusses various components of Jimmy Carter's evangelical presidential style. It describes his evangelical faith and his views on the integration of religion and politics. It documents his understanding of politics as a form of lay ministry. It shows the religious character of his 1976 campaign, and it looks at two domestic cases during his presidency when he seemingly put his faith in action: his energy policy, which he called "the moral equivalent of war," and what may be termed his "religious contempt" for Congress. This chapter will illustrate that Carter's faith mattered in terms of his understanding of politics, his presidential style, and how he saw his role as president. The two cases examined here are chosen because they are often seen as defining features of, or problems with, the Carter presidency. Moreover, and significantly, they are instances to which he chose to best direct his religious

\footnotetext{
${ }^{3}$ Quoted in "The Democrats: God in the Garden?" Christianity Today, August 6, 1976, 34.

${ }^{4}$ Quoted in Peter G. Bourne, Jimmy Carter: A Comprehensive Biography from Plains to Postpresidency (New York: Scribner, 1997), p. 210.

"Hendrik Hertzberg, "Jimmy Carter, 1977-1981," in Character Above All: Ten Presidents from FDR to George Bush, ed. Robert A. Watson (New York: Simon and Schuster, 1995), p. 180.

${ }^{6}$ Leslie Wheeler, Jimmy Who? An Examination of Presidential Candidate Jimmy Carter, the Man, His Career, His Stands on the Issues (Woodbury, NY: Barron's, 1976), p. 135.
} 
principles. ${ }^{7}$ It is the view here that Carter cannot be fully understood as a candidate or a president without due attention to his religion.

\section{The Presidential Exceptionalism of Carter}

While the Constitution bars formal religious tests for public office, Americans like, and perhaps expect, their presidents to express minimally a generic belief in God and show some appreciation for the role of religion in American life. Surveys consistently show that Americans are not comfortable with the prospects of an atheistic president. In a 2006 Gallup poll, $84 \%$ said they believed that the country was not ready for a president who openly disavowed God's existence; only $14 \%$ said the country was ready for such a president. ${ }^{8}$ Among Democrats and non-whites, a mere $8 \%$ and $9 \%$ respectively said the country was ready to elect an atheistic president.

As seen in chapter two, the conventional presidential protocol has been to affirm that religion is a private affair, too personal to be political, too mysterious to proclaim with certainty, too sacred to enter the world of the profane. For most presidents, the separation of church and state has largely meant the separation of religion and politics.

While many presidents were raised in religious homes, were regular churchgoers, affirmed some sort of denominational loyalty, and invoked the blessings and succor of the Divine, "past American presidents have followed a long tradition of keeping private faith separate from public performance of duty" and have been largely theological

\footnotetext{
${ }^{7}$ James S. Wolfe, "Exclusion, Fusion, or Dialogue: How Should Religion and Politics Relate?" Journal of Church and State 22.1 (Winter 1980): 104.

${ }^{8}$ Jeffrey M. Jones, "Six in 10 Americans Think U.S. Ready for a Female President; Vast majority think country would not accept atheist or gay president," Gallup Poll News Service, October 3, 2006
} 
moderates and mainline Protestants. ${ }^{9}$ Religion may be contemplative, but not

politically transformative. There have been many personally religious presidents. but few would qualify as what is termed here as evangelical-styled presidents.

Not President Carter, however. Carter was different. He made the sources of that difference known and much of it he claimed was religious: "I was a Southerner. a born-again Christian, a Baptist, a newcomer. ${ }^{\cdot 10}$ As a candidate and president. he said that he was a believer in God and that he was neither ashamed of it nor afraid to publicly say so. He proudly said he was religious and "America is a religious nation." He also stated that much of the country"s strength was rooted in the "belief in God."11 Unlike the Soviet Union, which is "an atheistic nation." Carter said the United States is "a nation with deep ethical standards and religious beliefs." 12

Carter also believed that it was his responsibility to align the behavioral standards of being president with "the standards set for us by Jesus Christ" and "make

\footnotetext{
${ }^{9}$ Richard G. Hutcheson. Jr.. God in the White House: How Religion Has Changed the Modern Presidency (New York: Collier Books, 1988). p. 2: Charles W. Dunn, "The Theological Dimensions of Presidential Leadership: A Classification Model," Presidential Studies Quarterly 14. no. 1 (Winter 1984): 64: Albert J. Menendez has also noted that historically references to God in the Democratic and Republican party platforms have been rare. Menendez, "Taking a "quiet" position," Religious News Service, October 17, 1992: A. James Reichley, Faith in Politics (Washington. DC: Brookings lnstitution Press, 2002) pp. 4-5.

${ }^{10}$ Carter, "Interview with Charles O. Jones. H. Clifton McCleskey, Kenneth W. Thompson, James Sterling Young, Richard Neustadt, David B. Truman, Richard F. Fenno, Jr., and Edwin C. Hargrove." Carter Presidency Project, November 29, 1982, Plains, Georgia. Transcript available online at the Miller Center for Public Affairs, University of Virginia, http: Www millercenter virginia.edu/index.php scripps/digitalarchive/oralhistories detail 3260 .

${ }^{11}$ Carter, "Remarks at a Democratic Party Rally for John lngram in Wilson. North Carolina." August 5. 1978, in Public Papers of the Presidents, Book II. p. 1389.

12 Carter. "Remarks at the Annual Convention of the Building and Construction Trades Department of the AFL-ClO in San Diego, California." October 11. 1979. in Public Papers of the Presidents, Book II. p. 1871.
} 
our own societal structure a better demonstration of what Christ is."13 "The perfect example of Christ," he asserted before a Sunday school class in July 1977, "is what our nation ought to be."14 He was readily viewed by many at the time, with hope and anticipation, as "the evangelical president."15

As a presidential candidate and president, Carter repeatedly crossed that line of separation and candidly admitted that his religious faith influenced his presidential behavior. ${ }^{16}$ In fact, Carter may indeed be "the most religious U.S. president of the $20^{\text {th }}$ century." $" 17$ As president, for instance, he taught Sunday school on thirteen occasions and had a church attendance rate of at least $90 \%$ every year as president (Figure 4.1). ${ }^{18}$ Even during the 1976 campaign, other candidates, such as Ford and Reagan, began to emphasize their own religious activities only in response to Carter's quite public display. But still, as David Kucharsky noted, "None of these men...ever approached the outspokenness evinced by Carter."19

\footnotetext{
${ }^{13}$ Carter, "Remarks at the Baptist Brotherhood Commission of the Southern Baptist Convention," May 13, 1977, Public Papers of the Presidents, Book 1, p. 877; Quoted in "The Democrats: God in the Garden?" Christianity Today, August 6, 1976, 34.

${ }^{14}$ Carter, "Remarks Before Couples' Class at First Baptist Church in Washington, D.C.," July 31, 1977 , in Wesley Pippert, The Spiritual Journey of Jimmy Carter: In His Own Words (New York: Macmillan Publishing Company, 1978), p. 193.

${ }^{15}$ Martin E. Marty and R. Scott Appleby, The Glory and the Power: The Fundamentalist Challenge to the Modern World (Boston, MA: Beacon Press, 1992), p. 71.

${ }^{16}$ Hutcheson, God in the White House, p. 3; Carter, "Interview with Bob Abernathy," Religion and Ethics Newsweekly, October 29, 1999.

${ }^{17}$ Robert E. Dewhirst, Encyclopedia of American Religion and Politics, eds. Paul Djupe and Laura Olson (New York: Facts on File, Inc., 2003), p. 76; Robert F. Drinan, "Reflections on Nobel Laureate Jimmy Carter," National Catholic Reporter, October 25, 2002.

${ }^{18}$ Complete data provided in the Appendix.
} 
Figure 4.1 President Carter's Weekly Church Attendance Rate, 1977-1981

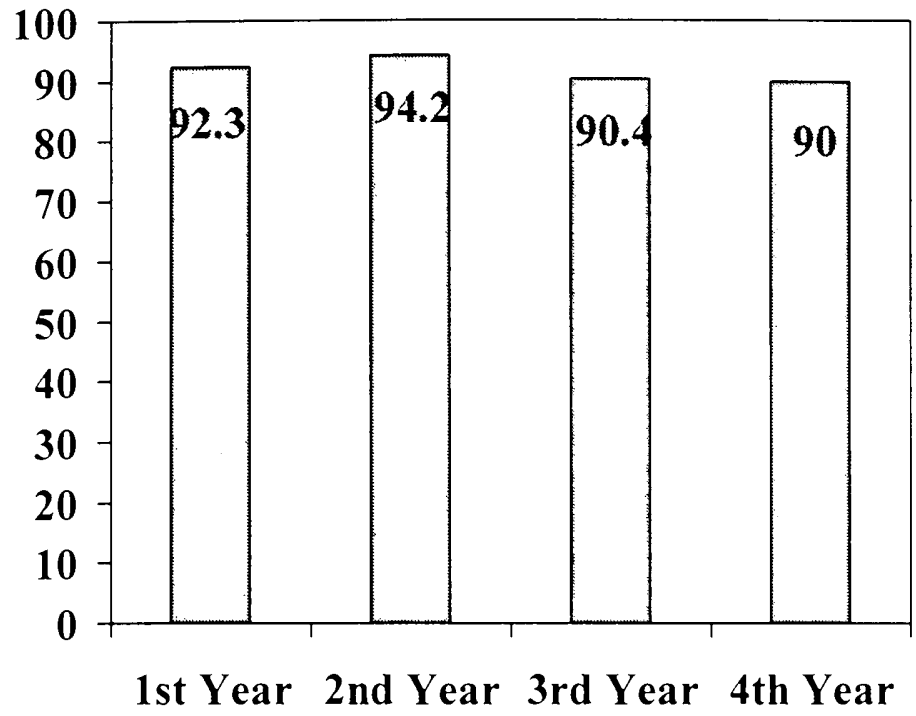

Source: Compiled by Author from "The Jimmy Carter Presidential Daily Diary Online," Jimmy Carter Library and Museum website.

http: www.jimmycarterlibrary.gov documents diary index phtml.

\section{The Year of the Evangelical}

*Ever since the election of Jimmy Carter in 1976, the taboo on public expression of religious sentiments by American political leaders seems to have been steadily eroding, to the extent that presidential candidates [since] have been publicly invoking God and Jesus Christ at a pace not seen since the days of William Jennings Bryan. ${ }^{.20}$

After a period of scandal, in 1976, Americans elected a president who seemed to meet their religious expectations and reflected their values; they elected a man of strong traditional faith who promised to bring that faith into the White House. Before

\footnotetext{
${ }^{19}$ David Kucharsky, The Man from Plains: The Mind and Spirit of Jimmy. Carter (New York: Harper and Row Publishers, 1976), pp. 5-6.

${ }^{20}$ Wilfred M. McClay, "Two Concepts of Secularism." The H'ilson Quarterly 24.3 (Summer 2000): 57 : Kucharsky, The Man from Plains, pp. 105-109.
} 
members of the California State Senate, Carter stated, "If I had to sum up in one word what this campaign is all about, the word would be 'faith'.,21 And they voted largely for him because of his "good intentions and his faith," not really because they perceived that he offered a political agenda radically different from President Ford. ${ }^{22}$

During the 1976 campaign, his faith was widely reported by the mainstream press. Candidate Carter rarely missed an opportunity to speak about his faith and what it meant to him, his commitment to Christ, his love for Scripture, how his faith personally changed his life, and his desire to bring "a new spirit" to government. He quickly became a symbol of the rekindled religious and political vigor of American evangelicalism. $^{23}$

Carter's race for the nomination and his election to the presidency established for many the arrival of a new force on the American scene: the Protestant evangelical. ${ }^{24}$

During the 1976 campaign the evangelical movement in Protestantism, which had long been gathering strength, reached the level of public awareness, thanks in considerable measure to Carter... Both religiously and politically, the Carter presidency exemplified the 'signs of the times. ${ }^{25}$

"It seems scarcely believable that when Jimmy Carter ran for president in 1976, many people outside the South had never heard the phrase 'born-again Christian." 26

\footnotetext{
${ }^{21}$ Carter, "Remarks Before the California State Senate in Sacramento, California," May 20, 1976, in A Government As Good As Its People (Fayetteville, AR: The University of Arkansas Press, 1996;

Originally published in 1977), p. 82.

${ }^{22}$ William G. McLoughlin, Revivals, Awakenings, and Reform: An Essay on Religion and Social Change in America, 1607-1977 (Chicago, 1L: University of Chicago Press, 1978), p. 213.

${ }^{23}$ Michael Corbett and Julia Mitchell Corbett, Politics and Religion in the United States (New York: Garland Publishing, 1999), p. 134.

${ }^{24}$ Robert Booth Fowler, A New Engagement: Evangelical Political Thought, 1966-1976 (Grand Rapids, M1: William B. Eerdmans Publishing Company, 1982), p. 1.

${ }^{25}$ Hutcheson, God in the White House, p. 113.
} 
After Vietnam, the turbulent 60 s, the resignation of a vice president for corruption. and the resignation of a president for abuses of power. Americans appeared ready to be "born again" in its bicentennial year. Newsweek magazine and George Gallup. Jr. dubbed 1976 "the year of the Evangelicals," a reference to the 1976 contest between two self-proclaimed evangelical Christian candidates and the growing visibility of an American religious subculture. ${ }^{27}$

President Gerald Ford, though uncomfortable about publicly discussing his deep faith, did seek and court Evangelical votes. He became the first president to address the Southern Baptist Convention. he spoke before the annual meeting of the National Association of Evangelicals, and he sought support from Evangelist Billy Graham. ${ }^{28}$ But it was Democratic candidate Jimmy Carter, a devout Southern Baptist, a "bornagain" Evangelical Christian, a church deacon. a Sunday school teacher. a missionary. who best symbolized the country"s desire for spiritual renewal and embodied the new rigor of the evangelical world. "I'm running for President because I'm a deeply religious person. ${ }^{.29}$ As George Will explained. Carter "was elected as a national penance for Nixon`s lawlessness. ${ }^{.30}$

\footnotetext{
${ }^{26}$ Christopher Clausen, “America's Design for Tolerance," Wilson Quarterly 31.1 (Winter 2007): 27.

27 Kenneth L. Woodward, "Born Again!" Newsweek. 25 October 1976. p. 68-78: Fowler. A . Vew Engagement: Evangelical Political Thought, 1966-19-6. pp. 236-237.

${ }^{28}$ Leo P. Ribuffo. "God and Jimmy Carter," in Transforming Faith: The Sacred and the Secular in Modern American History, eds. M.L. Bradbury and James B. Gilbert (New York: Greenwood Press. 1989), p. 144: Robert Booth Fowler. Religion and Politics in America (Metuchen. NJ: The Scarecrow Press, 1985), p. 122.

${ }^{29}$ Robert Shogan. Promises to Keep: Carter's First Hundred Dans (New York: Thomas Y. Crowell Company, 1977), p. 36.

${ }^{30}$ George Will, ${ }^{\cdots}$ The nation needs an adult hour. “' Washington Post. January 31. 2006.
} 
he was a candidate for president of the United States. With the 1960s counterculture, Vietnam, Watergate, and the imperial presidencies of Johnson and Nixon in mind, Carter declared, "We have been shaken by a tragic war abroad and by scandals and broken promises at home. Our people are searching for new voices and new ideas and new leaders." 31 He hoped to be that "new leader and "new voice."

Carter campaigned to restore the federal government to its proper function: "to make it easy for people to do good and difficult for them to do evil." ${ }^{32}$ Good government, according to Carter, was "not a matter of being liberal or conservative" and it was more than the efficient distribution of goods and services or representing constituent needs. Fundamentally, he believed, "good government is the art of doing what is right," not the art of compromise. ${ }^{33}$ If "the art of compromise was built into the fiber of [Franklin] Roosevelt's faith," ${ }^{34}$ a conviction of certainty was built into Carter's.

Government at all levels can be competent, economical and efficient. Yet I would hasten to point out that nowhere in the Constitution of the United States, or the Declaration of Independence, or the Bill of Rights, or the Emancipation Proclamation, or the Old Testament or the New Testament do you find the words 'economy' or 'efficiency.' Not that these two words are unimportant. But you discover other words like honesty, integrity, fairness, liberty, justice, courage, patriotism, compassion, love-and many others which describe what

\footnotetext{
${ }^{31}$ Carter, "Presidential Nomination Acceptance Speech at the Democratic National Convention in New York City, New York," July 15, 1976, in A Government As Good As Its People, p. 103.

${ }^{32}$ Carter, "Inaugural Address in Atlanta, Georgia," January 12, 1971, in A Government As Good As Its People, p. 5; Carter, "Presidential Nomination Acceptance Speech at the Democratic National Convention in New York, New York," July 15, 1976, in A Government As Good As Its People, p. 108.

${ }^{33}$ Carter, "Remarks to the Town Hall Forum in Los Angeles, California," August 23, 1976, in $A$ Government As Good As Its People, p. 116.

${ }^{34}$ Robert S. Alley, So Help Me God: Religion and the Presidency, Wilson to Nixon (Richmond, VA: John Knox Press, 1972), p. 63.
} 
a human being ought to be. These are also the same words which describe what a government of human beings ought to be. ${ }^{35}$

Heralding a restoration of faith in government, Carter believed that "it is time for us to reaffirm and to strengthen our ethical and spiritual and political beliefs" ${ }^{36}$ and reverse "the steady erosion and weakening of our families" caused by divorce, premarital sex, single parenthood, sexually-transmitted diseases, and increasing alcohol and drug use. ${ }^{37}$ Many family problems, Carter believed, could be greatly reduced if "we would all obey the Biblical command to honor our father and mother." ${ }^{38}$ Besides, according to two Newsweek correspondents, Carter believed that the likely presidential contenders drank too much and that he was as smart as they were. ${ }^{39}$

[D]uring 1971 and 1972 I met Richard Nixon, Spiro Agnew, George McGovern, Henry Jackson, Hubert Humphrey, Ed Muskie, George Wallace. Ronald Reagan, Nelson Rockefeller, and other presidential hopefuls, and I lost my feeling of awe about presidents. This is not meant as a criticism of them, but it is merely a simple statement of fact. ${ }^{40}$

\footnotetext{
${ }^{35}$ Carter, Why Not the Best? (New York: Bantam Books, 1976), p. 132; Carter, "Remarks to the National Wildlife Federation in Pittsburgh, Pennsylvania," March 15, 1975, The Presidential Campaign 1976:

Jimmy Carter (Washington, DC: United States Government Printing Office, 1978), p. 61: "Remarks and Question-and-Answer Session at Johns Hopkins University in Baltimore, Maryland," April 2. 1975. The Presidential Campaign 1976: Jimmy Carter, p. 44.

${ }^{36}$ Quoted in Niels C. Nielsen, Jr., The Religion of President Carter (Nashville. TN: Thomas Nelson, lnc.. Publishers, 1977), p. 67.

${ }^{37}$ William Martin, With God on Our Side (New York: Broadway Books, 1996), p. 155: Carter, "Statement during a campaign tour of Manchester, New Hampshire," August 3, 1976, The Presidential Campaign 1976: Jimmy Carter, pp. 462-465.

${ }^{38}$ Carter, "Statement during a campaign tour of Manchester, New Hampshire," August 3, 1976. The Presidential Campaign 1976, 463.

${ }^{39}$ Peter Goldman and Eleanor Clift, "Carter on the Rise," Newsweek, March 8, 1976, p. 29.

${ }^{40}$ Carter, Why Not the Best?, pp. 158-159.
} 
After more than a year of campaigning, Carter was still unknown to most Americans, he was still "Jimmy Who?" It was not until after he pulled off a strong showing in the Iowa Caucus and won the New Hampshire primary that his campaign caught fire and captured the attention of the national media.

More than any other candidate in the field of Democrats, Carter instinctively understood what Americans were looking for in 1976. Americans were looking for a president as the head of state who embodied the goodness of the people, not just a president as a head of government who could get things done. As William Martin characterized it, "He knew how to present himself as the embodiment of the bedrock values, deep concerns, and honest aspirations of millions of his fellow citizens, and he knew, as his detractors did not, that his own quite genuine religious faith was an asset. $^{, 41}$

Wherever and whenever he campaigned, Carter promised voters that he would give them a government "as good and honest, decent, truthful, and competent and compassionate and filled with love as are the American people." ${ }^{42}$ He promised he would restore the people's trust and that he would never tell a lie. ${ }^{43}$ He expressed this hope again in his inaugural address, saying the Carter Presidency would be remembered

\footnotetext{
${ }^{41}$ Martin, With God on Our Side, p. 148.

${ }^{42}$ Carter, "Remarks at Bethune-Cookman College in Daytona Beach, Florida," October 29, 1975, in $A$ Government As Good As Its People, p. 52. Carter has long argued that honesty is a fundamental responsibility for elected leaders and he has carried this message abroad. For instance, in 2003, in Bolivia, Carter made this very point. "Remarks to a Joint Session of Congress in La Paz, Bolivia," December 18, 2003, http://www.cartercenter.org.

${ }^{43}$ According to UPI reporter Wesley Pippert, Carter says that the first verse of the Bible he learned as a child was I John 4:8: "Whoever does not love does not know God, for God is love." As such, for America to love, it is to know God. Pippert, The Spiritual Journey of Jimmy Carter, p. 4.
} 
for creating "a new national spirit of unity and trust" and enabling "our people to be proud of their own Government once again. ${ }^{.4+}$ Carter was convinced that he won precisely because the American people believed that he "would never permit any repetition of such embarrassments" as Vietnam and Watergate. ${ }^{+5}$ He understood that candidates who are in tune with the prevailing national mood increase their chances for winning the White House. ${ }^{+6}$ "Perhaps my campaign would not have been so successful if I had run for president four years ago or eight years ago. But I think this year my candidacy coincided with a new mood in America. ${ }^{.47}$

Many Carter supporters even viewed the campaign as sort of missionary work. William Lee Miller quoted one volunteer, "We felt like missionaries. I never felt like supporting anybody like I supported him. We did it with missionary zeal because he stood for something good." When he pressed Carter volunteers to articulate "what was the gospel" they were propagating. Miller wrote that he got the impression that "Jimmy was the gospel, or Jimmy's axiomatic goodness." Further. wrote Miller. "neighbors and friends of Jimmy's would knock on doors telling voters—testifying to voters. from personal experience —of his moral worth—not of his ideology. or his policies. but of his -integrity $\cdots+\cdots$

\footnotetext{
H4 .Jimmy Carter's Inaugural Address," in Religion in .America, ed. George C. Bedell. Leo Sandon. Jr. and Charles T. Wellborn (New York: Macmillan Publishing Company. 1982), 64-66.

${ }^{45}$ Carter. Keeping Faith: Vemoirs of a President (New York: Bantam Books. 1982). p. 125.

${ }^{46}$ James W. Ceaser and Andrew E. Busch. The Perfect Tie: The True Storn of the 2000 Presidential Election (Lanham, MD: Rowman \& Littlefield Publishers, Inc., 2001). p. 60-61.

t` Kenneth E. Morris, Jimmy Carter: American Moralist (Athens. GA: University of Georgia Press. 1996). p. 203.
} 
In Jimmy Carter's Peanut Brigade, Harold Isaacs reported similar findings. ${ }^{49}$

He noted that Carter canvassers from Georgia went up to New Hampshire to tell voters that they were backing the former Georgia governor because of his character, because of his scandal-free four years as governor, and because they believed in him. One canvasser who happened to stay at the same hotel as Morris Udall happened to run into the Arizona congressman at the hotel. Upon seeing her many Carter buttons, Isaacs explained, Congressman Udall "groaned, 'God, he's everywhere'." To which the canvasser responded, "Yes, God is everywhere and so is Jimmy Carter."

The national media was not so much interested in the message as it was in the messenger. The issue of a candidate's religion was raised to levels not seen since John Kennedy's Catholicism in 1960. Carter did not hide his evangelical faith on the campaign trail. Sometimes he would raise it, at other times, curious election observers would.

For many, Carter was an oddity — he was a Bible-believing, born-again Christian who was comfortable with and did not shy away from discussing such topics as sin, salvation, prayer, or Christian love and service. ${ }^{50}$ In the Deep South, the country's "Bible Belt," religion is very much a part of everyday life. So for Carter, it was not unusual to candidly and publicly discuss his faith. As church historian Martin Marty explained, "For Jimmy Carter to say he is 'born again' is like you or I saying 'good

\footnotetext{
${ }^{48}$ William Lee Miller, Yankee from Georgia: The Emergence of Jimmy Carter (New York: Times Books, 1978), p. 178. Emphases in quotes are Miller's.

${ }^{49}$ Harold Isaacs, Jimmy Carter's Peanut Brigade (Dallas, TX: Taylor Publishing Company, 1977), pp. 10-28.

${ }^{50}$ Susan Fraker and Eleanor Clift, "Carter and the God lssue," Newsweek, 5 April 1976, p. 18; James Wooten, Dasher: The Roots and Rising of Jimmy Carter (New York: Warner Books, 1979), pp. 265.
} 
morning. " "'51 His campaign biography, Why Not the Best?, was published by the Southern Baptist publishing house Broadman Press. ${ }^{52}$ He even chose Walter Mondale. "the son of an intense. teetotaling Methodist minister," who circuit-rode southern Minnesota, as his running mate. ${ }^{53}$ In their enthusiasm, many Southern Baptist and evangelical leaders, such as Pat Robertson, flocked to Carter. A future president of the Southern Baptist Convention. Bailey Smith. remarked that the country needs "a bornagain man in the White House... and his initials are the same as our Lord's. ${ }^{54}$ For many, as suggested by one biography title, 1976 was about "the miracle of Jimmy Carter. ${ }^{.55}$ An independent group of evangelicals formed Citizens for Carter. promoting the idea that the country needed "a dedicated evangelical in the White House." 56 Carter's religion was bound to become a campaign issue for a preponderantly secular media. $^{57}$

${ }^{51}$ Nielsen, The Religion of President Carter, p. 24.

52 Ibid., p. vii. Carter has explained that Broadman Press was chosen because they "print all the Southern Baptist literature" and because he "had some influence with them as a member of the Baptists" Brotherhood Commission." "From Politics to Poetics," July 2. 1995. The Carter Center. http: "www cartercenter.org. Still, as Hutcheson asked. "What other politicians in history would have run for the presidency with a campaign biography from Broadman Press. the publishing arm of the Southern Baptist Convention?" Hutcheson, God in the White House, p. 99.

${ }^{53}$ Tom Mathews, "Who is Fritz Mondale?" Newsweek, 26 July 1976, p. 29.

${ }^{54}$ Martin, With God on Our Side, p. 157; James T. Baker, A Southern Baptist in the White House (Philadelphia, PA: The Westminster Press, 1977), p. 105; Edward E. Plowman, "Southern Baptists: Platform for Presidents," Christianity Today, 16 July 1976. p. 51 ; Hertzberg. "Jimmy Carter, 1977-1981," in Character Above All, p. 184.

${ }^{55}$ Howard Norton and Bob Slosser, The Miracle of Jimmy Carter (Plainfield, NJ: Logos International. 1976).

${ }^{56}$ Arthur H. Matthews, "Crusade for the White House: Skirmishes in a 'Holy War', "Christianity. Todal. 19 November 1976, p. 51.

${ }^{57}$ Studies have shown that many journalists are secular. According to one study, $86 \%$ said they do not go to church and $50 \%$ claimed no religious affiliation. See Robert Booth Fowler. Allen D. Hertzke, and 
Members of the press hounded the candidate and the campaign for answers to such questions as "What does it mean to be born-again?" "What is an evangelical?" "What do Baptists believe?" Kenneth Briggs, the religion editor for the New York Times, said that the press tended to react to Carter's evangelical faith "with about as much befuddlement as if Mr. Carter had said he had ridden in a flying saucer." ${ }^{58}$ Carter press secretary, Jody Powell, had this to say about the general media discomfort with Carter:

For most journalists, Carter was different-not only from most politicians and Presidents they had covered, but from them. He was a small-town Southern Baptist with a set of values and beliefs that made many of them decidedly uncomfortable.

It was not so much his outward signs of religion that pained the press. They were accustomed to and reasonably tolerant of hypocrites. As at least three of them later would say, in separate interviews: 'The problem with Carter was that we knew he meant it' —or words to that effect...

The sad fact is that many political reporters are a good bit more familiar and comfortable with politicians who lie, cheat, and steal than with one who praysparticularly if he prays in private and with conviction. ${ }^{59}$

Powell recalled that he spent far more time than he ever anticipated in trying to explain to the national press the fundamentals of Southern Baptist theology. ${ }^{60}$

Many were wondering what kind of man were the Democrats about to nominate.

For a third of the American people, "the Carter phenomenon," as it what called, was

Laura R. Olson, Religion and Politics in America: Faith, Culture, and Strategic Choices (Boulder, CO: Westview Press, 1999), p. 256. Carter's faith probably also caught many in the secular media and academia off guard because of the prevailing expectation among elites that religion would fade away as society modernized and rationalized. See Alan Wolfe, "What Scholarship Reveals About Politics and Religion," The Chronicle of Higher Education, September 8, 2000, p. B7.

\footnotetext{
${ }^{58}$ Ellen M. Rosenberg, The Southern Baptists: A Subculture in Transition (Knoxville, TN: The University of Tennessee Press, 1989), p. 175.

${ }^{59}$ Jody Powell, The Other Side of the Story (New York: William Morrow and Company, 1984), p. 206.
} 
understood. At the time, the Gallup Organization found that $38 \%$ of Americans. $38 \%$ of all whites. $58 \%$ of all blacks. $53 \%$ of all Protestants. and $54 \%$ of Southerners identified themselves as "born-again" Christians. ${ }^{61}$ In fact, evangelical Christianity has historically been among the predominant religious forms in America and has had a substantial influence on American culture. ${ }^{62}$

Carter's reputation as a religious man also helped him with black voters, especially in the South. Carter earned support and respect from "Daddy" King, Coretta Scott King. and Reverend Andrew Young probably because they shared a Baptist faith. $^{63}$ Young was particularly impressed by Carter`s faith. "His religion was really way down deep in the marrow of his bones. And I said. 'That's the kind of guy that ought to be running this country." 64

Carter could speak the language of both the Southern and religious experiences of many African Americans like no other candidate in 1976 could. He felt comfortable with predominantly black audiences and spoke their common religious tongue. As one African American woman explained why she and other blacks supported Carter was

\footnotetext{
${ }^{60}$ Martin. With God on Our Side, p. 149.

${ }^{61}$ George Gallup. Jr. and D. Michael Lindsay. Survering the Religious Landscape: Trends in L'S. Beliets (Harrisburg. PA: Morehouse Publishing. 1999), p. 68.

${ }^{62}$ Garry Wills, Under God: Religion and American Politics (New York: Simon and Schuster. 1990). p. 19-20: William G. McLoughlin, The American Evangelicals, 1800-1900 (New York: Harper \& Row Publishers, 1968), p. 1: George M. Marsden. Fundamentalism and American Culture: The Shaping of Twentieth-Century Evangelicalism, 1870-1925 (New York: Oxford University Press. 1980): Robert T. Handy, A Christian America: Protestant Hopes and Historical Realities (New York: Oxford University Press. 1984).

${ }^{6 \hat{3}}$ Nicol C. Rae, Southern Democrats (New York: Oxford University Press. 1994). p. 56.

${ }^{64}$ Young. Transcript, American Experience: Jimmy Carter. narrated by Linda Hunt, directed by Adriana Bosch (WGBH Educational Foundation, 2002) http: www.pbs.org wgbh amex carter filmmore pt.html.
} 
because "He's a Jesus man." ${ }^{65}$ Another said he was convinced, "God's going to straighten things out through Jimmy Carter."

Carter shared with many African Americans the belief that Christians are required to be politically active. With shared convictions, Martin Luther King, Sr. could confidently proclaim in his benediction prayer at the Democratic Convention that "surely the Lord sent Jimmy Carter to come on out and bring America back where she belongs. " 67 Young was especially crucial for Carter’s success. For instance, he worked on Carter's behalf in crucial northern primaries, such as in Pennsylvania, to rally black Baptists and black clerics and persuade his colleagues in the Congressional Black Caucus to support this white southern governor. Young claims that the role of the black clerical leadership, including Congressman Bill Gray, a Baptist minister, was critical for ensuring a Carter win in the Pennsylvania primary. ${ }^{68}$ For his efforts, Carter named

${ }^{65}$ Kandy Stroud, How Jimmy Won: The Victory Campaign from Plains to the White House (New York: William Morrow and Company, 1977), p. 421.

${ }^{66}$ Ibid., p. 422.

${ }^{67}$ Ribuffo, "God and Jimmy Carter," p. I44; Edward E. Plowman, "The Democrats: God in the Garden?" Christianity Today, 6 August 1976, pp. 34-36. In fact, at one point in the campaign, Carter nearly jeopardized his relations with black voters. On the primary campaign trail, Carter remarked that he would preserve the "ethnic purity" of American neighborhoods. Not surprisingly, this was seen as a possible reference to supporting housing segregation. As a white southern governor, Carter was already viewed by some with suspicion. Key members of the Congressional Black Caucus, such as Shirley Chisholm and Charles Rangel, were supporting other candidates. Fortunately for Carter, through the mediating efforts of "Daddy" King and Rep. Young, the controversy blew over. Peter Goldman, "Carter's Trip of the Tongue," Newsweek, 19 April 1976, p. 14; Dennis A. Williams, "Blacks and Politics '76," Newsweek. 26 April 1976, p. 22; Susan Franker, "Carter and the Blacks," Newsweek, 19 July 1976, p. 29; Dennis A. Williams, "Young: Getting Out the Vote," Newsweek, 6 September 1976, p. 14-15. Years later, another African-American leader, Dr. Benjamin Mays, remarked that "since God moves in a mysterious way his wonders to perform - it may that God has called Jimmy Carter out of Plains, Georgia, out of Georgia- a [state] that did its share of discrimination and lynching Negroes. It may be that God has called" a white Southern politician to lead the way in advancing civil rights and social justice. "Remarks at President Carter's Signing of Executive Order I2232 on Historically Black Colleges and Universities," August 8. 1980, Public Papers of the Presidents, Book II, p. 1517. 
Young U.S. Ambassador to the United Nations. Stuart Eizenstat, Carter`s domestic affairs advisor during the campaign. concurred with surprise on how important Carter ${ }^{\circ}$ Baptist faith was to winning black votes. "The Baptist background was a very important thing in establishing the chemistry between black voters and Jimmy Carter. You could feel it when you came into a black church. a sort of instant sense of communication. It had a deeply felt resonance among black voters. ${ }^{.69}$

On November 2. 1976, the American people elected Jimmy Carter as their $39^{\text {th }}$ president. In a very close election. Carter won the electoral vote $297-240$ and the popular vote win $50 \%-48 \%$. Though the vote was one of the closest in American history, by Democratic Party standards, it was an impressive win. He defeated a sitting president. He nearly put back together the state that once made up the old Solid South. something that had not been done since Franklin Roosevelt in 1944. Carter was the last Democrat of the century to win a popular majority and. since World War II. and he was only one of two Democratic presidents to win a majority of the popular vote, the other being Lyndon Johnson in 1964. Of further importance. Carter was the first Southerner from the Deep South to be elected directly to the White House since Zachary Tay lor in 1848. For many, including Carter, the election of a white Southerner signaled the political readmission of the South into the Union.

\footnotetext{
${ }^{68}$ Andrew Young. A Wan Out of No Wan: The Spiritual Memoirs of Andrew Young (Nashville. TN: Thomas Nelson Publishers. 1994). pp. 121-122.

${ }^{69}$ Martin. With God on Our Side, p. 152.
} 
Carter won solid support from his southern kinfolk, especially southern blacks, winning 10 of 11 of the states of the Old Confederacy plus Kentucky and the border states of Missouri, West Virginia, Maryland, and Delaware. All along that was the first pillar of his general election strategy: "Count on a near-sweep of the South and Border States, with their 178 electoral votes, as the core of the drive to win the 270 electoral votes needed to gain the Presidency." electoral votes ran strong in the East and the Midwest. Most importantly, in spite of the Playboy faux pas, Carter gained solid support from his coreligionists. Carter won 50\% of the white evangelical vote. ${ }^{71}$ He became the first Democrat since Harry Truman to win the national Baptist vote (57\%-43\%) and he won 58\% of the country's 96 most Baptist counties, including Appalachian mountain Baptist counties with historically strong Republican tendencies. Carter was also highly competitive in the densest Methodist counties in the Midwest and Border states. Among African Americans, Carter impressively won $92 \%$ of the vote. According to Albert Menendez, it was the religion vote that gave Carter his margin of victory. "Protestants of all stripes," he explained, "clearly gave Carter a substantially higher-than-usual vote for a Democrat" not only in his home region, but also up North. ${ }^{72}$

\footnotetext{
70 "Is '76 the Democrats' Year?," U.S. News \& World Report, July 26, 1976, 15.

${ }^{71}$ Robert Booth Fowler and Allen D. Hertzke, Religion and Politics in America: Faith, Culture, and Strategic Choices (Boulder, CO: Westview Press, 1995), pp. 90, 98.

${ }^{72}$ Albert J. Menendez, Evangelicals at the Ballot Box (Amherst, NY: Prometheus Books, 1996), pp. 128$13 \mathrm{I}$.
} 


\section{The Religious Faith of Jimmy Carter}

"Religious faith has always been at the core of my existence. ${ }^{.73}$

Sensing his different presidential style. New York Times columnist James Reston wrote. "What sets the new president aside from all his predecessors since Wilson is that religion lies at the center of his life. ${ }^{74}$ Even when other presidents, such as Richard Nixon, tried to directly appeal to religious voters it did not come across as genuine. In contrast. Carter`s religious appeals, as Michael Novak put it, seemed comfortable and natural. "He's for real. ${ }^{.75}$ Even international observers sensed Carter's religious political style. Tom McNally, a former political advisor to British Prime Minister James Callaghan. said:

I recall my initial puzzlement at this man of apparent deep sincerity and conxiction, who was willing to talk about certain values. about God and the family and the American pioneer spirit and to talk about national and international problems in ways which would have been mawkish and embarrassing coming from other lips. In the end. I came to the conclusion that Carter was for real; but I can well understand how he unnerved some of the old Washington professionals. ${ }^{76}$

One church historian explained, Carter knows no other way to be. "Jimmy Carter is a public Christian... he doesn`t know how to be a private Christian. Religion for him goes right to the streets, and he successfully relates his Sunday faith to his Monday world.."77

\footnotetext{
Carter. Living Faith. p. 16. Carter is also quoted as saying that when he was governor of Georgia. "I have considered myself in full-time Christian service every day 1 have been governor. "Hefley and Hefley. The Church that Produced a President. p. 248.

${ }^{-4}$ Quoted in James Hefley and Marti Hefley. The Church that Produced a President (New York: Wyden Books. 1977). p. 224. The Hefley's also note that Carter was the first and only American president to teach Sunday school as president. Also as president, in a highly unusual move for a president. Carter called upon his fellow Southern Baptists, in a videotape address to their 1977 annual convention. to step up their global missionary activities. Hefley and Hefley. The Church that Produced a President. pp. 228. 238.

${ }^{-5}$ Quoted in Kucharsky, The .Man from Plains, pp. 95-96.
} 
Carter's pastor, Dan Ariail of the Maranatha Baptist $\mathrm{Church}^{78}$ in Plains, Georgia. once wrote, "The key to understanding Jimmy Carter is understanding Jimmy Carter's Christian faith... There has been an almost universal reading of Jimmy Carter’s faith as being a department of his life, an addendum with little relationship to the rest of him.

But I have discovered that you can never adequately grasp Jimmy Carter unless you see his Christian faith." and what he sets out to do. It forms "the steel foundation on which his entire life is constructed."

Like the Shaker motto, "Hands to work, Hearts to God," Carter's faith may be found in all he does; all is part of "the cause of Christ." Faith is inseparable from work; faith is putting God's love in action and teaching others the fundamental truth that "God is love." For Carter, the sacred and the profane overlap, intercept, and compliment one another. "Whether he is swinging a hammer," wrote Linda and Millard Fuller, founders of Habitat for Humanity, "resolving a conflict, monitoring elections in a distant land, stamping out human rights abuses, lending a helping hand to a neighbor, or teaching

\footnotetext{
${ }^{76}$ Tom McNally, "The Carter Years," International Affairs 59.3 (Summer 1983): 465.

${ }^{77}$ Historian Martin Marty quoted in Dan Ariail and Cheryl Heckler-Feltz, The Carpenter's Apprentice: The Spiritual Biography of Jimmy Carter (Grand Rapids, MI: Zondervan Publishing House, 1996), p. 52.

${ }^{78}$ Maranatha Baptist Church is "a Bible-believing, Christ-centered fellowship dedicated to the worship of Almighty God and the taking of the gospel message to the ends of the earth...our focus is on Jesus Christ, the crucified Son of God who came to reveal to all humankind the love and grace of God." Maranatha Baptist Church, http://www.maranathachurchplains.org.

${ }^{79}$ Ariail and Heckler-Feltz, The Carpenter's Apprentice, pp. 45-46.
} 
Sunday school, it is obvious that Jimmy Carter takes great joy in being a servant of God, a true apprentice of the Carpenter." 80

Carter believes his faith is central to understanding who he is as a man and was as a president. "What is meaningful," he said, "is the application of religious ideas to life." 81 "I am a Christian. I'm very proud of my faith. It's the most important element of my life." 82 "It's been a guide to me... a stabilizing factor in my life. It has permeated my consciousness." 83 "I am not ashamed of it." ${ }^{84}$ He believes his faith made him a different kind of person, a different kind of president. But Carter was more specific than that. A Carter presidency would be different because Jesus was among his political models. "Christ has set the standard I am to attain as his representative. I try to pattern my life after his life., ${ }^{, 85}$

The South is a region where religion is culture, the culture is religious, and Southern Baptist churches are found in the center of it all. In fact, because of the degree to which the Southern Baptist Convention (SBC) has shaped Southern life, regional identity, and cultural mores, the SBC has been described as "the Catholic Church of the

\footnotetext{
${ }^{80}$ Linda and Millard Fuller, "Foreword," in Ariail and Heckler-Feltz, The Carpenter's Apprentice: The Spiritual Biography of Jimmy Carter, p. 10.

${ }^{81}$ Carter, Living Faith (New York: Random House, Inc., 1998), p. 221.

${ }^{82}$ Carter, "Remarks on Lighting the National Community Christmas Tree," December 18, 1980, Public Papers of the Presidents, Book III, p. 28 I 8.

${ }^{83}$ Carter, "Interview with GQ Magazine," GQ Online, January 2006, http://men.style.com/gq/features/archive/0601.

84 "I'm Jimmy Carter, and..." Time: Man of the Year issue, January 3, 1977.

${ }^{85}$ Hefley and Hefley, The Church that Produced a President, p. 248.
} 
South." ${ }^{86}$ Like many others in the American South, long among the country's most religiously observant and culturally conservative regions, religion has long been a part of Jimmy Carter's life. Marty explained, Carter "could not avoid Jesus talk, even if he wanted to[;] where he comes from Jesus talk is... a kind of static in the air... [a] social glue." ${ }^{87}$ Carter, too, has said that his religion "is as natural to me as breathing." $" 88$ "I worship daily. The last thing 1 do every evening is to have a private worship service with my wife. We never fail to do this. I pray frequently during the day. 1 seek God's guidance." 89 He believes in the "efficacy of prayer," "the power of prayer," wrote staffers. ${ }^{90}$ In a letter to one citizen, Assistant Press Secretary Jim Purks wrote, "President Carter is one of the nation's firmest advocates of prayer. He finds it inspirational, and believes it helps him." ${ }^{91}$ In another letter, Daniel M. Chew, Director of Presidential Correspondence, wrote, "The President strongly shares your belief in the importance of prayer. Prayer is central to the President's personal life and to his conduct of the Presidency.",92

\footnotetext{
${ }^{86}$ Bill J. Leonard, God's Last and Only Hope: The Fragmentation of the Southern Baptist Convention (Grand Rapids, MI: William B. Eerdmans Publishing Company, 1990).

${ }^{87}$ Quoted in Nielsen, The Religion of President Carter, pp. 24-25.

${ }^{88}$ Ibid., p. 18.

${ }^{89}$ Carter, "Remarks and a Question-and-Answer Session at a Town Meeting with New Hampshire High School Students," February 18, 1978, Public Papers of the Presidents, Book I, p. 370.

${ }^{90}$ Letter, Jody Powell to Samuel W. Collins, January 27, 1977, Folder RM2, 1-20-1977-1-20-81, Box RM1, Collection Title: Religious Matters, Jimmy Carter Library, Atlanta, Georgia; Letter, Assistant Press Secretary, Office of Media Liaison, Jim Purks to Garrett Ray and Friends, July 30, 1979, Folder RM2, 120-1977-1-20-81, Box RM1, Collection Title: Religious Matters, Jimmy Carter Library, Atlanta, Georgia.

${ }^{91}$ Letter, Jim Purks to John Myers, April 2, 1980, Folder RM2, 1-20-1977-1-20-81, Box RM1, Collection Title: Religious Matters, Jimmy Carter Library, Atlanta, Georgia.

${ }^{92}$ Letter, Daniel M. Chew to Chrystal Carr Jeter, August 25, 1980, Folder RM2, 1-20-1977-1-20-81, Box RM1, Collection Title: Religious Matters, Jimmy Carter Library, Atlanta, Georgia.
} 
Jimmy Carter said his "first church was my family," where he "first heard the Bible read," where he "first heard prayer," and where he first "learned about God." 93 Carter was raised in a religious home. went to church most Sundays. was baptized at age 11 , and later met future wife Rosalynn at a church social. Carter says, "I never knew anything except going to church. My wife and I were born and raised in innocent times. The normal thing to do was to go to church." ${ }^{94}$ The Baptist church. he explained, was "the first organization that 1 belonged to." 95 For reading, he recalled. "the Bible was the center of people's reading.",96

His father Earl taught Sunday School and was a church deacon, and he and his wife, Lillian. made sure that their children regularly attended church. "Our family never missed worship services on Sunday mornings." "97 "Sunday mornings were for Sunday School and preaching at the Plains Baptist Church," and Sunday afternoons a time for Southern food, conviviality, recreation, and rest. ${ }^{98}$ It was a life, Carter says, where "we felt close to nature, close to the members of our family, and close to God.."99

\footnotetext{
${ }^{93}$ Carter, "Remarks at Mormon Church Ceremonies Honoring Family Unity in Salt Lake City. Utah." November 27, 1978, Public Papers of the Presidents, Book I, p. 2085.

${ }^{94}$ Carter, "Interview with Robert Scheer," Playboy' (November 1976), p. 86.

${ }^{95}$ Carter, "Remarks at a meeting of the Future Farmers of America," July 19, 1979. Public Papers of the Presidents, Book II, p. 1267.

${ }^{96}$ Carter, "Interview with the Academy of Achievement in Atlanta. Georgia," October 25, 1991. http:/www achievement.org.

${ }^{97}$ Carter, Christmas in Plains (New York: Simon and Schuster, 2001), p. 40; "Interview with the Academy of Achievement in Atlanta, Georgia," October 25. 199 I, http//www achievement.org.

${ }^{98}$ Carter, Living Faith, p. 11.

${ }^{99}$ Carter, Why Not the Best? , p. 31.
} 
Life "was a simple, family-centered, deeply religious, working existence." 100 And the role of religion was not confined to church and home; religion was reinforced at school, too:

We accepted that one major role of our teachers was to be intimately involved in religious instruction. After all, we were all Christians or - if we were still too young to have personally accepted Christ as Saviour-these observances... were preparation for that almost inevitable decision. ${ }^{101}$

While in the Navy, Carter sometimes led religious services "right there between the torpedo tubes of the submarine."102 After his father died in 1953, Carter left the Navy and returned home to take over his father's business. He began teaching Sunday School and became a church deacon.

It is commonly believed that the "born-again" experience for evangelical Christians is a one-time, momentous event. For many, it is. But for other evangelicals, being "born-again" is a life-long process of growing and renewing faith. The latter is true for Carter; his faith "has been a changing and evolving experience, beginning when I was a child of three, memorizing Bible verses in Sunday school." 103

Being born again didn't happen to me when I was eleven. For me, it has been an evolutionary thing. Rather than a flash of light or a sudden vision of God speaking, it involved a series of steps that have brought me steadily closer to Christ. My conversion at eleven was just one of these steps. ${ }^{104}$

His wife Rosalynn concurred:

\footnotetext{
${ }^{100}$ Carter, Living Faith, p. 11.

${ }^{101}$ Carter, Christmas in Plains, p. 42.

${ }^{102}$ Ariail and Heckler-Feltz, The Carpenter's Apprentice, p. 119.

${ }^{103}$ Carter, Living Faith, p. 16; Betty Glad, Jimmy Carter: In Search of the Great White House (New York: W.W. Norton and Company, 1980), pp. 114-118.

${ }^{104}$ Carter, Living Faith, pp. 21-22.
} 
This was Jimmy's famous 'born-again' experience-no flashing lights, no weeping, no trauma or emotional scene, just a quiet acceptance of God and God's will for his life. ${ }^{105}$

Though Carter has always been religious, he found his faith wanting after his failed bid for governor in 1966. His loss to a staunch segregationist. Lester Maddox. Carter recalled, made him question his faith and made him angry with God. "I could not believe that God would let this person beat me and become the governor of our state. ${ }^{106}$ But conversations with his sister Ruth Carter Stapleton, a charismatic evangelist and faith healer, and work as a lay missionary convinced him to see that God was not the one to blame, but that it was he who was not giving his best for God.

Through political defeat, he came to the realization that he had only been "a lukewarm follower of Christ," a "church Christian"; he subsequently rededicated his life to Christ. $^{107}$

Pastor Ariail said there are three fundamentals in Carter's faith: 1) Jesus is his personal Savior: 2) Scripture is the primary source for understanding God's will for his life; and 3 ) the best way to serve God is by serving others. ${ }^{108}$ And these fundamentals are supplemented by others. For instance, according to Carter. one must not only accept Christ as one's personal Savior, but must lead a life in "obedience to God's

\footnotetext{
${ }^{105}$ Rosalynn Carter, First Lady from Plains (New York: Ballantine Books, 1984), p. 62.

${ }^{106}$ Carter. Living Faith. p. 202.

${ }^{10 ?}$ Carter. Living Faith, p. 209; Glad, Jimmy Carter: In Search of the Great White House, p. 112 : Wooten, Dasher: The Roots and Rising of Jimmy. Carter, pp.265-270.

${ }^{108}$ Ariail and Heckler-Feltz. The Carpenter's Apprentice, pp. 49-50. Father Robert Drinan, too, remarked that in Carter's faith, "it is the person of Christ that is central rather than the church of the Eucharist." "Reflections on Nobel Laureate Jimmy Carter," National Catholic Reporter, October 25, 2002.
} 
commandments," making one's life "consistent with Christ's life," and loving and serving one another. Together, this is "the philosophy under which we live."

To be Christians, Carter says, the faithful must emulate Jesus and put their faith in action. Based on his reading of the Book of James, Carter says, Christians "can't have true faith without good works." 109 "If we have faith, let's show it."110 "My best explanation is that a Christian is a person professing Jesus Christ as a personal savior, and striving to have the qualities demonstrated by Jesus." 111

As president, he continued to teach Sunday School, found occasions to share his faith with foreign leaders, readily admits in his post-presidential works that religion was an indispensable guide for his presidential behavior. "It just came natural to me," said Carter. ${ }^{112} \mathrm{He}$ believed that Americans "have a responsibility to try to shape government so that it does exemplify the will of God." 113 At one point in his presidency, Carter even stated that when his presidency ended he was considering becoming a missionary. ${ }^{114}$ Another writer noted that Carter "once said that if he could come back in

${ }^{109}$ Carter, Sources of Strength: Meditations on Scripture for a Living Faith (New York: Three Rivers Press, 1997), p. 235.

${ }^{110}$ Ibid., p. 236; Virtues of Aging (New York: The Ballantine Publishing Group, 1998), p. 124.

${ }^{111}$ Carter, Living Faith, p. 234.

112 Carter, "Interview with Rich Cline," Evangelical Alliance of the United Kingdom, NovemberDecember 2006, http://www.eauk.org/resources/idea/NovDec2006/the-power-of-unity.

${ }^{113}$ Hutcheson, God in the White House, p. 1.

${ }^{114}$ Carter, "The President's News Conference," January 30, 1978, in Public Papers of the Presidents, Book I, p. 249; Bruce Mazlish and Edwin Diamond, Jimmy Carter: A Character Portrait (New York: Simon and Schuster, 1979), pp. 139-140. 
another life, it would be as a Mennonite, a member of an austere religion that holds the Bible as its sole rule of faith. ${ }^{.115}$

Even into his eighties, President Carter continued to teach at his church every Sunday when he was home in Plains. According to his pastor. he taught the adult Sunday School class "about $75 \%$ of the time. ${ }^{-116}$ As when he was in public life. his daily spiritual regimen included frequent prayer and devotional Bible reading in the morning and evening with his wife, and to make his study more challenging, he often read the Bible in Spanish.

\section{Separation of Church and State, Integration of Religion and Politics}

"Despite what I consider to be a constitutional and biblical requirement for the separation of church and state. I must acknowledge that my own religious beliefs have been inextricably entwined with the political principles I have adopted." $" 117$

It has been argued that. although personally religious, Jimmy Carter strictly separated his religion and his politics. In comparing Carter and George W. Bush. Bush biographer Stephen Mansfield explained. "Jimmy Carter claimed to be born-again and even taught Sunday school during his White House years, yet he seemed to erect a wall of separation between faith and practice when it came to being president. ${ }^{.118}$ Similarly. Newsweek's Kenneth Woodward wrote, "Carter's faith, while strong, was more private

\footnotetext{
115 Kati Marton, "Rosalynn and Jimmy Carter: Virtue Unrewarded," chap. in Hidden Power: Presidential Marriages That Shaped Our History (New York: Anchor Books Edition, 2002), p. 221.

${ }^{116}$ Michael J. Brooks. "Former President Continues Life of Christian Service." The Political Bandwagon (September 2005): 18.

${ }^{1-}$ Carter. Our Endangered Values: America's Moral Crisis (New York: Simon and Schuster. 2005). p. 6.

${ }^{118}$ Stephen Mansfield, The Faith of George W. Bush (New York: Tarcher/Penguin, 2003). p. xviii.
} 
than Bush's." "19 Political scientist John Green saw it differently. When asked if he agreed whether the view that "President Bush is the most religious president of the last 25 years," Green said he did not. "One only has to think of Jimmy Carter."

On the separation of church and state, Jimmy Carter describes himself as a traditional or "conservative Southern Baptist."121 He affirms the classic Baptist position, and strictly so, that church and state are to be separate and that matters of faith are between the individual and God. Baptists have long prided themselves as a "noncreedal people."122 They have historically believed in "soul competency"-- every person is competent in matters of faith and not answerable to any human ecclesial agency. The 1963 "Baptist Faith and Message" states:

God alone is the Lord of the conscience, and He has left it free from the doctrines and commandments of men which are contrary to His word or not contained in it. Church and state should be separate. ${ }^{123}$

This tradition, Carter affirmed and upheld: "Baptists are among the most fervent advocates of all legal separation between the church and the state, between religion and

\footnotetext{
${ }^{119}$ Kenneth L. Woodward, "Gospel on the Potomac," Newsweek, March 10, 2003, p. 29.

${ }^{120}$ John Green, "Interview," PBS Frontline: The Jesus Factor," December 5, 2003, http:/www.pbs.org/wgbh/pages/frontline/shows/jesus/interviews/green.html.
}

${ }^{121}$ Carter, "Judge Not: Leaders of the Christian Right Have Injected into America's Political Debate Some Divisive Religious Questions," Atlanta Journal and Constitution, February 27, 1996; "Prayer and the Civic Religion," The New York Times, December 24, 1996; Our Endangered Values: America's Moral Crisis, pp. 16-29.

${ }^{122}$ William Powell Tuck, Our Baptist Tradition (Macon, GA: Smyth and Helwys Publishing, Inc.. 1993), pp. 15-28.

${ }^{123}$ The Baptist Faith and Message (Nashville, TN: The Sunday School Board of the Southern Baptist Convention, 1963), p. 19. 
government." ${ }^{-124}$ This principle, Carter said, is based on the Biblical command to,

"Render to Caesar the things that are Caesar's and to God the things that are God's."125

And because of this, Carter said he had no interest in being the "national pastor."

However, he stressed. "It goes without saying that I will continue to make my personal witness. $" 127$

As president, to the dismay of many fellow evangelical Christian leaders, he opposed movement, organized efforts to ban abortion and the teaching of evolution. reinstate school prayer, give tax monies for religious schools and charities, and using formal presidential powers to promote one religion over others. "I be an evangelical, but I'm not part of the group [the Moral Majority] that's been highly publicized recently as being directly involved in trying to shape political contests based on religious faith." 129

${ }^{12+}$ Carter, "Remarks at the Baptist Brotherhood Commission of the Southern Baptist Convention," May 13. 1977. Public Papers of the Presidents, Book I, p. 877; "Interview with Editors of Time Magazine." August 2, 1976, The Presidential Campaign 1976: Jimmy Carter, p. 446.

${ }^{125}$ Carter, "Remarks at the Opening of the China Bible Ministry Exhibition at the Second Ponce de Leon Baptist Church in Atlanta, Georgia," May 19. 2006, http: www.christianpost.com (accessed June 29. 2006): "Interview with Jeff Fleischer," Mother Jones, June 2, 2006, http: www. motherjones.com (accessed December 5, 2006); "Interview with Pat Robertson of the 700 Club," taped during the 1976 campaign, in Pippert, The Spiritual Journey of Jimm! Carter. p. 106.

${ }^{126}$ Handwritten Note, Jimmy Carter to Susan Clough, September 23, 1978. Folder RM 1-20-77-12-31-78. Box RM-1. Collection Title: Religious Matters, Jimmy Carter Library, Atlanta, Georgia.

${ }^{127}$ Letter. Jimmy Carter to Pastor Robert Maddox, October 3. 1978. Folder RM 1-20-77-12-31-78. Box RM-1, Collection Title: Religious Matters, Jimmy Carter Library. Atlanta. Georgia.

${ }^{128}$ Ronald B. Flowers, "President Jimmy Carter, Evangelicalism, Church-State Relations, and Civil Religion." Journal of Church and State 25 (Winter 1983): 114-123; Carter, Our Endangered l'alues: America's Moral Crisis, pp. 53-64.

129 Carter. "Question-and-Answer Session with New Jersey News Editors in Perth Amboy. New Jersey." September 9, 1980, Public Papers of the Presidents, Book II. p. 1685. 
Carter respected and vowed to uphold Supreme Court rulings on religious

matters. On the issue of school prayer, for example, one White House staffer explained to a citizen that "our Constitution is based on the separation of church and state and he [the President] is sworn by his Oath of Office to respect that." She further added:

In a press conference, President Carter once said, "I am a Christian, I happen to be a Baptist. I believe that the subject of prayer in school ought to be decided between a person individually and privately, and God. And the Supreme Court has ruled on this issue. I personally don't think that the Congress ought to pass any legislation requiring or permitting prayer being required or encouraged in school.","30

Carter remained firm on this position even after his 1980 defeat. He explained to a citizen that he favored "voluntary prayers in the schools provided they can be carried out in a manner consistent with the Supreme Court's ruling."

Carter has long been troubled by Southern Baptist ministers who since the 1970s have, in his view, sought to erode church-state separation, unreflectively embraced the conservative agenda, aligned with the Republican Party, and imposed doctrinal standards within the Southern Baptist Convention. ${ }^{132}$ In 2000 , he finally left the SBC over such concerns, and in 2007, he announced with Bill Clinton, his intentions to form a new Baptist organization, the New Baptist Covenant, to improve the image of the Baptist tradition. "Our goal," he explained, "is to have a major demonstration of

\footnotetext{
${ }^{130}$ Letter, Deputy Press Secretary Patricia Y. Bario to James E. Damron, April 18, 1980, Folder RM2 120-77-1-20-81, Box RM-1, Collection Title: Religious Matters, Jimmy Carter Library, Atlanta, Georgia.

${ }^{131}$ Letter, Jimmy Carter to Love M. Pattie, November 25, 1980, Folder RM2 1-20-77-1-20-81, Box RM1, Collection Title: Religious Matters, Jimmy Carter Library, Atlanta, Georgia.

${ }^{132}$ Carter, "Judge Not"; "Prayer and the Civic Religion"; Our Endangered Values: America's Moral Crisis, pp. 30-35, 53-64.
} 
harmony and a common commitment to honor the goals of Jesus Christ. We want to be

all-inclusive. and we call on all Baptists to share those goals and join us." 133

\section{The Presidency as a Form of Christian Ministry}

"Give thy servant an understanding mind to govern your people, that I might discern between good and evil. ${ }^{.13+}$

*Anyone who accepts kingship based on serving the devil rather than God will end up a tyrant, not a benevolent leader. ${ }^{.135}$

Though Carter accepted the institutional separation of church and state and

opposed efforts "to use our government to force others to worship as we do, or treat

those who differ as secondary citizens," he did not accept the idea that one should leave

his faith at home and. in fact. he claimed that he "never found any incompatibility

between my own religious faith and my duties as President."

1: Ernie Suggs and John Blake. "Carter. Clinton Woo Baptists to New Coalition." Atlanta JournalConstitution. January 10. 2007.

${ }^{1: 4}$ During his 1978 National Prayer Breakfast speech. Carter quoted this verse from I Kings (3:9). The verse was King Solomon's request to God for what he needed to best serve the people of Israel. See Carter. "Remarks at the $26^{\text {th }}$ National Prayer Breakfast." February 2. 1978. Public Papers of the

Presidents. pp. 26+-265.

135 Carter. Living Faith. p. 229.

${ }^{130}$ Carter. Living Faith. p. 185: "Interview with World Religious Yews." 1976. in Jessyca Russell Gaver. The Faith of Jimmy. Carter (New York: Manor Books. 1977), p. 19: "Remarks at the A frican Methodist Episcopal Zion Church in Buffalo. New York," March 21, 1976, in Pippert, The Spiritual Journey of Jimm. Carter. p. 115; "Response to a Question asked by Cal Thomas of KPRC-TV News in Houston. Texas." April 20. 1976. in Pippert. The Spiritual Journey of Jimm! Carter. pp. 117-118: "Remarks Before the Men`s Bible Class at Plains Baptist Church in Plains, Georgia," August 29, 1976, in Pippert. The Spiritual Journey of Jimmy. Carter. p. 114: "Interview with Ralph Blodgett of Liberty magazine." September-October 1976, in Pippert. The Spiritual Journey of Jimm Carter, p. 115: "Interview with National Religious Broadcasters in Indianapolis. Indiana." October 14, 1976, in Pippert. The Spiritual Journey of Jimm. Carter. p. 1 16: "Remarks at the Annual Meeting of the National Religious Broadcasters," January 21, 1980, Public Papers of the Presidents, Book I. p. 182: "Remarks and Question-and-Answer Session at a Townhall Meeting in Independence. Missouri," September 2, 1980. Public Papers of the Presidents, Book II, pp. 1612-1613: "Interview with Joe Stroud and Remer Tyson of the Detroit Free Press in Flint. Michigan." October 1. 1980. Public Papers of the Presidents. Book III. p. 
explained before the Southern Baptist Brotherhood Commission, "detected nor

experienced any conflict between God's will and my political duty." 137 In office, wrote Frank Moore, he aimed "to uphold the ideals" of his Christian faith. ${ }^{138}$

Carter thought it was "perfectly legitimate and even admirable for Americans to promote their personal beliefs through either religious or political processes," 139 "to try to elevate those standards to meet the standards set for us by Jesus Christ." ${ }^{\text {140 }}$ In 1978, he plainly told members of the Southern Baptist Brotherhood Commission, "Too many of us as Americans, as Christians, are derelict in the duty of taking our influence, our power, our wealth, our free time, and dealing with those issues that still remain as a great challenge to us all." ${ }^{\prime 141}$ In other words, Christians have a duty to become involved in politics.

For Carter, the separation of church and state "does not mean that leaders of our Nation and the people of our Nation are not called upon to worship, because those who wrote the Declaration of Independence and the Bill of Rights and our Constitution did it

2010; "Remarks and Question-and-Answer Session at a Town Meeting in Miami, Florida," October 21, 1980, Public Papers of the Presidents, Book III, p. 2387.

${ }^{137}$ Carter, "Remarks to Members of the Southern Baptist Brotherhood Commission in Atlanta, Georgia." June 16, 1978, Public Papers of the Presidents, Book I, p. 1115.

${ }^{138}$ Letter, Assistant to the President for Congressional Liaison, Frank Moore to Elsie M. Joiner, May 12, 1980, Folder RM 1-20-77-1-20-81, Box RM-1, Collection Title: Religious Matters, Jimmy Carter Library, Atlanta, Georgia.

${ }^{139}$ Carter, Living Faith, p. 185; Carter, "Judge Not."

${ }^{140}$ Carter, "Remarks at the Baptist Brotherhood Commission of the Southern Baptist Convention," May 13, 1977, Public Papers of the Presidents, Book I, p. 877; "Interview with Rich Cline," Evangelical Alliance of the United Kingdom, November-December 2006.

${ }^{141}$ Carter, "Remarks to Members of the Southern Baptist Brotherhood Commission in Atlanta, Georgia," June 16, 1978, Public Papers of the Presidents, Book I, p. 1115. 
under the aegis of, guidance of, with a full belief in God."142 Indeed, Carter believed, "the structure of [presumably Western/American] law is founded on the Christian ethic that you shall love the Lord your God and your neighbor as yourself.", ${ }^{43}$ After his "born-again" rededication experiences in 1966-1967, Carter said he began to more clearly "see that the teachings of Christ could be applied to a secular existence."

The separation of church and state, in Carter's view, did not and could not mean the separation of religion and politics, faith and policy, believer and politician. ${ }^{145}$ "There is nothing wrong with bringing" faith and politics "together, because you can't divorce religious beliefs from public service." ${ }^{146}$ Powell explained that Carter "didn't...ever imagine that the separation of church and state could be construed as prohibiting a president from the free exercise of religion." ${ }^{\text {147 }}$ Other Carter officials agreed.

Carter's friend and Baptist minister Robert Maddox, who served as Carter's presidential liaison to religious communities (1979-1981) and later the executive director of Americans United for the Separation of Church and State, said, "religion and politics can be friends while still maintaining their proper distance", "church and state

\footnotetext{
${ }^{142}$ Carter, "Remarks at the $26^{\text {th }}$ National Prayer Breakfast," February 2, 1978, Public Papers of the Presidents, p. 264.

${ }^{143}$ Carter, "'Law Day' Address at the University of Georgia in Athens, Georgia," May 4, 1974, www.jimmycarterlibrary.org.

${ }^{144}$ Carter, Living Faith, p. 225.

${ }^{145}$ Carter, Living Faith, p. 9; "Remarks to Ministers of the African Methodist Episcopal Church in Atlanta, Georgia," June 18, 1976, in Pippert, The Spiritual Journey of Jimmy' Carter, p. 242.

${ }^{1+6}$ Carter, "Remarks to Members of the Southern Baptist Brotherhood Commission in Atlanta, Georgia," June 16, 1978, Public Papers of the Presidents, Book I, p. 1115.

${ }^{147}$ Hutcheson, God in the White House, pp. 205-206.
} 
can and must cooperate to make life better for all our people", and Christians are called to be "the salt, light, and leaven" of the world. ${ }^{148}$ Andrew Young said, "American politics are supposed to be separated from religion, but this is a largely institutional separation. The average voter in this nation is strongly influenced by ideals and values which come from his or her faith and religious upbringing."149

In this sense, Carter is not a strict separationist; he disagreed with the view that "an impenetrable wall must be maintained between religion and all aspects, substantive or symbolic, of public life." 150 In A. James Reichley's four categories of church-state relations, Carter is most likely a "liberal social activist": one who believes in the institutional separation of church and state, and "churches and other religious bodies are morally obliged to play active political roles in promoting 'social justice' and other worldly social causes."151

In his post-presidential publications, Carter admitted, often in detail, the profound effect of religion on his life and his politics. He recognizes that his faith does not always provide the clearest political roadmap. ${ }^{152}$ But, he said, it does offer political

\footnotetext{
${ }^{148}$ Robert L. Maddox, Preacher at the White House (Nashville, TN: Broadman Press, 1984), pp. 155. $201-211$.

${ }^{149}$ Young, A Way Out of No Way: The Spiritual Memoirs of Andrew Young, pp. 117-118.

${ }^{150}$ Reichley, Faith in Politics, p. 3.

${ }^{151}$ Ibid. Reichley's other two categories were moderate accommodationists, who believe in maintaining the symbolic presence of religion in the public square and political life, and direct interventionists, who believe that religion and politics "should participate as organized interest groups in all phases of elective and legislative politics."

${ }^{152}$ He warns against the temptation to claim Biblical sanction for policies that the Bible is silent on. "My religion is an important part of my life. I've studied the Bible all my life. But nowhere in the Bible, Old or New Testament, are there instructions on how to balance the budget or how to choose between the B-1 bomber and the air-launched cruise missile. What I do find is, 'Judge not that ye be not judged,' and the
} 
leaders guidelines and narrows choices, and, through prayer, one can find a sense of calm and self-assurance about decisions made.

For a Christian, the life and teachings of Jesus offer a sound moral foundation that includes all the most basic elements that should guide us. Since these highest standards are eternal, we have an obligation to comprehend what they are and what they mean for us. Our faith can provide enough courage to apply these biblical lessons to our daily lives. If specific guidelines or examples are not always available, at least our basic principles can help narrow the options. ${ }^{153}$

Carter believed that politics, including the presidency, was a vocation in the religious sense, a calling, a form of ministry, an opportunity for witness, and a means to practically apply the Gospel in the world. ${ }^{154}$ As a Christian, a Christian politician, and a Christian president, Carter said he aimed to emulate Christ through courage, humility, compassion, inclusion, long-suffering patience, sacrifice, and peacemaking. ${ }^{155}$ One of his favorite verses is Psalms 19:14: "Let the words of my mouth and the meditation of my heart, be acceptable in thy sight, O Lord, my strength, and my redeemer.","156

For Carter, religious faith is holistic; it is neither one small, concealed part of one's life or something showy for all to see. Faith is private and public, personally sustaining and socially transformative. Religious faith is not anachronistic either. "Our

\footnotetext{
commandment to love my neighbor." "Remarks at the Alfred E. Smith Memorial Dinner in New York City," October I6, I980, Public Papers of the Presidents, Book III, p. 2312.

${ }^{153}$ Carter, Living Faith, p. 14.

${ }^{154}$ Wheeler, Jimmy Who?, p. 139; Baker, A Southern Baptist in the White House, pp. 93-94, 135.

155 These are virtues Carter often highlights in his writings, have said to others as what living a Christian life entails, or what others have observed what his faith means to him. See Hutcheson, God in the White House, pp. 99-152.

${ }^{156}$ Ariail and Heckler-Feltz, The Carpenter's Apprentice, p. 86.
} 
religious faith is, indeed, relevant to a modern world." 157 It is not "a valued relic of a bygone age," but an anchor, a "practical necessity" in changing times.

In our rapidly changing world, we need to cling to things that don't change- to truth and justice, to fairness, to brotherhood, to love, and to faith. And through prayer, I believe we can find those things. ${ }^{158}$

On being born again, he said that a commitment to Christ marks the beginning of "a new life, not of perfection but of striving, stretching, and searching-a life of intimacy with God through the Holy Spirit." 159 Faith "is a highly personal and subjective experience" in which we "know, understand, and experience God...in Jesus." 160 But it is more; it is public, too. As stated in "The Baptist Faith and Message," and in the title of one of his books, faith for Carter is "a living faith."161

Religion is not simply a private matter, spiritual exercises conducted in solitude or doctrines affirmed in certitude without consequence. Faith is not passive or contemplative; "faith is not just a noun but also a verb." 162 It should be faith in action. "Our values, our beliefs, our faith are forged and made meaningful only through action." 163

${ }^{157}$ Carter, "Remarks at White House Reception for Pope John Paul II," October 6, 1979, Public Papers of the Presidents, Book II, p. 1830.

${ }^{158}$ Carter, "Remarks at the $26^{\text {th }}$ National Prayer Breakfast," February 2, 1978, p. 264.

${ }^{159}$ Carter, Living Faith, p. 20.

${ }^{160}$ Ibid., pp. 20-21.

${ }^{161}$ Ibid., p. 3; The Baptist Faith and Message, p. 5.

162 Ibid., p. 4.

${ }^{163}$ Carter, "Remarks at the Welcoming Ceremony for Pope John Paul II," October 6, 1979, Public Papers of the Presidents, Book II, p. 1828; "Remarks and Question-and-Answer Session at a Townhall Meeting in Dolton, Illinois," October 16, 1979, Public Papers of the Presidents, Book II, p. 1941. 
His faith brought him rebirth and purpose in his personal life, and his faith gave him the hope and conviction that the country could experience a similar rebirth at home and renewed sense of purpose abroad. He rejected the conventional wisdom that the separation of church and state meant that believing politicians "ought to live two different lives, one as politician and the other one as a churchman." "164 That was the problem Carter saw in Lyndon Johnson and Richard Nixon. Because of his faith, Carter did not think he would exhibit their moral failings or abuses of power. Carter promised to repudiate what Michael Nelson called "the Satan model" of the Johnson and Nixon presidencies, presidencies that were morally flawed and imperial. ${ }^{165}$

I don't think I would ever take on the same frame of mind that Nixon or Johnson did-lying, cheating, and distorting the truth...I think my religious beliefs alone would prevent that from happening to me. I have that confidence. ${ }^{166}$

Keeping with this theme, years later when Carter was asked, "What can a leader do to avoid corruption," he replied, "the adherence to simple ethical standards-my preference would be founded on religious belief - is a good prohibition to corruption." $" 167$

\footnotetext{
${ }^{164}$ Carter, "Remarks to Ministers of the African Methodist Episcopal Church in Atlanta, Georgia," June 18, 1976, in Pippert, The Spiritual Journey of Jimmy Carter, p. 242. Carter did, however, affirm the classic "separationist" Baptist position on church-state issues, such as opposition to federal aid for parochial and religious schools, tax credits for parents who send their children to such schools, and school prayer and pro-life constitutional amendments, and he even said he would consider taxation of church properties other than the primary place of worship. See Ronald B. Flowers, "President Jimmy Carter, Evangelicalism, Church-State Relations, and Civil Religion," Journal of Church and State 25 (Winter 1983): 114-123.

${ }^{165}$ Michael Nelson, "Evaluating the Presidency," in The Presidency and the Political System, ed. Michael Nelson (Washington, DC: CQ Press, 2003), p. 4.

${ }^{166}$ Carter, "Interview with Robert Scheer," Playboy (November 1976), p. 86.

${ }^{167}$ Carter, "Interview with Leaders Magazine," April 1985, in Conversations with Carter, edited by Don Richardson (Boulder, CO: Lynne Rienner Publishers, 1998), p. 268.
} 
he explained that greatness was not in just being the president. Instead, greatness is found in Christian service: "If you act like Jesus, you'll be good Christians."

Using secular parlance, Carter desired to be James David Barber's "activepositive" president- - that is, he aspired to do great things as president and enjoyed the experience of being president. ${ }^{174}$ But to leave it at that misses Carter's religious motives for aspiring to be the "active-positive." And for Carter, his religious faith mattered politically. Carter aimed to be more than a trustee president. He aimed to be more than a president who sought to be an exemplar and teacher of American culture, providing "cultural leadership [that] appeals to 'the better angels of our nature.",175 He claimed that his intentions, policies, and style were "pure," "honest," "proper," "pleasant," "self-sacrificial," "idealistic," and may be even as some have described "pious." $" 176$

While it may not be accurate to say that he wore his religion on his sleeve, his faith did rule his heart and he sought to apply his faith to politics and guide his presidential behavior. As evangelist Billy Graham once opined, "I don't believe it is on his sleeve, I believe it is in his heart." 177 Another religious observer claimed that Carter "made a tremendous contribution by showing a politician could live by his faith."

${ }^{173}$ Douglas Brinkley, The Unfinished Presidency: Jimmy Carter's Journey Beyond the White House (New York: Penguin Books, 1999), p. 30.

174 James David Barber, The Presidential Character: Predicting Performance in the White House (Saddle River, NJ: Prentice Hall, 1992), pp. 8-9, 399.

${ }^{175}$ Erwin C. Hargrove, The President as Leader: Appealing to the Better Angels of Our Nature (Lawrence, KS: University of Kansas Press, 1998), p. 39.

${ }^{176}$ Carter, "Interview with Charles O. Jones, H. Clifton McCleskey, Kenneth W. Thompson, James Sterling Young, Richard Neustadt, David B. Truman, Richard F. Fenno, Jr., and Edwin C. Hargrove," Carter Presidency Project, November 29, 1982. 
Carter's view of politics was that it was a legitimate means to live out his faith, a type of religious vocation, maybe a form of ministry. ${ }^{179}$ It was a legitimate means of spreading and implementing the gospel of Christ, doing the necessary, yet thankless, work of God in a sinful world. Politics, in short, was another means of fulfilling the "Great Commission." Therefore, Carter believed that the presidency could be a powerful means of serving God and neighbor.

As early as 1962, when he was preparing for a run for the Georgia state senate, Carter was beginning to see politics as a means of promoting God's work. During the exploratory phase, he met with several Baptist preachers telling them of his plans to run. On one occasion, a visiting minister tried to dissuade him from entering the dirty business of politics. Carter's response was, "How would you like to be a pastor of a church with 80,000 members?"180 Later, before the 1976 Pennsylvania primary, Carter said, "I would try to exemplify in every moment of my life those attitudes and actions of Christianity that I believe in. I would ask God for guidance on decisions affecting our country and make those decisions after evaluating the alternatives as best I could. I would recognize that my influence on others would be magnified a hundred times over as President." 181 Therefore, when he was president, it is reasonable to conclude that he saw himself as having the extraordinary opportunity to share his ministry with more

\footnotetext{
${ }^{177}$ Quoted in Brinkley, The Unfinished Presidency, p. 54.

${ }^{178}$ Frank Davies, “An Independent Statesman,” The Miami Herald, May 12, 2002, 6L.

${ }^{179}$ Baker, A Southern Baptist in the White House, p. 94.

${ }^{180}$ Ibid., pp. 93-94.

${ }^{181}$ Ibid., p. 135.
} 
Politics was not ultimately about winning or losing. It was about doing the right thing; it was a way of Christian service that could "be of benefit to Your Kingdom and to my fellow human beings." 168 Politics was a means of conveying in the world "the universality of God's truth" and "the universality of God's love" to friend and foe alike. ${ }^{169}$ In fact, "the essence of theology and political science and philosophy" is the same - waging "a fierce struggle," like Martin Luther and Coretta Scott King did, "for freedom and justice and to do it peacefully." 170

Presidential leadership for Carter meant presidential service; being president meant being "First Servant," not "First Boss."171 As Jesus told his disciples, "Whosoever will be chief among you, let him be your servant." On one occasion, he declared, the Bible verse that says "The last shall be first" should be the standard of service for government agencies in the executive branch. ${ }^{172}$ He expressed a similar point again even after his defeat in 1980. In his last Sunday school class as president.

${ }^{168}$ Pippert, The Spiritual Journey of Jimmy Carter, p. 32.

${ }^{169}$ At the 1980 National Prayer Breakfast, Carter admitted he even prayed for the Ayatollah Khomeini. "Every day, I pray for the Ayatollah Khomeini. Every day I pray for the kidnapers who hold our innocent Americans." For Carter, this was the test of the Gospel. One not only had to show God's love to friends and allies, but even to the worst of enemies. Such a remark is remarkable, given that Carter had low approval numbers, was up for reelection, and in the midst of a serious contest for the nomination. It was an extraordinary admission. "Remarks at the National Prayer Breakfast," February 7, 1980, Public Papers of the Presidents, Book I, p. 277. But Carter believes that Jesus commanded his followers to "Love the ones who hate you." "Interview with Elizabeth Sams," Beliefnet, March 27, 2007, http://www.beliefnet.com/story/214/story 21478.html.

${ }^{170}$ Carter, "Remarks at the Funeral of Coretta Scott King at New Hope Missionary Baptist Church in Lithonia, Georgia," February 7, 2006.

${ }^{171}$ Pippert, The Spiritual Journey of Jimmy Carter, p. 25; "Remarks and Discussion with Employees at the Department of Health, Education, and Welfare," February 16, 1977, Public Papers of the Presidents. Book I, p. 167; "Acceptance Speech at the Democratic National Convention in New York City," August 14, 1980, Public Papers of the Presidents, Book II, p. 1533.

172 Carter, "Remarks at the Swearing In of F. Ray Marshall, Secretary of Labor," January 27, 1977 , Public Papers of the Presidents, Book I, p. 26. 
than 200 million at home and billions abroad. In this way, Carter could literally fulfill the Christian obligation of bringing the message of Jesus to the world "to make disciples of all nations." Former Carter advisor Peter Bourne says that for Carter there is "a close analogy" between "an elected politician and his constituency and a pastor and his congregation."

As a member of the Baptist faith in which preachers are not appointed by a church hierarchy, but elected by the congregation they serve, the analogy seemed to him quite apt. ${ }^{182}$

\section{The Evangelism of Energy}

"God doesn't want us to waste what He gives." 183

When American presidents appeal to God, they frequently ask the Almighty to bless and sanction our history, our mission, our policies, and our people. As Robert Bellah observed, Americans have pretty much always seen themselves as the "New Israel" with a "Manifest Destiny" to make "God's work our own" and furthering "God's will on earth." 184 And it is these visions that presidents typically refer. What is often missing, though, in the American civil religion is a sense of humility, sacrifice, and recognition of the country's own transgressions and shortcomings. Presidents have typically preferred the role of priest to prophet, preferring exhortations that sanctify the

\footnotetext{
${ }^{182}$ Bourne, Jimmy Carter: A Comprehensive Biography from Plains to Postpresidency, p. 113.

${ }^{183}$ Carter, "Remarks and a Question-and-Answer Session at a Town Meeting in Tampa, Florida," August 30, 1979, in Public Papers of the Presidents, Book II, p. 1578.

${ }^{184}$ Robert N. Bellah, "Civil Religion in America," in Religion in America, ed. George C. Bedell, Leo Sandon, Jr., and Charles T. Wellborn (New York: Macmillan Publishing Company, 1982), pp. 24-32.
} 
status quo. ${ }^{185}$ But Carter chose to promote different images. From the beginning, wrote

Dan Hahn, Carter frequently spoke in the style of a Southern preacher, presenting his case in "eternal moralistic generalization." 186 He sought to be a prophet, a messenger who brings God's words into the very corridors of political power, words of humility, sacrifice, and warnings about limits and excessive materialism. ${ }^{187}$ In the eyes of one scholar, Carter earned the description of "the prophet of diminishing expectations." 188 In his inaugural he quoted the prophet Micah (6:8): "He hath showed thee, O man, what is good; and what doth the Lord require of thee, but to do justly, and to love mercy, and to walk humbly with thy God."189 For Carter, even a superpower must "walk humbly" and do what is right before God. He aimed to lower expectations of the

${ }^{185}$ Rosemary Radford Ruether, "Mystification or Liberation?" The Christian Century, January 5-12, 1977, 4; Richard V. Pierard and Robert D. Linder, "Jimmy Carter and that Old-Time (Civil) Religion," in Civil Religion and the Presidency (Grand Rapids, MI: Zondervan Publishing House, 1988), 23 1-256. Pierard and Linder said Carter's embrace of the prophetic role was key to understanding his "failure as a political leader." They noted that Carter's style and tone offended. Even many evangelicals were turned off. Americans, they noted, "wanted to hear words of joy about America's power and plenty, not the pious homilies of a Baptist lay preacher or the calls to sacrifice and repentance of a civil prophet.

${ }^{186}$ Dan F. Hahn, "The Rhetoric of Jimmy Carter, 1976-1980," Presidential Studies Quarterly 14.2 (Spring 1984): 269.

${ }^{187}$ Pippert, The Spiritual Journey of Jimmy Carter, p. 23; Jeff Walz, "Religion and the American Presidency," in In God We Trust? Religion and American Political Life, edited by Corwin E. Smidt (Grand Rapids, MI: Baker Book House Company, 2001), pp. 198-199.

${ }^{188}$ David D. Lee, "The Politics of Less: The Trials of Herbert Hoover and Jimmy Carter," Presidential Studies Quarterly 13 (1983): 311.

${ }^{189}$ Carter, however, wanted to cite II Chronicles 7:14. "If my people, which are called by my name, shall humble themselves, and pray, and seek my face, and turn from their wicked ways, then will I hear from heaven, and will forgive their sin, and will heal their land." Carter's advisors counseled against using it, arguing that it would make him sound too judgmental and preachy, and as though he was shifting the blame for the country's loss of faith from government to the people. Bourne, Jimmy Carter: A Comprehensive Biography from Plains to Postpresidency, p. 365. Speechwriter Patrick Anderson said that it appeared as though Carter was confusing himself with King Solomon or perhaps with God." Patrick Anderson, Electing Jimmy Carter: The Campaign of 1976 (Baton Rouge, LA: Louisiana State University Press, 1994), p. 157. Richard V. Pierard notes that this verse was a favorite of evangelicals at the time of the 1976 Bicentennial. It was a verse that captured their "unwavering call for national 
presidency and of America itself. "We have learned that 'more' is not necessarily 'better,' that even our great nation has its recognized limits and that we can neither answer all questions nor solve all problems. We cannot afford to do everything... in a spirit of individual sacrifice for the common good, we must simply do our best." 190 More than any other domestic issue, Carter focused on energy. "The number one issue for us on the domestic scene, by far, is energy", ${ }^{191}$ it was, he believed, "the gravest domestic issue." "T2 "The energy problem" represented "a clear and present danger to our lives and to our livelihood." 193 To meet the challenge, he cast the issue in moral terms. He believed that the country must wage "the moral equivalent of war."

Of Carter's twelve national television addresses, five were devoted to energy, four more than to any other issue (Figure 4.2). ${ }^{194}$ In his first major address to the American people, his "fireside chat" on February 2, 1977, where he sat wearing a cardigan sweater, the topic was energy. In Protestant-like terms, Carter called on the

repentance" at a time the country had "undergone a great apostasy." Pierard, "Evangelicals and the Bicentennial," The Reformed Journal (October 1976): 22.

${ }^{190}$ Carter, "Inaugural Address," in Religion in America, ed. George C. Bedell, Leo Sandon, Jr., and Charles T. Wellborn, pp. 64-66.

${ }^{191}$ Carter, "Remarks and Interview with a Group of Editors and News Directors," October 14, 1977, Public Papers of the Presidents, Book II, p. 1799; "Remarks and a Question-and-Answer Session at a Town Meeting in St. Louis, Missouri," October 13, 1980, Public Papers of the Presidents, Book III, p. 2209.

${ }^{192}$ Carter, "The President's News Conference," June 13, 1977, Public Papers of the Presidents, Book I, p. 1103; "Remarks and Question-and-Answer Session with Du Page County Residents in Addison, Illinois," October 6, 1980, Public Papers of the Presidents, Book III, p. 2082.

${ }^{193}$ Carter, "Remarks on the Signing of the Energy Security Act," June 30, 1980, Public Papers of the Presidents, Book II, pp. 1252.

${ }^{194}$ Samuel Kernell, Going Public: New Strategies of Presidential Leadership (Washington, DC: CQ Press, 1997), p. 110. 
American people "to live thriftily," suggesting that they could help him in this crisis by "simply keeping our thermostats" down in the winter and up in the summer. Vice President Walter Mondale recalled that afterwards he even had the air conditioners turned off in the White House. ${ }^{195}$ Carter would issue two more major television addresses (April 18 and November 8) and one address before a joint session of Congress on the subject that year (April 20). According to the Congressional Quarterly, Carter's agenda in the first year was "energy and everything else." 196

\section{Figure 4.2 President Carter's Major Addresses by Topic}

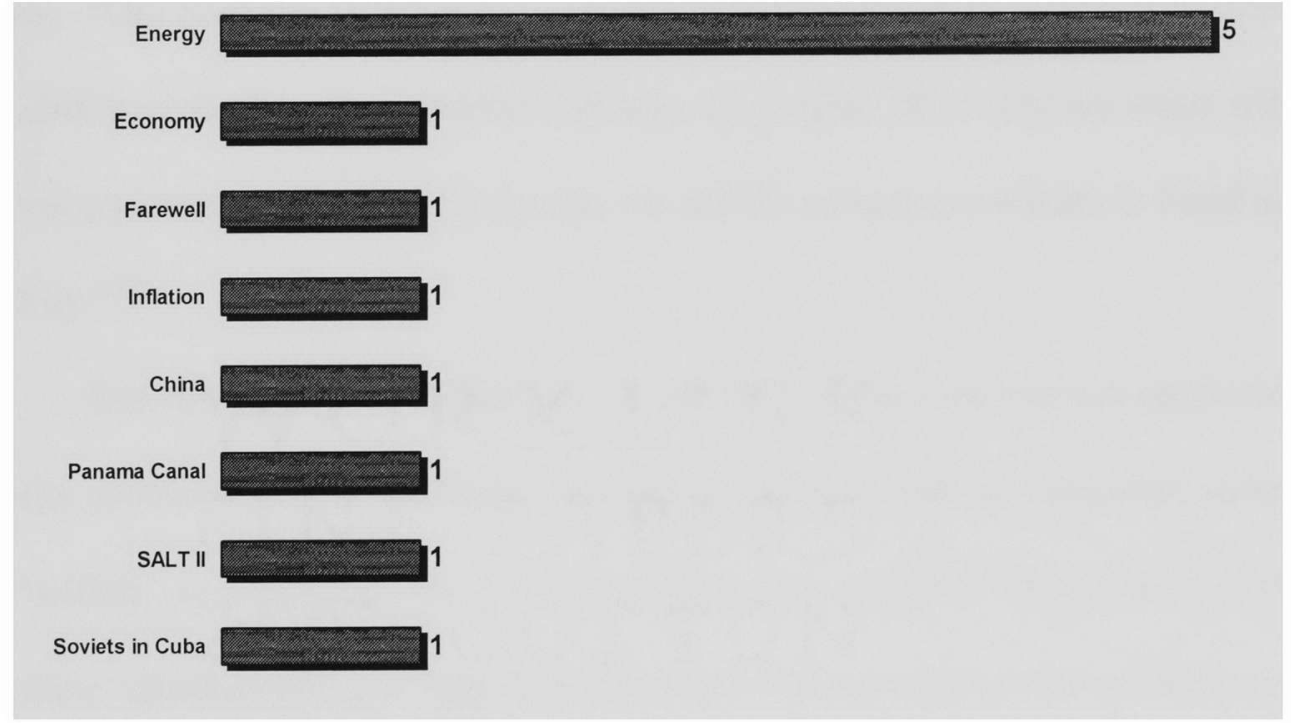

Source: Samuel Kernell, Going Public: New Strategies of Presidential Leadership (Washington, DC: CQ Press, 1997), p. 110.

At the time, energy was no longer a major concern for Americans; it was not even a major issue in the campaign. ${ }^{197}$ The 1973 crisis had passed, the long gas lines were over, and the country was on to other things. The Democratic Congress was not

\footnotetext{
${ }^{195}$ Mondale, Transcript, American Experience: Jimmy Carter.

${ }^{196}$ Morris, Jimmy Carter: American Moralist, p. 254.
} 
interested in the issue and, as one biographer put it, "there was no constituency solidly in favor of the policy." "198 In fact, Carter noted that his energy proposals offended "labor, consumers, oil and gas producers, the utility companies, and environmentalists!" "199 The priority Carter gave it, then, Colleen Shogan offered, came as a "surprise." 200 Even so, she continued, Carter saw it as his responsibility, his "moral responsibility," to tackle the tough problems and address issues before they became crises.

In his April address the President described the energy issue in terms of a moral cause. "Our decision about energy will test the character of the American people and the ability of the President and the Congress to govern. This difficult effort will be the 'moral equivalent of war'- except that we will be uniting our efforts to build and not destroy."201

Interestingly, the President knew that many Americans did not appreciate the energy problem the country faced. Though he pleaded with the American people not to be "selfish," to quit being "the most wasteful nation on Earth" and to think of the future for their "children and grandchildren," he knew that the signs of the problem were

${ }^{197}$ Ibid.

${ }^{198}$ Carter apparently concurred with Congressional Quarterly's assessment for he cited it in Keeping Faith, p. 101.

${ }^{199}$ Ibid., p. 106.

${ }^{200}$ Colleen J. Shogan, The Moral Rhetoric of American Presidents (College Station, TX: Texas A\&M University Press, 2006), p. 73.

${ }^{201}$ Carter, "Address to the Nation on the Energy Problem," April 18, 1977, in Public Papers of the Presidents, Book I, p. 656; "Address Delivered Before a Joint Session of Congress on the Energy Problem," April 20, 1977, in Public Papers of the Presidents, Book I, p. 671. 
hidden and not self-evident. ${ }^{202}$ He knew many did not believe there was a crisis. "but it was true." 203 And he knew that "all the special interests in the country will attack. ${ }^{2(14}$ Two days later, he told Congress that because of what he had to tell them about the emerging energy crisis and what was necessary to prepare for it that he did not "expect much applause."205

After his presidency was over, Carter recalled, "It was like pulling teeth to convince the people of America that we had a serious problem in the face of apparently plentiful supplies, or that they should be willing to make some sacrifices or change their habits to meet a challenge which, for the moment, was not evident. ${ }^{.206}$ Nevertheless. President Carter felt compelled to issue his energy jeremiad, consequences-political or otherwise-be damned.

With the exception of preventing war, this is the greatest challenge our country will face during our lifetimes. The energy crisis has not yet overwhelmed us. but it will if we do not act quickly.

I know that some of you may doubt that we face real energy shortages. The 1973 gasoline lines are gone, and our homes are warm again. But our energy

202 Carter, "Address to the Nation on the Energy Problem," April 18, 1977, in Public Papers of the Presidents. Book I, p. 656-658: "Remarks to Participants of the CLOSE-UP Program," April 21. 1977, in Public Papers of the Presidents, Book I, p. 694.

${ }^{203}$ Carter, "Remarks During Radio Call-out Program on KSTT/WXLP Stations in Davenport. Iowa." August 21, 1979, Public Papers of the Presidents, Book II, p. I480; "Remarks to Lincoln Land Community College Students and Local Residents in Springfield. Illinois." September 22. 1980. Public Papers of the Presidents, Book II, p. 1866; "Remarks at a White House Briefing for Community Leaders," May 27, 1980, Public Papers of the Presidents, Book II, p. 977: "Remarks and Question-andAnswer Session with Newhouse Newspaper Editors," May 28, 1980, Public Paper's of the Presidents. Book II. p. 986; "Remarks at a Carter/Mondale Fundraising Dinner in Cleveland. Ohio," May 29. 1980. Public Papers of the Presidents, Book II, p. 1006.

${ }^{204}$ Carter, "Address to the Nation on the Energy Problem," April 18, 1977, Public Papers of the Presidents, Book I, p. 661 .

${ }^{205}$ Carter, "Address Delivered Before a Joint Session of Congress on the Energy Problem." April 20. 1977, Public Papers of the Presidents, Book I, p. 663.

${ }^{206}$ Carter, Keeping Faith, 97. 
problem is worse tonight than it was in $1973 \ldots$... is worse because more waste has occurred, and more time has passed by without our planning for the future. And it will get worse every day until we act. ${ }^{207}$

The President went on to describe how the country was depleting its oil and natural gas supplies, that the country's consumption was outpacing production, and that the country had become ever so dangerously dependent on Middle Eastern oil.

Here was a president who assumed the mantle of prophet. He believed that it was his responsibility to tell the unvarnished truth. "If I don't tell you the truth, then my voice will not be meaningful. ${ }^{208}$ On energy, he called on the people to respond to a crisis that was not evidently a crisis at the moment; it was a problem he and no one else. not the people, his party, or the Congress, recognized. ${ }^{209}$ He did not expect applause or accolades for his efforts; he knew he would offend, fully expecting his popularity to drop. $^{210}$ "I was warned that this would not be good politics. Nobody likes bad news." 211 He knew that his message "sounded a warning in harsh terms," that he used "terms not often used by a President speaking to the people." 212 But he said he had to

${ }^{207}$ Carter, "Address to the Nation on the Energy Problem," April 18, 1977, Public Papers of the Presidents, Book I, p. 656.

${ }^{208}$ Carter, "Remarks and a Question-and-Answer Session at the Annual Convention of the Communications Workers of America in Detroit, Michigan," July 16, 1979, Public Papers of the Presidents, Book II, p. 1256.

${ }^{209}$ Carter, "Remarks and Question-and-Answer Session at a Town Meeting in Torrance, California," September 22, 1980, Public Papers of the Presidents, Book II, pp. 1869-1870.

${ }^{210}$ Carter, Keeping Faith, p. 98; Carter, "Interview with Members of the Radio-Television News Directors Association," April 29, 1977, in Public Papers of the Presidents, Book I, p. 753.

${ }^{211}$ Carter, "Remarks at the Annual Convention of the American Public Transit Association in New York," September 25, 1979, Public Papers of the Presidents, Book II, p. 1740.

${ }^{212}$ Carter, "Remarks and a Question-and-Answer Session at the Annual Convention of the Communications Workers of America in Detroit, Michigan," July 16, 1979, Public Papers of the Presidents, Book II, p. 1248. 
speak in such stark terms "because it is the truth" and Americans had "to be honest about ourselves." "Every single American," he exclaimed, "must stop wasting energy."213 "Sometimes," as president he believed, "you have to do something that is not popular." 214 Some were identifying already that Carter had a tendency for "preaching. ${ }^{215}$ In atypical presidential fashion, Carter began his April energy speech with, "Tonight I want to have an unpleasant talk with you.",216

Carter pleaded with Americans to recognize "that there are indeed limits on what God has given us... There is a limit on energy reserves. "217 He wanted Americans to have a "keener appreciation of limits," particularly "the limits of manipulating" the natural world. ${ }^{218}$ Though Americans were unaccustomed to hearing such talk of national limitation, Carter urged the country to adopt a "more careful stewardship" and "more responsible approach to conservation and the elimination of waste." At the 1978 Colorado Governor's Annual Prayer Breakfast, he began his speech saying that while the country was certainly "blessed by God with riches of all kinds," he warned that

213 Carter, "Remarks at the Annual Convention of the National Association of Counties in Kansas City, Missouri," July 16, 1979, Public Papers of the Presidents, Book II, p. 1243; "Address to the Nation on National Energy Plan." November 8, 1977, in Public Papers of the Presidents, Book II. p. 1983.

${ }^{214}$ Carter, "Interview with Members of the Radio-Television News Directors Association." April 29. 1977, in Public Papers of the Presidents, Book I. p. 753.

215 Carter, "Question-and-Answer Session with European Broadcast Journalists," May 2, 1977. in Public Papers of the Presidents, Book I, p. 762.

${ }^{216}$ Carter, "Address to the Nation on the Energy Problem," April 18, 1977, in Public Papers of the Presidents, Book I, p. 656.

217 Carter, "Remarks and Question-and-Answer Session at League of Women Voters Convention." May 5, 1980, Public Papers of the Presidents, Book I, p. 829; "Remarks at the Swearing In of Neil Goldschmidt as Secretary of Transportation and Moon Landrieu as Secretary of Housing and Urban Development," September 24, 1979, Public Papers of the Presidents, Book II, p. 1719.

${ }^{218}$ Carter, "Remarks at the Dedication Ceremonies for the John F. Kennedy Library in Boston. Massachusetts," October 20, 1979, Public Papers of the Presidents, Book II, p. 1981. 
there appeared to be "a growing sense that these blessings of God" seemed to be "appreciated to little and cared for with disdain or neglect."219 We need to be mindful. Carter continued, that "God said, "The Earth is Mine and the fullness thereof."' Only by returning to "our faith in God," he concluded his remarks, could the United States renew its spirit and take up its "responsibility for stewardship" of its natural resources. ${ }^{220}$ "We ought to be on our knees thanking God for what we have in this country." 221 Saving energy and the wise use of resources is "compatible with what the Bible teaches.",222

After nearly two years of hard work and harangue, Congress did pass five pieces of energy legislation on October 15, 1978. However, they had been the easier recommendations of the President. The President vowed to continue the fight: "Our work on energy was far from over." 223 He appreciated that his "repeated calls for action on energy had become aggravating, and were increasingly falling on deaf ears among American citizens...After two years of struggle, I really hated to stir up the energy pot all over again." 224 Carter was undeterred. He wrote, "The hard fact was that Americans still had to reduce oil consumption, particularly of foreign imports. Duty demanded that

${ }^{219}$ Carter, "Remarks at the Colorado Governor's Annual Prayer Breakfast in Denver, Colorado," May 4, 1978, Public Papers of the Presidents, Book I, p. 829.

${ }^{220}$ Ibid., pp. 831-832; see also "Remarks at a Meeting with Civic and Community Leaders in Albuquerque, New Mexico," October 11, 1979, in Public Papers of the Presidents, Book II, p. 1864.

${ }^{221}$ Carter, "Remarks to Delegates at the National 4-H Club's $5^{\text {th }}$ Anniversary Conference," April 17. 1980, Public Papers of the Presidents, Book I, p. 703.

222 Carter, "Remarks and a Question-and-Answer Session at a Town Meeting in Tampa, Florida," August 30, 1979, in Public Papers of the Presidents, Book II, p. 1578.

${ }^{223}$ Carter, Keeping Faith, p. 108.

${ }^{224}$ Ibid., pp. 108-109. 
I act, but political expediency cried out against it. ${ }^{.225}$ After the fall of the Shah in Iran in January 1979 and the nuclear-power accident at Three Mile Island in March. the President addressed the country for a fourth time on energy (April 5). ${ }^{226}$ Again. the speech fell on deaf ears in the public and in Congress. Carter said he had a difficult time containing his ire. In his diary, he blamed "the irresponsibility of Congress." the action of its members "disgusting." and various European leaders for colluding to block any energy reform. ${ }^{227}$

In early July. President Carter prepared for his fifth national address on energy. However, after consultation with pollster Pat Caddell and his wife Rosalynn. Carter decided to can his speech. "I told her [Rosalynn] I couldn't deliver it, that I had already made four speeches to the nation on energy and that they had been increasingly ignored...I had to do something to get the attention of the news media and the public." 228 The American people "were aggravated every time I went on TV. They weren 't interested" in the energy issue. "I had been to the public so many times it was like the guy crying wolf." 229

Subsequently, the President held a ten-day summit of various leaders and advisors at Camp David as to what he should do and what he should say. Carter

\footnotetext{
25 Ibid. p. 110.

${ }^{226}$ Ibid., pp. 110-111.

227 Ibid.. p. 111.

228 Ibid.. p. 115.

229 Carter, "Interview with Charles O. Jones, H. Clifton McCleskey, Kenneth W. Thompson, James Sterling Young. Richard Neustadt, David B. Truman, Richard F. Fenno. Jr., and Edwin C. Hargrove." Carter Presidency Project, November 29, 1982.
} 
listened to many complaints about his performance. He remembered that they criticized him for being "bogged down in the details of administration," that he "was involved in too many things simultaneously," that he "had delegated too much authority to [his] Cabinet members," and that he lacked the ability or will "to follow through." ${ }^{230} \mathrm{He}$ admitted that this was a painful experience: "It's not easy for me to accept criticism and to reassess my way of doing things.,231

On Sunday, July 15, 1979, Carter was expected to give his fifth major national address on energy. However, Carter decided not to directly address the energy crisis. Instead, he decided to speak of the issue as symptomatic of something greater, a much greater national problem, incorporating many things "I had learned at Camp David."232 For Carter, the funk the country was in was more than long gas lines, more than dependency on foreign oil, more than rising fuel prices. For Carter, a crisis of the spirit, a crisis of confidence was at the heart of the matter.

Once more, Carter assumed the prophetic role. He said he was going to tell the truth "literally from the bottom of my heart"; he believed it was his responsibility to tell the American people not what they wanted to hear but what they needed to hear. ${ }^{233}$ "First of all, we must face the truth.,"234 His message was one of warning and

\footnotetext{
${ }^{230}$ Carter, Keeping Faith, p. 117.

${ }^{231}$ Ibid., p. 118.

232 Ibid., 120.

${ }^{233}$ Carter, "Remarks and Question-and-Answer Session with Editors and News Directors," July 27, 1979. Public Papers of the Presidents, Book II, p. 1325.

${ }^{234}$ Carter, "Address to the Nation on Energy and National Goals," July 15, 1979, Public Papers of the Presidents, Book II, p. 1238.
} 
repentance, "a church sermon about sin and redemption." said Shogan. ${ }^{235}$ He lamented the growing materialism, the "worship of self-indulgence and consumption," the growing distrust in government, and the decline of families and traditional values. ${ }^{236}$ He explained that wanton material acquisition was unsatisfying; the country was painfully learning that "owning things and consuming things does not satisfy our longing for meaning" and that "piling up material goods cannot fill the emptiness of lives which have no confidence or purpose."

Taking his message on the road, to a crowd in Detroit, to have meaning and purpose, Carter urged, "we must believe and we must belong to something bigger than just ourselves." "237 Americans need "to count our blessings," "say something good about our country," "have a renewed sense of the history of our country," and return to "morality, ethics, the standards of our own lives," and a "deeper commitment to our religious beliefs." 238 This is what Americans are looking and long for. Carter thought. This is the source of the "crisis of confidence." "I think there's an innate hunger in our country for moral and ethical and religious principles...I believe there's a hunger for things that are decent and honest. ${ }^{.239}$

235 Shogan, The Moral Rhetoric of American Presidents, p. 78.

${ }^{236}$ Carter, "Address to the Nation on Energy and National Goals," July 15, 1979, Public Papers of the Presidents, Book II, p. 1238.

${ }^{237}$ Carter, "Remarks and a Question-and-Answer Session at the Annual Convention of the Communications Workers of America in Detroit, Michigan." July 16, 1979, Public Papers of the Presidents, Book II, p. 1248.

${ }^{238}$ Carter, "Remarks During Radio Call-out Program on KSTT/WXLP Stations in Davenport. Iowa." August 21, 1979, Public Papers of the Presidents, Book II, p. 1487.

${ }^{239}$ Carter, "The President's News Conference," October 9, 1979, Public Papers of the Presidents, Jimm!. Carter, 1979, Book II, p. 1839. At this news conference, though he did not use it in his July speech. Carter said "there is a degree of malaise in the country." 
The religious undertones of the speech, particularly the evangelical call for the rededication and renewal, were hard to miss. Though pollster Pat Caddell was the author of much of the speech, Leo Ribuffo rightly noted that the moral language "fit the President's evangelical style." 240 Some at the time referred to the speech as Carter's "Sunday night sermon."241 According to a Newsweek report, Carter's summit in mountains and subsequent descent evoked the "Old Testament imagery" of Moses going up to Mount Sinai and returning to the people with the Ten Commandments. ${ }^{242}$ The report noted that "it did not pass notice that one of the programs [the President] preempted was an installment in CBS-TV's series Moses the Lawgiver." The national magazine also included a cartoon depicting this image with the caption, "Down from the mountain: The President bumped Moses with his own television sermon." For his part, Carter believed "it was the most successful speech" he ever delivered. ${ }^{243}$

I want to talk to you right now about a fundamental threat to American democracy...It is a crisis of confidence. It is a crisis that strikes at the very heart and soul and spirit of our national will. We can see this crisis in the growing doubt...the loss of a unity of purpose... The erosion of our confidence in the future... Our people are losing that faith.

${ }^{240}$ Ribuffo, "God and Jimmy Carter," p. 154.

241 James M. Wall, “Jimmy Carter's Sunday Night Sermon,” The Christian Century, August I-8, I979, 747-748. Hugh Carter admitted that the speeches of his cousin could come across with a "goody-goody sound, like a preacher." Hugh Carter and Frances Spatz Leighton, Cousin Beedie and Cousin Hot: My Life with the Carter Family in Plains, Georgia (Englewood Cliffs, NJ: Prentice-Hall, I978), p. 288. Carter, too, admitted that when he speaks some interpret it more as preaching. "Remarks at the 1988 Democratic National Convention in Atlanta, Georgia," July 18, 1988, transcript from Atlanta JournalConstitution.

242 "To Lift a Nation's Spirit," Newsweek, July 23, 1979, 24-25.

${ }^{243}$ Carter, "Interview with Charles O. Jones, H. Clifton McCleskey, Kenneth W. Thompson, James Sterling Young, Richard Neustadt, David B. Truman, Richard F. Fenno, Jr., and Edwin C. Hargrove," Carter Presidency Project, November 29, 1982. 
In a nation that was proud of hard work, strong families, close-kit communities. And our faith in God, too many of us now tend to worship self-indulgence and consumption. Human identity is no longer defined by what one does. but by what one owns...there is a growing disrespect for government and for churches and for schools, the news media, and other institutions. This is not a message of happiness or reassurance, but it is the truth and it is a warning."

Restoring that faith and that confidence to America is now the most important task we face... The strength we need will not come from the White House. but from every house in America.

Energy will be the immediate test of our ability to unite this Nation... On the battlefield of energy we can win for our Nation a new confidence...

We can succeed only if we tap our greatest resources-America`s people. America's values, and America's confidence.

I will do my best. but I will not do it alone... With God's help and for the sake of our Nation, it is time for us to join hands... Let us commit ourselves together to a rebirth of the American spirit... ${ }^{244}$ (Emphasis added).

For "there is more than one form of hunger." "Neither the rich nor the poor." he argued, "will be satisfied without being fed in body and in spirit."

While the energy issue may not be an issue that immediately comes to mind when one thinks of moral issues, Carter believed that it did. He admitted that this could be seen as bizarre. "It might seem strange to some...that the conservation of oil has a religious connotation. ${ }^{.246}$ But he was convinced that energy conservation was "compatible with what the Bible teaches. God does not want us to waste what He gives. ${ }^{247}$

${ }^{244}$ Carter, "Address to the Nation on Energy and National Goals." July 15. 1979. Public Papers of the' Presidents, Book II, pp. 1235-1241.

${ }^{245}$ Carter, "Remarks Before the Indian Parliament in New Delhi, India." January 2. 1978. Public Papers of the Presidents, Book I, p. 5.

${ }^{246}$ Carter, "Remarks at a White House Briefing on Energy Conservation for Religious Leaders," Januar! 10, 1980, Public Papers of the Presidents, Book I. pp. 49-51. 
In a White House briefing with religious leaders, he gave some insights into his understanding of why tackling the country's energy problems was appropriately the "moral equivalent of war." He explained that because God gave humanity "dominion" over the Earth, human beings must be responsible "stewards under God's guidance." This meant, for Carter, that human beings as both individuals and as leaders of government agencies must "protect not only those who are fortunate enough to grasp an advantage or a temporary material blessing or enjoyment," but also guarantee "a quality of life for those less fortunate in our own generation." Additionally, to be good stewards of God's creation, humans of today are morally obligated to provide "for those who will come after us." Unfortunately, Carter lamented, "Our country is comprised of profligate wasters of the Earth's precious resources." Nevertheless, he hoped the country would respond during this "time of trial and tribulation." "The United States," he said, "is being severely tested today—tested for our moral courage, tested for our willingness to forego economic profit, test for our basic military strength, tested for our national unity, tested for our economic strength. ${ }^{248}$ This was the thrust behind Carter's focus on energy in his speeches and his so-called malaise speech. He was being the president-as-prophet—saying things that the country may not want to hear, but must hear anyway. He wanted to remind Americans that in the past, during times "of testing, questioning," the people "always turned to basic unchanging principles, moral beliefs,

\footnotetext{
${ }^{247}$ Carter, "Remarks and Question-and-Answer Session at a Town Meeting in Tampa, Florida," August 30, 1979, Public Papers of the Presidents, Book II, p. 1578.

${ }^{248}$ Carter, "Remarks at the Opening Session of the White House Conference on Small Business," January' 13, 1980, Public Papers of the Presidents, Book I, p. 69.
} 
deep religious convictions, and they have turned to God for guidance in managing the

secular challenges which confront us. ${ }^{2+9}$

With the difficulties of the 1970s, Carter posited the possibility that God may

have even been "cleansing us." As such, the response of the country should be one of "recommitment to basic ideas." Though he tried to assure his guests that he was "not trying to preach a sermon," he wanted to make it clear that he was "very deeply concerned about how Americans look upon resolving the energy question." "For the first time." Carter argued, "Americans had to shape up to the fact that our natural resources blessed for us by God were not unlimited. ${ }^{250}$ Carter would continue to express these points on energy conservation and independence in moral terms many years later.

\footnotetext{
${ }^{249}$ After his "crisis of confidence" address, Carter took his message of restoring faith and frugal living on the road, particularly to the "first-in-the-nation" caucus state of lowa, to remind his fellow Americans of the many blessings God had given them and that as a country those many blessings should be used prudently. See Carter, "Remarks on Arrival in Alma, Wisconsin," August 18, 1979, Public Papers of the Presidents, Book II, p. 1470; "Remarks on Arrival in McGregor. Iowa," August 19, 1979. Public Papers of the Presidents, Book II, p. 1473; "Remarks on Arrival in Dubuque, Iowa." August 20, 1979, Public Papers of the Presidents, Book II, p. 1475; "Remarks on Arrival in Davenport, Iowa," August 21, 1979. Public Papers of the Presidents, Book II, p. 1478; "Remarks on Arrival in Muscatine, Iowa," August 21. 1979, Public Papers of the Presidents, Book II, p. 1493; "Remarks and Question-and-Answer Session at a Town Meeting in Burlington, Iowa," August 22, 1979, Public Papers of the Presidents, Book II. p. 1495 : "Remarks on Arrival in St. Louis, Missouri," August 24, 1979, Public Papers of the Presidents, Book II. p. 1512: "Remarks at a White House Briefing for Religious Leaders on Energy Conservation," January 10, 1980, Public Papers of the Presidents, Book 1, p. 49.

${ }^{250}$ Carter, "Remarks at a Carter/Mondale Fundraising Dinner in Cleveland, Ohio." May 29. 1980. Public Papers of the Presidents, Book II, p. 1006; "Remarks on Arrival in Wabasha, Minnesota," August 18, 1979, Public Papers of the Presidents, Book II, p. 1469. Many years after his presidency, Carter continued to express these points on energy conservation and independence in moral terms. In early 2006, Carter told Larry King, "We must face the fact that the energy shortage is permanent. There is no way we solve it quickly but if we all cooperate and make modest sacrifices, if we learn to live thriftily and remember the importance of helping our neighbors, then we can find ways to adjust and to make our society more efficient and our own lives more enjoyable and productive." See Carter, "Interview with Larry King," CNN's Larry King Live, February 1, 2006; see also "Arctic Folly," Washington Post,
} 


\section{A Religious Contempt for Congress}

"If the trumpet give an uncertain sound, who shall prepare himself to the battle?"251

Presidential scholars are in general agreement that President Carter had difficult relations with Congress. Though he had "the right impulses," Morris Fiorina described Carter as "something less than a virtuoso politician." 252 Douglas Brinkley said his problems partly stemmed from his "political obtuseness." 253 David Mayhew noted Carter's "well-known distaste for politics" as part of the reason he failed to pass major legislation in a Congress dominated by his own party. "Carter's Ninety-fifth Congress of 1977-1978, despite Democratic majorities of 62-38 in the Senate and 292143 in the House, proved to be a cemetery for liberal aspirations." ${ }^{255}$ Philip Kunhardt. Jr., et al., attributed part of Carter's failure to his outsider status, independent mindset, and his "do-it-yourself approach." 256 They wrote, "When Jimmy Carter came into

September 13, 2005; "Interview with Wolf Blitzer," CNN's The Situation Room, January 19, 2007, this portion was aired on CNN's Late Edition, January 21, 2007.

${ }^{251}$ Carter, Why Not the Best?, p. 173; "Remarks to the National Wildlife Federation in Pittsburgh. Pennsylvania," March 15, 1975, The Presidential Campaign 1976: Jimmy Carter, p. 61.

252 Morris P. Fiorina, Congress: Keystone of the Washington Establishment (New Haven, CT: Yale University Press, 1989), p. 131.

${ }^{253}$ Douglas Brinkley, "Jimmy Carter," in To the Best of My Ability": The American Presidents, ed. James M. McPherson (New York: DK Publishing, 2004), p. 283.

${ }^{254}$ David R. Mayhew, Divided We Govern: Party Control, Lawmaking, and Investigations, 19+6-1990 (New Haven, CT: Yale University Press, 1991), pp. 116-117.

${ }^{255}$ Ibid., p. 98.

${ }^{256}$ Philip B. Kunhardt, Jr., Philip B. Kunhardt III, and Peter W. Kunhardt, The American Presiden (New York: Riverhead Books, 1999), p. 158. 
office in 1977 he refused to engage in party politics. Distancing himself from fellow Democrats, he so outraged the [Democratic] National Committee that it formally rebuked him." Jules Witcover observed that Carter's problems began almost immediately; he was unfamiliar with Washington, "alien to the nation's capital." came across "as an uncertain and indecisive figure." and was out of step with his party. ${ }^{257}$ James Pfiffner said, "Carter"s decision to run for president as an outsider rather than a traditional party regular" and his "disdain for bargaining with Congress" made his presidency unnecessarily difficult. ${ }^{258}$ Psychologists Steven Rubenzer and Thomas Faschingbauer noted Carter's refusal "to manipulate people or stretch the truth as much as most presidents. ${ }^{.259}$ One international observer also said the same character traits that got Carter in trouble at home got him in trouble abroad: "Carter's naivete and inconsistency...ultimately cost America its claim to leadership in world affairs. ${ }^{.260}$

He was not a Neustadian president; he was not a lover of politics. In this regard. perhaps, Barber"s "active-negative" category might better describe Carter. Throughout his four years. Carter displayed little concern for the political interests of others and the ways of Washington, and had little interest in protecting his reputation with the constituencies he needed most. As Jack Germond and Jules Witcover explained. he paid "too little attention to his party" and disdained doing "the little favors that are the

\footnotetext{
257 Jules Witcover, Party of the People: A History of the Democrats (New York: Random House. 2003). p. 603.

258 James P. Pfiffner. The Modern Presidency (New York: St. Martin’s Press. 1994). p. 163.

259 Steven J. Rubenzer and Thomas R. Faschingbauer, Personality: Character, and Leadership in the White House: Psychologists Assess the Presidents (Washington. DC: Brassey.s lnc.. 2004). p. 231.

${ }^{260}$ Friedbert Pflüger, "Human Rights Unbound: Carter's Human Rights Policy Reassessed." Presidential Studies Quarterly 19, no. 4 (Fall 1989): 705.
} 
bricks and mortar in building a loyal political following" around an issue. ${ }^{261} \mathrm{He}$ believed members of Congress should be motivated more by being right than being reelected. ${ }^{262}$

According to a 1999-2000 C-SPAN survey of 58 presidential historians, (Table 4.1) Carter was ranked $33^{\text {rd }}$ among the 41 men who served as president in his relations with Congress. Though President Clinton was ranked lower $\left(36^{\text {th }}\right)$, he had a Republican congress for six of his eight years. Republican presidents who had Democratic congresses even fared better in their relations with Congress. President Ford, for instance, was ranked $12^{\text {th }}$ and George H.W. Bush was ranked $20^{\text {th }}$. President Reagan who had a divided congress (a Republican Senate and Democratic House) for six of his eight years had a ranking of $8^{\text {th }}$ place, and President Eisenhower who had a Democratic congress for most of his eight years was ranked $7^{\text {th }}$. Even President Nixon, with all his Watergate problems, the Vietnam War, and having a Democratic congress throughout his tenure, was given a higher mark than Carter. In fact, as Table 4.1 shows. nearly all modern presidents, regardless of party, were judged in this survey as having among the best all-time relations with the legislative branch. Put differently, though without scandals or a divisive war, Carter is the only modern president to have had abysmal relations in a time of unified party government.

261 Jack W. Germond and Jules Witcover, Blue Smoke and Mirrors: How Reagan Won and Why Carter Lost the Election of 1980 (New York: Viking Press, 1981), 27, 197.

${ }^{262}$ James P. Pfiffner, The Strategic Presidency: Hitting the Ground Running (Chicago, IL: Dorsey Press, 1988), pp. 150-151. 


\section{Table 4.1 1999-2000 C-SPAN Historian Assessments of Modern Presidential Relations with Congress}

$\underline{\text { President }}$

Lyndon Johnson (D)

Franklin Roosevelt (D)

Dwight Eisenhower (R)

Ronald Reagan (R)

Gerald Ford (R)

John Kennedy (D)

Harry Truman (D)

George H.W. Bush (R)

Richard Nixon (R)

Jimmy Carter (D)

Bill Clinton (D) $\underline{\text { Ranking }}$

1

2

7

8

12

13

15

20

30

33

36
Government

Unified Democratic Unified Democratic Mostly Divided Mostly Divided

Divided

Unified Democratic

Mostly Unified Democratic

Divided

Divided

Unified Democratic

Mostly Divided

Source: 1999-2000 C-SPAN Historian Survey of Presidential Leadership:

Relations with Congress, http:/ www.americanpresidents.org/survey historians congress.asp.

It is frequently noted that President Carter's poor relations with Congress stemmed from his atypical disdain for Congress and congressional politics. Explained Gaddis Smith, Carter did not just campaign against Washington, he "hated Washington." ${ }^{263}$ Robert Krueger, a former House Democrat from Texas (1975-1979). wrote that Carter, who had campaigned on being "cleaner, freer from taint and corruption, and a person of traditional, rural American values." was very "suspicious of Washington and its ways. ${ }^{26+}$ His suspicions of Congress continued into his postpresidency. In 1987, for example, enjoying the freedom of movement and contact as an ex-president. Carter wrote, "As a private citizen, I am no longer constrained by the

${ }^{263}$ Gaddis Smith, "Carter's Political Rhetoric," in The Carter Presidency: Fourteen Intimate Perspectives of Jimmy Carter, Portraits of American Presidents, Vol. VIII, edited by Kenneth W. Thompson (Lanham. MD: University Press of America, 1990), p. 207. 
limits I had as president."265 As late as the 2004 dedication ceremony of the Clinton Presidential Library, Carter quipped that what was nice about post-presidential life was "neither the media nor any member of the House or Senate can tell us how to do our job. $" 266$

Typically, Carter was unsympathetic to, if not contemptuous of, what David Mayhew called the electoral incentives of members of Congress, such as claiming personal credit, and the political practices of compromise, bargaining, logrolling, pork spending, and patronage. ${ }^{267}$ According to Mayhew, members of Congress want to be perceived as a "doers," suppliers of public goods and programs to the home constituency, and deliverers of "particularized benefits." Through such services, members of Congress enhance their reelection prospects. Carter, however, thought such practices made government wasteful, woefully inefficient and inert, inattentive to real problems, and obdurate to any reform. He characterized these practices as "insidious legal bribery." 268 Playing politics was "anathema" to him, and being party leader, and choosing ideological sides were obstacles to doing what is best for the American people. $^{269}$

\footnotetext{
${ }^{264}$ Robert Krueger, email correspondence with the author, October 2, 2006.

${ }^{265}$ Carter, "Middle East Peace: New Opportunities," Washington Quarterly, 10.3, June 1, 1987.

${ }^{266}$ Carter, "Remarks at the Clinton Presidential Center Dedication in Little Rock, Arkansas," November $18,2004$.

${ }^{267}$ David R. Mayhew, Congress: The Electoral Connection (New Haven, CT: Yale University Press, 1974), pp. 52-61.

${ }^{268}$ John A. FarrelI, Tip O'Neill and the Democratic Century (Boston, MA: Little, Brown and Company, $2001), 447$.

${ }^{269}$ Carter, "Interview with GQ Magazine," GQ Online, January 2006,

http://men.style.com/gq/features/archive/0601.
} 
Carter's attitude was essentially anti-party. ${ }^{270}$ As he explained in a 2003

interview, "I have always been a Democrat, and my choice is a natural one; I do not have any compunction about my choice, nor have I ever felt bound by it. ${ }^{271}$ When asked what his ideological perspective was, he quipped during the 1976 primary season. "I don't have to choose, so I won 't." 272 As president, he reminded Americans that he "ran for president as an outsider, as an independent person, a Democrat, but one who did not owe special interest groups anything."273 "I vote on each issue as it arises." not as a matter of ideology. ${ }^{274}$ It was not surprising then that Carter would be challenged in the 1980 primaries by Edward Kennedy, the voice of the party's liberal and northeastern wing, a consummate party insider, and a congressional powerhouse in a contest characterized as a fight for "the soul of the Democratic Party." 275

${ }^{270}$ Several Carter officials have also displayed this independence. For a time, Press Secretary Jody Powell worked for Independent presidential candidate Ross Perot in 1992. In 2006. Chief of Staff Hamilton Jordan and communications advisor Gerald Rafshoon explored the possibility of running a third-party ticket in 2008, a ticket that could include a Democrat and a Republican. The project was called Unity 2008.

${ }^{271}$ Carter, "Interview with Charles Trumbull," Encyclopedia Britannica, June 26, 2003. http: /www britannica.com.

272 Goldman and Clift, "Carter on the Rise," p. 24. As far as can be determined did not ever commit himself to being either a liberal or a conservative. See Carter. "Remarks and Question-and-Answer Session with Reporters," November 12, 1980, Public Papers of the Presidents, Book III, p. 2710.

${ }^{273}$ Carter, "Remarks and Question-and-Answer Session at a Town Meeting in Spokane, Washington," May 5, 1978, Public Papers of the Presidents, Book I, pp. 860.

${ }^{274}$ Carter, "Remarks at a Campaign Rally for Democratic Candidates in Norfolk, Virginia," September 24. 1977, in Public Papers of the Presidents, Book II, p. 1656.

275 Burns, "The Carter-Clinton Connection," chap. in Running Alone, p. 128. Among Democratic party activists, Carter's weakest support and Kennedy's strongest were those who described themselves as "very liberal," $60 \%$ favored Kennedy and $40 \%$ favored Carter. In contrast, among "moderate-toconservative" activists, Carter was favored over Kennedy 85\%-15\%. Walter J. Stone and Alan 1. Abramowitz, "Winning May Not Be Everything, But It's More Than We Thought: Presidential Party Activists in 1980," American Political Science Review 77.4 (December 1983): 948. Another study showed that Kennedy convention delegates were to the left of Carter delegates ideologically and on matters of defense, relations with Russia, and school busing. Richard Herrera, "The Crosswinds of 
Early in his term, Carter terminated nineteen water projects, including one in his home state of Georgia, without consulting fellow Democrats. ${ }^{276}$ From Carter’s perspective the elimination of the water projects was fiscally sound. The cuts for fiscal year 1978 would save the American taxpayer over $\$ 500$ million and $\$ 5$ billion over time. ${ }^{277}$ Several prominent Democrats were directly affected by the proposed cuts, like House Majority Leader Jim Wright, House Interior Committee chairman Morris Udall. Senate Armed Services Committee chairman John Stennis, and Senate Finance Committee chairman Russell Long. ${ }^{278}$ Unfortunately for Carter, "no interest of political significance in Washington," namely Congress and organized interests in the Democratic Party, "cared much for Carter's idea of changing the way government worked. ${ }^{279}$ It should be no surprise then that of all Democratic presidents since John Kennedy, Carter was the least popular Democratic president and the least effective with Democratic congresses. And this was true from the beginning of his presidency. ${ }^{280}$

Table 4.2 shows that, since Kennedy, Carter had the worst track record with congressional Democrats than any recent Democratic president. He had the lowest mean support (63\%) from House Democrats and the third lowest mean support (68\%) from Senate Democrats. It is true that Carter had slightly more support among Senate

Change: Sources of Change in the Democratic and Republican Parties," Political Research Quarterly 48.2 (June 1995): 304.

${ }^{276}$ Kernell, Going Public, p. 44.

${ }^{277}$ Shogan, Promises to Keep, pp. 2 I2-213.

${ }^{278}$ Ibid., p. 213.

${ }^{279}$ Stephen Skowronek, The Politics Presidents Make: Leadership from John Adams to Bill C'linton (Cambridge, MA: Harvard University Press, 1997), p. 385; Pfiffner, The Strategic Presidency, pp. 150. 
Democrats than President Johnson (68\% to 64\%), however. Carter was not trying to push through a comprehensive civil rights agenda as Johnson had.

\section{Table 4.2 Democratic Presidents and Democratic-controlled Congresses}

\author{
\% House Democrats Support \\ for Democratic President
}

$\begin{array}{ll}\text { Kennedy } & 78 \\ \text { Clinton } & 75 \\ \text { Johnson } & 74 \\ \text { Carter } & 63\end{array}$
$\%$ Senate Democrats Support

for Democratic President

$\begin{array}{ll}\text { Clinton } & 83 \\ \text { Kennedy } & 71 \\ \text { Carter } & 68 \\ \text { Johnson } & 64\end{array}$

Source: Richard Fleisher and Jon R. Bond, "Partisanship and the President's Quest for Votes on the Floor of Congress," in Polarized Politics: Congress and the President in a Partisan Era. ed. Jon R. Bond and Richard Fleisher (Washington, DC: Congressional Quarterly Inc.. 2000). pp. 169. 172.

Given Carter's difficulty working with Congress, it is perhaps not surprising that he was more likely to issue executive orders than other contemporary Democratic president (Figure 4.3). He issued more executive orders than any president during a full four-year term since Eisenhower. Furthermore, Carter issued more presidential retoes than any Democratic president who had a Democratic Congress. ${ }^{281}$ Together. contrary to the advice of Neustadt, this suggests that Carter was a president who preferred to operate by command, to exercise unilateral authority, and a president who possessed a negative attitude toward the legislative process-even if controlled by co-partisans. ${ }^{282}$

But how does one account for Carter`s difficult relationship with a Congress controlled by his own party or his frequent disdain for Congress and Beltway politics? Carter aide Hamilton Jordan once remarked that while the president respected the ways

\footnotetext{
${ }^{280}$ See Richard Fleisher and Jon R. Bond, "Assessing Presidential Support in the House: Lessons from Reagan and Carter." Joumal of Politics 45.3 (August 1983): 745-758.

${ }^{281}$ Lyn Ragsdale, Vital Statistics on the Presidency: II ashington to Clinton (Washington. DC: Congressional Quarterly, Inc.. 1998), pp. 402-405.
} 
of Congress, "the bottom line will be that the programs Jimmy will advocate will be programs supported by the American people." In fact, Jordan continued, this was the strategy Carter successfully employed in Georgia, and he confidently predicted that it would be successful in Washington. In other words, a recalcitrant legislature can be forced "into line" if popular pressure is applied. ${ }^{283}$

\section{Figure 4.3 U.S. Presidents and Executive Orders, 1953-2001}

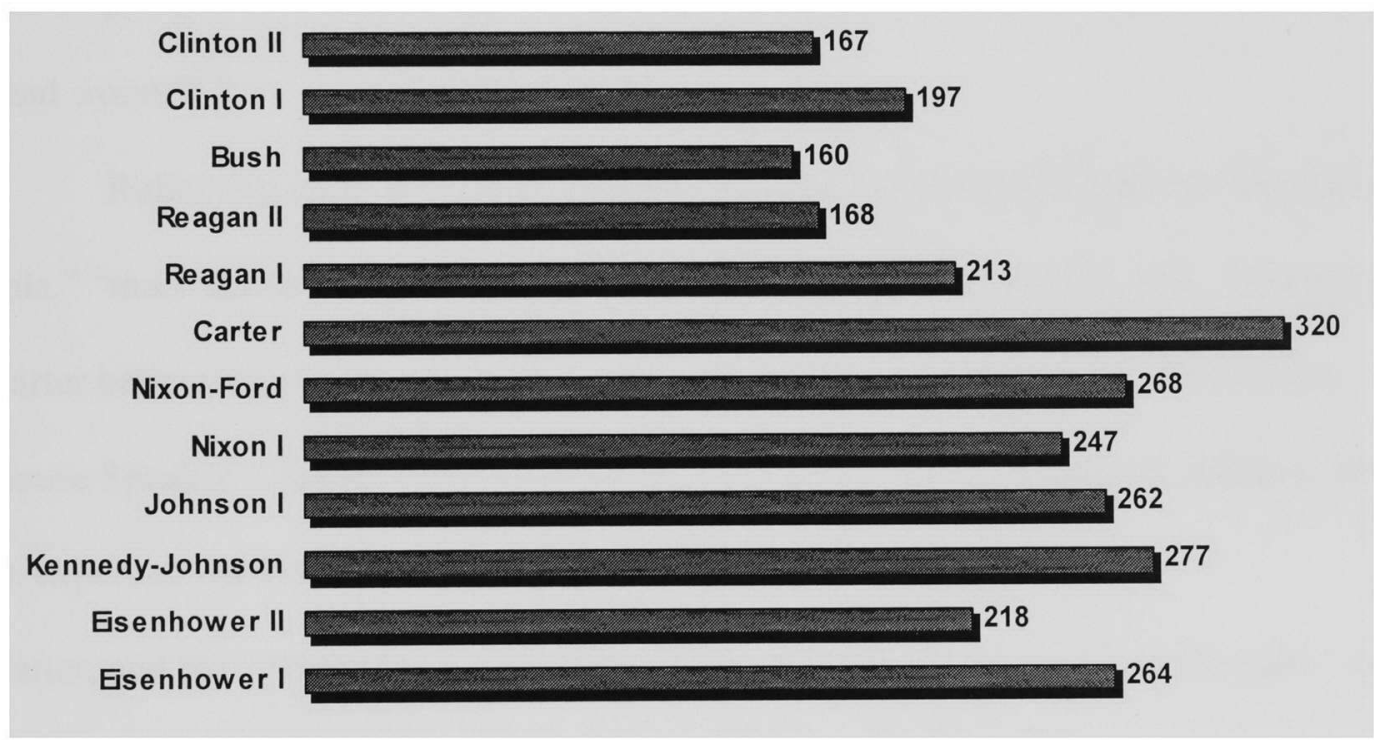

Source: Lyn Ragsdale, Vital Statistics on the Presidency: Washington to Clinton (Washington, DC: Congressional Quarterly, Inc., 1998), pp. 351-352; Joseph A. Pika, John Anthony Maltese, and Norman C. Thomas, The Politics of the Presidency $\left(5^{\text {th }}\right.$ ed; Washington, DC: Congressional Quarterly Press, 2002), p. 230.

House Speaker Tip O’Neill, believing that Carter did not understand how Washington worked, pleaded with him not to underestimate members of Congress. Carter's response, "I'll handle them just as I handled the Georgia legislature. Whenever

\footnotetext{
${ }^{282}$ See Kenneth R. Mayer and Kevin Price, "Unilateral Presidential Powers: Significant Executive Orders, 1949-1999," Presidential Studies Quarterly 32.2 (June 2002): 367-386.

${ }^{283}$ Shogan, Promises to Keep, p. 211.
} 
I had problems with the Georgia legislature I took the problems to the people of Georgia." 284 On election night 1980, when it was clear that a Reagan landslide was in the making, Carter conceded to Governor Reagan at 9pm. EST. The early concession infuriated Congressional Democrats, who feared the concession was premature and may hurt have other Democrats down-ticket. Angrily, Speaker O'Neill quipped to Carter`s congressional liaison Frank Moore, "You guys came in like a bunch of jerks. and I see you're going out the same way." $" 285$ Tom Foley agreed. "It was vintage Carter at its dead worst. $" 286$

Reflecting upon the Carter presidency, O'Neill described Carter as "the most able," "most talented," and most "brilliant" president he had worked with. However, Carter believed himself to be an "expert" on everything. explained the Democratic House Speaker. "Jimmy was an expert on finances, he was an expert on military. he was an expert on the NASA problems, he was an expert on energy." Plus,

Carter, and the "extremely parochial group" he brought with him "from Georgia." came to Washington "with a chip on their shoulder against the establishment." With the Congress, including Democrats, "it hurt him badly." ${ }^{287}$ He tried to do too much too quickly, not giving Congress sufficient time to deliberate. He did not. or could not. understand that things get done on Capitol Hill "all in due time."

\footnotetext{
${ }^{28+}$ Kernell, Going Public, p. 45.

${ }^{285}$ Brinkley, The Unfinished Presidency, pp. 1-2.

${ }^{286}$ Ibid., p. 2.

287 "O'Neill's Observations on Seven Presidents," New Y'ork Times. August 23, 1983.

${ }^{288}$ Tip O'Neill with Gary Hymel, All Politics is Local and Other Rules of the Game (Holbrook. MA: Bob Adams, Inc., 1994). p. 95.
} 
On several occasions after he left office, Carter mentioned that the biggest critics of his presidency were from within his own party, especially from liberal Democrats.

As president, generally I had a better relationship with the Republicans in Congress than with the Democrats... My main challenge when I was president was from the liberal wing of the Democratic Party. ${ }^{289}$

My main handicap for re-election came from the liberal wing of the Democratic party. ${ }^{290}$

In 2006, Carter that his "main problem was with the liberal Democrats," in particular they did not like his more conservative stance on defense and government spending. ${ }^{291}$ The following year, he told Frank Lockwood of the Arkansas Democrat-Gazette that. besides the hostages in Iran, his defeat was caused by the fact that "Ted Kennedy wanted to be president and the liberal wing of the Democratic Party, influenced by Ted Kennedy and his supporters, voted for the third-party candidate, John Anderson. So those were the two major factors. ${ }^{, 292}$

Various scholars have portrayed Carter as an amateur, a man elected at the wrong time, too ordinary, too inexperienced, and he was insufficiently partisan. Carter frequently admitted that when it came to knowing the ways of Washington politics he had "a lot to learn" and an "over-optimism about the speed with which Congress could

${ }^{289}$ Carter, "Interview with Charles Trumbull," Encyclopedia Britannica, June 26, 2003.

${ }^{290}$ Carter, "Interview with Charles O. Jones, H. Clifton McCleskey, Kenneth W. Thompson, James Sterling Young, Richard Neustadt, David B. Truman, Richard F. Fenno, Jr., and Edwin C. Hargrove," Carter Presidency Project, November 29, I982, Plains, Georgia.

${ }^{291}$ Carter, "Interview with GQ Magazine," GQ Online, January 2006.

${ }^{292}$ Carter, "Interview with Frank Lockwood, Arkansas Democrat-Gazette," May 19, 2007, Bible Belt Blogger, http://www.biblebeltblogger.com/biblebelt/2007/05/president carte.html. 
act. ${ }^{293}$ Be that as it may. Carter was not really an amateur. Amateurs are people who do not have enough knowledge or specialized skills. Carter was skillful. intelligent, and a fast learner. On most issues. Pfiffner wrote. "-President Carter had an in-depth understanding." and "he would often know more about an issue than those briefing him. .294

Carter. however, knew what it took to succeed politically. His problem was he simply was too uncomfortable playing politics and being a party leader. He "did not think in terms of appealing to the political incentives of other power holders. " such as Congressional Democrats or traditional Democratic constituencies. ${ }^{295}$ The First Lady. Vice President Mondale. White House staff, and members of Congress repeatedly informed him what it took to work with Congress or to improve his standing in the polls, but Carter often refused to do so. The First Lady remembered it this way:

When he was in Washington. I don t think he cared if the picture out there was that he wasn't doing what he ought to do. because he was confident that he was doing what was right and best... He thought he was doing the right thing and

\footnotetext{
293 Uncommon for presidents to so forthrightly and publicly acknowledge. Carter frequently said that he had "a lot to learn" about the ways of Washington and that he did not always have the answers to national problems. Carter. "Remarks and Question-and-Answer Session with Emplovees at the Department of State." February 24, 1977. Public Papers of the Presidents, Book I. p. 236: "Remarks and Question-andAnswer Session at Town Meeting in Clinton. Massachusetts." March 16, 1977. Public Pupers of the Presidents. Book I. p. 383: "Question-and-Answer Session with European Newspaper Journalists." April 25. 1977. Public Papers of the Presidents, Book 1.p. 776: "Question-and-Answer Session with European Broadcast Journalists." May 2, 1977. Public Papers of the Presidents, Book I, p. 770: "Remarks by Telephone to the United States Conference of Mayors." June 13. 1977. Public Papers of the Presidents. Book I.p. 1102: "Remarks to Participants in the National Rural Electric Cooperative Association Youth Tour." June 15. 1977. Public Papers of the Presidents, Book I. pp. 1120-1121: "President 's News Conference." July 28. 1977. Public Papers of the Presidents. Book I. pp. 1370-1371: "Remarks and Question-and-Answer Session with Editors and Broadcasters." May 13. 1980. Puhlic Pupers of the Presidents, Book I, p. 906: "Remarks and Question-and-Answer Session with Local Residents in Lansdowne. Pennsylvania." October 2. 1980. Public Papers of the Presidents. Book l. p. $20+2$.

${ }^{294}$ Pfiffner. The Strategic Presidency. p. 40.

${ }^{295}$ Hargrove and Nelson. Presidents. Politics, and Policy. p. 118.
} 
didn't worry about it. I worried about it. He didn't. I worried about it when we looked at the polls, but he never did. It didn't deter him. He didn't change his way of governing. ${ }^{296}$

Mrs. Carter added that if she ever said to him "Do this" in order to improve his political reputation, "he would never do it." He was perhaps naïve, but not an amateur. Carter was a president who did not care to learn or appreciate the Washington way.

As Erwin Hargrove and Michael Nelson put it, "It was not so much that Carter was politically naïve or inexperienced, but rather that he did not believe in developing [legislative] measures on the strengths of bargains."297 It just "was not Carter's nature" to do so. ${ }^{298}$ Carter, said Larry Berman, simply believed, or at least "projected the attitude of being morally superior to Congress."299 He believed "all this stuff" about doing good, and that his appointees and fellow Democrats would naturally follow his optimistic, idealistic lead. ${ }^{300}$ On the water projects, for example, James Pfiffner observed Carter's problem was "not a case of not being adequately warned against the congressional fallout." ${ }^{301}$ Speaker O’Neill confirmed Carter's negative attitude, too. Simply, he said, "Washington" to Carter and his entourage from Georgia "was evil." They were determined "to change everything." 302

\footnotetext{
${ }^{296}$ Rosalynn Carter, "The Perspective of the First Lady," in The Carter Presidency: Fourteen Intimate Perspectives of Jimmy Carter, pp. 230-231.

${ }^{297}$ Erwin C. Hargrove and Michael Nelson, Presidents, Politics, and Policy (New York: Alfred A. Knopf. 1984), p. 119.

${ }^{298}$ Ibid., p. 117.

${ }^{299}$ Larry Berman, "Presidents as Leaders: Carter and Reagan," chap. in The New American Presidency (Boston, MA: Little, Brown and Company, 1987), p. 316.

${ }^{300}$ Pfiffner, The Strategic Presidency, p. 56.

${ }^{301}$ Ibid., p. 147.
} 
Neustadt was right when he said that a president must love politics, and it is true Carter did not. ${ }^{303}$ He had an intense disdain for Congress, for career politicians, for pure partisans, for interest groups. He was not interested in nurturing the petty egos of key legislative members. He plainly explained to Speaker O'Neill, "I don't want to stroke you.",304 Similarly, Vice President Mondale said, "Carter was not a buddy... No backslapping, and he did not want to deal with the Congress from a bargaining-type psychology where they would give something and he'd give something, they'd get a deal and go out and get it done."305 Instead, Mondale continued, Carter's view of presidential-congressional relations was the president leads and Congress follows.

Carter "often projected," explained Larry Berman, "the attitude of being morally superior to Congress." 306 He came to be perceived as "a self-righteous preacher." 307 He made it seem "everything your doing is dirty," Texas Democrat Jim Wright remembered. 308 Dan Rostenkowski remarked, "Carter's attitude was members of the House and Senate are bad guys."309 "You have to understand," said one White House staffer, "that Carter simply did not like politicians." 310

\footnotetext{
${ }^{302}$ Farrell, Tip O'Neill and the Democratic Century, 446. to Reagan (New York: The Free Press, 1990), p. 152.

${ }^{304}$ Farrell, Tip O'Neill and the Democratic Century, 455. Thompson (Lanham, MD: University Press of America, 1990), pp. 240-241.

${ }^{306}$ Berman, "Presidents as Leaders: Carter and Reagan," p. 316.

${ }^{307}$ Pfiffner, The Strategic Presidency, p. 151.

${ }^{308}$ Farrell, Tip O'Neill and the Democratic Century, 445.
}

${ }^{303}$ Neustadt, Presidential Power and the Modern Presidents: The Politics of Leadership from Roosevelt

${ }^{305}$ Walter Mondale, "The Perspective of the Vice President," in The Carter Presidency: Fourteen Intimate Perspectives of Jimmy Carter, Portraits of American Presidents, Vol. VIII, edited by Kenneth W. 
Carter had, said National Security Council member William Quandt. "a moral streak, and some would say moralistic streak—where if he thinks he's doing the right thing, he's just going to do it no matter what." 311 Reflecting on his troubled time in the Carter Administration and his "cultural" differences with the President, Carter"s Secretary of Health, Education, and Welfare (1977-1979), Joseph Califano said.

For all my Washington experience, I was not prepared for the cultural chasm between me and President Carter... Jimmy Carter saw me as a Washington insider and was proud of himself as an outsider. He felt isolated in the capital. and his experience in the White House sharpened his sense that cynical, gotcha obsession motivated the press and that selfish political ambition and need for campaign money drove members of Congress. He saw the capital city as corrupted and one of his missions as cleaning it up; and failing that, he seemed determined not to get any Washington political dirt under his fingernails. ${ }^{312}$

The evidence presented here shows that the Carter presidency, in many respects, did not have to be, as described by Stephen Skowronek, an era of "disjunction"- - "an impossible leadership situation" where the president leads a party whose ideological views are in serious decline. ${ }^{313}$ In such circumstances, Skowronek explained, the president lacks the "authority to repudiate" the past and lacks the "power to recreate" the political order. ${ }^{314}$ As such, Carter, like other disjunctive presidents, was caught between the push of an emerging conservative political era and the pull of his party's more liberal policy commitments.

\footnotetext{
${ }^{309}$ Rostenkowski, Transcript, American Experience: Jimmy Carter.

${ }^{310}$ Quote found in Berman, The New American Presidency, p. 316.

311 Quoted in "Jimmy Carter's Book Stirs Criticism, Complaint," National Public Radio, December 11. 2006, http://www.npr.org.

${ }^{312}$ Califano, Inside: A Public and Private Life (New York: Public Affairs, 2004), pp. 333, 369-370.

${ }^{313}$ Skowronek, The Politics Presidents Make, pp. 39-41.

${ }^{314}$ Ibid., p. 27.
} 
Rather than attributing his difficulties to his place in political time. Fred Greenstein rightly observed that "the Carter presidency provides a catalogue of avoidable errors," particularly "failing to build bridges to key Washington policymakers. ${ }^{.315}$ Carter could have bargained with Congress, a Democratic-controlled Congress. He simply chose not to on many occasions and he often expressed his frustrations with the dilatory legislative process. He purposely alienated members of Congress, the electoral base of his party, and the interests loyal to his party. Biographer Kenneth Morris argued that the situation for Carter was not necessarily ungovernable. ${ }^{316}$ "It is conceivable" at least. he said, that had Carter been "a doctrinaire liberal" or pragmatically moved leftward. his party in Congress might have "coalesced around him and persuaded the people to follow." But since he did not, or would not. "we will never know what might have happened."

But this was not going to happen. Carter's attitude was. "I have never depended on powerful political figures to put me in office" whether in the Georgia state senate. the governor's mansion, or the White House. 317 "Most of the time they" re against me. because I don't yield to them and I don't trade with them. ${ }^{.318}$

When asked whether the President understood the negative ramifications of unilaterally eliminating nineteen water projects a month into his presidency. Hamilton

\footnotetext{
315 Fred I. Greenstein. "George W. Bush and the Ghosts of Presidents Past," PS: Political Science and Politics 34.1 (March 2001): p. 78.

${ }^{316}$ Morris. Jimm. Carter: American Moralist. p. 246.

317 Shogan. Promises to Keep, p. 40.

$\$ 18$ Ibid.
} 
Jordan quipped, "Oh hell, yes."319 For Carter, the elimination of what he perceived to be wasteful spending was the moral equivalent to human rights in Russia, they were non-negotiable. "Just like the dams are not negotiable domestically," Jordan said. "human rights [in the Soviet Union] are not negotiable either." 320 In fact, when Democratic members of Congress objected to his heavy-handedness in eliminating the projects, at one point, he raised the number of projects to be eliminated to thirty. As Bert Lance explained, Carter was not political enough to do what he had to do to work with Congress. "The quid-pro-quo was not in him. If you came to him and said, 'Look. we can get so-and-so to vote for us,' he would turn a deaf ear." ${ }^{, 321} \mathrm{He}$ "disdained political calculations for major decisions," Carter staffer Anne Wexler explained. "I would say, on several occasions, that there were political consequences to be faced by making a decision, and he would say he didn't want to hear about that. He wanted to do what was right., 322

The analyses offered by Neustadt, Skowronek, and others are valid, reasonable. and plausible explanations for what went wrong with the Carter presidency and why he failed to work with Congress. But I would like to offer yet another possibilityCarter's faith. It is from this largely unappreciated source that motivated Carter into politics to do good. It is also from this same very source that many of his oft-cited negative traits come.

\footnotetext{
${ }^{319}$ Ibid., p. 215.

${ }^{320}$ Ibid.

${ }^{32 !}$ Lance, Transcript, American Experience: Jimmy Carter.

${ }^{322}$ Farrell, Tip O'Neill and the Democratic Century, p. 447.
} 
In Living Faith, Carter explained why he tends to distrust established secular authority, such as Congress, and politics as usual. "Jesus went to his death and Paul spent his final years in prison rather than conform to religious and secular laws they could not accept... We [as Christians] are not required to submit to the domination of authority without assessing whether it was contrary to our faith or beliefs. ${ }^{323}$

Continuing, he said, "even in a democracy like ours, each of us must confront and examine our national policies. When I was in the White House, I disagreed with some of the laws I was sworn to enforce. such as those concerning energy, the environment. and abortion, and I attempted in every legitimate way to change or minimize what I considered to be their adverse effect. ${ }^{.324}$

If government fails in its basic obligations to the people. Carter said. it is the "duty for citizens informed by religious faith and a sense of morality to challenge the powerful and demand change." ${ }^{325}$ Quoting Protestant theologian Reinhold Niebuhr. he asserted that "the sad duty of politics is to establish justice in a sinful world. ${ }^{-326}$ Also citing the Prophet Amos. President Carter said the responsibility of politicians "is older than our Constitution, older than the Bill of Rights, older even than the tradition of the common law." "It comes from the roots of our Western heritage." he explained. "with

"3arter, Living Faith. p. 117; see also "Interview with World Religious New's," 1976, in Gaver, The Faith of Jimmy Carter. pp. 17-18.

\$2t Carter. Living Faith. pp. 117-118; "Interview with World Religious New's." 1976, in Gaver. The Fuith of Jimm! Carter. p. 18.

325 Carter, Living Faith, p. 118.

326 Shogan, Promises to Keep, p. 41; Carter, "Interview with Jim Newton, editor of the Horld Mission Journal," 1976. in Gaver, The Faith of Jimmy. Carter, p. 24; "Remarks at the $100^{\text {th }}$ Anniversary Luncheon of the Los Angeles Bar Association," May 4, 1978, Public Papers of the Presidents, Book I. p. 835. 
the prophet Amos, who said, 'Let justice roll down like waters, and righteousness like an ever-flowing stream.",327

Evangelist Dwight Moody said, "God has given me a lifeboat" in a fallen. sinking world, and he "said to me, 'Moody, save all you can." ${ }^{328}$ Similarly, for Carter, it might be said that God gave him a political office in America at a time of military defeat and scandal, and he "said to me, "Carter, do as much good as you can."

Candidate Carter promised to shake up Washington. In a Jesus-like manner, Carter promised not to bring peace to Washington, but a sword. In his view, reporter Wesley Pippert explained, "Carter classifies himself with Isaiah and Jeremiah in the Old Testament, "who pronounced God's judgment in the very center of political power."' And following the Apostle Paul, Pippert submitted, Carter sees that "God's will can be carried out in government; that God's will, indeed, should 'shape government.",329 In his campaign autobiography Why Not the Best?, Carter explained why he was not going to Washington to get along or bargain. He said, "The Bible says: 'If the trumpet give an uncertain sound, who shall prepare himself to the battle?"330

Carter aimed to be an iconoclast who sought to throw the "moneychangers" out of the people's temple. He wanted to bring "integrity and competence" back to Washington, reaffirm and strengthen "our ethical and spiritual and political beliefs"; he

${ }^{327}$ Carter, "Remarks at the $100^{\text {th }}$ Anniversary Luncheon of the Los Angeles Bar Association," May 4 , 1978, Public Papers of the Presidents, Book I, p. 841.

${ }^{328}$ Quoted in George M. Marsden, Fundamentalism and American Culture: The Shaping of TwentiethCentury Evangelicalism: 1870-1925 (New York: Oxford University Press, 1980), p. 38.

${ }^{329}$ Pippert, The Spiritual Journey of Jimmy Carter, p. 23.

${ }^{330}$ Carter, Why Not the Best?, p. 173. 
quit serving hard liquor in the people`s house, and. to Speaker O`Neill's initial

displeasure, begin having congressional leaders say grace when eating with him. ${ }^{331}$

Carter "had a kind of negative moralistic attitude toward patronage appointments" and other customary congressional activities, explained Democratic Majority Leader Jim Wright. He "saw something tawdry in the process." ${ }^{.332}$

To do politics as usual was ungodly. To focus on improving his image in the press was unthinkable; to delay agenda items that might be more suited in a second term was unconscionable. ${ }^{33}$ Carter freely admitted that he has never been "*a good compromiser," especially "if I think I'm right." 334

I can't be a quiescent or a timid leader. I wasn't when I was Governor. I wasn't when I was a candidate. 1 don't intend to be when I am President. 335

Before he took office. Time magazine quoted him as saying. " I am pretty rigid.

It's been difficult for me to compromise when I believe in something deeply. I generally prefer to take it to the public. to fight it out to the last vote. and if I go down. I

\footnotetext{
$\therefore$ Ibid.. pp. 178-179: Brinkley. The Lnfinished Presidenc1. 6: Farrell. Tip O Teill and the Democratic Centur7. 450: Jim Wright, Balance of Power: Presidents and Congress from the Era of Mc Carthy to the Age of Gingrich (Atlanta. GA: Turner Publishing. 1996). p. 271. Short after taking office. Carter told employees at the Department of Housing and Urban Development. "Those of you who are living in sin. I hope you get married. I think it's very important that we have stable family lives. I am serious about that." Pippert. The Spiritual Journey" of Jimm! Carter. p. 18: Carter and Leighton. Cousin Beedie and Cousin Hot. p. 266.

332 Wright. Balance of Power, pp. 278-279.
}

333 See Mark J. Rozell. "President Carter and the Press: Perspectives from White House Communications Advisers." Political Science Quarterly 105.3 (Autumn 1990): 419-43t.

${ }^{3 i 4}$ Norton and Slosser. The Miracle of Jimm! Carter. p. 94: Carter. "Remarks and Interview' with the Board of Directors of the Radio-Television New's Directors Association." April 29. 1977. Public Papers of the Presidents, Book I, p. 750.

335 Carter. "Remarks and Interview with the Board of Directors of the Radio-Television News Directors Association." April 29. 1977. Public Papers of the Presidents, Book I. p. 750. 
go down in flames." 336 Towards the end of his term, he believed that he kept his

promise to tackle the tough issues, to address what had heretofore been avoided by his

predecessors, and to not worry about the political repercussions.

We've never flinched in any way from addressing an issue that I consider to be important to our Nation domestically or in foreign matters because of adverse political consequences. I can well understand now why some of my

predecessors did not bring these issues up...[S]ome the things we've done have been very difficult, they've not been political winners. ${ }^{337}$

Vice President Mondale once explained that Carter would not play politics, would not do what was customarily expected of politicians. Instead, he said, "Carter thought politics was sinful." 338 "Many times the one argument that I would find ruin a person's case," Mondale said on another occasion, "is when he'd say, 'This is good for you politically.' He didn't want to hear that. He didn't want to think that way and he didn't want his staff to think that way. He wanted to know what's right." ${ }^{339}$ On another occasion, Mondale explained, Carter had "kind of Baptist antagonism as to the real world would respond to his concept of what his faith indicated should be done." Such a view, he added, made Carter "strangely antipolitical." 340 Particularly, said Mondale. "Carter often thought lobbying groups distorted and twisted the public interest and he

336 "I'm Jimmy Carter, and..." Time: Man of the Year issue, January 3, 1977.

${ }^{337}$ Carter, "Remarks and Question-and-Answer Session with Editors and Broadcasters from Minnesota," October 26, 1979, Public Papers of the Presidents, Book II, pp. 2053-2054; see also "The President's News Conference Held in Chicago, Illinois," May 25, 1978, Public Papers of the Presidents, Book I, p. 979.

${ }^{338}$ Lewis L. Gould, The Modern American Presidency (Lawrence, KS: University Press of Kansas, 2003), p. 182.

${ }^{339}$ Mondale, Transcript, American Experience: Jimmy Carter.

${ }^{340}$ Mondale, "The Perspective of the Vice President," p. 243. 
resisted them. ${ }^{-3+1}$ According to one unidentified Carter aide the differences between Carter and his vice president's views of politics was all too evident. "Carter thought Fritz may have been a little too political and Fritz thought Carter may have been too apolitical." Additionally: when making foreign policy decisions. Carter did not think "in terms of domestic politics" or how various domestic constituencies would react.

Mondale. in contrast. could not think "otherwise. ${ }^{* 342}$ To the frustration of his communications staff. he refused to curry the favor of newspaper columnists and editorials boards to artificially create favorable press coverage. Said Carter advisor James Fallows. "That's not the way his mind works. ${ }^{.3+3}$ The media just was not his audience; he had contempt for "establishment media" types.

So when it came to the business of politics. Carter constantly believed he had to resist the temptation to sin. While he may not have been always successful in this. he believed that those entrusted with political power must not accept the false and "fatal provisos" of Satan: "an abandonment of God" and "an acknowledgement of earthly things as dominant. ${ }^{.34 t}$ Carter had little or no interest in being a Neustadt president. He made it perfectly clear even before he took the oath of office that he would prefer to "go down in flames" than compromise his deeply held beliefs. To do otherwise would be a

\footnotetext{
${ }^{3+1}$ Mondale. email correspondence with the author. November 2. 2006.

342 Bernard Weinraub, "Mondale's Tightrope Act on the Carter Problem." Vew York Times. October 24. 1983.

it: Rozell, "President Carter and the Press." p. 422.

${ }^{344}$ Carter. Living Faith. p. 229.
} 
service to the devil and not God. "Anyone who accepts kingship based on serving the devil rather than God will end up a tyrant, not a benevolent leader."345

"Perhaps as proof of his moral purity," wrote Kati Marton, "Carter seemed almost deliberately to embrace [enjoy?] unpopular decisions."346 Similarly, Mark Rozell explained, "his tendency" in speeches "was to identify bad news without offering any immediate cure" or noting good news. ${ }^{347}$ He tended to choose issues he thought important, regardless if they were "political losers," issues that lacked a constituency, lacked Democratic party support, or were "too ambitious" to be realistically accomplished. ${ }^{348}$ In Michael Meagher's view, Carter appeared to have a "fascination with negativity." "349 In contrast to Reagan's happy, uplifting God, his sunny, Emersonian, positive-thinking gospel, “conservatism without anxieties," Carter's rhetoric was filled with sermon-like admonitions on original sin, the iniquities of pride and greed, the recognition of human limits, expectation of suffering, and the virtue of sacrifice. $^{350}$

Carter warned persons in power, whether in politics, business, or the media, that, "Jesus said that it's easier for a camel to go through the eye of a needle than for a rich

${ }^{345}$ Ibid.

${ }^{346}$ Marton, "Rosalynn and Jimmy Carter: Virtue Unrewarded," Hidden Power, p. 232.

${ }^{347}$ Rozell, "President Carter and the Press," p. 426.

${ }^{348}$ Ibid, 426-427.

${ }^{349}$ Michael Meagher, "Fear and Malaise: The Impact of Words in Presidential Leadership," White House Studies (Winter 2006).

${ }^{350}$ Gary Scott Smith, "Ronald Reagan: Making America God's Shining City on a Hill," chapter in Faith and the Presidency, p. 36I; George F. Will, "The Limits of Sunniness," Washington Post, February 11. 2007. 
man to get into Heaven." 351 Those who pursue power or money "to the exclusion of other goals in life has likely forgone the possibility of acceptance in God's kingdom." For many Americans, Carter's views may have breached the separation of church and state. Carter would disagree. While he affirmed the separation of church and state as president—-that is, institutional separation— he said that "he came to realize while holding public office how ambiguous is the line between the secular and the sacred." ${ }^{352}$ Citing the civil rights movement of the 1950s and 1960s and the work of Mahatma Gandhi, he said religion and politics can be successfully mixed and religion can be a force for good, reform, and national renewal. ${ }^{353}$ In the Preface to Father Robert F. Drinan's book, God and Caesar on the Potomac, Carter praised the former Massachusetts congressman and Jesuit priest for applying "the broad ethical precepts of his Jesuit upbringing," "his religious views of human dignity," "the full thrust of his religious heritage," to the political world. Drinan's service, Carter added, highlighted "the constructive role which religious principles can play in world politics" and the "blending [of] time-honored principles with modern realities." 354

Besides, Carter argued, the principal tenets of Christianity, as he understood them, are remarkably compatible with American freedom, democracy, and the pursuit of justice. ${ }^{355}$ "The fact is that the basic political principles of America are compatible

\footnotetext{
${ }^{351}$ Carter, "Interview with Leaders Magazine," April 1985, in Conversations with Carter, p. 269.

${ }^{352}$ Carter, Living Faith, p. 127.

${ }^{353}$ Ibid., p. 118.

${ }^{354}$ Carter, "Preface" to Robert F. Drinan, God and Caesar on the Potomac: A Pilgrimage of C'onscience (Wilmington, DE: Michael Glazier, 1985), ix-x.

${ }^{355}$ Carter, Living Faith, p. 125.
} 
with our deepest religious beliefs." 356 Therefore, we citizens can address our flag and pledge allegiance without qualms to "one nation under God." ${ }^{357}$ And if for some reason, says Carter, the principles of government no longer reflect religious principles. Therefore, the duty of American citizens is "to try to shape the government so that it does exemplify the teachings of God. ${ }^{\text {358 }}$ The United States is not a perfect country. and never will be. Nonetheless, he believed, following the thinking of theologian Paul Tillich, there must be a "constant searching to be better as a nation, as a human being. as a political leader." 359 "We can’t be perfect," Carter argued, "but we ought to strive for perfection."

\footnotetext{
${ }^{356}$ Ibid., p. 132.

357 Ibid.

${ }^{358}$ Robert W. Turner, "I'll Never Lie to You": Jimmy Carter in His Own Words (New York: Ballantine Books, 1976), p. 82.

${ }^{359}$ Carter, "Interview with World Religious News," 1976, in Gaver, The Faith of Jimmy Carter, p. 20.
} 


\section{The "Real" Carter Doctrine:}

\section{Foreign Policy Guidelines from the Sermon on the Mount}

"Our [foreign] policy...must always reflect our moral values."

"I want to see our country set a standard of morality."

"If we insist that the golden rule be applied in all public matters, then potential inequities can be prevented, and wrongs can be righted... To establish and maintain such a government is the proper purpose of public service."

Jimmy Carter was frequently criticized for lacking a compelling political vision. $^{+}$It is said Carter took on too many issues; lacked focus, lacked priorities. While such assessments may be truer on the domestic front, Carter did have a foreign policy vision. He had a vision for the country's role in the world, a doctrine, an understanding of the use of force, and a passion to promote human rights and find peace in the Middle East. ${ }^{5}$ As Erwin Hargrove explained, Carter "brought a coherent world view about

\footnotetext{
'Jimmy Carter. "Report to the American People," February 2, 1977. Public Papers of the Presidents. Jimmy. Carter, 1977, Book I (Washington. DC: United States Government Printing Office. 1978). p. 75 : "Remarks at Graduation Commencement at the University of Notre Dame." May 22. 1977. Public Papers of the Presidents, Book I, p. 961.

2 Carter, "Remarks and Question-and-Answer Session at Town Meeting in Clinton, Massachusetts." March 16, 1977, Public Papers of the Presidents, Book I, p. 385.

${ }^{3}$ Carter, Why Not the Best? (New York: Bantam Books, 1976), p. 157.

+ This point was among the earliest offered about the meaning and legacy of the Carter presidency. Steven V. Roberts, "Analysts Give Carter Higher Marks in Foreign Affairs Than in Domestic Policy." New York Times, January 19, 1981.

5 During his first visit to Europe, Carter noted that the issues of peace and human rights were his foreign policy specialties. Carter, "Remarks During Exchange with Reporters Following a Dinner Hosted by. British Prime Minister James Callaghan." May 6. 1977. Public Papers of the Presidents. Book 1. p. 814
} 
foreign policy into the presidency." ${ }^{\prime 6}$ Carter had a vision, a vision he shared with his

"Christian brother" Pope John Paul II: "We do share a common desire for peace, for the broadening of the beneficial effects of religion throughout the world" and the advancement of human rights. ${ }^{7}$ After meeting with Carter, the Pope told Brzezinski, "You know, after a couple of hours with President Carter, I had the feeling that two religious leaders were conversing." ${ }^{8}$ Carter also recognized that many of his positions would make him unpopular with certain elements in Washington, with Republicans and his fellow Democrats, but, as in the past, "difficult decisions" are often "based on principles of religion."

Formally, the Carter Doctrine was a 1979 policy announcement, issued after the Soviet invasion of Afghanistan, that the United States would use military force if the Soviet Union expanded further into the Middle East or if it interfered with Western access to the oil resources in the Persian Gulf region. ${ }^{10}$ But the real "Carter Doctrine" was rooted in his religion. ${ }^{11}$ Specifically, Carter aimed to align U.S. foreign policy

\footnotetext{
${ }^{6}$ Erwin C. Hargrove, Jimmy Carter as President: Leadership and the Politics of the Public Good (Baton Rouge, LA: Louisiana State University Press, 1988), p. 111.

${ }^{7}$ Carter, "Remarks and a Question-and-Answer Session with Editors and News Directors," July 27, 1979, Public Papers of the Presidents, Book II, p. 1322; Moni Basu, "Exhibit on Carter, Pope Opens Feb. 2," Atlanta Journal-Constitution, January 25, 2007.

${ }^{8}$ Zbigniew Brzezinski, Power and Principle: Memoirs of the National Security Adviser, 1977-1981 (New York: Farrar, Straus, and Giroux, 1983), p. 27.

${ }^{9}$ Carter, "Remarks and a Question-and-Answer Session at a Town Meeting with New Hampshire High School Students," February 18, 1978, Public Papers of the Presidents, Book I, pp. 364-383.

${ }^{10}$ Burton I. Kaufman, The Presidency of James Earl Carter, Jr. (Lawrence, KS: University Press of Kansas, 1993), p. 164; Stephen E. Ambrose and Douglas G. Brinkley, Rise to Globalism: American Foreign Policy Since 1938 (New York: Penguin Books, I997), pp. 305-306.

"Yael S. Aronoff, "In Like a Lamb, Out Like a Lion: The Political Conversion of Jimmy Carter," Political Science Quarterly 121.3 (Fall 2006): 433-435.
} 
more consistently with the New Testament teachings of Jesus, specifically teachings

from the "Sermon on the Mount." Fundamentally, President Carter believed that U.S.

policy should follow the Golden Rule of Jesus: "do unto others as you would have them

do unto you." ${ }^{\prime 2}$ If the United States wants peace, promote it. If the United States wants fair play, be fair. If the United States wants others to admit wrongs, repent also.

Much of Jimmy Carter's public career was preoccupied with and defined by foreign policy issues. The Camp David Accords and the Panama Canal treaties, for instance, are counted among the more notable achievements of the Carter presidency. The Iranian hostage crisis, the failed hostage rescue mission, the Soviet invasion of Afghanistan, and the highly publicized and controversial boycott of the 1980 Moscow Olympics were among the events that made the Carter presidency appear weak and unprepared. After leaving office, from monitoring elections in emerging democracies to mediating crises in Haiti and North Korea, Carter continued to be involved in and outspoken on international issues. Such efforts, though he does not care for the label. earned him the reputation of being the best ex-president the United States ever had. His earning of the 2002 Nobel Peace Prize was a testament to the respect and reputation he earned over the years for his involvement in foreign affairs, his efforts to reduce international conflict, and his forthrightness on issues of war and peace. ${ }^{13}$ Much of his

\footnotetext{
12 Carter, "Interview with John Hart of NBC News," March 28, 1976, in Pippert. The Spiritual Journey of Jimmy Carter: In His Own Words (New York: Macmillan Publishing Company, 1978), p. 101.

13 Evidence exists that part of the reason Carter won the award in 2002 was because some members of the Nobel Prize Committee wanted highlight the former president's public opposition to the looming lraq War and embarrass the Bush Administration. About Carter's selection, Nobel Committee Chair Gunnar Berge said, "It should be interpreted as a criticism of the line that the [Bush] administration has taken. See "Carter's award a swipe at Bush," CNN.com, October 11, 2002; "Former President Carter Wins 2002 Nobel Peace Prize," PBS New'shour. October 11, 2002. http. www pbs.org'newshour updates carter 1011-02.html. Despite Berge's desire to take a shot at President George W. Bush on this occasion and the
} 
post-presidential work was merely a continuation of what likely would have ensued in a second term. These activities were all evidentiary markers of what Douglas Brinkley called "the unfinished presidency."14

The purpose of this chapter is to briefly provide an overview of Carter's foreign policy vision. It looks at his views of what makes a superpower and the principles he claimed guided his foreign policy. David Skidmore characterized Carter's foreign policy vision as "liberal internationalism" and he claimed that scholars "err in viewing Carter's foreign policies as uniquely a product of the president's own admittedly moralistic personality." internationalism. While Skidmore is correct that Carter shared "ideas widely advocated among liberal foreign policy specialists," his vision was not a secular vision devoid of theological content. What Carter offered was more than mere "adjusting U.S. foreign policy to account for declining American power." "16 Rather, as Paul Charles Merkley explained, Carter provided an "ideological alternative," which was particularly evident in the case of the Arab-Israeli conflict. ${ }^{17}$ However, this alternative was not only

assertion of conservative critics that this was proof that Carter was unworthy of the recognition. Berge did note in his remarks that "Jimmy Carter should of course have been awarded the Peace Prize a long time ago...the by-passing of Carter had been one of the real sins of omission in Peace Prize history." Gunnar Berge, "2002 Nobel Peace Prize Presentation Speech in Oslo, Norway," December 10, 2002 , http://nobelprize.org/peace/laureates/2002/presentation-speech.html.

${ }^{14}$ Douglas Brinkley, The Unfinished Presidency: Jimmy Carter's Journey to the Nobel Peace Prize (New York: Penquin Books, 1999).

${ }^{15}$ David Skidmore, "Carter and the Failure of Foreign Policy Reform," Political Science Quarterly 108.4 (Winter 1993-1994): 699-729.

${ }^{16}$ Ibid., pp. $702-703$.

${ }^{17}$ Paul Charles Merkley, American Presidents, Religion, and Israel: The Heirs of Cyrus (Westport, CT: Praeger Publishers, 2004), p. 233. 
presented in regard to this conflict area. Motivated by faith, Carter promoted a moral understanding of superpower status and responsibility. He offered a program that included several key principles rooted in the Sermon on the Mount given by Jesus. Among the principles Carter advanced were the application of the Golden Rule, its prohibitive corollary of not judging others, and the necessity of peacemaking. Even when he made adjustments in foreign policy later in his administration from a more liberal to conservative direction, one cannot escape his frequent and consistent use of moral and religious language and his deep reluctance to use force as a means of solving international problems. In fact, Yael Aronoff claimed that this change could be attributed to Carter's religious faith. ${ }^{18}$ Carter was no Walter Mondale, Edward Kennedy, George McGovern, Henry Jackson, or Hubert Humphrey, and they were not Jimmy Carters. In these, Carter stands apart from his immediate presidential predecessors and successors. Within his party, the liberal wing of the Democratic Party had difficulty embracing him and he them.

\section{The Foreign Policy Vision of an Evangelical President}

"The real meaning of America is not encompassed in the material wealth and the military power of our country, for we know that wealth and power can be a potential for evil as well as for good."19

In chapter 3 , it was noted that one of the defining features of evangelicalism is a sense of religious mission and it was identified as a feature of the evangelical style of

\footnotetext{
${ }^{18}$ See Aronoff, "In Like a Lamb, Out Like a Lion: The Political Conversion of Jimmy Carter," Political Science Quarterly 121.3 (Fall 2006): 425-449.

${ }^{19}$ Carter, "Remarks at Emory University in Atlanta, Georgia," August 30, 1979, in Public Papers of the Presidents of the United States, Book II, p. 1563.
} 
governing. In the case of foreign policy, it may be said that evangelical presidents are more idealists than realists. That is, they tend to see the world more in terms of possibility than reality. Following Fred Greenstein, evangelical presidents have "political vision." Like the evangelist who may carry his message around the world, the evangelical president similarly aims to bring his message to those abroad.

If evangelical presidents have a vision of the world and America's role in the world, using James David Barber's terms, evangelical presidents are likely to be "active" foreign-policy presidents. However, unlike other "active" or politically visionary presidents, evangelical presidents have an ostensible religious and moral dimension to their foreign-policy program. They seek to be consequential presidents and tend to prefer bold, comprehensive, faith-based solutions to international problems. Observers may be tempted to describe them as "Wilsonian."

\section{Carter in Charge}

In the conduct of foreign policy, presidential involvement, direction, and interest varies. Some presidents are more aloof and allow a greater role for subordinates to shape the contours and focus of foreign policy. Some presidents may exercise what Fred Greenstein called the "hidden hand" approach. That is, the president may appear to have a relaxed, laissez-affaire approach, but from behind the scenes they are quite involved. And yet others, there is no doubt- they are the president, they are in charge, and people know it. The latter was Jimmy Carter.

According to historian Burton Kaufman, from the very beginning, Carter, though short on foreign policy background training, was long on interest and 
involvement. ${ }^{20}$ Carter. he wrote. "devoted considerable attention to matters of foreign policy:" Like his handling of domestic affairs. Carter was hands-on: he was "determined to play a dominant role. proposed a number of bold new measures." Critics did not charge Carter for being too distant or too cautious in the conduct of foreign policy: They criticized him for trying "to do too much too quickly."

Carter vowed that career bureaucrats at the State Department, the National Security Council. or the Secretary of State would not drive his foreign policy. The foreign policy of the Carter Administration would be Carter`s and his alone. President Carter. said Kaufman. "alone would establish priorities. set direction. and make the final decisions." "Foreign policy would originate in the Oval Office. not the Department of State." Quoting Hamilton Jordan. Carter`s Chief of Staff. Carter believed officials at the State Department were too elistist and arrogant for his taste.

Given this. what follows in the pages here, as I see and interpret it. can be trusted as the underlying premises of Carter`s foreign policy. One can argue with the author"s interpretations and conclusions. and for that 1 am responsible. But. given the heary use of Carter's own speeches. interviews, and other writings, it is harder to argue with a president who was in charge. who made the decisions, and who repeatedly through the vears tells us what he did and over and over why he did it. When one reads Carter's works. we know it is his words. and not the work of ghostwriters.

\footnotetext{
"Kaufman. The Presidency of James Earl Carter. Jr. p. 37.
} 


\section{What Some International Leaders Said}

Though some severely criticized his foreign policy and foreign-policy style at home and abroad, several international leaders, particularly from the Arab and Muslim world, not only recognized and acknowledged the moral leadership Carter sought to offer, but their comments seem to suggest that they viewed his policy objectives and leadership style in essentially moral terms. Or, they at least tried to curry his favor by appealing to what they perceived as his principal motivation. The Arab-Muslim leaders thanked Carter for his idealism, his reintroduction of morality into international relations, his advocacy of human rights, his faith in peace, his moral example, and his personal moral character.

Pakistani President Mohammed Zia said Carter was "a man of deep understanding, a humane personality, and who has at the bottom of his heart love of humanity."21 The President of Bangladesh, Ziaur Rahman, thanked Carter for the value he attached "to the question of human rights and human dignity" during his term. ${ }^{22}$ Saudi Crown Prince Fahd acknowledged that Carter believed that "international relations should be based on the solid ground of morality, high ideals, and genuine respect for human rights." ${ }^{23}$ King Hussein of Jordan praised Carter's rejection of "the cynical notion that morality has no place in the foreign affairs of states." 24 Syrian

\footnotetext{
${ }^{21}$ Mohammed Zia-ul-Haq, "Remarks to Reporters following Meeting with President Carter," October 3, 1980, Public Papers of the Presidents, Book III, p. 2056.

${ }^{22}$ Ziaur Rahman, "Remarks following Meeting with President Carter," August 27, 1980, Public Papers of the Presidents, Book II, p. 1579.

${ }^{2.3}$ Crown Prince Fahd, "Remarks at a Toast with President Carter," May 24, 1977, Public Papers of the Presidents, Book I, p. 1008.
} 
President Hafiz al-Asad praised Carter for creating "an atmosphere of faith and an encouraging atmosphere of optimism" and that his efforts for peace in the region represented "a noble target." 25 Carter. Asad declared. merely sought "what is good. what is just" and acknowledged the importance of the "ethical principles" he attached to policy. ${ }^{26}$ Egyptian President Anwar Sadat. Carter`s favorite international leader. called Carter "the personification of the new spirit" that rejects the old ideas that "politics is amoral and that international relations are not the domain of idealism or spirituality: ${ }^{-27}$ "You listen only to the dictates of your conscience. Your first and foremost allegiance is to the truth. ${ }^{28}$ He said Carter possessed an "unwavering commitment to justice and morality" and that he set for the world "a shining example for genuine concern and unselfish concern for peace and stability in every corner of the world. ${ }^{* 29}$

While the above remarks could be mere flattery, it is interesting that such comments from allied leaders in Europe were typically absent. Not surprisingly. leaders such as French President Valery Giscard d'Estaing and German Chancellor Helmut

\footnotetext{
24 King Hussein, "Remarks at the Welcoming Ceremony with President Carter." April 25. 1977. Public Papers of the Presidents, Book I.p. 711.

${ }^{25}$ Hafiz al-Asad, "Remarks Prior to His Meeting with President Carter in Geneva. Switzerland." May 9. 1977. Public Papers of the Presidents, Book I, p. 843.

${ }^{26}$ Hafiz al-Asad. "Remarks at a Toast with President Carter in Geneva. Switzerland" May 9. 1977. Public Papers of the Presidents, Book I. p. 845.847.

2 Anwar Sadat. Jimmy Carter. "Remarks at the Welcoming Ceremony with President Carter." April 4. 1977. Public Papers of the Presidents. Book I. p. 562.

${ }^{28}$ Sadat, "Remarks at a Toast with President Carter." April 4. 1977. Public Papers of the Presidents. Book I. p. 568

${ }^{29}$ Sadat. "Remarks at a Toast with President Carter," April 8. 1980. in Public Papers of the Presidents. Book I, p. 619.
} 
Schmidt did not appreciate or welcome Carter's human rights and moralistic talk. ${ }^{30}$ Carter was too "preachy," his promotion of human rights too provocative and "inflexible," and his response to the 1979 Soviet invasion of Afghanistan excessive. With a letter carried by Chancellor Schmidt and delivered to President Carter, all the leaders of the European Community formally expressed their desire for Carter "to moderate his campaign on human rights. ${ }^{31}$ On these counts, it was Carter who was blamed for the worsening relations with the Soviet Union, and not the Soviets for their conduct. $^{32}$ In fact, only British Prime Minister Margaret Thatcher backed Carter's "tough line toward Moscow." 33 In return, Carter thought of Chancellor Schmidt, in particular, as a "pain in the ass." Carter was caught between bipartisan complaints in the United States, Burton Kaufman judged, that thought Carter was "not being firm enough on national defense," and European charges that he was "too inflexible in his conduct of foreign affairs. ${ }^{, 35}$

For many international leaders, especially in the more advanced and more secular countries, a moralistic foreign policy and an evangelical style coming from the White House was more appalling than appealing. Peter Bourne, one of Carter's special assistants, recounted that "Carter never really warmed to the European leadership. He

\footnotetext{
${ }^{30}$ Brinkley, The Unfinished Presidency, p. 20; Hargrove, Jimmy Carter as President, p. 172.

${ }^{31}$ Kaufman, The Presidency of James Earl Carter, Jr., pp. 49-50.

${ }^{32}$ Ibid., p. 185.

${ }^{33}$ Ibid., p. 165; John Dumbrell, "Jimmy Carter and 'Global Community," chap. in American Foreign Policy: Carter to Clinton (New York: St. Martin's Press, 1997), p. 25.

${ }^{34}$ Rosalynn Carter, First Lady from Plains (New York: Ballantine Books, 1984), p. 326.

${ }^{35}$ Kaufman, The Presidency of James Earl Carter, Jr., p. 49.
} 
had little in common with their urbane cultural style. their general desire to maintain the interests of their own elites. and their skepticism about his religious beliefs and desire to introduce morality into foreign policy. ${ }^{.36}$ The European press thought he was "an uncultured hayseed. ${ }^{37}$

Unlike his feelings for the Middle East. as we shall see. Carter simply "felt no passion" for Europe. ${ }^{38}$ The only European leader that Carter had some close personal connection to, said Bourne, was British Prime Minister James Callaghan. Part of the reason for this, Bourne suspected. was that "they were both populist politicians who shared similar Protestant sectarian roots. ${ }^{.39}$

\section{Carter's Religious-Political Vision of a Superpower}

"A country will have authority and influence because of moral factors, not military factors...A nation without morality will soon lose its influence around the world...A nation, like a person. has to continually be on an inward journey and an outward journey.

Jimmy Carter has rhetorically asked, "What is it that makes a superpower? ${ }^{\cdot+1}$

For him, the answer is not found, as realists argue, in material capabilities. economic or

\footnotetext{
${ }^{36}$ Peter G. Bourne. Jimmy Carter: A Comprehensive Biography from Plains to Postpresidency (New York: Scribner, 1997), p. 398.

Ibid.. p. 396

is lbid., p. 398

39 Ibid. p. 397.

${ }^{40}$ Carter. "Remarks to Members of the Southern Baptist Brotherhood Commission in Atlanta. Georgia." June 16. 1978. Public Papers of the Presidents. Book I. p. 1117.

${ }^{+1}$ Carter, "Interview with Charlayne Hunter-Gault." PBS. Yewshour. November 19. 1996. http: "Www.pbs.org newshour bb religion carter_11-19.html: "Interview with Don Richardson." October 17, 1997. in Comersations with Carter, edited by Don Richardson (Boulder. CO: Lynne Rienner
} 
military. It is not found in military training and preparedness, in nuclear technology and stockpiles, in providing for the security of a network of allies. or in maintaining any particular balance-of-power arrangement. While he recognized that "military, economic and political strength certainly favors the more powerful side" in international affairs and that the United States certainly "is the undisputed superpower" in the world, Carter rejected the primacy of realist assumptions and has believed that these assumptions. which had been prevalent at the highest levels in American politics, have contributed to past foreign policy failures. ${ }^{42}$ "Being a superpower does not guarantee super wisdom." ${ }^{43}$

For too long, our foreign policy has consisted almost entirely of maneuver and manipulation, based on the assumption that the world is a jungle of competing national antagonisms, where military supremacy and economic muscle are the only things that work and where rival powers are balanced against each other to keep the peace. ${ }^{44}$

For Carter, the making of a superpower is found in immaterial capabilities - spiritual or ethical, if you will. It is found in qualities that "cannot be measured. They're invisible." ${ }^{45}$

Publishers, 1998), 336. In a 1991 interview, he asked, "What is a great nation?" "Interview with the Academy of Achievement in Atlanta, Georgia," October 25, 1991, http://www.achievement.org.

${ }^{42}$ Carter, "Interview with Charlayne Hunter-Gault," PBS Newshour, November 19, 1996; Negotiation. The Alternative to Hostility, The Carl Vinson Memorial Lecture Series Inaugural Lecture (Macon, GA: Mercer University Press, 1984; paperback edition 2003), 19; "Foreword," in Where We Stand: Voices of Southern Dissent, ed. Anthony Dunbar (Montgomery, AL: New South Books, 2004), p. 9.

${ }^{43}$ Carter, "Foreword," in Where We Stand: Voices of Southern Dissent, ed. Anthony Dunbar (Montgomery, AL: New South Books, 2004), p. 10.

${ }^{44}$ Turner, "I'll Never Lie to You": Jimmy Carter in His Own Words, p. 119.

${ }^{45}$ Carter, "Remarks at Emory University in Atlanta, Georgia," August 30, 1979, in Public Papers of the Presidents of the United States, Book II, p. 1563. 
We are a superpower, not just because we're the strongest nation on Earth militarily and economically and politically, but because, in my judgment, we are the strongest nation on Earth morally and ethically. ${ }^{46}$

Citing the prophet Zechariah (4:6), Carter believed the strength of a country is found "not by might, not by power but by my spirit, saith the Lord of hosts." ${ }^{47}$ Unfortunately, he thought, the United States all too often had "an excessive dependence on our own military strength.",48 Too many Americans are full of pride and "worship our nation.,"49 "Sometimes," he said, "it is easier for us to be humble as individuals than it is for us to admit that our nation makes mistakes."

What Americans must understand, said Carter to his Sunday school class, just weeks before his nomination at the Democratic Convention, is "in the eyes of God we're no better than anyone else. We're not saved because we're Americans... we're saved because God loves us; we're saved by grace through one required attitude -that's faith in Christ. We're saved by grace through faith in Christ. So is everybody else. So is everybody else."

\footnotetext{
${ }^{46}$ Carter, "Remarks and Question-and-Answer Session at Townhall Meeting, Temple University, Philadelphia, Pennsylvania," May 9, 1980, Public Papers of the Presidents, Book I, p. 891; "Remarks at the State Democratic Party's Jefferson-Jackson Day Dinner in Milwaukee, Wisconsin," March 31, 1979, Public Papers of the Presidents, Book I, pp.574-575.

${ }^{47}$ Carter, "National Day of Prayer Proclamation," September 19, 1979, Public Papers of the Presidents, Book II, p. 1694.

${ }^{48}$ Carter, "Remarks at a Toast with Canadian Prime Minister Pierre Trudeau," February 21, 1977, Public Papers of the Presidents, Book I, p. 211.

${ }^{49}$ Carter, "Remarks at the Annual National Prayer Breakfast," January 27, 1977, in Public Papers of the Presidents, Book I, p. 24. See also "Remarks Before Men's Class at First Baptist Church in Plains, Georgia," January 9, 1977, in Pippert, The Spiritual Journey of Jimmy Carter, p. 176; "Remarks Before Couples' Class at First Baptist Church in Washington, D.C.," July 31, 1977, in Pippert, The Spiritual Journey of Jimmy Carter, p. 193.

${ }^{50}$ Carter, "Remarks Before Men's Class at First Baptist Church in Plains, Georgia," June 20, 1976, in Pippert, The Spiritual Journey of Jimmy Carter, p. 162.
} 
To be a superpower, Carter said, is to lead by moral example, not "to impose our values on others by force of arms." ${ }^{, 51}$ It is not about trying to "bully" others. ${ }^{52}$ Specifically, a Carterian superpower is a "champion of peace, freedom, and democracy, of human rights, environmental quality, and the alleviation of suffering.".53 It is obeying "the Biblical injunction to "follow after the things which make for peace." "54 It is being a leader in caring for the poor, particular reducing "the growing chasm between rich and poor" countries. ${ }^{55}$ It is being an example to the world of "benevolent sharing" and "love." 56 For a superpower like the United States that has been given by God so much, Carter said, "the Bible tells us that to whom much is given, much will be required." ${ }^{, 57}$ In

\footnotetext{
${ }^{51}$ Carter, "Foreword," in Where We Stand: Voices of Southern Dissent, p. 9; "The State of the Union Annual Message to Congress," January 21, 1980, Public Papers of the Presidents, Book I, p. 177.

${ }^{52}$ Carter, "Remarks at a Democratic Party Rally for John Ingram in Wilson, North Carolina," August 5 , 1978, in Public Papers of the Presidents of the United States, Book II, p. 1389.
}

${ }^{53}$ Carter, Talking Peace: A Vision for the Next Generation (New York: Puffin Books, 1995), p. 106; "Interview with Charlayne Hunter-Gault," PBS Newshour, November 19, 1996; "A 20 th Anniversary Q\&A with President Carter," October 10, 2002,http://www.cartercenter.org; "Remarks to a Joint Session of the State Legislature in Atlanta, Georgia," April 8, 2003; "Sixth U Thant Distinguished Lecture given at United Nations University in Tokyo, Japan," September 5, 2003; "The Seeds of a Rights Scandal in Iraq," Washington Post, May 14, 2004.

${ }^{54}$ Carter, "Remarks at the $31^{\text {st }}$ Annual Meeting of the Southern Legislative Conference in Charleston, South Carolina," July 21, 1977, in Public Papers of the Presidents, Book II, p. 1315.

${ }^{55}$ Carter, "Universities Can Be of Greatest Benefit by Concentrating on the Third World," Chronicle of Higher Education, June 7, 1989; "Remarks at the World Health Assembly," May 19, 2004, available at the Carter Center website, http://www.cartercenter.org; "Inequitable Resources, Benefits Put World at Risk," USA Today, February 16, 2004; "Remarks at the Organization of American States in Washington, DC," January 25, 2005; "Interview with Patricia Miotto," The Voice of Success (March 2006), 5; "Interview with Rich Cline," Evangelical Alliance of the United Kingdom, November-December 2006; "Let's Bridge the Rich-Poor Gap," January 10, 2007.

${ }^{56}$ Carter, "Interview with the Academy of Achievement in Atlanta, Georgia," October 25, 1991, http://www achievement.org.

${ }^{57}$ Carter, "Remarks Before the Brazilian Congress in Brasilia, Brazil," March 30, 1978, Public Papers of the Presidents, Book I, p. 636; "Remarks to Members of the Southern Baptist Brotherhood Commission in Atlanta, Georgia," June 16, 1978, Public Papers of the Presidents, Book I, p. 1115. 
fact, as he explained in a speech before the Congressional Black Caucus. the Bible says political leaders who mistreat the weakest and most vulnerable members of their societies will be judged and sentenced by God to an eternity in hell. ${ }^{58}$ Citing Matthew 25. Carter explained what Jesus said,

"Then shall He say also unto them on the left hand. Depart from me. ye cursed. unto everlasting fire. prepared for the devil and his angels: For I was hungry. and ye gave me no meat; I was thirsty, and ye gave me no drink; I was a stranger. and ye took me not in; I was naked, and ye clothed me not; and in prison, and ye visited me not." Jesus warned. Carter said, "Verily I say unto you, inasmuch as ye did it not unto one of the least of these, ye did it not to me. And these shall go away unto everlasting punishment: but the righteous into life eternal." Therefore, Carter strongly urged. "let our Nation exemplify what we as individuals ought to in the eyes of God.. ${ }^{-59}$

The power of the United States, Carter claimed, rests with its "soft" power. its values, its generosity to other nations, and its commitment to the poor of the world. However, all too often, "we are the stingiest country on earth," having ignored "the growing gap between rich and poor." and with an impatient tendency to seek quick solutions to international disputes (often by resorting to force). to view diplomacy as "an obstacle to overcome," and to "create deadlines to encourage more immediate action." 60

\footnotetext{
${ }^{58}$ Carter, "Remarks at the Annual Dinner of the Congressional Black Caucus," September 30, 1978. in Public Papers of the Presidents, Book II, p. 1680.

${ }^{59}$ Carter, "Remarks at the Annual National Prayer Breakfast." January 27, 1977, in Public Papers of the Presidents, Book I, p. 25.

${ }^{60}$ Carter. "Interview with Charlayne Hunter-Gault," PBS N'ewshour. November 19. 1996: "Interview with Robert Fulghum on C-SPAN's About Books," December 19, 1996, in Conversations with Carter. 306-
} 
their rhetorical overkill, their reckless tendency to oversimplify and transform foreign policy issues into contests of good and evil. ${ }^{61}$ "It is too easy to demonize leaders with whom we disagree." "For some reason, Americans tend to see conflicts in terms of friend/enemy, angel/devil." ${ }^{, 63}$ He criticized, for instance, President Reagan's "evil empire" rhetoric in dealing with the Soviet Union. "President Reagan claims...that we are the epitome of goodness and righteousness - representing God himself in our dealings with the Soviets, who are the personification of total evil." ${ }^{64}$ He criticized those who sought to "demonize" and isolate China. ${ }^{65}$ He criticized President George W. Bush for his "axis of evil" rhetoric toward Iraq, Iran, and North Korea. ${ }^{66}$ He also has rejected efforts to destabilize nascent democracies in the event the winners at the polls are parties that the United States government does not Iike. ${ }^{67}$

307; "A 20 $0^{\text {th }}$ Anniversary Q\&A with President Carter," October 10, 2002, http $/ /$ www.cartercenter.org: "Keynote Speech delivered at the meeting of the Organization of American States in Washington, DC." The Carter Center, January 25, 2005; Negotiation: The Alternative to Hostility, p. 16; "Interview with Jeff Fleischer," Mother Jones, June 2, 2006, http://www.motherjones.com (accessed December 5, 2006).

${ }^{61}$ Douglas Brinkley, "Jimmy Carter's Modest Quest for Global Peace," Foreign Affairs 74.6 (November/December 1995): 96.

${ }^{62}$ Carter, Talking Peace, p. 171.

${ }^{63}$ Carter, Living Faith, p. 139.

${ }^{64}$ Carter, Negotiation: The Alternative to Hostility, pp. 23-24.

${ }^{65}$ Carter, "It's Wrong to Demonize China," New York Times, August 10, 1997.

${ }^{66}$ Carter, "Interview with Larry King," CNN's Larry King Live, September 13, 2006; "Introduction," to Marion V. Creekmore, Jr., A Moment of Crisis: Jimmy Carter, The Power of a Peacemaker, and North Korea's Nuclear Ambitions (New York: Public Affairs Books, 2006), xxiii.

${ }^{67}$ The 2006 victory of Hamas in the Palestinian territories is an example of this. Carter condemned efforts by the United States and Israel to withhold monies to the Palestimian Authority and to isolate the Hamas government. Carter argued that such efforts would only punish the Palestinian people. make Hamas more popular, and undermine U.S. claims that it actually desired democracy in the Middle East. 
For Carter, stigmatization and pronouncements of evil are the initial steps down the path for war; such language forecloses "any sort of substantive move toward accommodation." "68 "[D]emonizing the other," says Carter, "tends to preclude objective thinking and makes it extremely difficult to find a mutually acceptable compromise. ${ }^{.69}$

One of Carter"s poems. "With Words We Learn to Hate," summarizes his views on this. It is quoted in part here:

We justify our nation's wars each time with words to prove we kill in a moral cause...

[W] hen others disagree we hate again, and with our might. war by war, name by dirty name, prove we' re right. ${ }^{70}$

Rather than vilifying other countries or appearing "arrogant or self-righteous." rather than trying to succeed "through arrogance, vituperation, jingoism, or the disparagement of others." Carter recommended, the United States must embrace "bright thinking. unanticipated approaches, and unorthodox ideas to achieve the ancient goals

\footnotetext{
"Interview with Wolf Blitzer," CNN's Late Edition, January 29, 2006: "Don't Punish the Palestinians," Washington Post. February 20. 2006; "Interview with Wolf Blitzer," $C N N$ 's The Situation Room. February 20. 2006: "Remarks and Question-and-Answer Session at the Council on Foreign Relations." March 2. 2006, http: www.cfr.org publication/10024 peace versus democracy in palestine html: "Remarks at the Opening of the Human Rights Defenders Policy Forum in Atlanta, Georgia," May 23. 2006, http. www.cartercenter.org: "Remarks at Mansfield College. Oxford University, United Kingdom," June 21, 2007.

${ }^{68}$ Carter, "Interview with Larry King." CNN's Lam. King Live, September 13, 2006; "Solving the Korean Stalemate. One Step at a Time," New York Times, October 11, 2006: "Interview with David Shuster." MSNBC's Hardball with Chris Matthews, November 28, 2006.

${ }^{69}$ Carter. "Introduction," to Creekmore, A Moment of Crisis, p. xxiii.

${ }^{70}$ Carter, "With Words We Learn to Hate," in Alwals a Reckoning and Other Poems (New York: Times Books, 1995), p. 81.
} 
of better justice and peace in the world."71 He urged Americans to reject "the myth that we must choose between confrontation and capitulation" in dealing with adversaries. ${ }^{72}$

Furthermore, without neglecting their specific responsibilities of protecting and serving the interests and values of the United States, he has suggested that American leaders engage in direct talks with problematic regimes and look at international disputes from the other party's perspective. "Often I would sit [as president] by a large globe, imagine myself to be Brezhnev, Sadat, Begin, Deng Xiaoping or Torrijos, and try to understand the issues in question from their points of view," trying "to understand their frames of reference, their motivations, and the pressures on them. ${ }^{.74}$

"Even when we disagree with the policies of political leaders," Carter says he tried to "approach each society with great respect for its peoples and customs."75 Sometimes, too, the United States and the American people need to learn how to forgive. As in domestic political affairs, such his joint call with President Ford for national healing after the Clinton impeachment, "In international diplomacy," he said, "it is often necessary to grant amnesty to former oppressors and corrupt officials in order to reconcile antagonists and bring peace, justice, and respect for human rights to a

\footnotetext{
${ }^{71}$ Carter, "It's Wrong to Demonize China," New York Times, August 10, 1997; Negotiation: The Alternative to Hostility, p. 6; Cathy S. Dolman, "Carter is first American to win World Methodist Peace Award," Atlanta Journal-Constitution, March 13, 1985, A3.

${ }^{72}$ Carter, "State of the Union Address," January 23, 1979, Public Papers of the Presidents, Jimmy Carter, 1979, Book I, p. 104.

${ }^{73}$ Carter, "Interview with Wolf Blitzer," CNN's The Situation Room, May 24, 2006.

${ }^{74}$ Carter, Negotiation: The Alternative to Hostility, p. 13; "Introduction," to Creekmore, A Moment of Crisis, p. xxv.

${ }^{75}$ Carter, "Question-and-Answer Session on Middle East Peace, Multiculturalism, and Fishing.." July 23. 1995, http://www.cartercenter.org; "Introduction," to Creekmore, A Moment of Crisis, p. xxv.
} 
troubled nation. ${ }^{.76}$ Sometimes, as with individual sinners, nations and peoples need to offer those who offend, hurt, and betray the "opportunity for redemption."

To be and remain a superpower, he says, the United States must return to "the advantageous values of our religious faith and historic ideals. ${ }^{.77}$ The country. especially in rapidly changing and perilous times. must have a "foreign policy...tied in with ancient and unchanging principles of decency and honesty and strength and regard for human and basic rights. ${ }^{.78}$ American strength rests on "its moral integrity. " its "derived from commitment to principles." "from doing what's right-caring for the poor, providing food, becoming the breadbasket of the world instead of the arms merchant of the world. "79 Superpower strength does not come from "bombast and threats." In Carter's vision. the calling of the United States is not to be "the world's policeman." but rather "the world's peacemaker. ${ }^{* 00}$

\footnotetext{
${ }^{-6}$ Carter and Gerald Ford, "A Time to Heal Our Nation," Vew York Times, December 22, 1998: "It "s Time to Forgive Pete Rose." USA Todar. October 30. 1995. This may explain his possible intercession on behalf of a Nazi SS guard. Martin Bartesch, and his family living in the United States. According to the document, which was received by the Office of Special Investigations on September 23. 1987, the apparent note at the top from Carter reads: To Director. O.S.1. 1 hope that in cases like this. that special consideration can be given to affected families for humanitarian reasons. Signed Jimmy Carter." Document acquired from the New York Sun website on January 19. 2007.

- Carter. Our Endangered l'alues: America's Moral Crisis (New York: Simon and Schuster. 2005). p. 101: "Remarks During the Second Presidential Debate with President Gerald Ford in San Francisco. California." October 6. 1976. moderated by Pauline Frederick of National Public Radio. the Commission on Presidential Debates. http: "www.debates.org.

${ }^{-8}$ Carter. "Remarks and Question-and-Answer Session at Townhall Meeting. Temple University. Philadelphia. Pennsylvania." May 9. 1980. Public Papers of the Presidents, Book I, p. 875.

${ }^{-9}$ Carter, "Remarks During the Second Presidential Debate with President Gerald Ford in San Francisco. California." October 6, 1976.

${ }^{80}$ Carter, "State of the Union Address." January 23, 1979. Public Papers of the Presidents. Book I. p. 106.
} 
Our foreign policy ought not to be based on military might nor political power nor economic pressure. It ought to be based on the fact that we are right and decent and honest and truthful and predictable and respectful. ${ }^{81}$

I don't see any difference in the morality that we ought to assert in foreign affairs than what the character of the American people is. ${ }^{82}$

I don't equate pre-eminence solely with military might nor with the ability to subjugate others or to demonstrate prowess on the battlefield. ${ }^{83}$

Truth is the foundation of our global leadership. ${ }^{84}$

\section{A Values-Based Foreign Policy}

"It's not a matter of diplomacy or trade with me. It's a matter of morality." 85

Jimmy Carter offered a foreign policy that emphasized human rights, energetic conflict resolution, and the selflessness of the United States. Together, Zbigniew Brzezinski wrote, these goals constituted the core of Carter's "compassionate mission" to the world. ${ }^{86}$ Carter was determined, Brzezinski added, to bring to the forefront "the

${ }^{81}$ Carter, "Remarks at the National Democratic Issues Conference in Louisville, Kentucky," November 23, 1975, in A Government As Good As Its People, p. 55; "Remarks at the Foreign Policy Association in New York City, New York," June 23, 1976, in A Government As Good As Its People, p. 94.

${ }^{82}$ Carter, "Remarks at Florida State University in Tallahassee, Florida," September 28, 1975, in $A$ Government As Good As Its People, p. 48.

${ }^{83}$ Carter, "Remarks at Dedication of Martin Luther King Portrait in Atlanta, Georgia," February 17, 1974, in A Government As Good As Its People, p. 15.

${ }^{84}$ Carter, "Remarks at the 2004 Democratic National Convention in Boston, Massachusetts," July 26. 2004, http://www.cartercenter.org.

${ }^{85}$ Carter, "Remarks During the Second Presidential Debate with President Gerald Ford in San Francisco, California," October 6, 1976.

${ }^{86}$ Brzezinski, Power and Principle, p. 123. 
primacy of the moral dimension. .87 And this, he said, was rooted in "Carter" s own

religious beliefs." $" 88$

The promotion of human rights. Carter believed. was to be "' a core value of my administration," "the soul of our foreign policy. $" 89$ "As a Christian. I think we can prove that it is possible to support the religious or spiritual values of compassion. sharing. and peace along with the democratic principles of freedom. equality. human rights, and self-rule. $" 90$ "As president. I tried to make human rights a core value of my administration."91 And why not? Carter believed that God was the author of human rights. the Bible the revealed source "of the modern concept of human rights [going] back to the laws and the prophets of the Judeo-Christian traditions," and every person in the world "a child of God." $" 92$

I've been steeped in the Bible since early childhood, and I believe that anyone who reads the ancient words of the Old Testament with both sensitivity and care will find there the idea of government as something based on a voluntary covenant rather than force-the idea of equality before the law and the supremacy of law over the whims of any ruler; the idea of the dignity of the

${ }^{8\urcorner}$ Ibid., p. 81 .

${ }^{88}$ Ibid.. pp. 48-49.

${ }^{89}$ Carter. Living Faith. p. 123: Ambrose and Brinkley. Rise to Globalism. p. 282.

${ }^{90}$ Carter. Living Faith. p. 138. Carter admits that his understanding of human rights has evolved since leaving the White House. Since then. he explains that his understanding has become more holistic and comprehensive. moving beyond "an almost exclusive concentration on political rights." "At the Carter Center. we have broadened our efforts to include the right of people to live in peace. to have adequate food and health care. and to have strong voices in choosing their own political leaders. We have learned that there is no way to separate these crucial rights. ".A $20^{\text {th }}$ Anniversary Q\&A with President Carter." October 10, 2002. http. www cartercenter.org.

${ }^{91}$ Carter, Living Faith, p. 123.

92 Pippert. The Spiritual Journey of Jimm. Carter. 29; Ronald G. Flowers, "President Jimmy Carter. Evangelicalism. Church-State Relations, and Civil Religion." Journal of Church and State 25.1 (Winter 1983): 128: Walter Mondale, Transcript Part Two. American Experience: Jimmy Carter: narrated by Linda Hunt. directed by Adriana Bosch (WGBH Educational Foundation. 2002). http: Www pbs.org wobh amex carter filmmore pt 2.html. (accessed September 18. 2006). 
individual human being and also of the individual conscience; the idea of service to the poor and to the oppressed; the idea of self-government and tolerance and of nations leaving together in peace. ${ }^{93}$

He insisted that a president's focus on human rights and values was neither a naïve nor amateurish. ${ }^{94}$ Instead, he believed such a commitment embodies the best of earlier American (and Southern) presidents, Thomas Jefferson and Woodrow Wilson. ${ }^{95}$ When he tried to make him more of a realist and less Wilsonian, Brzezinski said, Carter resented his efforts. ${ }^{96}$

\section{Idealism as Realism}

In 2007, British Prime Minister Tony Blair wrote, "In my nine years as prime minister, I have not become less idealistic or more cynical. I have simply become more persuaded that the distinction between a foreign policy driven by values and one driven by interests is wrong." "Idealism," he concluded, is "realpolitik." 97 Similarly, three decades earlier, President Carter adamantly rejected the assumption that policymakers must choose between idealism and realism, or between morality and the exercise of power." 98

\footnotetext{
${ }^{93}$ Carter, "Remarks at the Meeting of the General Council of the World Jewish Congress," November 2. 1977, Public Papers of the Presidents, Book II, p. 1953.

${ }^{94}$ Carter, "Remarks at the Human Rights Defenders on the Frontlines of Freedom conference in Atlanta, Georgia," November 11-12, 2003, http://www.cartercenter.org.

${ }^{95}$ Carter, Keeping Faith, p. 146.

${ }^{96}$ Brzezinski, Power and Principle, pp. 30-31.

${ }^{97}$ Blair, "A Battle for Global Values," Foreign Affairs 86.1 (January/February 2007): 90.

${ }^{98}$ Carter, Keeping Faith, p. 147.
} 
Carter believed that "the demonstration of American idealism was a practical and realistic approach to foreign affairs. and moral principles were the best foundation for the exertion of American power and influence." "Our interests and our ideals serve each other. Our power must be used in the service of both-interest and ideals." 99 Carter said his approach was "realism with principle.,"100 a balance of "military strength" and "moral strength. ${ }^{.101}$ Power was not found in the barrel of the gun and international influence was not gained or secured through deception and diplomatic machinations. "The purpose of America's military is not to wage war but to preserve the peace."102 The military capacity of the United States "gives us a rare opportunity to lead the world toward peace."

In fighting evil, Carter stated, one cannot play "by the same rules or lack of rules as the evildoers" or "making accommodation with evil practiced in countries which might be our allies. ${ }^{\circ 103}$ Rather, the power and influence of the United States was to be found in moral service, in making amends for past abuses, in speaking out against current injustices, in balancing security concerns with doing "what's fair, what"s right.

${ }^{99}$ Carter, "Address before the World Affairs Council of Philadelphia," May 9. 1980, Public Papers of the Presidents, Book I, p. 874: "Remarks at a Special Convocation of the Georgia Institute of Technology in Atlanta. Georgia," February 20, 1979. Public Papers of the Presidents, Book I. p. 306.

${ }^{100}$ Carter, "Remarks at the $31^{\text {st }}$ Annual Meeting of the Southern Legislative Conference, Charleston. South Carolina," July 21, 1977, Public Papers of the Presidents, Book II, pp. 13 I 4.

${ }^{101}$ Carter. "Acceptance Speech at the Democratic National Convention in New York City." August 14. 1980. Public Papers of the Presidents, Book II, p. 1534; "Remarks at the Annual Conference of the American Federation of Teachers in Detroit, Michigan," August 22, 1980. Public Papers of the Presidents, Book II. p. 1562.

102 Carter, "Remarks at the State Democratic Party's Jefferson-Jackson Day Dinner in Richmond. Virginia." April 7, 1979. Public Papers of the Presidents, Book I. p. 636.

${ }^{103}$ Carter, Keeping Faith, p. 147; "Excerpts of Remarks to the New York Board of Rabbis." New York Times, May 18, 1981. 
what's decent" and treating other countries "with respect." 104 In short, the foundation of Carter's foreign policy principles was unmistakably grounded religiously: American repentance, "Good Samaritan" service, prophetic criticism, and purposeful peacemaking. This was the Carterian formula for a superpower to remain a superpower while walking humbly before the Lord. It was, said one scholar, "an ambitious new messianism."

\section{Worshipping the Prince of Peace, Not War}

"I worship the Prince of Peace, not war.", 106

Given Carter's distrust of "hard" power, it is not surprising that Carter deployed American forces in only two minor military operations, both rescue missions, during his entire four-year term: providing logistical support in Zaire in 1978 to assist Belgian and French forces to rescue Westerners and the hostage rescue mission in Iran in $1980 .^{107}$

${ }^{104}$ Carter, "Remarks to Reporters following meeting with President Joaquin Balaguer of the Dominican Republic," September 8, 1977, Public Papers of the Presidents, Book II, p. 1552.

${ }^{105}$ Coral Bell, "Virtue Unrewarded: Carter's Foreign Policy at Mid-Term," International Affairs 54.4 (October 1978): 560.

${ }^{106}$ Carter, "Interview with Larry King," CNN's Larry King Live, September 19, 2003; "Interview with Ayelish McGarvey," The American Prospect Online, April 5, 2004, http://www.prospect.org; "Interview with Chris Matthews," MSNBC's Hardball with Chris Matthews, October 18, 2004; "Interview with Tavis Smiley," PBS's Tavis Smiley Show, December 15, 2004; "Interview with Larry King," CNN's Larry King Live, November 3, 2005; "Remarks at the Funeral Service for Coretta Scott King in Lithonia, Georgia," February 7, 2006, http://www.cartercenter.org; "Remarks and Question-and-Answer Session at the Council on Foreign Relations," March 2, 2006, http://www.cfr.org/publication/10024/peace versus_democracy in palestine.html; "Interview with Jeff Fleischer," Mother Jones, June 2, 2006; "Interview with Rich Cline," Evangelical Alliance of the United Kingdom, November-December 2006; "Interview with Elizabeth Sams," Beliefnet, March 27, 2007. http://www.beliefnet.com/story/214/story_21478.html.

${ }^{107}$ Lyn Ragsdale, Vital Statistics on the Presidency: Washington to Clinton (Washington, DC: Congressional Quarterly Press, 1998), pp. 338-339; "U.S. Military Deployments/Engagements, 1975 2001," Center for Defense, http://www.cdi.org/issues/USForces/deployments.html (accessed November 1, 2004); Richard F. Grimmett, "Instances of Use of United States Armed Forces Abroad, 1798-2001." 
No other post-World War II president has been as reluctant to use force than President

Carter. and. during his term, he often noted this fact. ${ }^{108}$."When given the opportunity...

CRS Report for Congress, published by the Congressional Research Service and the Library of Congress. February 5. 2002.

${ }^{108}$ Kenneth W. Stein, "Book Review of Douglas Brinkley's The Linfinished Presidency:" Middle East Quarterly. (September 1999). http: ww meforum.org article 1320. Versions of this fact were repeated by Carter late in his term and became a staple stump phrase in his bid for re-election. "Remarks at a Reception for Democratic Senate Candidate John Ingram in Asheville. North Carolina." September 22. 1978. Public Papers of the Presidents, Book II, p. 1581; "Remarks at a Rally for Bill Roy and John Carlin in Wichita. Kansas," October 21. 1978. Public Papers of the Presidents, Book II, p. 1817: "Remarks at a Democratic-Farmer-Labor Party Victory Rally in Minneapolis, Minnesota." October 21. 1978. Public Papers of the Presidents, Book II, p. 1832; "Remarks and Question-and-Answer Session at a Townhall Meeting in Dolton. Illinois." October 16. 1979. Public Papers of the Presidents, Book 1I. p. 1946: "Interview with Dick Leone of WNET-TV in East Rutherford. New Jersey," October 25. 1979. Public Papers of the Presidents. Book II. p. 2033; "Remarks and Question-and-Answer Session with Editors and Broadcasters from Minnesota," October 26. 1979, Public Papers of the Presidents, Book II. p. 2047: "Remarks and Question-and-Answer Session with Editors and News Directors," January 30, 1980, Public Papers of the Presidents, Book III, pp. 243-244; "Remarks and Question-and-Answer Session with Student Leaders," February 15, 1980, Public Papers of the Presidents, Book I, p. 331: "Remarks at a Democratic National Committee Fundraising Reception in Beverly Hills, California," September 22. 1980, Public Papers of the Presidents, Book II. p. 1892: "Remarks at a Democratic National Committee Fundraising Reception in Portland. Oregon," September 23, 1980. Public Papers of the Presidents, Book II, p. 1902; "Remarks in an Interview with KOMO-TV in Tacoma. Washington," September 23. 1980. Public Papers of the Presidents, Book II. pp. 1910: "Remarks and Question-and-Answer Session with Du Page County Residents in Addison. Illinois," October 6, 1980. Public Papers of the Presidents. Book III. p. 2088: "Remarks and Question-and-Answer Session with Residents in Lyndhurst. New Jersey," October 15. 1980. Public Papers of the Presidents, Book III. p. 2269: "Remarks during Presidential Debate with Governor Ronald Reagan in Cleveland. Ohio." October 28. 1980. Public Papers of the Presidents, Book III. p. 2479: "Remarks and Question-and-Answer Session at a Town Meeting in Columbia. South Carolina." October 31, 1980. Public Papers of the Presidents, Book III, p. 2564: "Remarks at Campaign Rally in Lakeland, Florida," October 31, 1980, Public Papers of the Presidents, Book III, p. 2582: "Remarks and Question-and-Answer Session at a Town Meeting in Memphis, Tennessee," October 31. 1980. Public Papers of the Presidents, Book III. p. 2587: "Remarks at Campaign Rally in Jackson. Mississippi." October 31. 1980, Public Papers of the Presidents, Book III. p. 2600: "Remarks at Campaign Rally in Houston, Texas." October 31. 1980. Public Papers of the Presidents, Book III. p. 2606: "Remarks at a Campaign Rally in Brownsville. Texas." November 1. 1980. Public Papers of the Presidents, Book III. p. 2621: "Remarks at a Campaign Rally in San Antonio, Texas," November 1. 1980. Public Papers of the Presidents, Book III. pp. 2623-2624; "Remarks at a Campaign Rally in Abilene. Texas," November 1, 1980, Public Papers of the Presidents, Book III. p. 2630; "Remarks at a Campaign Rally in Fort Worth, Texas." November 1, 1980, Public Papers of the Presidents, Book III. p. 2639: "Remarks at Reception for Campaign Supporters in Milwaukee. Wisconsin," November 1, 1980. Public Papers of the Presidents, Book III. p. 2643: "Remarks at a Campaign Rally in Akron, Ohio." November 3, 1980. Public Papers of the Presidents, Book III. p. 2657: "Remarks at a Campaign Rally in Granite City. Illinois." November 3, 1980. Public Papers of the Presidents. Book III. p. 2662: "Remarks at a Campaign Rally in Springfield. Missouri." November 3. 1980. Public Papers of the Presidents, Book III. p. 2668: "Remarks at a Campaign Rally in Portland. Oregon." November 3. 1980. Public Papers of the Presidents, Book III. p. 2675: "Remarks at a Campaign Rally in Seattle, Washington." November 3. 1980. Public Papers of the Presidents, Book III. p. 2680: "Remarks at a Campaign Rally in Plains. Georgia," November 4. 1980. Public Papers of the Presidents. Book III, p. 2684. 
our country has not always chosen the option of peace" or exhausted "the opportunities for peaceful resolution of the dispute." ${ }^{109}$ After leaving office, Carter has continued to tout the absence of war on his watch--"never fired a bullet, never dropped a bomb while I was in office, and still kept our nation secure."

In the case of Iran, Carter has explained his reluctance to use force. He says he "could have launched a very popular military strike," "could have destroyed Iran," and was advised to punish that country for taking 52 American hostages. Through incessant prayer, he, however, decided against it. Carter reckoned that such an undertaking would cost the lives of "thousands of innocent Iranians" and probably also the lives of the hostages. In the end, he believed God did answer his prayers for the hostages` safe release and for their release without war." "In the last analysis, every hostage came home safe and free, and that was my goal.",112

Carter believed that American presidents, especially his immediate predecessors and successors, had a penchant to rush to using the military option. ${ }^{113}$ "When given the opportunity...our country has not always chosen the option of peace," or exhausted "the opportunities for peaceful resolution of the dispute." ${ }^{114}$ He also charged that they often

${ }^{109}$ Carter, Living Faith, p. 138.

${ }^{110}$ Carter, "Interview with Tavis Smiley," PBS's Tavis Smiley Show, December 15, 2004, http:/www.pbs.org/kcet/tavissmiley/archive/200412/20041215 transcript.html.

111 "Interview with Bob Abernathy," PBS's Religion and Ethics Newsweekly, October 29, 1999.

112 “Interview with Tavis Smiley," PBS's Tavis Smiley Show, December 15, 2004; "Interview with Chris Matthews, MSNBC's Hardball with Chris Matthews, October 18, 2004; "Interview with Wolf Blitzer," CNN's Late Edition, January 19, 2007, aired January 21.

${ }^{113}$ David Brooks, "The Party of Kennedy, or Carter?" New York Times, February 17, 2004.

${ }^{114}$ Carter, Living Faith, p. 138. 
acted unethically, including "secrecy and outright lying." "As it has related to such areas as Pakistan. Chile. Cambodia. and Vietnam. our government's foreign policy has not exemplified any commitment to moral principles. ${ }^{.115}$ Consequently. he intended to reverse that; he made clear his intention "to restore the moral bearings of American foreign policy."116 And this restoration included submission to "the Biblical injunction to follow after the things which make for peace. $\cdots$

In contrast to the absence of military conflict in the Carter years. "military activity accelerated during the Reagan. Bush. and Clinton administrations. ${ }^{.117}$ Regarding his opposition to the 2003 Iraq War. he wrote in an op-ed to the New York Times.

As a Christian and as a president who was severely provoked by international crises. I became thoroughly familiar with the principles of a just war, and it is clear that a substantially unilateral attack on Iraq does not meet these standards. ${ }^{118}$

It was a "radical departure" from previous American wars. He called it "a completely unjust and unnecessary war... launched unilaterally: .119

Carter was and is not a pacifist — and he certainly does not consider pacifism "a necessary element of Christianity. ${ }^{-120}$ Carter graduated from the U.S. Naval Academy

\footnotetext{
115 Carter. Why . Vot the Best?. pp. 140-141.

${ }^{116}$ Carter, "Remarks at the $31^{\text {st }}$ Annual Meeting of the Southern Legislative Conference. Charleston. South Carolina." July 21. 1977, Public Papers of the Presidents, Book II. pp. 1312.1315.

11- Louis Fisher. Presidential War Power (Lawrence. KS: University of Kansas Press. 1995). p. 134.

${ }^{118}$ Carter. "Just War-or a Just War?" New York Times. March 9. 2003.

${ }^{119}$ Carter. "Interview with Chris Matthews," MSNBC"s Hardball with Chris . Matthews. December 11. 2003.

${ }^{120}$ Carter, Living Faith. p. 100.
} 
and served eleven years (1943-1954) in the military, originally planning on making a career in the military. ${ }^{121}$ Only his duty to his dying father superceded his military duty to country.

As president, Carter also demonstrated that he could adjust to changing circumstances and take a harder line toward countries, such as the Soviet Union after it invaded Afghanistan in December 1979. Robert Gates, for instance, who became George W. Bush's Defense Secretary in 2006 and who had served in the Carter Administration, said that unlike many Americans who thought Carter was weak, "the Soviets saw a very different Jimmy Carter...different and more hostile and threatening." In fact, he said, it was Carter who initiated the 1980s arms buildup; he provided "a strong foundation for Ronald Reagan to build upon." Moreover, though Reagan would get much of the credit for the collapse of the Soviet Union, Gates believes it was Carter's vigorous promotion of human rights that challenged for the first time the moral "legitimacy of Soviet rule at home." Carter's efforts were "the first steps" to signal the coming end of the Soviet Union itself. ${ }^{122}$

Carter is a firm believer that all peaceful, diplomatic means must first be thoroughly exhausted. War must be the last recourse. ${ }^{123}$ "With faith and perseverance,"

\footnotetext{
${ }^{12 !}$ Brinkley, The Unfinished Presidency, p. 21.

122 Thomas E. Ricks, "Surprises from Gates' 1996 Memoir," Washington Post, January 23, 2007.

${ }^{123}$ For instance, Carter supported U.S. war efforts in Afghanistan as a legitimate response to $9 / 11$, but he opposed Iraq as a diversion from the war on terror. See Carter, "Interview with Jim Lehrer," $P B S$ Newshour, July 26, 2004, http://www.pbs.org/newshour/bb/politics/july-dec04/carter 7-26.html; "Interview with Tim Russert," NBC's Meet the Press, December 3, 2006.
} 
the awesome responsibility of the American president is to "search for justice and peace" in the world. ${ }^{124}$ During the 1980 debate with Governor Reagan. Carter said this:

[T] he build-up of military forces is good for our country because we ve got to have military strength to preserve the peace. But I'll always remember that the best weapons are the ones that are never fired in combat, and the best soldier is one who never has to lay his life down on the field of battle. ${ }^{125}$

For those who would challenge his less than muscular foreign policy, he would cite his own military service. "I was trained in the art of war."126 On more than one occasion he has noted that unlike some of the more recent presidents, he actually served in the armed forces:

I obviously am prepared to use military weapons if I had to. I devoted 11 years of my life to the U.S. Navy. In fact. I've served more time in the military than any other President since the Civil War era except Dwight Eisenhower. So I was prepared to give my life for my country and to use military weapons if necessary. But I think that we should go to war and kill a lot of our own people and a lot more other people only as an absolute last resort. And we should explore every possible alternative to war before we send our troops into battle. $^{127}$

Except for General Dwight Eisenhower, I spent more years in active military service than any other president since those who had served as generals in the War Between the States. Although prepared to give my life if necessary as a submarine officer, I joined other officers and men in a common commitment that America's obvious strength and steadfastness would be a deterrent to warthat we were the ones preserving peace. I never felt that my dedication to military service was a violation of my faith in Jesus Christ, the Prince of Peace. $^{\text {128 }}$

\footnotetext{
${ }^{124}$ Carter, Negotiation: The Alternative to Hostility: p. 24.

125 Carter, "Remarks during Presidential Debate with Governor Ronald Reagan in Cleveland, Ohio." October 28, 1980, Public Papers of the Presidents, Book III, p. 2480.

${ }^{126}$ Carter, "Remarks Accepting the Martin Luther King, Jr. Nonviolent Peace Prize in Atlanta, Georgia." January 14, 1979, Public Papers of the Presidents, Book I, p. 32.

${ }^{127}$ Carter, "Interview with Tavis Smiley." PBS's Tavis Smiley. Show'. December 15. 2004.

${ }^{128}$ Carter. Our Endangered Values: America's Moral Crisis, p. 147.
} 
Based on his Christian faith and presidential experience, Carter rejected the Clauswitzian notion that war is a normal extension of politics. Instead, Americans, whether they are public officials or private citizens, should strive for peace. "Peace is everyone's job." 129 And as Jesus said in his famous Sermon on the Mount, "Blessed are the peacemakers, for they will be called children of God."130 Although Carter accepted the occasional necessity to use military force, he opposed the notion that there are "good wars" and "bad wars." For him, all war is evil. For instance, after he won the 1976 Democratic nomination, he told Playboy magazine that he would never use the U.S. military "for the purpose of overthrowing a government" and that he could never use measures against another country "that would be a contravention of the moral and ethical standards that I would exemplify in my own life as an individual."13! When he received the Nobel Peace Prize in 2002, he closed with these words:

War may sometimes be a necessary evil. But no matter how necessary, it is always an evil, never a good. We will not learn how to live together in peace by killing each other's children. The bond of our common humanity is stronger than the divisiveness of our fears and prejudices. God gives us the capacity for choice. $^{132}$

For Carter, moral law is moral law, mutually binding individuals and states.

Though he highly respected and often quoted the theological work of Reinhold Niebuhr,

\footnotetext{
${ }^{129}$ Carter, "Peace is Everyone's Job," New York Times, May 21, 1995.

${ }^{130}$ On more than one occasion, Carter precisely used these words to describe the purpose of the Camp David accords. Pippert, The Spiritual Journey of Jimmy Carter, p. 138; Hutcheson, God in the White House, p. 119.

${ }^{131}$ Carter, "Interview with Robert Scheer," Playboy, November 1976, p. 74.

${ }^{132}$ Carter, The Nobel Peace Prize Lecture (New York: Simon and Schuster, 2002), p. 20.
} 
he has not accepted the popular reasoning that there is a separate moral code for

individual conduct and a separate moral code for state conduct. ${ }^{133}$

There is no possible means of isolating ourselves from the rest of the world. so we must provide leadership. But this leadership need not depend on our inherent military force, or economic power. or political persuasion. It should derive from the fact that we try to be right and honest and truthful and decent...There is no need for lying. Our best national defense is the truth. ${ }^{134}$

A nation's domestic and foreign policies actions should be derived from the same standards of ethics, honesty and morality which are characteristic of the individual citizens of the nation. The people of this country are inherently unselfish, open. honest, decent, competent, and compassionate. Our government should be the same, in all its actions and attitudes. ${ }^{135}$

The standards of government should exemplify the highest attributes of mankind. and not the lowest common denominator. There is no legitimate reason for different standards in our home, our office, our church, or our government. In every component of life we should continually strive for perfection as commanded by God. ${ }^{136}$

As in the case with a human being. admirable characteristics of a nation are not defined by size and physical prowess. What are some of the other attributes of a superpower? Once again, they might very well mirror those of a person. These would include a demonstrable commitment to truth, justice. peace. freedom. humility, human rights, generosity, and the upholding of other moral values. There is no inherent reason that our nation cannot be the international example of these virtues. ${ }^{137}$

Given this, Carter believes that just wars are rare.

[T] he causes and ultimate results of conflicts are often shaped by relatively minor factors, avoidable mistakes of leaders, and subtle nuances of fact and opinion. In almost every case, there is a peaceful alternative to war. ${ }^{138}$

\footnotetext{
133 Carter, "Remarks at Emory University in Atlanta. Georgia." August 30. 1979, in Public Papers of the Presidents, Book II, p. 1562.

${ }^{134}$ Carter, Why Not the Best?'. p. 146.

135 Ibid., p. 141.

${ }^{136}$ Turner, "I'll Vever Lie to You": Jimm. Carter in His Own Hords, p. 81.

139 Carter, Our Endangered Values: America's Moral Crisis. p. 199.
} 
Carter is not a Christian pacifist; he is more an exponent of the Christian just war tradition. In a 2003 op-ed piece criticizing the imminent war with Iraq, Carter shared his thoughts on how he approached international crises when he was president. He explained that modern war and an American president's consideration of the war option must be "predicated on basic religious principles, respect for international law, and alliances."139 Before going to war, a president must first exhaust all other options. Then, if all other options have been exhausted and a president must lead the country to war, the president must seek the legitimate authority to wage war. Once authority has been given, the president must judiciously discriminate between military and civilian targets, consider the proportionality of violence, and make the necessary preparations that the post-war situation is a marked improvement on the pre-war situation.

In the months leading up to the 1991 Gulf War, Carter made similar arguments. ${ }^{140}$ For Carter, the issue was not whether or not the United States could expel Iraq from Kuwait or destroy Iraq's war-making capabilities, because the "military forces of America and its allies can surely prevail." The issue was whether or not the United States was rushing to war, whether it was involving Arab leaders enough, whether it was just issuing inflexible ultimata and if it was adequately preparing for the long-term stability and peace of the region. At the time, Carter did not think the United States was doing all it could. Therefore, he urged the first Bush administration to take

\footnotetext{
${ }^{138}$ Carter, "Interview with Ellen Fried," "The Revolution in the South: President Carter's New Novel Brings History to Life," Prologue 36.2 (Summer 2004).

${ }^{139}$ Carter, "Just War--or a Just War?" New York Times, March 9, 2003.

${ }^{140}$ Carter, "The Need to Negotiate," Time, October 22, 1990; "First Steps Toward Peace," Newsweek, December 17, 1990; "Don't Reject a Cease-Fire," Time, February 25, 1991; Talking Peace, p. 18.
} 
advantage of all opportunities to avert war and lay the foundation for a lasting Mideast peace. Carter also opposed the 1983 U.S. retaliatory strikes on Beirut, Lebanon, for the deaths of more than 200 Marines killed in a suicide attack. the 1986 U.S. bombing of Libya and the 1989 U.S. invasion of Panama to remove General Manuel Noreiga. ${ }^{1+1}$ Even more extraordinary, he wrote that the war phases of the American Revolution and the Civil War (what he, like most Southerners. called the War Between the States) were probably unnecessary. ${ }^{1+2}$

Carter's views on war and peace are not purely partisan, either: he spoke against President Clinton's 1999 Kosovo campaign, too. In a piece entitled, "Have We Forgotten the Path to Peace?", he wrote that the United States had "become increasingly inclined to sidestep the time-tested premises of negotiation," that attacking Serbia "has been counterproductive," and that the aerial campaign has become "senseless and excessively brutal. ${ }^{\prime 1+3}$ Though Carter held that the United States and the world community certainly had a just interest in protecting the lives and property of the Kosovars, he concluded, "The ends don't always justify the means"-meaning. military action, even for noble goals, may not always be the wisest and moral approach.

Without mentioning Clinton by name, it is clear that Carter accused his administration for choosing "a solution that best suits its own purposes." He specifically charged that

${ }^{1+1}$ William E. Schmidt, "Carter and Ford Oppose U.S. Strike." New York Times. November 7. 1983: Carter, "Interview with Barbara Reynolds of USA Todal:" May 12. 1986. in Conversations with Carter. p. 271 .

142 Carter, "Interview with Barbara Reynolds of USA Todan." May' 12. 1986, in Conversations with Carter, p. 271; Bill Shipp, "Will Jimmy Carter defeat Jordan in bid for U.S. Senate Nomination," Atlanta Journal-Constitution. June 4, 1986, A 11; Carter, Talking Peace. p. 36.

14: Carter, "Have We Forgotten the Path to Peace?" New York Times. May 27. 1999. 
it sought only "tacit support in whichever forum it can best influence," for providing "dominant military force," and for presenting "an ultimatum to recalcitrant parties, and then take punitive action against the entire nation to force compliance."

Whether Carter is right or not is not of interest here. What is of interest and worthy of note is Carter's consistency and his exceptional policy positions. Unlike other major national Republican and Democratic figures since 1991, Carter is the lone figure who opposed the 1991 Gulf War, the 1999 Kosovo campaign, and the 2003 Iraq War. Rather than being partisan, he has been authentic. He publicly opposed two wars led by Republican presidents and one led by a Democratic president. Table 5.1 shows how remarkable and exceptional Carter's position on war and peace has been.

Among national Republican and Democratic leaders, major presidential candidates of both parties, and other notable personalities, Carter is the only one to have consistently opposed war. Exhibitions of partisanship on war and peace better described the actions of other major Republicans and Democrats. Collectively, partisanship appears to more accurately describe the group behavior of House Republicans, Senate Republicans, and House Democrats.

Some national figures, all Democrats, have been selective in their support or opposition to war. For these individuals, factors other than pure partisanship seem to have influenced their voting behavior. Quite likely, concerns about reelection or the desire to be president were important. It was frequently mentioned at the time that Democrats who had voted against the 1991 Gulf War would not make, politically speaking, the same mistake twice. 
Table 5.1 Carter in Comparative Perspective on War and Peace

\begin{tabular}{|c|c|c|c|c|}
\hline & 1991 & 1999 & 2003 & \\
\hline & Gulf War & $\underline{\text { Kosovo }}$ & $\underline{\text { Iraq War }}$ & Type \\
\hline Jimmy Carter & No & No & No & Nonpartisan Dove \\
\hline Other Presidents & & & & \\
\hline George W: Bush & Yes & Yes & Yes & Nonpartisan Hawk \\
\hline Bill Clinton & Yes & Yes & Yes & Nonpartisan Hawk \\
\hline Other Republicans & & & & \\
\hline Sam Brownback & NA & No & Yes & Partisan Hawk Dove \\
\hline Richard Cheney & Yes & No & Yes & Partisan Hawk Dove \\
\hline Robert Dole & Yes & Yes & Yes & Nonpartisan Hawk \\
\hline Bill Frist & NA & No & Yes & Partisan Hawk Dove \\
\hline Newt Gingrich & Yes & No & Yes & Partisan Hawk Dove \\
\hline Dennis Hastert & Yes & Yes & Yes & Nonpartisan Hawk \\
\hline Orrin Hatch & Yes & Yes & Yes & Nonpartisan Hawk \\
\hline Jesse Helms & Yes & No & Yes & Partisan Hawk Dove \\
\hline Trent Lott & Yes & No & Yes & Partisan Hawk Dove \\
\hline Richard Lugar & Yes & Yes & Yes & Nonpartisan Hawk \\
\hline John McCain & Yes & Yes & Yes & Nonpartisan Hawk \\
\hline Mitch McConnell & Yes & Yes & Yes & Nonpartisan Hawk \\
\hline Dan Quayle & Yes & No & Yes & Partisan Hawk Dove \\
\hline Arlen Specter & Yes & Yes & Yes & Nonpartisan Hawk \\
\hline Strom Thurmond & Yes & No & Yes & Partisan Hawk Dove \\
\hline Other Democrats & & & & \\
\hline Eran Bayh & $\mathrm{NA}$ & Yes & Yes & Nonpartisan Hawk \\
\hline Joe Biden & No & Y'es & Yes & Selective Hawk Dove \\
\hline Robert Byrd & No & Yes & No & Partisan Hawk Dove \\
\hline Hillary Clinton & Yes & Yes & Yes & Nonpartisan Hawk \\
\hline Tom Daschle & No & Yes & Yes & Selective Hawk Dove \\
\hline Howard Dean & Yes & Yes & No & Selective Hawk Dove \\
\hline John Edwards & NA & Yes & Yes & Nonpartisan Hawk \\
\hline Richard Gephardt & No & Yes & Yes & Selective Hawk Dove \\
\hline Al Gore & Yes & Yes & No & Selective Hawk Dove \\
\hline Bob Graham & Yes & Yes & No & Selective Hawk Dove \\
\hline Tom Harkin & No & Yes & Yes & Selective Hawk Dove \\
\hline Ernest Hollings & No & No & Yes & Selective Hawk Dove \\
\hline Jesse Jackson & No & Yes & No & Partisan Hawk Dove \\
\hline Edward Kennedy & No & Yes & No & Partisan Hawk Dove \\
\hline Bob Kerrey & No & Yes & $\mathrm{NA}$ & Partisan Hawk Dove \\
\hline John Kerry & No & Yes & Yes & Selective Hawk Dove \\
\hline Dennis Kucinich & $\mathrm{NA}$ & Yes & No & Partisan Hawk Dove \\
\hline Joe Lieberman & Yes & Yes & Yes & Nonpartisan Hawk \\
\hline Nancy Pelosi & No & Yes & No & Partisan Hawk Dove \\
\hline Harry Reid & Yes & Yes & Yes & Vonpartisan Hawk \\
\hline Bill Richardson & No & Yes & Yes & Selective Hawk Dore \\
\hline Paul Wellstone & No & Yes & No & Partisan Hawk Dove \\
\hline
\end{tabular}


Table 5.1 Carter in Comparative Perspective on War and Peace (Cont.)

\begin{tabular}{|c|c|c|c|c|}
\hline & $\begin{array}{l}1991 \\
\text { Gulf War }\end{array}$ & $\begin{array}{l}1999 \\
\underline{\text { Kosovo }}\end{array}$ & $\begin{array}{l}2003 \\
\text { Iraq War }\end{array}$ & Type \\
\hline Jimmy Carter & No & No & No & Nonpartisan Dove \\
\hline \multicolumn{5}{|l|}{ Minor Party Figures } \\
\hline Pat Buchanan & No & No & No & Nonpartisan Dove \\
\hline Jim Jeffords & Yes & Yes & No & Selective Hawk/Dove \\
\hline Ralph Nader & No & No & No & Nonpartisan Dove \\
\hline Ron Paul & No & No & No & Nonpartisan Dove \\
\hline Bernie Sanders & No & Yes & No & Partisan Hawk/Dove \\
\hline House Republicans & Yes & No & Yes & Partisan Hawk/Dove \\
\hline Senate Republicans & Yes & No & Yes & Partisan Hawk/Dove \\
\hline House Democrats & No & Yes & No & Partisan Hawk/Dove \\
\hline Senate Democrats & No & Yes & Yes & Selective Hawk/Dove \\
\hline
\end{tabular}

Other prominent officials have demonstrated that they can go beyond partisanship and support a war effort led by presidents of either party. These are the nonpartisan or bipartisan war hawks. Carter does not fit in these three common categories; among the most prominent of American politicians, he is by himself in publicly opposing all three wars.

Moreover, contrary to what many Carter critics often claim, since the American people supported each war at the time it began, it would be hard to argue that Carter's opposition was driven by concerns to improve his image with the American people. This is especially true of the 1991 Gulf War, which was supported at the time by both Republicans and Democratic survey respondents. ${ }^{144}$ If anything, by going public with his opposition to both Republican and Democratic presidents, he risked offending everyone in the political mainstream. Carter opposed the most popular and bipartisan (in terms of public opinion) of the three wars (1991 Persian Gulf War) and the most 
divisive and partisan (2003 Iraq War). Though the public was initially wary of intervention, $47 \%$ for and $47 \%$ against on the eve of the campaign, the Kosovo campaign became popular after the bombing campaign began, $60 \%$ for and $31 \%$ against. A majority of Americans, 51\%, approved of Clinton's handling of the situation, while $32 \%$ opposed. When Carter wrote his piece in May, a majority (53\%) still approved of Clinton's handling. Additionally, from April to June 1999. a majority of Americans thought the military action in Kosovo was "the right thing"; $54 \%$ thought so at the time of Carter's opinion piece. ${ }^{145}$

The only figures presented here that took war and peace positions identical to Carter`s were one-time minor party presidential candidates, Pat Buchanan. Ron Paul. and Ralph Nader. These "nonpartisan doves" were opposed to both Republican and Democratic wars. This suggests that on matters of war and peace, Carter was outside the mainstream of American politics, on the political fringes with former Reform, Libertarian. and Green party presidential nominees.

The difference, however, is that Buchanan, Paul, and Nader seemingly did not oppose these military campaigns for ostensibly religious reasons. Instead, their opposition was expressed in purely secular terms - war was not in the country`s interests, there was no imminent or direct security threat, is produced of imperialism. the president failed to ask for a proper declaration of war. Not Carter. As shown above. he argued from the standpoint of Christian just war principles. Based on these three cases, it is highly suggestive that Carter's reluctance to use force during his four-year

\footnotetext{
144 Jeffrey M. Jones, "War Through Partisan Lenses," Gallup Poll New's Service, November 15, 2005.

145 "Kosovo," Washington Post, June 16, 1999, www.washingtonpost.com, accessed April 16, 2003.
} 
term was rooted in his Christian faith perspective, namely his understanding of what constitutes a just war. No other major national figure has an equivalent record or have offered such faith-based opposition to war. In this regard, Carter probably stands closest to Pope John Paul II, who also opposed, for religious reasons, all three campaigns.

\section{Applying the Golden Rule}

"If we insist that the golden rule be applied in all public matters, then potential inequalities can be prevented, and wrong can be righted... To establish and maintain such a government is the proper purpose of public service."146

For Carter, the New Testament teachings of Jesus offered some sound principles for U.S. foreign policy. Most importantly, he believed that U.S. policy should be based on the Golden Rule: "do unto others as you would have them do unto you."

This was true in the case of the Panama Canal. On this issue, Carter devoted a great deal of energy to the negotiation and ratification of the Canal treaties. Unlike Nixon and Ford, Carter was willing to risk his public prestige on an issue many of his fellow Democrats interpreted as "an act of political recklessness." 147 However, the treaties for Carter were an expression of national guilt, an act of atonement. ${ }^{148}$ "I was convinced that we needed [it] to correct an injustice" committed by the United States. ${ }^{149}$

\footnotetext{
${ }^{146}$ Carter, Why Not the Best?, p. 157.

${ }^{147}$ Ambler H. Moss, Jr., "The Panama Treaties: How an Era Ended," Latin American Research Review' 21.3 (1986): 176.

${ }^{148}$ Kenneth E. Morris, Jimmy Carter: American Moralist (Athens, GA: University of Georgia Press. 1996), p. 271.

${ }^{149}$ Hutcheson, God in the White House, p. 124.
} 
Rejecting suggestions that he postpone a fight over the Canal treaties to a second term. Carter preferred more immediate action and was prepared to take on whatever political consequences ensued. ${ }^{150}$ "I put my whole [political] life on the line on the Panama Canal treaty. ${ }^{-151}$ For Carter, correcting a past wrong in Panama and living up to the Golden Rule was more important than political expedience. Peter Bourne said Carter saw the Panama Canal issue as "a prime opportunity to apply moral values to foreign policy. ${ }^{.152}$ Similarly. Zbigniew Brzezinski explained. "Carter clearly enjoyed his role as the political emancipator of a downtrodden people." In his mind, the signing of the Panama Canal treaty "represented the ideal fusion of morality and politics: he was doing something good for peace. ${ }^{.153}$ Though Carter understood the political costs to himself and the 68 senators who supported his position. he thought. wrote Gregory Domin. that the senators " "political sacrifice was noble," for their courageous rotes "transcended the import of political careers and [potential] electoral defeats. ${ }^{.154}$ A corollary to correcting past wrongs was Carter's opposition to imposing democracy or any other form of government on other peoples. "America`s concern for human rights does not reflect a desire to impose our particular political or social

${ }^{150}$ Bourne. Jimmy Carter: A Comprehensive Biography from Plains to Postpresidency: p. 382.

${ }^{151}$ Carter. "Interview with Charles O. Jones. H. Clifton McCleskey. Kenneth W. Thompson. James Sterling Young. Richard Neustadt, David B. Truman. Richard F. Fenno. Jr., and Edwin C. Hargrove." Carter Presidency Project. November 29. 1982. Transcript available at the Miller Center for Public Affairs. University of Virginia, http: www. millercenter.virginia.edu index.php scripps digitalarchive oralhistories detail 3260 .

152 Bourne. Jimmy Carter: A Comprehensive Biography from Plains to Postpresidency: p. 382.

153 Brzezinski. Power and Principle. p. 137.

${ }^{15+}$ Gregory Paul Domin. Jimmy. Carter. Public Opinion, and the Search for l'alues. 19-- 1981 (Macon. GA: Mercer University Press. 2003). pp. 82-83. 
arrangements on any other country."

most deeply felt values of the American people." The reason for not wanting to impose American standards on others, Carter explained, is that God forbids judging: "Judge not, that ye be not judged." 156 Instead, the United States should "raise high the banner of human rights," become an evangelist of democracy, "a beacon light of something that's clean and decent and proper," and set a democratic "example for the world."157

155 Carter, "Remarks at the NATO Ministerial Meeting in London, United Kingdom," May 10, 1977. Public Papers of the Presidents, Book I, p. 850.

${ }^{156}$ Carter, "Interview with John Hart of NBC News," March 28, 1976, in Pippert, The Spiritual Journey of Jimmy Carter, p. 101; Sources of Strength, p. 77; "Interview with Harry Reasoner of $A B C$ News in Plains, Georgia," August 2, 1976, in Pippert, The Spiritual Journey of Jimmy Carter, p. 76.

${ }^{157}$ Carter, "Remarks and Interview with a Group of Publishers, Editors, and Broadcasters," May 20, 1977, Public Papers of the Presidents, Book I, p. 947; "Remarks at $14^{\text {th }}$ Annual Democratic Congressional Dinner," May 25, 1977, Public Papers of the Presidents, Book I, p. 1016; "Remarks and Question-and-Answer Session with Members of the Advertising Council, Inc.," June 22, 1977, Public Papers of the Presidents, Book I, p. 1147; "Remarks at the Democratic National Committee Fundraising Dinner in New York City," June 23, 1977, Public Papers of the Presidents, Book I, p. 1156; "Remarks at a Democratic Party Campaign Luncheon in Atlantic City, New Jersey," September 20, 1978, Public Papers of the Presidents, Book II, p. 1555; "Remarks at a Rally for Bill Roy and John Carlin in Wichita, Kansas," October 21, 1978, Public Papers of the Presidents, Book II, p. 1817; "Acceptance Speech at the Democratic National Convention in New York City," August 14, 1980, Public Papers of the Presidents, Book II, p. 1536; "Remarks at Campaign Rally in Tuscumbia, Alabama," September 1, 1980, Public Papers of the Presidents, Book II, p. 1604; "Remarks at the National Italian-American Foundation Dinner," September 13, 1980, Public Papers of the Presidents, Book II, p. 1721; "Remarks at a Democratic National Committee Fundraising Luncheon in Houston, Texas," September 15, 1980, Public Papers of the Presidents, Book II, p. 1741; "Remarks at Dedication Ceremonies for the Hartsfield Atlanta International Airport," September 16, 1980, Public Papers of the Presidents, Book II, p. 1757; "Remarks at a Cuyahoga County Democratic Party Reception in Cleveland, Ohio," September 16, 1980, Public Papers of the Presidents, Book II, p. 1765; "Remarks at a Democratic National Committee Fundraising Luncheon in Boston, Massachusetts," October 15, 1980, Public Papers of the Presidents, Book III, p. 2248; "Remarks at a Democratic National Committee Fundraising Reception in Secaucus, New Jersey," October 15, 1980, Public Papers of the Presidents, Book III, p. 2277; "Remarks at a Meeting with New York Labor Leaders," October 16, 1980, Public Papers of the Presidents, Book III, p. 2308; "Remarks at White House Reception for Black Ministers," October 23, 1980, Public Papers of the Presidents, Book III, p. 2428; "Remarks during Presidential Debate with Governor Ronald Reagan in Cleveland, Ohio," October 28, 1980, Public Papers of the Presidents, Book III, p. 2501; "Remarks at the International Ladies' Garment Workers Union Rally in New York City" October 30, 1980, Public Papers of the Presidents, Book III, p. 2545; "Remarks at Campaign Rally in Saginaw, Michigan," October 30, 1980, Public Papers of the Presidents, Book III, p. 2550; "Remarks at White House Dinner Honoring Labor Leaders," January 13, 1981, Public Papers of the Presidents, Book III, p. 2885; "Farewell Address to the Nation," January 14, 1981, Public Papers of the Presidents, Book III, p. 2892; "Keynote Speech delivered at the meeting of the Organization of American States in Washington, DC," The Carter Center, January 25, 2005, http://www.cartercenter.org. 
"Without trying to impose our will on other nations, let us continue to hold high the torch of liberty and democracy that has illuminated our land." was to be conducted by "laying aside arrogance and false pride." Americans need to confess their shortcomings. "We don't claim to be perfect or holy," said the evangelical president from Georgia. "We've got our own problems in this country."159 "We are not a nation of infallibility"; "We all know of the fallibility of man."160 "We have had our faults. We have had our failures. The United States is not a perfect nation."161 These are more than the musings of a liberal internationalist trying to come to terms of declining American power. They are efforts by an evangelical president who tried to convince the country of the reality of original sin and to need to return to first principles.

To lead, the United States and the "great democracies" of the world, Carter affirmed, have to model it too, setting "sterling examples."162 "The best way, I think, to

${ }^{158}$ Carter, "National Day of Prayer Proclamation," September 22, 1980, Public Papers of the Presidents, Book II, p. 1858.

${ }^{159}$ Carter, "Remarks at the Democratic National Committee's Quarterly Meeting," October 7, 1977. Public Papers of the Presidents, Book II, p. 1749; "Remarks and Question-and-Answer Session at a Town Meeting in Shimoda, Japan," June 27, 1979, Public Papers of the Presidents, Book II, p. 1176; "Remarks and Question-and-Answer Session at a Townhall Meeting in Dolton, 1llinois," October 16. 1979, Public Papers of the Presidents, Book II, p. 1953; "Remarks at the Conference on Security and Cooperation in Europe Commemorating the Fifth Anniversary of the Signing of the Final Act in Helsinki," July 29, 1980, Public Papers of the Presidents, Book II, p. 1438.

${ }^{160}$ Carter, "Remarks and Question-and-Answer Session with Student Leaders." February 15, 1980, Public Papers of the Presidents, Book I, p. 325; "'Law Day' Address at the University of Georgia in Athens, Georgia," May 4, 1974, www.jimmycarterlibrary.org.

${ }^{161}$ Carter, "Remarks at a White House Reception for Delegates to the Democratic National Convention," July 19, 1980, Public Papers of the Presidents, Book II, p. 1382; "Remarks at a Dallas County Democratic Committee Voter Registration Rally in Dallas, Texas," July 21, 1980, Public Papers of the Presidents, Book II, p. 1392.

${ }^{162}$ Carter, "Remarks at the Opening of the Human Rights Defenders Policy Forum in Atlanta. Georgia," May 23, 2006, http://www.cartercenter.org. 
induce other people to adopt our own persuasion in democratic principles is to make our own system work." "63 Unfortunately, "as a nation, we have not always had the courage of our professed convictions when they have appeared to threaten our self-interest or convenience"; Americans must "examine the human rights record of our own country." "High human rights standards can be maintained in many other countries only if we Americans remain true to our ideals." "64 "We can hardly clamor for justice in other parts of the world if we will not pledge to provide justice for our own citizens. ${ }^{.165} \ln$ effect, Carter was using Jesus' response to those who wanted to judge and punish others for violating God's law. For in the same passage that one finds the "Judge not" injunction are the following words that justify why one should not judge:

How can you say to your brother, 'Let me remove the speck from your eye'; and look, a plank is in your own eye? Hypocrite! First remove the plank from your own eye, and then you will see clearly to remove the speck from your brother's eye. (Matthew 7:4-5)

"I want to make sure," Carter insisted, "that we eliminate in our own country those vestiges of hatred or discrimination or deprivation of human rights that we still retain so

${ }^{163}$ Carter, "Interview with John Hart of NBC News," March 28, 1976, in Pippert, The Spiritual Journey of Jimmy Carter, p. 101. Carter has written several pieces offering suggestions how the United States can improve its democracy. See "Let 'Motor Voter' Pick Up Lost Souls," Los Angeles Times, June 18, 1992; "Peru Can Give U.S. Lessons on How to Hold Elections," Atlanta Journal-Constitution, April 22, 2001; "Still Seeking a Fair Florida Vote," Washington Post, September 27, 2004; "U.S. Should Join the World in Halting Juvenile Executions," USA Todoy, October 13, 2004; Carter and James Baker, "Interview with Margaret Warner," PBS Newshour with Jim Lehrer, September 19, 2005, transcript available at http://www.pbs.org/newshour/bb/politics/july-dec05/reform 9-19.html; signatory to "Torture is a Moral Issue" advertisement sponsored by the National Religious Campaign Against Torture that appeared in New York Times, June 13, 2006; "We Need Fewer Secrets," Washington Post, July 3, 2006.

${ }^{164}$ Carter and Dominique de Menil, "USA Can't Point Finger at Others on Human Rights," USA Today, December 10, 1992.

${ }^{165}$ Carter, "U.S. Finally Ratifies Human Rights Covenant," Christian Science Monitor. June 29, 1992 
that when we criticize other countries, or when we do speak out to deplore the loss of those rights in other nations, that we, ourselves, might be free of justified criticism. " Americans must ask of their own government. Carter urged, "how do we appear to our own people, how do we appear to observers from other nations?" in dealing with human rights. As the United States promotes human rights and democracy, Carter admonished, "we had better get our own houses in order, we had better make a good image available to the outside world. ${ }^{167}$ If foreign observers wanted to come and investigate the state of human rights in the United States, Carter said "so be it." Regardless of the consequences, "I think [promoting human rights] is the right thing to do. If it hits ourselves as self-criticism, so be it. If it touches the Soviet Union and they interpret it as intrusion, so be it." 168 According to Carter, "No country should be offlimits for criticism." 169

While such principles may appear paradoxical and hypocritical to many observers, Carter saw no conflict. As president, he believed he could maintain alliances with the dictatorships of Iran, the Philippines, and Nicaragua. negotiate with the Soviet Union and China, and simultaneously promote human rights, and remain consistent with the teachings of Jesus. The saint can associate with sinners with the hope of

\footnotetext{
${ }^{166}$ Carter. "Remarks and Question-and-Answer Session with Employees at the Department of State." February 24, 1977, Public Papers of the Presidents, Book I. pp. 237-238.

${ }^{167}$ Carter, "The President's News Conference," June 13. 1977. Public Papers of the Presidents, Book I. p. 1107.

${ }^{168}$ lbid.

${ }^{169}$ Carter, "Statement to the U.N. Human Rights Council," March 29, 2007, http www.cartercenter.org.
} 
redeeming them, while at the same time keeping himself sinless. ${ }^{170}$ Even dictators. he seemed to believe, are not beyond redemption. They, too, need to be offered an open hand. Rather than branding unseemly leaders and states as ultimate villains or an "axis of evil," rather than isolating them and working to undermine them, Carter believed. that when and where possible, they should be engaged and exposed to direct moral suasion. ${ }^{171}$ In fact, he says, no country, not even the United States, is immune to evil. "There's evil in all countries." 172 Besides, he said, negotiating with "unsavory characters" is the very purpose of negotiation. He rhetorically asked, if one refuses to negotiate with dictators, "With whom do you negotiate? With leaders who are at peace? With leaders who are eager to give their people democracy? With leaders who are willing to honor all the elements of human rights? With leaders who are not abusive? You know, there's nothing to negotiate."173

At the heart of this diplomatic style, Bourne believed, was Carter's commitment "to the Christian doctrine of love," and Christian love "does not distinguish between the

\footnotetext{
${ }^{170}$ Patrick Anderson, Electing Jimmy Carter: The Campaign of 1976 (Baton Rouge, LA: Louisiana State University Press, 1994), p. 2; James and Marti Hefley, The Church that Produced a President (New York: Wyden Books, 1977), p. 250. Speechwriter Anderson made this observation. He said that Carter presented the image of a saint, yet surrounded himself with sinners, such as Powell, Jordan, and Rafshoon. The Hefleys note that "Jesus also chose his inner circle from outside the religious establishment." So if it is true that Carter aimed to model himself after Jesus as he claimed then one should not be surprised that Carter would be at ease with having advisors who were competent than righteous. Carter could be righteous enough for all of them.

${ }^{171}$ An illustration of this can be found in Carter's views on Cuba, see Carter, Our Endangered Values: America's Moral Crisis, pp. 102-105; Stein, "Book Review of Douglas Brinkley's The Unfinished Presidency," Middle East Quarterly (September 1999).

${ }^{172}$ Carter, "Interview with Jane O. Hansen," Atlanta Journal-Constitution, December 8, 2002.

${ }^{173}$ Carter, "Interview with Katie Couric," NBC's Today, October 8, 2004, http://www.msnbc.msn.com/id/6138962/.
} 
worthy and unworthy, or between friends and enemies. ${ }^{.174}$ Instead, Christian love is the promotion of "redemptive goodwill." For Carter's perspective, this was the source of and motivation for preventive diplomacy.

One last time before the November vote. he pleaded to his fellow Americans to join him on the course he had set:

To stay strong, to stay at peace, to raise high the banner of human rights. to set an example for the rest of the world, to let our deep beliefs and commitments be felt by others in other nations, is my place for the future. I ask the American people to join me in this partnership.

It was a call that went unheeded. With his defeat, from the Carterian perspective, the country under his predecessors returned to normalcy-reliance on hard power. exhibitions of national arrogance and pride without self-reflection and selfimprovement, and the worship at the altar of the god of war at the expense of the Prince of Peace. For the next four presidencies, there were to be no more Camp Davids and no more claims from presidents that the blood of American soldiers had not been spilled. Carter took his 1980 defeat hard not simply because he was politically ambitious and wanted to win for winning's sake, but because he feared what a Reagan victory might mean for the country. His faith in the people to respond to his foreign policy aims had proven misplaced. "Democrats as well as Republicans and liberals as well as conservatives," explained Kaufman, rejected Carter’s foreign policy approach and style. ${ }^{176}$ Once again, as the Bible might say, a prophet was rejected by his own.

\footnotetext{
${ }^{174}$ Bourne. Jimmy Carter: A Comprehensive Biography from Plains to Postpresidency: p. 495.

${ }^{175}$ Carter. "Remarks at the 1980 Presidential Debate with Governor Ronald Reagan." October 28. 1980. Public Papers of the Presidents, Book III. p. 2501.

${ }^{196}$ Kaufman. The Presidency of James Earl Carter. Jr. . p. 50.
} 


\section{"Blessed Are the Peacemakers":}

\section{Carter's Mission and Vision for Middle East Peace}

"There is no other single item that has addressed my attention as President, on which I've spent more time, more effort, more study, more prayer, than to bring peace to Israel and her neighbors."

"I will do everything in power to make our nation an agent of peace in the Middle East; a just and lasting peace that will be in keeping with the teaching of Scripture."2

As president, Carter said, "I pledged to work tirelessly for peace." "Peace is

my passion," he claimed, "join in with me in a crusade to keep this Nation on the road

to peace." "Peace is what we want. Peace is what we have maintained. Peace is a

prerequisite for progress. Peace is a policy of our country." "Real moves toward

' Jimmy Carter, "Remarks and Question-and-Answer Session at the Foreign Policy Conference for Editors and Broadcasters," February 22, 1979, Public Papers of the Presidents, Jimmy Carter, Book I (Washington, DC: United States Government Printing Office, 1981), p. 313; "Remarks and Questionand-Answer Session with Editors and News Directors," September 22, 1978, Public Papers of the Presidents, Book II, p. 1590; "Remarks at President's News Conference," February 12, 1979, Public Papers of the Presidents, Book I, p. 263; "Remarks at President's News Conference," February 27, 1979. Public Papers of the Presidents, Book I, p. 346.

${ }^{2}$ Carter, "Remarks on Middle East Policies in Elizabeth, New Jersey," June 6, 1976, The Presidential Campaign 1976: Jimmy Carter (Washington, DC: United States Government Printing Office, 1978), p. 221.

${ }^{3}$ Carter, "Remarks at the National Conference for the AFL-CIO Building and Construction Trades Department," April 1, 1980, Public Papers of the Presidents, Book I, p. 579; "Transcript of News Conference Held by President-Elect Carter in Plains, Georgia," New York Times, November 5, 1976, 14.

${ }^{4}$ Carter, "Foreign Policy Radio Address to the Nation," October 19, 1980, Public Papers of the Presidents, Book III, p. 2340; "Remarks at a Campaign Rally in Granite City, Illinois," November 3 , 1980, Public Papers of the Presidents, Book III, p. 2663; "Remarks at a Campaign Rally in Portland, Oregon," November 3, 1980, Public Papers of the Presidents, Book III, p. 2675.

${ }^{5}$ Carter, "Remarks at a Campaign Rally in Fort Worth, Texas," November 1, 1980, Public Papers of the Presidents, Book III, p. 2640. 
peace demand bold actions by leaders. ${ }^{-7}$ Carter sought to bring such passion and boldness to the Middle East. He aimed to pursue Middle East peace "aggressively" and "put his prestige on the line. ${ }^{.8}$ Carter pledged he would "never let the fear of failure be an excuse for not trying."

No global problem. Carter explained, is "more important than finding peace in the Middle East. ${ }^{10}$ The Holy Land is "a tinderbox. ${ }^{.11}$ In his presidential memoir. Keeping Faith. he noted that he came to "realize that I spent more of my time working for possible solutions to the riddle of Middle East peace than on any other international problem."12 Bringing peace to Israel, specifically, was "a major goal of my life."13 He has said it has bee a constant "on my agenda, and on my mind."

\footnotetext{
"Carter. "Address before the World Affairs Council of Philadelphia," May 9. 1980. Public Papers of the Presidents. Book I, p. 871 .

${ }^{7}$ Carter. "Middle East Accord Offers 'Best' Chance for Peace," USA Toda:, November 3. 2003.

${ }^{8}$ Carter. "Interview with Bob Edwards," National Public Radio 's Morning Edition. February 25. 2003. available at http. www.npr.org programs morning transcripts 2003 teb 030225 .edwards.html: "Interview with Bob Edwards." National Public Radio 's Morning Edition. September 17. 2003. available at http: Www npr.org programs morning transcripts 2003 sep 030917 carter html.

${ }^{9}$ Carter. "Interview on the $25^{\text {th }}$ Anniversary of the Carter Center." April 5, 2007. http: www caltercenter.org.
}

${ }^{10}$ Carter. "Remarks at the Meeting of the General Council of the World Jewish Congress." November 2. 1977. Public Papers of the Presidents, Book II, p. 1954.

${ }^{11}$ Carter. "Stop the Band-Aid Treatment: We Need Policies for a Real. Lasting Middle East Peace." Washington Post, August 1, 2006; "The Choice for Israelis." Washington Post, September 23. 2003.

12 Carter, Keeping Faith: Memoirs of a President (Fayetteville, AR: The University of Arkansas Press. 1995: originally published in 1982), p. 438.

${ }^{13}$ Carter, "Interview with Wolf Blitzer." CNN"s The Situation Room. January 19. 2007: "Remarks at Brandeis University in Waltham. Massachusetts." January 23. 2007. http: WWw cartercenter.org: "Interview with Jennifer Siegel," Jewish Daily. Forward, November 16. 2006. http: www forward com/articles/carter-discusses-new-book-on-lsrael-and-the-middle: "Remarks at Mansfield College. Oxford University, United Kingdom." June 21, 2007: http: www cartercenter.org.

${ }^{14}$ Carter, Keeping Faith, p. 280. 
$[P]$ eace in the Middle East for Israel, and I would say justice for the Palestinians, has been a burning issue with me ever since even before I was inaugurated as president... And it still is. ${ }^{15}$

One of the deepest commitments I ever made in public life and private life... has been to bring peace to the Israelis and peace and justice... to their immediate neighbors. I devoted a large portion of my administration to that and formed a treaty between Israel and Egypt. ${ }^{16}$

It is often said that Carter's greatest accomplishment as president was his mediation of the 1978-1979 Camp David peace accords between two old enemies, Israel and Egypt. ${ }^{17}$ It was the first such peace agreement between these two old nations in "some 3,000 years."18 As Jack Germond and Jules Witcover explained, Camp David was a rare case of where presidential "words and good intentions" became a reality in "a remarkable achievement for peace." "Camp David," wrote Burton Kaufman, "was hailed throughout the world as a monumental diplomatic accomplishment," a "personal triumph" for Carter and "his administration's crowning achievement." ${ }^{, 20}$ Carter, said

${ }^{15}$ Carter, "Interview with Larry King," CNN's Larry King Live, December 12, 2003; Palestine: Peace Not Apartheid (New York: Simon and Schuster, 2006), p. 11; "Interview with Riz Khan," Al Jazeera. December 12, 2006; "Remarks at Mansfield College, Oxford University, United Kingdom," June 21. 2007.

${ }^{16}$ Carter, "Interview with Chris Matthews," MSNBC's Hardball with Chris Matthews, October 18, 2004.

${ }^{17}$ Bob Chaundy, "Profile: Jimmy Carter," BBC News, October 11, 2002, htttp://news.bbc.co.uk/2/hi/americas/2296467.stm; "President, peacemaker, peanut farmer," CNN.com. October 10, 2002, http://edition.cnn.com/2002/US/South/10/10/carter.profile/index.html; Richard G. Hutcheson, Jr., God in the White House: How Religion Has Changed the Modern Presidency (New York: Collier Books, 1988), p. 127; Adam Clymer, "Camp David at Top in U.S. Policy Poll," New York Times, April 1, 1985.

${ }^{18}$ Aase Lionaes, "Presentation Speech at the 1978 Nobel Peace Prize Ceremonies in Oslo, Norway," December 10, 1978, http://nobelprize.org.

${ }^{19}$ Jack Germond and Jules Witcover, "It's a shame Carter can't play role in Middle East," Atlanta Journal-Constitution, April 8, 1985, A10.

${ }^{20}$ Burton I. Kaufman, The Presidency of James Earl Carter, Jr. (Lawrence, KS: University Press of Kansas, I993), p. 117. 
Aase Lionaes in his presentation speech at the 1978 Nobel Peace Prize ceremonies, was "the masterbuilder" of the peace accords. ${ }^{21}$

Immediately after his election in 1976. Carter was hopeful that his administration could "help to alleviate problems in the Middle East" and negotiate "a general agreement. ${ }^{22}$ After becoming president, the search for peace in the Middle East indeed became a top priority. As evinced by his invitation and meetings with "key Middle East leaders" in Washington "to discuss prospects for a strong effort toward lasting peace" within the first few months of his administration. working for peace in the Middle East was "one of my earliest acts as president." ${ }^{23}$ Toward the close of his term in office. he informed audiences. "There is no other single issue on which I spent more time or more effort. On one occasion. as you know. I have abandoned, to a major degree, my other duties to go into relative seclusion at Camp David for 13 days. " 24 Then, as in his post-presidential years, he said Camp David was his proudest achievement and was his hope that "the history books... will say that President Jimmy" Carter was able to contribute to a comprehensive peace in the Middle East. ${ }^{1.25}$ Camp

21 Lionaes. "Presentation Speech at the 1978 Nobel Peace Prize Ceremonies in Oslo. Norway." December 10. 1978.

"Carter. "Transcript of News Conference Held by President-Elect Carter in Plains, Georgia." Vew York Times, November 5. 1976. 14.

"Carter, "Can Peace Still Come to Israel?" Atlanta Journal-Constitution. December 12. 1995: "Remarks at the $25^{\text {th }}$ Anniversary Reunion of the Camp David Accords held in Washington. DC." September 17. 2003. http: 'Www. cartercenter.org.

${ }^{24}$ Carter, "White House Briefing on Administration Policies, Remarks to a Group of Civic and Community Leaders from New York," March 11. 1980, Public Papers of the Presidents. Book I. p. 459.

${ }^{25}$ Carter. "Interview with UBS Wealth Management," July 2005. http: www.cartercenter.org: "Remarks and Question-and-Answer Session at a Townhall Meeting in 1ndependence. Missouri." September 2. 1980. Public Papers of the Presidents, Book II. pp. 1625: see also "Remarks at the Annual Conference of the American Federation of Teachers in Detroit, Michigan." August 22. 1980. Puhlic Papers of the 
David was more than "a weekend retreat" for Carter; "it's a symbol."26 It became his model for his subsequent post-presidential peacemaking activities at the Carter Center. Reflecting on the original intention for the Center, he said "its facilities would be used as was Camp David when I negotiated a peace agreement between Israel and Egypt. ${ }^{-27}$

Former President Richard Nixon described Carter's efforts as "one of the greatest American diplomatic achievements of the postwar [World War II] period," and he strongly recommended that future presidents follow his example. ${ }^{28}$ President Ronald Reagan said he "hoped to build on the peace process in the Middle East that had been started by Jimmy Carter at Camp David." 29 While he praised George H.W. Bush for merely starting talks in the Middle East and generically acknowledged Gerald Ford's "wise leadership," President Bill Clinton described Carter's Camp David efforts as a tangible contribution, a "miracle," and said it was the foundation for the 1994 IsraeliJordanian peace treaty. ${ }^{30}$ Even foreign observers noted the importance of Carter's

Presidents, Book II, p. 1562; "Remarks at the B'nai B'rith International Convention," September 4, 1980 , Public Papers of the Presidents, Book II, p. 1655.

${ }^{26}$ Carter, "Remarks at the 1988 Democratic National Convention in Atlanta, Georgia," July 18, 1988, transcript from Atlanta Journal-Constitution.

${ }^{27}$ Carter, "A 20"th Anniversary Q\&A with President Carter," October 10, 2002, http:/www.cartercenter.org; "Interview with Patricia Miotto," The Voice of Success (March 2006), p. 2.

${ }^{28}$ Richard Nixon, 1999: Victory Without War (New York: Pocket Books, 1989), pp. 276-277.

${ }^{29}$ Ronald Reagan, An American Life: The Autobiography of Ronald Reagan (New York: Simon and Schuster, 1990), p. 407.

${ }^{30}$ Bill Clinton, "Remarks at a Dinner Honoring Former Presidents," September 13, 1993, Public Papers of the Presidents, Book II, p. 1484; "Remarks on Departure for the Middle East." October 25, 1994, in Public Papers of the Presidents, Book II, p. 1868; "Exchange with Reporters Abroad Air Force One." November 5, 1995, in Public Papers of the Presidents, Book II, p. 172I; "Remarks at the Opening of the Summit of the Peacemakers in Sharm al-Sheikh, Egypt," March 13, 1996, in Public Papers of the Presidents, Book I, p. 436; "Remarks on Presenting the Presidential Medal of Freedom to Former President Jimmy Carter and Rosalynn Carter in Atlanta, Georgia." Weekly Compilation of Presidential Documents, August 16, 1999, transcript from http://www. findarticles.com (accessed May 21, 2006). 
Mideast work. An advisor to British Prime Minister James Callaghan said the Camp

David Accords represented "a great effort of personal diplomacy on the part of Jimmy

Carter and one which will, I think, be seen as the high point of his Presidency." 31

It is argued here that Carter's role as facilitator, partner, and mediator in the

Camp David peace process was largely driven by profound religious convictions and his faith helped build trust with the parties involved. This was an instance where the faith of religious-styled president "moved mountains" and forged friendships. While security and strategic concerns certainly were important and his position as president of the United States did set perimeters for action, Carter was motivated by a deeply held religious belief that it was his moral obligation to pursue not just peace, but peace in the Holy Land: "That is my prayer.,"32

Though ignored by many and doubted by some, ${ }^{33}$ religion, in Carter's words, "can be significant for peacemaking" and the Camp David accords would have been unthinkable without it; it was a crucial dimension of his statecraft. ${ }^{34}$ Though he knew attaching so much personal commitment to the process "carried high political risks"

31 Tom McNally, "The Carter Years," International Affairs 59.3 (Summer 1983): 468.

${ }^{32}$ Carter, "Remarks at the $25^{\text {th }}$ Anniversary Reunion of the Camp David Accords held in Washington, DC," The Carter Center, September 17, 2003, http://www.cartercenter.org.

3.3 Though he conceded that "a common interest in religion seems to have served at least as a diplomatic lubricant among" Carter, Sadat, and Begin, Leo P. Ribuffo denied that Carter's faith played much of a role in his pursuit of a negotiated Middle East settlement. Ribuffo wrote, "To be sure, his Middle East policy derived less from theology than from geopolitics and personal affinities." See "God and Jimny Carter," in Transforming Faith: The Sacred and the Secular in Modern American History, eds. M.L. Bradbury and James B. Gilbert (New York: Greenwood Press, 1989), p. 152. Tom Princen argued that ultimately Carter acted on the basis of protecting American interests, "to salvage his presidency," resorting to the use of "hard-bargaining" and "carrots and sticks." "Camp David: Problem-Solving or Power Politics as Usual?" Journal of Peace Research 28.1 (1991): 65-68.

${ }^{34}$ Carter, "Foreword," in Religion, the Missing Dimension of Statecraft, eds. Douglas Johnston and Cynthia Sampson (New York: Oxford University Press, 1994), p. vii. 
with "certainly no guarantee of success," it was Carter's faith that provided the foundation for and force behind what Jules Witcover called his "sheer grit,

determination and unexpected diplomatic skill" in reaching "a remarkable breakthrough in the long impasse between Israel and Egypt."35

\section{Why Camp David Succeeded}

"I thought the single most thrilling moment of the four years was the day that Sadat and Begin, under the president's leadership, agreed to the Camp David accords and the Egyptian-Israeli peace treaty." 36

---Vice President Walter Mondale

"Mr. President, you're not just a deacon anymore, but a pope!"37

---House Speaker Tip O`Neill

There is widespread agreement that the 1978 Camp David Accords and

subsequent 1979 Egyptian-Israeli peace treaty would not have been possible without the diligence and passion of President Carter. Though he had his doubts about the chances of success going into Camp David, he made it clear, "I intend not to fail."

According to Kenneth Stein, a former director of the Carter Center, Camp David was possible because of Carter's tireless commitment to Middle East peace and his

\footnotetext{
${ }^{35}$ Carter, "Remarks at the B'nai B'rith International Convention," September 4, 1980. Public Papers of' the Presidents, Book II, p. 1657; Jules Witcover, Party of the People: A History of the Democrats (New York: Random House, 2003), p. 605.

${ }^{36}$ Mondale, "Interview with Wolf Blitzer," CNN's The Situation Room, January 19, 2007. This portion was aired on CNN's Late Edition, January 21, 2007.

${ }^{37}$ Carter, Keeping Faith, p. 435.

${ }^{38}$ Zbigniew Brzezinski, Power and Principle: Memoirs of the National Security Adviser, $1977-1981$ (New York: Farrar, Straus, and Giroux, 1983), pp. 254, 258.
} 
"unprecedented" focus on personally "resolving one international problem." ".Success at Camp Darid was due to Carter`s commitment to see Egyptian-Israeli negotiations reach a conclusion." Additionally: Stein continued. Carter succeeded because he "displayed an extraordinary command of detail and stamina" and possessed a "dogged determination and faith" that motivated him "to find compromises when others might have willingly and easily relented." "Whithout those qualities. the Camp David Accords would not have been signed." he concluded. ${ }^{39}$ (Ironically, after his resignation from the Carter Center over differences with 2006 Carter`s book. Palestine: Peace. Not Apartheid. he subsequently claimed that Carter`s success was more ordinary. less heroic, more lucky and just "fortunate".) ${ }^{40}$

Carter`s National Security Advisor Zbigniew Brzezinski judged Camp David a success because President Carter took "a huge step" to immerse himself in the details of the issues between Israel and Egypt and of the wider region. and he was willing to put "the credibility of American leadership" and his presidency on the line. ${ }^{+1}$ " Without Carter`s persistence, dedication. grasp of the issues but above all persistence. willingness to press both. there would have been no accord. ${ }^{*+2}$ "I must say." Brzezinski wrote in his memoirs. Carter "is driving himself mercilessly. spending most of his time

\footnotetext{
\$9 Kenneth W. Stein. Heroic Diplomacy: Sadat. Kissinger. Carter, Begin, and the Quest for Arub-Israeli Peace (New York: Routledge. 1999). p. 252.

${ }^{\text {to }}$ Stein. "My Problem with Jimmy. Carter`s Book." .Middle East Quarterly (Spring 2007). p. 6. http: www.meforum.org.

${ }^{41}$ Brzezinski. "Interview with Neal Conan." Vational Public Radio's Talk of the Vation. September 16. 2003, available at http: WwW.npr.org programs totn transcripts 2003 sep 030916 .conan.html.

42 Brzezinski, "Interview with Ray Suarez." PBS Yewshour. October 11. 2002. http: www pbs.org newshour bb international july-dec02 nobel 10-11.html.
} 
either debating with the Egyptians or the Israelis or drafting and revising texts that are being submitted to him. He has single-handedly written the proposed document of the Sinai formula." "I "I must say I am immensely impressed by the amount of determination and concentration on detail that the President has been displaying." ${ }^{44}$

Unlike others who attempted to find peace in the region, Carter, Brzezinski continued, provided "genuine presidential leadership." actively engaged, and he played the critical role, the essential role" of unbiased mediation. "He established his credibility of being fair and balanced" to both parties; he was not "an advocate of one side against the other." Though Brzezinski advised and assisted Carter at Camp David, he said that it was Carter "who was carrying the ball and providing leadership and, in a sense, defining the U.S. position." "Unfortunately," Brzezinski concluded, Carter's successors did not provide the presidential leadership to keep the momentum of Camp David going and "the United States has not continued to play the role of a balanced and fair mediator."

Secretary of State Cyrus Vance said Carter's Camp David Summit was "a daring stroke," riddled with the risk of dramatized failure and with nary a presidential precedent. ${ }^{46}$ "Not since Theodore Roosevelt mediated the treaty negotiated in Portsmouth, New Hampshire, that ended the Russo-Japanese War," Vance observed,

\footnotetext{
${ }^{43}$ Brzezinski, Power and Principle, p. 269.

${ }^{44}$ Ibid., p. 264.

${ }^{45}$ Brzezinski, "Interview with Neal Conan," National Public Radio's Talk of the Nation, September 16, 2003.

${ }^{46}$ Vance, Hard Choices: Critical Years in America's Foreign Policy (New York: Simon and Schuster, 1983), pp. 217-218.
} 
"had an American president even approached what Jimmy Carter was about to attempt."

But "when we investigated that parallel," said Vance, "we found it dissimilar, for Roosevelt had remained on Long Island and had not participated directly in the Portsmouth talks himself." Robert A. Strong agrees saying that. unlike other presidents in similar situations, Carter did not simply delegate the finer points of diplomacy to his staff. Rather, he became "both master of the minutiae which preoccupied Begin and a holder of the long-term vision that energized Sadat. ${ }^{-17}$ The only historic equivalent to Carter's efforts, wrote Gaddis Smith, was Woodrow Wilson's high-profile, intimate role at Versailles. ${ }^{48}$ "Not since Woodrow Wilson attended the Paris Peace Conference of 1919 had an American President thrown himself so deeply and personally into diplomatic negotiations... During his Presidency, the Middle East took more of [Carter's] time than any other issue. The fact that he devoted thirty percent of his memoirs to the Middle East. and eighty-five pages to Camp David alone. is an accurate measure of his involvement." According to Bill Moyers" count, during his interview with Carter in November 1978, he said to the President, "The Camp David log showed that you spend 271/2 hours with Sadat and 29 hours with Begin. and 9 hours alone with Sadat and 6 hours alone with Begin, with no one else in the room. ${ }^{-49}$

\footnotetext{
${ }^{47}$ Robert A. Strong, "Shuttle Diplomacy: President Carter in the Middle East," chapter in Working in the World: Jimmy. Carter and the Making of American Foreign Policy. (Baton Rouge. LA: Louisiana State University Press, 2000), p. 206.

${ }^{48}$ Gaddis Smith, "Searching for Peace in the Middle East," chapter in Morality: Reason and Power: American Diplomacy in the Carter Years (New York: Hill and Wang. 1986), p. 165.

${ }^{49}$ Moyers, "Interview with the President," November 13, 1978, Public Papers of the Presidents, Book II. p. 2022.
} 
Carter's National Security Mideast specialist, William Quandt (1977-1979),

explained that although he did not achieve "his more ambitious goals" for the region,

Carter's mediating role at Camp David demonstrated that "determined presidential leadership can help to resolve complex international disputes." "Corter brought the necessary sense of dedication, determination, and decency, and he achieved impressive results. His willingness to become personally involved in the negotiations was important to the outcome." ${ }^{, 51}$ In this regard, compared with other presidents, Quandt judged Carter to be "unique in the depth of his concern to find a peaceful resolution of the conflict between Israel and its Arab neighbors." Above all other issues, it "occupied his time and energies." ${ }^{52}$ As with his focus on the energy issue, Carter focused on the Middle East not because there was a crisis, but to prevent a potential one. ${ }^{53}$

Democratic Majority Leader Jim Wright said Carter was "the glue that held it all together." ${ }^{54}$ He was "the patient, insistent friend who repeatedly kept the other two from flying apart by the centripetal force of rival nationalist ambitions and the political realities ingrained by history."

\footnotetext{
${ }^{50}$ William B. Quandt, Camp David: Peacemaking and Politics (Washington, DC: The Brookings Institution, 1986), p. 29.

${ }^{51}$ Quandt, "Camp David and Peacemaking in the Middle East," Political Science Quarterly 101.3 (1986): 376; Quandt, Camp David, p. 338.

52 Quandt, Camp David, p. 320; Quandt, "Camp David and Peacemaking in the Middle East," p. 361: Quandt, Peace Process: American Diplomacy and the Arab-Israeli Conflict Since 1967 (Washington. DC: The Brookings Institution, 2001; revised edition), p. 240.

${ }^{53}$ Quandt, Camp David, p. 32.

${ }^{54} \mathrm{Jim}$ Wright, Balance of Power: Presidents and Congress from the Era of McCarthy to the Age of Gingrich (Atlanta, GA: Turner Publishing, 1996), p. 307.
} 
Menachem Begin said Carter was "the hardest worker" at Camp David. ${ }^{55}$ The Accords were possible because of his "unforgettably invested unsparing effort. untiring energy and great devotion. ${ }^{.56}$ Carter was "a soldier in the service of peace" whose efforts and commitment "bore God-blessed fruit. ${ }^{-57}$ He was "the architect" of the treaty. 58

In her diary, Rosalynn noted at the time that Israeli Foreign Minister Moshe Dayan told her that the Camp David Accords would not have been possible without her husband"s direct and persistent involvement. She wrote that Dayan believed "there had never been a president in the past willing to devote as much time to an all-out effort as President Carter. He said Nixon wanted to help but he was not willing to put his personal prestige on the line. and without this. the meeting would not have been possible. ${ }^{.59}$ Though doubtful and apprehensive about the prospects for success, stating in fact that "failure seemed so certain" even before the Camp David summit began.

Israeli Defense Minister Ezer Weizman praised Carter"s "bulldoglike persistence." his dedication " day and night to the cause of peace in the Middle East. ${ }^{* 60}$ " As far as I know." he concluded. "no American president has erer helped Israel as much as Jimmy

\footnotetext{
\$5 Menachem Begin. "Interview with Time Magazine." Time. October 2. 1978.

${ }^{56}$ Begin. "1978 Nobel Peace Prize Lecture in Oslo. Norway." December 10. 1978. http: nobelprize.org.

$5^{-}$Begin. "Remarks at the Signing Ceremony of the Egyptian-Israeli Peace Treaty with President Carter and President Sadat." March 26. 1979. Public Papers of the Presidents. Book I. pp. 520-521.

${ }^{58}$ Begin. "Remarks at Dinner with President Carter," April 15. 1980. Public Papers of the Presidents. Book I.p. 692.

${ }^{59}$ Rosalynn Carter. First Lady from Plains (New York: Ballantine Books. 1984). pp. 238-239.

${ }^{60}$ Ezer Weizman. The Battle for Peace (New York: Bantam Books. 1981). pp. 3+1. 362.
} 
Carter."61 Tragically, he believed, "I cannot claim that Israel has responded with appropriate gratitude."

Anwar Sadat said, Carter is "a man of the highest integrity" and deserves everyone's "keenest appreciation" for his involvement. ${ }^{62}$ "If it was not [for] the effort and perseverance of President Carter," peace between Egypt and Israel would not have happened. ${ }^{63} \mathrm{He}$ "was the architect of the entire process. " ${ }^{64}$ Carter, Sadat explained, was "the man who performed the miracle" at Camp David and over the course of following months until the treaty was signed. ${ }^{65}$ The American president, he added, "devoted his skill, hard work, and, above all, his firm belief in the ultimate triumph of good against evil." Carter "is a man of faith and compassion."

We could have never achieved [Camp David] without the help of President Carter...[His] decision to act as full partner was a turning point in the history of this conflict. ${ }^{66}$

Egyptian Vice President Hosni Mubarak, who later succeeded Sadat as president in 1981 after his assassination, said, "Much of the credit for these positive

\footnotetext{
${ }^{61}$ Ibid., p. 382.

${ }^{62}$ Anwar Sadat, "1978 Nobel Peace Prize Lecture in Oslo, Norway," December 10, 1978, http://nobelprize.org.
}

${ }^{63}$ Sadat, "Remarks during Informal Exchange with American Television Correspondents with President Carter on Train Trip from Cairo to Alexandria, Egypt," March 9, 1979, Public Papers of the Presidents. Book I, p. 409; Sadat, "Remarks following Meeting with President Carter in Giza, Egypt," March 10. 1979, Public Papers of the Presidents, Book I, p. 415.

${ }^{64}$ Sadat, "Remarks at a State Dinner Honoring with President Carter and Prime Minister Begin," March 26, 1979, Public Papers of the Presidents, Book I, p. 524.

${ }^{65}$ Sadat, "Remarks at the Signing Ceremony of the Egyptian-Israeli Peace Treaty with President Carter and Prime Minister Begin," March 26, 1979, Public Papers of the Presidents. Book I, p. 519: "Remarks at a State Dinner Honoring with President Carter and Prime Minister Begin," March 26, 1979, Public Papers of the Presidents, Book I, p. 526.

${ }^{66}$ Sadat, "Remarks to Reporters following meeting with President Carter," April 9, 1980, in Public Papers of the Presidents, Book I, p. 623. 
developments goes to you, Mr. President. ${ }^{\circ 67}$ He thanked Carter for his "compassion and understanding." his "vision and a deep sense of commitment." "Lnder your leadership." Mubarak explained, the United States is at last "playing the role which is worthy of a great nation - the role of peacemaker." Israeli Foreign Minister Moshe Dayan said. "Had it not been for you, we couldn"t have done it. ${ }^{.68}$

Scholars with varying views of his presidency could at least agree on a number of personal traits that made Camp David possible. Linda Miller. for example. wrote. "Carter's persistence paid off." He remained involved when others would have given up long before. ${ }^{69}$ Brinkley credited Carter's "tenacity. ${ }^{.70}$ Smith did as well. Carter succeeded, he said. because of his "personal tenacity and capacity for hard work. ${ }^{.71}$ Strong pointed to his "persistence, mastery of detail. a special relationship with Anwar Sadat, and a clear sense of what was possible. ${ }^{.72}$

\section{Middle East Peace Not Easy: But Not Impossible}

As with many other issues. Carter was not afraid to tackle tough issues. issues whose resolution his predecessors had tried but failed to find. He was not afraid to

\footnotetext{
${ }^{67}$ Hosni Mubarak, "Remarks following Meeting with President Carter and Israeli Foreign Minister Dayan." September 17, 1979. Public Papers of the Presidents. Book II. p. 1685.

${ }^{68}$ Moshe Dayan, "Remarks following Meeting with President Carter and Egypt Vice President Mlubarak." September 17, 1979, Public Papers of the Presidents, Book II. p. 1685.

${ }^{69}$ Linda B. Miller. "Shadow and Substance: Jimmy Carter and the Camp David Accords." Pew Case Studies in International Affairs (Washington. DC: Institute for the Study of Diplomacy. 1992). pp.6. 13.

${ }^{70}$ Brinkley, "Interview with Ray Suarez." PBS Newshour. October 11. 2002.

${ }^{7}$ Smith. "Searching for Peace in the Middle East," Morality; Reason and Power. p. 178.

"2 Strong, "Shuttle Diplomacy: President Carter in the Middle East." Horking in the Horld. p. 183.
} 
stoke controversy, be provocative. ${ }^{73}$ Peace in the Middle East was such an issue.

Jimmy Carter was under no illusion that peace in the Middle East would be easy. He recognized that no instant solution was available. ${ }^{74}$

On the campaign trail in I976, Carter asserted, "Peace in the Middle East is not an impossible dream.", As president, in May 1977, he said, "I don't want to mislead anyone. The chances for Middle Eastern peace are still very much in doubt. We have a long way to go."76 In August 1977, he said that when it came to the search for peace in the Middle East, "no one can expect miracles." of the most complicated international questions which has ever been addressed, I guess, in the history of human beings." 78 Three years later, during his reelection campaign, Carter said, "In the real world we know that we cannot expect miracles on the Middle East peace negotiations. The issues are too emotional. The difficulties are too great. The obstacles sometimes appear to be insurmountable."79

${ }^{73}$ Carter, "Interview with Larry King," CNN's Larry King Live, November 27, 2006; "Interview with Judy Woodruff," PBS Newshour, November 28, 2006.

${ }^{74}$ Carter, "Interview with John Mashek of U.S. News \& World Report," May 24, 1976. The Presidential Campaign 1976: Jimmy Carter, p. 202; "Remarks and Interview with a Group of Editors and News Directors," August 26, 1977, Public Papers of the Presidents, Book II, p. 1516.

${ }^{75}$ Carter, "Remarks on Middle East Policies in Elizabeth, New Jersey," June 6, 1976, The Presidential Campaign 1976: Jimmy Carter, pp. 221.

${ }^{76}$ Carter, "The President's News Conference," May 12, 1977, Public Papers of the Presidents, Book I. p. 862.

${ }^{77}$ Carter, "ABC News Interview with Harry Reasoner and Sam Donaldson, Plains, Georgia," August 10 , 1977, Public Papers of the Presidents, Book II, p. I 469.

${ }^{78}$ Carter, "Remarks and Interview with a Group of Editors and News Directors," October 14, 1977, Public Papers of the Presidents, Book II, p. 1800.

${ }^{79}$ Carter, "Remarks at the Annual Convention of the American Legion in Boston, Massachusetts," August 21, 1980, Public Papers of the Presidents, Book II, p. 1555. 
Gaddis Smith observed that since the Truman presidency, U.S. interests

(guaranteed security for Israel, secured Western access to oil, and containment of Soviet influence) have fundamentally remained constant. ${ }^{80}$ Still, peace in the region eluded Carter's predecessors (and his successors). Carter, nevertheless, believed that peace must still be pursued. In an August 1977 interview, he said, "We may or may not be successful, but we're going to continue to try in a very determined and tenacious way." ${ }^{81}$ In spite of the daunting task and the seemingly interminable nature of the conflict, Carter said two weeks later, "We're not going to slacken our effort." 82 To this day, he is firm and consistent in this: peace in the Middle East is "not impossible," but the United States must be actively engaged. ${ }^{83}$

Though it led to more of a "cold peace" than a true peace based on collective trust and friendship, Carter proudly and repeatedly states that after a quarter-century "not a word of that treaty has been violated." peace, what contributed to his emotional endurance, according to Israel President

\footnotetext{
${ }^{80}$ Smith, "Searching for Peace in the Middle East," Morality, Reason and Power, p. 157.

${ }^{81}$ Carter, "ABC News Interview with Harry Reasoner and Sam Donaldson, Plains, Georgia," August 10, 1977, Public Papers of the Presidents, Book Il, p. 1469.

${ }^{82}$ Carter, "Remarks and Interview with a Group of Editors and News Directors," August 26, 1977, Public Papers of the Presidents, Book II, p. 1515.

${ }^{83}$ Carter, "Interview with Wolf Blitzer," CNN's The Situation Room, February 20, 2006; "Interview with Larry King," CNN's Larry King Live, September 13, 2006.

${ }^{84}$ Christopher Dickey and Zvila Krieger, "Egypt and Israel: A Cold Peace," Newsweek International, October 16, 2006, http:/www.msnbc.com; Carter, "Precedents for Mideast Peace," New' York Times, December 23, 2001; "Interview with Tim Sebastian," BBC World New's Hardalk with Tim Sehastiun. December 10, 2002, http://news.bbc.co.uk/1/hi/programmes/hardtalk/2568809.stm; "Remarks at the World Council of Churches' Ecumenical Accompaniment Programme in Palestine and Israel," January 10, 2005, http://www.eappi.org (accessed July 8, 2006); "Interview with Wolf Blitzer," CNN's The Situation Room, February 20, 2006; "Remarks and Question-and-Answer Session at the Council on Foreign Relations," March 2, 2006; "Interview with Larry King," CNN's Larry King Live, September 13.
} 
Yitzhak Navon, was Carter's faith. "You have within you that fountain of living waters from which you can draw a never-failing source of inner faith. ${ }^{185}$ His efforts, Israeli Prime Minister Begin believed, would earn Carter "a higher title than even that of President of the United States." That title would be "servant of peace."

Despite the difficulties of forging regional peace, the amount of time and energy it consumed, the high-stakes summitry, the shuttle diplomacy, the consistent criticisms from the pro-Arab side that he had not gone far enough and the pro-Israel side that he had gone too far, Carter was extremely gratified when the 1979 Egyptian-Israel peace treaty was signed.

"After the signing of the peace treaty," wrote Brzezinski, "the President made it clear to us that he no longer wished to play a highly visible role in Middle East affairs" and "is totally disinterested in any further discussion of Middle East strategy," at least. for the remainder of his first term. ${ }^{87}$ As the 1980 election season approached, Carter became concerned, belatedly, "with increasing difficulties within the Democratic Party" that his leadership style, attitude toward Congress, and policies (including the Middle East) had already engendered. Recognizing that Massachusetts Senator Edward Kennedy would likely challenge him for the party's nomination, Carter began to give

2006; "Telephone Interview with Christopher Dickey of Newsweek," MSNBC.com/Newsweek, October 7, 2006; "Interview with Larry King," CNN's Larry King Live, November 27, 2006.

${ }^{85}$ Yitzhak Navon, "Remarks at Dinner Honoring President Carter in Jerusalem, Israel," March I I, 1979. Public Papers of the Presidents, Book I, p. 419.

${ }^{86}$ Menachem Begin, "Remarks at Dinner Honoring President Carter in Jerusalem, Israel," March 11. 1979, Public Papers of the Presidents, Book I, p. 422.

${ }^{87}$ Brzezinski, Power and Principle, pp. 437-438. 
priority "to damage control at home." $" 88$ Still, as Erwin Hargrove noted, what this shows is Carter's first priority was to pursue an ideal, then to worry about the politics later. ${ }^{89}$

\section{Carter's Middle East Priority}

Table 6.1 shows that Carter made the Middle East a priority early on in his presidency. "One of my earliest acts as president was to invite key Middle East leaders to Washington to discuss prospects for a strong effort toward lasting peace" in the troubled region. ${ }^{90}$ Given the amount of attention the President gave to the issue from the outset, Brzezinski described Carter's first year as "the year of the Middle East."

During his first 100 days, according to the President's daily diary, Carter met with 12 foreign leaders in the White House. He met with the leaders of the country's two largest neighbors, Canadian Prime Minister Pierre Trudeau and Mexican President Jose Lopez Portillo. He met with key U.S. allied leaders, Britain’s James Callaghan and Japan's Takeo Fukuda. He had two meetings with United Nations Secretary General Kurt Waldheim. And he met briefly with leaders from Portugal, Spain. Gabon. and Austria. But most importantly he met with leaders in the Middle East who were among the most crucial to the peace process. He spent more than seven hours with Egyptian President Anwar Sadat, more than six hours with Israeli Prime Minister Yitzhak Rabin.

\footnotetext{
${ }^{88}$ Miller, "Shadow and Substance," p.13.

${ }^{89}$ Erwin C. Hargrove, Jimmy Carter as President: Leadership and the Politics of the Public Good (Baton Rouge, LA: Louisiana State University Press, 1988), p. 169.

${ }^{90}$ Carter, "Can Peace Still Come to Israel?," Atlanta Journal-Constitution, December 12, 1995.

${ }^{91}$ Brzezinski, Power and Principle, p. 235.
} 
and more than five hours with Jordan's King Hussein. From the beginning, Brzezinski said, "Carter plunged himself into the [Middle East] negotiating process."

Quandt said there was no inevitability to Carter's Middle East focus or to peace between Egypt and Israel. 93 "Left to themselves," he said, "they would probably not have found their way to agreement." It was not an issue thrust upon him by outside events; there was no immediate crisis at hand. There was no negotiation momentum to sustain either. President Gerald Ford, Quandt wrote, had not given the Middle East much attention since $1975 .^{94}$ Besides, given the anticipated controversies and passions involvement stirs, he continued, "presidents rarely tackle Middle East issues with much enthusiasm," especially during the election season. ${ }^{95}$ But Carter did, and Quandt believed, the Middle East became one of Carter's "main preoccupations" early on because of his religious faith, his idealism, his penchant to tackle tough, seemingly intractable problems, and his support for human rights. ${ }^{96}$ Though he lacked foreign policy experience, as a self-identified born-again Southern Baptist whose "religion was important to him," Carter came into office with "a great interest in the Holy Land., And to this, thought Quandt, Carter was able to link his domestic priority of addressing the problem of energy - another issue, as we saw in chapter 4 , he cast in unmistakable

\footnotetext{
${ }^{92}$ Ibid., p. 89.

${ }^{93}$ Quandt, Camp David, pp. 4, 30.

${ }^{94}$ Ibid., p. 33.

${ }^{95}$ Ibid., pp. 5, 27

${ }^{96}$ Ibid., p. 30.

${ }^{97}$ Ibid., p. 31.
} 
moral terms. (See Table 6.2 at the end of the chapter for a timeline of key events in the Middle East peace process during the Carter years.)

\section{Table 6.1 Meetings with Foreign Leaders During Carter's First 100 Days}

\begin{tabular}{|c|c|c|}
\hline Hrs Minutes & Foreign Leader & Date(s) \\
\hline $7: 23$ & Anwar Sadat, President of Egypt & April 4-5.1977 \\
\hline 7:09 & Pierre Trudeau, Prime Minister of Canada & February 21-22, 1977 \\
\hline $6: 57$ & James Callaghan. Prime Minister of Great Britain & March 10-11.1977 \\
\hline $6: 39$ & Yitzhak Rabin, Prime Minister of Israel & March 7-8. 1977 \\
\hline $6: 29$ & Jose Lopez Portillo, President of Mexico & February 14-15, 1977 \\
\hline $6: 20$ & Takeo Fukuda. Prime Minister of Japan & March 21-22. 1977 \\
\hline $5: 46$ & Hussein I, King of Jordan & April 25-26. 1977 \\
\hline $2: 22$ & Kurt Waldheim. Secretary-General of the United Nations & $\begin{array}{l}\text { February } 25.1977 \\
\text { March } 17,1977\end{array}$ \\
\hline $1: 13$ & Mario Alberto Soarez, Prime Minister of Portugal & April 21, 1977 \\
\hline $1: 13$ & Adolfo Suarez Gonzalez. President of Spain & April 29, 1977 \\
\hline $1: 11$ & El Hadj Omar Bongo. President of Gabon & March 3. 1977 \\
\hline $0: 25$ & Bruno Kreisky, Chancellor of Austria & March 14. 1977 \\
\hline
\end{tabular}

Source: Compiled by Author from the Daily Diary of President Jimmy Carter, http: "www.jimmycarterlibrary.org documents diary/1977.

\section{Carter's Evangelical Mission and Political Vision for the Middle East}

"Behold, how good and how pleasant it is for brethren to dwell together in unity!",98

Though he clearly recognized that peace in the Middle East would serve U.S.

interests in the region. President Carter believed in a mission for peace. especially in the

\footnotetext{
${ }^{98}$ Carter, "Remarks at a State Dinner Honoring President Sadat and Prime Minister Begin," March 26. 1979. Public Papers of the Presidents, Book I, p. 523.
} 
Middle East, was not only good policy, it was "sacred work," a "sacred task," and a "sacred cause." 99 Duty as a Christian, serving God with boldness - these were key in shaping Carter's view of the world and the Middle East and compelled him toward action. ${ }^{100}$ In late 1979 , for example, citing the authority of the Bible in typical evangelical fashion, he said, "The Bible says, 'Let me hear what God will speak, for he will speak peace to His peace"” and "the Bible also says, 'Depart from evil, do good. seek peace, pursue it—pursue it actively, search for peace.",101

Carter argued that promoting peace in the Middle East, "the land of the Bible." was not a new vision, but an ancient one. ${ }^{102}$ It "exemplified the finest ideals based on the Hebrew scriptures that I have taught on Sundays... since I was 18 years old, where, in the English language version of Hebrew scriptures, the word 'justice' is mentioned 28 times and the word "righteousness' 196 times." 103 It was a crucial part of "trying to find the ideal of Christ: peace on earth." 104 As the prophet Isaiah foretold, Carter explained in his address to the Knesset (March 12, 1979) - the first ever delivered by an

\footnotetext{
${ }^{99}$ Carter, "Remarks at Welcome Ceremony with Egyptian President Sadat in Cairo, Egypt," March 8, 1979, Public Papers of the Presidents, Book I, p. 406; "Remarks at Welcoming Ceremony with President Yitzhak Navon in Tel Aviv, Israel," March 10, 1979, Public Papers of the Presidents, Book I, p. 417; "Remarks at Departure Ceremony with Prime Minister Begin in Tel Aviv, Israel," March 13, 1979. Public Papers of the Presidents, Book I, p. 428.

${ }^{100}$ Princen, "Camp David: Problem-Solving or Power Politics as Usual?", p. 58.

${ }^{101}$ Carter, "Remarks at a White House Reception for Participants at the World Conference on Religion and Peace," September 6, 1979, Public Papers of the Presidents, Book II, p. 1598.

${ }^{102}$ Carter, Keeping Faith: Memoirs of a President (Fayetteville, AR: University of Arkansas Press, 1995: originally published in 1982), p. 280.

${ }^{103}$ Carter, "Remarks at Brandeis University in Waltham, Massachusetts," January 23, 2007.

${ }^{104}$ Carter, "Remarks at the Annual Convention of the National Religious Broadcasters," January 21 , 1980, Public Papers of the Presidents, Book I, p. 181.
} 
American president before the Israeli parliament — that the Camp David project and peace treaty were good-faith steps towards "pounding Middle East swords into plowshares." ${ }^{105}$ Upon his return to the United States, Carter praised Begin and Sadat for "following the advice of the Biblical proverb. "When a man's way pleases the Lord. he maketh even his enemies to be at peace with Him."106 In this, Carter said, "I believe that God has answered our prayers." 107

It is often argued that Carter failed to articulate a broad political vision for his presidency. It is one of the lasting impressions of his four years. He promised too much and took on many issues that were unrelated to a cohesive and coherent program. However, the same cannot be said of his views of the Middle East.

\section{Because It s the Holy Land}

President Carter ignored, wrote Fred Greenstein, "the near-unanimous advice of his aides not to put his prestige on the line for such a high risk cause."108 Given the risks, Carter understood why "Presidents Eisenhower, Kennedy, Johnson, and Ford had apparently tried to avoid any active involvement in Middle East disputes" and showed "restraint." 109 However, with caution, but with his usual confident determination and

\footnotetext{
${ }^{105}$ Carter, "Address Before the Knesset in Jerusalem, Israel," March 12, 1979, Public Papers of the Presidents, Book I, p. 425.

${ }^{106}$ Carter, "Remarks on Arrival with Vice President Mondale at Andrews Air Force Base, Maryland," March 14, 1979, Public Papers of the Presidents, Book I, p. 431.

${ }^{107}$ Ibid., p. 432.

${ }^{118}$ Fred I. Greenstein, The Presidential Difference: Leadership Style from FDR to Clinton (Princeton. NJ: Princeton University Press, 2000), p. 137.

${ }^{109}$ Carter, Keeping Faith, p. 282.
} 
stubbornness to touch what he politically probably should not, his often disregard for sound calls for pragmatism, and his repeated claim that he could prophetically foresee what others could not, Carter wanted to try his hand at brokering Middle East peace. "I had my own ideas about what might be done."110

[T]old by almost every adviser to stay out of the Middle East situation. It seemed that all the proposed solutions had already been tried and failed. However, I could see growing threats to the United States in the Middle East, and was willing to make another try-perhaps overly confident that I could now find answers that had eluded so many others. ${ }^{11}$

I've moved into areas that have been avoided for a long time in the past. I'm not criticizing my predecessors. But the Egyptians and the Israelis have been at war for 30 years. They've been filled with hatred for centuries. And to see now Sadat and Begin sitting down, working out a peace agreement between them, because of action that we took in this country, is gratifying, indeed. $^{112}$

Though Greenstein does not fully explore Carter's motivation to pursue this high-risk adventure that had bedeviled previous administrations, he rightly notes that Carter was "spurred by the knowledge that it was the Holy Land in which he was seeking peace."113 Others have identified Carter's faith as the fundamental source of his motivation as well. ${ }^{114}$

${ }^{110}$ Ibid.

${ }^{11}$ Carter, Keeping Faith, p. 286; "Question-and-Answer Session at a Town Meeting in Queens, New York," September 25, 1979, Public Papers of the Presidents, Book II, p. 1751; "Remarks and a Questionand-Answer Session at a Town Meeting in Nashville, Tennessee," October 9, 1980, Public Papers of the Presidents, Book III, pp. 2135-2136.

${ }^{112}$ Carter, "Interview with Dick Leone of WNET-TV in East Rutherford, New Jersey," October 25, 1979. Public Papers of the Presidents, Book II, p. 2033.

113 Greenstein, The Presidential Difference, p. 137.

${ }^{114}$ See Hutcheson, God in the White House, p. 125; Robert Booth Fowler, Allen D. Hertzke. and Laura R. Olson, Religion and Politics in America: Faith, Culture, and Strategic Choices (Boulder, CO: Westview Press, 1999), p. 118; J.J. Goldberg, Jewish Power: Inside the American Jewish Establishment (Reading, MA: Addison-Wesley, 1996), p. 209. 
More than in any other region. Peter Bourne. Carter`s special assistant on health issues (1977-1978). noted that Carter had long had an abiding interest in. "a passionate affinity." the Middle East. According to Bourne. the source of this "passionate affinity." was "Carter"s religious beliefs and especially his deep knowledge of the Bible made the Middle East a region of unique consequence and interest to him. ${ }^{.15}$

Bourne added that Jimmy Carter was baptized by Royall Callaway, a minister who "held more fundamentalist views than his predecessors" at Plains Baptist Church and who "was a pre-millennialist who preached that the Jews would soon reclaim Palestine and that Christ's return to earth was imminent. ${ }^{-116}$ He also claimed that Carter`s high religiosity likely influenced his preoccupation with the Middle East:

Through his study of the Bible and his regular attendance at Sunday school. Jimmy acquired a broad familiarity with the Holy Land. By the time he was ten years old. he had a greater knowledge about Palestine than he did the rest of America. It seemed a fascinating. exotic place associated with an aura of deep religious reverence. ${ }^{117}$

Majority Leader Wright agreed. He said President Carter enthusiastically engaged the issue because he had a "lifelong interest in the region. stemming from his study of the Bible." 118

In choosing him for the 2002 award. Gunnar Berge of the Norwegian Nobel Committee recognized the power of Carter 's faith in achieving one of the greatest diplomatic successes in the history of U.S. foreign policy:

\footnotetext{
"Is Peter G. Bourne, Jimmy Carter: A Comprehensive Biography from Plains to Postpresidency (New York: Scribner. 1997). p. 382.

${ }^{116}$ Ibid.. p. 31.

${ }^{117}$ Ibid.. p. 32

${ }^{118}$ Wright. Balance of Power, p. 307.
} 
Jimmy Carter only served one term as President of the United States. In a country where such importance is attached to outward success, that has cast a shadow. Carter's principal concern was to do what he felt was right, even when it was not the smartest political step to take...

Our historical perspective enables us to see much more clearly those features of Carter's presidency that were forward-looking. We can see them in the Middle East... The peace between Egypt and Israel was the great triumph of his presidency...

Jimmy Carter sees this as his duty as a Christian... His deep faith goes hand in hand with an exceptional degree of religious tolerance.

Carter's work on so many fronts has been marked by the finest form of Christian optimism. He has often told his Sunday school in Plains that "We'll never know whether something new and wonderful is possible unless we try. Let's scratch our heads, stretch our minds, be adventurous! Serve God with boldness, and who knows what wonders the Lord may work? ${ }^{119}$

Carter was motivated by a belief that as a Christian the pursuit of Middle East peace was obligatory for him. As a candidate, he pledged, "If I become your President. I will do everything in power to make our nation an agent of peace in the Middle East," to pursue "a just and lasting peace that will be in keeping with the teaching of Scripture."120

"The land of Israel," he confessed, "has always meant a great deal to me. As a boy I read of the prophets and martyrs in the Bible.", "The Jewish people are entitled to one place on this earth where they can have their own state on soil given them by God from time immemorial."122 "Our nation's overwhelming support for Israel comes

\footnotetext{
119 Gunnar Berge, "2002 Nobel Peace Prize Presentation Speech in Oslo, Norway," December 10, 2002, http://nobelprize.org/peace/laureates/2002/presentation-speech.html.

${ }^{120}$ Carter, "Remarks on Middle East Policies in Elizabeth, New Jersey," June 6, 1976. The Presidential Campaign 1976: Jimmy Carter, p. 221.

${ }^{121}$ Ibid., p. 216.

122 Ibid., p. 220.
} 
from among Christians like me who have been taught since I was three years old to honor and protect God's chosen people from among whom came our own Christian savior. Jesus Christ." 23 As both candidate and president. he affirmed. "The establishment of the nation of Israel is a fulfillment of Biblical prophecy and the very essence of its fulfillment."

Describing his first visit (or pilgrimage) to Israel in 1973, Carter wrote about being torn about how best to spend his limited time there: "I was torn between the pleasure of visiting the Christian holy places I had longed to see since I was a child and the knowledge that I should be preparing for a future career" and learning about the politics and political personalities of the country. ${ }^{125}$ After leaving, Carter said, "I was excited and optimistic about the apparent commitment of the Israelis to establish a nation that would be a homeland for the Jews. dedicated to the Judeo-Christian principles of peace and justice, and determined to live in harmony with all their neighbors." 126

In his presidential memoirs. Keeping Faith, before he mentioned any other reason for supporting Israel and regional peace, such as the shared democratic values

\footnotetext{
${ }^{123}$ Carter, "Remarks at Brandeis University in Waltham, Massachusetts," January 23. 2007: "Letter to Jewish Community on Palestine: Peace Not Apartheid," December 15, 2006, www cartercenter.org; "Interview with David Postman," Seattle Times, December 13, 2006; "Remarks at Mansfield College. Oxford University, United Kingdom," June 21, 2007.

124 James and Marti Hefley. The Church that Produced a President (New York: Wyden Books. 1977). p. 229: Carter. "Remarks Commemorating the $30^{\text {th }}$ Anniversary of the State of Israel with Prime Minister Begin." May 1. 1978, Public Papers of the Presidents, Book I, p. 813.

${ }^{125}$ Carter, The Blood of Abraham: Insights into the Middle East (Fayetteville. AR: University of Arkansas Press, 1993; originally published in 1985), pp. 21-22; Palestine: Peace Not Apartheid. pp. 2224. During Carter's ten-day visit, he traveled to Jerusalem, Bethlehem, Hebron, Jericho. Nazareth. the Mount of Olives, the Garden Tomb, Cana, Mount Carmel, the Sea of Galilee, the Mount of Beatitudes. Capernaum, Bethsaida, and the Jordan River.
} 
between the United States and Israel or his admiration for their military courage and prowess, Carter cited religious justifications. ${ }^{127}$

In my affinity for Israel, I shared the sentiment of most other Southern Baptists that the holy places we revered should be preserved and made available for visits by Christians, and that members of other faiths should have the same guaranteed privileges concerning their sacred sites.

The Judeo-Christian ethic and study of the Bible were bonds between Jews and Christians which had always been part of my life.

I also believed very deeply that the Jews who had survived the Holocaust deserved their own nation, and that they had a right to live in peace among their neighbors. I considered this homeland for the Jews to be compatible with the teachings of the Bible, hence ordained by God.

"These moral and religious beliefs," Carter concluded, "made my commitment to the security of Israel unshakable."

In The Blood of Abraham, an obviously religious title for his first book on the Middle East, Carter asserted, "For me there is no way to approach or enter Israel without thinking first about the Bible and the history of the land and its people. The names and images have long been an integral part of my life as a Christian."128 In Living Faith, he wrote, "The power of faith is a unifying bond between Christian and Jew and between the heroes of ancient Israel and those of New Testament times." 129 In a 2006 interview with Riz Khan of Al Jazeera, he said, like many Americans, "Ever

\footnotetext{
${ }^{126}$ Carter, Palestine: Peace Not Apartheid, p. 34.

${ }^{127}$ Carter, Keeping Faith, p. 281.

${ }^{128}$ Carter, The Blood of Abraham, p. 29.

${ }^{129}$ Carter, Living Faith (New York: Times Books, 1998; originally published in 1996), p. 37.
} 
since I was 3 years old. I've always looked upon Israel as a people that was blessed by

God through his covenant by Abraham. ${ }^{.130}$

Though such remarks make him theological kin to many evangelicals who view the Jewish people and their ties to the land of Israel similarly. it would be inaccurate to characterize Carter as a typical Christian Zionist. Unlike many pro-Israel evangelicals whose Zionism precludes virtually any positive divine recognition of the Arab people and lands. Carter believes that the Arab people, too, have been blessed by God. heirs to the promise through Abraham and his firstborn son Ishmael, " a founder of the Arab nations in general. ${ }^{\prime 131}$ Therefore. by Carter's reckoning. Egypt. the largest and most powerful Arab country at the time of his presidency, deserved peace and to be at the center of the peace process.

In the Bible. Carter explained. Egypt was often a site of "biblical drama. ${ }^{.132}$ In his chapter on Egypt in The Blood of Abraham, the first thing Carter noted was that Egypt is home to Mount Sinai. "where Moses received the Ten Commandments from God" and where Sadat hoped to build a shrine as a "symbol of peace" for the three great religions of Abraham: Judaism. Christianity. and Islam. ${ }^{133}$

\footnotetext{
${ }^{130}$ Carter, "Interview with Riz Khan." Al Jazeera. December 12. 2006.

1:1 D. Jason Berggren. "Obstacles to an Alliance: Muslims and the Christian Right." Middle East fffuirs Joumal 9.1-2 (Winter Spring 2003): 95-114: "Interview with Riz Khan." Hl Jazeera. December 12. 2006. However. it should be noted that despite their pro-Israel sympathies. most evangelicals have supported an independent Palestine. According to a 2003 Gallup poll. $58 \%$ of Americans supported an independent Palestinian state. But so did $53 \%$ of evangelicals. Gallup analyst Lydia Saad concluded that few Americans $(6 \%)$ fit the profile of Christian Right leader Pat Robertson: "born again. consider Israel a holy land based on biblical prophecy. and oppose the creation of a Palestinian state." Saad. "Holy Land. or Just Ancient?" Gallup Poll Vews Service. July 29. 2003.

132 Carter. The Blood of Abraham. p. 149.

133 Ibid.. p. 143.
} 
Of particular interest to Carter was the biblical role Egypt played as a refuge to the heroes of the Bible. He observed that the Patriarch Abraham took refuge there, as did his grandson Jacob, later renamed Israel. ${ }^{134}$ Even "the family of Jesus," Carter observed, "was forced to seek refuge from the vassal King Herod the Great, who had ordered all male babies around Bethlehem to be killed." The holy family "escaped into Egypt and stayed there until the death of Herod."135 Carter has also noted Egypt's ties to historic Christianity. Specifically, he mentioned that St. Catherine's monastery, "the oldest continuously occupied Christian monastery on earth," is located on the Sinai and that the patron of the old Coptic Church in Egypt is "Saint Mark."136

In his 2002 Nobel lecture, Carter acknowledged the inspiring source of his

Middle East policy and why he sought peace:

The unchanging principles of life predate modern times. I worship Jesus Christ, whom we Christians consider to be the Prince of Peace. As a Jew, he taught us to cross religious boundaries, in service and in love. He repeatedly reached out... I am convinced that Christians, Muslims, Buddhists, Hindus, Jews, and others can embrace each other in a common effort to alleviate human suffering and to espouse peace. ${ }^{137}$

Carter believed that the Bible provides a political vision for the Middle East.

During his first meeting with Prime Minister Begin in July 1977, Carter noted the words of Isaiah, "And the work of righteousness shall be peace, and the effects of

\footnotetext{
${ }^{134}$ Ibid., p. 149.

${ }^{135}$ Ibid., p. 149-150.

${ }^{136}$ Ibid., p. 143, 148.

${ }^{137}$ Carter, The Nobel Peace Prize Lecture (New York: Simon and Schuster, 2003), pp. 16-17.
} 
righteousness, quietness and assurance forever." ${ }^{138}$ In November 1977. before the

World Jewish Congress, Carter said, "The Old Testament offers a vision" of what peace

in the region might entail. Quoting the Prophet Micah at length (1:1-5). Carter said.

But in the last days it shall come to pass, that the mountain of the house of the Lord shall be established in the top of the mountains, and it shall be exalted above the hills; and people shall flow into it.

And many nations shall come, and say, Come, and let us go up to the mountain of the Lord, and to the house of the God of Jacob; and he will teach us of his ways, and we will walk in his paths: and the law shall go forth from Zion. and the word of the Lord from Jerusalem.

And he shall judge among many people, and rebuke strong nations afar off: and they shall beat their swords into plowshares, and their spears into pruninghooks: nation shall not lift up a sword against nation, neither shall they learn war any more.

But they shall sit every man under his vine and under his fig tree: and none shall make them afraid: for the mouth of the Lord of hosts hath spoken it.

For all people will walk every one in the name of his god, but we will walk in the name of the Lord our God for ever and ever. ${ }^{139}$

This vision, Carter concluded, would be his guide and ought to be that of all who wish to see peace in the Middle East. In fact, he said, "it is our duty to walk together toward the fulfillment of this majestic prophecy."

Later that month, in an exchange with reporters as he left the First Baptist Church in Washington, where he had offered a prayer for regional peace from the pulpit at the very time Egyptian President Anwar Sadat made his historic visit to Israel to address the Knesset, Carter explained that his prayer echoed the will and hope of the

\footnotetext{
${ }^{138}$ Carter, "Remarks at Welcoming Ceremony with Prime Minister Begin," July 19. 1977. in Public Papers of the Presidents of the United States, Book II, p. 1282.

${ }^{139}$ Carter, "Remarks at the Meeting of the General Council of the World Jewish Congress." November 2. 1977. Public Papers of the Presidents, Book II, p. 1957.
} 
world for peace, that people in the region were exhausted from war and violence, and that "Christ, our Savior, is the Prince of Peace." 140 He also noted that on this same day Prime Minister Begin, "a very deeply religious man," had "worshipped God in a Jewish temple," and President Sadat had "worshipped the same God in a Moslem mosque" and then "worshipped the same God in a Christian holy place where Christ was buried."1+1 One reporter asked, "You see the hand of God moving in all this, don't you?" This shared faith in God, a faith that Christians, Jews, and Muslims all share, Carter characterized as "an avenue of communication and common purpose" among the disputing parties. Carter also mentioned to members of the press on this occasion that he had similar discussions with Saudi Crown Prince Fahd. In Middle East discussions, a "common religious bond," he said, "provides a possible avenue for peace."

During his visit with President Sadat in February 1978, Carter called his involvement in the Middle East peace process a "sacred mission for peace."142 He said that he and the Egyptian President shared the same vision for the region. "This is the vision that we share."143 Describing the search for regional peace a "calling," citing the Bible's authority and the Biblical honor of being a "son of God," Carter proclaimed, There is no nobler calling on this Earth than the seeking for peace. For it is that reason which caused the Bible to say that peacemakers shall be called the sons of God.

\footnotetext{
${ }^{140}$ Carter, "Remarks during Informal Exchange with Reporters on Departure from the First Baptist Church in Washington, DC," November 20, 1977, Public Papers of the Presidents, Book II, p. 2042.

${ }^{141}$ Ibid., p. 2043.

${ }^{142}$ Carter, "Remarks on the Arrival of President Sadat," February 3, 1978, Public Papers of the Presidents, Book I, p. 274.

${ }^{143}$ Carter, "Remarks on the Departure of President Sadat," February 8, 1978, Public Papers of the Presidents, Book I, p. 290.
} 
At the annual National Prayer Breakfast, in January 1979, looking back over the events of the previous year, Carter cited that several of "most interesting news events of the year...had some religious connotation. ${ }^{1+4}$ Among the events the President cited was the signing of the Camp David Accords. Though conventionally the modern world is considered to be "highly secular," Carter explained that events like Camp David showed that people were still motivated by faith. To begin their 13-day summit. which had been intended to last three days but no more than seven, Carter said that he. Begin, and Sadat prayed for peace and called upon the world to join in their "common prayer for peace." Secretary Vance said, President Carter was determined "at the outset to put the summit on a high plane, reflecting the deep religious faith and humane purposes of the three leaders." 145

In his memoirs, Carter reported that when he left for Camp David. "on Monday. September 4 ...I went... with all my maps, briefing books. notes. summaries of past negotiations, and my annotated Bible, which I predicted-accurately, as it turned outwould be needed in my discussions with Prime Minister Begin.." ${ }^{\circ 6}$ After Camp David, Brzezinski noted. Carter even envisioned that a final peace accord could be signed at "the Monastery of St. Catherine in the middle of the Sinai," the place traditionally believed to be where Moses received the Ten Commandments from God. ${ }^{147}$

\footnotetext{
${ }^{144}$ Carter. "Remarks at the Annual National Prayer Breakfast," January 18, 1979. Public Papers of the Presidents, Book I, p. 59.

${ }^{145}$ Vance, Hard Choices, p. 220.

${ }^{146}$ Carter, Keeping Faith, p. 329

147 Brzezinski, Power and Principle, pp. 274-275.
} 
For his second summit with Begin and Sadat, as Carter prepared to depart for the Middle East in March 1979, Vice President Mondale wished Carter well and cited the Bible's blessing for peacemakers: "There is no challenge more urgent than seeking [Middle East] peace, for as the Bible tells us, it is the peacemakers who are blessed." Upon Carter's arrival in Cairo (March 8), he told Sadat that he was "determined to persevere" in concluding the Egyptian-Israeli peace treaty because "our common dedication, our common determination is rooted in the soil of common religious truth." The President pointed to their shared belief in God and in truth. Though the particular truths of their faith traditions may vary, Carter explained, the "underlying message is the same-it's a message of love, of faith, and of peace." He asked his Egyptian partner to pray with him "in the words of the Christian gospel," for God "to guide our feet into the way of peace."

Two days later (March 10), in his address before the People's Assembly of Egypt, Carter began with the words, "I...come before you in the name of God" and "as a partner" and "friend" of the Egyptian President. In this address, Carter cited the religious texts of Muslims, Jews, and Christians, to remind all of their obligations to God and each other to pursue the age-old hope for peace in the region. Again, Carter invoked images from sacred texts. From the Quran, he used words to encourage Egyptians to reach out to their old adversary Israel: "If thine adversary incline towards peace, do thou also incline towards peace and trust in God, for he is the one that heareth

\footnotetext{
${ }^{1+8}$ Mondale, "Remarks on President Carter's Departure to Egypt and 1srael," March 7, 1979, Public Papers of the Presidents, Book I, p. 394.

${ }^{149}$ Carter, "Remarks at Welcoming Ceremony with President Sadat in Cairo, Egypt," March 8, 1979 , Public Papers of the Presidents, Book I, p. 407.
} 
and knoweth all things." From the Hebrew Scriptures, he cited the words, "Depart from evil and do good; seek peace, and pursue it." He then invoked the famous words of Jesus from his Sermon on the Mount, "Blessed are the peacemakers, for they shall be called the children of God." ${ }^{150}$

Two weeks later (March 25), Carter, Begin. and Sadat issued a joint statement that grounded the occasion in unmistakable religious terms. The statement read:

At the convening of the Camp David summit meeting we issued a communication which stated in part- Conscious of the grave issues that face us, we place our trust in the God of our fathers from whom we seek wisdom and guidance. We request people of all faiths to pray with us that peace and justice will result from these deliberations."

Our trust in God was well-placed. On Monday, a treaty of peace will be signed between Egypt and Israel within the framework of a comprehensive peace settlement in the area. We are grateful to the people around the world who joined us in prayer. We now ask people of all faiths to join again in a day of prayer and thanksgiving for what has been accomplished. and then ask God to guide our nations in the days ahead as we continue to work for a comprehensive, just and lasting peace. With God's help, we and generations to come will know peace between our peoples. To this end, we ask that Monday, March 26, be a day of prayer around the world. ${ }^{151}$

At the signing ceremony the following day, Carter concluded his remarks pointing to his repeated vision for the region. ${ }^{152}$ Quoting the Prophet Isaiah in full. Carter spoke the ancient words: "Nations shall beat their swords into plowshares and their spears into pruninghooks: nation shall not lift up sword against nation, neither shall they learn war any more." He then said, as the prophet foretold, "So let us now

\footnotetext{
${ }^{150}$ Carter, "Address before the People's Assembly in Cairo, Egypt," March 10, 1979, Public Papers of the Presidents, Book I, pp. 412, 414.

151 ."Joint Statement Issued by President Carter, President Anwar Sadat of Egypt, and Prime Minister Menachem Begin of Israel," March 25, 1979. Public Papers of the Presidents, 1979. Book I. pp. 490-491.

${ }^{152}$ Carter, "Remarks at the Signing Ceremony of the Egyptian-Israeli Peace Treaty with President Sadat and Prime Minister Begin," March 26, 1979, Public Papers of the Presidents, Book I, p. 518.
} 
lay aside war." Carter finished his remarks looking ahead to the wider political vision for the region.

Let us now reward all the children of Abraham who hunger for a comprehensive peace in the Middle East. Let us now enjoy the adventure of becoming fully human, fully neighbors, even brothers and sisters. We pray God, we pray God together, that these dreams will come true. I believe they will.

That night, at a dinner honoring Sadat and Begin, President Carter invoked the biblical vision of regional peace and expressed his hope that indeed that vision was coming to pass. "The peace that was born today has a meaning that comes down to us through many years or generations, even centuries." 153 This vision, for Carter, has its origins in Genesis, the Bible's first book.

In ancient days, God promised Abraham that from his seed would come many nations. And as you know, that promise has been fulfilled. Yet for much too long, the people of Israel and the people of Egypt- two of the nations of the children of Abraham, trusting in the same God, hoping for the same peace-knew only enmity between them.

Hopeful that another promise of the Bible was in the process of being fulfilled during his presidency, Carter said, "That time, thank God, is now at an end."

Citing "the vision of the psalmist," Carter said, "Behold, how good and how pleasant it is for brethren to dwell together in unity." "We share a vision of a time when all the people of the Middle East may turn back their energies backs to the works of life," building families, watching their children grow, and living to old age, sustained by "the depth of our common faith in a just and merciful God.", 54

\footnotetext{
${ }^{153}$ Carter, "Remarks at a State Dinner Honoring President Sadat and Prime Minister Begin," March 26. 1979, Public Papers of the Presidents, Book I, p. 522.

${ }^{154}$ Ibid., p. 523.
} 
Quoting the book of Ecclesiastes. a book traditionally attributed to King Solomon. son of David and ancient Israel"s third king. Carter said. "For every thing there is a season. and a time to every purpose under the heaven." And for Carter. the signing of the peace treaty marked "a season of renewal" for the peoples of Egypt and Israel who have had to endure too many centuries of persecution and dominance at the hands of foreign powers. ${ }^{155}$

Together, in the words of Solomon, the peoples of Egypt and Israel experienced "a time to die." of the planted being plucked up. "a time to kill. a time of breaking down. a time to mourn. a time of weeping. a time to lose. a time to hate, and a time for war." For both countries, "we pray that the season of weeping is past" and that they were entering " a time to heal. a time to plant. a time to build up. a time to laugh. a time to dance. a time to embrace. a time to love." "We pray to God." Carter said. "that at last the children of Abraham have come to a time of peace. ${ }^{-156}$

\section{Carter and Sadat: Evangelical Personalism and Political Skill}

"Anwar Sadat was my best friend. He and I were intimate friends. ${ }^{.157}$

To be a successful mediator in bilateral conflicts, the mediator has to be trusted by the two parties. The parties involved must perceive the mediator to be either wholly unbiased or at least not excessively so. The mediator must have an interest in seeing the

\footnotetext{
Is: lbid.

${ }^{156}$ Ibid.. p. 524.

I:- Carter. "Interview with James Laue at the $5^{\text {th }}$ National Conference on Peacemaking and Conflict Resolution in Charlotte. North Carolina." June 7. 1991. in Comersations with Carter. edited by Don Richardson (Boulder, CO: Lynne Rienner Publishers, 1998). p. 285.
} 
conflict resolved. "A mediator who is indifferent over the issue outcomes and just wants to resolve the conflict," wrote Andrew Kydd, "will not be credible." 158 One way a mediator may gain trust is to bond with the parties, such as emphasizing common personal traits, beliefs, and backgrounds. ${ }^{159}$ That is what Carter attempted.

The Mideast conflict for Carter was not merely another puzzle awaiting an engineer's solution or an issue needing resolution for the sake of national interest. He did not view his role and responsibility as an "engineering consultant" who "master[s] the facts and then present[s] his solution," as Tom Princen claimed. ${ }^{160}$ Undoubtedly, he did immerse himself in studying the weighty details of Mideast politics and he clearly recognized that regional peace served U.S. interests. But such factors were available to his predecessors, and they did not engage the issue or "master the facts" like Carter did. And when they did, it was only in the immediate aftermath of a regional war. ${ }^{161}$

What fundamentally motivated Carter, and here Princen is correct, was that he saw international conflict, especially the Middle East conflict, "in very personal terms." He believed that "if protagonists understood each other and appreciated each other's basically good intentions" a reasonable and just solution could be found. ${ }^{162}$ In his relationship with Egyptian President Anwar Sadat and Israeli Prime Minister

\footnotetext{
158 Andrew H. Kydd, "When Can Mediators Build Trust?" American Political Science Review 100.3 (August 2006): 459

${ }^{159}$ Ibid, pp. 450-451.

${ }^{160}$ Princen, "Camp David: Problem-Solving or Power Politics as Usual?", p. 59.

${ }^{161}$ Moshe Dayan, Breakthrough: A Personal Account of the Egypt-Israel Peace Negotiations (New York: Alfred A. Knopf, 1981), p. 197.

${ }^{162}$ Princen, "Camp David: Problem-Solving or Power Politics as Usual?", p. 58.
} 
Menachem Begin. President Jimmy Carter aimed to do just that. From Carter`s perspective, in his preparations for Camp David, he wanted "to understand these men!...I wanted to know all about Begin and Sadat."163 Beyond the issues. Carter believed in was incumbent upon him to know what made these men tick.

What had made them national leaders? What was the root of their ambition? What were their most important goals in life? What events during the past years had helped to shape their characters? What were their religious beliefs? Family relations? State of their health? Political beliefs and constraints? Relations with other leaders? Likely reaction to intense pressure in a time of crisis? Strengths and weaknesses? Commitments to political constituencies? Attitudes toward me and the United States? Whom did they really trust? What was their attitude toward one another?

While he was considering these questions, Carter said that he was convinced they were likewise preparing for him.

Though it did not work particularly well with Begin, he applied what is termed here as "evangelical personalism." With this approach—akin to those of Franklin Roosevelt and Winston Churchill, Ronald Reagan and Margaret Thatcher. and George W. Bush and Tony Blair--Carter forged with Anwar Sadat one of the most successful bonds an American president has had with another international leader. Perhaps. the Carter-Sadat bond was also the most successful ever forged between an American president and a leader of a non-European country. ${ }^{16+}$ This bond contributed to Carter`s successes in the Camp David negotiations. In particular, it gave Carter diplomatic

\footnotetext{
${ }^{163}$ Carter, Keeping Faith, p. 327; Talking Peace: A l'ision for the Next Generation (New York: Puffin Books, 1995; Originally Published in 1993), pp. 10-11.

${ }^{16+}$ Smith, "Searching for Peace in the Middle East." Morality: Reason and Power, pp. 161. 246-247: "Carter's Political Rhetoric," in The Carter Presidency: Fourteen Intimate Perspectives of Jimm. Carter. Portraits of American Presidents, Vol. VIII, edited by Kenneth W. Thompson (Lanham, MD: University Press of America, 1990), p. 214.
} 
leverage over Sadat, who greatly valued their personal friendship, by threatening to withdraw such close ties when the Egyptian President threatened to withdraw from Camp David.

\section{Evangelical Personalism}

As explained in chapter 3, evangelical Christianity is a personalistic faith tradition. It stresses the individual decision to choose God, the confession of one's personal depravity, the development of a strong personal relationship with God through Christ, and the subsequent fellowship with other like believers as "brothers and sisters." Evangelicals tend to publicly share very personal stories about their moral failings, their recognition of their status as sinners, and their decision for Christ. Jimmy Carter, for instance, has frequently admitted and discussed his struggles with pride and has publicly confessed the doubts he had about God and his own commitment to Christ after losing to segregationist Lester Maddox in the 1966 Georgia governor's race. Over the years, too, he has publicly discussed how he could have been a better husband and father.

Like the lay evangelist who canvasses the neighborhood going door-to-door to give a personal witness of Christ with anyone who will listen, Carter believed that open and frank discussion of religion can provide the necessary groundwork for successful diplomacy. It can "remove the obstacles that men create" between one another as individuals and nations. The sharing of faith can be "a binding force" between and among rivals. It can provide an "avenue of communication" and establish a "common 
purpose. ${ }^{165}$ It can be a means of providing intimacy and building trust one heart at a time. While the initial effort may not work, the lay evangelist asks if he/she can come back and share again. Rejections may be many. but a few may respond and invite the witnessing lay person back. But importantly, no person is unworthy of such a visit; all have fallen short and are in need of the personal message of salvation.

In Living Faith. Carter explained that among his "most memorable religious experiences" was the time after his first run for governor, "when I reached out to others in personal witnessing." He said what he enjoyed most about those experiences were "the clear religious atmosphere. the opportunity for binding with others who are different. a deep and difficult challenge. a sense of selflessness. and the faith that our best efforts will be rewarded with success. ${ }^{166}$ However, he noted what his missionary partner. Milo Pennington. told him in 1967 as they prepared for their visits in Pennsylvania. Milo said. "We don"t have to worry about the reception we will get or the results of our efforts. We'll pray a lot. do our best. and depend on the presence of the Holy Spirit to determine the outcome. ${ }^{-167}$ Similarly, years later as president, with little regard for political consequence. Carter believed that if could knock on as many doors as possible, somebody in the Middle East. including the PLO. was bound to let

\footnotetext{
${ }^{165}$ Carter. "Informal Exchange with on Departure from First Baptist Church in Washington. D.C.." November 20. 1977. Public Papers of the Presidents, Book II. p. 2043.

${ }^{166}$ Carter. Living Faith, pp. 211-212. In their study of Carter, Bruce Mazlish and Edwin Diamond were also convinced that Carter's missionary experiences in the late 1960s was likely the source of his "highly personalistic approach to political leadership." "If a religious missionary-or a political leader." they wrote, "' gets down' with the people. feels with them, then he can win them over. convert them. lead them." Mazlish and Diamond. Jimmy. Carter: A Character Portrait (New York: Simon and Schuster. 1979). pp. 160-161.

${ }^{16-}$ Ibid.. p. 212.
} 
him in to share his witness of peace. ${ }^{168}$ There might be failures, few successes, and maybe even a surprise or two; many might turn away, but some might invite him back.

To be successful in a world with leaders with a variety of religious backgrounds, an ecumenical approach was needed. Carter said, "the fellowship of faith is even larger than the Christian world."169 "By the grace of God," no matter one's "cultural, or geographical, or political nature," believers in God are bound together and can become "true brothers and sisters with each other." 170 He also believed that one-on-one meetings could even change the hearts of the most implacable foes and enemies of the United States can be changed or perhaps redeemed. ${ }^{171}$ In the case of the Middle East, he thought there was potential for leader-to-leader fellowship and that those relations could lead to peace in the region. "As children of God and brothers in Christ," Carter said, "I don't doubt the efficacy and ultimate success of our sustained prayers that this dream of ours - for the benefit of Israel, for the benefit of Palestine, and for the benefit of the whole world-can be realized." ${ }^{\text {172 }}$ Though his personalistic approach did not work with every leader he met, it was a crucial part of his presidential style as chief diplomat of the United States.

\footnotetext{
${ }^{168}$ Quandt, Camp David, p. 131.

${ }^{169}$ Carter, Living Faith, p. 36.

${ }^{170}$ Carter, "Remarks at the Opening of the China Bible Ministry Exhibition at the Second Ponce de Leon Baptist Church in Atlanta, Georgia," May 19, 2006, http://www.christianpost.com (accessed June 29, 2006).

${ }^{171}$ Carter, Living Faith, p. 146; Terence Smith, "Winning Trust Was Carter's Principal Aim, and He Did It," New York Times, March 18, 1979.

${ }^{172}$ Carter, "Remarks at the World Council of Churches' Ecumenical Accompaniment Programme in Palestine and Israel," January 10, 2005, http://www.eappi.org (accessed July 8, 2006).
} 


\section{Bonding with Faith}

A key part of President Carter`s foreign policy style was to share his faith or discuss religion with other world leaders and audiences. "I've shared my faith with leaders of Korea, Poland, and other nations that I"ve visited." of faith is a unifying bond." ${ }^{174}$ It can overcome differences and become an avenue by which international relations can be built. It can be a means of communication and a source of conflict resolution. "When people become alienated from one another. it is important to search for a healing force." That "healing force," according to Carter. is "our faith in God" and that can become "a unifying role among believers." It can also be personally satisfying. "As I have come to know, reaching out to others in the name of God can be one of the most deeply rewarding experiences any person can enjoy. ${ }^{.175}$

On one occasion in 1978, he revealed how he bonded with the leaders of India:

A few weeks ago, I was in India. As part of my preparation for meeting with Indian leaders. I read the Bhagavad-Gita and later visited the site where Mahatma Gandhi's body was cremated and thought about his simply. deeply committed life, his knowledge of Christianity and Judaism, his worship of God. the simplicity and humility and sensitivity of his life. And I felt a kinship with him and a kinship with Indian leaders who have not only been our friends in recent years. And as I talked to Prime Minister [Morarji] Desai. this was a common thread that ran through the conversations between us---how we shared something. ${ }^{176}$

\footnotetext{
17 Carter, "Remarks at the Opening of the China Bible Ministry Exhibition at the Second Ponce de Leon Baptist Church in Atlanta, Georgia," May 19, 2006: "Remarks at the Annual Convention of the National Religious Broadcasters," January 21, 1980. Public Papers of the Presidents, Book I. p. 181.

${ }^{174}$ Carter, Living Faith, p. 37.

${ }^{175}$ Ibid., p. 38.

${ }^{176}$ Carter, "Remarks at the Annual National Prayer Breakfast," February 2, 1978. Public Papers of the Presidents, Book I, p. 264.
} 
In his relations with Japanese Prime Minister Masayoshi Ohira, National Security

Advisor Brzezinski observed that "Carter was especially captivated by the fact that Ohira was a practicing Christian."

In his first visit to Israel in 1973, while he was governor of Georgia and preparing for presidential run, Carter was struck by Israel's secularism: There were "few indications of a religious commitment during our visit." 178 Evidently expecting the Jewish state and society to be ostensibly religious and troubled that it was not, he pointedly asked Israeli Prime Minister Golda Meir "if she was concerned about the secular nature of her Labor government." He explained that "I had long taught lessons from the Hebrew Scriptures and that a common historical pattern was that Israel was punished whenever the leaders turned away from devout worship of God." ${ }^{179}$ Prime Minister Meir laughed. After lighting a cigarette, she said that Orthodox Judaism was alive and well and "could assume that portion of the nation's responsibility." (Some Jewish Americans became extremely disturbed when these comments were published in Carter's 2006 book Palestine: Peace Not Apartheid. ${ }^{180}$ However, Carter published much of these same remarks twenty years earlier in The Blood of Abraham. $)^{181}$

${ }^{177}$ Brzezinski, Power and Principle, p. 291.

${ }^{178}$ Carter, Palestine: Peace Not Apartheid, p. 29.

${ }^{179}$ Ibid., p. 32.

${ }^{180}$ See Rick Richman, "The World According to Jimmy Carter," American Thinker, November 14, 2006: Michael D. Oren, "A Religious Problem: Jimmy Carter's Book: An 1sraeli View," Wall Street Journal. December 26, 2006.

${ }^{181}$ See Carter, The Blood of Abraham, pp. 27-28. 
In his preparations before meeting Israeli Prime Minister Yitzhak Rabin in March 1977, Carter met with National Security Advisor Brzezinski. According to his memoirs, Brzezinski noted that the meeting was "one of the best conversations yet" with Carter. "It dealt not only with the Middle East but also the President's religious beliefs, and revealed a lot to me about the man with whom I would work closely for the next four years." 182

In his meeting with Rabin, though it did not go particularly well, Brzezinski recalled that Carter had "tried to charm" the Israeli Prime Minister and "give him some sense of his religious interest in 'the land of the Bible,' and to engage him as a human being."183 Quandt noted this as well. Carter, he said, "gave full vent to his sentimental and biblical commitment to the idea of a Jewish state" when he first met Rabin. Then, he closed their session together "by saying he believed Israel was the fulfillment of biblical prophecy."184 Rabin observed, "In Washington, I found a new president who had visions of curing all the ills of the American people and restoring its faith in the presidency. He was imbued with profound religious conviction and believed that the American electorate had charged him with the mission of carrying through a great metamorphosis in substance as well as in style. $" 185$

\footnotetext{
${ }^{182}$ Brzezinski, Power and Principle, p. 89.

${ }^{183}$ Ibid., p. 90.

${ }^{184}$ Quandt, Camp David, pp. 44, 46

${ }^{185}$ Yitzhak Rabin, The Rabin Memoirs (Reprint and Expanded version of $2^{\text {nd }}$ edition; Berkeley. CA: University of California Press, 1996), p. 292.
} 
With Israeli President Yitzhak Navon, Carter once "had an interesting

discussion about the ancient texts of the Bible, the Talmud, and the Midrashim, and how scholars were still working on interpreting them." 186

\section{Carter and Begin}

"In Begin's world, everything is hardball politics, including his dealings with Israel's benefactor, the USA. Communication and understanding and religious belief are fine, but in the Middle East the question is national survival, nothing less. [Carter and Begin] were clearly playing different games." 187

In contrast to the secularism of most other prominent Israeli leaders he knew,

Carter described Menachem Begin as someone who drew his political strength "from his deep religious convictions." 188 He pictured himself "as a man of destiny, cast in a biblical role as one charged with the future of God's chosen people." Begin was "a man of deep beliefs," "a student of the Bible" who "preferred to use biblical names for places, and referred frequently to God's messages to Moses and to other leaders of the Jews." Begin, Carter recalled, also understood the monumental prospects an accord with Egypt would signify. "He pointed out to me that there had not been an agreement between a Jewish nation and Egypt for more than two thousand years, and that our meeting was historically unprecedented."189

\footnotetext{
${ }^{186}$ Carter, Keeping Faith, p. 434.

${ }^{187}$ Princen, "Camp David: Problem-Solving or Power Politics as Usual?", p. 62.

${ }^{188}$ Carter, Palestine: Peace Not Apartheid, p. 32; Talking Peace, p. 14.

${ }^{189}$ Carter, Keeping Faith, p. 337.
} 
Carter's key foreign policy advisors had similar impressions. Brzezinski thought Begin was a man "torn by two conflicting pulls: one, that of a religious and historical zealot, who really wants to hang on to what he calls Judea and Samaria [the West Bank]; and the other by a sense of history and opportunity, perhaps even eternity, in the sense that he now has the genuine chance to create peace. ${ }^{190}$ Vance characterized the Israeli Prime Minister as a cross between "Old Testament prophet and courtly European." He held an intense belief that "the Jewish state should by right encompass the whole of biblical Israel," including the West Bank-what he referred to as "biblical Judea and Samaria"-while often maintaining a "warm and gracious" formal manner. ${ }^{191}$

Carter could appreciate Begin's strong faith and commitment to the Jewish people. Notwithstanding, he had difficulty, as he had with the fundamentalist wing of his own Southern Baptist Convention, with Begin's religious exclusivism/nationalism. Carter's view, as exemplified by the life and teachings of Jesus, was that the thrust of faith is not to "husband to ourselves the mercy of God. the forgiveness of our sins, the knowledge of Christ." Instead, the purpose of faith is "to tear down barriers, to reach out and share, to affect other people's lives in a benevolent way and an unselfish way...instead of being narrow." 192 "The natural instinct of any religion on earth. including our own," President Carter explained to the couples' Sunday school in

\footnotetext{
${ }^{190}$ Brzezinski, Power and Principle, p. 117.

${ }^{191}$ Vance, Hard Choices, pp. 180-181.

192 Carter, "Remarks Before the Couples' Class at First Baptist Church in Washington, D.C.," November 6, 1977, in Wesley Pippert, The Spiritual Journey of Jimmy Carter: In His Own Words (New York: Macmillan Publishing Company, 1978), p. 92.
} 
November 1977, is feeling "superior" to others ${ }^{193}$ As Christ transgressed the social and religious taboos against the Samaritans in his time, the President ended his lesson with this prayerful plea. "God show me how to tear down the barriers that separate me from you and others. Let me tear down the barriers that separate other people from you."194 From this perspective, Begin's religious nationalism and the fundamentalism of some of his fellow Southern Baptists were of the same religious type--too divisive, too sectarian, and maybe even too nationalistic.

Meanwhile, Carter found Sadat, though a Muslim, and his courageous initiative to Jerusalem, on which he would embark in the coming weeks (November 20), a better reflection of what he believed Christ expects leaders to do. ${ }^{195}$ However, regarding the initial intentions of the Carter Administration, Sadat's visit, observed Vance, made it "clear to us that the probable outcome" of the trip "would be an initial peace agreement between Egypt and Israel" rather than a comprehensive regional settlement. ${ }^{196}$

Coupled with "a healthy dose of Southern hospitality," Carter tried to reach out to Begin and forge a personal bond through faith, fellowship, and face-to-face persuasion (conversion?). ${ }^{197}$ By suspending negotiations on Saturdays at Camp David, Carter was sensitive to Begin's Sabbath observance. ${ }^{198}$ He also appealed to Begin's

${ }^{193}$ Ibid., p. 196.

${ }^{194}$ lbid., p. 205

${ }^{195}$ According to Quandt, Sadat may have been moved by Carter's October 21, 1977 letter that solicited his help to make some dramatic gesture to break the stalemate in negotiations. Quandt, Camp David, pp. 139-146.

${ }^{196}$ Vance, Hard Choices, p. 195.

${ }^{197}$ Quandt, Camp David, p. 184; Strong, "Shuttle Diplomacy: President Carter in the Middle East," Working in the World, p. 205. 
Jewish faith. Carter tried to get him to recognize that "a continuing military occupation and deprivation of basic citizenship rights about the Arabs" was not merely "unacceptable to the world," but was a violation of "the principles which had always been such an integral part of Jewish teachings and religious beliefs about freedom from persecution of others and personal liberty for all human beings. " 199 In part, too, this was why he wanted to be alone with Begin and Sadat at Camp David. Carter said. "My hope was that. in the quiet and peaceful atmosphere of our temporary home. both Begin and Sadat would come to know and understand each other better. and that they would trust me to be honest and fair in my role as mediator and active negotiator. ${ }^{200}$

Unfortunately. he said. Begin did not trust him enough. "My greatest strength here is your confidence---but I don't feel that I have your trust...I believe I can get from Sadat what you really need. but I just do not have your confidence.."201

The two leaders had a tough, often turbulent, relationship. Begin's "toughness and bluntness." said Brzezinski, could stimulate Carter’s "adrenaline flow. "202 Carter said Begin was often "unpleasant" and "interrupted me" during their meetings. ${ }^{203} \mathrm{He}$ was "rigid. unimaginative. preoccupied with the meaning of words, and unwilling to

\footnotetext{
${ }^{198}$ Keeping Faith. p. 351.

${ }^{199}$ Carter. Keeping Faith. p. 356. Before Jewish audiences, Carter has frequently appealed to the Jewish religious tradition to argue that the occupation of Palestinian land and suppression of Palestinian rights is a violation. See "Letter to Jewish Community on Palestine: Peace Not Apartheid." December 15. 2006.

${ }^{200}$ Carter. Keeping Faith. pp. 329. 331.

201 Ibid., p. 356.

202 Brzezinski. Power and Principle, p. 280.

${ }^{203}$ Ibid. p. 285.
} 
look at the subject in a broader perspective." ${ }^{204}$ Brzezinski said Carter would often return from meetings with Begin "in a fighting mood."205 He told Rosalynn that Begin was a "psycho."206 "Carter repeatedly appealed to Begin to be more accommodating and generous" in his peace offerings to Egypt, "but to no avail."207 Carter was convinced that Begin was not only motivated by a grand desire for a greater Israel that would include the whole West Bank, but also wanted to undermine his political position. He flatly told Begin, "My reelection is not nearly as important to me as the resolution of the Middle East issue."208 At one meeting in 1979, Carter got so angry with Begin that "if he hadn't been my guest I would have asked him to get the hell out." ${ }^{209}$ At Camp David, the two leaders were at it again. Expressing their heated disagreements over the meaning of UN Resolution 242, this is what Brzezinski reported occurring on September 10, $1978 .^{210}$

Begin: "The war of 1967 gives Israel the right to change frontiers."

Carter (shouting): "What you say sounds to me that Sadat was right-- that you want land."

Carter: "This is not the time to beat around the bush. If you disavow UN 242, I would not have called this meeting."

\footnotetext{
${ }^{204}$ Ibid., p. 255.

${ }^{205}$ Ibid., p. 246; Quandt, Camp David, p. 184.

${ }^{206}$ Ibid., p. 262.

${ }^{207}$ Ibid., p. 257.

208 lbid.

${ }^{209}$ Ibid., p. 281.

${ }^{210}$ Ibid., pp. 260-261; see also Carter, Keeping Faith, pp. 382-385.
} 
Begin: "We do not consider the resolution to be self-implementing. "All its parts' includes the preamble. That has been our position for eleven years."

Carter: "Maybe that's why you don't have peace for eleven years."

[Brzezinski: "The discussion again became heated on the subject of the future of the West Bank. After Begin outlined all of the controls, veto rights, and privileges that he would retain for Israel while giving the Arabs a form of self-rule...]

Carter (exploding): "What you want to do is to make the West Bank part of Israel."

Vance: "The whole idea was to let the people govern themselves. You are retaining a veto."

Carter: "No self-respecting Arab would accept this. This looks like subterfuge."

Brzezinski: "This is profoundly sad-you really want to retain political control-vetoes, military governor, broad definition of public order. We thought you were willing really to grant genuine self-government. Now it's clear you are not."

Dayan: "Professor Brzezinski, we are not after political control. If it looks that way to you. we will look at it again."

\section{Carter and Sadat}

Of all foreign leaders, Jimmy Carter has said that Egyptian President Anwar Sadat was his favorite and his "closest personal friend. ${ }^{211}$ He often expressed to Brzezinski how much "he and Sadat have in common, how Sadat is always willing to accommodate him when he calls upon him, and 'I feel very comfortable with him. My chemistry with him is good. " 212 Carter`s feeling toward him was one of ".genuine affection. $" 213$

${ }^{211}$ Carter, Palestine: Peace Not Apartheid, p. 89.

212 Brzezinski, Power and Principle, p. 259 
For Carter, Sadat was a "special ally" and "partner"; indeed, Carter said. he was like "my own brother.,"214 The Egyptian president "was the best friend I ever had in international circles." Of all leaders he knew, Sadat, Carter explained, "was by far the most outstanding and the closest to me." Carter admired his "personal courage," his willingness to look beyond mere "parochial" issues of national interest, and his "aggressive" generosity with Israel. ${ }^{215}$ From the very first, Carter and Sadat, said Brzezinski, "hit it off extremely well."216 After meeting key Middle East leaders early in his term, he noted that "only Sadat responded with any enthusiasm toward a peace initiative." 217 "There was an easy and natural friendship between us from the first moment I knew Anwar Sadat," Carter asserted. "We trusted each other. Each of us began to learn about the other's family members, hometown, earlier life, and private plans and ambitions, as though we were tying ourselves together for a lifetime."218 This first meeting, Carter described in Keeping Faith, "on April 4, 1977" was like "a shining light burst on the Middle East scene." 219 "He and I developed a quick and permanent

\footnotetext{
${ }^{213}$ Quandt, Camp David, p. 167.

${ }^{214}$ Carter, "Remarks and Question-and-Answer Session at the Council on Foreign Relations," March 2. 2006; "Telephone Interview with Christopher Dickey of Newsweek," October 7, 2006; "Remarks at Dinner with President Sadat in Alexandria, Egypt," March 9, 1979, Public Papers of the Presidents, Book I, p. 411 .

${ }^{215}$ Carter, "Interview with Larry King," CNN's Larry King Live, November 27, 2006.

${ }^{216}$ Brzezinski, Power and Principle, p. 93.

${ }^{217}$ Carter, "Can Peace Still Come to Israel?" Atlanta Journal-Constitution, December 12, 1995.

${ }^{218}$ Keeping Faith, p. 291.

${ }^{219}$ Ibid., p. 289.
} 
friendship," Carter wrote. ${ }^{220}$ "I found him always to be like a breath of fresh air."

Admittedly, he said, "it is not easy for me to assess him and the impact of his life in a purely objective fashion."

In his second meeting with Sadat, Carter described their relationship as "one of my most valued possessions. ${ }^{, 221}$ In his third meeting with the Egyptian President,

Carter said Sadat had emerged as "the world's foremost peacemaker." 222

At the 1978 National Prayer Breakfast, Carter said, "I felt an instant friendship with President Sadat." What particularly impressed him were the Egyptian president's repeated references to the fact that "Egyptians and Jews are sons of Abraham, worship the same God, share a common heritage and a common faith. ${ }^{, 223}$

At a town hall meeting nearly two weeks later, Carter revealed to a crowd of high school students in New Hampshire that, in his negotiations with Sadat and Begin. he was appealing to their "deep religious conviction" and the shared ancestry of Jews and Arabs that could be traced back to Father Abraham. Seven months before the thirteen-day Camp David summit, he added that he was hopeful that religion would ultimately contribute to "finding a resolution of the differences in the Middle East" because Egyptian-Israeli peace was prophesied in the Bible. "I think [Sadat and Begin]

\footnotetext{
${ }^{220}$ Carter, "Foreword: A Personal Tribute to Anwar Sadat," in Anwar el-Sadat, Those I Have Known (New York: Continuum Publishing Company, 1984), p. vii.

${ }^{221}$ Carter, "Remarks following Meeting with Anwar Sadat in Aswan, Egypt," January 4, 1978, in Public Papers of the Presidents, Book I, p. 19.

${ }^{222}$ Carter, "Remarks on the Departure of President Sadat," February 8, 1978, Public Papers of the Presidents, Book I, p. 290.

${ }^{223}$ Carter, "Remarks at the Annual National Prayer Breakfast," February 2, 1978, in Public Papers of the Presidents, Book I, p. 264.
} 
understand...the prophesies in Isaiah as applying to both peoples, that peace between Egypt and Israel is foreordained by God, and that they play a role in carrying out God's purposes." 224 Also, in preparation for his negotiations with Arab leaders, he said. "I tried to learn as much as possible about the Moslem faith."225

In his memoirs, Carter described Sadat as "strong and bold," someone who "looked upon himself as inheriting the mantle of authority from the great pharaohs and was convinced that he was a man of destiny." He was "deeply religious." On the first day of the Camp David summit, Carter recalled Sadat requested "a special place be found for him to worship." 226 In The Blood of Abraham, Carter explained that at Camp David, when he wanted to discuss religion with his two guests, "the three monotheistic religions and their influence on the ancient and current relationships among people in the Middle East and also on us as individuals - - Jew, a Moslem, and a Christiansearching for peace," Sadat was more interested than Begin. ${ }^{227}$ For his part. Carter, said, Begin was more interested in the post-biblical history of the Jewish people, "particularly concerning how their faith influenced the Jews of the Diaspora." The one part of the Bible that was of keen interest to Begin, and his Likud Party supporters, was the period of "Israel's ancient glory, when kings led the Jews and when King David won many military victories and ruled over much of the region." "Sadat," Carter said. "seemed particularly fascinated with the subject, and he often referred to his plans to

\footnotetext{
${ }^{224}$ Carter, "Remarks and Question-and-Answer Session at a Town Hall Meeting with New Hampshire High School Students," February 18, 1978, Public Papers of the Presidents, Book I, p. 370.

${ }^{225}$ Carter, "Rushdie's Book Is an Insult," New York Times, March 5, 1989.

${ }^{226}$ Carter, Keeping Faith, p. 335

${ }^{227}$ Carter, The Blood of Abraham, p. 8.
} 
build a holy shrine on Mount Sinai, so that believers of all three faiths could go there to worship together."

From Carter`s standpoint, Begin lacked Sadat's religious curiosity and ecumenism. "I do not recall any occasion... when he initiated a discussion about Christianity or Islam or participated in any comparative analysis of religious beliefs. ${ }^{\circ 22}$ Perhaps, in hoping that he would eventually become more like Sadat. Carter may have underestimated the depth of Begin's intensity in keeping the West Bank as a part of Eretz Israel and may have felt that Begin`s spoken word was as sufficient as his written word. This may explain Carter's original emphasis in his relations with Begin to win his personal "trust and confidence." ${ }^{.22}$ Resorting to word games and legalisms, in Carter's mind, might seem to him impediments to forging a genuine fellowship between friends.

Sadat was different. "In our private quarters and during our early morning walks at Camp David," the Egyptian President willingly "discussed his own 1slamic beliefs and was glad to answer my numerous questions. In preparing for the Middle East peace discussions, I had made a brief study of the Koran, which made my discussions with Sadat much more meaningful, but he knew a great deal more about Judaism and Christianity than I knew about his faith."

As an expression of their close ties, Carter noted that Sadat was the first leader he invited to visit him at Camp David (February 1978). ${ }^{230}$ For his bold visit to

\footnotetext{
${ }^{228}$ lbid., p. 9.

${ }^{229}$ Quandt, Camp David, pp. 49, 78.

${ }^{230}$ Carter, Keeping Faith, p. 335.
} 
Jerusalem in November 1977 and his steadfastness in the face of ostracism in the Arab world, Carter called Sadat "one of the bravest men on Earth."231 When asked about Sadat's assassination in 1981, a quarter-century later, Carter still cited his fraternal bond with the slain leader. He told a Newsweek reporter that his death was "like losing my own brother.",232 "I lost a beloved friend."233

In his memoir, Brzezinski confirmed Carter's closeness to Sadat. Of all international leaders, "His clear favorite was Sadat." About their first meeting, he added, "it was love at first sight." "Carter," he continued, "spoke of Sadat as his dearest friend, a person who would do anything for Carter and to whom Carter was utterly committed." In fact, Brzezinski said, Carter came to view Sadat as "quite literally family, in the Southern sense." Indeed, Carter was so infatuated with the Egyptian President that it became "a bit of hero worship." 234 Unlike his raucous relations with Begin, here is how Brzezinski described a typical Carter-Sadat meeting. This one from early March 1979:

In my journal I commented on the enormous contrast between a dialogue involving Begin and Carter and one between Carter and Sadat. Carter's discussions with Sadat were punctuated by comments such as 'I will represent your interests as if they were my own. You are my brother.' Or Sadat saying to the President, 'My people admire you. I shall always be proud of our friendship, of our brotherhood.' Carter to Sadat: 'I hope I will never let you down. You are probably the most admired statesman in the United States.' Sadat to Carter: 'My people and I are grateful to you.' In contrast, exchanges

\footnotetext{
${ }^{231}$ Carter, "Remarks with Vice President Walter Mondale on Arrival from Overseas Trip," January 6 , 1978, in Public Papers of the Presidents of the United States, Book I, p. 40.

${ }^{232}$ Carter, "Telephone Interview with Christopher Dickey of Newsweek," October 7, 2006.

${ }^{233}$ Carter, "Foreword: A Personal Tribute to Anwar Sadat," p. viii.

${ }^{234}$ Brzezinski, Power and Principle, p. 24.
} 
between Carter and Begin were icy, even mutual praise was formalistic and devoid of any personal feeling. ${ }^{235}$

The close bond between the two was so obvious. Israeli Foreign Minister Moshe Dayan attempted at one point to exclude Carter from future summits on the grounds that "he too frequently sides with Sadat." ${ }^{236}$

Sadat`s feelings toward Carter were mutually fraternal. He was ready to develop a strong bond with Carter from the beginning. At their first meeting. April 1977, Sadat said, "For so long we have been told that politics is amoral and that international relations are not the domain of idealism or spirituality, but one of expediency and the pursuit of selfish interests." He recognized that Carter seemed to offer a "revival of idealism." a commingling of "spirituality and human liberty." which enliven and enrich human existence. "individually and collectively." 237 He praised Carter"s commitment to truth and "to the cause of peace and the universal brotherhood of man. .238 Sadat singled out Carter`s views on the Palestinians as "a positive signal" to the Arab world. "It was the first time," Sadat explained, "since 1947 that an American President has ever spelled out his convictions that the Palestinians should have their homeland where they could establish their state. "239 Sadat came to call

$\because 5$ Ibid.. p. 284.

${ }^{2 \$ 6}$ Bill Roeder, "A Summit Without Carter?". Newsweek. January 29. 1979. 19.

237 Sadat, "Remarks at Welcoming Ceremony with President Carter," April 4. 1977, in Public Papers of the Presidents, Book I. p. 562.

${ }^{238}$ Sadat, "Remarks at Dinner Ceremony with President Carter," April 4, 1977, in Public Papers of the Presidents, Book I, p. 568.

${ }^{239}$ Ibid., p. 569: see also Sadat, Those I Have Known. p. 99. 
Carter his "dear friend" and "brother". 240 "To me, he has been the best companion and partner along the road to peace.",241

In explaining why he fully trusted Carter, according to the New York Times.

Sadat said, "I find that I am dealing with a man who understands what I want, a man impelled by the power of religious faith and lofty values - a farmer like myself." ${ }^{242}$ Jim Wright, who led a congressional delegation with Republican James Quillen of

Tennessee to Egypt and Israel days prior to Sadat receiving Israel's formal invitation to make his historic speech before the Knesset, said Sadat told him why he trusted Carter.

"He is a man of the book, and a man of truth. I believe he is a man of God." 243

At the March 26, 1979 signing ceremony of the Egyptian-Israeli peace treaty,

Sadat described Carter as a leader who had "the blessing of God" and who consistently

"raised the banner of morality and ethics as a substitute for power politics and

opportunism" in international relations. ${ }^{244}$

${ }^{240}$ Sadat, "Remarks following Meeting with President Carter in Aswan, Egypt," January 4, 1978. in Public Papers of the Presidents, Book I, p. 19; Sadat, "Remarks on Arrival with President Carter." February 3, 1978, in Public Papers of the Presidents, Book I, pp. 274-275; "Remarks on His Departure with President Carter," February 8, 1978, Public Papers of the Presidents, Book I, p. 291; "Remarks at Welcoming Ceremony with President Carter in Cairo, Egypt," March 8, 1979, Public Papers of the Presidents, Book I, p. 405; Sadat, "Remarks at Dinner Honoring President Carter in Alexandria, Egypt." March 9. 1979, Public Papers of the Presidents, Book I, p. 411.

${ }^{241}$ Sadat, "Remarks at the Signing Ceremony of the Egyptian-Israeli Peace Treaty with President Carter and Prime Minister Begin," March 26, 1979, Public Papers of the Presidents, Book I, p. 519; "Remarks at a State Dinner with President Carter and Prime Minister Begin," March 26, 1979, Public Papers of the Presidents, Book I, p. 524.

${ }^{242}$ Quoted in Christopher S. Wren, "Sadat's Peace Path: From 'Never' to a Pact," New York Times. March 25, 1979; Sadat, In Search of Identity: An Autobiography (New York: Harper \& Row Publishers, 1978), p. 302.

${ }^{243}$ Wright, Balance of Power, p. 300.

${ }^{244}$ Sadat, "Remarks at the Signing Ceremony of the Egyptian-Israeli Peace Treaty with President Carter and Prime Minister Begin," March 26, 1979, Public Papers of the Presidents, Book I, p. 519. 
Though Secretary Vance described their close. "sincere and real" bond as "something of a mystery." Carter was convinced at the time that "the depth of our common faith in a just and merciful God" in the end contributed mightily to building a special trust between him and Sadat. In particular, he believed that it helped to sustain him during the many difficult moments. and it laid the groundwork for the historic agreement between two old foes. ${ }^{245}$ The following year. he repeated this point. "When I went to Camp David with Prime Minister Begin, a Jew, and with President Sadat, a Muslim Arab, the first day there didn't seem to be a chance in the world that we would be successful." To reduce some of the tensions, Carter explained, "the first thing we decided to do was to pray to God" and "to issue a statement to everyone in the world who would, to join us in praying to God that we could have success there and find peace for Israel and for her neighbors. That's what we did the first day." Because of prayer. Carter stated, the results of Camp David are "proof that God heard all our prayers... There's no question in my mind about it." ${ }^{2+6}$

In 1989, in an op-ed piece for the New York Times, Carter said that he, Sadat. and Begin "had several talks about our common religious beliefs." For example, Carter said, "Sadat emphasized the reverence that Moslems have for Jesus and the Old

\footnotetext{
245 Vance. Hard Choices, p. 175: Carter. "Remarks at a State Dinner Honoring President Sadat and Prime Minister Begin." March 26. 1979. Public Papers of the Presidents, Book I, p. 523.

${ }^{2}+6$ Carter, "Remarks and a Question-and-Answer Session at a Town Meeting in Yatesville. Pennsy.lvania." October 15. 1980, Public Papers of the Presidents, Book III. pp. 2259-2260: "Remarks at the Alfred E. Smith Memorial Dinner in New York City." October 16. 1980. Public Papers of the Presidents, Book 1II. p. 2311: "Remarks and a Question-and-Answer Session at a Town Meeting in Miami, Florida." October 21, 1980. Public Papers of the Presidents, Book III, p. 2387.
} 
Testament Prophets." ${ }^{247}$ In 1994, Carter reiterated this point. "Personal experience underlies my conviction that religion can be significant for peacemaking." He said, "the negotiations" and the participants at Camp David, including himself, "were greatly influenced by our religious backgrounds." Religion shaped the "personalities, historical perspectives, and political convictions." "As the mediator of the talks," Carter recalled, "I am convinced that to have overlooked the importance of religion for both Sadat and Begin would have resulted in failure to understand these two men." The implication is clear. Another president with a different style of governing, a president with a more secular mindset, would likely have led to a "pervasive and incalculable" failure. ${ }^{248}$

What Carter's bond with Sadat brought was political leverage at Camp David. ${ }^{249}$ Above all, said Secretary Vance, Sadat prized "loyalty and friendship" and "once his trust was gained, he would stand with you unfailingly. ${ }^{, 250}$ When the peace process was unraveling toward the end of 1977 , Carter sent Sadat a personal note in October to make some dramatic gesture. According to Brzezinski, the Egyptian president viewed it as request from Carter for him "to prove his friendship."251 A month later, Sadat would make his historic move - he traveled to Israel, the first Arab head of state to do so. This greatly impressed the President and his Middle East team. "We all felt," Brzezinski

\footnotetext{
${ }^{247}$ Carter, "Rushdie's Book Is an Insult," New York Times, March 5, 1989.

${ }^{248}$ Carter, "Foreword," to Religion, The Missing Dimension of Statecraft, ed. Douglas Johnston and Cynthia Sampson (New York: Oxford University Press, 1994), p. vii.

${ }^{249}$ Shibley Telhami, "Evaluating Bargaining Performance: The Case of Camp David," Political Science Quarterly 107.4 (Winter 1992-1993): 644.

${ }^{250}$ Vance, Hard Choices, p. 174.

${ }^{251}$ Brzezinski, Power and Principle, p. 110.
} 
wrote. "that the Egyptian leader had gone out on a limb in order to promote peace in the region. . 252 Unfortunately, he added, "Begin was busy sawing the limb off."

Carter recalls that Sadat was eager to please him. "Sadat. on his first visit to the White House. made it plain to me that he would do anything I asked him to do concerning the peace process. It was almost like a blank check. ${ }^{.253}$ He was " almost completely accommodating. ${ }^{.25 t}$ At one point in the process. Brzezinski remembered Sadat saying to Carter, "I will not fail you, Mr. President." ${ }^{255}$ Above most other considerations. Cyrus Vance said. Sadat "valued loyalty and friendship. ${ }^{.256}$

Sadat viewed his friendship with Carter of great value in its own right. It made him, wrote one scholar. more "accommodating" than even his close advisors. ${ }^{257}$ In contrast. Begin. who lacked such close personal ties to Carter. could be "tougher" in the negotiations. the toughest member of the Israeli team. Sadat. too. wanted to strengthen Carter's electoral position heading into the 1980 election. He feared the election of an American president who was not as balanced as Carter was in his approach to the Mideast. $^{258}$ Sadat. said Brzezinski. “showed great concern for Carter”s [political]

252 Ibid., p. 243.

253 Carter, "Interview with James Laue at the $5^{\text {th }}$ National Conference on Peacemaking and Conflict Resolution in Charlotte. North Carolina." June 7, 1991, in Conversations with Carter. p. 285.

${ }^{25+}$ lbid.. p. 286.

25 Brzezinski. Power and Principle. p. 117.

${ }^{256}$ Vance. Hard Choices, p. 174.

${ }_{257}$ Miller, "Shadow and Substance," p. 8.

${ }_{258}$ Ibid.. p. 10; Keeping Faith. p. 427. 
position and with real emotion affirmed his determination to help Carter overcome Begin's obstacles.",259

Carter appreciated Sadat's full trust in him and he trusted his own abilities. Begin was uncomfortable with the leader-only talks at Camp David. He preferred to be surrounded by his main advisors Foreign Minister Dayan and Defense Minister Ezer Weizman. Often, before agreeing to anything, he would say he could commit only with the approval of his full Cabinet or the Knesset. Sadat, in contrast, enjoyed the one-one meetings with the American President. Carter recalled, "Sadat wanted to make Egypt's decisions himself, did not like to have aides present when he was with me, and seemed somewhat uncomfortable when they were around him... Throughout our stay at Camp David, Sadat spent little time with his staff.",260

For Carter's purposes, this worked to his advantage. "On any controversial issue, I never consulted Sadat's aides, but always went directly to their leader."26! Sadat did not want to disappoint his friend and he "was much more forthcoming than his chief advisors."262 From 1977-1978, for example, two Egyptian foreign ministers, Ismail Fahmy and Muhammad Ibrahim Kamel resigned in protest to Sadat's actions. ${ }^{263}$ Fahmy resigned to protest the Egyptian president's 1977 Jerusalem initiative and Kamil resigned in protest to the signing of the 1978 Camp David Accords. Brzezinski noted.

\footnotetext{
${ }^{259}$ Brzezinski, Power and Principle, p. 282.

${ }^{260}$ Carter, Keeping Faith, p. 349.

${ }^{261}$ Ibid., p. 364.

${ }^{262}$ Ibid., p. 349; see also Brzezinski, Power and Principle, p. 265; Quandt, Camp David, p. 233; Weizman, The Battle for Peace, p. 350.

${ }^{263}$ Quandt, Camp David, p. 262; Dayan, Breakthrough, p. 182.
} 
too, that Boutros Ghali, the Egyptian Minister of State for Foreign Affairs, the third ranking member of the Egyptian delegation, did not want Sadat to agree to the Accords, fearing that it would put Sadat "in a most vulnerable position not only in regard to the rest of the Arab world but perhaps even domestically in Egypt. ${ }^{26+}$ Carter added that the Egyptian Under Secretary of Foreign Affairs, Osama el-Baz, was "the most militant of the Egyptians" and was apparently "deeply committed to the goals of the Palestinian Liberation Organization and other radical groups. "265 From Carter's perspective, it was clear that "Sadat had been and was making decisions" with which el-Baz and others "strongly disagreed."

The opposite was true for the Israelis; Begin was the more recalcitrant than Dayan, Attorney General Aharon Barak, and Weizman, especially, whose amicability made him "a special favorite of Sadat.",266 In fact, Carter said, if any of the other Israelis had been prime minister, "we would have already reached agreement.",267

At Camp David, Carter explained that he was "stricken" when he found out that Sadat was ready to leave. "He was my friend," the President said. He said he did not know what to do. Choked up and with tears in his eyes, he told a crowd in 2007 that he

\footnotetext{
${ }^{26+}$ Brzezinski, Power and Principle, p. 269.

${ }^{265}$ Carter, Keeping Faith, pp. 396-398; Dayan, Breakthrough, p. 173.

${ }^{266}$ Carter, Keeping Faith, pp. 350, 364, 390. According to Dayan, though the Knesset overwhelmingly approved the Accords, 84 in favor, 19 opposed, and 17 abstentions, those most opposed to Camp David in Israel "came from Begin's own party and from the National Religious Party." Dayan, Breakthrough, pp. $194,198$.

${ }^{267}$ Carter, Keeping Faith, p. 386.
} 
went alone into a room and to pray. Afterwards, when he caught up with Sadat. Carter told Sadat face-to-face that he was being betrayed. He threatened the end of his friendship and lasting damage to U.S.-Egyptian relations. Sadat decided to stay. ${ }^{268}$

It is certainly true and obvious that Carter's evangelical personal style did not provide him a specific and consistent technique to use in the negotiations. As situations and feelings changed, he often had to adjust. Whether through meetings of the principals (Carter, Sadat, and Begin alone together), shuttling from cabin to cabin, presenting proposals, awaiting reactions, and making modifications, or appealing directly, as in the case of Sadat, to personal loyalty and threatening the withdrawal of that personal friendship, the central tactic was the same-Carter's personal and direct involvement. Against advice, Carter alone, wrote Vance, "was convinced that only his personal mediation stood a chance of gaining the peace treaty."269 He would save the promise of the Camp David framework for Egyptian-Israeli peace and personally get involved again going to the Middle East. It was "a breathtaking gamble," "an act of political courage." "Failure in personal presidential diplomacy," warned Vance, "could have sapped the administration's political strength" to move on other foreign policy objectives. Nevertheless, Carter, wrote Hargrove, "believed that people of goodwill who had [to learn] to work together would develop the right policies. This was the Baptist rather than the engineer."270

\footnotetext{
${ }^{268}$ Carter, "Remarks and a Question-and-Answer Session at the Carter Presidency \& Lessons for the $21^{\text {st }}$ Century Conference in Athens, Georgia," January 20, 2007. See also Carter, Keeping Faith, pp. 400-403: Talking Peace, pp. 15-16; Brzezinski, Power and Principle, pp. 271-272.

269 Vance, Hard Choices, p. 245.

${ }^{270}$ Hargrove, Jimmy Carter as President, p. 31.
} 
Carter's personalistic style, however, did not shield him from a few major mistakes. His optimism that the Arab world would rally to the process after Camp David and his willingness ultimately to trust Begin`s word on the West Bank settlements, particularly, "came back to haunt us," wrote Brzezinski. ${ }^{271}$ Though Carter believed he had Begin"s word—spoken, not written — the "worst failure" at Camp David, he said, was the President's failure to acquire "Begin's clear-cut acquiescence to a freeze on settlements activity" in the West Bank (emphasis added). Carter. too, acknowledged these limitations of the Accords. ${ }^{272}$ So did Sadat. "Right to the last moment," Vance recorded, "some of Sadat's advisers were still arguing that the agreements were slanted toward Israel's positions." Notwithstanding this, he added. "Sadat trusted President Carter and gave his consent" (emphasis added).

Carter was often naïve in thinking as well. Sadat said that Carter believed that leaders who gave him their word was sufficient. Unfortunately, the Egyptian President wrote, when it came to the Syrians, Carter was "taken aback when he found that the word of a Syrian was in fact a thousand and one words, and that what they agreed to one day they rejected the next, returning to it the day after." Such tactics bewildered Carter and "he found himself at a loss." He was simply convinced that "his efforts alone were enough to secure for him the cooperation and gratitude of all concerned. ${ }^{.273}$

\footnotetext{
${ }^{271}$ Brzezinski, Power and Principle, pp. 273-274; see also Stein, Heroic Diplomacy. pp. 235-236. 255256: Vance, Hard Choices, pp. 228-229. For the Israeli view of the West Bank settlements issue. see Dayan. Breakthrough, pp. 183-188.

${ }^{272}$ Carter, Palestine: Peace Not Apartheid, p. 50; see also Keeping Faith, p. 406: The Blood of Abraham. p. 157: Vance, Hard Choices, p. 226.

273 Sadat, Those I Have Known, pp. 100-101.
} 
In Quandt's view, he was "terribly naïve" to think "Begin and Sadat would come to trust each other" if they could only discuss matters away from outside political distractions, meeting together one-on-one or in Carter's presence. ${ }^{274}$ After a few days at Camp David, Carter had to separate the two and negotiate with them individually. The meetings had been "totally fruitless," wrote Weizman. ${ }^{275}$ "They did nothing for the peace negotiations." "All the other participants at the conference," he explained, "soon realized that further meetings between Sadat and Begin were a sure recipe for failure."

Carter should have anticipated this, said Princen. After their meeting in Ismailiya, Egypt, in December 1977, Begin and Sadat clashed repeatedly. "This was in part due to incompatible personalities, but also to a long history of distrust and enmity." personally and collectively between the two countries. ${ }^{276}$ But, evidently, Carter still believed that the personalistic approach would and could overcome such idiosyncrasies and forces of history.

As the days dragged on, too, the isolation of Camp David was causing "claustrophobia" to set in. "Almost everyone wanted to get away" from the Carter retreat, Quandt reported. "The outside world was beginning to seem remote and exotic. Jokes were being made about 'prison' and the 'concentration camp' atmosphere.,"277

The most serious unintended consequence of the bilateral peace treaty between Israel and Egypt, Carter has explained, was that "Egypt's considerable strength from the

\footnotetext{
${ }^{274}$ Quandt, Camp David, p. 235.

${ }^{275}$ Weizman, The Battle for Peace, p. 357.

${ }^{276}$ Princen, "Camp David: Problem-Solving or Power Politics as Usual?", p. 63.

${ }^{277}$ Quandt, Camp David, p. 235; see also Weizman, The Battle for Peace, pp.342-345.
} 
military equation of the Middle East" had been "removed." allowing the Israelis after he left the presidency "renewed freedom to pursue" settlement expansion in the occupied territories and the freedom to use military power on other fronts. Among the activities that occurred almost immediately after Reagan replaced Carter in the White House were the Israeli bombing of Iraq's nuclear reactor in 1981, its annexation of the Golan Heights. and its invasion of Lebanon in 1982. ${ }^{278}$ With Reagan. Carter wrote. the Middle East peace efforts "came to a screeching halt." 279

To his great concern, increasingly, Carter believed that "there were two Israels. ${ }^{280}$ One Israel "encompassed the ancient culture and moral values of the Jewish people, defined by the Scriptures with which I had been familiar since childhood and representing the young nation that most Americans envisioned." The other Israel "existed within the occupied Palestinian territories. with policies shaped by a refusal to acknowledge and respect the basic human rights of the citizens."

For their part, other than Sadat, Arab leaders, wrote Stein, were not "psychologically prepared to recognize Israel"s existence" so they refused to accept Camp David and punished Egypt for its participation and recognition of the Jewish State. ${ }^{281}$ On these critical issues, Carter's positive outlook, hope for the future. and faith in his personal ability to connect with other leaders got the best of him.

\footnotetext{
${ }^{278}$ Carter, The Blood of Abraham. pp. 158-160; Palestine: Peace Not Apartheid. pp. 52. 94-95. 103-104.

279 Carter, The Blood of Abraham, p. 186; "Interview with Kenneth W. Thompson and James Sterling Young." 1987, in The Carter Presidencr: Fourteen Intimate Perspectives of Jimmy Carter. pp. 12-14.

${ }^{280}$ Carter, Palestine: Peace Not Apartheid. p. 112

${ }^{281}$ Stein, Heroic Diplomacy, pp. 259, 265: Vance, Hard Choices. p. 166.
} 
Still, Carter believes that his personalistic style was effective with Israeli

Defense Minister Weizman. Carter wrote,

One personal benefit to me from the long days of negotiation was a lifetime friendship with Ezer Weizman...More than any other member of Begin's team, I found Ezer eager to reach a comprehensive peace agreement, and he was a person with whom I could discuss very sensitive issues with frankness and confidence. He also had a good personal relationship with the Egyptians and would often go by Sadat's cabin for private discussions or a game of backgammon. These peace talks proved to be something of an epiphany for Weizman... He had been a leading 'hawk' all his life but was converted during the weeks of negotiations into a strong proponent of reconciliation with the Arabs. ${ }^{282}$

Carter added that during the 1980 election Weizman even campaigned on his behalf.

"Without my asking him, Ezer Weizman came to America during my reelection campaign in 1980 and visited several cities, publicly urging Jewish leaders to support my candidacy." Until his death in 1993, Carter said he was "my closest friend in the Holy Land and an invaluable source of information and advice."283

A secondary problem with Carter's style and approach, Brzezinski thought, was that "Camp David had worked because Carter had been able to keep both parties under his control.",284 "Neither dared to assume the responsibilities of failure" in Carter's presence and after he had risked so much of his own political prestige. But when Carter was not intimately involved, the hard-won momentum waned. It would not pick up again until Carter reinserted himself in early 1979. Because "the Camp David Accords had been a major personal triumph" for the President, it became clear, Brzezinski wrote,

\footnotetext{
${ }^{282}$ Carter, Palestine: Peace Not Apartheid, p. 51.

${ }^{283}$ Ibid., p. 110.

${ }^{284}$ Brzezinski, Power and Principle, p. 277.
} 
that "unless Carter again injected himself personally and made another major effort" a final treaty would not happen if the parties were left to themselves or if they had to deal with anyone but the President. ${ }^{285}$ Linda Miller concurred with this view. She wrote. "The President's growing involvement with the minutiae of diplomacy meant that Middle East political figures would not be satisfied with dealing with lesser officials. " 286

This is the quandary in the search for Middle East peace for any American president. The consensus is that presidents need to be intimately involved as Carter was. But such personal involvement can take its toll on the president, whether he succeeds as Carter did in 1978-1979 and Clinton did in 1993-1994, or fail as Clinton did in 2000. Brzezinski wrote that after Camp David, Carter "was eager to turn his attention to other matters." 287

Attaining peace in the Middle East may be important for a president, as it was for Carter; it was a key part of his presidential mission and vision. But it was not his only presidential goal. Personal involvement is very time-consuming and exhausting. "The Middle East," Brzezinski continued, "had been an enormous drain on his time and energy." with many emotional highs and lows. As such, once the Camp David Accords were signed, Carter not only took great satisfaction in the success, but it was "also a source of considerable relief" for him.

\footnotetext{
285 Ibid.. p. 278 .

${ }^{286}$ Miller, "Shadow and Substance," p. 3.

287 Brzezinski, Power and Principle, p. 278.
} 


\section{The Calming Effect of Prayer and Emotional Intelligence}

"A Christian must have the willingness of a soldier to give his life...the discipline of an athlete to train... and the patience of a farmer who plows in hope." 288

"We place our trust in the God of our fathers, for whom we seek wisdom and guidance." 289

President Carter's evangelical faith provided him a political vision for the

Middle East and it provided him the political skill to bond with and earn the trust of

Sadat. His faith also provided him the emotional intelligence to endure the difficulties

and pressures of his intimate involvement in the peace negotiations, dealing with the

various personalities, the precision and patience needed in finding the right and

acceptable language for the parties involved, and the constant criticisms from the pro-

Israel and pro-Arab sides that he was either going too far or not far enough. To handle

the variety of pressures, frequently, Carter says he resorted to prayer and asked for

others to pray for a policy success. ${ }^{290}$

Jimmy Carter says prayer is simply "a part of my nature, a part of my

character." "At night the last thing I do," he told one reporter, "every night, is to have a

brief period of worship." Prayer, he says, is as natural as "breathing." "291 "I pray as a

${ }^{288}$ Carter, "Remarks Before the Couples' Class at First Baptist Church in Washington, D.C.," June 12, 1977, in Pippert, The Spiritual Journey of Jimmy Carter, p. 38.

289 "Joint Statement Issued by President Carter, President Sadat, and Prime Minister Begin at the Start of the Camp David Summit Meeting," September 6, 1978, in Public Papers of the Presidents, Book II, p. 1501 .

${ }^{290}$ Carter, "The President's News Conference," August 17, 1978, in Public Papers of the Presidents. Book I, p. 1441; "Remarks on Departure to Camp David Summit," September 4, 1978, in Public Papers of the Presidents, Book II, p. 1497; "Remarks at the Annual Convention of the National Religious Broadcasters," January 21, 1980, Public Papers of the Presidents, Book I, p. 181.

${ }^{291}$ Carter, "Interview with Wesley Pippert in Plains, Georgia," July 9, 1976, in Pippert, The Spiritual Journey of Jimmy Carter, p. 40. 
routine thing. " 292 Whether in "moments of tension or quietness," he told Pat Robertson on the "700 Club," it is habitual for him to seek "God in a brief prayer.",293

I recognize my own sinfulness and the fact that I can't be perfect as a human being but that with God's presence and the presence of the Holy Spirit I can strive ever more effectively to pattern my own life after the teachings of the Bible.

I have my own doubts - like everyone else does - about my own abilities or success. But I'm able to accept, I think, with a great deal of equanimity, the prospect of defeat or failure... I can face either victory or defeat without any tensions or fear. This has been translated in the minds of some newspeople as being self-confident or even as arrogance. To me, at least, it s just a sense of being at home with myself and realizing the presence of God in my life. ${ }^{294}$

Carter explained many times that he did not ask in prayers for either electoral success or to save his presidency. Rather. he asserted. "I do ask God to let me do the right thing, whether I win or lose." 295 "I am close to God and I do pray often and seek his guidance before I make any major decision," he explained before a Sunday school class on the first Easter Sunday of his presidency. "I pray every day," in fact, "that I don 't disappoint you or do anything that will make you ashamed" of his presidential behavior. $^{296}$

\footnotetext{
292 Carter, "Interview with the National Religious Broadcasters in Indianapolis, Indiana." October 14. 1976. in Pippert. The Spiritual Journey of Jimmy Carter, p. 40.

${ }^{293}$ Carter, "Interview with Pat Robertson on the 700 Club taped during the 1976 Presidential Campaign." in Pippert. The Spiritual Journey of Jimmv Carter, pp. 41-42. Pippert noted that the interview was taped during the presidential campaign, but was not aired on the Christian Broadcasting Network until after the general election.

294 Ibid. pp. 57-59.

${ }^{295}$ Carter, "Interview with John Hart of NBC New's," March 28, 1976, in Pippert, The Spiritual Journey of Jimmy Carter, pp. 43-44.

${ }^{296}$ Carter. "Remarks Before Men's Bible Class at the First Baptist Church in Calhoun, Georgia." April 10. 1977, in Pippert, The Spiritual Journey of Jimmy. Carter, pp. 44-45.
} 
A few days after he received the 1976 Democratic nomination for president,

Carter, back in his hometown of Plains, defined what doing the right thing meant. He told the men's Bible class that "patterning" one's life "after Christ" is the essence of righteous living. ${ }^{297}$ Among the imitable Christ-like traits Carter identified were "simplicity and humility and compassion and love and truth." ${ }^{298}$ These are "the simple truths" of faith, and "if we believe this, God, with all our hearts and souls, we know that we can have eternal life." 299 Though all have sinned and "deserve death", Carter said, the Christian can be certain "You love us" and that "You sent Your Holy and only Son on earth to be like us and to take the punishment for our sins." This, the Bible tells us. "You've given us Your Holy word, the Bible, where we can study in solitude to what kind of life Christ lived, the perfect example for us all." To close the morning service that day, he told the congregation that "although we might have very difficult decisions that we might struggle with or we might have burdens that seem sometimes too hard to bear," the believer in Christ can find the solemnity to endure. ${ }^{300}$ "If we accept Christ as

${ }^{297}$ Carter, "Remarks Before Men's Bible Class at the Plains Baptist Church in Plains, Georgia," July 18 , 1976, in Pippert, The Spiritual Journey of Jimmy Carter, pp. 46-47. See also "Remarks Before Men's Bible Class at the Plains Baptist Church in Plains, Georgia," February 13, 1977, in Pippert, The Spiritual Journey of Jimmy Carter, p. 51; "Remarks Before Men's Bible Class at the Plains Baptist Church in Plains, Georgia," August 7, 1977, in Pippert, The Spiritual Journey of Jimmy Carter, p. 53.

${ }^{298}$ Carter, "Remarks Before Men's Bible Class at the Plains Baptist Church in Plains, Georgia," February 13, 1977, in Pippert, The Spiritual Journey of Jimmy Carter, p. 51. See also "Prayer at Morning Worship Service at the First Baptist Church in Lagos, Nigeria," April 3, 1978, in Pippert, The Spiritual Journey of Jimmy Carter, p. 55.

${ }^{299}$ Carter, "Remarks Before Men's Bible Class at the Plains Baptist Church in Plains, Georgia," July 18. 1976, in Pippert, The Spiritual Journey of Jimmy Carter, pp. 46-47.

${ }^{300}$ Carter, "Morning Service Benediction Prayer at the Plains Baptist Church in Plains, Georgia," July 18. 1976, in Pippert, The Spiritual Journey of Jimmy Carter, p. 47. 
our Saviour and open our hearts to him," all the difficulties and burdens "can be wiped away."

Through these assurances of faith, God's love, and Christ's redemption, Carter boldly claimed that his faith gave him the ability to take "a calmer approach to crises." "I have," he said in a interview during the 1976 fall campaign, "a great deal of peace with myself and with other people just because of my religious convictions.",301

Inner peace and self-assurance is not guaranteed, President Carter insisted. These personal qualities, he told a Sunday school class in 1978, are found only "if we subjugate our lives to God, if we open our hearts to the Holy Spirit, if our life is consistent with the purposes or example of Christ...in our relationship with God and others, then we will have inner peace. ${ }^{, 302}$

Carter was cognizant of the high risks involved in immersing himself in the Middle East peace process. He knew that if he failed, he would "certainly have to share part of the blame for that failure." However, he proceeded to explain, "I don't see that I could do anything differently." "I decided on my own" to pursue the personal highstakes summitry without "any assurance of success." He felt that with his personal, intimate approach, "if we can get them to sit down and discuss honestly and sincerely" the issues, priorities, and differences involved, he could in effect convert them and get them to come to an agreement. ${ }^{303}$

\footnotetext{
${ }^{301}$ Carter, "Interview with Raiph Blodgett," September-October 1976, Liberty magazine, in Pippert, The Spiritual Journey of Jimmy Carter, pp. 56-57.

${ }^{302}$ Carter, "Remarks Before Couples' Class at First Baptist Church in Washington, D.C.." January 29. 1978, in Pippert. The Spiritual Journey of Jimmy Carter, p. 60.

${ }^{303}$ Carter. "The President's News Conference," August 17, 1978, in Public Papers of the Presidents, Book I. p. 1440.
} 
He admitted that "one of the most difficult and frustrating and discouraging experiences" of his presidency was "dealing with the Mideast settlement between Israel and Egypt." 304 For too long, "the Middle East has been a textbook for pessimism" and "diplomatic ingenuity was no match for intractable human conflicts." 305 However, though he "despaired many times," he said he never fully got to "a state of discouragement" where he felt like "giving up." 306

When asked by Bill Moyers if the success at Camp David was "the high of your administration," Carter replied, "I'd say the first $12 \frac{1}{2}$ days were probably the lower of my administration; the last half day at Camp David was one of the highest." ${ }^{307}$ In his memoirs, he described these mixed emotions. "Some of the most unpleasant experiences of my life occurred during these days - and, of course, one of the most gratifying achievements came at the end of it." ${ }^{308}$ Still, Carter felt emboldened to proceed. In between negotiations, Carter said, he would exercise and go to some quiet place to reflect and pray. ${ }^{309}$ In his address before a joint session of Congress the day

\footnotetext{
${ }^{304}$ Carter, "Remarks at a White House Dinner Honoring Governors Attending the National Governors" Association's Winter Session," February 27, 1979, in Public Papers of the Presidents, Book I, p. 357.

${ }^{305}$ Carter, "Remarks Before a Joint Session of Congress on the Camp David Meeting on the Middle East," September 18, 1978, in Public Papers of the Presidents, Book II, p. 1537.

${ }^{306}$ Carter, "Interview with Dan Shilon of Israeli Television," March 22, 1979, in Public Papers of the Presidents, Book I, p. 455.

${ }^{307}$ Carter, "Interview with Bill Moyers of the Public Broadcasting Service," November 13, 1978, in Public Papers of the Presidents, Book II, p. 2023.

${ }^{308}$ Carter, Keeping Faith, p. 411.

${ }^{309}$ Ibid., p. 372.
} 
after the Accords were signed, he said, "the prayers at Camp David were the same as those of the shepherd King David" found in Psalms $85 .^{310}$

Wilt thou not revive us again: that thy people may rejoice in thee?... I will hear what God the Lord will speak: for he will speak peace unto his people, and unto his saints: but let them not return again unto folly.

Carter then concluded his remarks, "as a Christian," to Congress with "the words of Jesus. 'Blessed are the peacemakers for they shall be the children of God."'

After the peace treaty was signed in March 1979, Carter recalled, Sadat told him that he and Begin "could finally take the burden of negotiating" from his shoulders. Carter responded, "If you do, my fervent prayers will have been answered!".311 Prayer evidently provided Carter the emotional fortitude to endure when he was involved at Camp David and reinvigorated him again in 1979. Nonetheless, all presidents tire. There are simply limitations to what a president can do, particularly in such a difficult part of the world. There are other pressing commitments that presidents have made and need their attention. There are uncontrollable, unexpected, intervening events that take place that demand a president's immediate focus, such as the Iranian hostage crisis that came to preoccupy the attention of the Carter presidency from November 1979 through its waning moments on January 20.1981. And. whether a president has an evangelical leadership style or not, elections, whether his own or the party`s, are always just around the corner. As Quandt explained, sooner or later. no matter the president, "the need to appeal to the electorate, to have congressional

\footnotetext{
${ }^{310}$ Carter. "Remarks Before a Joint Session of Congress on the Camp David Meeting on the Middle East," September 18, 1978, in Public Papers of the Presidents. Book II. p. 1537.

:II Carter. Keeping Faith, p. 437.
} 
support, and to prepare for reelection comes to dominate thinking at the White

House. $" 312$

\section{Critics of Carter and Camp David}

The 1978 Camp David accords, and the subsequent peace treaty signed in 1979 , were not welcomed in all quarters. Critics have charged that the bilateral agreement between Egypt and Israel virtually ignored the Palestinian question, the future of Jewish settlements in the West Bank and Gaza, and the status of the Palestinian diaspora and East Jerusalem. While Carter scored some political points for mediating a peace accord, it has been charged that the principal winner at Camp David was Menachem Begin. $^{313}$

The Soviets opposed the agreements. Soviet Premier Leonid Brezhnev said the agreement would make the Middle East "more explosive than ever." 314 PLO Chairman Yasser Arafat described Camp David as "a dirty deal" and said "Carter will pay for it." 315 Zehdi Terzi, the PLO's permanent observer at the UN, claimed, "Begin secured all he wanted, Sadat did not get anything, and Carter gave the cosmetic touches. He is

\footnotetext{
${ }^{312}$ Quandt, Camp David, p. 28.

${ }^{313}$ Edward W. Said, The Question of Palestine (New York: Vintage Books, 1979); "Views from Abroad: Who Won at Camp David?" Journal of Palestine Studies 8.2 (Winter 1979): 168-173; "Carter from a Saudi Perspective," Journal of Palestine Studies 10.2 (Winter 1981): 125-127; Zahid Mahmood, "Jimmy Carter and Camp David," Journal of Palestine Studies 15.1 (Autumn 1985): 125-128; Zahid Mahmood. "Sadat and Camp David Reappraised," Journal of Palestine Studies 15.1 (Autumn 1985): 62-87: Shibley Telhami, "Evaluating Bargaining Performance: The Case of Camp David," Political Science Quarterly. 107.4 (Winter 1992-1993): 629-653.

${ }^{314}$ Quoted in "Carter's Swift Revival," Time, October 2, 1978.

${ }^{315}$ Ibid.
} 
the Elizabeth Arden of the deal." ${ }^{316}$ The late Edward Said, who taught English and comparative literature at Columbia University. said.

This agreement is based essentially on [an earlier] plan submitted by Begin... It makes no concessions whatever to Palestinian self-determination. It will keep Israeli military forces and settlements on the West Bank. It attempts to circumvent completely the PLO and the two million Palestinians who do not live on the West Bank and Gaza. Above all, it attempts to make Jordan and Egypt. under Israeli and US guidance, partners in the creation of a Palestinian - Bantustan. ${ }^{317}$

Similarly, Noam Chomsky of the Massachusetts Institute of Technology said:

It reads very much like the recapitulation of Begin's plan and it offers no meaningful self-determination for Palestinians and no recognition of Palestinian national or human rights. ${ }^{318}$

Hani al-Hassan, political advisor to PLO Chairman Yasser Arafat, complained that

Camp David was part of a US-Israeli "divide and conquer" strategy:

Camp David has complicated the whole Middle East situation, and does not advance a peaceful solution. They [the Americans and Israelis] have separated Egypt from the Arab world. ${ }^{319}$

By isolating Egypt, the Israelis had strengthened their position in the region. paving the way toward hegemony. Without fear of a security threat in the rear, the Israelis could safely wage war against the Palestinians in southern Lebanon. Camp David. al-Hassan believed, was a plan to militarily and politically "liquidate the Palestinians." Terzi. the PLO`s observer at the UN. said Camp David essentially legitimized the Israeli occupation in the West Bank and the Gaza Strip.

\footnotetext{
$\$ 16$ "Views from Abroad," p. 169.

317 Ibid., p. 171.

318 Ibid.

${ }^{319}$ Hani al-Hassan, "PLO on Camp David: "The Plan is to Liquidate the Palestinians Politically"." interview with MERIP, MERIP Reports 72 (November 1978): 12-13.
} 
European allies, particularly the French, were also critical of the agreement. ${ }^{320}$ They, too, contended that before peace could be had the Palestinian question must be addressed. They worried that the Israelis would have a freer hand in the region. They complained that the Carter Administration had gone about negotiations unilaterally by not including the Soviets and moderate Arab leaders, or consulting with the Europeans. $^{321}$ Like the Soviets, they were concerned that the agreements would aggravate regional tensions.

Carter critics are, perhaps, right that he could have done more to advance Palestinian interests. Echoing points made by others in other contexts, Shibley Telhami argued that Carter's lack of a sophisticated "understanding of Washington politics" and "the prevailing norms of international relations hurt his position in the negotiations. ${ }^{322}$ Further, Telhami added, Carter was unable to "correctly perceive his own dependence on domestic politics." And there is truth here too. In all fairness, however, though he hoped for a comprehensive regional settlement, Carter never believed or claimed that Camp David and the subsequent bilateral treaty were the limits of his vision for regional peace. Rather, he recognized that the Camp David Accords were but a beginning, not an ending. He always envisioned that the process for peace would continue. ${ }^{323}$ The

\footnotetext{
${ }^{320}$ Pamela Ann Smith, "European Leaders Unhappy with Sadat-Begin Treaty," MERIP Reports 80 (September 1979): 19-2 I; Carter, "Remarks and a Question-and-Answer Session with Representatives of the American Jewish Press Association," June 13, 1980, Public Papers of the Presidents, Book II, pp. 1116-1117.

${ }^{321}$ Smith, "European Leaders Unhappy with Sadat-Begin Treaty," p. 20.

322 Telhami, "Evaluating Bargaining Performance: The Case of Camp David," p. 647.

${ }^{323}$ Carter, "Remarks and Question-and-Answer Session with Editors and News Editors," February 9 , 1979, Public Papers of the Presidents, Book I, p. 251; "Remarks at President's News Conference," February 27, 1979, Public Papers of the Presidents, Book I, p. 346; "Remarks on Departure to Egypt and
} 
Preamble of Egyptian-Israeli treaty, in fact, makes clear that the treaty "is an important step in the search for comprehensive peace in the area and for the attainment of the settlement of the Arab-Israeli conflict in all its aspects. ${ }^{-324}$

Carter, the Palestinians' Cause, and Jewish Reaction

"[Carter] has shown an unparalleled understanding of the plight of the Palestinian people. He is sensitive to their legitimate call for the eradication of the injustice that was inflicted upon them in the unhappy past. ${ }^{-325}$

---Anwar Sadat

The Israeli-Palestinian question has been described as "the mother of all problems. ${ }^{326}$ Carter recognized this as well. It was his desire. and that of his principal foreign policy advisors. Secretary of State Cyrus Vance and National Security Advisor Zbigniew Brzezinski, that the Middle East peace process would ultimately entail a comprehensive settlement. not just piecemeal or partial agreements. Consistently, and to the ire of many in Israel and in the American Jewish community, Carter stressed the importance of a balanced approach between Israel and the Arabs for an effective

Israel," March 7, 1979, Public Papers of the Presidents, Book I, p. 395: "Remarks at Welcome Ceremony" with Egyptian President Sadat in Cairo, Egypt," March 8, 1979, Public Papers of the Presidents, Book I. p. 406; "Address Before the People's Assembly in Cairo, Egypt," March 10. 1979. Public Papers of the Presidents, Book I, p. 413 ; "Remarks following Meeting with Egyptian President Sadat in Cairo. Egypt." March 13. 1979, Public Papers of the Presidents, Book I, p. 430; "Remarks at News Conference in Dallas, Texas," March 25, 1979, Public Papers of the Presidents. Book I. p. 488: "Remarks at a State Dinner Honoring President Sadat and Prime Minister Begin." March 26, 1979. Public Papers of the Presidents, Book I. p. 523.

324 "Preamble to the Egyptian-Israeli Peace Treaty," March 26, 1979, Public Papers of the Presidents. 19-9. Book I, p. 496.

${ }^{325}$ Carter, "Remarks at a State Dinner with President Carter and Prime Minister Begin," March 26. 1979. Public Papers of the Presidents, Book I, p. 524.

${ }^{326}$ Romano Prodi, "Interview with Jeff 1sraely," Time, May 1, 2006, 4. 
mediator and he repeatedly noted the need to improve the political, economic. and social status of the Palestinians. ${ }^{327}$ "Domestic politics," he said, "cannot be allowed to create timidity or to propose obstacles or delay or to subvert the spirit of Camp

David." 328 According to William Quandt, Carter often drew parallels between the status of Palestinians under Israeli occupation and that of blacks in the American South.

Combined with his commitment to human rights, he "saw the Palestinian issue through that lens. ${ }^{, 329}$ From his regional experience, explained Kenneth Morris, beginning with his inaugural address, Carter may have come to believe that he could "extend the domestic principle of racial equality to a national mandate for global human rights."

In his 1980 State of the Union address, President Carter proclaimed, "We are now engaged in further negotiations to provide full autonomy for the people of the West Bank and Gaza, to resolve the Palestinian issue in all its aspects." ${ }^{\text {331 }}$ This was not something Carter came to belatedly in his presidency; it was not something he only came to acknowledge after Camp David. Even before he was elected, as he stated in a September 1976 interview with U.S. News and World Report, he recognized that "some

${ }^{327}$ Stein, Heroic Diplomacy, p. 248; Brzezinski, Power and Principle, pp. 104-105.

${ }^{328}$ Carter, "Remarks on the First Anniversary of the Egyptian-Israeli Peace Treaty with Egyptian Ambassador Ashraf A. Ghorbal and Israeli Ambassador Ephraim Evron," March 23, 1980, Public Papers of the Presidents, Book I, p. 527.

${ }^{329}$ Quandt, Camp David, p. 31. See also Carter, Sources of Strength: Meditations on Scripture for a Living Faith (New York: Three Rivers Press, 1997), pp. 74, 98.

${ }^{330}$ Kenneth E. Morris, Jimmy Carter: American Moralist (Athens, GA: University of Georgia Press, 1996), pp. 253, 263-264.

${ }^{331}$ Carter, "The State of the Union Address," January 23, 1980, Public Papers of the Presidents, Book I, p. 197. 
resolution of the Palestinian question is certainly inevitable." ${ }^{332}$ He made this point on several other occasions during the 1976 campaign.

As early as April 1975. when he was not even registering in the national opinion polls. Carter explained before a gathering at Johns Hopkins University. "We have to have a recognition of the Palestinian people and their right to exist as an independent people." Though he was not precisely certain where Palestinians would be "occupying territories." "that will be laid out later." he did think they would have a permanent place "mostly on the west bank of the Jordan." ${ }^{333}$ The following month in Tokyo. Japan. he again stated that "the rights of the Palestinians must also be recognized as part of any final solution ${ }^{\text {.334 }}$ (emphasis added). Later that fall, at a Democratic Party issues conference, Carter said. "I think one of the integral parts of an ultimate settlement has got to be the recognition of the Palestinians as a people. as a nation. with a place to live and a right to choose their own leaders. ${ }^{-335}$

Toward the end of the primary process. in an interview conducted in May 1976. he reiterated his position that "the legitimate interests of the Palestinians have to be

\footnotetext{
${ }^{332}$ Carter, "Interview with the Editors of U.S. New's \& World Report." September 13. 1976. in Conversations with Carter. p. 29.

${ }^{33}$ Carter. "Remarks and Question-and-Answer Session at Johns Hopkins University in Baltimore. Maryland." April 2, 1975. The Presidential Campaign 19-6: Jimm. Carter, p. 56. Rabin. too. supported some sort of Jordanian-Palestinian state. In contrast to Begin, in his memoirs. he affirmed his belief that "there should be two states." Rabin, The Rabin Memoirs, p. 332.

${ }^{3 i 4}$ Carter. "Remarks to the American Chamber of Commerce in Tokyo. Japan." May 28. 1975. The Presidential Campaign 1976: Jimm. Carter. p. 70.

335 Carter, "Remarks and Question-and-Answer Session at the National Democratic Issues Conference in Louisville. Kentucky." November 23, 1975. The Presidential Campaign 1976: Jimmy. Carter. p. 82.
} 
recognized." 336 Two weeks later, he expressed his hope that "the status of the

Palestinians can be resolved," "they have rights which must be recognized in any settlement." 337 Again in July, he stated "the legitimate interest of Palestinians is probably the most important aspect of the Middle East settlement. They ought to be recognized. Automatically there ought to be territories ceded for the use of the Palestinians."338

Within his first 100 days, Carter made clear that peace in the region is "a quarter of a century overdue." ${ }^{, 33}$ He explained that he did not want to mislead anyone about the chances of success; he could not "guarantee any success." 340 But if peace is to come, "the Palestinian problem" has to be addressed; "there has to be a homeland provided for the Palestinian refugees." 341 This unprompted remark, the mere mention of a Palestinian homeland by an American president, said Brzezinski, stoked and stirred "Jewish public opinion in the United States," creating "the impression that the new Administration was tilting away from Israel."342 By the summer of 1977, New York

\footnotetext{
${ }^{336}$ Carter, "Interview with John Mashek of U.S. News \& World Report," May 24. 1976, The Presidential Campaign 1976, p. 202.

${ }^{337}$ Carter, "Remarks on Middle East Policies in Elizabeth, New Jersey," June 6, 1976, The Presidential Campaign 1976, pp. 219-220.

${ }^{338}$ Carter, "Interview with Editors of Hearst Newspapers in New York City," July 22, 1976, The Presidential Campaign 1976, p. 441.

${ }^{339}$ Carter, "Address to the United Nations General Assembly," March 17, 1977, Public Papers of the Presidents, Book I, p. 445.

${ }^{340}$ Carter, "Remarks and Question-and-Answer Session with Employees of the Department of the Interior," February 18, 1977, Public Papers of the Presidents, Book I, pp. 203-204;

${ }^{341}$ Carter, "Remarks and Question-and-Answer Session at a Town Meeting in Clinton, Massachusetts," March 16, 1977, Public Papers of the Presidents, Book I, p. 387; "The President's News Conference," March 9, 1977, Public Papers of the Presidents, Book I, p. 343.
} 
Senator Jacob Javits, according to one reporter, believed Carter was "pushing Israel too far" and other pro-Israel leaders thought perhaps Carter was "selling lsrael down the river. ${ }^{3+3}$ According to one internal Administration report, there was a growing sense among Jewish leaders that Carter was "less than evenhanded." has "developed an image of insensitivity toward Jewish concerns for Israel," and "the Palestinians appear to far more popular in the Administration than in the country at large." 344 Weeks later, in a memo to Hamilton Jordan, Mark Siegel, Carter`s liaison to the Jewish community, wrote, "Jimmy Carter's stock in the American Jewish community [is] substantially below any U.S. President since the creation of the State of Israel. ${ }^{345}$

The homeland remark, said Quandt, was both "innovative" and "controversial." Reflecting "his instinct for fairness," it was a clear articulation of "a new position for the United States on the Palestinian question." Without thinking through the political ramifications whether at home or in Israel and reflecting his typically unconventional political style. Carter's "idealistic impulse, his concern for human rights, seemed to propel him into these uncharted waters" where no previous president had gone. Though

\footnotetext{
${ }^{342}$ Brzezinski, Power and Principle, p. 91; Stein, Heroic Diplomacy, p. 248: Stein. "My Problem with Jimmy Carter's Book," p. 4.

343 Carter, "The President's News Conference," June 30. 1977. Public Papers of the Presidents, Book II. p. 1200 .

34t Reasons Why the Jewish Community and Other Israeli Supporters are Disturbed by Administration Actions and Inactions Since the July 6 Meeting, Edward Sanders and Roger Lew is to Hamilton Jordan and Robert Lipshutz, September 19, 1977, Folder Middle East. 1977 (2), Box 35, Collection Title: Hamilton Jordan's Files, Jimmy Carter Library, Atlanta, Georgia.

345 Memo, Mark Siegel to Hamilton Jordan, October 3, 1977, Folder Middle East. 1977. Box 35. Hamilton Jordan's Files, Jimmy Carter Library, Atlanta, Georgia.
} 
Carter would later mute some of this, it showed that he would not hesitate to "inject controversial ideas into the debate over the Middle East." 346

Secretary Vance agreed with Carter's Palestinian assessment. In his memoirs, Hard Choices, he wrote, "for Carter to adopt an activist, balanced policy" in Mideast talks "carried a significant political risk.",347 Such a posture, he averred, "could be seen both at home and in Israel as tilting toward the Arabs and pressuring Israel to make dangerous territorial concessions." Expectedly, Vance added, "as in many other decisions at the outset of his administration," the President "unflinchingly refused to take the easy course on politically sensitive foreign policy matters."

In May 1977, in his meeting with Syrian President Hafiz al-Asad, Carter stated "there must be a resolution of the Palestinian problem and a homeland for the Palestinians." "348 This is "obviously of crucial importance"; the Palestinians need "to have a homeland and for the refugee question to be resolved." 349 "All of the United Nations resolutions," he explained, "have contemplated a homeland for the Palestinians." 350

In October 1977, the United States and the Soviet Union issued a joint communiqué on the Middle East. In hopes for a comprehensive settlement, this

\footnotetext{
${ }^{346}$ Quandt, Camp David, pp. 60-61.

347 Vance, Hard Choices, p. 163.

${ }^{348}$ Carter, "Remarks at Prior to Meeting with Syrian President Hafiz al-Asad," May 9, 1977, in Public Papers of the Presidents, Book I, p. 842.

${ }^{349}$ Carter, "The President's News Conference," May 12, 1977, in Public Papers of the Presidents, Book I, p. 861 .

${ }^{350}$ Carter, "Remarks to Reporters on the Departure of Saudi Crown Prince Fahd," May 25, 1977. in Public Papers of the Presidents, Book I, p. 1012.
} 
initiative declared that for there to be peace there should be a "resolution of the Palestinian question, including insuring the legitimate rights of the Palestinian people." and that an international conference should be convened. by the end of the year. to discuss such matters with "the representatives of all the parties involved in the conflict including those of the Palestinian people. ${ }^{351}$ This U.S.-Soviet proposal. Vance stated. signified the Carter Administration"s "conviction that a just solution to the Palestinian problem was morally and politically essential to any lasting Middle East settlement. ${ }^{* 352}$ The Israelis were angered. They opposed the communiqué's recognition of "the legitimate rights of the Palestinian people." By the end of the year, in an interview with correspondents of the leading news outlets. Carter reaffirmed his earlier endorsement of ${ }^{*}$ a homeland or an entity wherein the Palestinians can live in peace. $" 353$

Such comments and the wording of the October communiqué statement. Brzezinski noted, led to "intensifying attacks by the Jewish community" on the President and members of his foreign policy team. ${ }^{35+}$ For himself, he added. "I was presented as anti-Israeli. perhaps even worse than that, and the references to my Polish and Catholic background became increasingly pointed in some of the commentaries on the subject of the Middle East. ${ }^{.355}$ Brzezinski additionally indicated that his

\footnotetext{
351 Vance. Hard Choices, p. 463.

$\$ 52$ Ibid.. p. 193.

Carter. "Interview with Tom Brokaw of NBC News. Bob Schieffer of CBS News. Robert MacNeil of PBS, and Barbara Walters of ABC News," December 28. 1977, in Public Papers of the Presidents, Book II. p. 2190.

${ }^{354}$ Brzezinski. Power and Principle, p. 97.

355 Ibid.. p. 98 .
} 
appointment of Quandt to the National Security Council was opposed by the AmericanIsraeli Political Action Committee (A1PAC) and Florida Senator Richard Stone "on the grounds that Quandt was pro-Palestinian." 356

A little more than six months into the presidency, $\mathrm{ABC}$ News' Harry Reasoner said to Carter that "a number of 1sraeli leaders in private say that you have made drastic changes in America's attitude toward Israel and that they regard you with considerable trepidation." Reasoner asked the President if he was aware of such feelings. Carter replied that he was and noted that he also understood, "There's no single attitude among all Jews in the world or all Israeli citizens." If Israel wants peace, he continued, a key aspect that had to be addressed is "the question of the enormous numbers of Palestinian refugees who have been forced out of their homes and who want to have some fair treatment." ${ }^{357}$ Carter's statement obviously did not mollify pro-Israel critics at home or abroad. He knew that. But, it was more important, he believed, "to be fair" in his dealings with the Israelis and the Arabs. What the comment showed, wrote Brzezinski, is that in spite of "increasingly severe criticism from the Jewish community," Carter was determined "to show his understanding and compassion for the Palestinian situation." $" 358$

In contrast to European leaders such as French President Valery Giscard d'Estaing, who considered "the Israelis as 'international bandits," Carter was torn,

\footnotetext{
${ }^{356}$ Ibid., p. 77.

${ }^{357}$ Carter, "Interview with ABC News Correspondents Harry Reasoner and Sam Donaldson in Plains, Georgia," August 10, 1977, in Public Papers of the Presidents, Book II, p. 1470.

${ }^{358}$ Brzezinski, Power and Principle, pp. 104-I05.
} 
Brzezinski observed. "One the one hand, he felt that Israel was being intransigent; on the other, he genuinely did have an attachment to the country as "the land of the Bible. " ${ }^{\cdots 59}$ To the frustration of one White House aide, "if we're not behind [Israel] $300 \%$, they think we're against them. ${ }^{\text {"360 }}$

Near the beginning of his second year in office, in what would be termed the Aswan Declaration. Carter restated after his second meeting with Sadat. "There must be a resolution of the Palestinian problem in all its aspects. The problem must recognize the legitimate rights of the Palestinian people and enable the Palestinians to participate in the determination of their own future. ${ }^{.361}$ At the end of January 1978, he said at his presidential news conference.

Our position on [Israeli] settlements in the occupied territory has been that they are illegal, that they are an obstacle to peace.

I've always operated and made statements under the framework and within the constraints of United Nations Resolution 242. which calls for Israel to withdraw from occupied territories. ${ }^{362}$

(Despite claims to the contrary, this has been Carter's consistent view. In The Blood of Abraham, he wrote. "Israel must reconfirm its willingness to withdraw from occupied territories, as required by U.N. Resolution 242 and reconfirmed in the Camp David

\footnotetext{
359 lbid. p. 97.

${ }^{360}$ Quoted in "Geneva: Push Comes to Shove," Time, October 17. 1977. 30.

${ }^{361}$ Carter, "Remarks following Meeting with President Sadat in Aswan, Egypt," January 4, 1978, Public Papers of the Presidents, Book I. p. 20; Quandt, Camp David. pp. 160-161.

362 Carter. "The President's News Conference," January 30. 1978, Public Papers of the Presidents, Book 1. p. 247. Ken Stein argued that Carter first adopted this view in his 2002 Nobel Peace Prize speech on December 10, 2002. Stein, "My Problem with Jimmy Carter's Book." p. 8.
} 
accords." 363 Nearly twenty years later, Carter said, "U.N. Security Council Resolution $242 \ldots$ requires, in effect, a withdrawal of Israel from occupied territories, in exchange for ensured peace and recognition from all Arab governments and other organizations." ${ }^{364}$ )

A month later, during his third visit with President Sadat, Carter reaffirmed that if peace in the region is to occur, "a just solution to the Palestinian question is essential." 365 There must be, said the White House, a "resolution of the Palestinian problem in all its aspects," a recognition of "the legitimate rights of the Palestinian people," and Palestinian participation "in the determination of their own future."366 Additionally, the White House declared, "Israeli settlements in occupied territory are contrary to international law and an obstacle to peace," and any "further settlement activity would be inconsistent with the effort to reach a peace agreement."

After his March meeting with Prime Minister Begin, Carter said that he emphasized to Begin "the importance of reaffirming that all the principles of [UN] Security Council Resolution 242 must apply to all fronts if peace negotiations are to succeed" (emphasis added). ${ }^{367}$ This is a position the Begin government rejected. Said one news report, while "previous Israeli governments had accepted 242, to the distress

\footnotetext{
${ }^{363}$ Carter, The Blood of Abraham, p. 190.

${ }^{364}$ Carter, "The Choice for Israelis," Washington Post, September 23, 2003.

${ }^{365}$ Carter, "Remarks on the Departure of President Sadat," February 8, 1978, Public Papers of the Presidents, Book I, p. 290
}

360 "White House Statement on the Final Meeting Between President Carter and President Sadat," February 8, 1978, Public Papers of the Presidents, Book I, p. 292.

${ }^{367}$ Carter, "Remarks on the Departure of Prime Minister Begin," March 22, 1978, Public Papers of the Presidents, Book I, p. 551. 
of the Carter White House and many Israelis, Begin's view was 242 only vaguely referred to unnamed occupied territories, and it did not apply to the West Bank." To the contrary, Yitzhak Rabin explained, "There was no question in my mind but that the resolution meant to cover the West Bank" (emphasis added). ${ }^{368}$ Rabin also added that the Begin government "took an extreme position" with regard to the West Bank and settlement activity, "especially demanding the extension of Israeli sovereignty" in the area. Begin's policies constituted "a radical departure from the policies that had been advocated and pursued by my government. $" 369$

At the President`s news conference the following week, Carter noted that his deepest concerns were "Israel's refusal to acknowledge that United Nations Resolution 242 applies clearly to the West Bank" and its "unwillingness to grant to the West Bank Palestinians, the Palestinian Arabs, a right to participate in the determination of their own future. ${ }^{370}$ In answering critics, Carter said his administration had been neither "timid" nor "cowardly". but had gone further than any other in publicly raising "the basic problems of the Palestinians. ${ }^{.371}$ He said his policy and attitude toward the Palestinian situation has been "very consistent from the beginning."

\footnotetext{
${ }^{368}$ Raymond Carroll with Milan J. Kubic. Scott Sullivan. Thomas M. DeFrank, Eleanor Clift, and LarsErik Nelson, "Begin Under Fire." Newsweek. March 20, 1978, 25.

${ }^{369}$ Rabin, The Rabin Memoirs, p. 317.

${ }^{370}$ Carter, "The President's News Conference Held in Brasilia, Brazil," March 30. 1978. Public Papers of the Presidents, Book I, p. 631.

$3^{31}$ Carter, "Remarks and a Question-and-Answer Session at a Town Meeting in Aliquippa. Pennsylvania," September 23. 1978. Public Papers of the Presidents. Book II. p. 1609.

372 Carter, "Remarks and a Question-and-Answer Session with Editors and News Directors," April 6. 1979. in Public Papers of the Presidents, Book I. p. 623.
} 
Carter's comments continued to cause rifts between the Democratic president and the mostly Democratic Jewish community, which votes close to $80 \%$ Democratic and provides party candidates "much of the private money and key manpower in Presidential and Congressional campaigns." ${ }^{373}$ According to a Newsweek cover story, entitled "Carter and the Jews," Carter was being seriously hurt because he "believes that Israel must make concessions" in the search for Mideast peace. ${ }^{374}$ For many Jews, this pressure created an image of a president who was either "naïve or unsympathetic to Israel." Carter was also accused of "trying to impose his views on the Israelis," "colluding with Sadat" against Israel, and, incredibly, of being "more concerned with the Palestinian question than Sadat was." 375

In his evaluation, historian Paul Charles Merkley would go so far as to label Carter's policies as "anti-Israeli," because "he pursued a policy much less friendly to Israel's own views of its needs and interests than that pursued by any president up to that date. ${ }^{376}$ In other words, because Carter sought a fair and just peace between Israel and her Arab neighbors, because he sought an outcome more consistent with his understanding of the scriptures, because he sought a policy that he believed was in American long-term interests, rather than doing only what is best for Israel, Carter is judged to be "anti-Israeli." As to Carter's religion, Merkley charged that his theology

\footnotetext{
${ }^{373}$ David M. Alpern, with Hal Bruno, Henry W. Hubbard, and Martin Kasindorf, "Carter and the Jews," Newsweek, March 20, 1978, 28.

374 Ibid.

${ }^{375}$ Quandt, Camp David, p. 187.

${ }^{376}$ Paul Charles Merkley, American Presidents, Religion, and Israel: The Heirs of Cyrus (Westport, CT: Praeger Publishers, 2004), p. 142.
} 
was anti-Judaic, "a champion of Christian anti-Zionism." "self-consciously and explicitly anti-Zionist," and after leaving the White House. his attitude became "more blatantly anti-Israeli as every year went by. "377 The reason for this assessment. said Merkley, is that Carter believed that God's blessings were not exclusively limited to the Jews, but that Jews, Christians, and Muslims were joint heirs. ${ }^{378}$ As such. for the Jewish people. Carter, in Merkley`s view, was hardly a righteous gentile leader. no friend of Israel; he was "the evangelical anti-Cyrus." 379

Ever since Carter used the words "Palestinian homeland," "a concept never before accepted by an American President," back in March 1977. "Jewish suspicions" of Carter had grown. ${ }^{380}$ "There is no question that the President's Middle East policy is costing him," said Democratic National Committee Chair Robert Strauss. ${ }^{381}$ According to one White House aide identified in the report as being "non-Jewish," the President"s regional and religious background was an additional factor fueling the tension. "For a Southern Baptist like Carter to be able to push Israel," the aide said, "he has to give excessive reassurance to American Jews. ${ }^{382}$

Meanwhile, the resignation of Siegel in 1978 over Mideast policy differences. including his opposition to the proposed F-15 fighter sale to Saudi Arabia and Egypt.

\footnotetext{
Ibid., pp. 140, 143-144.

${ }^{3\urcorner 8}$ Ibid., pp. 143-I44.

${ }^{379}$ Ibid., p. 139.

${ }^{380}$ Alpern. et. al., "Carter and the Jews." p. 28.

381 Ibid., 29.

382 Ibid.
} 
only reconfirmed to Carter's pro-Israel critics that something was seriously amiss with the direction of his administration, that "Jimmy Carter is not completely to be trusted on matters concerning Israel. ${ }^{, 383}$ When the vote finally came, the Administration barely won. The consequences for the President, recalled Brzezinski, were not good. ${ }^{384}$ Though the arms sale served U.S. interests in the region and the Administration's plan to develop closer ties to moderate Arab governments included balancing arms sales to Israel, the effect on the President's support within the party, the sometimes negative press coverage, the many meetings, that "were rarely pleasant" and consumed too much time, and the "severe attack from the Jewish lobby," was "a costly victory," "a costly diversion" for Carter. Newsweek also reported the cultural differences between Siegel and the Carter team. Just as Carter's Southern and religious background was suspect to many in the Jewish community, Siegel "was never really accepted into the tight circle of Georgians. His aggressive, wisecracking ways made them nervous. And his readiness to talk freely with Washington reporters made him suspect as a leaker." ${ }^{385}$

Consistent with his general attitude toward Congress and the art of political compromise, Quandt noted, Carter was advised to delay the arms sale package, and, if he did, "the administration could count on substantial Jewish and congressional support." ${ }^{386}$ However, the President "ignored this offer and decided to proceed with the sales." When he asked Carter in 1985 about this, Quandt said, Carter reemphasized his

\footnotetext{
${ }^{383}$ Don Holt with Hal Bruno, Eleanor Clift, and Thomas M. DeFrank, "A Painful Exit," Newsweek, March 20, 1978, 27.

${ }^{384}$ Brzezinski, Power and Principle, pp. 247-249.

${ }^{385}$ Holt, et. al., "A Painful Exit," 27.

${ }^{386}$ Quandt, Camp David, p. 188.
} 
point that "he normally paid little attention to his political advisers when they urged him to postpone one controversial move in order to enhance the chances of positive action on another issue. ${ }^{387}$

The next year, in May 1979, two months after the signing of the Egyptian-Israeli peace treaty, Carter once again explained that "the most difficult single issue" that remains in the Middle East "concerns Palestinians." including "the basic problem of the Palestinian refugee." 388 In election-year 1980, during Begin's visit, Carter stated that Camp David was "founded on the principles espoused in U.N. Resolution 242," "calls for the establishment of a self-governing authority" for the Palestinians in the West Bank and Gaza, calls for the removal of the Israelis' military and civil administrative presence in those areas, "calls for the recognition of the legitimate rights of the Palestinians" and their right of participation "in the determination of their own future." and "calls for us to resolve the Palestinian question in all its aspects," including "the refugee problem. ${ }^{* 389}$

Later that year. in a meeting with members of the American Jewish Press Association a month before his renomination as the Democratic candidate for president. he characterized "the establishment of additional Israeli settlements on the West Bank" as wholly unnecessary and "an obstacle to peace. ${ }^{\text {"390 }}$ Such settlements complicate "a

${ }^{387}$ Ibid., p. $188 n 17$.

${ }^{388}$ Carter. "Remarks at the $30^{\text {th }}$ Annual Brotherhood Citation Dinner of the National Conference of Christians and Jews," May 29, 1979. Public Papers of the Presidents, Book I. p. 971.

${ }^{389}$ Carter, "Remarks at Dinner Honoring Prime Minister Begin," April 15. 1980, Public Papers of the Presidents, Book I, p. 688.

${ }^{390}$ Carter. "Remarks and a Question-and-Answer Session with Representatives of the American Jewish Press Association," June 13, 1980, Public Papers of the Presidents, Book II. p. 1120. 
comprehensive agreement" and indicate "to the Palestinian Arabs, to the Egyptians, and to others, that Israel will not carry out the principles of the Camp David accord."

Days later, in his meeting with Jordan's King Hussein, Carter said that while there were disagreements over the meaning and significance of Camp David, he agreed that there had to be a "solution of the Palestinian question in all its aspects, the right of the Palestinians to have a voice in the determination of their own future, the security of Israel, and a comprehensive and just peace for the region."391 The following week at the Venice Economic Summit, he told reporters that he fully shared with European leaders the pressing need to resolve the Palestinian question and that "the Palestinian rights must be honored and the Palestinians must have a voice in this decision." 392 Looking back, Brzezinski observed that, beginning with Carter's first year, "the most controversial of the points" in his approach "proved to be the idea of the Palestinian homeland." Repeatedly, he continued, "there was a very intense domestic reaction... it seems fair to conclude that the Palestinian issue was introduced too early" in his term. $^{393}$

Even so, as Weizman observed, the importance of Camp David included that Israel for the first time put its signature on a document recognizing Palestinians ' had "legitimate rights" and Palestinians were a "people." 394 Not long before, he added.

\footnotetext{
${ }^{391}$ Carter, "Remarks following Meeting with King Hussein of Jordan," June 18, 1980, Public Papers of the Presidents, Book II, p. 1129.

${ }^{392}$ Carter, "Interview with Reporters following the Conclusion of the Venice Economic Summit Conference in Venice, Italy," June 23, 1980, Public Papers of the Presidents, Book II, p. 1196.

${ }^{393}$ Brzezinski, Power and Principle, p. 234.

${ }^{394}$ Weizman, The Battle for Peace, pp. 364, 366, 368-369, 372, 375.
} 
Begin believed such language represented the first steps toward Palestinian statehood.

Moreover, by the fact it was signed coterminous with the framework for peace with Egypt meant there exists a "conditional link" between the two. That is, wrote

Weizman, it could legitimately be interpreted that a separate peace was not signed at all. "The mere fact of their simultaneous signing constitutes a kind of conditional link." Rabin concedes this point. too. "It is true that there is no legal or operative linkage between the two agreements signed at Camp David. Israel was very cautious to ensure that point. But when it comes to the question of political linkage, I can see how there might well be different interpretations of the question." 395

Critics also need to bear in mind that Carter did not win a second term in 1980. As Stein explained, "After Carter's defeat, an absence of continuity in presidential commitment...contributed to a steady decline in attention to the Arab-Israeli conflict." 396 "Ronald Reagan." he assessed. "did not have the passion. dedication. or personality Carter demonstrated for the issue." Further, unlike most of the players crucial to peace in the region, the tenure of American presidents is quite brief. Carter understood this and the urgency, because "Sadat, Begin, Carter will not be in office many years under the best of circumstances. ${ }^{\text {397 }}$

Carter made it clear that had he won it was his intention to make "further progress toward a comprehensive Mideast peace" that included "resolution of the

\footnotetext{
${ }^{395}$ Rabin. The Rabin Memoirs, p. 328.

${ }^{396}$ Stein, Heroic Diplomacy, p. 263.

397 Carter. "Interview with Dan Shilon of Israeli Television." March 22. 1979. in Public Papers of the Presidents of the United States, Book I, p. 453.
} 
Palestinian question." 398 "My goal in the next four years is to continue this progress." ${ }^{399}$ Quandt made the same point. "Carter almost certainly had hoped to work on the Palestinian question in a second term, but he never had the chance." ${ }^{400}$ Even so, promotion of Middle East peace, including the Palestinian cause, was part of his "unfinished presidency." After he left office, he continued to call for the Palestinian issue to be addressed and warned if it was not, no "alleviation of the tension in the Middle East" would come. ${ }^{401}$ "I don't see any way for any substantive progress to be made in the Middle East peace process without the Palestinians being intimately involved in the process.

Unfortunately, he said, many pro-Israel critics in the United States, including "most of the vocal American Jewish community," emboldened Israeli intransigence and

${ }^{398}$ Carter, "Remarks and Question-and-Answer Session at a Townhall Meeting in Dayton, Ohio," October 2, 1980, Public Papers of the Presidents, Book III, p. 2025; see also "Question-and-Answer Session at a Town Meeting with Residents in Queens, New York," September 25, 1979, Public Papers of the Presidents, Book II, p. 1752; "Remarks and Question-and-Answer Session with Magazine Editors," February 15, 1980, Public Papers of the Presidents, Book I, p. 338; "Remarks at the United Jewish Appeal's National Young Leadership Conference," February 25, 1980, Public Papers of the Presidents, Book I, p. 378; "The President's News Conference," March 14, 1980, Public Papers of the Presidents, Book I, p. 486; "White House Briefing to Community Leaders on Inflation and Energy," March 20. 1980. Public Papers of the Presidents, Book 1, p. 511; "Remarks and Question-and-Answer Session at a Townhall Meeting in Independence, Missouri," September 2, 1980, Public Papers of the Presidents, Book II, p. 1619.

${ }^{399}$ Carter, "Remarks at a Democratic National Committee Fundraising Reception in Beverly Hills, California," September 22, 1980, Public Papers of the Presidents, Book II, p. 1888.

${ }^{400}$ Quandt, "Camp David and Peacemaking in the Middle East," p. 365.

${ }^{401}$ Carter, "Interview with Barbara Reynolds of USA Today," May 12, 1986, in Conversations with Carter, p. 274; "Transcript of News Conference Held by Presidents Jimmy Carter and Gerald Ford in flight from Cairo to Washington." New York Times, October 12, 1981.

${ }^{402}$ Carter, "Interview with Mike Wallace on CBS's 60 Minutes," March 24, 1985, in Conversations with Carter, p. 261. 
tried to silence any serious debate on U.S. policy toward Israel and the wider region. ${ }^{403}$

Unlike Israel. "a democracy with almost unrestricted freedom of speech." where one could "hear a wide range of opinion" on matters of Middle East peace and the nature of Israeli involvement in Palestinian areas for three decades, Carter wrote in 2006 that in America. "I have witnessed and experienced the severe constraints on any free and balanced discussion of the facts. This reluctance to criticize any policies of the Israeli government is because of the extraordinary lobbying efforts of the American-Israel Political Action Committee and the absence of any significant contrary voices. ${ }^{.40+}$ To challenge this prevailing posture, to sponsor "a balanced position," said Carter. is "politically suicidal." Even the media, he charged, have exercised "similar selfrestraint" in their coverage. What particularly annoyed Carter, as it did across an array of issues, was "the degree to which some senators are afraid to stand up for the American national interest and will simply do the bidding of a powerful lobby. "405 Carter at the time was frank about the limitations of Camp David. He

${ }^{403}$ Carter, "A New Chance for Peace?" Washington Post. January 18. 2007: "Remarks at a Book Signing Event in Virginia," November 28, 2006, http. www democracynow org article.pl? sid =0611 301452225.

${ }^{404}$ Carter. Palestine: Peace Not Apartheid, pp. 68, 209; "How I See Palestine," Los Angeles Times. December 8, 2006; "Interview with Eleanor Clift." December 25, 2006-January' 1, 2007, Newsweek International, http. www.msnbc.msn.com. Carter is not the only one who has raised this problem. Even before the controversy over Carter's 2006 book erupted, National Public Radio did a report entitled. "Is an Israel Policy Debate Possible in the U.S.?" after a scheduled lecture at the Polish Consulate by New' York University Professor Tony Judt was canceled due to pressure from pro-1srael groups. See "Is an Israel Policy Debate Possible in the U.S.?" National Public Radio, October 30. 2006, http: www.npr.org. Earlier in the year, too, Foreign Policy magazine ran a cover story entitled, "Does the Israel Lobby Have Too Much Power?" Professors Stephen Walt, John Mearsheimer, and Zbigniew Brzezinski answered in the affirmative. Professor Aaron Friedberg, former U.S. Ambassador to Israel Dennis Ross, and former Israeli foreign minister Shlomo Ben-Ami answered in the negative. "The War over Israel 's Influence." Foreign Policy (July/August 2006): 56-66. In this essay collection. Brzezinski said that it is fair to criticism any "ethnic or foreign-supported" interest group much like the one-time influential Polish lobbs was by Franklin Roosevelt. To argue otherwise "is to claim an altogether unique immunity for Israel. untouchable by the kind of criticism that is normally directed at the conduct of states." See Brzezinski. "A Dangerous Exemption," pp. 63-64. 
recognized that "the Camp David accords are a long step" toward a greater and wider peace in the region. ${ }^{406}$ It was "a partial victory." 407 On one occasion, citing what Benjamin Franklin once said after concluding a peace treaty between the new United States and Great Britain, he said that "he had never seen a peace made, however advantageous, that was not censured as inadequate. No treaty can possibly embody every aim." ${ }^{408}$ Carter said he did not ever "claim that we've done enough yet, but we have laid a groundwork now, a basis for future progress." 409 "Much remains to be done. Progress may be slow," but the goal remained "to complete the process so hopefully begun at Camp David." 410 Though he later charged that his immediate successor. President Reagan, stood largely "more aloof," and that George W. Bush had "abandoned" the area and became decidedly and uncritically too pro-Israel, it was Carter's hope that his successors would "continue the Camp David process to bring peace to the Mideast and to let there be a continued search for peace by the Egyptians and the Israelis."

${ }^{405}$ Brzezinski, Power and Principle, p. 248.

${ }^{406}$ Carter, "Statement on the First Anniversary of the Camp David Agreements," September 17. 1979. Public Papers of the Presidents, Book II, p. 1681.

${ }^{407}$ Carter, Keeping Faith, p. 438.

${ }^{408}$ Carter, "Remarks on the First Anniversary of the Egyptian-Israeli Peace Treaty with Egyptian Ambassador Ashraf A. Ghorbal and Israeli Ambassador Ephraim Evron," March 23, 1980. Public Papers of the Presidents, Book I, p. 526.

${ }^{409}$ Carter, "Remarks and Question-and-Answer Session at a Townhall Meeting in Independence, Missouri," September 2, 1980, Public Papers of the Presidents, Book II, pp. 1624-1625.

${ }^{410}$ Carter, "Interview with Dan Raviv of Israel Television," September 8, 1980, Public Papers of the Presidents, Book II, p. 1670.

411 Carter, "Middle East: Time for Negotiations," Time, April 20, 1987; "Casting a Vote for Peace," New' York Times, November 12, 2004; "Remarks at the Geneva Initiative Public Commitment Event," December 1, 2003, www.cartercenter.org; "Remarks and Question-and-Answer Session with Reporters," 
Carter described Camp David and the Egyptian-Israeli peace treaty as an "achievement but with promise"- a promise that included "a possibility for the realization of the hopes of the Palestinians and the hopes of all Israel's neighbors and. indeed, all the nations of the Arab world to live in peace and to slowly but inevitably remove hatred from their hearts and to seek for common understanding. ${ }^{.412}$ Camp David was "the first step of peace, a first step on a long and difficult road. We must not minimize the obstacles which still lie ahead. ${ }^{+13}$ "We must," therefore, "rededicate ourselves to the goal of a broader peace with justice for all who have lived in a state of conflict in the Middle East. ${ }^{,+14}$

Middle East peace is possible. Carter affirmed, and the 1978 Camp David Accords and the 1979 peace treaty were evidence of that. Still, those agreements are but steps toward peace. Though they were viable and valuable documents, they "can be modified" as circumstances warrant. "It's not a Biblical text," he said. ${ }^{+15}$

November 12. 1980. Public Papers of the Presidents, Book III, p. 2704; "Informal Exchange with Reporters in Plains, Georgia." December 24. 1980, Public Papers of the Presidents, Book III, p. 2834: "Interview with James Laue at the $5^{\text {th }}$ National Conference on Peacemaking and Conflict Resolution in Charlotte. North Carolina." June 7, 1991, in Conversations with Carter, p. 287.

\$12 Carter. "Remarks at a Toast Honoring Egyptian President Sadat," April 8. 1980, in Public Papers of the Presidents, Book I, p. 618.

41: Carter. "Remarks at the Signing Ceremony of the Egyptian-Israeli Peace Treaty with President Sadat and Prime Minister Begin." March 26, 1979, in Public Papers of the Presidents, Book I. p. 517.

${ }^{41+}$ Ibid., p. 518

Hs Carter. "Interview with James Laue at the $5^{\text {th }}$ National Conference on Peacemaking and Conflict Resolution in Charlotte. North Carolina," June 7. 1991, in Comersations with Carter. p. 289. 
Carter has urged his critics to keep Camp David in perspective. ${ }^{416}$ In direct terms, he declared, "Before I became President there was no Camp David accords and there was no Middle East peace treaty. Before Camp David, Israel and Egypt were poised across barbed wire, confronting each other with guns and tanks and planes." For thirty years, Carter explained, "it was inconceivable that Israel and Egypt would be sitting down together working on ways to alleviate tensions between them, with open borders and diplomatic recognition, exchange of ambassadors, tourism, trade being established." 418 Camp David made that a reality and now "we have a basis for progress." To the surprise of all, Carter brought together, he noted, "this seemingly incompatible pair, Begin and Sadat," to make a positive contribution toward peace in the war-torn region. ${ }^{419}$ Because of their efforts, Carter insisted, there was "a way to resolve the Palestinian issue, to give the Palestinians a voice in the determination of their own future, to resolve the Palestinian question in all of its aspects." ${ }^{420}$ Moreover, though "the Camp David process has been much maligned" by non-participating Arab countries, Camp David and the 1979 peace treaty, he argued, showed the Arab world "it

${ }^{416}$ Carter, "Interview with Daniel Schorr and George Watson of the Cable News Network," May 31 , 1980, Public Papers of the Presidents, Book II, p. 1017; "Remarks on Middle East Peace at the Herzliya Conference, Israel," January 23, 2006; "Interview with Wolf Blitzer," CNN Late Edition. January 29. 2006.

${ }^{417}$ Carter, "Acceptance Speech at the Democratic National Convention in New York City," August 14. 1980, Public Papers of the Presidents, Book II, p. 1535.

${ }^{418}$ Carter, "Interview with Arrigo Levi of La Stampa and Sergio Telmon of RAI-TV," June 12, 1980. Public Papers of the Presidents, Book II, p. 1104.

${ }^{419}$ Carter, "Can Peace Still Come to Israel?" Atlanta Journal-Constitution, December 12, 1995.

${ }^{420}$ Carter, "Interview with Arrigo Levi of La Stampa and Sergio Telmon of RAI-TV," June 12, 1980. Public Papers of the Presidents, Book II, p. 1104. 
is possible to negotiate successfully with Israel," agreements obtained, occupied land recovered, and Israeli settlements removed. ${ }^{421}$

Carter acknowledged that the criticisms of Camp David were legitimate and he hoped that they could be addressed in a second term, if he was given the chance. However, he also wanted his critics to acknowledge what had been accomplishedpeace between Israel and Egypt, her largest Arab neighbor. Things take time. Carter insisted, "everything that's right can't be accomplished overnight." ${ }^{+422}$ Still, he hoped that what was accomplished would be remembered and inspire others to follow his path. In the end, history will be the judge of what was or was not accomplished. "Only history will reveal if my hopes and prayers are to be answered - or if another round of bloody confrontation will ultimately lead to an international tragedy."

\section{Conclusion}

"We saw a remarkable ceremony, headed by a Jew, the leader of Israel. a Moslem, the President of Egypt, and myself, a Christian, the President of our country, signing a treaty of peace. This peace treaty was a historic development. and it was compatible with the commitment that we feel so deeply in the religious season [Christmas] now upon us. $"+24$

The quest for peace in the Middle East has been "one of my main commitments in life," says Jimmy Carter. ${ }^{425}$ It was a crucial part of his evangelical mission as

\footnotetext{
${ }^{+21}$ Carter, "Middle East: Time for Negotiations," Time, April 20, 1987.

${ }^{422}$ Carter, "Remarks at the Zion Baptist Church in Philadelphia, Pennsylvania," September 3, 1980. Public Papers of the Presidents, Book II, p. 1634.

423 Carter, Keeping Faith, p. 438.

424 Carter, "Remarks at the Christmas Pageant of Peace, Lighting the National Community Christmas Tree," December 13, 1979. Public Papers of the Presidents, Book II. p. 2244.
} 
president. Though, he says, "you can never be certain in advance that negotiations on difficult circumstances will be successful," American presidents must try. "Real moves toward peace demand bold actions by leaders," such as that taken by Sadat, Begin, and himself. ${ }^{426}$ It involves the "search for different avenues," being "innovative," and engaging in "creative risk-taking." 427 It may even include acts of "desperation." ${ }^{428}$ If not, "you can be certain in advance if you don't negotiate that your problem is going to continue and maybe even get worse." friend and foe together and working "to modify adamant positions of adversaries.",430 While it may be true that Carter's evangelical style caused him problems in other situations, such as in his relations with Congress, as we saw in chapter 4 , it served him rather well at Camp David and during the process to conclude a final peace treaty. Against the advice within his own administration not to take such a personal role in the negotiations and endure heavy criticism "by powerful lobbying forces" for his attempt to be an unbiased mediator, Carter's evangelical style of leadership provided him with a

\footnotetext{
${ }^{425}$ Carter, "Telephone Interview with Christopher Dickey of Newsweek," October 7, 2006; "Remarks and Question-and-Answer Session at the Council on Foreign Relations," March 2,2006; "Letter to Jewish Community on Palestine: Peace Not Apartheid," December 15, 2006; Ernie Suggs, "Carter hurt by backlash against book; Apologizes at Brandeis for passage on Israel," Atlanta Journal-Constitution, January 24, 2007.

${ }^{426}$ Carter, "Middle East Accord Offers 'Best' Chance for Peace," USA Today, November 3, 2003; "Middle East: Time for Negotiations," Time, April 20, 1987.

${ }^{427}$ Carter, "Interview with James Laue at the $5^{\text {th }}$ National Conference on Peacemaking and Conflict Resolution in Charlotte, North Carolina," June 7, 1991, in Conversations with Carter, p. 287: "Middle East Peace: New Opportunities," Washington Quarterly, 10.3, Summer 1987.

${ }^{428}$ Carter, Keeping Faith, p. 425.

${ }^{429}$ Carter, "Interview with Der Spiegel," August 15, 2006, http://service.spiegel.de/cache/international/spiegel $/ 0,1518,431793,00 \mathrm{html}$.

${ }^{430}$ Carter, "Needed: Middle East Peace Talks," New York Times, January 2, 1991.
} 
sense of mission and political vision to bring peace to the region in accordance with "the teaching of Scripture," the political skill and personalism to forge a unique bond with Sadat, and the emotional strength through prayer to pursue a worthwhile goal with no guarantee of success. ${ }^{431}$ Carter's successful Middle East mediation, though deemed at the time exceedingly risky and politically foolish, was the crown of his foreign policy objectives and accomplishments.

Figure 6.1 shows on the specific question of his handling of foreign policy, Carter received his first and only majoritarian level of support of his presidency; he received a 56\% approval rating in a September 1978 poll, the month of the Camp David summit. What the foreign policy data show is that his involvement in the Middle East peace process actually improved his standing with the American people in this general

\section{Figure 6.1 Approval of President Carter's Handling of Foreign Policy, 1977-1979}

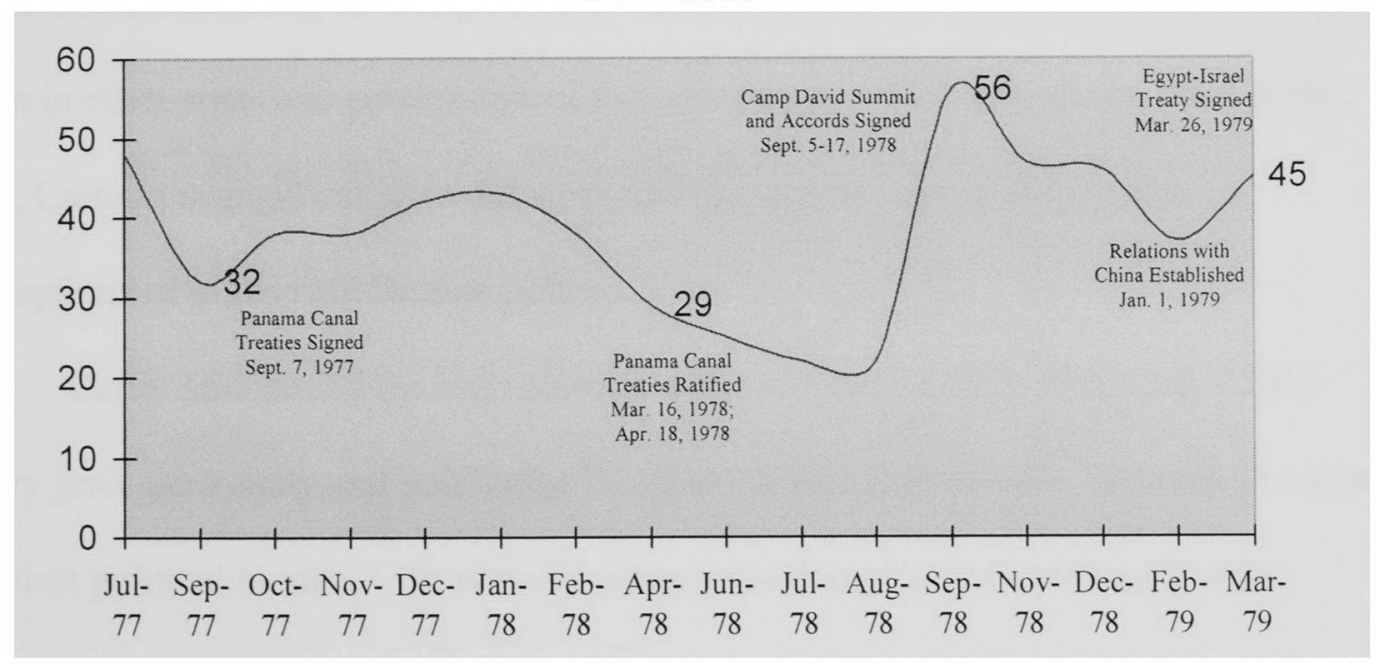

Source: Lyn Ragsdale, Vital Statistics on the Presidency: Washington to Clinton (Washington, DC: Congressional Quarterly Inc., 1998), p. 240.

\footnotetext{
${ }^{431}$ Carter, "Remarks and Question-and-Answer Session at the Council on Foreign Relations," March 2. 2006.
} 
policy area. From 1977-1979 where data is available on this question, September 1978 represented his best foreign policy month. In fact, his approval numbers jumped $34 \%$ points from the previous month.

March 1979 was also a good month for the Carter Administration. Compared with the data between June 1977 and August 1978, the period between September 1978 and March 1979 was the best period of Carter's first two years. If anything, it may have been the Panama Canal treaties and the Senate ratification process that appear to have dragged down Carter's foreign policy ratings during this time, not his involvement in and pursuit of Middle East peace between Israel and Egypt. It may be further said that his Middle East efforts and successes at least, no matter how temporarily, improved his standing to his pre-Panama level of $48 \%$ support. Therefore, it may be judged that while Carter's overall numbers did not benefit from his intense involvement he did gain support in his handling of foreign policy, but it was insufficient to overcome decisions made in other areas and perceptions of the overall state of his presidency. But in this case, Carter's evangelical style did work and did improve, at least for a time, perceptions of his overall foreign policy.

Carter understood the high political risks involved, and he ultimately paid a heavy price personally and politically. ${ }^{432}$ "The Middle East dispute," he said, "was the heaviest political burden." "It was very time-consuming" and involvement was commonly "frustrating and thankless." 433 Politically, Brzezinski noted, for instance, the negative media coverage Carter was receiving. He said, "a significant portion of the

\footnotetext{
${ }^{432}$ Miller, "Shadow and Substance," p. 3.

${ }^{433}$ Carter, Keeping Faith, p. 421.
} 
American press...portrayed him as anti-Israeli. ${ }^{+34}$ Carter understood that he would share with Sadat and Begin the blame of personal failure. a failure that imminently loomed in the air many times. ${ }^{435}$ For instance, just two days before they finally reached an agreement, Carter and his team were preparing for "how to deal with our failure." +36 Carter "instructed staff members to begin drafting an outline of a speech for me to make to Congress. explaining what we had attempted during the two weeks at Camp David and why we had not been successful."

Carter understood the stakes. He recognized that failure could hinder his other foreign policy goals and diminish his standing among world leaders. He recognized that failure would further weaken his popular standing at home and within his own party. This explains, said former Press Secretary Jody Powell, why future presidents after Carter did not make Middle East peace a priority. They understood "that making peace in the Middle East was a political loser. ${ }^{+37}$ In the long run. Strong explained. "Those successes earned relatively little, if any, domestic political advantage."

Though his success at Camp David improved his foreign policy standing. Carter`s efforts angered many Jewish Americans. a loyal Democratic constituency, out of fear that he was jeopardizing Israel's security. In 1980, only 45\% of American Jews

\footnotetext{
${ }^{+34}$ Brzezinski. Power and Principle, p. 280.

${ }^{435}$ Ibid., p. 286.

${ }^{436}$ Carter, Keeping Faith, p. 400.

137 Quoted in Tom Baxter, "Carter expected firestorm over book. ex-aide says." Atlanta JournalConstitution, January 19, 2007.

${ }^{4} 38$ Strong, "Shuttle Diplomacy: President Carter in the Middle East." Working in the World. p. 183.
} 
supported Carter's reelection, a loss of $19 \%$ points from 1976. But even more startling, Carter's 45\% represented the lowest level of Jewish support for a Democratic candidate since 1920 (Figure 6.2). ${ }^{439}$ Unfortunately, said Mondale, though he did more for bringing peace to Israel than any other president, Carter was "unable to gain the defense of the constituency that should have been the most grateful. That had serious political repercussions in certain states in the union."

\section{Figure 6.2 Jewish Vote for Democratic Presidential Candidates, 1916-2004}

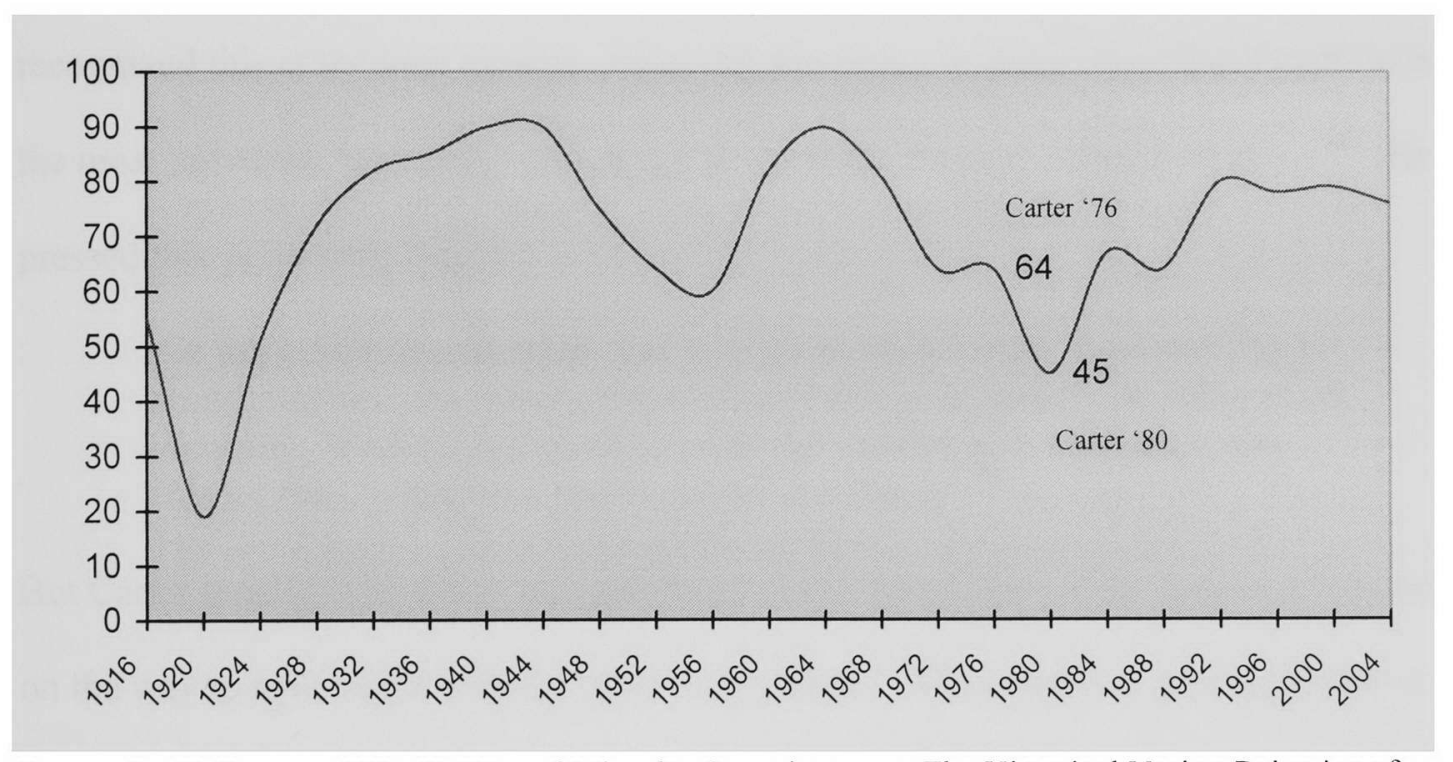

Source: Ira N. Forman, "The Politics of Minority Consciousness: The Historical Voting Behavior of American Jews," in Jews in American Politics, eds. L. Sandy Maisel and Ira N. Forman (Lanham, MD: Rowman \& Littlefield Publishers, 2001), p. 153.

Many of Carter's actions, too, particularly the personal summits, were taken against the advice of even Vice President Walter Mondale and his closest advisors. Brzezinski observed that "Vance and Jody [Powell] were lukewarm, while Fritz

${ }^{439}$ David G. Dalin and Alfred J. Kolatch, The Presidents of the United States and the Jews (Middle Village, NY: Jonathan David Publishers, 2000), pp. 236-243.

${ }^{440}$ Mondale, "The Perspective of the Vice President," in The Carter Presidency: Fourteen Intimate Perspectives of Jimmy Carter, p. 245. 
Mondale maintained his earlier position that the President should not engage in such a risky enterprise. ${ }^{+4+1}$ According to one study, as of the late 1990s, political scientists had not yet rewarded Carter, either. The study showed, for example. that very few collegelevel American government textbooks mention the Camp David Accords and most portray Carter as incompetent in foreign affairs. ${ }^{4+2}$

Critics make legitimate points that the agreements did not go far enough and may have in the long run been more beneficial to Israeli interests than Arab. Carter recognized this at the time as well. First and foremost, he understood that Egypt "was the most powerful Arab state“ and posed the greatest threat to Israel's security. ${ }^{4+3} \mathrm{He}$ pressed this point with Begin:

It is important to remember that an agreement between Israel and Egypt would preclude any successful attack against your country by other Arab countries. Without Egypt, they could not successfully challenge you. This in itself would be a major source of security. ${ }^{4+4}$

But Carter quickly added that any agreement with Egypt "should be seen as a first step on the way to agreement with the other Arab states." Whatever was accomplished at Camp David, "cannot be merely an Israeli-Egyptian treaty." had other ideas, much narrower ambitions, Carter’s sights were always higher-a comprehensive peace as the ultimate goal. Furthermore, as Rabin observed. Sadat's visit to Jerusalem in 1977 effectively undercut Carter`s grand ambition for a wider

\footnotetext{
${ }^{+41}$ Brzezinski. Power and Principle, p. 282.

4+2 J.M. Sanchez, "Awaiting Rehabilitation: The Carter Presidency in Political Science Textbooks," Presidential Studies Quarterly 27 (Spring 1997): 284-296.

4+3 Carter. Talking Peace, p. 9.

${ }^{+4 t}$ Carter. Keeping Faith, p. 381.
} 
peace agreement. "It was clear," Rabin wrote in his memoirs, "without his spelling it out, that if the other Arabs rejected his terms for peace, Sadat would go it alone." 446 The Egyptian President essentially said to the Israelis: "Accept the American concept of peace, and I won't wait for Mr. Arafat or President Assad or even King Hussein." Consequently, the Carter administration "found itself forced to shelve its declared policy that peace cannot be achieved on any one front but must be secured on all fronts of the Arab-Israeli conflict simultaneously."

Still, Carter succeeded where other presidents, before or since, either failed in the quest for peace in the Middle East or refused to take the personal and political risks. To date, three decades and four presidents later, Carter's effort and success have been inimitable. For presidents who got involved, a Camp David-type moment has remained elusive. It was something "not witnessed before or since in the quest for Arab-Israeli peace." 448 Carter's efforts offered the region and the world a brief moment of hope that peace was possible. As Brzezinski put it, "No other U.S. President has made a comparable personal effort to obtain peace in the Middle East. No other President has ever been as directly involved in the search for compromise. No other President has negotiated as actively to overcome the enormous psychological and historical barriers..."449 Though Brzezinski, like Carter, recognized the real limitations of Camp

\footnotetext{
${ }^{445}$ Ibid., p. 384.

${ }^{446}$ Rabin, The Rabin Memoirs, p. 323.

${ }^{447}$ Ibid., p. 324.

${ }^{448}$ Stein, Heroic Diplomacy, p. 268.

${ }^{449}$ Brzezinski, Power and Principle, p. 288.
} 
David and the final peace treaty — namely, that it fell "far short of a comprehensive solution" for the region—for the foreseeable future it greatly minimized the chances for another pan-Arab-Israeli war.

The Camp David agreements also became a cornerstone of U.S. Middle East policy for succeeding administrations and a model for President Bill Clinton and his efforts in 2000 to forge an agreement between Israeli Prime Minister Ehud Barak and Palestinian President Yasser Arafat. As one member of the Knesset, Yossi Beilin, explained, "Carter has secured his place in history as the man who brokered the first peace agreement between Israel and an Arab nation. The Camp David summit he convened in September 1978, which resulted in the signing of the peace treaty between Israel and Egypt, was a historical watershed for the entire region. It inaugurated the Arab-Israeli peace process, without which the [1993] Oslo peace process would not have been possible, nor the 1994 peace agreement between Israel and Jordan." Furthermore, Beilin added, the many criticisms President Carter levied against Israel. particularly those made in his 2006 controversial book, Palestine: Peace Not Apartheid. are "entirely harmonious with the kind of criticism that Israelis voice about their own country. There is nothing in the criticism that Carter has for Israel that has not been said by Israelis themselves." ${ }^{450}$

Even Carter critics conceded his monumental contribution at Camp David. One critic, for instance, who argued that Carter had betrayed the philo-Semitic religious tradition of the United States in some comments in Palestine: Peace Not Apartheid. still said that after "nearly six decades of American mediation" there has been "only one 
lasting [policy] success: the 1979 treaty between Egypt and Israel." Interestingly, though he mentioned by name the failures of presidents going back to Harry Truman, this Carter critic failed to even mention the name of the president intimately involved in that lone, Iasting presidential success. ${ }^{451}$

Carter lamented that his successors in the White House became too one-sidedly pro-Israel at the expense of the Palestinian cause for justice and true peace and security for Israel. ${ }^{452}$ To be successful, he asserted, "the mediator," the United States, the U.S. president, must "maintain at least the semblance of neutrality." The mediator must have the "mutual confidence" of both parties. ${ }^{453}$ He was greatly disappointed that the peace process was not vigorously pursued. Additionally, he laments that the United Nations Human Rights Council has adopted a "singular focus on the violations committed by Israel, while failing to address with the same vigor serious human rights abuses in many other parts of the world." ${ }^{454}$ To single Israel out for criticism was "counterproductive."

Towards the end of his term, for instance, Carter noted that "we presume that the Reagan Administration will continue to play an aggressive role in carrying out the Camp David peace commitments." "W55 "Without our strong leadership" in the future, he

\footnotetext{
${ }^{450}$ Yossi Beilin, "Carter is No More Critical of Israel Than Israelis Themselves," Jewish Daily Forward, January 19, 2007; see also Henry Siegman, "Hurricane Carter," The Nation, January 22, 2007.

${ }^{451}$ Michael Oren, "America's many failed attempts at Mideast peace," Boston Globe, January 2, 2007.

${ }^{452}$ Carter, "Mideast Needs New Mediator," USA Today, July 1, 2002.

${ }^{453}$ Carter, "A Jerusalem Settlement Everyone Can Live With," New York Times, August 6, 2000.

${ }^{454}$ Carter, "Statement to the U.N. Human Rights Council," March 29, 2007, http:/www.cartercenter.org.

${ }^{455}$ Carter, Keeping Faith, p. 598.
} 
said, "it is highly unlikely that Sadat and Begin can make any appreciable progress" on other regional matters. Under the administration of George W. Bush, he charged. "our government" abandoned "any sponsorship of substantive negotiations between Palestinians and Israelis" and seemed "to support almost every Israeli action in the occupied territories," and "condemn and isolate the Palestinians."

He long believed that the United States could use a tough-love approach with Israel, such as withholding loan guarantees, as George Bush threatened to do in 1992. to get the Israelis to dismantle settlements in the West Bank and Gaza. ${ }^{457}$ Despite repeated charges of being "anti-Israel," Carter argued "that Israel will never find peace until it is willing to withdraw from its neighboring occupied territories and permit the Palestinians to exercise their basic human and political rights. ${ }^{.48}$ So long as Israel continued to build settlements in the occupied territories, built barriers that confiscated Palestinian lands, treated innocent Palestinians "like animals," and destabilized the legitimately elected Palestinian governing bodies. Israel would be further isolated in the international arena and would find no peace. ${ }^{459}$ Such actions obstructed "a

\footnotetext{
${ }^{456}$ Carter, "The Troubling New Face of America," Washington Post, September 5. 2002.

${ }^{457}$ Carter, "America Can Persuade Israel to Make a Just Peace," New' York Times, April 21. 2002: Palestine: Peace Not Apartheid, pp. 131-132.

${ }^{458}$ Carter, "A New Chance for Peace?", Washington Post, January 18, 2007; "Interview with Steve Inskeep," National Public Radio, January 25, 2007, www.npr.org; Palestine: Peace Not Apartheid, p. 53: "Stop the Band-Aid Treatment: We Need Policies for a Real, Lasting Middle East Peace," Washington Post, August 1, 2006; "Middle East Accord Offers "Best' Chance for Peace," USA Todal: November 3. 2003; "The Choice for Israelis," Washington Post, September 23, 2003; "For 1srael. Land or Peace." Washington Post. November 26, 2000.

${ }^{459}$ Carter, "Israel's New Plan: A Land Grab," USA Today, May 16, 2006; "Punishing Innocent Palestinians is a Crime," International Herald Tribune. May 7, 2006: "Colonization of Palestine Precludes Peace," Ha'aretz. March 13, 2006; "Don't Punish the Palestinians." Washington Post. February 20, 2006; "Casting a Vote for Peace," New' York Times, November 12, 2004: "Remarks at Brandeis University in Waltham, Massachusetts," January 23, 2007.
} 
comprehensive peace settlement in the HoIy Land" and continued to be at odds with long-established U.S. policy toward the occupied areas. ${ }^{460}$ They constituted "an underlying reason that years of U.S. diplomacy failed and violence in the Middle East persists." ${ }^{461}$ Though controversy erupted in 2006 with Carter's description of Israeli policies in the West Bank as a form of apartheid, Brzezinski had accused Begin as early as 1977 of wanting to create a situation in the occupied territories that "could resemble South African-controlled black enclaves, or Bantustans." ${ }^{462}$

Carter lamented the taking prisoner of Israeli soldiers and the decision by some Palestinian factions resorting "to unconscionable acts of terrorism." constituted "a repetitive cause of violence" and "it is inarguable that Israel has a right to defend itself against attacks on its citizens." ${ }^{, 464}$ Unfortunately, from his view, when such acts have occurred Israel's response was often disproportional, including the targeting of civilian population centers. (This line of thinking was very similar to Carter's response to Israeli attacks on Lebanon in 1978 in response to a PLO terror attack on Israeli civilians. As Quandt observed, Carter deemed the Israeli action "disproportionate to the threat.") ${ }^{465}$ Both sides, he has repeatedly made clear, contribute

\footnotetext{
${ }^{460}$ Carter, "Colonization of Palestine Precludes Peace," Ha'aretz, March 13, 2006; "The Troubling New Face of America," Washington Post, September 5, 2002.

${ }^{46 !}$ Carter, "For Israel, Land or Peace," Washington Post, November 26, 2000; Palestine: Peace Not Apartheid, p. 202.

${ }^{462}$ Quandt, Camp David, p. 156; Brzezinski, Power and Principle, p. 118.

${ }^{46.3}$ Carter, "Casting a Vote for Peace," New York Times, November 12, 2004.

${ }^{464}$ Carter, "Stop the Band-Aid Treatment: We Need Policies for a Real, Lasting Middle East Peace," Washington Post, August 1, 2006; Palestine: Peace Not Apartheid, p. 199; "Letter to Jewish Community on Palestine: Peace Not Apartheid," December 15, 2006.

${ }^{465}$ Quandt, Camp David, p. 183.
} 
to this cycle of violence. This cycle includes the "continuing violent attacks by

Palestinian terrorist groups and increasingly harsh reprisals from Israel," "abhorrent terrorist acts perpetrated by Palestinians." "harsh military crackdowns from the Israeli military." Palestinian honor given to "suicide bombers as martyrs." celebration of "the killing of Israeli civilians." Israeli belief that "their West Bank and Gaza settlements to be sacrosanct." and Israel "s justification of "sustained subjugation" of Palestinians. ${ }^{466}$

Carter lamented the continued strife among "the People of the Book" in the Holy Land and that "the scriptures are a source of more difference than agreement, inspiring more hatred than love, more war than peace. ${ }^{467}$ He lamented that his own denomination. the Southern Baptist Convention. has been led since 1979 by intransigent Christian Zionist ministers. who merely see Israel and the region through the lens of their "eschatological, or final days, theology."

Still. for all that was not accomplished. much was. Carter played a key role in closing one of the most contentious fronts in the wider Arab-Israeli conflict; the Accords provided greater peace and security for Israel and for the largest Arab country.

\footnotetext{
${ }^{+66}$ Carter. "Middle East Accord Offers 'Best" Chance for Peace." LS.4 Todan: November 3. 2003: "America Can Persuade 1srael to Make a Just Peace." New l'ork Times. April 21, 2002: "The Choice for Israelis," Hashington Post. September 23. 2003; "Mideast Needs New Mediator," LSA Todan: July 1. 2002.

${ }^{46^{-}}$Carter. The Blood of Abraham. p. 5; Talking Peace, p. 5.

${ }^{468}$ Carter, "Just War-or a Just War?," New York Times, March 9. 2003: Our Endangered Ialues. America's Moral Crisis (New York: Simon and Schuster, 2005). pp. 113-114: "Interview with David Postman." Seattle Times, December 13, 2006. Carter certainly would not endorse the extreme Christian Zionism of some religious leaders. For instance. Carter. like many other evangelicals. including President George W. Bush. would not have supported Pat Robertson's assessment of Sharon's illness. After Israeli Prime Minister Ariel Sharon suffered a debilitating stroke in early 2006. Robertson said that Sharon was being punished by God for unilaterally withdrawing from Gaza. "He was dividing God's land. And I would say, 'Woe unto any Prime Minister of Israel who takes a similar course to appease the E.U.. the United Nations or the United States of America.' God says. 'This land belongs to me. You better leave it alone." Robertson's quote printed in "Notebook." Time. January 16. 2006. p. 19.
} 
Egypt. Egypt, too, recovered the Sinai Peninsula and Israeli settlements were removed. This, said Brzezinski, "established the important precedents of trading territory and the dismantling of settlements for a binding peace treaty." for the first time, "Camp David brought the Palestinian question to the top of negotiating issues" and that, after the Egyptian-Israeli treaty was signed, it would become "the single focus of the negotiating process." achievement yielded Carter little politically in the long run, he was prepared to undertake a difficult issue. Sometimes, as he explained at a townhall meeting in New Hampshire in 1978, the most difficult decisions a president has to make are "based on the principles of religion."

Time's Hugh Sidey caught a glimpse of the importance of Carter's evangelical style and the political skill and the emotional intelligence it gave him to succeed in negotiating the peace agreements. "Carter's penchant for prayer," Sidey observed, "so suspect in other climes, was a reassurance at this particular summit [Camp David]. Indeed, the bond of spirituality among those three men may have been the most important emotional conduit. None was embarrassed by the others' deep convictions. Flowing out of the spiritual bond was trust." ${ }^{472}$ Similarly, the New York Times' Terence Smith wrote, "In many ways, it was reminiscent of his campaign for the Presidency...

\footnotetext{
${ }^{469}$ Brzezinski, Power and Principle, p. 288.

${ }^{470}$ Vance, Hard Choices, p. 228.

${ }^{471}$ Carter, "Remarks and Question-and-Answer Session at a Town Hall Meeting with New Hampshire High School Students," February 18, 1978, Public Papers of the Presidents, Book I, p. 376.

${ }^{472}$ Quoted in "Carter's Swift Revival," Time, October 2, 1978.
} 
Jimmy Carter's mission to the Middle East reflected the same kind of "born-again' confidence, the same sense of personal mission that put him in the White House. ${ }^{.473}$

Though religion has long been a source of conflict among Christians. Jews. and Muslims in the Middle East. Carter understood that religion could be a source for peace and inspire a political vision. In his vision, he recognized that the adherents of the three faiths shared a belief in the one true God, shared in "the blood of Abraham," shared in the territorial and spiritual blessings of the Patriarch, and, thus, shared the designation of God`s chosen people. Jews are blessed through Abraham's son Isaac, Muslims through Abraham's son Ishmael, and Christians through Jesus who was a descendent of King David and Abraham.

In December 1977, Carter explained to James Reston of the New York Times. "I was always convinced that if Sadat and Begin could get together, they would be bound by that common belief" that Jews and Muslims "worship the same God." ${ }^{.474}$ To justify his involvement and clarify his vision. Carter cited, in typical evangelical fashion, the authority of Bible:

The Bible says that when the first blood was shed among His children, God asked Cain, the slayer, 'Where is Abel thy brother?' And he said, 'I know not. Am I my brother's keeper?' And the Lord said, 'What hast thou done? The voice of thy brother's blood crieth unto me from the ground. And now art thou cursed...' (Genesis 4:9-11). The blood of Abraham. God's father of the chosen. still flows in the veins of Arab. Jew, and Christian, and too much of it has been spilled in grasping for the inheritance of the revered patriarch in the Middle East. The spilled blood in the Holy Land still cries out to God - an anguished cry for peace. ${ }^{475}$

\footnotetext{
473 Smith. "Winning Trust Was Carter's Principal Aim, and He Did It." New York Times. March 18, 1979.

${ }^{47}$ Carter. "Interview with James Reston, New York Times," December 1. 1977, in Pippert, The Spiritual Jouney of Jimmy Carter, p. 134.

${ }^{475}$ Carter, The Blood of Abraham, p. 193: Palestine: Peace Not Apartheid, pp. 18-19.
} 
Table 6.2

Timeline of Key Events in the Middle East Peace Process, 1977-1981

January 20, 1977

March 7-8, 1977

March 16, 1977

April 4-5, I977

April 8, 1977

April 25-26, 1977

May 9, 1977

May 17, 1977

May 24-25, 1977

June 21, 1977

July $19-20,1977$

July 26, 1977

October 1,1977

November 17, 1977

November 19-20, 1977

December 16, 1977
Inauguration of President Carter

Carter Meets with Israeli Prime Minister Yitzhak Rabin

Carter Announces Support for Palestinian Homeland at Townhall Meeting in Clinton, Mass.

Carter Meets with Egyptian President Anwar Sadat; Praised for Palestinian Homeland Remark

With Financial Scandal, Rabin Resigns, Won't Seek $2^{\text {nd }}$ Term

Carter Meets with Jordan's King Hussein

Carter Meets with Syrian President Hafiz al-Asad in Geneva, Switzerland

Likud Party Wins Israeli Election; First Electoral Defeat for Ruling Labor Party Since Independence

Carter Meets with Saudi Crown Prince Fahd, Praised for Palestinian Homeland Remark

Likud Leader Menachem Begin Assumes Office as New Israeli Prime Minister

Carter Meets with Begin

Begin Approves Three West Bank Settlements

U.S-Soviet Joint Middle East Communiqué Issued; Affirms Need to Resolve "Palestinian Question" and Respect for "Legitimate Rights" of Palestinians

Egyptian Foreign Minister Ismail Fahmy Resigns in Protest to Upcoming Sadat Visit to Israel

Sadat Makes Historic Visit to Israel, Addresses Knesset Begin Agrees In Principle to Return Sinai 
December 25-26, 1977

January 4. 1978

January 30,1978

February 3-4. 1978

February 26, 1978

March 14. 1978

March 21-22. 1978

April 7. 1978

May 1, 1978

June 13.1978

July 30.1978

August 14, 1978

September 5-17, 1978

September 20, 1978

September 24. 1978

September 28, 1978

October 12-21, 1978
Begin and Sadat Meet in Ismailiya, Egypt

Carter Meets with Sadat in Egypt; He Issues Aswan

Declaration on Need to Resolve All Aspects of "Palestinian Problem"

Carter Affirms UN Resolution 242 Calls for Israel to Withdraw from Occupied Palestinian Territories

Carter Meets with Sadat at Camp David

Israeli Cabinet Approves Settlements Expansion in Sinai

In Response to Terror Attacks. With a Force of 22.000. Israel Invades Lebanon

Carter Meets with Begin; Disagree Over Whether UN Resolutions 242 Applies to West Bank

U.S. Charge Israel Broke Pledge By Using Cluster Bombs in Lebanon

Carter Meets with Begin

Israel Withdraws Last of Troops from Lebanon

Carter Decides to Hold Camp David Summit with Sadat and Begin

Israeli Cabinet Approve 5 New Military Settlements in West Bank

13-Day Camp David Summit; Camp David Accords Signed

Jordan Says It's Not Bound by Camp David Accords

Israeli Cabinet Approves Camp David Accords. 11-2. with 3 abstentions

Knesset Approves Camp David Accords. 84-19, with 17 Abstentions

Blair House Egyptian-Israel Peace Talks 
November 5, 1978

November 16, 1978

December 8, 1978

December 10, 1978

March 2-4, 1979

March 8-10, 1979

March 10-13, 1979

March 13, 1979

March 24, 1979

March 26, 1979

August 13-15, 1979

September 24, 1979

October 2I, 1979

February 1980

February 17,1980

March 23, 1980
Arab Summit in Baghdad Condemns Camp David Accords

Carter Meets with Egyptian Vice President Hosni Mubarak

Former Israeli Prime Minister Golda Meir Dies

Sadat and Begin Receive Nobel Peace Prize

Carter Meets with Begin

Carter in Egypt

Carter in Israel; First President to Address Knesset (March 10)

Carter Returns to Egypt

Egyptian Mahmoud Riad Resigns as Secretary General of the Arab League in Protest to Pending Israeli-Egyptian Peace Treaty

Israeli-Egyptian Peace Treaty Signed

US Ambassador to UN Andrew Young Meets with PLO Representative; Violates the 1975 Memorandum of Understanding; Young Resigns Two Days Later

Arab League Headquarters Relocated from Cairo. Egypt To Tunis, Tunisia in Protest of Egyptian-Israeli Peace

Israeli Foreign Minister Moshe Dayan Resigns in Protest of Begin's West Bank Settlement Policy

US Ambassador Donald McHenry Votes for UN

Resolution "including Jerusalem"; Carter says vote due to Miscommunication

Israeli Embassy Opens in Cairo, Egypt

Carter Celebrates with Israeli and Egyptian Ambassadors One-Year Anniversary of Peace Treaty 
March 25, 1980

April 8-9, 1980

April 15-16. 1980

May 28, 1980

November 4. 1980

January 20, 1981
Carter Loses New York Democratic Presidential Primary; Defeat Attributed to Anti-Carter Sentiment Among NY Jewish Voters

Carter Meets with Sadat

Carter Meets with Begin

Defense Minister Ezer Weizman Resigns; Protests

Begin's Continued Israeli Settlements and

"Unnecessary Land Confiscations" and His Retreat from Peace Process

Carter Loses General Election in Landslide; Receives Lowest Jewish Vote for a Democratic Candidate Since $1920(45 \%)$

Carter Leaves Office

Sources: Elizabeth Jewell, U.S. Presidents Factbook (New York: Randon House Reference, 2005). pp. 385-396: Chronicle of the 20 ${ }^{\text {th }}$ Century (Mount Kisco, NY: Chronicle Publications, 1987), pp. 1120-1184; William B. Quandt, Camp David: Peacemaking and Politics (Washington, DC: The Brookings Institution. 1986), pp. 407-411; Ezer Weizman, The Battle for Peace (New York: Bantam Books, 1981), pp. 383-384; "Foreign Minister Quits in Egypt; Successor Resigns Hours Later," New York Times, November 18, 1977; "Riad Quits as Head of the Arab League." New' York Times, March 24, 1979. 


\section{Israel, the Arabs, and the Middle East in Presidential Memory: \\ Carter in Comparative Perspective}

"The Jewish people are entitled to one place on this earth where they can have their own state on soil given them by God from time immemorial."I

"Let us now reward all the children of Abraham who hunger for a comprehensive peace in the Middle East. Let us now enjoy the adventure of becoming fully human, fully neighbors, even brothers and sisters. We pray God, we pray God together, that these dreams will come true. I believe they will.",2

---Jimmy Carter

"It is God's will that Israel, the biblical home of the people of Israel, continue forever and ever." 3

---Pastor W.O. Vaught to Bill Clinton

"In the Bible we are told that when they were grown, Isaac, the patriarch of the Jews, and Ishmael, the patriarch of the Arabs, met but once. They came together at the death of Abraham, the father they shared, the father of both peoples. Today the descendants of Isaac and Ishmael have joined together in a spirit of rebirth to secure the shared promise of a life of peace for all the peoples of this region."

$---B i l l$ Clinton

\footnotetext{
'Jimmy Carter, "Remarks on Middle East Policies in Elizabeth, New Jersey," June 6, 1976. The Presidential Campaign 1976: Jimmy Carter (Washington, DC: United States Government Printing Office, 1978), p. 220.

${ }^{2}$ Carter, "Remarks at the Signing Ceremony of the Egyptian-Israeli Peace Treaty with President Sadat and Prime Minister Begin." March 26, 1979, Public Papers of the Presidents, Book I (Washington, DC: United States Government Printing Office), p. 518.

${ }^{3}$ Quoted in Bill Clinton, "Remarks to the Knesset in Jerusalem, Israel," October 27, 1994, in Public Papers of the Presidents, Book II, p. 1892.

${ }^{4}$ Clinton, "Remarks at the Opening of the Summit of the Peacemakers in Sharm al-Sheikh, Egypt." March 13, 1996, in Public Papers of the Presidents, Book I, p. 437.
} 
In the last chapter, we saw that Carter had an unmistakable religious vision and a biblically-inspired sense of mission for Israel and her Arab neighbors, particularly Egypt. The focus of this chapter is not to explore or explain the Middle East policies of American presidents. Nor is it the purpose here to confirm or "correct" their recollections of events and their actual level of interest and involvement. Rather. the purpose here is to put the views and perceptions of Jimmy Carter in comparative perspective.

The first purpose here, using survey data from the Gallup Organization and the Pew Research Center. is to establish that white evangelicals generally hold similar views toward Israel and the Middle East and that Carter shares them. This suggests that there is not only a particular evangelical perspective, but may well verify that a president, such as Carter, may approach or engage the region evangelically. Unlike the majority of white mainline Protestants and white Roman Catholics. white evangelicals, like Carter, typically see Israel and the Middle East in religious terms, not historical or political terms. ${ }^{5}$ Though there is certainly diversity within the evangelical perspective. a supermajority of white evangelicals view the area as either the location where future Biblical events will occur or where important religious events took place and where important religious figures once lived. More than two-thirds of

\footnotetext{
${ }^{5}$ Polling data show that black Protestants hold similar view's to white evangelicals. For instance. according to a 2006 Pew poll, $60 \%$ of black Protestants said they believed God gave the Jew's the land of Israel and $56 \%$ said the establishment of the modern Jewish state was a fulfillment of Biblical prophecy. See "Many Americans Uneasy with Mix of Religion and Politics," Pew Research Center Report. August
} 
white evangelicals also generally believe that the land of Israel is God's gift to the Jewish people. Most white mainline Protestants and Catholics do not believe this. Nearly $60 \%$ of white evangelicals claim that the establishment of modern Israel is a fulfillment of Bible prophecy. Again, most white mainliners and Catholics do not accept this. More than a third of all white evangelicals and nearly half of all highlycommitted white evangelicals additionally assert that the biggest influence on their views toward the Middle East are their religious beliefs. For white mainliners and Catholics, their views are generally shaped by secular influences, such as the news media and education.

This leads us to the second purpose of this chapter. Had Carter's vice president. Walter Mondale, been president instead, would he have pursued Middle East peace with the same vigor and focus as Carter? To answer this, Mondale's views and political style is compared with Carter. It is found that Mondale had a view and style quite different. As a counterfactual case, this suggests that had Mondale been president, even during the same four-year period (1977-1981), he would have governed differently and likely would not have pursued Middle East peace with the same intensity and focus Carter did. Next, it is explored whether or not Carter's presidential contemporaries shared the basic assumptions about Israel and the Middle East that Carter and most white evangelicals hold? Did they have what might be called a (white) evangelical perspective? To answer this, the memoirs of every president since Lyndon Johnson are examined and their respective views on Israel and the Middle East described. George W. Bush is

24, 2006, p. 20, http://people-press.org/reports. However, they are excluded here for the simple reason that no African American at the time of this writing had served as president. 
excluded from full examination here because at the time of this writing he was still in office and obviously his memoirs were not yet written.

Since the birth of the Jewish State in 1948. every American president has claimed to be pro-Israel. However. judged Paul Charles Merkley, none since Harry Truman (except George W. Bush in his view), has been motivated by Christian Zionism. the desire to be God's instrument, "the righteous gentile ruler," like the ancient Persian king. Cyrus the Great, who aided the Jewish people and permitted them to resettle their land and rebuild their temple. and "prefer" Israel in her struggles" with the Arabs (emphasis his). ${ }^{6}$ While Merkley is right that presidents have not been Christian Zionists as he understands it. they have all supported Israel, affirmed their commitment to Israel's security, and have supported the right of Jews from other countries to migrate there. But what is at issue here is why have presidents supported Israel? Why have they all wanted to see a peaceful resolution of Israeli-Arab differences? Using their own "final" memories, these questions are investigated. What is found is that most presidents do not necessarily view the significance of Israel and the Middle East the same way Carter and most evangelicals do: there is simply little or nothing about their faith. Other than for Carter. and perhaps Clinton, neither does it appear that the other presidents possessed an evangelical leadership style in this issue area. This suggests that presidential support for Israel and regional peace efforts varied. and religion may not be the most important for them. This further highlights the wider claims of this project that Jimmy Carter had a different way and style of presidential leadership than his contemporaries. 
Other presidents may have indeed personally believed in the religious significance of the Middle East and may have been motivated or inspired by it and may have claimed it on other presidential occasions. But it is noteworthy that they did not claim such an influence in their memoirs. Based on their memoirs, the only other president approaching the evangelical views of Carter is fellow Southern Democrat Bill Clinton. In fairness to each former president, admittedly a broad survey of their other writings, speeches, and comments would need to be examined to make a more definitive judgment. This is a clear limitation here. Nonetheless, use of presidential memoirs is one accepted means of "getting inside the mind" of a president. Certainly, if sincerely held, such a profound influence as religious faith (or Christian Zionism from Merkeley's view) would be readily evident in presidential memoirs. With no more elections to win, no more voters to court, writing a memoir gives a president the opportunity to tell their fellow citizens what they really thought and why they did what they did.

In assessing and analyzing the views of presidents, a key problem for several critics is that there is a data reliability problem with using presidential "speeches, statements, and writings." It is often argued that because much of their work may have been "ghost-written," or the language used may not actually reveal the real opinions of presidents. Instead, it may be no more than instrumental language intended "to influence or even manipulate a particular domestic or international audience." Analyses

\footnotetext{
${ }^{6}$ Paul Charles Merkley, American Presidents, Religion, and Israel: The Heirs of Cyrus (Westport. CT: Praeger Publishers, 2004), pp. viii-ix.
} 
of presidential rhetoric thus do not actually tap the president's personal "values and attitudes. ${ }^{77}$

Certainly, the reliability of presidential rhetoric can be problematic. Still, memoirs should provide us important clues to the Mideast views of the presidents. Presidents. regardless of their level of involvement in writing their memoirs, in the end give their approval of what was written in their name. Either way, if President Ronald Reagan was correct when he wrote that a presidential memoir is an opportunity for a president "to tell his story in his own words. ${ }^{.8}$ the absence of religious motivations and language is revealing.

In studying the Arab-Israeli conflict, argued William Quandt, an important dimension is "to know how the president... makes sense of the many arguments, the mountain of 'facts.' the competing claims he hears whenever his attention turns to the Arab-Israeli conflict." 9 Presidents, he asserted, certainly are not purely rational or strategic in their thinking. neither are presidents mere prisoners of so-called national interest or bureaucratic politics. While what constitutes the country`s interests may in

\footnotetext{
"Ibrahim A. Karawan, "Sadat and the Egyptian-Israeli Peace Revisited," International Journal of Middle East Studies 26 (1994): 258. The reliability of Carter's work, however, is harder to dispute. Unlike some other presidents, Carter makes clear that he wrote every one of his books and articles and "never have had any co-authors." See "Interview with Steve Inskeep," National Public Radio. January 25. 2007.

www.npr.org. However, Kenneth Stein explained that he "collaborated" with Carter on The Blood of Abraham, pressing him to describe the Middle East situation and events with "balance." "We argued," he said, "over word choice, phrases, and claims." Kenneth W. Stein, "My Problem with Jimmy Carter's Book," Middle East Quarterly (Spring 2007), pp. 1-2, http: www meforum.org. Carter, too. acknowledges his partnership with Stein and his "generous" assistance, proofreading. historical factchecking. and contributions in preparation of the manuscript. The Blood of Abraham: Insights into the Middle East (Fayetteville. AR: University of Arkansas Press. 1993: originally published in 1985). p. vii.

${ }^{8}$ Ronald Reagan, An American Life: The Autobiography of Ronald Reagan (New York: Simon and Schuster, 1990), p. 7.

${ }^{9}$ William B. Quandt, Peace Process: American Diplomacy and the Arab-Israeli Conflict Since $196^{-}$ (Washington, DC: Brookings Institution Press, 2001; revised edition), p. 9.
} 
fact be generally static over time, all presidents have some particular views of the region and the nature of the conflict, and their degree of interest and involvement varies. For instance, Shibley Telhami agrees that "presidential personality and inclinations" can have a tremendous effect on diplomatic situations. He observed that Carter was fully in charge of the American Middle East negotiations. As in domestic matters, he involved himself "in the minutest details" and "while he often listened to the advice of his aides, his decisions were final." ${ }^{10}$ Zbigniew Brzezinski made a similar observation.

Regarding the makeup of the "American delegation" to Camp David, he said, "Carter was its outstanding personality, and this was openly acknowledged by both the Israelis and the Egyptians."11

After all, said Quandt, what exactly constitutes a nation's interest "contains a strong subjective element." notions, inclinations, biases, predispositions, fragments of knowledge." 13 And these views and feelings, he added, are quite durable. "Presidents and their advisers seem reluctant to abandon central beliefs. Basic positions are adhered to with remarkable tenacity." "14 Use of presidential memoirs provides us with clues as to what these were for each late-twentieth-century president.

\footnotetext{
${ }^{10}$ Shibley Telhami, "Evaluating Bargaining Performance: The Case of Camp David," Political Science Quarterly 107.4 (Winter 1992-1993): 641.

11 Zbigniew Brzezinski, Power and Principle: Memoirs of the National Security Adviser, 1977-1981 (New York: Farrar, Straus, and Giroux, 1983), pp. 238, 263.

${ }^{12}$ Quandt, Peace Process, p. 11.

${ }^{13}$ Ibid., p. 9
} 


\section{American Attitudes toward Israel}

In contrast to other major Western democracies, Americans, like their presidents and most of their congressional representatives, are, and have consistently been. much more sympathetic to the Israelis than the Palestinians. ${ }^{15}$ This is true not only in the national aggregate. but true across the four major regions, with the American South leading the way over a four-year period (2002-2006), with $61 \%$ for the Israelis and $13 \%$ for the Palestinians. ${ }^{16}$

Comparatively, according to a 2002 Gallup poll, $48 \%$ of Americans sympathized with the Israelis, followed by $18 \%$ favoring neither. $11 \%$ the Palestinians. $10 \%$ both. In Great Britain, by contrast, a $27 \%$ plurality sympathized with the Palestinians. $22 \%$ with the Israelis, $18 \%$ with neither, and $10 \%$ with both. ${ }^{17}$ Three years later, a 2005 Gallup poll showed that more than half of Americans surveyed (52\%) were more sympathetic to the Israelis than the Palestinian Arabs (18\%); $30 \%$ chose both/neither. ${ }^{18}$ In the same polling report, a plurality of British $(45 \%)$ and Canadian $(36 \%)$ respondents were either sympathetic to both groups or sympathetic to neither of them. Canadians were only slightly more sympathetic to the Israelis $(34 \%)$ than the

\footnotetext{
${ }^{14}$ Ibid., p. 10.

15 Jodie T. Allen and Alec Tyson, "The U.S. Public's Pro-Israel History," Pew Research Center Commentary, July 19, 2006. Available at http:/pewresearch.org/pubs/39/the-us-publics-pro-israelhistory; Lydia Saad, "Palestinian-Israeli Dispute Engenders American Sympathy for Israelis." Gallup Poll News Service, March 5. 2007.

${ }^{16}$ Frank Newport and Joseph Carroll, "Republicans and Religious Americans Most Sympathetic to Israel." Gallup Poll New's Service, March 27, 2006.

${ }^{17}$ Simon Sarkar, "British Public Divided Over Middle East Conflict," Gallup Poll Vews Service, May 14. 2002.
}

${ }^{18}$ Lydia Saad, "Americans Stand Apart in Support for 1srael," Gallup Poll News Service, May 31. 2005. 
Palestinians (30\%), while more Britons were sympathetic to the Palestinians (31\%) than the Israelis (24\%). Americans also have a comparatively more favorable view of 1srael than the British and Canadians. More than two-thirds of Americans viewed Israel favorably $(69 \%)$, compared with $51 \%$ of Canadians and $39 \%$ of British.

\section{White Evangelicals and Israel}

Consistent over time, most Americans, like Carter, claim that their religious beliefs are relevant to the modern world. ${ }^{19}$ According to Gallup, not only do Americans say that religion is very important in their daily lives, roughly $60 \%$ of Americans say that "religion can answer all or most of today's problems." Figure 7.1 shows that between 1994 and 2006 this view has been the majority position. In contrast, only between $20 \%-25 \%$ of Americans say that "religion is largely old-fashioned and out of date." As shown in chapter 4, Carter believes in the relevance of religion in public affairs, that religious values can be applied to modern life, and that religion can be a useful guide in the area of policy formation and articulation. In this regard, Carter is fully within the mainstream of American opinion. He, like most Americans, rejects the idea that religion is anachronistic and politically irrelevant.

In the last chapter, it was shown that Carter viewed the Middle East not just in terms of national security or national interest. He viewed it as the "Holy Land," a region full of religious significance. Many Americans do, too. In a 2003 Gallup survey, respondents were asked if the Middle East had any personal religious

\footnotetext{
19 "Poll Topics A to Z: Religion," Gallup Poll News Service. Data accessed February 21, 2007.
} 
significance, either as the place where "biblical events will eventually occur" in the future or if it was religiously significant for other reasons..$^{20}$ If not, respondents could choose "it is a land that is historically significant but does not have any personal religious significance." Fifty-percent of Americans claimed that region was religiously significant, $30 \%$ choosing the futuristic biblical event option and $20 \%$ choosing "religious significance for other reasons." Forty-seven percent of those surveyed said it was a place of historical significance, but not "any personal religious significance."

Figure 7.1 Relevance of Religion: Can Answer All or Most of Today's Problems or Is Largely Old-Fashioned and Out of Date

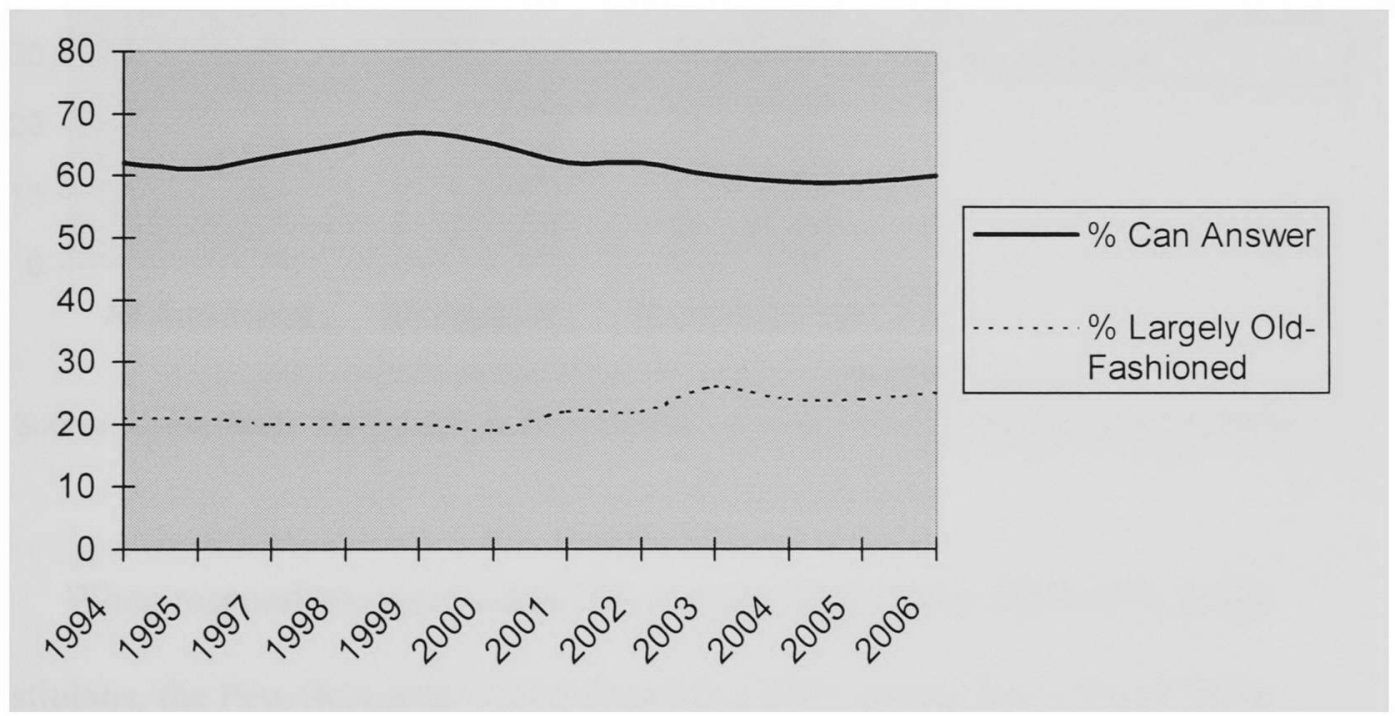

Source: "Poll Topics A to Z: Religion," Gallup Poll News Service. No data for 1996.

But what is of particular interest is that $70 \%$ of those who claimed to be "bornagain," evangelical Christians said the Middle East has personal religious significance, $54 \%$ said so based on events to come and $16 \%$ for other personal religious reasons

\footnotetext{
${ }^{20}$ Lydia Saad, "Holy Land, or Just Ancient?" Gallup Poll New's Service, July 29, 2003.
} 
(Figure 7.2). Only $27 \%$ said that the region was more historically significant. Of those who said they were not "born-again," 64\% said the region was historically significant rather than religiously, while just 34\% said the Middle East was personally important for some religious reason.

Figure 7.2 Viewing Israel and the Middle East: Religiously Significant or Not?

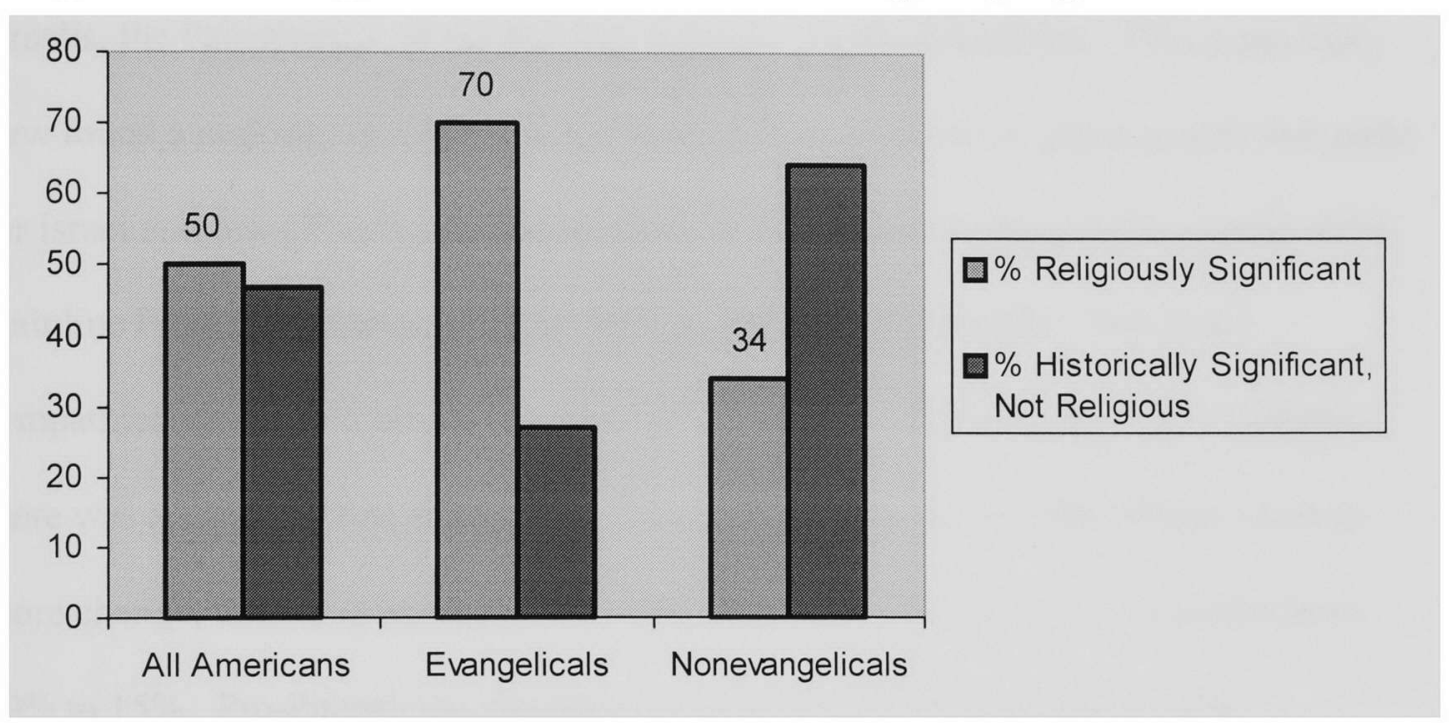

Source: Lydia Saad, "Holy Land, or Just Ancient?" Gallup Poll News Service, July 29, 2003.

When respondents were asked if they sympathize more the Israelis or the Palestinians, the Pew Research Center found in a 2003 survey that $55 \%$ of white evangelicals sympathized with the Israelis and only $6 \%$ said the Palestinians. Another $6 \%$ said both, $12 \%$ said neither and $21 \%$ did not know. For white mainline Protestants, only $34 \%$ said the Israelis, $17 \%$ the Palestinians, $10 \%$ both, $19 \%$ neither, and $20 \%$ did not know. Thirty-nine percent of white Roman Catholics said they sympathized more with the Israelis, $13 \%$ the Palestinians, $6 \%$ both, $22 \%$ neither, and $20 \%$ did not express a view. For secular Americans, a category that includes "atheists, agnostics and those 
with no religious preference who rarely, if ever. attend religious services." only $24 \%$ said the Israelis. $20 \%$ the Palestinians. $11 \%$ both. $26 \%$ neither. and $19 \%$ expressed no view. Given this. white evangelicals were the only religious grouping where a majority expressed sympathy more for Israel. Among white mainline Protestants and white Catholics, the Israelis received a plurality. Among secularists. sympathy for the Israelis. the Palestinians. or neither was virtually evenly distributed. Two years later. Pew found a majority of white evangelicals (54\%) continued to claim greater sympathy for Israel and few (7\%) for the Palestinians. ${ }^{21}$ Sympathy for the Israelis among white mainline Protestants increased from $34 \%$ in 2003 to $40 \%$ in 2005 . Pro-Israel sympathies among secularists remained steady at $25 \%$, while among white Catholics. there was a slight decline from $39 \%$ to $35 \%$. Sympathy for the Palestinians showed more change. declining among white mainliners from $17 \%$ to $9 \%$ and seculars from $20 \%$ to $15 \%$. Pro-Palestinian sympathy among white Catholics was at $12 \%$.

In 2003. Pew found that for white evangelicals $39 \%$ said their religious beliefs were "the biggest influence on their thinking about the Middle East." compared with $20 \%$ for all Americans (Figure 7.3).22 For "highly committed" white evangelicals (those who attend religious services regularly), that number increases to $46 \%$. For white mainline Protestants and white Catholics. 10\% and 9\% respectively said their religion had the most influence on their views.

\footnotetext{
21 "Religion a Strength and Weakness for Both Parties." Pew Research Center Report. August 30. 2005. p. 15. Report available at http: people-press.org reports.

22 "Religion and Politics: Contention and Consensus," Pew Research Center Report. July 24. 2003. p. 17 Report available at http: people-press.org reports:
} 
According a 2005 Pew report, for those who sympathize more with the Israelis, the largest influence on their views were their religious beliefs (34\%), followed by information from news media reports (27\%) and education (16\%). Among pro-Israel white evangelicals, $54 \%$ said their religious beliefs were "the most important factor shaping their views on the issue." For those who sympathize with the Palestinians, the biggest factors of influence are media reports (36\%) and education (26\%). Only 9\% claimed religious beliefs were the most important influence. ${ }^{23}$

Figure 7.3 Religious Beliefs as Biggest Influence on Middle East Views (\% Yes)

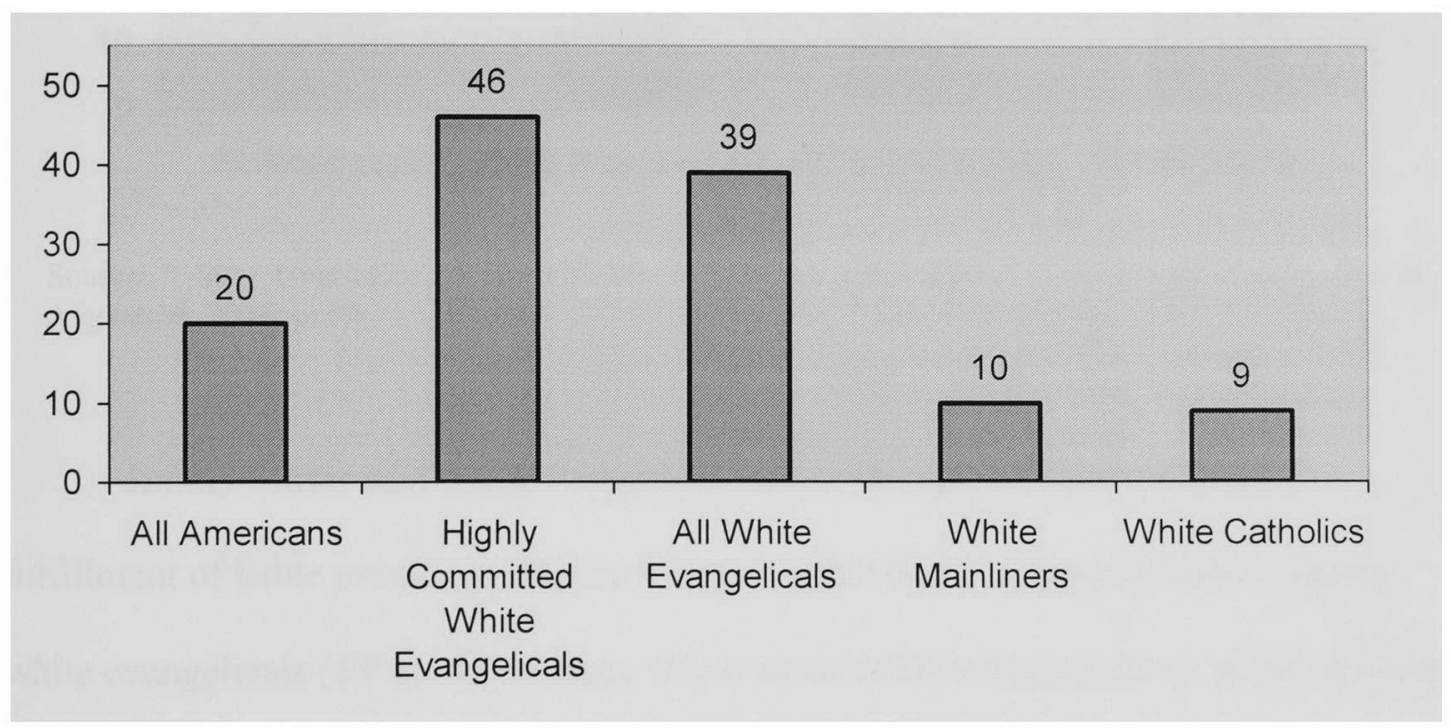

Source: "Religion and Politics: Contention and Consensus," Pew Research Center Report, July 24, 2003, pp. 16-17.

Among the religious beliefs that shape the thinking of white evangelicals is the belief that God gave the land of Israel to the Jewish people. In 2006, Pew found 69\% of

\footnotetext{
23 "Religion a Strength and Weakness for Both Parties," Pew Research Center Report, August 30, 2005. p. 16.
} 
white evangelicals believed this, whereas less than $30 \%$ of white mainline Protestants $(27 \%)$ and white Catholics (29\%) did (Figure 7.4)..$^{24}$

Figure 7.4 Land of Israel Given By God to the Jewish People (\% Yes)

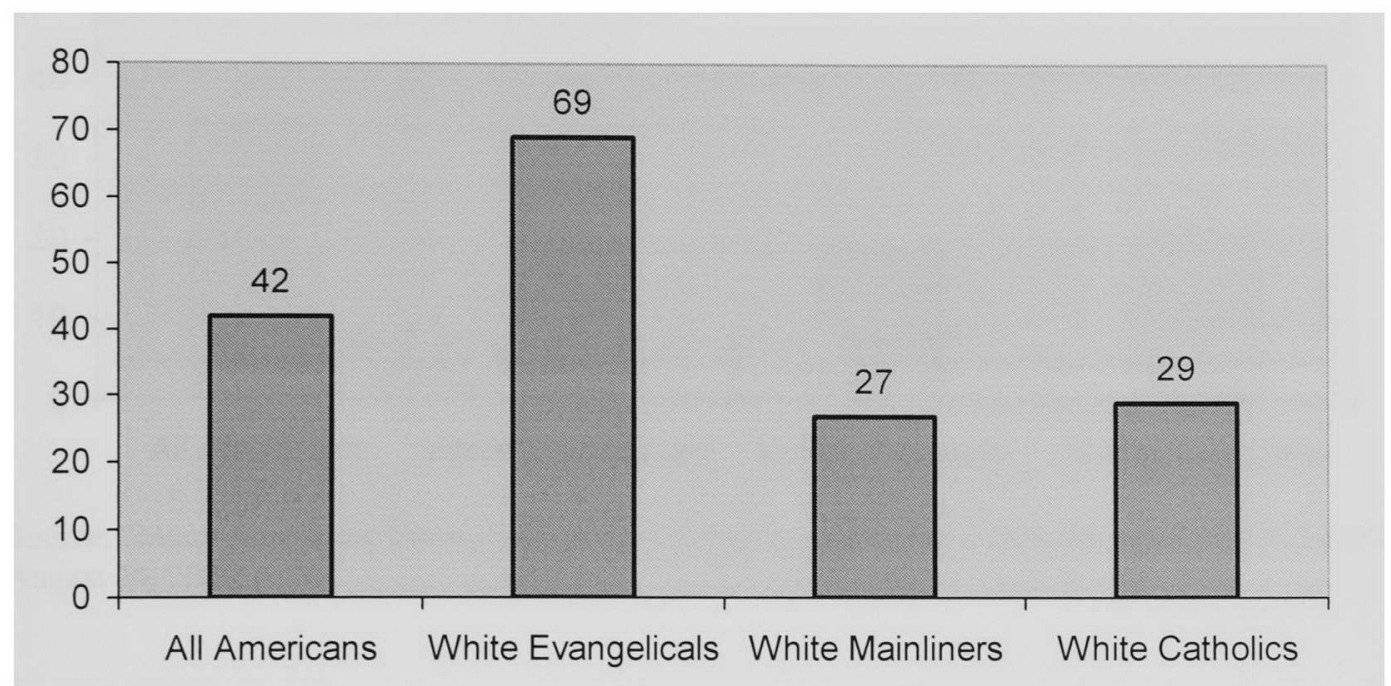

Source: "Many Americans Uneasy with Mix of Religion and Politics," Pew Research Center Report, August 24, 2006, p. 20.

Jimmy Carter said that the establishment of the modern state of Israel is a fulfillment of Bible prophecy. Figure 7.5 shows that this is a common belief among white evangelicals (59\%). In contrast, this is not a belief widely held by white mainline Protestants or white Catholics. ${ }^{25}$

\footnotetext{
24 "Many Americans Uneasy with Mix of Religion and Politics," Pew Research Center Report, August 24, 2006, p. 20.
} 
Figure 7.5 Modern State of Israel as a Fulfillment of Bible Prophecy (\% Yes)

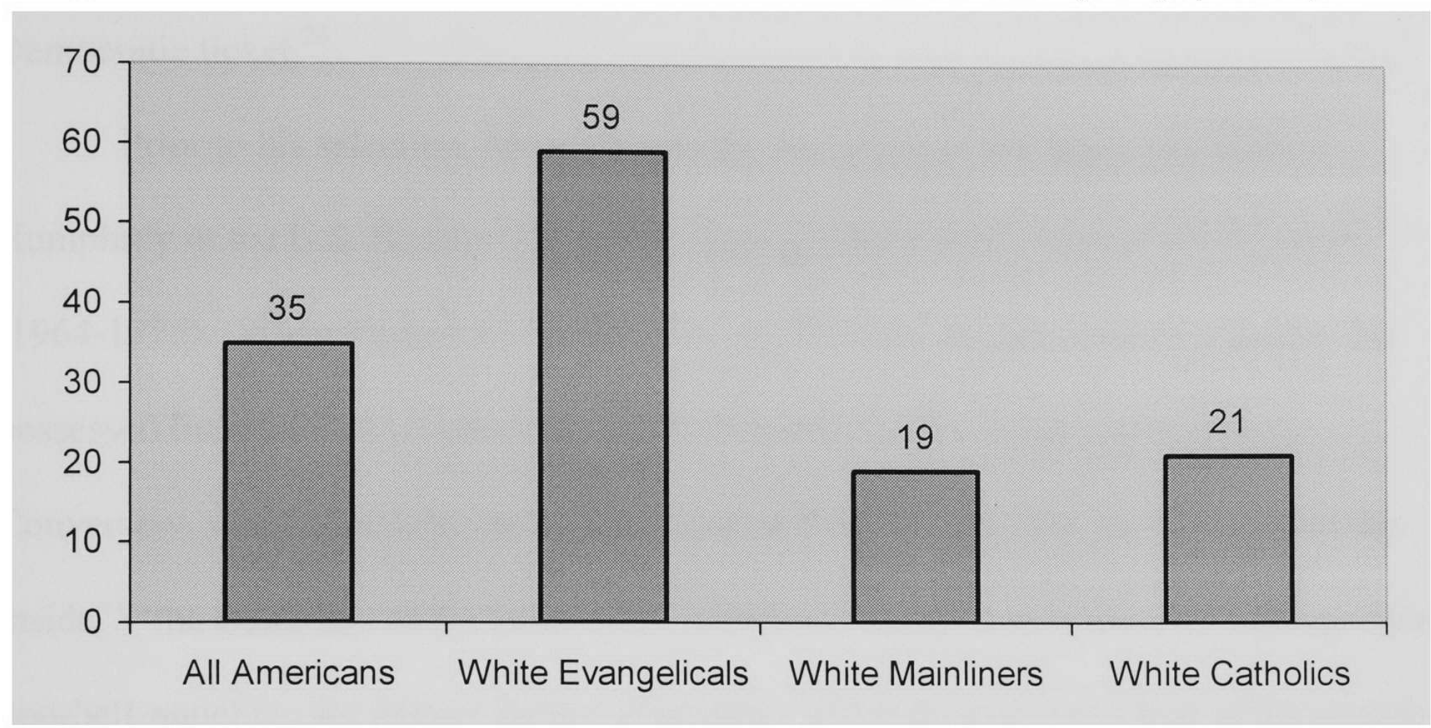

Source: "Many Americans Uneasy with Mix of Religion and Politics," Pew Research Center Report, August 24, 2006, p. 20.

\section{Carter in Comparative Perspective}

Based on their memoirs (and secondary sources for Mondale), we now turn to what Jimmy Carter's vice president and his presidential contemporaries had to say about Israel and the Middle East.

Carter and Vice President Walter Mondale

In terms of understanding President Carter and his views on and priorities for the Middle East, it is useful to compare him to his Vice President. Unlike Carter, Walter Mondale was a seasoned politician in the politics of the Washington Beltway. To compensate for a comparatively light resume, his Southern origins, and centrist ideological image, Mondale's congressional experience, liberal voting record, and being

\footnotetext{
${ }^{25}$ Ibid.
} 
a Northerner were key factors in Carter's decision to select him to join the 1976 Democratic ticket. $^{26}$

Prior to his selection. Mondale was the successor to the legendary Hubert Humphrey in the U.S. Senate. He served there as Minnesota`s senator for 12 years (1964-1976). When Carter ran for president in 1976, he was an obvious outsider. He possessed little political experience and had little to no ties to the national party.

Conversely, when Mondale ran for president in 1984. he was "the party"s man on the inside," "the candidate of the party establishment," hardly "a new face."27 Going "from doorbell-punching for Mayor Hubert Humphrey of Minneapolis to a seat of his own in the Senate and to an activist vice presidency." for the former vice president, running for president was "the logical next step in his career." 28

In the arena of ideas. Carter offered a new, reformist agenda. He came to be seen as the one of the first "new Democrats," promoting and pushing for a conservative and progressive policy mixture. He was "a Democrat who thought like a Republican." 29 Mondale, however, "was the last New Dealer, the surviving heir to a tradition of thought and politics handed down from Roosevelt to Truman to Johnson to Humphrey

\footnotetext{
26 "Why Mondale Won No. 2 Spot," U.S. New's \& World Report, July 26, 1976, pp. 21-22; Carter. "Interview with U.S. News \& World Report," July 15, 1976, published "In His Own Words: How Carter Decided on Mondale," July 26, 1976, p. 23; Paul Kengor, "A Political Vice President: Walter Mondale (1977-1981)," chap. in Wreath Laver or Policy Plạer? The I'ice President's Role in Foreign Policy. (Lanham, MD: Lexington Books, 2000), p. 84.

${ }^{27}$ Peter Goldman and Tony Fuller, The Quest for the Presidency; 1984 (New York: Bantam Books, 1985), pp. 52-53.

${ }^{28}$ lbid., p. 45, 51.

${ }^{29}$ Steve M. Gillon, The Democrats' Dilemma: Walter F. Mondale and the Liberal Legacy (New York: Columbia University Press, 1992), p. 169.
} 
and finally to him." 30 Whereas Carter was hard to pin down ideologically, there was no question about Mondale's life-long commitment to the liberal wing of the Democratic Party.

When Carter ran, he hardly concealed his distaste for and disparagement of the so-called "special interest groups." In contrast, wrote Steve Gillon, "Mondale's political topography revealed a landscape deeply divided by partisan clusters which represented distinct class and racial groupings." ${ }^{\text {31 }}$ For each grouping, he consistently did what he could to curry their favor and give voice to their pet issues. This, according to the Vice President, was the essence of good government - "the careful cultivation of, and service to, Democratic interest groups." 32 Not surprisingly, then, one of Mondale's key vulnerabilities as he prepared for his presidential run in 1984 was his reputation for catering to special interests. To counter this image, Mondale campaign staffers hoped that "the Mondale agenda for the 1980s" would be "more than the agendas of the NEA, AFL-CIO, UJA, NAACP, Sierra Club, LULAC, NOW, and the Gertrude Stein Club stapled together." ${ }^{33}$ However, when he made history by choosing New York congresswoman Geraldine Ferraro as his running mate, the old Mondale reputation returned. The choice of Ferraro was widely perceived that Mondale once more caved in

\footnotetext{
${ }^{30}$ Goldman and Fuller, The Quest for the Presidency, 1984, p. 48.

${ }^{31}$ Gillon, The Democrats' Dilemma, p. 170.

${ }^{32}$ Ibid.

${ }^{33}$ Goldman and Fuller, The Quest for the Presidency, 1984, p. 52.
} 
to the pressure put on him by the National Organization for Women that had "resorted to open threat" against him. ${ }^{34}$

The Carter-Mondale styles were different, too. Newsweek’s Peter Goldman and Tony Fuller described Mondale as "the organization man." "W5 "Walter Fritz Mondale," they wrote, "had always been a meticulous man, the kind who hated being seen in public with a crease unpressed or a stray hair uncombed; he had grown up believing that those were the things people judged you by." In contrast, here is how Brzezinski remembered his foreign policy briefing with Carter in preparation for the presidential debate in San Francisco with President Ford. ${ }^{36}$ "I still did not know him well, and I was struck by the fact that he was wearing blue jeans and was barefoot; I said greeting him. "Ah, our barefoot candidate.'” During the course of their meeting. Brzezinski added. that he was impressed by Carter's religiosity. Until then, he said, "I had wondered whether his proclaimed religious convictions" during the campaign season "were real or simply politically expedient." "The feeling," he received, was "that I was dealing with a man of genuine conviction."

Mondale lacked Carter's evangelical, religious style and appeal. Unlike Carter. he was of the older, pre-Carter school of national politicians. He believed that religion was a private matter, "a good and godly man...did not advertise."

\footnotetext{
${ }^{34}$ Ibid., p. 212.

35 Ibid., p. 45.

${ }^{36}$ Brzezinski, Power and Principle, p. 9.

${ }^{37}$ Goldman and Fuller, The Quest for the Presidencr; 1984. p. 50.
} 
Finally, Carter and Mondale's respective stances on Israel were different. Carter believed in a balanced approach to the question of Middle East peace. For religious and secular reasons, he spoke of security for God's chosen balanced with justice for the Arabs, the co-heirs in the region of the Abrahamic promise. He had a political vision of peace for the region inspired by the Bible. Throughout his career, Mondale had a strong, unwavering pro-Israel reputation. ${ }^{38}$ In a 2007 interview, CNN's Wolf Blitzer identified the former vice president, with President Carter seated next to him, as someone who has "always been a very, very strong supporter of Israel." 39 Whether the year was 1977 or 2007, "very, very pro-Israel" is not, will not, and cannot be said of Carter-unless, of course, it is conjoined with "very, very pro-Arab, too."

From a 1991 interview with Ken Stein, Carter acutely explained this difference between Mondale and himself. ${ }^{40}$ "Fritz Mondale was much more deeply immersed in the Jewish organization leadership than I was. That was an alien world to me." Carter sensed that the feeling was mutual. In 1976, "I was looked upon as an alien challenger to their own candidate [Washington Senator Henry Jackson]." Consequently, he said, "I didn't feel obligated to them." However, "Fritz... was committed to Israel...It was an act just like breathing to him-it wasn't like breathing to me." "So," when it came to the politics of the Middle East, Carter explained, "I was willing to break the shell more than he was."

\footnotetext{
${ }^{38}$ Kengor, "A Political Vice President: Walter Mondale (1977-1981)," chap. in Wreath Laver or Policy. Player? The Vice President's Role in Foreign Policy, p. 100.

${ }^{39}$ Carter, "Interview with Wolf Blitzer," CNN's The Situation Room, January 19, 2007.

${ }^{40}$ Quoted in Stein, "My Problem with Jimmy Carter's Book," Middle East Quarterly (Spring 2007), p. 3.
} 
For his part, Vice President Mondale, along with other Democratic leaders. often expressed his concern that Carter needed to secure domestic Jewish support. ${ }^{+1}$ Unlike Carter, Brzezinski observed. Mondale was usually reluctant "to risk his standing with the Jewish community" and typically encouraged the President to be much more cautious and "passive" in his Mideast dealings. ${ }^{42}$ While he supported the President's peace efforts, he had many misgivings along the way. For instance, he became particularly agitated when Secretary "Vance suggested we initiate contacts with the PLO." 43

Mondale's essential argument, as the National Security Advisor understood it. was that Carter's hands-on approach and his desire to pressure Begin "would provoke controversy and be politically counterproductive. ${ }^{" 4+}$ Instead, after the first year and second year, the Vice President wanted Carter to "simply let things go on their own." Anything "thereafter," wrote Brzezinski, Mondale believed would cost the President too much politically if "Israel's many supporters, both Jewish and non-Jewish," were alienated. ${ }^{45}$ Quandt noted this, too. ${ }^{46}$ He wrote that in the summer of 1978 "Mondale argued the case for pulling back and rebuilding confidence with the Jewish community"*

\footnotetext{
${ }^{41}$ Brzezinski. Power and Principle, p. 92.

42 Ibid., p. 96.

${ }^{43}$ Ibid., p. 278.

${ }^{44}$ Ibid., p. 279; Paul Kengor, "A Political Vice President: Walter Mondale (1977-1981)," chap. in Wreuth Layer or Policy Player? The Vice President's Role in Foreign Policy, p. 101.

${ }^{45}$ Ibid., p. 239.

${ }^{46}$ Quandt, Camp David: Peacemaking and Politics (Washington, DC: The Brookings Institution. 1986). pp. 197-198; see also Robert A. Strong, "Shuttle Diplomacy: President Carter in the Middle East." chapter in Working in the World: Jimm. Carter and the Making of American Foreign Policy. (Baton Rouge. LA: Louisiana State University Press, 2000), pp. 192. 207.
} 
before the fall congressional mid-terms. Continued direct involvement by the President was simply too risky electorally. To protect the President's prestige, shielding him from any further controversies, he recommended that Carter pull back in favor of a "political negotiator" to handle the personal diplomacy. Mondale provided his input to Carter, but in many instances on this issue he lacked the influence. To paraphrase Paul Light, Mondale had Carter's ear, but he did not have his mind on the Middle East. ${ }^{47}$ This suggests that had Mondale been the President the peace accords likely would never have occurred. Compared to Carter, his approach, while supportive, was generally cautious and much more focused on the potential effects the peace process was having on domestic support. ${ }^{48}$

\section{Lyndon Johnson}

Over his career, Lyndon Johnson considered Jews "one of his natural constituencies. ${ }^{, 49}$ In contrast to the more Arabist officials in the federal bureaucracy. particularly the State Department, he had long expressed sympathy for "the Zionist cause" and he "felt a natural antipathy" toward the pan-Arabism of Egyptian President

\footnotetext{
${ }^{47}$ Paul Light, "Vice Presidential Influence Under Rockefeller and Mondale," Political Science Quarterly 98.4 (Winter 1983-1984): 619.

${ }^{48}$ Gillon, The Democrats' Dilemma, p. 171.

${ }^{49}$ Randall B. Woods, LBJ: Architect of American Ambition (New York: Free Press, 2006), p. 768. Though by 1966, Woods wrote, Johnson's "natural sympathy for Jews in general and lsrael in particular was partially eclipsed by his anger over growing antiwar sentiment in the American Jewish community." Exasperated, Johnson even "told Tel Aviv that if they did not get their American friends off his back over Vietnam they could forget about further aid." Ibid., p. 772. For many "rank and file" Jewish Americans, ever since Johnson became president, the man "from oil-rich Texas" was "an object of suspicion." lbid.. p. 768.
} 
Gamal Abdel Nasser. ${ }^{50}$ Still, writes biographer Randall Woods, Johnson was determined to follow the even-handed Middle East strategy of his predecessors Dwight Eisenhower and John Kennedy, maintaining strong ties with Israel and key Arab states. In the case of the Arabs. Johnson understood the importance of the region`s oil for the country and Soviet desire to expand its influence there.

President Johnson had no plans for any bold involvement in the Middle East. The region may have been important, but throughout his presidency, Vietnam was to be Johnson`s foreign policy preoccupation. burden, and eventual political undoing. He did not give the region any serious attention until the 1967 Six-Day War. In fact, his inattention was blamed in some quarters for the war itself. Woods notes, for instance. that the Baltimore Sun ran the headline, "U.S. Ignored Crisis Signs in Mideast" and described the outbreak of war "one of the worst failures of United States foreign policy" since the U.S. began its involvement in Southeast Asia. ${ }^{51}$

Johnson identified the region as dangerous. With the Six-Day War of June 1967. he came to see that "trouble" in the Middle East was "potentially far more dangerous than the war in Southeast Asia. ${ }^{.52}$ As his successors would, Johnson feared that Soviet influence in the region might transform more moderate regimes into Soviet clients or pan-Arab radicals. ${ }^{53}$ Moreover, with increased Soviet influence. Johnson

\footnotetext{
50 Ibid.. p. 769.

51 lbid., p. 782.

52 Lyndon B. Johnson. The I'antage Point: Perspectives of the Presidency, 1963-1969 (New York: Holt. Rinehart and Winston. 1971). p. 287

53 bid.. p. 288.
} 
worried that every little incident in the region could produce "an ultimate confrontation" between the two superpowers. ${ }^{54}$

In his memoirs, President Johnson did not characterize the region or his efforts in religious terms. For him, U.S. interests were material interests, matters of security. The closest he came to discussing the region and Israel in Carteresque, evangelical terms came in two passages. In one, likely thinking about the events of the Holocaust and the birthpangs of war surrounding Israel's independence, he stressed his admiration for the Jewish people. "I have always had a deep feeling of sympathy for Israel and its people, gallantly building and defending a modern nation against great odds and against the tragic background of Jewish experience." as the place "where our civilization began." 56

Though he did not present any compelling regional vision for peace in the 18 pages he dedicated to the Middle East out of 569 pages, he concluded that two things must occur if peace was to happen. ${ }^{57}$ First, he said, "there could be no satisfactory future for the Middle East until the leaders and the peoples of the area turn away from the past, accepted Israel as a reality, and began working together to build modern societies, unhampered by old quarrels, bitterness, and enmity." Second, and more specifically, he explained, "while I understood the special problems of the people of

\footnotetext{
${ }^{54}$ Ibid.

${ }^{55}$ Ibid., p. 297.

${ }^{56}$ Ibid., p. 304

${ }^{57}$ Ibid.
} 
Israel, living in a harassed and beleaguered fortress." Israel. with its recent victory. needed to be magnanimous. With the Arab powers humiliated in defeat. "I believed the Israelis would have to reach out and help provide a basis of dignity for their neighbors... An Israel overconfident in victory would only weaken" the prospects for "a solid peace."

\section{Richard Nixon}

Though burdened by the American involvement in Southeast Asia he inherited from the previous administration, finding peace in the Middle East was an early and continuing priority for President Richard Nixon. But Nixon's interest and pursuit of peace in the region, based on his memoirs, evidently had nothing to do with his religious faith. The interest of the Quaker president was predicated on fear of Soviet influence and expansion and fear that another Arab-Israeli war could draw in the two superpowers.

In Nixon`s view, the Soviets were determined to increase and expand their presence in the Middle East. though not for expanding and promoting communism per se. He said the Soviets were seeking access to what they long desired-"land. oil. power and the warm waters of the Mediterranean" rather than ideological conversions. ${ }^{58}$ As he wrote in a memorandum to Secretary of State William Rogers. "The difference between our goal and the Soviet goal in the Middle East is very simple and fundamental. We want peace. They want the Middle East" (emphases Nixon`s). ${ }^{59}$

\footnotetext{
${ }^{58}$ Nixon. The Memoirs of Richard Nixon (New York: Grosset \& Dunlap. 1978). p. 477.
} 
To counter the designs of the Soviet Union, Nixon sought "a new balance of power" in the region. He said "the United States could not stand idly by and watch Israel being driven into the sea" or continuing to risk "the possibility of a direct U.S.Soviet confrontation." ${ }^{60}$ To prevent these two outcomes, Nixon said U.S. policy needed a good dose of realism. ${ }^{61}$ That is, to prevent their becoming Soviet satellites, the United States must reach out to the "moderate Arab states, particularly Jordan, Egypt, and Saudi Arabia." Such overtures served both U.S. and Israeli security interests. "Israel cannot survive forever," he explained, "as an island in a sea of hatred."62 So peace was in their interest. Mere preparation for war was not a real policy choice for Israel, especially "over a long period of time with a hundred million Arabs around them." And for the United States, a successful mediation of "a peace settlement of Arab-Israeli differences" would constitute "a serious blow to the Soviet presence and prestige in the Middle East." ${ }^{64}$ Working for peace, Nixon stated, enhanced U.S. credibility with the Arabs. It offered them "a place other than Moscow to turn." ${ }^{65}$ Simply, as he wrote in his diary in 1973, Nixon believed "we just can't let the thing ride and have a hundred

\footnotetext{
${ }^{59}$ Ibid.

${ }^{60}$ Ibid., p. 483.

${ }^{61}$ Nixon, 1999: Victory Without War (New York: Pocket Books, 1989), p. 278.

${ }^{62}$ Ibid., p. 277

${ }^{63}$ Nixon, The Memoirs of Richard Nixon, pp. 943, 1008.

${ }^{64}$ Ibid., p. 885.

${ }^{65}$ Ibid., p. 941.
} 
million Arabs hating us and providing a fishing ground not only for [Arab] radicals. but. of course, for the Soviets. .66

Nixon was dismayed that many American Jewish leaders were too "unyielding and shortsighted" to see the larger strategic picture. ${ }^{67}$ They failed to understand that "those who deviate from the hard line of some of Israel's more extreme supporters" were not necessarily "anti-Israel." 68 "Everyone must understand that being a friend of Israel's neighbors does not make one an enemy of Israel." Risking an Arab oil embargo and confrontation with the Soviet Union. he argued that he was fully committed to Israel's security as evinced "in the I973 war, [when] I ordered the massive airlift of equipment and materiel that enabled Israel to stop the two-front advance of Syria and Egypt. " ${ }^{69}$ "Our commitment to the survival of Israel runs deep." he asserted. Though the United States and Israel were not formally aligned, the two countries were "bound together by something much stronger than any piece of paper: a moral commitment." This is something past and future presidents have and "will faithfully honor" as he did. "America will never allow the sworn enemies of Israel to achieve their goal of destroying it."

With regard to the occupied territories in the West Bank and Gaza. Nixon said he was concerned that if Israel tried to annex or absorb them. its Western-style

\footnotetext{
${ }^{66}$ Ibid. p. 787.

${ }^{67}$ Ibid.. pp. 481, 1007.

${ }^{68}$ Nixon, 1999: Victory Without War, p. 279.

${ }^{69}$ Ibid.. p. 276.
} 
democracy would be transformed into "a binational garrison state." ${ }^{70}$ Citing the views of Israel's first prime minister, in 1999: Victory Without War, Nixon said that David Ben-Gurion believed that if Israel's extremists succeed, given the higher birth rate among Palestinians, "Israel will be neither Jewish nor democratic." In time, "the Arabs will outnumber us, and undemocratic, repressive measures will be needed to keep them under control." This, Nixon added, will not only destroy the democratic character of the Jewish state, it will "eventually bring about a united Arab world hostile to Israel" and provide "greater opportunities for Moscow to enter the region than ever before."

In 1970, in a memorandum to then-National Security Advisor Henry Kissinger, the President discussed his feelings and indicated the lurking "danger for Israel of relying on the prominent liberal and dove senators of both parties to come through in the event a crisis arose in which Israel was attacked by the Arabs or was even threatened directly by Soviet power." He told Kissinger that the pro-Israel community "must recognize that our interests are basically pro-freedom and not just pro-Israel because of the Jewish vote. We are for Israel because Israel in our view is the only state in the Mideast which is pro-freedom and an effective opponent to Soviet expansion." In other words, from his perspective, Israel was a valuable ally of the United States not because there was a "pro-Israel attitude prevalent in large and influential segments of the American Jewish community, Congress, the media, and in intellectual and cultural circles," but because it could be an effective ally in stopping the Soviets. For Nixon, issues of U.S.-Soviet superpower rivalry were of paramount concern, not the more

\footnotetext{
${ }^{70}$ Ibid., pp. 278-279.
} 
mundane and parochial differences between Arab and Israeli. Therefore, the goal of the Nixon Administration was "to construct a completely new set of power relationships in the Middle East-not only between Israel and the Arabs, but also among the United States, Western Europe, and the Soviet Union."

\section{Gerald Ford}

In his memoir, A Time to Heal. Gerald Ford's view of the Middle East was wholly secular and realist. Though personally religious, Ford believed it improper to mix religion and politics and unseemly for presidents to discuss their religious views. This is certainly reflected in his descriptions of Israel and the U.S. role in the Middle East. In his writings, there is no sense of evangelical mission or vision. The region's issues are not communicated in theological or Biblical terms. No Bible verses are invoked to justify involvement or policy positions, and instances of prayer are not cited as evidence that he was emboldened when things got tough.

Like Johnson and Nixon, Ford said the Middle East was "one of my chief concerns." 71 He considered it important for the United States to secure the region's oil supply to the West. ${ }^{72}$ He pledged to check Soviet power and influence. "*Their only aim was to promote instability, so I wanted to keep them out." ${ }^{, 73}$ He reaffirmed the country's commitment to a "free and secure Israel" and to maintaining its "national

\footnotetext{
${ }^{71}$ Gerald R. Ford, A Time to Heal: The Autobiography of Gerald R. Ford (New York: Harper and Row Publishers, 1979), 183.

${ }^{72}$ Ibid., p. 151.

${ }^{73}$ Ibid., p. 183.
} 
integrity." 74 Echoing Nixon, Ford said he feared that if the peace process failed,

moderate Arabs could be radicalized, creating more enemies for the United States. ${ }^{75}$

This, too, could create conditions for yet another Arab-Israeli war. ${ }^{76}$

But Ford spent much of his Middle East reflections not by reviewing his vision or policies so much as charging Israel and "the Israeli lobby" in the United States with blocking progress. Though Merkley completing ignores this, Ford, like Carter, used these words to describe the Israelis: "tough in their demands," "less flexible," "didn't seem to understand that only by giving do you get something in return," "stalling," "their tactics frustrated the Egyptians and made me mad as hell," "dragging their feet," "didn't want to budge," "the strong objections of the Israelis." Unlike the Egyptians who "bent over backward," "again, the Israelis resisted." 77 He asserted that he believed that "the Israelis had been engaged in a not very subtle campaign to discredit Kissinger."78 "Because Henry was a Jew," President Ford continued, "the Israeli hardliners said, he was bending over backward to be 'fair' to the Arabs. He was 'outGentiling the Gentiles." Ford said, "The fact that I had said I wanted to establish a personal relationship with Sadat seemed to worry the Israelis, and they decided to

\footnotetext{
${ }^{74}$ Ibid., p. 286.

${ }^{75}$ Ibid., p. 247.

${ }^{76}$ Ibid., p. 286.

77 Ibid., pp. 246-247, 287, 291. See Merkley, American Presidents, Religion, and Israel, pp. 80-86. Though Ford does not claim a religious influence, Merkley nonetheless concludes, "There is no reason to doubt the sincerity of Ford's effort to establish his moral commitment to Israel and to represent this effort as following from his own personal religious commitment."

${ }^{78}$ Ibid., p. 287.
} 
launch a counterattack" on him. ${ }^{79}$ "We had been engaged in a war of nerves with Israel. ${ }^{* 80}$ The problem with the Israelis. Ford explained, was that they "were always insisting that we supply them more military equipment than our own experts thought they needed and far more than I thought we could afford. ." "Their shopping list." he added. "included sophisticated weaponry that eren our own forces hadn "t received yet."

To the pressure of a singularly focused "Israeli lobby." he said he "was not going to capitulate“ and threatened instead to go public with U.S.-Israel differences. ${ }^{82}$ For merely "suggesting the possibility of a reassessment of our policy toward Israel." he claimed some in the American Jewish community thought "I must be anti-Israel or even anti-Semitic. $^{.03}$

When Secretary of State Kissinger finally succeeded in concluding an agreement with Israel and Egypt in September 1975. known as Sinai 1I. President Ford had only this to say in his memoirs. After he had congratulated both Sadat and Rabin for their efforts. he called Kissinger. " This is a great achievement...And I know that the American people will be most grateful for the successful efforts that you made.. ${ }^{.84}$

\footnotetext{
${ }^{-9}$ Ibid.. p. 287.

${ }^{80}$ Ibid.. 308 .

${ }^{81}$ Ibid.. 308.

\$2 Ibid.. pp. 2+7-248. 288.

${ }^{83}$ Ibid.. p.286.

${ }^{84}$ Ibid.. p. 309.
} 
In An American Life, Reagan made his pro-Israel views clear. "I've believed many things in my life, but no conviction I've ever held has been stronger than my belief that the United States must ensure the survival of Israel." ${ }^{, 85}$ But Reagan's proIsrael position and his justification for U.S. involvement in the region were seemingly not based on religious reasons. If his personal faith was a factor, he did not mention it in his accounts.

Not surprisingly, as in Europe, Africa, and Latin America, Reagan was especially concerned about Soviet expansion. William Quandt wrote, "Reflecting his general view of foreign policy, Reagan placed primary emphasis on the Soviet threat to the Middle East, not on the Arab-Israeli dispute." 86 Reagan came into office "as a determined anti-communist." ${ }^{, 87}$ Consistent with this, Reagan listed fear of Soviet expansionism first among his reasons for backing Israel. He wrote, "Under Leonid Brezhnev, the Soviet Union was eager to exploit any opportunity to expand its influence and supplant the United States as the dominant superpower in this oil-rich and strategically important part of the world. $" 88$

Second, Reagan expressed his "irreversible commitment to the survival and territorial integrity of Israel." ${ }^{, 89}$ Based on these two points, Reagan viewed Israel "as an

\footnotetext{
${ }^{85}$ Reagan, An American Life, p. 410.

${ }^{86}$ Quandt, Camp David, p. 18.

${ }^{87}$ Quandt, Peace Process, p. 245.

${ }^{88}$ Reagan, An American Life, p. 418; see also Reagan, The Reagan Diaries, edited by Douglas Brinkley (New York: HarperCollins Publishers, 2007), p. 14.

${ }^{89}$ Reagan, An American Life, p. 4 I 8.
} 
important strategic asset in the confrontation with the Soriet Union. ${ }^{.90}$ In this role as a strategic ally. Reagan saw Israel as part of a global strategy in confronting and containing the Soviets.

Reagan further explained that he wanted to resist Soviet expansion in the region and protect the region's oilfields. "coveted by the Communist world.".91 Reagan believed as well that U.S. involvement would deter "the radical, anti-American Iranian revolution from spreading" and the consequences that would likely bring to "our economy. ${ }^{.92}$ Reagan said he wanted to send a message to "our allies and to Moscow that the United States supported its friends" in the Middle East. ${ }^{93}$ From this president. he argued. there would not be an abandonment of U.S. allies as the Carter administration had done with Iran. Reagan believed that U.S. involvement would protect Israel, "a small country virtually surrounded by enemies. ${ }^{.94}$ "I repeatedly emphasized that the United States was committed to ensuring Israel's survival and would do nothing to diminish its position of military superiority " in the region. ${ }^{95}$

Though strongly supported by conservative evangelicals. a constituency that sees Israel and the Middle East region from a Biblical perspective, there is nothing in

\footnotetext{
${ }^{90}$ Steven L. Spiegel. "Israel and Beyond: American Jews and U.S. Foreign Policy." in Jews in . Americum Politics, eds. L. Sandy Maisel and Ira N. Forman (Lanham. MD: Row'man \& Littlefield Publishers. 2001), p. 263: Stephen E. Ambrose and Douglas G. Brinkley. Rise to Globalism: American Foreign Policy Since 1938 (New York: Penguin Books, 1997), p. 306.

${ }^{91}$ Reagan, An American Life, pp. $410-411$.

92 Ibid., p. 411

${ }^{93}$ Ibid.

${ }^{94}$ Ibid.. p. 414.

${ }^{95}$ Ibid.. p. 415.
} 
his memoirs that suggest that Reagan's views toward Israel and the Middle East were

motivated or influenced by his self-proclaimed evangelical faith. ${ }^{96}$ There are no citations from the Bible, no proclamations of Bible prophecy being fulfilled, no lessons learned from Sunday school, and virtually nothing remotely "holy" about the region. ${ }^{97}$ The closest reference of any sort to the Middle East having Biblical significance is a brief comment about the source of the conflict. Reagan described the Middle East as "a region where hate has roots reaching back to the dawn of history. It's a place where the senseless spilling of blood in the name of religious faith has gone on since biblical times, and where modern events are forever being shaped by momentous events of the past, from the Exodus to the Holocaust." ${ }^{98}$ Unlike Carter, who saw in his religious faith key sources of inspiration and solutions for conflict resolution, Reagan seems to have identified religion as not much more than a source of regional violence.

If Reagan had an idealist reason, the closest thing one finds is that he noted a moral reason for his commitment to Israel: the legacy of the Holocaust. He wrote, "The Holocaust, I believe, left America with a moral responsibility to ensure that what had

\footnotetext{
${ }^{96}$ William Martin, "The Christian Right and American Foreign Policy," Foreign Policy (Spring 1999): 72-73; Jerry Falwell, Listen, America! (New York: Bantam Books, 1980), pp. 93-98; Paul Boyer, When Time Shall Be No More: Prophecy Belief in Modern American Culture (Cambridge, MA: Harvard University Press, 1992), pp. 203-208; Sara Diamond, Spiritual Warfare: The Politics of the Christian Right (Boston, MA: South End Press, 1989), pp. 200-204.

${ }^{97}$ There is evidence, however, that Reagan did believe in end-time Bible prophecies. In his diary, for instance, after the Israelis bombed the nuclear power plant in Iraq in June 1981, Reagan wrote, "I swear I believe Armageddon is near." Later in 1983, worried that the fighting in Lebanon could lead to a wider war, Reagan said, "The possibility of an Israeli-Syrian (plus Soviet) confrontation cannot be ruled out. Armageddon in the prophecies begins with the gates of Damascus being assailed." Reagan, The Reagan Diaries, pp. 19, 24, 150. See also Boyer, When Time Shall Be No More, pp. 142-143, 162; Grace Halsell. Forcing God's Hand: Why Millions Pray for a Quick Rapture---And Destruction of Planet Earth (Revised Edition; Beltsville, MD: Amana Publications, 2003), pp. 17, 21, 102.

${ }^{98}$ Reagan, An American Life, p. 407.
} 
happened to the Jews under Hitler never happens again. We must not let it happen again. The civilized world owes a debt to the people who were the greatest victims of Hitler`s madness. ${ }^{99}$ Reagan. like other presidents before him. also mentioned the shared values between the two countries. He wrote. "My dedication to the preservation of Israel was as strong when I left the White House as when I arrived there, even though this tiny ally. with whom we share democracy and many other values, was a source of great concern for me while I was president. ${ }^{* 100}$

George H.W. Bush

Though the Palestinian intifada. which began in 1987. was well underway at the start of his presidency, resolution of the Arab-Israeli conflict was not a high priority for George H.W. Bush. President Bush did not give serious attention to the region until August 1990 when Saddam Hussein`s Iraq invaded Kuwait. He did not turn his focus to the Arab-Israeli peace process until after the war with Iraq ended.

After the Iraqi invasion. the President described Hussein as "evil" and the Iraqi occupation of its neighbor as a matter of "good versus evil," "right versus wrong. .101 In a letter to Saudi King Fahd (November 22. 1990). Bush noted how proud he was that the United States and Saudi Arabia were "standing shoulder against Iraq"s evil dictator." ${ }^{102}$ Sometimes, he wrote in a letter to Bernard Cardinal Law (January 22.

\footnotetext{
${ }^{99}$ Ibid., p. 410.

${ }^{100}$ Ibid.. p. 410.

${ }^{101}$ George H.W. Bush, All the Best, George Bush: My Life in Letters and Other Writings (New York: Scribner. 1999). pp. 503, 506.

102 Ibid., p. 490.
} 
I991), "failing to use force" to resist armed aggressions "is an immoral position." $\mathrm{He}$ added, "in certain situations, using force is not immoral, not against God's will."103

From this point through the conclusion of the 1991 Gulf War, the President's main focus was to rally international opinion against the invasion and forge a WesternArab coalition to expel Iraqi forces.

In his book, All The Best, George Bush, comments about Israel and Middle East were virtually absent. Of Israeli prime ministers, only Labor Party leader Shimon Peres was mentioned in an approving way, and that was from a letter written while Bush was the Vice President (August 3, 1986). In it, Bush said, "I am convinced that Peres wants peace." ${ }^{04}$ His only references to the American Jewish community were some remarks concerning the Jewish Defense League, an organization "led by the outrageous and radical Meir Kahane" that "used disruptive, radical tactics against the Soviet Union" to protest treatment of Soviet Jews. ${ }^{105}$

Regarding Middle East policy, Bush declared in a letter to Syrian President Hafez al-Assad that the United States' position was, "Territory for peace applied to all fronts, including the Golan Heights. We will not change this fundamental policy position of ours; nor will we change our non-recognition of Israel's purported 'Annexation' of the Golan Heights" (June 1, 1991). ${ }^{106}$ It was Bush's hope that the

\footnotetext{
${ }^{103}$ Ibid., p. 507.

${ }^{104}$ Ibid., p. 350. Reagan, too, was very fond of Prime Minister Peres. In his diary (September 15, 1986), he wrote, "I admire him very much and am sorry the political rotation agreement [between the Labor and Likud parties] will see him replaced with P.M. Shamir...He's done a great job seeing the way toward peace in the Middle East." Reagan, The Reagan Diaries, p. 437.

${ }^{105}$ Ibid., p. $141 n$.

${ }^{106}$ Ibid., p. 524.
} 
successful conclusion of the 1991 Gulf War "created new opportunities for progress in the peace process" between Israel and its Arab neighbors; he wanted Syria to take advantage of "these new opportunities" that "may not come again."

In his book with National Security Advisor Brent Scowcroft, $A$ World Transformed, beyond Iraq, very little was described or discussed about the Arab-Israeli conflict and the peace process. Purposely, they noted up front that their book would contain little on these points, except for the war with Iraq. ${ }^{107}$

The few points that were included about Israel centered on administration fears that Israel would jeopardize the fragile Western-Arab war coalition against Iraq if it responded to an attack from Iraq during the war. ${ }^{108}$ Israeli Prime Minister Yitzhak Shamir was praised for his restraint; it was "one of his finest moments," wrote Scowcroft. ${ }^{109}$ "Whatever other problems may have arisen between us and Shamir from time to time, on this occasion, he showed himself a strong, stalwart ally." Bush asserted, "Because of the Arab-Israeli tensions, throughout the crisis Israel remained very carefully placed outside the coalition." "I knew," he said, "we could not build a truly broad coalition, one that included many Arab nations. if Israel were part of it." When violence broke out at the Temple Mount in Jerusalem in October 1990 and Israeli forces "fired into the crowd, killing 21 Palestinians and injuring more than 150 ," the Bush Administration supported a UN resolution condemning Israel "for using excessive force and called for a more restricted" investigative mission in "the occupied

\footnotetext{
${ }^{107}$ George Bush and Brent Scowcroft, A World Transformed (New York: Alfred A. Knopf. 1998), p. xi.

${ }^{108}$ Ibid., pp. 452, 455.

${ }^{109}$ Ibid., p. 456.
} 
territories." 110 From the viewpoint of the Bush administration, the U.S.-sponsored measure viewed Israel "as the occupying power under the Geneva Convention" and was responsible for the "protection" of Palestinians under their jurisdiction. ${ }^{11}$ Not surprisingly, the Israelis were not pleased with this. Bush and Scowcroft wrote, "our relations with Israel hit a new low" and "the Jewish community in the United States was surprised, hurt, and furious."

After the war with Iraq, President Bush observed that the organization of the Madrid Conference in October 1991 was "a quick and substantial payoff" that came from "our new credibility" in simultaneously working with various Arab states to liberate a fellow Arab country and coming to the defense of Israel. ${ }^{112}$ It "was one of the direct fruits of the Gulf War."113 "Without the successful prosecution of that conflict and our coalition-building with our Arab allies," he said, "such a meeting would have been impossible." He explained that he "hoped to take advantage of the goodwill we had forged with our Arab allies to advance regional peace and security." Bush particularly thanked Secretary of State James Baker for his role in making the conference possible. But this was all the $41^{\text {st }}$ President had to say on the matter. His thoughts quickly turned to developments in the near moribund Soviet Union and his relations with Mikhail Gorbachev. Bush ended his brief mention of Madrid with "I

\footnotetext{
${ }^{110}$ Ibid., pp. 378-379.

${ }^{111}$ Ibid., p. 379.

112 Ibid., p. 490.

113 Ibid., pp. 547-548.
} 
looked forward to another opportunity to see Gorbachev in Madrid and talk to him at length.".114

\section{Bill Clinton}

Based solely on his memoirs, there does not appear to be as much weighty evidence that President Bill Clinton possessed an evangelical vision, evangelical sense of mission, or that he relied on the certainty of faith that Carter had when he labored for peace. Rather than being central player to the 1993 Oslo agreement and the 1994 Israeli-Jordanian peace treaty as Carter had been at Camp David and the 1979 IsraeliEgyptian peace treaty, Clinton was more of a host and "witness" to events that happened largely without his personal efforts. ${ }^{115}$

Nevertheless, like Carter. Clinton often did use the language of faith in his public communications. There are, too, glimpses of a sense of mission and vision for the region akin to Carter's and there are some hints of an evangelical personalism at work in his relations with Yitzhak Rabin. Perhaps, it is significant that the only two American presidents to address the Knesset. Israel's parliament. were two former Southern Democratic governors, two self-proclaimed evangelicals. Presidents Jimmy Carter (March 12, 1979) and Bill Clinton (October 27. 1994).

\footnotetext{
${ }^{114}$ Ibid., p. 548.
} 
Following Carter, Bill Clinton made an effort to distinguish the "travesty" of Islamic terrorism from the "tolerance" of the Islamic faith. ${ }^{116}$ "It is profoundly wrong to equate Palestinians, in particular, and Islam, in general, with terrorism or to see a fundamental conflict between Islam and the West." "For the vast majority of the more than one billion Muslims in the world," he said before the Palestinian National Council in 1998, "tolerance is an article of faith." Earlier, in his 1994 address before the Jordanian parliament in Amman, the first given before the body by an American president, Clinton said, "The best received lines in the speech were directed to the Arab world at large." 117 Countering the controversial thesis advanced by Harvard political science professor Samuel Huntington, Clinton said,

America refuses to accept that our civilizations must collide. We respect Islam...the traditional values of Islam, devotion to faith and good work, to family and society, are in harmony with the best of American ideals. Therefore, we know our people, our faiths, our cultures can live in harmony with each other.

What Clinton left out in his memoirs were his concluding remarks. In closing, citing both the Prophets Moses and Muhammad, he said,

This was the message of Moses' farewell address to the children of Israel as they gathered to cross the River Jordan, when he said, 'I have set before you life and death, blessings and curses. Choose life so that you and your descendants may live.' And it is the message the Prophet Mohammed brought to the peoples of other faiths when he said, 'There is no argument between us and you. God shall bring us together, and unto him is the homecoming.'

\footnotetext{
${ }^{115}$ Ibid., pp. 54 I, 625.

${ }^{116}$ Clinton, "Remarks to the Palestine National Council and Other Palestinian Organizations in Gaza City, Gaza" December 14, 1998, in Public Papers of the Presidents, Book II, p. 2178.

${ }^{117}$ Clinton, My Life (New York: Alfred A. Knopf, 2004), p. 626.
} 
Today the people of Jordan and the people of Israel have reached across the Jordan River. They have chosen life. They have made a homecoming. And tonight we say, thanks be to God, Ilham du Illah. ${ }^{118}$

On another occasion. in preparation for his remarks to celebrate the signing of the Oslo peace agreement between the Israelis and Palestinians in September 1993. Clinton said that the night before he had trouble sleeping. "Unable to go back to sleep." he said. "I got my Bible and read the entire book of Joshua." Clinton noted that his readings prompted him to rework his remarks the next day and "to wear a blue tie with golden horns." The tie. he claimed. was symbolic of the horns Joshua and the Israelites "used to blow down the walls of Jericho." But for this occasion, "the horns would herald the coming of peace that would return Jericho to the Palestinians.." ${ }^{-19}$ About the ceremony the next day, he wrote that. when Israeli Prime Minister Rabin spoke, using quotes from the Hebrew Bible, he sounded "like an Old Testament prophet." He added that he closed his own remarks "by bidding the descendants of Isaac and Ishmael. both children of Abraham. 'Shalom. salaam. peace.' and urging them to 'go as peacemakers. $\cdots 120$

Clinton recalled that Rabin supported the Oslo talks and agreement not for religious reasons but for purely practical reasons. ${ }^{121}$ According to the President. Rabin came to see that continued Israeli occupation of Palestinian lands was not contributing to Israel's security. Instead. as proven by the Palestinian intifada and Iraq's ability to

\footnotetext{
${ }^{118}$ Clinton, "Remarks to the Jordanian Parliament in Amman. Jordan." October 26. 1994. in Public Papers of the Presidents, Book II. p. 1881.

${ }^{119}$ Clinton. My Life. p. 542.

${ }^{120}$ Ibid.. pp. 544-545.

121 Ibid.. p. 545.
} 
hit his country with missiles, they were in fact "a source of insecurity" and an inadequate "security buffer against attacks with modern weapons from the outside." Rabin concluded, wrote Clinton, "if Israel were to hold the West Bank permanently, it would have to decide whether to let the Arabs there vote in Israeli elections." But this was problematic. First, the Prime Minister explained, "If the Palestinians got the right to vote, given their higher birthrate, within a few decades Israel would no longer be a Jewish state." Second, and perhaps most importantly, he said, "If they were denied the right to vote, Israel would no longer be a democracy but an apartheid state" (emphasis added). Given these two factors, both of which would destroy the Jewish and democratic character of Israel, Rabin came to believe that adopting the land-for-peace formula was necessary.

Probably hoping to imitate his Southern Democratic predecessor, particularly in his second term with the 1998 Wye Plantation Agreement and his own Camp David summit in 2000 with Israeli Prime Minister Ehud Barak and Palestinian President Yasser Arafat, Clinton said he aimed to advance the "cause" and "mission" of peace in the region. ${ }^{122}$ While "it is not in our power to rid the world of evil," Clinton told students in Tel Aviv, "it is within our power to fight on for peace." 123 Like Carter, he characterized the region as "sacred" or "holy ground," a land full of "sacred heritage," producing "religions and [the] Bible," a "sacred corner of [the] Earth." 24 He expressed

\footnotetext{
${ }^{122}$ Clinton, "Exchange with Reporters Abroad Air Force One," November 5, 1995, in Public Papers of the Presidents, Book II, p. 172I; "Remarks at the President's News Conference with Prime Minister Shimon Peres of Israel," December 11, 1995, in Public Papers of the Presidents, Book II, p. 1877.

${ }^{123}$ Clinton, "Remarks and Question-and-Answer Session with Students in Tel Aviv, Israel," March 14. 1996, in Public Papers of the Presidents, Book I, p. 453.
} 
the same hope as the Georgian president that all religious faiths in the region could live together in peace, "to share the land of their fathers" and "the land which gave the world Islam and Judaism and Christianity, to be "the home of all people who love one God and respect every life our one God has created. ${ }^{-125}$

At the 1996 Summit of the Peacemakers in Sharm al-Sheikh. Egypt. Clinton said. "We stand today...not far from the mount where God gave the word to Moses. the law of humanity, tolerance, and faith that guides our way today." Jews, Christians, and Muslims are "the heirs of that moral legacy." 126

During his visit to the West Bank and Gaza in 1998, he thanked Palestinian President Arafat for the opportunity for his family, "a Christian family to light the Christmas tree in Bethlehem" in the "home of Islam, Judaism, and Christianity." where the physical "embodiment of my faith was born a Jew and is still recognized by Muslims as a prophet. $" 127$ For him and other Christians, President Clinton said. "we celebrate at Christmastime the birth of the Prince of Peace."

${ }^{124}$ Clinton, "Remarks to the Palestine National Council and Other Palestinian Organizations in Gaza City." December 14, 1998, in Public Papers of the Presidents, Book II, p. 2177; "Remarks on Arrival in Tel Aviv, Israel." March 13. 1996, in Public Papers of the Presidents, Book I, p. 443: "Remarks at the Arrival Ceremony in Tel Aviv, Israel," December 13. 1998. in Public Papers of the Presidents. Book II. p. 2160; "Remarks at President's News Conference with Prime Minister Shimon Peres in Jerusalem. Israel." March 14. 1996, in Public Papers of the Presidents. Book I, p. 445: "Remarks on the Death of King Hussein 1 of Jordan." February 7. 1999, in Public Papers of the Presidents. Book I. p. 178.

${ }^{125}$ Clinton, "Remarks at a Luncheon Hosted by Chairman Yasser Arafat of the Palestinian Authority in Gaza City," December 14, I998, in Public Papers of the Presidents. Book II, p. 2174: "Remarks at the Wye River Memorandum Signing Ceremony," October 23, 1998, in Public Papers of the Presidents. Book $I I$, p. 1838.

${ }^{126}$ Clinton, "Remarks at the Opening of the Summit of the Peacemakers in Sharm al-Sheikh. Egypt." March 13, 1996, in Public Papers of the Presidents. Book I. p. 437.

${ }^{127}$ Clinton, "Remarks to the Palestine National Council and Other Palestinian Organizations in Gaza City. Gaza" December 14, 1998, in Public Papers of the Presidents, Book II. p. 2179. 
On November 4, 1995, when he was informed that Rabin had been shot by an Israeli extremist opposed to his peace efforts with the Palestinians, Clinton said he "prayed to God to spare Yitzhak's life." ${ }^{28}$ Perhaps echoing Carter's evangelical personalistic relationship with Anwar Sadat and his open expressions of brotherly love toward him, when word came that Rabin was dead, Clinton cast his relationship with the fallen Israeli leader in analogous terms. He said they "had developed an unusually close relationship, marked by candor, trust, and an extraordinary understanding of each other's political positions and thought processes."129 "We had become friends," Clinton said, "in that unique way people do when they are in a struggle that they believe is great and good. With every encounter, I came to respect and care for him more." "By the time he was killed," he reflected, "I had come to love him as I had rarely loved another man.",130

In his eulogy for his friend, President Clinton joined "Jews around the world" who "were studying that portion of the Torah in which God commanded Abraham to sacrifice his beloved son Isaac, or Yitzhak.",131 "Once Abraham demonstrated his willingness to obey, God spared the boy." But Clinton said, "Now God tests our faith even more terribly, for he has taken our Yitzhak." Urging them not to lose faith, Clinton stated, "Israel's covenant with God, for freedom, for tolerance, for security, for

\footnotetext{
${ }^{128}$ Ibid., p. 678.

${ }^{129}$ Ibid., p. 679.

${ }^{130}$ See also Clinton, "Remarks on the Death of Prime Minister Yitzhak Rabin of Israel," November 4 , 1995, in Public Papers of the Presidents, 1995, Book II, p. 1721.

${ }^{131}$ Clinton, My Life, p. 680; see also "Remarks at the Funeral of Prime Minister Yitzhak Rabin in Jerusalem, Israel," November 6, 1995, in Public Papers of the Presidents, 1995, Book 11, p. 1724.
} 
peace-that covenant must hold." 132 Commitment to the principles of the covenant was

"Prime Minister Rabin`s life's work." The President closed with the words. "Shalom.

chaver." meaning "Good-bye, friend."

\section{Religious Pilgrimages to Israel}

Israel is a favorite international travel destination for American evangelicals.

Not surprisingly, given the polling data presented above, many evangelicals annually visit the holy sites of Israel. ${ }^{133}$ To capitalize on the religious sentiments of evangelicals, the Israeli Ministry of Tourism has made special efforts to boost evangelical travel to the Holy Land. ${ }^{134}$ In 2004. Tourism Minister Binyamin Elon explained the view of the Israeli government: "We view the evangelical Christian market as a powerful mechanism to increase tourism in the land of Israel. Evangelicals are visiting Israel in tremendous numbers, and we want to continue to increase tourism to the land of the Bible. ${ }^{135}$

Though Elon's efforts were designed to build political and economic support for Israel among evangelicals, his perception that evangelicals generally hold basic

\footnotetext{
132 lbid. Though not in his memoirs. Clinton said in his remarks to the people of Israel, "In the Knesset. in your homes, in your places of worship, stay the righteous course. As Moses said to the children of Israel when he knew he would not cross over into the Promised Land, 'Be strong and of good courage. fear not for God will go with you. He will not fail you. He will not forsake you.'”

133 Bill Broadway, "The Evangelical-Israeli Connection; Scripture Inspires Many Christians to Support Zionism Politically, Financially," Washington Post. March 27. 2004, B9.

${ }^{134}$ Kevin Peraino, "Babes in the Holy Land." Newsweek, April 9, 2007. p. 52.

135 Quoted in Gaby Wenig, "Evangelical Media Gather Around Israel," Jewish Journal. March 26. 2004. http. www.jewishjournal.com. Elon believes that Israel's biblical heritage is the country"s "unique selling proposition." Peraino, "Babes in the Holy Land," Newsweek, April 9, 2007. p. 52.
} 
assumptions about Israel and the Middle East different from non-evangelicals reinforce the evidence from polling data. Furthermore, pilgrimages are not merely religious acts. They can also reveal the political motivations and perspectives of the pilgrims themselves. This is particularly in the case of evangelical pilgrimages to Israel. ${ }^{136}$

Supplementing the general findings from the presidential memoirs, since the 1960s, four presidents have noted in either their memoirs or campaign autobiographies that they had made a visit to Israel prior to their election: Nixon and the three Southern. born-again governors, Carter, Clinton, and George W. Bush. However, only Carter, Clinton, and Bush described their visit as a religious pilgrimage. In contrast, Nixon's descriptions of his 1967 visit contained nothing of religious significance.

While known for making many public appeals to religion, Nixon's description of his visit in his memoirs was all business, all secular. ${ }^{137}$ He neither mentioned visits to holy sites nor commented whether the region had any religious significance to him. He said he visited the country after its remarkable military victories in Six-Day War and talked with future prime minister General Yitzhak Rabin. Nixon explained that he "pointed out that Israel had a stake in the outcome of the war in Vietnam," because if the United States lost, "the American people could well turn isolationist and be unwilling to come to the aid of other small nations, like Israel." Notwithstanding his respect for "the courage and toughness of the Israeli leaders and people" during the recent conflict, Nixon said he feared that Israel's "swift and overwhelming victory over

\footnotetext{
${ }^{136}$ Yaniva Belhassen and Carla Almeida Santos, "An American Evangelical Pilgrimage to Israel: A Case Study on Politics and Triangulation," Journal of Travel Research 44 (May 2006): 431-441.

${ }^{137}$ Nixon, The Memoirs of Richard Nixon, p. 283.
} 
the Arabs had created a feeling of overconfidence about their ability to win any war in the future." Such an attitude. he believed, would likely make the Jewish state unwilling to work for a peace "that would involve return of any of the territories they had occupied. Their victory had been too great." Later, he observed that he worried that in the next war all the United States could do was "arm Israel against the next Arab onslaught." action which could ultimately lead to "a direct confrontation" between the superpowers. making the region an "international powder keg. $" 138$

In the last chapter. Governor Carter’s 1973 visit to Israel was described. On September 17.2003, at an event commemorating the 25 -year anniversary of the signing of the Camp David Accords, Carter recounted his first visit there when he was governor and said the visit marked "the earliest stages of my involvement in the Middle East." Half the time, he said. he spent learning about the politics and problems of Israel and the other half of the time "looking at biblical places." This visit. he said. influenced him to make Middle East peace a priority when he became president a few years later. $^{139}$

Like Carter. Arkansas Governor Bill Clinton made a journey to the land of Israel. Clinton said he "came on a religious pilgrimage." looking "not through political eyes but through the eyes of a Christian. ${ }^{140}$ In December 1981. before he made his political comeback in Arkansas after losing his bid for reelection in 1980. Clinton said

\footnotetext{
${ }^{138}$ Ibid., p. 343.

139 Carter, "Remarks at the $25^{\text {th }}$ Anniversary Reunion of the Camp David Accords held in Washington. DC." September 17, 2003, http: www.cartercenter.org.

${ }^{1+0}$ Clinton. "Remarks at a Dinner Hosted by Prime Minister Benjamin Netanyahu in Jerusalem. Israel." December 13, 1998. in Public Papers of the Presidents. Book 11. p. 2172.
} 
he took "a pilgrimage with Hillary to the Holy Land."

Vaught, Clinton wrote that he walked "the steps Jesus walked...meeting local

Christians." He visited areas in Galilee where Jesus preached, the Sea of Galilee

"where Jesus walked on water," and visited the places in Jerusalem "where Christians

believe Jesus was crucified and the small cave where Christ is believed to have been

buried and from which He arose."

Clinton and his tour group also visited Jewish and Muslim holy sites, including the Wailing Wall, Masada, the Dome of the Rock, and the Al-Aqsa Mosque. They also, Clinton reported, visited the site where great armies of the past had gathered and where "the Book of Revelation says that at the end of time, the valley will flow with blood." Clinton said, "That trip left a lasting mark on me."

I returned home with a deeper appreciation of my own faith, a profound admiration for Israel, and for the first time, some understanding of Palestinian aspirations and grievances. It was the beginning of an obsession to see all the children of Abraham reconciled on the holy ground in which our three faiths came to life.

Previously, we saw that Carter believed that the birth of the modern state of Israel was a fulfillment of Bible prophecy and the Jews a chosen people of God. Clinton hinted in his memoirs that he shares this belief common among evangelicals. He wrote, without comment or further reflection, that the final advice his pastor gave him before he died was that it was his religious obligation to always stand with Israel.

The final thing Dr. Vaught said took me aback. He said, "Bill, I think you're going to be President someday. I think you'll do a good job, but there is one thing above all you must remember: God will never forgive you if you don't stand by Israel.' He believed God intended the Jews to be at home in the Holy

${ }^{141}$ Clinton, My Life, p. 294. 
Land. While he didn't disagree that the Palestinians had been mistreated. he said the answer to their problem had to include peace and security for Israel. ${ }^{1+2}$

In 1998. Texas Governor George W. Bush visited the Jewish state. In his campaign autobiography. A Charge to Keep. Bush explained that he and his wife Laura visited a number of sacred sites. Among these were the Western Wall. the Church of the Holy Sepulcher, the Sea of Galilee, and "the hill where Jesus delivered the Sermon on the Mount." Governor Bush described Jesus" sermon as "the most famous speech in the history of the world" and in which he "outlined the character and conduct of a believer and gave his disciples and the world the beatitudes, the golden rule, and the Lord's Prayer." As members of his delegation took turns reading Scripture at this memorable location. Bush said he chose to read his favorite hymn, "Amazing Grace. ${ }^{.1+3}$ His father, by contrast. made no such references in his 1988 presidential campaign autobiography. In Looking Forward. George H.W. Bush merely had this to say about Israel: "loyal ally."

\section{Conclusion}

The United States is the most pro-Israel country in the world. and a key reason for this is because of white evangelicals who view the country and the wider region

\footnotetext{
142 Ibid.. pp. 353-354: "Remarks at a Dinner Hosted by Prime Minister Benjamin Netanyahu in Jerusalem, Israel," December 13, 1998. in Public Papers of the Presidents. Book II. p. 2172. See also "Remarks to the Knesset in Jerusalem. Israel," October 27, 1994. in Public Papers of the Presidents. Book II, p. 1892. In this address, Clinton added that his pastor also told him. "It is God's will that Israel. the biblical home of the people of Israel, continue forever and ever."

${ }^{14 \hat{s}}$ George W. Bush, A Charge to Keep (New York: William Morrow and Company. 1999). pp. 138-139.

${ }^{144}$ George Bush with Victor Gold, Looking Forward: An Autobiography. (New York: Doubleday, 1987). p. 241.
} 
through a religious lens. Using public opinion data, this chapter showed that white evangelical Christians in the United States hold views toward Israel and the Middle East that most other Christians (except for black Protestants) and other Americans do not.

Unlike most other Americans, a majority of white evangelicals tend to be more sympathetic to the Israelis than the Palestinians. In contrast to white mainline Protestants and white Catholics, white evangelicals claim that God gave the land of Israel to the Jewish people and that the creation of the modern state of Israel is a fulfillment of Bible prophecy. They further say that their religious views are more important to shaping their views toward Israel and the Middle East than information from the news media, education, personal experience, and friends and family. If these points are true at the mass levels, one could hypothesize that white evangelical presidents are more likely than other presidents to make similar claims as to why they support Israel and why they may actively pursue certain Middle East policies.

Consistent with majoritarian evangelical views, Carter has claimed that God has blessed Israel and has said the modern rebirth of Israel was foretold in the Bible. Since his youth, nurtured by Sunday school lessons, readings of the Bible, the views of his pastor, and a pilgrimage to Israel while governor of Georgia, he asserted he had a deep and abiding interest in the region.

As president, Carter not only used religious rhetoric in his public pronouncements when he talked about Israel and the Middle East, he also had a sense of mission that guided his efforts to help the parties involved achieve a peaceful settlement of differences. He claimed he took comfort in his faith when things did not go as planned and said he found renewed strength and courage in prayer to continue forward 
in spite of the difficulties. political costs. and risks of dramatic failure. His faith. too. provided him a diplomatic style to build a personal bond of trust and friendship with Middle East leaders and then use that personal leverage over them when he encountered intransigence. This worked particularly well with Egyptian President Anwar Sadat.

However. as described in chapter 3, mere claims of being a born-again evangelical are not sufficient for understanding presidential views and behavior. In the case of Israel and the Middle East. neither Ford. Reagan. nor George H.W. Bush claimed any religious justification for their actions in the Middle East in their memoirs or other post-presidential writings. Though they claimed to be evangelicals and received strong electoral support from white evangelicals, there is little to nothing in their works of views commonly expressed by evangelicals. In fact. since Lyndon Johnson, only President Carter made consistent and explicit claims of a religious. biblical-inspired influence on his presidential behavior.

The only other president that comes closest to Carter was Bill Clinton. Clinton provided hints of a religious influence in his memoirs. and upon further investigation. it appears that he may have influenced by his faith in ways akin to Carter. Like Carter. he spoke of his desire to see peace between the descendants of Father Abraham's two sons Isaac and Ishmael and used scriptural supports to foster such a vision. Additionally. there are some clues that Clinton may have used the evangelical personalistic style. as Carter had with Sadat, to build trust and forge close ties with Israeli Prime Minister Rabin.

Carter's Vice President, Walter Mondale, also had views and a style quite different. Based on secondary sources, the former senator from Minnesota was more 
similar in his views and style to other presidents than to the president under whom he served. Had he been president, it is highly probable that the success at Camp David and the signing of the subsequent peace treaty would not have occurred. Mondale lacked Carter's personalistic approach to diplomacy, his sense of vision, and his determination to press forward in the face of political criticism. In other words, there was nothing inevitable about Camp David or the coming of Israeli-Egyptian peace. 


\section{Conclusion:}

\section{"More Missionary Than Politician"}

In 1976, election campaign of President Gerald Ford put together a rather insightful profile of Democratic challenger Jimmy Carter. In a memorandum to President Ford, given to him just prior to the Republican Convention, the campaign staff noted Carter's positives and actual strengths and his negatives and actual weaknesses.'

Among the positives and strengths mentioned were Carter's "religious background," "a man with strong spiritual and moral values," "an honest man of character," "a family man," "religious, ethical, conservative, regular Democrat." "a Democrat, but not an extremist." and "has a conservative lifestyle." Carter"s negatives were itemized as "an arrogant man," "a man who wears his religion on his sleeve," "self-righteous," "lack humility," “a Southerner," "overly ambitious," and "appears to be vindictive, arrogant, egotistical, bullheaded." As such, it was recommended to highlight his perceived "arrogant," "devious" traits and paint him "as one who uses religion for political purposes; an evangelic."

In 1979, Bruce Mazlish and Edwin Diamond wrote: "To ignore or underestimate Jimmy Carter's religious experiences is to forgo any serious understanding of him or his

\footnotetext{
'Martin Schram, Running for President 1976: The Carter Campaign (New York: Stein and Day Publishers, 1977), pp. 256-262.
} 
presidency."2 Unfortunately, however, as noted in chapter 1, Carter's faith and its influence on his politics has often been ignored or only marginally noted in previous studies. Picking up on Mazlish and Diamond's assessment, this study has aimed to fill in part of that important dimension of the thirty-ninth president.

Jimmy Carter was a different kind of president; he had "a different way of governing." ${ }^{3}$ More than being a trustee president or a non-political politician, Carter once claimed he was "more a missionary than a politician."4

Richard Neustadt said, "The Presidency is a place for men of politics." ${ }^{5}$ Unlike his own Vice President, Walter Mondale, Carter did not love or enjoy politics in the way Richard Neustadt and Max Weber recommended. He despised the give-and-take necessities and niceties of politics. He characterized bargaining as if it was a sin. He was contemptuous of Congress, including his fellow Democrats. ${ }^{6}$ He often asserted that he owed the "special interests" nothing. Whether in Atlanta as governor or in Washington as president, political compromise was difficult for him as it was for

\footnotetext{
${ }^{2}$ Bruce Mazlish and Edwin Diamond, Jimmy Carter: A Character Portrait (New York, 1979), 14.

${ }^{3}$ Quoted in Erwin C. Hargrove, Jimmy Carter as President: Leadership and the Politics of the Public' Good (Baton Rouge, LA: Louisiana State University Press, 1988), p. 15; Fred I. Greenstein, The Presidential Difference: Leadership Style from FDR to Clinton (Princeton, NJ: Princeton University Press, 2000), p. 128.

${ }^{4}$ Katie Couric quoting Jimmy Carter in "Interview," NBC's Today, October 8, 2004, http://www.msnbc.msn.com/id/6138962/.

${ }^{5}$ Richard E. Neustadt, Presidential Power and the Modern Presidents: The Politics of Leadership from Roosevelt to Reagan (New York: The Free Press, 1990), p. 152.

${ }^{6}$ Cyrus Vance, "Carter's Foreign Policy: The Source of the Problem," in The Carter Presidency: Fourteen Intimate Perspectives of Jimmy Carter, Portraits of American Presidents, Vol. VIII, edited by Kenneth W. Thompson (Lanham, MD: University Press of America, 1990), p. 139.
} 
William Jennings Bryan and Woodrow Wilson. Thus, many of his particular political successes and failures were more likely the result of the man than the moment.

\section{Evangelical Ambition: A Purpose Driven Life}

The protocol for most presidents prior to Carter was to separate their religion and politics. For them. religion was largely a private affair. It was improper to discuss their personal faith on the campaign trail and it was unthinkable to suggest that it qualified them in any way to be president. However. Carter did not see it this way. Even before his term ended, Mazlish correctly argued at the time that above his many other personal traits, Carter was foremost "a religious figure, and only afterward a political one. ${ }^{.7}$ When I asked Vice President Mondale about this. he explained. "President Carter was. and is. a devout Christian and his faith deeply affected his presidency. ${ }^{.8}$

Presidents, even evangelical-styled presidents, are ambitious politicians. One does not become president without ambition. Carter. like all who seek the presidency. is very ambitious, and he forthrightly proclaimed, "I have been ambitious all my life." Hugh Carter, Carter`s first cousin, explained that not only was he competitive, he did not like to lose period. irrespective if its softball. hunting. fishing, tennis, or politics. ${ }^{10}$

\footnotetext{
'Mazlish. Jimmy Carter: A Character Portrait, p. 264.

${ }^{8}$ Walter Mondale. email correspondence with the author. November 2, 2006: "The Perspective of the Vice President," in The Carter Presidency, p. 240.

${ }^{y}$ Carter. Sharing Good Times (New York: Simon and Schuster. 2004), p. 13.

${ }^{10}$ Hugh Carter and Frances Spatz Leighton, Cousin Beedie and Cousin Hot: My Life with the Carter. Family in Plains, Georgia (Englewood Cliffs, NJ: Prentice-Hall, 1978), p. 176.
} 
Biographer Betty Glad said Carter was "the ultimate politician in practice."11

Jules Witcover described him as "a climber."12 MSNBC's Chris Matthews told Carter,

"You're the most hard working guy I've ever met in my life." ${ }^{3}$ Certainly, anyone

elected president must have extraordinary political ambition and skill. In this respect,

Carter was no different than other presidents. He was competitive, ambitious, and wanted to win. ${ }^{14}$

When facing the prospect of being challenged by Massachusetts Senator Edward Kennedy in 1980, Carter quipped, "I'll whip his ass." As early as 1971, he was

${ }^{11}$ Betty Glad, Jimmy Carter: In Search of the Great White House (New York: W.W. Norton and Company, 1980), p. 18.

12 Jules Witcover, Marathon: The Pursuit of the Presidency, 1972-1976 (New York: Viking Press, 1977), p. 105.

${ }^{13}$ Chris Matthews, "Interview with Jimmy Carter," MSNBC's Hardball with Chris Matthews, December $10,2004$.

${ }^{14}$ James Wooten, Dasher: The Roots and Rising of Jimmy Carter (New York: Warner Books, 1979), pp. 27-28; Robert W. Turner, "I'll Never Lie to You": Jimmy Carter in His Own Words (New York:

Ballantine Books, 1976), pp. 6-7. Carter was famous for making quips about what his opponents can do and what he would do to them. He especially had a tendency to challenge Edward Kennedy. In 1976, he said he did not have to rely on Kennedy's help to win. "I don't have to kiss his ass." Turner. "I'll Never Lie to You": Jimmy Carter in His Own Words, p. 57.

${ }^{15}$ Hamilton Jordan, Crisis: The Last Year of the Carter Presidency (New York: G.P. Putnam's Sons, 1982), p. 20; Jack W. Germond and Jules Witcover, Blue Smoke and Mirrors: How Reagan Won and Why Carter Lost the Election of 1980 (New York: Viking Press, 1981), p. 52; Richard E. Burke with William and Marilyn Hoffer, The Senator: My Ten Years with Ted Kennedy (New York: St. Martin's Press, 1992), p. 195; Burton Hersh, The Shadow President: Ted Kennedy in Opposition (South Royalton, VT: Steerforth Press, I997), p. 24; Adam Clymer, Edward M. Kennedy: A Biography (New York: HarperCollins, 1999), p. 280. Even years after, Carter admitted that he was still bitter about Kennedy's challenge. "We didn't feel, and I still don't feel, that Ted Kennedy had any reason to challenge me as an incumbent Democratic President and therefore destroy the unity of the party." He also said that he not only expected, but also hoped, that Senator Kennedy would never receive the Democratic presidential nomination. "Interview with Mike Wallace on CBS's 60 Minutes," March 24, 1985, in Conversations with Carter, edited by Don Richardson (Boulder, CO: Lynne Rienner Publishers, 1998), p. 264. In 1991, he said that Kennedy made his last year in office "pure hell." Carter also blamed him for inaccurately associating the word "malaise" with his administration "and then Reagan adopted the same concept" to use against him in the fall campaign. "Interview with the Academy of Achievement in Atlanta, Georgia," October 25, 1991, http:/www.achievement.org. Carter staffers shared their boss' contempt for Kennedy. Press secretary Jody Powell accused the media of being biased toward Kennedy. "Compared to Carter," he wrote, [Kennedy] was always treated like the second coming, particularly by the networks." Powell, 
considering "a nationwide race," and by 1972, privately he had "decided to run for the presidency."16 Political defeat, as in 1966 and 1980, too, was taken hard. ${ }^{17}$ His competitiveness at times led to charges that he had a "mean" streak and to his use of what his Chief of Staff. Hamilton Jordan, and media advisor, Gerald Rafshoon. called "the old Carter hyperbole," his "tendency toward overstatement."18 He believed. too. that he was smarter and more upright than most politicians, including most congressional Democrats. ${ }^{19}$ Particularly disturbing to Carter were candidates who believed they were entitled to occupy the Oval Office. Obviously, he felt that way about Kennedy. He said that, because of the Kennedy family, he was running not merely against the senator, but " a myth of perfection" and the seeming political invincibility of that clan. ${ }^{20}$ As one Kennedy biographer explained. Carter " plainly

The Other Side of the Story (New York: William Morrow and Company, I984), 201. Jordan wrote. "I deeply resented Ted Kennedy and his millions." Jordan. Crisis: The Last Year of the Carter Presidency. p. 354.

${ }^{16}$ Carter, "Interview with Charles O. Jones, H. Clifton McCleskey. Kenneth W. Thompson. James Sterling Young, Richard Neustadt, David B. Truman, Richard F. Fenno, Jr., and Edwin C. Hargrove." Carter Presidency Project, November 29, 1982. Plains, Georgia, The Miller Center for Public Affairs. http: www millercenter.virginia.edu index.php scripps digitalarchive/oralhistories detail 3260: "Question-and-Answer Session with Florida Newspaper Editors in Tampa, Florida," August 30. I979. Public Papers of the Presidents, Jimmy Carter. 1979, Book II (Washington. DC: United States Government Printing Office. 1980), p. 1582.

${ }^{17}$ See Jimmy and Rosalynn Carter. Evervthing to Gain: Making the Most of the Rest of Your Life (Fayetteville, AR: The University of Arkansas Press. 1995: Originally published in 1987), pp. 1-28: Virtues of Aging (New York: The Ballantine Publishing Group, 1998), pp. 3-4; Jordan, Crisis: The Last Year of the Carter Presidency. pp. 24, 371. Jordan recalled that after his loss in 1966. Carter "packed up his family" and left Atlanta immediately for Plains without thanking his campaign workers."

${ }^{18}$ Jordan. Crisis: The Last Year of the Carter Presidency, pp. 343-344, 350-351: Germond and Witcover. "War. Peace. and Meanness," chap. in Blue Smoke and .Mirrors. pp. 243-266.

${ }^{19}$ Douglas Brinkley, The Unfinished Presidency: Jimm. Carter's Joumey to the Nobel Peace Prize (New York: Penguin Books, 1999), p. 6.

20 Jordan, Crisis: The Last Year of the Carter Presidency, p. 58; Hersh. The Shadow President. p. 27: Clymer, Edward M. Kennedy. p. 278. When his faith was questioned by Rev. Jerry Falwell. founder of the Moral Majority, Carter flatly said. he can "go to hell." "I don't let Jerry Falwell or anyone else define 
regarded Kennedy as a fat rich kid too accustomed to getting his way." ${ }^{21}$ Carter no doubt had his personal faults. Those closest to him admitted that. He admitted that. But politics and merely doing the political thing was rarely Carter's overriding concern.

For Carter, politics was not fundamentally about the efficient and equitable distribution of goods and services. It was not about finding common ground among various politicians and interests and more than trusteeship and the public good. Politics was about fighting for and taking political risks on issues he considered right and moral. Carter wanted to win elections so he could do some good, so he could do what he saw as the Lord's work. He had evangelical ambition; he possessed what evangelical author Rick Warren called "the purpose-driven life.",22

Though he certainly aimed to make government better, Carter understood politics as a means to a purposeful, moral end. Politics is fundamentally about Christian service, love, and honesty; a form of ministry, a legitimate avenue to put his faith in action. ${ }^{23}$ As entitled one of his books, religion for Carter is a "living faith." As Glad recognized, "Carter said he saw his role in politics as an implementation of his religious beliefs_-doing what he believed was right to fulfill human needs." ${ }^{24}$ Whether in Plains.

for me what is a Christian." "Carter tells Falwell where to go for questioning his faith," Atlanta JournalConstitution, September 12, I986, A I. On another occasion, he described Vice President George H.W. Bush as "effeminate" and "silly." Quoted in Brinkley, The Unfinished Presidency, p. 249.

${ }^{21}$ Clymer, Edward M. Kennedy, p. 313.

${ }^{22}$ Rick Warren, The Purpose-Driven Life: What on Earth Am I Here For? (Grand Rapids, MI: Zondervan Publishing House, 2002).

${ }^{23}$ Bill Clinton also described Carter's life work as "ministry," too. Clinton, "Remarks on Presenting the Presidential Medal of Freedom to Former President Jimmy Carter and Rosalynn Carter in Atlanta, Georgia," Weekly Compilation of Presidential Documents, August I6, 1999, transcript from http://www findarticles.com (accessed May 21, 2006).

${ }^{24}$ Glad, Jimmy Carter: In Search of the Great White House, p. 111. 
Atlanta. or Washington, whether as governor, president, or ex-president, James Wall wrote. "serving God has driven Jimmy Carter's career." "25 "For Carter." Steve Gillon explained. "'the people' were his flock and he was the shepherd. ${ }^{-26}$ That is what made political compromise and bargaining difficult for him. That is what made it difficult for him to do the politically right thing than the morally right thing.

Carter understood political persuasion not as a means to reach a bargain. but more as religious conversion: tell the truth, study and present the facts. and others will listen and hopefully follow. ${ }^{27}$ And that is where difficulties emerged between this Democratic President and the Democratic Congress. As one writer explained. "Congress isn"t persuaded that way, and President Carter found it difficult to exchange the posture of a church leader for that of a political persuader. .28

When advised to take the more politically sound approach. he often bristled at the suggestion and ignored it. even if it came from his wife. ${ }^{29}$ He had a different conception of politics and political responsibility. Carter did love politics, but as a form or expression of Christian love. Again. for Carter. politics is Christian service.

Government needed not only to be efficient and effective. it needed to be good and

\footnotetext{
25 James M. Wall. "Doing the Best We Can: The Example of Jimmy Carter." Christian Century: April 9. 1997. transcript from http: Www. findarticles.con (accessed May 21. 2006).

2t Steve M. Gillon. The Democrats Dilemma: Walter F. Mondale and the Liberal Legacy (New York: Columbia University Press. 1992). p. 170

2- Terence Smith. "Winning Trust Was Carter's Principal Aim. and He Did It." New York Times. March 18. 1979.

Is John C. McCollister. God and the Oval Office: The Religious Faith of Our +3 Presidents (Nashville. TN: W Publishing Group. 2005), p. 208.

29 Rosalynn Carter. "The Perspective of the First Lady," in The Carter Presidency, pp. 230-231.
} 
rooted in love. He told Mark Updegrove that what he wanted to be remembered for was not presidential greatness, but "being a good Christian and a champion for peace and human rights. $" 30$

This is what distinguishes him from most other presidents. While he recognized he was morally flawed, he took comfort in the belief that God could still use him to do great things.

I'm glad that the Bible does not tell us just about mighty warriors or great prophets or wise leaders. It also tells us about sinful men and women, men like the Disciples - sometimes stubborn, reluctant, selfish, weak, struggling with their own fears and failures and lack of faith. Yet with God's help, they were able to do great things... I am thankful that God has always done his work through imperfect human beings. ${ }^{31}$

In the case of the Middle East, while other considerations mattered, Carter fundamentally believed that achieving peace in the Middle East was doing good and pleasing to God. Given the importance of the Middle East, especially the Israeli-Arab dimension, this region would be important for any American president. The risk of a region-wide war that could draw in the two superpowers, the threat of greater Soviet influence, and Western dependence on Mideast oil were all weighty matters for presidents. $^{32}$ "Peace in the Middle East is of vital interest to us all." "33 But for Carter, there was something more to protecting U.S. interests in the region.

\footnotetext{
${ }^{30}$ Mark K. Updegrove, "Jimmy Carter: Peacemaker," chapter in Second Acts: Presidential Lives and Legacies After the White House (Guilford, CT: The Lyons Press, 2006), p. 177.

${ }^{31}$ Carter, "Remarks at the Annual Convention of the National Religious Broadcasters," January 21, 1980, Public Papers of the Presidents, Book I, p. 181.

32 Carter, "Remarks and Question-and-Answer Session at a Town Meeting in Clinton, Massachusetts," March 16, 1977, in Public Papers of the Presidents, Book I, p. 387.
} 
Politically, he knew working for peace. seeking fairness had consequences. He knew it could be frustrating, divisive, and deeply emotional work. His wife Rosalynn recalled that her husband's key advisors cautioned him not to become intimately involved in Middle East peacemaking and "none of them thought he had much chance of success. ${ }^{.3+}$ Carter was warned, she continued, to "stay aloof as possible from direct involvement in the Middle East negotiations; it's a losing proposition." ${ }^{35}$ Carter also realized that he risked offending American Jews, a key Democratic constituency, if he pressed Israel too hard, asked it to give up too much, or gave any sort of credence to the Palestinian cause. Carter knew already that his Southern-ness and his evangelicalism had made some constituencies leery of him during the 1976 campaign. Despite the risks. he believed that if peace was to be secured he had to be fair, he had to earn "the trust of all sides," and "maintain good relations with the Arab countries as well as Israel. $" 36$

In this project. like Bryan and Wilson, it is argued that Carter was not just a religious president, but more precisely a president with an evangelical leadership style. For this subclass of political leaders, they believed that the ultimate judge of their

\footnotetext{
3 Carter, "Remarks to the American Chamber of Commerce in Tokyo, Japan." May 28, 1975. The Presidential Campaign 1976: Jimmy. Carter (Washington. DC: United States Government Printing Office, 1978), p. 69.

${ }^{34}$ Rosalynn Carter, First Lady from Plains (New York: Ballantine Books. 1984), p. 227.

${ }^{35}$ Carter, "Interview with Larry King," CNN's Larry King Live, November 27, 2006.

${ }^{36}$ Carter, "Remarks to the American Chamber of Commerce in Tokyo, Japan," May 28, 1975. The Presidential Campaign 1976: Jimmy Carter. p. 69.
} 
political performance are not the voters or even scholars. As Mazlish explained,

"Jimmy Carter appeals to a different sort of judge: God."

Employing Fred Greenstein's categories of presidential leadership, Carter's faith could be evinced in several ways.

\section{Carter as Evangelical Communicator}

Carter's faith provided him a language with which to articulate several of his policies, again, most notably, but not exclusively, his policy and hope for Middle East peace. While he was certainly not the best presidential orator, Carter was, said Gaddis Smith, "a talking president; he spoke on an extraordinary number of occasions," frequent news conferences, question-and-answer sessions with media, call-in shows, and townhall meetings. ${ }^{38}$ In his own way, like Bryan and Wilson, Carter tried to evangelize, bring his message directly to the people. In fact, Smith believed, if Carter's rhetoric is compared with other presidents, it would be most reminiscent of Woodrow Wilson. ${ }^{39}$ He was particularly at his best before small audiences, more intimate, personal situations, and his rhetoric commonly drew upon his personal life stories. Smith explained, "There is a very personal quality to his rhetoric, a constant reference back to his own life and his own experience." ${ }^{40}$ Even in his post-presidency, Carter

\footnotetext{
${ }^{37}$ Mazlish, Jimmy Carter: A Character Portrait, p. 264.

${ }^{38}$ Gaddis Smith, "Carter's Political Rhetoric,"in The Carter Presidency: Fourteen Intimate Perspectives of Jimmy Carter, Portraits of American Presidents, Vol. VIII, edited by Kenneth W. Thompson (Lanham, MD: University Press of America, 1990), p. 202.

${ }^{39}$ Ibid., p. 203.

${ }^{40}$ Ibid.
} 
continued to speak of the country's "moral hunger." its desire for "a corrective of absolute truth." and that "the morality issue" remained "a matter of transcendental importance. ${ }^{.+1}$

\section{Evangelical Mission and Political Vision}

Carter also had an evangelical sense of mission: it inspired his political vision at home and abroad. especially toward the Middle East. He had. said Edwin Diamond. "a moral vision of Sunday School homilies." +2

Ross Baker suspected that Carter would not pursue Middle East peace immediately in his term. He wrote. "it is unlikely that Carter would seek to press it on the Israelis so soon after his election and so soon before" the Israelis' 1977 election. He believed that Carter would prudently "want to make gestures of friendship to reassure the Israelis." In any case. Baker thought the prospects of a peace agreement were not particularly good. The Israelis were "wary" and the Egyptian President Sadat "footloose." ${ }^{.+3}$ However, as Yitzhak Rabin explained. "Jimmy Carter entered the White House and decided to speed up the diplomatic process in Middle East. despite the pending Israeli vote on its national leadership“ that May. ${ }^{4+}$ In Rabin`s words, Carter

\footnotetext{
41 ."Joseph F. Sullivan, "Carter Says 'Moral Hunger" is Key to '88 Race," Vew York Times. November 22. 1987: Steve Harvey. ". South is wide open for... a candidate who tells them the truth. "Carter says." Atlanta Joumal-Constitution. October 5. 1987. A2.

42 Diamond. Jimm. Carter: A Character Portrait, p. 267.

${ }^{43}$ Ross K. Baker. "The Outlook for the Carter Administration." in The Election of 19-6: Reports and Interpretations, edited by Marlene M. Pomper (New York: David McKay Company. Inc.. 1977). pp. 133134.

${ }^{4}$ Yitzhak Rabin. The Rabin Memoirs (Reprint and Expanded version of $2^{\text {nd }}$ edition: Berkeley. CA: University of California Press. 1996). p. 292.
} 
told him in their March 1977 meeting that "I have undertaken the difficult task of bringing a permanent peace to your region. ${ }^{, 45}$ Carter's vision for the region, a comprehensive peace, "was an ambitious goal, to say the least," added Rabin. ${ }^{46}$

Contrary to Menachem Begin's claim, Rabin said his meeting with Carter was not "the harshest discussion any Israeli prime minister has ever had with an American president." "That is," he said, "clearly an exaggeration." While he was not pleased with Carter's willingness to include the PLO in future negotiations, thoughts on the possibility of some form of Palestinian statehood, support for Israel to surrender most of the territory acquired during the 1967 war, and his subsequent public comments on these matters, Rabin pointedly said that Carter "expressed the most favorable views on the nature of peace that we had ever heard, and I don't think that point should be overlooked." Unlike his predecessors, Nixon and Ford, it was clear from the start, said Rabin, Carter was personally in charge of the American Mideast peace effort. He did not delegate the responsibility to others. He was "eager to take an active role in the preparatory work through direct contact with leaders visiting Washington." Carter brought a "personal approach" to the peace process previous administrations lacked. ${ }^{47}$

Working for peace in the Middle East, namely between Israel and her immediate Arab neighbors, has long been a political priority for Carter. As he explained to George Stephanopoulos in February 2007, "If I have had one burning desire in my heart and mind for the last thirty years, I would put peace for Israel at the top of the list. And

\footnotetext{
${ }^{45}$ Ibid., p. 298.

${ }^{46}$ Ibid., p. 316.

${ }^{47}$ Ibid.
} 
commensurate with that has to be justice and human rights for the Palestinians next door. $"+8$

To criticisms of being too pro-Arab and charges of anti-Semitism. Carter can. justifiably, be defensive. When asked in November 2006 what he thought of Democrats who distanced themselves from his controversial book. Palestine: Peace. Not Apartheid, he fired off. "I was the one who negotiated a peace agreement between Israel and Egypt...I don ${ }^{`} t$ have to explain my credentials in terms of bringing peace to Israel. ${ }^{.49}$ Carter insisted that his peace efforts were ultimately in Israel's best interests. He said his efforts were noble and came deep from within. As many other evangelicals say. Carter said. "My support for Israel is proven and deeply ingrained in my own soul." When asked what he meant that his support for Israel is "ingrained in your soul." he answered as he had throughout his public life. in typical evangelical fashion, that it comes from his understanding and teaching of the Bible.

I've been teaching the Bible since I was 18 years old. and half of each year I teach in the Jewish scriptures. in what we call the Old Testament. The other half of the year I teach in the New Testament. and for the last three months. 1 ve been teaching about God's covenants, with Noah, with Abraham, with Moses. and then with Joshua. and then in the times with the judges, and then going into King David, and Saul and Solomon and so forth... So I've been teaching the Bible and my belief is that God ordained that the Jews should have a homeland there.

\footnotetext{
${ }^{48}$ Carter. "Interview with George Stephanopoulos." ABC's This Week with George Stephanopoulos, February 25, 2007.

${ }^{49}$ Carter. "Interview with Jennifer Siegel." Jewish Daily. Forward. November 16. 2006. http: www forward com articles carter-discusses-new-book-on-Israel-and-the-middle.
} 
Though Carter said he "underwent a trial by fire in conflict mediation" at Camp David. he believed it was ultimately worth it. ${ }^{50}$

\section{Evangelical Personalism and Political Skill}

On the campaign trail in 1976 , to win support in Iowa, Democratic Party state chair Tom Whitney recalled how Carter approached him. "We spent two hours talking about Christ" and agreed that society would be served if "love-love thy neighbor" was more evident. "We explored the 'I Am Third' process in which God is first, family and friends second, and I am third. This nation needs a totally loving President." ${ }^{51}$ Later as president, this evangelical personal style provided him a means to identify and bond with certain foreign leaders, particularly Egyptian President Anwar Sadat. While all leaders did not respond positively to this approach, it did contribute to his success at Camp David in 1978 and getting the Egyptian-Israeli peace treaty signed in 1979.

\section{Evangelical Calmness and Emotional Intelligence}

As president, Carter's faith grounded him emotionally. Through prayer, he said, "I try to base my difficult decisions on the proper understanding of God's will." A2 As he titled yet another work, it provided him a "source of strength" as a private citizen and as a president. Though his defeat in 1980 was tough on him and his wife Rosalynn, he

\footnotetext{
${ }^{50}$ Carter, "Introduction," to Marion V. Creekmore, Jr., A Moment of Crisis: Jimmy Carter, The Power of a Peacemaker, and North Korea's Nuclear Ambitions (New York: Public Affairs Books, 2006), p. xxiii.

${ }^{51}$ Schram, Running for President 1976: The Carter Campaign, p. 10.

52 Carter, "Interview with Kim Watson of the Baptist Home Mission," 1976, in Jessyca Russell Gaver, The Faith of Jimmy Carter (New York: Manor Books, 1977), p. 40.
} 
thought his time in office was a positive one and he once again took solace in faith. "God has been good to me.".

\section{The Legacy Carter Desired}

"We told the truth and we obeyed the law and we kept the peace... Ours was an honest administration. $"$ "5t

\section{---Walter Mondale}

Before the 1976 election. Jimmy Carter was asked, "Mr. Carter, when your life is over, for what do you want to be remembered?" He said, I would like to have my frequent prayer answered that God let my life be meaningful in the enhancement of His Kingdom and that my life might be meaningful in the enhancement of the lives of my fellow human beings. "55 Politics, Carter believed, was one means to accomplish this, to "translate the natural love that exists in this world and do simply justice through government." He reiterated these points in a 1985 interview. When asked, "What taught you the most about succeeding in life," as a former president replied the same as he did as a presidential candidate. He said, "One of the things that shaped my life was realizing that I have one life to live on this earth. and I ask God frequently not to let me waste it and to let my life be beneficial for my fellow human beings in His kingdom. ${ }^{-56}$ "If there ever is any conflict between political benefit and his duties as a Christian," he explained, "then the matter should only be resolved. obviously. by doing what is right in

\footnotetext{
53 Carter. "Remarks on the Outcome of the 1980 Election." November 4. 1980. Public Papers of the Presidents, Book III, p. 2687.

${ }^{54}$ Walter Mondale, "Interview with Wolf Blitzer," CNN's The Situation Room, January 19, 2007.

¿5arter, "Interview with World Religious New's," 1976, The Faith of Jimm. Carter, p. 23.

5o Carter. "Interview with Leaders Magazine," April 1985. in Comersations with Carter. p. 267.
} 
the eyes of God." 57 This is the solemn duty of the Christian politician and president. to focus on "the long-range benefits" that would inevitably come "if God's will was done." To do the purely political thing, the politically wise thing, the benefits would be "short-range political benefits" and of "relative insignificance."

As president, without apology, Jimmy Carter often embarked on initiatives he considered right not politically expedient. ${ }^{58}$ "I would rather be right...even if it does cost me something politically." 59 He made it clear that as president he would not duck or hide, but tackle issues that may be politically best to avoid, such as energy or Middle East peace. ${ }^{60}$ Though charged with malaise-speak, he said he would tell the American people "the truth, the hard truth, the truth that sometimes hurts" about the limits of American power, resources, and ability to solve all problems. There would be no candy-coated, "make-believe world" that required "no hard choices, no sacrifice, no tough decisions" with Carter. ${ }^{61}$ For him, this was "the path of fantasy."

In this regard, he was not an ambitious politician or a politician who made protecting his reputation and prestige a priority as Richard Neustadt admonished, much

\footnotetext{
${ }^{57}$ Carter, "Interview with Kim Watson of the Baptist Home Mission," 1976, in The Faith of Jimmy. Carter, p. 41.

${ }^{58}$ Carter, "The President's News Conference," July 25, 1979, Public Papers of the Presidents, Book II, p. 1304; "Remarks and a Question-and-Answer Session at a Town Meeting in Bardstown, Kentucky," July 31, 1979, Public Papers of the Presidents, Book II, p. 1349.

${ }^{59}$ Carter, "Remarks and a Question-and-Answer Session at a Town Meeting in Bardstown, Kentucky," July 3 I, 1979, Public Papers of the Presidents, Book II, pp. 1349-1350.

${ }^{60}$ Carter, "Remarks at a Carter/Mondale Campaign Rally in Columbus, Ohio," May 29, 1980, Public Papers of the Presidents, Book II, p. 995; "Acceptance Speech at the Democratic National Convention in New York City," August 14, 1980, Public Papers of the Presidents, Book II, p. I 538.

${ }^{61}$ Carter, "Acceptance Speech at the Democratic National Convention in New York City," August 14, 1980, Public Papers of the Presidents, Book II, p. 1534.
} 
to the ire and dumbfounding of his fellow Democrats. Rather, Carter was an idealist inspired and guided by religious principles and Biblical commands who believed that the government of the United States could show love and compassion, work for peace, and be good and decent at home and abroad. ${ }^{62}$ Rhetorically, he was a lay prophet who preferred to call his country to repentance and embrace a "new spirit" of compassion. honesty, and love than a civic priest who nurtured feelings of greatness, crusading messianism, and American exceptionalism. He acted like, as German Chancellor Helmut Schmidt described, an evangelist who formulated "policy from the pulpit." was Carter's hope, his prayer, that his presidential years would be remembered as time when Americans lived up to the vision expressed in Isaiah 61:

We brought good tidings to the afflicted, proclaimed liberty to captives and comfort to all who mourn, that we repaired the ruined cities and the desolations of many generations, and that through us the Lord God will cause righteousness and praise to spring forth before all the nations. ${ }^{64}$

This was precisely the mark he hoped to leave behind, the legacy of a Carter presidency.

President Carter was no commander of armies in battle; he was the only elected president since Herbert Hoover not to have been at some point in his term a "full-time" war president. ${ }^{65}$ He said a president "can't be a war president one day and claim to be a

\footnotetext{
${ }^{62}$ Niels C. Nielsen, Jr., The Religion of President Carter (Nashville, TN: Thomas Nelson Publishers. 1977), 101-103.

${ }^{63}$ Steve V. Roberts, "Analysts Give Carter Higher Marks in Foreign Affairs Than in Domestic Policy," New York Times, January I9, 1981

${ }^{64}$ Carter, "Remarks at Emory University, Atlanta, Georgia," August 30, 1979. Public Pupers of the Presidents, Book $I I$, p. I565.

${ }^{65}$ Gerald Astor, Presidents at War: From Truman to Bush. The Gathering of Military Power to Our Commanders in Chief (Hoboken, NJ: John Wiley and Sons, 2006), p. 4.
} 
peace president the next." ${ }^{, 66}$ Instead, he would make the conscious and deliberate choice to be a full-time peace president.

Carter believed that his "proudest" and "greatest achievement" as president was the absence of war during his term. "I think my proudest achievement is having kept our Nation at peace, because it's a temptation, when there is a troubled area in the world, to want to stick American military forces in there to try to resolve it. I've not had to do that, and I believe that this is the most important, single thing that I've done." ${ }^{67}$ In agreement, wrote Jim Wright, Carter was "at heart a peacemaker in a world that glorifies war makers. ${ }^{.68}$

Some presidents were first in war; Jimmy Carter strove to be first in peace. He strove to serve his God.

\footnotetext{
${ }^{66}$ Carter, "Remarks at the 2004 Democratic National Convention in Boston, Massachusetts," July 26. 2004, http://www.cartercenter.org.

${ }^{67}$ See Carter, "Remarks and Question-and-Answer Session with Residents in Gloucester City, New Jersey," October 24, 1980, Public Papers of the Presidents, Book III, p. 2435; "Remarks and Questionand-Answer Session with High School Students in Wyoming, Michigan," October 24, 1980, Public Papers of the Presidents, Book III, p. 2449.

${ }^{68} \mathrm{Jim}$ Wright, Balance of Power: Presidents and Congress from the Era of Mc Carthy to the Age of Gingrich (Atlanta, GA: Turner Publishing, 1996), p. 280.
} 


\section{BIBLIOGRAPHY}

\section{Primary Sources}

Books and Book Forewords by. Jimmy Carter

Why .'ot the Best? New York: Bantam Books. 1976. Originally Published in 1975.

t Government As Good As Its People. Fayetteville. AR: The University of Arkansas Press. 1996. Originally Published in 1977.

Keeping Faith: Memoirs of a President. Fayetteville. AR: University of Arkansas Press. 1995. Originally Published in 1982.

"Foreword: A Personal Tribute to Anwar Sadat." In Anwar el-Sadat. Those I Have Known, pp. vii-viii. New York: Continuum Publishing Company. 1984.

legotiation: The Alternative to Hostility. The Carl Vinson Memorial Lecture Series Inaugural Lecture. Macon. GA: Mercer University Press. 1984: paperback edition 2003.

"Preface." To Robert F. Drinan, S.J.. God and Caesar on the Potomac: A Pilgrimage of Conscience, pp. ix-x. Wilmington. DE: Michael Glazier, 1985.

The Blood of Abraham: Insights into the Middle East. Fayetteville. AR: University of Arkansas Press. 1993. Originally Published in 1985.

Everything to Gain: Making the Most of the Rest of Your Life. With Rosalynn Carter. Fayetteville, AR: University of Arkansas Press. 1995. Originally Published in 1987.

Turning Point: A Candidate, a State, and a Nation Come of Age. New York: Times Books. 1992.

Talking Peace: A I'ision for the Vext Generation. New York: Puffin Books. 1995. Originally Published in 1993.

"Foreword." In Douglas Johnston and Cynthia Sampson, eds., Religion, The Missing Dimension of Statecraft, pp. vii-viii. New York: Oxford University Press. 1994.

Always a Reckoning and Other Poems. New York: Times Books, 1995.

Living Faith. New York: Random House, 1998. Originally Published in 1996. 
Sources of Strength: Meditations on Scripture for a Living Faith. New York: Three Rivers Press, 1997.

The Virtues of Aging. New York: The Ballantine Publishing Group, 1998.

An Hour Before Daylight: Memories of Rural Boyhood. New York: Simon and Schuster, 2001.

Christmas in Plains. New York: Simon and Schuster, 2001.

"Tribute." In Billy Graham: A Tribute from Friends, compiled by Vernon McLellan. Colorado Springs, CO: Warner Books, 2002, p. 33.

The Nobel Peace Prize Lecture. New York: Simon and Schuster, 2002.

"Foreword." In Anthony Dunbar, ed., Where We Stand: Voices of Southern Dissent, pp. 9-11. Montgomery, AL: New South Books, 2004.

Sharing Good Times. New York: Simon and Schuster, 2004.

Our Endangered Values: America's Moral Crisis. New York: Simon and Schuster, 2005.

"Introduction." To Marion V. Creekmore, Jr., A Moment of Crisis: Jimmy Carter, The Power of a Peacemaker, and North Korea's Nuclear Ambitions. New York:

Public Affairs Books, 2006, xxi-xxvi.

Palestine: Peace Not Apartheid. New York: Simon and Schuster, 2006.

Articles and Opinion Editorials by Jimmy Carter

(Most Found at http://www.cartercenter.org)

"Middle East: Time for Negotiations," Time, April 20, 1987.

"Middle East Peace: New Opportunities," Washington Quarterly, 10.3, June 1, 1987.

"Rushdie's Book is an Insult," New York Times, March 5, 1989.

"Universities Can Be of Greatest Benefit by Concentrating on the Third World," Chronicle of Higher Education, June 7, 1989.

"The Need to Negotiate," Time, October 22, 1990.

"First Steps Toward Peace," Newsweek, December 17, 1990. 
"Needed: Middle East Peace Talks." New York Times. January 2. 1991.

"Don't Reject a Cease-Fire." Time. February 25, 1991.

“Let 'Motor Voter’ Pick Up Lost Souls.” Los Angeles Times, June 18. 1992.

"U.S. Finally Ratifies Human Rights Covenant." Christian Science Monitor. June 29. 1992.

"USA Can "t Point Finger at Others on Human Rights." USA Today, December 10, 1992. With Dominique de Menil.

"Peace is Everyone’s Job." New York Times, May 21, 1995.

"From Politics to Poetics." The Carter Center. July 2. 1995.

"It's Time to Forgive Pete Rose." USA Today, October 30. 1995.

"Regaining Our Trust in Justice." Atlanta Journal-Constitution. November 20, 1995.

"Can Peace Still Come to Israel?" Atlanta Journal-Constitution. December 12. 1995.

"Judge Not: Leaders of the Christian Right Have Injected into America"s Political

Debate Some Divisive Religious Questions." Atlanta Journal-Constitution. February 27, 1996.

"Prayer and the Civic Religion." New York Times, December 24, 1996.

"It's Wrong to Demonize China." New York Times. August 10. 1997.

"A Time to Heal Our Nation." New York Times, December 22. 1998. With Gerald Ford.

"Have We Forgotten the Path to Peace?" New York Times. May 27. 1999.

"A Jerusalem Settlement Everyone Can Live With." New York Times. August 6. 2000.

"For Israel. Land or Peace." Washington Post, November 26. 2000.

"Peru Can Give U.S. Lessons on How to Hold Elections." Atlanta Journal-Constitution. April 22, 2001.

"Precedents for Mideast Peace." New York Times. December 23, 2001.

“American Can Persuade Israel to Make a Just Peace." New York Times. April 21. 2002. 
“Mideast Needs New Mediator." USA Today, July 1, 2002.

"The Troubling New Face of America." Washington Post, September 5, 2002.

“Just War-or a Just War?” New York Times, March 9, 2003.

"The Choice for Israelis." Washington Post, September 23, 2003.

"Middle East Accord Offers 'Best' Chance for Peace." USA Today, November 3, 2003.

"Inequitable Resources, Benefits Put World at Risk." USA Today, February 16, 2004.

"The Seeds of a Rights Scandal in Iraq." Washington Post, May 14, 2004.

"Still Seeking a Fair Florida Vote." Washington Post, September 27, 2004.

"U.S. Should Join the World in Halting Juvenile Executions." USA Today, October 13, 2004.

"Casting a Vote for Peace." New York Times, November 12, 2004.

"Arctic Folly." Washington Post, September 13, 2005.

"Don't Punish the Palestinians." Washington Post, February 20, 2006.

"Colonization of Palestine Precludes Peace." Ha'aretz, March 13, 2006.

"Punishing Innocent Palestinians is a Crime." International Herald Tribune, May 7, 2006.

"Israel's New Plan: A Land Grab." USA Today, May 16, 2006.

"Torture is a Moral Issue." New York Times, June 13, 2006. Signatory to Advertisement Sponsored by the National Religious Campaign Against Torture.

"We Need Fewer Secrets." Washington Post, July 3, 2006.

"Stop the Band-Aid Treatment: We Need Policies for a Real, Lasting Middle East Peace." Washington Post, August 1, 2006.

"Solving the Korean Stalemate, One Step at a Time." New York Times, October 11, 2006.

"How I See Palestine." Los Angeles Times, December 8, 2006. 
"Letter to Jewish Community on Palestine: Peace Not Apartheid." December 15, 2006.

"Let’s Bridge the Rich-Poor Gap." January 10. 2007.

“A New Chance for Peace?" Washington Post. January 18, 2007.

Interview's and Press Conferences by Jimmy Carter

Pre-Presidential Interview's and Press Conferences

"Interview with Kim Watson of the Baptist Home Mission," April 1974. In Jessyca Russell Gaver, The Faith of Jimmy Carter. New York: Manor Books. 1977. pp. $38-41$.

"Remarks at a News Conference in Little Rock, Arkansas," April 11. 1975. In A Government As Good As Its People, pp. 43-45.

"Interview with John Hart of NBC News." March 28. 1976. In Wesley Pippert. The Spiritual Journey of Jimmy Carter: In His Own Words. New York: Macmillan Publishing Company, 1978, pp. 43-44. 100-101.

"Response to a Question asked by Cal Thomas of KPRC-TV News in Houston. Texas." April 20. 1976. In Pippert. The Spiritual Journey of Jimmy Carter. pp. 117-118.

"Interview with Bill Moyers of the Public Broadcasting Service." May 6. 1976, in Conversations with Carter, edited by Don Richardson. Boulder, CO: Lynne Rienner Publishers, 1998, pp. 9-17; The Presidential Campaign 19'6: Jimmy' Carter. Washington. DC: United States Government Printing Office. 1978. pp. 163-182.

"Interview with John Mashek of U.S. News \& World Report." May 24. 1976. In The Presidential Campaign 1976: Jimmy Carter, pp. 199-205.

"Interview with Wesley Pippert in Plains. Georgia," July 9. 1976. In Pippert. The Spiritual Journey of Jimmy Carter. pp. 39-40.

"Interview with U.S. New's \& World Report." July 15. 1976. published as "In His Own Words: How Carter Decided on Mondale," July 26. 1976. p. 23.

"Interview with Editors of Hearst Newspapers in New York City." July 22. 1976. In The Presidential Campaign 1976: Jimmy Carter. pp. 427-445.

"Interview with Editors of Time Magazine." August 2. 1976. In The Presidential Campaign 1976: Jimmy Carter, pp. 445-448. 
"Interview with Harry Reasoner of $A B C$ News in Plains, Georgia," August 2. 1976. In Pippert, The Spiritual Journey of Jimmy Carter, p. 76.

"Interview with Editors and Reporters of the Washington Star," August 5, 1976. In The Presidential Campaign 1976: Jimmy Carter, pp. 448-452.

"Interview with Jim Castelli of the National Catholic News Service," August 9, 1976. In The Presidential Campaign 1976: Jimmy Carter, pp. 453-461.

"Interview with Congressional Quarterly," August 24, 1976. In The Presidential Campaign 1976: Jimmy Carter, pp. 548-555.

"Interview with Ralph Blodgett of Liberty magazine," September-October 1976. In Pippert, The Spiritual Journey of Jimmy Carter, pp. 56-57, 115.

"Interview with the Editors of U.S. News \& World Report," September 13, 1976. In Conversations with Carter, pp. 19-31.

"Interview with the National Religious Broadcasters in Indianapolis, Indiana," October 14, 1976. In Pippert, The Spiritual Journey of Jimmy Carter, pp. 40, 92, 116.

"Interview with Robert Scheer," Playboy, November 1976, pp. 63-86.

"Transcript of News Conference Held by President-Elect Carter in Plains, Georgia." New York Times, November 5, 1976, Al4.

"Interview with Jim Newton, editor of the World Mission Journal," 1976. In Jessyca Russell Gaver, The Faith of Jimmy Carter, pp. 24-27.

"Interview with Pat Robertson on the $700 \mathrm{Club}$ taped during the 1976 Presidential Campaign.” In Pippert, The Spiritual Journey of Jimmy Carter, pp. 41-42. 57-59, 106-107.

"Interview with World Religious News," 1976. In Jessyca Russell Gaver, The Faith of Jimmy Carter, pp. 14-24.

"Interview with Murray Gart, Hugh Sidey, Stanley Cloud, and Bonnie Angelo of U.S. News \& World Report," January 3, 1977. In Conversations with Carter. pp. 63-70.

Presidential Interviews Not Included in The Public Papers

"Interview with James Reston, New York Times," December 1, 1977. In Pippert, The Spiritual Journey of Jimmy Carter, pp. 133-134. 
"Transcript of News Conference Held by Presidents Jimmy Carter and Gerald Ford in flight from Cairo to Washington." New York Times, October 12, 1981.

"Interview with Charles O. Jones, H. Clifton McCleskey, Kenneth W. Thompson. James Sterling Young, Richard Neustadt, David B. Truman, Richard F. Fenno, Jr., and Edwin C. Hargrove." Carter Presidency Project, November 29. 1982, Plains, Georgia. Transcript available online at the Miller Center for Public Affairs, University of Virginia, http://www.millercenter.virginia.edu/index.php/scripps/digitalarchive/oralhistori es/detail/3260.

"Interview with Mike Wallace on CBS's 60 Minutes," March 24, 1985. in Conversations with Carter, 259-264.

"Interview with Leaders Magazine," April 1985, in Conversations with Carter, 265-270.

"Interview with Barbara Reynolds of USA Today," May 12, 1986, in Conversations with Carter, 271-275.

"Interview with Kenneth W. Thompson and James Sterling Young," 1987, in The Carter Presidency: Fourteen Intimate Perspectives of Jimmy Carter. Portraits of American Presidents, Vol. VIII. Edited by Kenneth W. Thompson, pp. 3-16. Lanham, MD: University Press of America, 1990.

"Interview with James Laue at the $5^{\text {th }}$ National Conference on Peacemaking and Conflict Resolution in Charlotte, North Carolina," June 7, 1991, in Conversations with Carter, 283-299.

"Interview with the Academy of Achievement in Atlanta, Georgia," October 25, 1991. http://www.achievement.org.

"Question-and-Answer Session on Middle East Peace, Multiculturalism, and Fishing." July 23, 1995.

"Interview with Charlayne Hunter-Gault," PBS Newshour, November 19, 1996. http://www.pbs.org/newshour/bb/religion/carter_11-19.html.

"Interview with Robert Fulghum on C-SPAN's About Books," December 19. 1996, in Conversations with Carter, 301-326. 
"Interview with Don Richardson," October 17, 1997, in Conversations with Carter, 327-336.

"Interview with Bob Abernathy," Religion and Ethics Newsweekly, October 29, 1999, http://www.pbs.org/wnet/religionandethics/week309/cover.html.

"A 20 ${ }^{\text {th }}$ Anniversary Q\&A with President Carter," October 10, 2002.

"Interview with Larry King," CNN's Larry King Live, November 15, 2002.

"Interview with Jane O. Hansen," Atlanta Journal-Constitution, December 8, 2002.

"Interview with Tim Sebastian," BBC World News ' Hardtalk with Tim Sebastian, December 10, 2002, http://news.bbc.co.uk/1/hi/programmes/hardtalk/2568809.stm.

"Interview with Bob Edwards," National Public Radio's Morning Edition, February 25, 2003, http://www.npr.org/programs/morning/transcripts/2003/feb/030225.edwards.htm $\underline{1 .}$

"Interview with Charles Trumbull," Encyclopedia Britannica, June 26, 2003, http://www.britannica.com.

"Interview with Bob Edwards," National Public Radio's Morning Edition, September 17, 2003, http://www.npr.org/programs/morning/transcripts/2003/sep/030917.carter.html.

"Interview with Larry King," CNN's Larry King Live, September 19, 2003.

"Interview with Massimo Calabresi," Time, December 8, 2003, p. 8.

"Interview with Chris Matthews," MSNBC's Hardball with Chris Matthews, December $11,2003$.

“Interview with Larry King," CNN's Larry King Live, December 12, 2003.

"Interview with Ayelish McGarvey, "Carter's Crusade," The American Prospect Online, April 5, 2004, http://www.prospect.org.

"Interview with Ellen Fried," "The Revolution in the South: President Carter's New Novel Brings History to Life," Prologue 36.2 (Summer 2004).

"Interview with Jim Lehrer," PBS Newshour, July 26, 2004, http://www.pbs.org/newshour/bb/politics/july-dec04/carter 7-26.html. 
"Interview with Katie Couric," NBC"s Today, October 8, 2004. http:/ www.msnbc.msn.com/id/6138962/.

"Interview with Chris Matthews," MSNBC"s Hardball with Chris Matthew's, October 18. 2004.

"Interview with Larry King," CNN's Larry King Live, December 9, 2004.

"Interview with Chris Matthews," MSNBC's Hardball with Chris Matthews, December 10, 2004.

"Interview with Tavis Smiley." PBS's Tavis Smiley Show. December 15, 2004.

“Interview with UBS Wealth Management." July 2005.

"Interview with Margaret Warner," PBS Newshour with Jim Lehrer, September 19. 2005. http://www.pbs.org/newshour/bb/politics/july-dec05/reform_9-19.html. With James Baker.

"Interview with Larry King," CNN’s Larry King Live, November 3. 2005.

"Interview with Wolf Blitzer," CNN's The Situation Room, November 4, 2005.

"Interview with Jonathan Serrie," Fox News' Special Report with Brit Hume. December 26, 2005.

"Interview with GQ Magazine." GQ Online. January 2006. http://men.style.com/gg/features/archive/0601.

"Interview with Wolf Blitzer," CNN's Late Edition. January 29. 2006.

"Interview with Larry King," CNN's Larry King Live. February 1, 2006.

"Interview with Wolf Blitzer," CNN's The Situation Room. February 20, 2006.

"Interview with Patricia Miotto," The Voice of Success, March 2006, 1-6.

"Interview with Wolf Blitzer," CNN's The Situation Room. May 24. 2006.

"Interview with Jeff Fleischer," Mother Jones, June 2. 2006. http://ww.motherjones.com.

"Interview with Der Spiegel," August 15, 2006, http://service.spiegel.de/cache/international/spiegel/0.1518.431793.00.html. 
"Interview with Larry King," CNN's Larry King Live, September 13, 2006.

"Telephone Interview with Christopher Dickey of Newsweek," MSNBC.com/ Newsweek, October 7, 2006.

"Interview with Rich Cline," Evangelical Alliance of the United Kingdom, NovemberDecember 2006, http://www.eauk.org/resources/idea/NovDec2006/the-powerof-unity.

"Interview with Jennifer Siegel," Jewish Daily Forward, November 16, 2006, http://www.forward.com/articles/carter-discusses-new-book-on-Israel-and-themiddle/.

“Interview with Larry King," CNN’s Larry King Live, November 27, 2006.

"Interview with David Shuster," MSNBC's Hardball with Chris Matthews, November $28,2006$.

"Interview with Judy Woodruff," PBS Newshour, November 28, 2006.

"Interview with Wolf Blitzer," CNN's The Situation Room, November 28, 2006.

"Interview with Tim Russert," NBC's Meet the Press, December 3, 2006.

"Interview with Riz Khan," Al Jazeera, December 12, 2006.

"Interview with David Postman," Seattle Times, December 13, 2006.

"Interview with Eleanor Clift," Newsweek International, December 25, 2006-January 1, 2007, http://www.msnbc.msn.com.

"Interview with Wolf Blitzer," CNN's The Situation Room, January 19, 2007.

"Interview with Steve Inskeep," National Public Radio, January 25, 2007.

"Interview with George Stephanopoulos," ABC's This Week with George Stephanopoulos, February 25, 2007.

“Interview with Lisa Miller," March 21, 2007, Newsweek, http://www.msnbc.msn.com.

"Interview with Elizabeth Sams," Beliefnet, March 27, 2007. http://www.beliefnet.com/story/214/story_21478.html.

"Interview on the $25^{\text {th }}$ Anniversary of the Carter Center," April 5, 2007. 
"Interview with Frank Lockwood. Arkansas Democrat-Gazette," May 19. 2007. http: "www.biblebeltblogger.com/biblebelt 2007/05/president_carte.html (accessed May 21. 2007).

Speeches and Debate Remarks by. Jimmy. Carter.

\section{Pre-Presidential Speeches}

"Inaugural Gubernatorial Address in Atlanta. Georgia." January 12. 1971. In A Government As Good As Its People. pp. 3-6.

"Remarks at the National Press Club in Washington. DC." February 9. 1973. In The Presidential Campaign 1976: Jimmy Carter. Washington. DC: United States Government Printing Office. 1978. pp. 32-39.

"Remarks at Dedication of Martin Luther King Portrait in Atlanta. Georgia." February 17. 1974. In A Government As Good As Its People. pp. 13-15.

"Remarks at the Leadership Prayer Breakfast in Orlando. Florida." March 27. 1974. In Jessyca Russell Gaver. The Faith of Jimmy' Carter. New York: Manor Books. 1977. pp. 27-37.

".'Law Day" Address at the University of Georgia in Athens. Georgia," May 4. 1974. итш.jimmicarterlibrary.org.

"Letter to Friends." December 4. 1974. In The Presidential Campaign 1976: Jimm! Carter. pp. 1-2.

"Formal Announcement as a President Candidate at the National Press Club in Washington. DC." December 12. 1974. In The Presidential Campaign 19-6. Jimmy' Carter. pp. 3-11.

"Remarks at a Campaign Rally at the Civic Center in Atlanta. Georgia." December 12. 1974. In The Presidential Campaign 19"6: Jimmy' Carter. pp. 11-12.

"Remarks to the National Wildlife Federation in Pittsburgh. Pennsylvania." March 15. 1975. In The Presidential Campaign 19-6: Jimmy Carter. pp. 58-66.

"Remarks and Question-and-Answer Session at Johns Hopkins University in Baltimore. Maryland." April 2, 1975. In The Presidential Campaign 1976: Jimmy Carter. pp. $40-58$.

"Remarks to the American Chamber of Commerce in Tokyo. Japan." May 28. 1975. In The Presidential Campaign 1976: Jimmy Carter. pp. 66-70. 
"Remarks at Florida State University in Tallahassee, Florida," September 28, 1975. In A Government As Good As Its People, pp. 45-49.

"Remarks at Bethune-Cookman College in Daytona Beach, Florida," October 29, 1975. In A Government As Good As Its People, pp. 49-52.

"Remarks and Question-and-Answer Session at the National Democratic Issues Conference in Louisville, Kentucky," November 23, 1975. In The Presidential Campaign 1976: Jimmy Carter, pp. 77-89.

“'Jimmy Carter's Code of Ethics' position paper," March 1, 1976. In The Presidential Campaign 1976: Jimmy Carter, pp. 90-92.

"Remarks at the Chicago Council on Foreign Relations," March 15, 1976. In The Presidential Campaign 1976: Jimmy Carter, pp. 109-119.

"Remarks at the African Methodist Episcopal Zion Church in Buffalo, New York," March 21, 1976. In Pippert, The Spiritual Journey of Jimmy Carter, p. 115.

"Remarks Before the California State Senate in Sacramento, California," May 20, 1976. In A Government As Good As Its People, pp. 82-83.

"Remarks on Middle East Policies in Elizabeth, New Jersey," June 6, 1976. In The Presidential Campaign 1976: Jimmy Carter, pp. 215-221.

"Remarks to Ministers of the African Methodist Episcopal Church in Atlanta, Georgia," June 18, 1976. In Pippert, The Spiritual Journey of Jimmy Carter, pp. 238-243.

"Remarks Before Men's Class at First Baptist Church in Plains, Georgia," June 20, 1976, in Pippert, The Spiritual Journey of Jimmy Carter, pp. 156-162.

"Remarks at the Foreign Policy Association in New York City, New York." June 23. 1976. In A Government As Good As Its People, pp. 93-100.

"Presidential Nomination Acceptance Speech at the Democratic National Convention in New York City, New York," July 15, 1976. In A Government As Good As Its People, pp. 103-111.

"Morning Service Benediction Prayer at the Plains Baptist Church in Plains. Georgia," July 18, 1976. In Pippert, The Spiritual Journey of Jimmy Carter, pp. 47-48.

"Remarks Before Men's Bible Class at the Plains Baptist Church in Plains, Georgia," July 18, 1976. In Pippert, The Spiritual Journey of Jimmy Carter, pp. 46-47. 
"Statement during a campaign tour of Manchester. New Hampshire," August 3, 1976. In The Presidential Campaign 1976: Jimmy Carter. pp. 462-465.

"Remarks to the American Bar Association in Atlanta, Georgia," August 11. 1976. In The Presidential Campaign 1976: Jimmy Carter. pp. 489-494.

"Remarks at a Town Hall Forum in Los Angeles, California," August 23. 1976. In The Presidential Campaign 1976: Jimmy Carter, pp. 503-510.

"Remarks Before the Men's Bible Class at Plains Baptist Church in Plains, Georgia," August 29, 1976. In Pippert, The Spiritual Journey of Jimmy Carter, p. 114.

"Remarks During First Presidential Debate with President Gerald Ford in Philadelphia. Pennsylvania," September 23, 1976. Moderated by Edwin Newman. The Commission on Presidential Debates, http://www.debates.org.

"Remarks During the Second Presidential Debate with President Gerald Ford in San Francisco, California," October 6, 1976. Moderated by Pauline Frederick of National Public Radio. The Commission on Presidential Debates.

"Remarks Before Men's Class at First Baptist Church in Plains, Georgia," January 9. 1977. In Pippert, The Spiritual Journey of Jimmy Carter, pp. 175-176.

Presidential Speeches Not Included in The Public Papers

"Remarks Before Men`s Bible Class at the Plains Baptist Church in Plains. Georgia," February 13, 1977. In Pippert, The Spiritual Journey of Jimmy Carter. pp. 51-52.

"Remarks Before Men's Bible Class at the First Baptist Church in Calhoun. Georgia," April 10, 1977. In Pippert, The Spiritual Journey of Jimmy Carter. pp. 44-45.

"Remarks Before Couples' Class at First Baptist Church in Washington. D.C.." June 12. 1977. In Pippert. The Spiritual Journey of Jimmy' Carter. p. 38.

"Remarks Before Couples' Class at First Baptist Church in Washington, D.C.," July 31. 1977. In Pippert, The Spiritual Journey of Jimmy Carter, pp. 187-193.

"Remarks Before Men's Bible Class at the Plains Baptist Church in Plains, Georgia," August 7, 1977. In Pippert, The Spiritual Journey of Jimmy Carter. pp. 52-54.

"Remarks Before the Couples' Class at First Baptist Church in Washington. D.C.." November 6, 1977. In Pippert, The Spiritual Journey of Jimmy Carter. pp. 91 92, 193-205. 
"Remarks Before Couples' Class at First Baptist Church in Washington, D.C.," January 29, 1978. In Pippert, The Spiritual Journey of Jimmy Carter, p. 60.

"Prayer at Morning Worship Service at the First Baptist Church in Lagos, Nigeria," April 3, 1978. In Pippert, The Spiritual Journey of Jimmy Carter, p. 55.

\author{
Post-Presidential Speeches \\ (Unless Otherwise Noted, Remarks May Be Found at http:/www.cartercenter.org)
}

"Excerpts of Remarks to the New York Board of Rabbis," New York Times, May 18, 1981.

"Remarks at the 1988 Democratic National Convention in Atlanta, Georgia," July 18, 1988, transcript from Atlanta Journal-Constitution.

"Remarks to a Joint Session of the State Legislature in Atlanta, Georgia," April 8, 2003.

"Sixth U Thant Distinguished Lecture given at United Nations University in Tokyo, Japan," September 5, 2003.

"Remarks at the $25^{\text {th }}$ Anniversary Reunion of the Camp David Accords held in Washington, DC," September 17, 2003.

"Remarks at the Human Rights Defenders on the Frontlines of Freedom Conference in Atlanta, Georgia," November 11-12, 2003.

"Remarks at the Geneva Initiative Public Commitment Event," December 1, 2003.

"Remarks to a Joint Session of Congress in La Paz, Bolivia," December 18, 2003.

"Remarks at the World Health Assembly in Geneva, Switzerland," May 19, 2004.

"Remarks at the 2004 Democratic National Convention in Boston, Massachusetts," July 26, 2004.

"Remarks at the Clinton Presidential Center Dedication in Little Rock, Arkansas," November 18, 2004.

"Remarks at the World Council of Churches' Ecumenical Accompaniment Programme in Palestine and Israel," January 10, 2005, http://www.eappi.org (accessed July 8, 2006).

"Remarks at the Organization of American States in Washington, DC," January 25. 2005. 
"Remarks on Middle East Peace at the Herzliya Conference. Israel," January 23. 2006.

"Remarks at the Funeral Service for Coretta Scott King in Lithonia. Georgia." February 7. 2006.

"Remarks and Question-and-Answer Session at the Council on Foreign Relations." March 2. 2006. http:/www.cfr.org/publication/10024/peace_versus_democracy_in_palestine.ht mil.

"Remarks at the Opening of the China Bible Ministry Exhibition at the Second Ponce de Leon Baptist Church in Atlanta. Georgia." May 19. 2006. http:/WWW.christianpost.com (accessed June 29, 2006).

"Remarks at the Opening of the Human Rights Defenders Policy Forum in Atlanta, Georgia," May 23, 2006.

"Remarks at a Book Signing Event in Virginia." November 28. 2006. http: $/$ ww democracsnow org/article.pl? sid=06/11/301452225.

"Remarks at the Funeral Service for President Gerald R. Ford at Grace Episcopal Church in Grand Rapids. Michigan." January 3. 2007.

"Remarks and a Question-and-Answer Session at the Carter Presidency \& Lessons for the $21^{\text {st }}$ Century Conference in Athens. Georgia." January 20. 2007.

"Remarks at Brandeis University in Waltham. Massachusetts," January 23. 2007.

"Statement to the U.N. Human Rights Council," March 29. 2007.

“Remarks at Mansfield College. Oxford University. United Kingdom.” June 21. 2007.

\section{IIritings by Carter Officials and Family}

Anderson. Patrick. Electing Jimmy Carter: The Campaign of 19-6. Baton Rouge. LA: Louisiana State University Press, 1994.

Ariail. Dan. and Cheryl Heckler-Feltz. The Carpenter's Apprentice: The Spiritual Biography of Jimmy Carter. Grand Rapids, MI: Zondervan Publishing House. 1996.

Bourne. Peter G. Jimmy Carter: A Comprehensive Biography from Plains to Postpresidency: New York: Scribner. 1997. 
Brzezinski, Zbigniew. "Exit Interview with Marie Allen, Presidential Papers Staff," February 20, 1981. Transcript available at Jimmy Carter Library and Museum, Oral History Transcripts, http://www.jinmycarterlibrary.gov/library/oral.phtml.

Brzezinski, Zbigniew. Power and Principle: Memoirs of the National Security Adviser. 1977-1981. New York: Farrar, Straus, and Giroux, 1983.

Brzezinski, Zbigniew. "Interview with Ray Suarez." PBS Newshour, October 11, 2002, http://www.pbs.org/newshour/bb/international/july-dec02/nobel_10-11.html.

Brzezinski, Zbigniew. "Interview with Neal Conan." National Public Radio 's Talk of the Nation, September 16, 2003, available at http:/www.npr.org/programs/totn/transcripts/2003/sep/030916.conan.html.

Brzezinski, Zbigniew. “A Dangerous Exemption.” Foreign Policy (July/August 2006): 63-64.

Califano, Joseph A., Jr., Governing America: An Insider's Report from the White House and the Cabinet. New York: Simon and Schuster, 1981.

Califano, Joseph A., Jr. Inside: A Public and Private Life. New York: Public Affairs, 2004.

Carter, Hugh, and Frances Spatz Leighton. Cousin Beedie and Cousin Hot: My Life with the Carter Family in Plains, Georgia. Englewood Cliffs, NJ: Prentice-Hall. 1978.

Carter, Rosalynn. First Lady from Plains. New York: Ballantine Books, 1984.

Carter, Rosalynn. "The Perspective of the First Lady." In The Carter Presidency: Fourteen Intimate Perspectives of Jimmy Carter, pp. 217-238.

Cutler, Lloyd. "Exit Interview with Marie Allen, Presidential Papers Staff," March 2. 1981. Jimmy Carter Library and Museum, Oral History Transcripts, http://www.jimmycarterlibrary.gov/library/oral.phtml.

Eizenstat, Stuart. "Exit Interview with Emily Soapes, Presidential Papers Staff," January 10, 1981. Transcript available at Jimmy Carter Library and Museum, Oral History Transcripts.

Fallows, James. "Exit Interview with Lee Johnson, Presidential Papers Staff." November 14, 1978. Transcript available at Jimmy Carter Library and Museum, Oral History Transcripts. 
Fallows. James. "The Passionless Presidency: The Trouble with the Jimmy Carter Administration." Atlantic .Monthly (May 1979). 33-47.

Hertzberg. Hendrik. "Jimmy Carter. 1977-1981." In Robert A. Wilson. ed.. Character Above All: Ten Presidents from FDR to George Bush. pp. 172-201. New York: Simon \& Schuster. 1995.

Jordan. Hamilton. Crisis: The Last Year of the Carter Presidency. New York: G.P. Putnam`s Sons. 1982.

Jordan. Hamilton. "Interview with Judy Woodruff." PBS Newshour. May 31. 2006. http://www.pbs.org/newshour/bb/politics/jan-jun06/unity 05-31.html (accessed June 1, 2006).

Lance. Bert. with Bill Gilbert. The Truth of the Matter: My Life In and Out of Politics. New York: Summit Books. 1991.

Maddox, Robert L. Preacher at the White House. Nashrille. TN: Broadman Press. 1984.

McHenry. Donald. "The Carter Presidency and the United Nations." In The Carter Presidency: Fourteen Intimate Perspectives of Jimmy Carter. pp. 159-175.

Mondale. Walter F. "Remarks Upon Return from Trip to Europe and Japan," February 1. 1977. In In Public Papers of the Presidents of the Lnited States: Jimmy Carter. 1977. Book I. Washington. DC: United States Government Printing Office, pp. 57-58.

Mondale. Walter F. "Remarks on President Carter"s Departure to Egypt and Israel." March 7. 1979. In Public Papers of the Presidents, Jimmy Carter, 19-9. Book I. p. 394.

Mondale. Walter F. "The Perspective of the Vice President." In The Carter Presidency: Fourteen Intimate Perspectives of Jimmy Carter. pp. 239-247.

Mondale. Walter F. "Interview with Wolf Blitzer." CNN"s The Situation Room. Januar! 19. 2007.

Powell. Jody: "Exit interview with David Alsobrook. Presidential Papers Staff." December 2, 1980. Transcript available at Jimmy Carter Library and Museum. Oral History Transcripts.

Powell. Jody. The Other Side of the Story. New York: William Morrow and Company. 1984. 
Quandt, William B. "Camp David and Peacemaking in the Middle East," Political Science Quarterly 101.3 (1986): 357-377.

Quandt, William B. Camp David: Peacemaking and Politics. Washington, DC: The Brookings Institution, 1986.

Quandt, William B. Peace Process: American Diplomacy and the Arab-Israeli Conflict Since 1967. Washington, DC: The Brookings Institution, 2001; Revised edition.

Stein, Kenneth W. Heroic Diplomacy: Sadat, Kissinger, Carter, Begin, and the Quest for Arab-Israeli Peace. New York: Routledge, 1999.

Stein, Kenneth W. "Book Review of Douglas Brinkley's The Unfinished Presidency." Middle East Quarterly (September 1999): 1-2, http://www.meforum.org/article/1320.

Stein, Kenneth W. "My Problem with Jimmy Carter's Book." Middle East Quarterly (Spring 2007): 1-13, http://www.meforum.org/article/1633.

Vance, Cyrus. Hard Choices: Critical Years in America's Foreign Policy. New York: Simon and Schuster, 1983.

Vance, Cyrus. "Carter's Foreign Policy: The Source of the Problem." In The Carter Presidency: Fourteen Intimate Perspectives of Jimmy Carter, pp. 135-144.

Young, Andrew. A Way Out of No Way: The Spiritual Memoirs of Andrew Young. Nashville, TN: Thomas Nelson Publishers, 1994.

Email Correspondence With Author

Anderson, John B., September 26, 2006.

Haynes, Ulrich, Jr., October 2, 2006.

Krueger, Robert, October 2, 2006.

Mondale, Walter F., November 2, 2006.

Moss, Ambler F., Jr., September 27, 2006. 
Asad. Hafiz. "Remarks Prior to His Meeting with President Carter in Geneva. Switzerland." May 9. 1977. In Public Papers of the Presidents. Book I. pp. 843-844.

Asad. Hafiz. "Remarks at a Toast with President Carter in Genera. Switzerland." May 9. 1977. In Public Papers of the Presidents. Book I. pp. 845-847.

Al-Hassan. Hani. "PLO on Camp David: 'The Plan is to Liquidate the Palestinians Politically.". MERIP Reports 72 (November 1978): 12-13.

Begin. Menachem. "Interview with Time Magazine." Time. October 2. 1978.

Begin. Menachem. "1978 Nobel Peace Prize Lecture in Oslo. Norway.." December 10. 1978. http: nobelprize.org.

Begin. Menachem. "Remarks at Dinner Honoring President Carter in Jerusalem. Israel." March 11. 1979. In Public Papers of the Presidents. Book I. pp. +20-422.

Begin. Menachem. "Remarks at the Signing Ceremony of the Egyptian-Israeli Peace Treaty with President Carter and Prime Minister Begin." March 26. 1979. In Public Papers of the Presidents. Book I. pp. 520-522.

Begin. Menachem. "Remarks at Dinner with President Carter." April 15. 1980. In Public Papers of the Presidents, Book I. pp. 689-693.

Beilin. Yossi. "Carter is No More Critical of Israel Than Israelis Themselves." Jewish Daily Forward. January 19. 2007.

Berge. Gunnar. "2002 Nobel Peace Prize Presentation Speech in Oslo. Norway." December 10. 2002. http. nobelprize org peace laureates 2002 presentationspeech.html.

Bush. George H. If.. with Victor Gold. Looking Forward: An Autobiography. New York: Doubleday. 1987.

Bush. George H.W.. with Doug Wead. George Bush: Man of Integrity. Eugene. OR: Harvest House Publishers. 1988.

Bush. George H.W. "Remarks at the Annual National Prayer Breakfast." February 2. 1989. George Bush Presidential Library and Museum. http: bushlibrary tamu.edu research papers $198989020200 . \mathrm{html}$.

Bush. George H.W. All the Best. George Bush: Mr Life in Letters and Other Writings. New York: Scribner. 1999. 
Bush, George H.W. "Remarks at the Billy Graham Library Dedication in Charlotte, North Carolina," May 31, 2007. Video clip of speech available at You Tube, http://www.youtube.com.

Bush, George H.W., and Brent Scowcroft. A World Transformed. New York: Alfred A. Knopf, 1998.

Bush, George W. A Charge to Keep. New York: William Morrow and Company, 1999.

Bush, George W. "Interview with Sir David Frost of BBC News," November 17, 2003. The White House, http://whitehouse.gov/news/releases/2003/11/200311171.html.

Bush, George W. "Interview with Diane Salvatore." Ladies' Home Journal (August 2004): 100-111.

Bush, George W. "Interview with Nancy Gibbs and John Dickerson," September 6, 2004. Time, pp. 38-43.

Clinton, Bill. "Remarks at a Dinner Honoring Former Presidents," September 13, 1993. In Public Papers of the Presidents, Book II, pp. 1484-1485.

Clinton, Bill. "Remarks on Departure for the Middle East," October 25, 1994. In Public Papers of the Presidents, Book II, pp. 1868-1869.

Clinton, Bill. "Remarks to the Jordanian Parliament in Amman, Jordan," October 26. 1994. In Public Papers of the Presidents, Book II, pp. 1879-1881.

Clinton, Bill. "Remarks to the Knesset in Jerusalem, Israel," October 27, 1994. In Public Papers of the Presidents, Book II, pp. 1890-1892.

Clinton, Bill. "Remarks on the Death of Prime Minister Yitzhak Rabin of Israel," November 4, 1995. In Public Papers of the Presidents, Book II, pp. 1720-1721.

Clinton, Bill. "Exchange with Reporters Abroad Air Force One," November 5, 1995. In Public Papers of the Presidents, Book II, pp. 1721-1722.

Clinton, Bill. "Remarks at the Funeral of Prime Minister Yitzhak Rabin in Jerusalem, Israel," November 6, 1995. In Public Papers of the Presidents, Book II, pp. 1723-1724.

Clinton, Bill. "Remarks at the President's News Conference with Prime Minister Shimon Peres of Israel," December 11, 1995. In Public Papers of the Presidents, Book II, pp. 1877-1881. 
Clinton. Bill. "Remarks at the Opening of the Summit of the Peacemakers in Sharm alSheikh. Egypt." March 13. 1996. In Public Papers of the Presidents. Book I. pp. $436-437$.

Clinton. Bill. "Remarks on Arrival in Tel Aviv. Israel." March 13. 1996. In Public Papers of the Presidents. Book I. pp. 443-444.

Clinton. Bill. "Remarks at President's News Conference with Prime Minister Shimon Peres in Jerusalem. Israel." March 14. 1996. In Public Papers of the Presidents. Book I. pp. $444-451$.

Clinton. Bill. "Remarks and Question-and-Answer Session with Students in Tel Aviv. Israel." March 14. 1996. In Public Papers of the Presidents. Book I. pp. $451-456$.

Clinton. Bill. "Remarks at the Wye River Memorandum Signing Ceremony." October 23. 1998. In Public Papers of the Presidents. Book II. pp. 1836-1838.

Clinton. Bill. "Remarks at the Arrival Ceremony in Tel Aviv. Israel." December 13. 1998. In Public Papers of the Presidents. Book II. pp. 2160-2161.

Clinton. Bill. "Remarks at a Dinner Hosted by Prime Minister Benjamin Netanyahu in Jerusalem. Israel." December 13. 1998. In Public Papers of the Presidents. Book II. pp. 2171-2172.

Clinton. Bill. "Exchange with Reporters Prior to Discussions with Chairman Yasser Arafat of the Palestinian Authority in Gaza City. Gaza." December 14. 1998. In Public Papers of the Presidents, Book II. pp. 2172-2173.

Clinton. Bill. "Remarks at a Luncheon Hosted by Chairman Yasser Arafat of the Palestinian Authority in Gaza City:" December 14. 1998. In Public Papers of the Presidents. Book II. pp. 2174-2175.

Clinton. Bill. "Remarks to the Palestine National Council and Other Palestinian Organizations in Gaza City. Gaza“ December 14. 1998. In Public Papers of the Presidents. Book II. pp. 2175-2179.

Clinton. Bill. "Remarks on the Death of King Hussein I of Jordan." February 7. 1999. In Public Papers of the Presidents. Book I. pp. 178-179.

Clinton. Bill. "Remarks on Presenting the Presidential Medal of Freedom to Former President Jimmy Carter and Rosalynn Carter in Atlanta. Georgia." Weekly Compilation of Presidential Documents. August 16. 1999. transcript from http: "www.findarticles.com (accessed May 21. 2006). 
Clinton, Bill. My Life. New York: Alfred A. Knopf, 2004.

Clinton, Bill. "Remarks at the Funeral Service for Coretta Scott King in Lithonia, Georgia." February 7, 2006.

Dayan, Moshe. "Remarks following Meeting with President Carter and Egypt Vice President Mubarak," September 17, 1979. In Public Papers of the Presidents, Book II, p. 1684-1686.

Dayan, Moshe. Breakthrough: A Personal Account of the Egypt-Israel Peace Negotiations. New York: Alfred A. Knopf, 1981.

Drinan, Robert F. "Carter's work touches many lives worldwide." National ('atholic Reporter, December 15, 1995.

Drinan, Robert F. "Reflections on Nobel Laureate Jimmy Carter," National Catholic Reporter, October 25, 2002.

Drinan, Robert F. "Jimmy Carter's book reflects the man of faith I knew," National Catholic Reporter, December 16, 2005.

Fahd, Crown Prince. "Remarks at a Toast with President Carter," May 24, 1977. In Public Papers of the Presidents, Book I, pp. 1007-1008.

Ford, Gerald R. A Time to Heal: The Autobiography of Gerald R. Ford. New York: Harper and Row Publishers, 1979.

Gerson, Michael. "Religion, Rhetoric and the Presidency: A Conversation with Michael Gerson." The Pew Forum on Religion and Public Life, December 6, 2004. http://pewforum.org/events.

Hoover, Herbert. The Ordeal of Woodrow Wilson. Washington, DC: Woodrow Wilson Center Press, Baltimore, MD: Johns Hopkins University Press, 1992; originally published in 1958.

Hussein, King. "Remarks at the Welcoming Ceremony with President Carter." April 25, 1977. In Public Papers of the Presidents, Book I, p. 711.

Johnson, Lyndon B. "Remarks at the Mormon Tabernacle in Salt Lake City, Utah," October 29, 1964. In Public Papers of the Presidents, Book II, pp. 1513-1516.

Johnson, Lyndon B. The Vantage Point: Perspectives of the Presidency, 1963-1969. New York: Holt, Rinehart and Winston, 1971. 
Lieberman. Joseph I. "Interview with Tim Russert." NBC"s. Meet the Press. March 27. 2005.

Lionaes. Aase. "Presentation Speech at the 1978 Nobel Peace Prize Ceremonies in Oslo, Norway." December 10. 1978. http://nobelprize.org.

Miller. Zell. A Vational Party Lo More: The Conscience of a Conservative Democrat. Atlanta. GA: Stroud \& Hall Publishers. 2003.

Mubarak. Hosni. "Remarks following Meeting with President Carter and Israeli Foreign Minister Dayan." September 17. 1979. In Public Papers of the Presidents, Book II. p. 1684-1686.

Navon. Yitzhak. "Remarks at Dinner Honoring President Carter in Jerusalem. Israel." March 11. 1979. In Public Papers of the Presidents. Jimmy Carter. 19-9. Book I. pp. 419-420.

Nixon. Richard. The Memoirs of Richard Nixon. New York: Grosset \& Dunlap. 1978.

Nixon. Richard. 1999: Victory Without Har. New York: Pocket Books. 1989.

O`Neill. Tip. "O`Neill’s Observations on Seren Presidents." New York Times. August 23. 1983.

O Neill. Tip. Man of the House: The Life and Political Memoirs of Speaker Tip O Teill. New York: Random House. 1987.

O`Neill. Tip with Gary Hymel. All Politics is Local and Other Rules of the Game. Holbrook. MA: Bob Adams. Inc.. 1994.

Rahman. Ziaur. "Remarks following Meeting with President Carter." August 27. 1980. In Public Papers of the Presidents, Book II. pp. 1578-1579.

Rabin. Yitzhak. The Rabin Memoirs. Reprint and Expanded version of $2^{\text {nd }}$ edition. 1994. Berkeley. CA: University of California Press. 1996.

Reagan. Ronald. "Remarks at the Dedication Ceremony for the Jimmy Carter Library in Atlanta. Georgia." October 1. 1986. http:/www.reagan.utexas.edu/achives/speeches 1986/100186a.htm.

Reagan. Ronald. An American Life: The Autobiography of Ronald Reagan. New York: Simon and Schuster. 1990.

Reagan. Ronald. The Reagan Diaries. Edited by Douglas Brinkley. New York: HarperCollins Publishers. 2007. 
Sadat, Anwar. "Remarks at Welcoming Ceremony with President Carter," April 4. 1977. In Public Papers of the Presidents, Book I, pp. 562-564.

Sadat, Anwar. "Remarks at Dinner Ceremony with President Carter," April 4. 1977. In Public Papers of the Presidents, Book 1, pp. 568-570.

Sadat, Anwar. "Remarks following Meeting with President Carter in Aswan, Egypt," January 4, 1978. In Public Papers of the Presidents, Book I, p. 19.

Sadat, Anwar. "Remarks on Arrival with President Carter," February 3, 1978. In Public Papers of the Presidents, Book I, pp. 274-275.

Sadat, Anwar. "Remarks on His Departure with President Carter," February 8, 1978. In Public Papers of the Presidents, Book I, p. 291.

Sadat, Anwar. "1978 Nobel Peace Prize Lecture in Oslo, Norway," December 10, 1978, http://nobelprize.org.

Sadat, Anwar. In Search of Identity: An Autobiography. New York: Harper \& Row Publishers, 1978.

Sadat, Anwar. "Remarks at Welcoming Ceremony with President Carter in Cairo, Egypt," March 8, 1979. In Public Papers of the Presidents, Book I, p. 405.

Sadat, Anwar. "Remarks during Informal Exchange with American Television Correspondents with President Carter on Train Trip from Cairo to Alexandria. Egypt," March 9, 1979. In Public Papers of the Presidents, Book I, pp. 407-410.

Sadat, Anwar. "Remarks at Dinner Honoring President Carter in Alexandria, Egypt." March 9, 1979. In Public Papers of the Presidents, Book I, pp. 410-411.

Sadat, Anwar. "Remarks following Meeting with President Carter in Giza. Egypt." March 10, 1979. In Public Papers of the Presidents, Book I, p. 415.

Sadat, Anwar. "Remarks at the Signing Ceremony of the Egyptian-Israeli Peace Treaty with President Carter and Prime Minister Begin," March 26, 1979. In Public Papers of the Presidents, Book I, pp. 518-520.

Sadat, Anwar. "Remarks at a State Dinner with President Carter and Prime Minister Begin," March 26, 1979. In Public Papers of the Presidents, pp. 524, 526.

Sadat, Anwar. "Remarks at a Toast with President Carter," April 8, 1980. In Public Papers of the Presidents, Book I, pp. 619-620. 
Sadat. Anwar. "Remarks to Reporters Following Meeting with President Carter." April 9. 1980. In Public Papers of the Presidents. BookI. p. 623.

Sadat. Anwar. Those I Have Known. New York: Continuum Publishing Company. 1984.

Weizman. Ezer. The Battle for Peace. New York: Bantam Books. 1981.

Wilson. Woodrow: "Remarks on Robert E. Lee at the Lniversity of North Carolina in Chapel Hill. North Carolina." January 19. 1909. (Speech later published as Robert E. Lee: An Interpretation. Chapel Hill. NC: University of North Carolina Press. 1924).

Wilson. Woodrow. "First Inaugural Address." March 4. 1913. The American Presidency Project. http www presidencr.ucsb.eduws.

Wilson. Woodrow. "Address at Congress Hall in Philadelphia. Pennsylvania." October 25. 1913. The American Presidency Project.

Wilson. Woodrow: "Remarks to the Southern Commercial Congress in Mobile. Alabama." October 27. 1913. The American Presidency Project.

Wilson. Woodrow: "Remarks at Independence Hall in Philadelphia. Pennsylvania." July 4. 1914. The American Presidency Project.

Wilson. Woodrow. "Remarks Before the American Bar Association." October 20, 1914. The American Presidency Project.

Wilson. Woodrow: "Address at the Young Men"s Christian Association"s Celebration in Pittsburgh. Pennsylvania." October 24. 1914. The American Presidency Project.

Wilson. Woodrow: "Address to Naturalized Citizens at Convention Hall in Philadelphia. Pennsylvania." May 10. 1915. The American Presidency Project.

Wilson. Woodrow: "Speech of Acceptance of the 1916 Democratic Party Nomination." September 2. 1916. The American Presidency Project.

Wilson. Woodrow: "Remarks to the U.S. Senate." January 22. 1917. The American Presidency Project.

Wilson. Woodrow: "Second Inaugural Address." March 5. 1917. The American Presidency Project.

Wilson. Woodrow: "War Message to Congress." April 2. 1917. The American Presidency Project. 
Wilson, Woodrow. "Address to Congress," February 11, 1918. The American Presidency Project.

Wilson, Woodrow. "Remarks in Support of the League of Nations in Pueblo, Colorado," September 25, 1919. The American Presidency Project.

Wright, Jim. Balance of Power: Presidents and Congress from the Era of Mc Carthy to the Age of Gingrich. Atlanta, GA: Turner Publishing, 1996.

Zia-ul-Haq, Mohammed. "Remarks to Reporters following Meeting with President Carter," October 3, 1980. In Public Papers of the Presidents, Book III, pp. 20562057.

\section{Secondary Sources on Jimmy Carter and the Carter Presidency}

American Experience: Jimmy Carter. Transcript. Narrated by Linda Hunt. Directed by Adriana Bosch. WGBH Educational Foundation, 2002, http://www.pbs.org/wgbh/amex/carter/filmmore/pt.html.

Aronoff, Yael S. "In Like a Lamb, Out Like a Lion: The Political Conversion of Jimmy Carter." Political Science Quarterly 121.3 (Fall 2006): 425-449.

Baker, James T. A Southern Baptist in the White House. Philadelphia, PA: The Westminster Press, 1977.

Baker, Ross K. "The Outlook for the Carter Administration." In The Election of 1976: Reports and Interpretations, edited by Marlene M. Pomper, pp. 115-146. New York: David McKay Company, Inc., 1977.

Bell, Coral. "Virtue Unrewarded: Carter's Foreign Policy at Mid-Term." International Affairs 54.4 (October 1978): 559-572.

Berggren, D. Jason. "I Had a Different Way of Governing": The Living Faith of President Carter." Journal of Church and State 47.1 (Winter 2005): 43-61.

Berggren, D. Jason, and Nicol C. Rae. "Jimmy Carter and George W. Bush: Faith, Foreign Policy, and an Evangelical Presidential Style." Presidential Studies Quarterly 36.4 (December 2006): 606-632.

Berman, Larry. "Presidents as Leaders: Carter and Reagan." Chapter in The New American Presidency. Boston, MA: Little, Brown and Company, 1987. pp. 309-337. 
Brinkley, Douglas. "Iimmy Carter`s Modest Quest for Global Peace." Foreign Affairs 74.6 (November/December 1995): 90-100.

Brinkley. Douglas. The Linfinished Presidency: Jimm. Carter's Journey to the lobel Peace Prize. New York: Penguin Books. 1999.

Brinkley. Douglas. "Jimmy Carter." In To the Best of My Ability": The American Presidents. ed. James M. McPherson. pp. 282-287. New York: DK Publishing. 2004.

Brooks. Michael J. "Carter Collectors Hear Former Press Secretary Jody Powell." The Political Bandwagon (December 2003): 4.

Brooks. Michael J. "Former President Continues Life of Christian Service." The Political Bandriagon (September 2005): 18.

Burns. James MacGregor. "The Carter-Clinton Connection." Chapter in Running .Alone. Presidential Leadership -JFK to Bush II (New York: Basic Books. 2006). pp. 119-129.

"Carter from a Saudi Perspective." Joumnal of Palestine Studies 10.2(Winter 1981): 125-127.

Cook. James F. "James Earl Carter. Jr.: From Plains to the Presidency:" In The Governors of Georgia. 175t-1995. Macon. GA: Mercer University Press. 1995. pp. 289-297.

Domin. Gregory Paul. Jimmy Carter, Public Opinion, and the Search for I Talues, 19--1981. Macon. GA: Mercer University Press. 2003.

Dumbrell. John. "Jimmy Carter and 'Global Community"." Chap. in Americun Foreign Policy: Carter to Clinton. New York: St. Martin`s Press. 1997. pp. 11-31.

Fink. Gary M. Prelude to the Presidency: The Political Character and Legislative Leadership Style of Governor Jimmy Carter. Westport. CT: Greenwood Press. 1980.

Fleisher. Richard. and Jon R. Bond. "Assessing Presidential Support in the House: Lessons from Reagan and Carter." Journal of Politics 45.3 (August 1983): 745-758.

Flint. Andrew R.. and Joy Porter. "Jimmy Carter: The Re-Emergence of Faith-Based Politics and the Abortion Rights Issue." Presidential Studies Quarterly 35.1 (March 2005): 28-51. 
Flowers, Ronald G. "President Jimmy Carter, Evangelicalism, Church-State Relations. and Civil Religion." Journal of Church and State 25.1 (Winter 1983): 113-132.

Frady, Marshall. "Interview with Ray Suarez." PBS Newshour, October 11, 2002.

Germond, Jack W., and Jules Witcover. Blue Smoke and Mirrors: How Reagan Won and Why Carter Lost the Election of 1980. New York: Viking Press, 1981.

Glad, Betty. Jimmy Carter: In Search of the Great White House. New York: W.W. Norton and Company, 1980.

Hahn, Dan F. "The Rhetoric of Jimmy Carter, 1976-1980." Presidential Studies Quarterly 14.2 (Spring 1984): 265-288.

Hargrove, Erwin C. Jimmy Carter as President: Leadership and the Politics of the Public Good. Baton Rouge, LA: Louisiana State University Press, 1988.

Hayward, Steven F. The Real Jimmy Carter: How Our Worst Ex-President Undermines American Foreign Policy, Coddles Dictators, and Created the Party of Clinton and Kerry. Washington, DC: Regnery Publishing Inc., 2004.

Hefley, James, and Marti Hefley. The Church that Produced a President. New York: Wyden Books, 1977.

Helicher, Karl. "The Response of the Soviet Government and Press to Carter's Human Rights Policies.” Presidential Studies Quarterly 13.2 (Spring 1983): 296-304.

Henderson, Phillip G. "Technocratic Leadership: The Policy Wonk Presidencies of Jimmy Carter and Bill Clinton." In The Presidency Then and Now, ed. Phillip G. Henderson, pp. 219-247. Lanham, MD: Rowman \& Littlefield Publishers, 2000.

Isaacs, Harold. Jimmy Carter's Peanut Brigade. Dallas, TX: Taylor Publishing Company, 1977.

Jones, Charles O. "Keeping Faith and Losing Congress: The Carter Experience in Washington." Presidential Studies Quarterly 14.3 (September 1984): 437-445.

Jones, Charles O. The Trusteeship Presidency: Jimmy Carter and the United States Congress. Baton Rouge, LA: Louisiana State University Press, 1988.

Kaufman, Burton I. The Presidency of James Earl Carter, Jr. Lawrence, KS: University Press of Kansas, 1993.

Krukones, Michael G. "The Campaign Promises of Jimmy Carter: Accomplishments and Failures." Presidential Studies Quarterly 15.1 (1985): 136-144. 
Kucharsky. David. The Man from Plains: The Mind and Spirit of Jimm Carter. New York: Harper and Row Publishers. 1976.

Lee. Darid D. "The Politics of Less: The Trials of Herbert Hoover and Jimmy Carter." Presidential Studies Quarterly 13 (1983): 305-312.

Leuchtenburg. William E. "Jimmy Carter and the Post-New Deal Presidency." In The Carter Presidency: Policy Choices in the Post-1ew Deal Era. edited by Gary M. Fink and Hugh Davis Graham. pp. 7-28. Lawrence. KS: University Press of Kansas. 1998.

Light. Paul. "Vice Presidential Influence Under Rockefeller and Mondale." Political Science Quarterly 98.4 (Winter 1983-1984): 617-640.

Mahmood. Zahid. "Jimmy Carter and Camp David." Joumal of Palestine Studies 15.1 (Autumn 1985): 125-128.

Martin. William. With God on Our Side. New York: Broadway Books. 1996.

Martin. William. "The Christian Right and American Foreign Policy." Foreign Policy (Spring 1999): 66-80.

Marton. Kati. "Rosalynn and Jimmy Carter: Virtue Lnrewarded." Chapter in Hidden Power: Presidential Marriages That Shaped Our History: New York: Anchor Books Edition, 2002. pp. 215-243.

Mazlish. Bruce. and Edwin Diamond. Jimmy Carter: A Character Portrait. New York: Simon and Schuster. 1979.

McNally. Tom. "The Carter Years." International Affairs 59.3 (Summer 1983): 465469.

Miller. Linda B. "Shadow and Substance: Jimmy Carter and the Camp Darid Accords." Pew Case Studies in International Affairs. Washington. DC: Institute for the Study of Diplomacy. 1992.

Miller. William Lee. Yankee from Georgia: The Emergence of Jimmy Carter. New York: Times Books, 1978.

Morgan. Iwan. "Jimmy Carter. Bill Clinton. and the New Democratic Economics." The Historical Journal 47.4 (2004): 1015-1039.

Morris, Kenneth E. Jimmy Carter: American Moralist. Athens. GA: Lniversity of Georgia Press. 1996. 
Moss, Ambler H., Jr., "The Panama Treaties: How an Era Ended." Latin American Research Review 21.3 (1986): 171-178.

Mullen, William F. "Perceptions of Carter's Legislative Successes and Failures: Views from the Hill and the Liaison Staff." Presidential Studies Quarterly 12.4 (Fall 1982): 522-533.

Newmann, William W. "The Structures of National Security Decision Making: Leadership, Institutions, and Politics in the Carter, Reagan, and G.H.W. Bush Years." Presidential Studies Quarterly 34. 2 (June 2003): 272-306.

Nielsen, Niels C., Jr., The Religion of President Carter. Nashville, TN: Thomas Nelson Publishers. 1977.

Norton, Howard, and Bob Slosser. The Miracle of Jimmy Carter. Plainfield, NJ: Logos International, 1976.

Oren, Michael D. "A Religious Problem: Jimmy Carter's Book: An Israeli View." Wall Street Journal, December 26, 2006.

Pflüger, Friedbert. "Human Rights Unbound: Carter's Human Rights Policy Reassessed." Presidential Studies Quarterly 19.4 (Fall 1989): 705-716.

Pierard, Richard V., and Robert D. Linder. "Jimmy Carter and that Old-Time (Civil) Religion." In Civil Religion and the Presidency. Grand Rapids, Ml: Zondervan Publishing House, 1988, pp. 231-256.

Pippert, Wesley G. The Spiritual Journey of Jimmy Carter: In His Own Words. New York: Macmillan Publishing Company, 1978.

Princen, Tom. "Camp David: Problem-Solving or Power Politics as Usual?" Journal of Peace Research 28.1 (1991): 57-69.

Reichard, Gary W. "Early Returns: Assessing Jimmy Carter." Presidential Studies Quarterly 20.3 (1990): 603-620.

Ribuffo, Leo P. "God and Jimmy Carter." In Transforming Faith: The Sacred and the Secular in Modern American History, eds. M.L. Bradbury and James B. Gilbert. pp. 141-159. New York: Greenwood Press, 1989.

Rose, Gary L. "The Lesson of the Carter Presidency." Chap. in The American Presidency Under Siege. Albany, NY: State University of New York Press, 1997. 
Rosenbaum. Herbert D.. and Alexej Ugrinsky. eds. Jimmy Carter: Foreign Policy and Post-Presidential Years. Westport. CT: Greenwood Press. 1994.

Rozell. Mark J. The Press and the Carter Presidency. Boulder. CO: Westriew Press. 1989.

Rozell. Mark J. "President Carter and the Press: Perspectives from White House Communications Advisers." Political Science Quarterly 105.3 (Autumn 1990): $419-434$.

Sanchez. J.M. "Awaiting Rehabilitation: The Carter Presidency in Political Science Textbooks." Presidential Studies Quarterly 27.2 (1997): 284-296.

Schram. Martin. Running for President 19-6: The Carter Campaign. New York: Stein and Day. Publishers. 1977.

Shogan. Robert. Promises to Keep: Carter's First Hundred Days. New York: Thomas Y. Crowell Company. 1977.

Skidmore. David. "Carter and the Failure of Foreign Policy Reform." Political Science Quarterly 108.4 (Winter 1993-1994): 699-729.

Smith. Gaddis. "Searching for Peace in the Middle East." Chapter in Morality: Reason and Power: American Diplomacy in the Carter Years. New York: Hill and Wang. 1986. pp. 157-179.

Smith. Gaddis. "Carter's Political Rhetoric." In The Carter Presidency: Fourteen Intimate Perspectives of Jimmy Carter. pp. 199-214.

Smith. Gary Scott. "Jimmy Carter: First Servant of the Nation." Chapter in Faith and the Presidency: From George Wrashington to George II. Bush. New York: Oxford University Press. 2006. pp. 293-324.

Strong. Robert A. "Shuttle Diplomacy: President Carter in the Middle East." Chapter in Horking in the IVorld: Jimmy Carter and the Making of American Foreign Policy: Baton Rouge. LA: Louisiana State University Press. 2000. pp. 183-207.

Stroud. Kandy: How Jimmy Won: The Iictory Campaign from Plains to the white House. New York: William Morrow and Company. 1977.

Troester. Rod. Jimmy Carter as Peacemaker. A Post-Presidential Biography. Westport. CT: Praeger Publishers. 1996.

Turner. Robert W. "I'll Never Lie to You". Jimmy. Carter in His Own Words. New York: Ballantine Books. 1976. 
Updegrove, Mark K. "Jimmy Carter: Peacemaker." Chapter in Second Acts:

Presidential Lives and Legacies After the White House. Guilford, CT: Lyons Press, 2006, pp. 145-177.

Wheeler, Leslie. Jimmy Who? An Examination of Presidential Candidate Jimmy Carter, the Man, His Career, His Stands on the Issues. Woodbury, NY: Barron's, 1976.

Wooten, James. Dasher: The Roots and Rising of Jimmy Carter. New York: Warner Books, 1979.

\section{Other Secondary Sources}

Abramowitz, Alan, and Kyle Saunders. "Why Can't We All Just Get Along? The Reality of a Polarized America." The Forum 3.2 (2005), Article 1.

Ahlstrom, Sydney E. A Religious History of the American People. New Haven, CT: Yale University Press, 1972.

Aikman, David. A Man of Faith: The Spiritual Journey of George W. Bush. Nashville, TN: W Publishing Group, 2004.

Alley, Robert S. So Help Me God: Religion and the Presidency. Wilson to Nixon. Richmond, VA: John Knox Press, 1972.

Ambrose, Stephen E., and Douglas G. Brinkley. Rise to Globalism: American Foreign Policy Since 1938. New York: Penguin Books, 1997.

American Experience: Woodrow Wilson. Transcript Part Two. Narrated by Linda Hunt. Directed and Produced by Carl Byker and Mitch Wilson. WGBH Educational Foundation, 2001, http://www.pbs.org/wgbh/amex/wilson/filmmore/fm_trans2.html, (accessed September 18, 2006).

Astor, Gerald. Presidents at War: From Truman to Bush, The Gathering of Military Power to Our Commanders in Chief. Hoboken, NJ: John Wiley and Sons, 2006.

Auchincloss, Louis. Woodrow Wilson. New York: Viking-Penguin Group, 2000.

Balmer, Randall. Mine Eyes Have Seen the Glory: A Journey into the Evangelical Subculture in America. New York: Oxford University Press, 1989.

Balmer, Randall. Encyclopedia of Evangelicalism. Louisville, KY: Westminster John Knox Press, 2002. 
The Baptist Faith and Message. Nashrille. TN: The Sunday School Board of the Southern Baptist Convention. 1963.

Barber. James David. The Presidential Character: Predicting Performance in the thite House. Saddle River. NJ: Prentice Hall. 1992.

Bass. Jack. and Walter DeVries. The Transformation of Southern Politics: Social Change and Political Consequence Since 1945. New York: Basic Books. 1977.

Belhassen. Yaniva. and Carla Almeida Santos. "An American Evangelical Pilgrimage to Israel: A Case Study on Politics and Triangulation." Journal of Travel Research +4 (May 2006): 431-441.

Bellah. Robert N. "Civil Religion in America." In Religion in America. ed. George C. Bedell. Leo Sandon. Jr.. and Charles T. Wellborn. pp. 24-32. New York: Macmillan Publishing Company. 1982.

Bellah. Robert N.. Richard Madsen. William M. Sullivan. Ann Swidler. and Steven M. Tipton. The Good Societr. New York: Vintage Books. 1992.

Bellah. Robert N.. Richard Madsen. William M. Sullivan. Ann Swidler, and Steren M. Tipton. Habits of the Heart: Individualism and Commitment in American Life. New York: Vintage Books. 1992.

Benson. Peter L.. and Dorothy L. Williams. Religion on Capitol Hill: Myths and Realities. New York: Harper and Row. 1982.

Berger. Peter L. "Religion and the West." National Interest (Summer 2005).

Berggren. D. Jason. "Obstacles to an Alliance: Muslims and the Christian Right." Middle East Affairs Joumal 9.1-2 (Winter Spring 2003): 87-122.

Berggren. D. Jason. “More Proud Being Southern: Jimmy Carter and Southern Identity." Paper presented at the 2006 Citadel Symposium on Southern Politics in Charleston. South Carolina.

Berggren. D. Jason. and Nicol C. Rae. "The American South: The 'Bible Belt' of America (and the Western World?)." Paper presented at the 2006 Annual Meeting of the Southern Political Science Association in Atlanta. Georgia.

Billington. Monroe. "Lyndon B. Johnson: The Religion of a Politician." Presidential Studies Quarterly· 17.3 (Summer 1987): 519-530.

Blais. Andre. To I'ote or . Yot to I'ote: The Merits and Limits of Rational Choice Theorn. Pittsburgh. PA: Lniversity of Pittsburgh Press. 2000. 
Bloesch, Donald G. The Evangelical Resurgence. Grand Rapids, MI: William B. Eerdmans Publishing Company, 1973.

Boller, Paul F., Jr. Presidential Campaigns. New York: Oxford University Press, 1996.

Boyer, Paul. When Time Shall Be No More: Prophecy Belief in Modern American Culture. Cambridge, MA: Harvard University Press, 1992.

Brands, H.W. Woodrow Wilson. New York: Times Books, 2003.

Brooks, David. "How Niebuhr Helps Us Kick the Secularist Habit: A Six-Step Program." In One Electorate Under God? A Dialogue on Religion and American Politics, eds. E.J. Dionne, Jr., Jean Bethke Elshtain, and Kayla M. Drogosz, pp. 67-71. Washington, DC: Brookings Institution Press, 2004.

Bruce, Steve. Pray TV: Televangelism in America. London, UK: Routledge, 1990.

Bruce, Steve. The Rise and Fall of the New Christian Right: Conservative Protestant Politics in America, 1978-1988. Oxford, UK: Clarendon Paperbacks, 1990.

Bulman, Raymond F. "'Myth of Origin,' Civil Religion and Presidential Politics." Journal of Church and State 33.3 (Summer 1991): 525-539.

Burke, John P. The Institutional Presidency: Organizing and Managing the White House from FDR to Clinton. Baltimore, MD: The Johns Hopkins University Press, 2000.

Burke, Richard E., with William and Marilyn Hoffer. The Senator: My Ten Years with Ted Kennedy. New York: St. Martin’s Press, 1992.

Busby, Russ. Billy Graham: God's Ambassador. San Diego, CA: W Publishing Group, 1999.

Byrnes, Timothy A. Catholic Bishops in American Politics. Princeton, NJ: Princeton University Press, 1991.

Cairncross, Frances. "The God Gulf." Index on Censorship 33.4 (October 2004).

Campbell, Colin, and Bert A. Rockman, eds. The Clinton Legacy. New York: Chatham House Publishers, 2000.

Caro, Robert A. Master of the Senate: The Years of Lyndon Johnson. New York: Alfred A. Knopf, 2002. 
Carter. Stephen L. The Culture of Disbelief: How American Law and Politics Trivialize Religious Devotion. New York: Basic Books. 1993.

Ceaser. James W.. and Andrew E. Busch. The Perfect Tie: The True Story of the 2000 Presidential Election. Lanham. .MD: Rowman \& Littlefield Publishers. Inc.. 2001.

Chace. James. "Imperial America and the Common Interest." Horld Policy Journal (Spring 2002): 1-9.

Cherny. Robert W. A Righteous Cause: The Life of Hilliam Jennings Bryan. Norman. OK: Lniversity of Oklahoma Press. 1994.

Chidester. David. Patterns of Pover: Religion and Politics in American Culture. Englewood Cliffs. NJ: Prentice- Hall. Inc.. 1988.

Chronicle of the 201" Century. Mount Kisco. NY: Chronicle Publications. 1987.

Clausen. Christopher. "America s Design for Tolerance." Irilson Quarterly 31.1 (Winter 2007): 26-32.

Clements. Kendrick A. Woodrow Wilson: Horld Statesman. Chicago. IL: Iran R. Dee. 1999.

Clymer. Adam. Edward M. Kennedy: A Biography. New York: HarperCollins. 1999.

Cochran. Augustus B.. III. Democracy Heading South: Yational Politics in the Shadow of Dixie. Lawrence. KS: Lniversity Press of Kansas. 2001.

Coletta. Paolo E. IHilliam Jennings Bryan: Political Evangelist. 1860-1908. Lincoln. XE: Lniversity of Nebraska Press. 1964.

Corbett. Michael. and Julia Mitchell Corbett. Politics and Religion in the Lnited States. New York: Garland Publishing. 1999.

Cornog. Evan. The Power and the Story: How the Crafted Presidential Varrative Has Determined Political Success from George Hashington to George II: Bush. New York: Penguin Press. 2004.

Cronin. Thomas E. "The Symbolic and Shamanistic Functions of the American Presidency." The Political Chronicle 1.2 (September 1989): 8-13.

Cronin. Thomas E.. and Michael A. Genorese. The Paradoxes of the Americun Presidency: New York: Oxford Lniversity Press. 1998. 
Crotty, William J., and Gary C. Jacobson. American Parties in Decline. Boston, MA: Little, Brown and Company, 1980.

Cunningham, Lawrence S., and John Kelsay. The Sacred Quest: An Invitation to the Study of Religion. Third Edition. Upper Saddle River, NJ: Prentice-Hall, 2002.

Dalin, David G., and Alfred J. Kolatch. The Presidents of the United States and the Jews. Middle Village, NY: Jonathan David Publishers, 2000.

Dallek, Robert. "Woodrow Wilson, Politician." The Wilson Quarterly (Autumn 1991): 106-114.

Davie, Grace. "Believing Without Belonging: Just How Secular is Europe?" The Pew Forum on Religion and Public Life, December 5, 2005, Key West, Florida, Event Transcript, http://pewforum.org/events (accessed March 16, 2006).

Davis, Derek H. "Thoughts on the Separation of Church and State under the Administration of President George W. Bush." Journal of Church and State 45.2 (Spring 2003): 229-235.

Dayton, Donald W. "Some Doubts about the Usefulness of the Category 'Evangelical"." In The Variety of American Evangelicalism, edited by. Donald W. Dayton and Robert K. Johnston, pp. 245-251. Downers Grove, IL: InterVarsity Press, 1991.

Deckman, Melissa. "Religion Makes the Difference: Why Christian Right Candidates Run for School Board." Review of Religious Research 42.4 (2001): 349-371.

Deering, Christopher J., and Steven S. Smith. Committees in Congress. Washington, DC: Congressional Quarterly Press, 1997.

DeGregorio, William A. The Complete Books of U.S. Presidents: From George Washington to George W. Bush. New York: Barnes and Nobles Books, 2004.

Dent, Harry S. The Prodigal South Returns to Power. New York: John Wiley and Sons, 1978.

De Tocqueville, Alexis. Democracy in America. Edited and Abridged by Richard D. Heffner. New York: Penguin Books, 1984.

Diamond, Sara. Spiritual Warfare: The Politics of the C'hristian Right. Boston, MA: South End Press, 1989.

Djupe, Paul, and Laura Olson, eds. Encyclopedia of American Religion and Politics. New York: Facts on File, Inc., 2003. 
Dunn. Charles W. "The Theological Dimensions of Presidential Leadership: A Classification .Model." Presidential Studies Quarterly 14.1 (Winter 1984): $61-72$.

Ellis. Richard J.. and Mark Dedrick. "The Rise of the Rhetorical Candidate." In The Presidency Then and Yow. ed. Phillip G. Henderson. pp. 185-200. Lanham. MD: Rowman \& Littlefield Publishers. 2000.

Genovese. Michael A. The Presidential Dilemma: Leadership in the American System. New York: HarperCollins. 1995.

George. Alexander L.. and Juliette L. George. Woodrow Wilson and Colonel House: A Personality Studr. New York: Dover Publications. 1964.

Fairbanks. James David. "The Religious Dimensions of Presidential Leadership: The Case of Dwight Eisenhower." Presidential Studies Quarterly 12.2 (Spring 1982): 260-267.

Falwell. Jerry. Listen. America!.' New York: Bantam Books. 1980.

Farrell. John A. Tip O Yeill and the Democratic Century. Boston. M.A: Little. Brown and Company. 2001.

Fenno. Richard F.. Ir. Home Strle: House Members and Their Districts. Boston. MA: Little. Brown and Company. 1978.

Fenno. Richard F.. Ir. Congress at the Grassroots: Representational Change in the South. 19-0-1998. Chapel Hill. IC: The Lniversity of Xorth Carolina Press. 2000 .

Fiorina. Morris P. Congress: Keystone of the IFashington Establishment. New Haven. CT: Yale Lniversity Press. 1989.

Fiorina. Morris P. with Samuel J. Abrams and Jeremy C. Pope. Culture IFar? The . Wyth of a Polarized America. New York: Longman. 2005.

Fisher. Louis. Presidential Irar Power. Lawrence. KS: Lniversity of Kansas Press. 1995.

Fleisher. Richard. and Jon R. Bond. "Partisanship and the President 's Quest for Votes on the Floor of Congress." In Polarized Politics: Congress and the President in a Partisan Era. ed. Jon R. Bond and Richard Fleisher. pp. 154-185. Washington. DC: Congressional Quarterly Inc.. 2000. 
Forman, Ira N. "The Politics of Minority Consciousness: The Historical Voting Behavior of American Jews." In Jews in American Politics, eds. L. Sandy Maisel and Ira N. Forman, pp. 141-160. Lanham, MD: Rowman \& Littlefield Publishers, 2001.

Fowler, Robert Booth. A New Engagement: Evangelical Political Thought, 1966-1976. Grand Rapids, MI: William B. Eerdmans Publishing Company, 1982.

Fowler, Robert Booth. Religion and Politics in America. Metuchen, NJ: The Scarecrow Press, 1985.

Fowler, Robert Booth, and Allen D. Hertzke. Religion and Politics in America: Faith, Culture, and Strategic Choices. Boulder, CO: Westview Press, 1995.

Fowler, Robert Booth, Allen D. Hertzke, and Laura R. Olson. Religion and Politics in America: Faith, Culture, and Strategic Choices. Boulder, CO: Westview Press, 1999.

Freud, Sigmund. The Future of an Illusion. Translated and Edited by James Strachey. Introduction by Peter Gay. New York: W.W. Norton and Company, 1989.

Gahl, Leslie L. "Moral Courage: The Essence of Leadership." Presidential Studies Quarterly 14.1 (Winter 1984): 43-52.

Gallup, George, Jr., and D. Michael Lindsay. Surveying the Religious Landscape: Trends in U.S. Beliefs. Harrisburg, PA: Morehouse Publishing, 1999.

Gamble, Richard M. "Savior Nation: Woodrow Wilson and the Gospel of Service." Humanitas 14.1 (2001): 4-22.

Gillon, Steve M. The Democrats' Dilemma: Walter F. Mondale and the Liberal Legacy. New York: Columbia University Press, 1992.

Goldberg, Bernard. 100 People Who Are Screwing Up America. New York: HarperCollins, 2005.

Goldberg, J.J. Jewish Power: Inside the American Jewish Establishment. Reading, MA: Addison-Wesley, 1996.

Goldman, Peter, and Tony Fuller. The Quest for the Presidency, 1984. New York: Bantam Books, 1985.

Gould, Lewis L. The Modern American Presidency. Lawrence, KS: University Press of Kansas, 2003. 
Graham. Billy. A Biblical Standard for Evangelists. Minneapolis. MN: World Wide Publications. 1984.

Graham. Billy. Living in God's Love: The Yew York Crusade. New York: G.P. Putnam s Sons. 2005.

Grantham. Dewey. W. Southern Progressivism: The Reconciliation of Progress and Tradition. Knoxville. TX: Lniversity of Tennessee Press. 1983.

Green. John C.. and James L. Guth. "Rehigion. Representatives. and Roll Calls." Legislative Studies Quarterly 16.4 (November 1991): $571-584$.

Green. John C.. L!man A. Kellstedt. Corwin E. Smidt. and James L. Guth. “The Soul of the South: Religion and the New Electoral Order." In The . Vew Politics of the Old South: An Introduction to Southern Politics. edited by Charles S. Bullock and Mark J. Rozell. pp. 261-276. Lanham. MD: Rowman and Littlefield Publishers. 1998.

Greenberg. Anna. and Jennifer Berktold. "Evangelicals in America." Washington. DC: Greenberg. Quinlan. Rosner Research Inc. Prepared for Religion and Ethics lewsweekl: 2004.

Greenstein. Fred I. The Hidden-Hand Presidenc1: Eisenhower as Leader. New York: Basic Books. 1982.

Greenstein. Fred I. The Presidential Difference: Leadership Style from FDR to Clinton. Princeton. NJ: Princeton Lniversity Press. 2000.

Greenstein. Fred I. "George W. Bush and the Ghosts of Presidents Past." PS: Political Science and Politics 34.1 (.March 2001): 77-80.

Greenstein. Fred I. "The Changing Leadership of George W. Bush: A Pre- and Post911 Comparison." The Forum 1.1 (2002). Article 6.

Greenstein. Fred I. "George W. Bush and the Politics of Agenda Control." Chapter in The Presidential Difference: Leadership Style from FDR to George It: Bush (2 $2^{\text {nd }}$ Edition: Princeton. NJ: Princeton Lniversity Press. 2004). pp. 190-210.

Greenstein. Fred I. "The Person of the President. Leadership. and Greatness." In The Executive Branch. edited by Joel D. Aberbach and Mark A. Peterson. Institutions of American Democracy series. New York: Oxford Lniversity Press. 2005. pp. 218-240. 
Greenstein, Fred I. "Presidential Difference in the Early Republic: The Highly Disparate Leadership Styles of Washington, Adams, and Jefferson." Presidential Studies Quarterly 36.3 (2006): 373-390.

Grimmett, Richard F. "Instances of Use of United States Armed Forces Abroad, 17982001." CRS Report for Congress. Published by the Congressional Research Service and the Library of Congress, February 5, 2002.

Guth, James L. "The Confessional Congress: Religion and Legislative Behavior." Paper presented at the 2005 annual meeting of the Southern Political Science Association.

Halsell, Grace. Forcing God's Hand: Why Millions Pray for a Quick Rapture---And Destruction of Planet Earth. Revised Edition. Beltsville, MD: Amana Publications, 2003.

Handy, Robert T. A Christian America: Protestant Hopes and Historical Realities. New York: Oxford University Press, 1984.

Hargrove, Erwin C. The President as Leader: Appealing to the Better Angels of Our Nature. Lawrence, KS: University of Kansas Press, 1998.

Hargrove, Erwin C., and Michael Nelson. Presidents, Politics, and Policy. New York: Alfred A. Knopf, 1984.

Hartz, Louis. The Liberal Tradition in America. Orlando, FL Harcourt Brace \& Company, 1991. Originally Published in 1955.

Henry, Carl. Carl Henry at His Best: A Lifetime of Quotable Thoughts. Edited by Steve Halliday and Al Janssen. Portland, OR: Multnomah Press, 1989.

Herrera, Richard. "The Crosswinds of Change: Sources of Change in the Democratic and Republican Parties." Political Research Quarterly 48.2 (June 1995): 291 312.

Hersh, Burton. The Shadow President: Ted Kennedy in Opposition. South Royalton, VT: Steerforth Press, 1997.

Hershey, Marjorie Randon. Party Politics in America. New York: Longman, 2005.

Hofstadter, Richard. Anti-Intellectualism in American Life. New York: Vintage Books, 1963. 
Holmes. Jack E.. and Robert E. Elder. Jr. "Our Best and Worst Presidents: Some Possible Reasons for Perceived Performance." Presidential Studies Quarterly. 19.3 (1989): $529-557$.

Howe. Daniel Walker. "Religion and Politics in the Antebellum North." In Religion and American Politics: From the Colonial Period to the 1980s. ed. Mark A. Noll. pp. 121-145. New York: Oxford Lniversity Press. 1990.

Huckfeldt. Robert. Eric Plutzer. and John Sprague. "Alternative Contexts of Political Behavior: Churches. Neighborhoods. and Individuals." Journal of Politics 55.2 (May 1993): 365-381.

Hudson. Winthrop S. Religion in America. New York: Macmillan Publishing Company. 1987.

Hunter. James Davison. American Evangelicalism: Conservative Religion and the Quandary of Modernity. New Brunswick. NJ: Rutgers Lniversity Press. 1983.

Hunter. James Davison. “The Evangelical Worldriew Since 1890." In Piety and Politics: Evangelicals and Fundamentalists Confront the Forld. edited by Richard John Neuhaus and Michael Cromartie. pp. 19-53. Washington. DC: Ethics and Public Policy Center. 1987.

Huntington. Samuel P. "Political Modernization: America rs. Europe." Chap. in Political Order in Changing Societies. New Haven. CT: Yale Lniversity Press. 1968. pp. 93-139.

Huntington. Samuel P. "The Lnited States." In The Crisis of Democracy. ed. Michael Crozier. Samuel P. Huntington. and Joji Watanuki. pp. 59-118. New York: Yew York Lniversity. Press. 1975.

Huntington. Samuel P. American Politics: The Promise of Disharmony: Cambridge. M.A: The Belknap Press of Harvard Lniversity Press. 1981.

Hutcheson. Richard G.. Ir.. God in the IThite House: How Religion Has Changed the Modem Presidency. New York: Collier Books. 1988.

Inglehart. Ronald. Modernization and Postmodernization: Cultural. Economic: and Political Change in +3 Societies. Princeton. NJ. Princeton Lniversity Press. 1997.

Jacobson. Gary C. A Divider. Yot a Lniter: George II: Bush and the American People. New York: Longman. 2006. 
Jacobson, Gary C. "The Polls: Polarized Opinion in the States: Partisan Differences in Approval Ratings of Governors, Senators, and George W. Bush." Presidential Studies Quarterly 36.4 (December 2006): 732-757.

Jewell, Elizabeth. U.S. Presidents Factbook. New York: Randon House Reference, 2005.

Johnston, Robert K. "American Evangelicalism: An Extended Family." In The Variety of American Evangelicalism, pp. 252-272.

Judis, John B., and Ruy Teixeira. The Emerging Democratic Majority. New York: Scribner, 2002.

Karawan, Ibrahim A. "Sadat and the Egyptian-Israeli Peace Revisited." International Journal of Middle East Studies 26 (1994): 249-266.

Kazin, Michael. A Godly Hero: The Life of William Jennings Bryan. New York: Alfred A. Knopf, 2006.

Kellstedt, Lyman A. "The Meaning and Measurement of Evangelicalism: Problems and Prospects." In Religion and Political Behavior in the United States, edited by Ted G. Jelen, 3-22. New York: Praeger Publishers, 1989.

Kengor, Paul. "A Political Vice President: Walter Mondale (1977-1981)." Chap. in Wreath Layer or Policy Player? The Vice President's Role in Foreign Policy. Lanham, MD: Lexington Books, 2000, pp. 83-123.

Kengor, Paul. "God \& W. at 1600 Penn." National Review, March 5, 2003.

Kengor, Paul. God and George W. Bush: A Spiritual Life. New York: Regan Books, 2004.

Kenney, Patrick J., and Tom W. Rice. "The Contextual Determinants of Presidential Greatness." Presidential Studies Quarterly 18.1 (1988): 161-169.

Kernell, Samuel. Going Public: New Strategies of Presidential Leadership. Washington, DC: Congressional Quarterly Press, 1997.

Khan, M.A. Muqtedar. "The Myth of Secularism." In One Electorate Under God? A Dialogue on Religion and American Politics, pp. 134-139.

King, Anthony. "Distrust of Government: Explaining American Exceptionalism." In Disaffected Democracies: What's Troubling the Trilateral Countries?, ed. Susan J. Pharr and Robert D. Putnam, pp. 74-98. Princeton, NJ: Princeton University Press, 2000. 
Kingdon. John W. America the Lnusual. New York: Worth Publishers. Inc.. 1999.

Klein. Joe. The Yatural: The Misunderstood Presidency of Bill Clinton. New York: Broadway Books. 2002.

Koopman. Doug. "Religion and American Political Parties." In In God the Trust?" Religion and American Political Life. edited by Corwin E. Smidt. pp. 1+2-160. Grand Rapids. .II: Baker Book House Company. 2001.

Kradel. Adam. "God on Our Side: The Religious Rhetoric of Recent U.S. Presidents." Paper presented at the Annual Meeting of the American Political Science Association. September 2004. Chicago. Illinois.

Kunhardt. Philip B.. Jr.. Philip B. Kunhardt III. and Peter W. Kunhardt. The tmerican President. New York: Riverhead Books. 1999.

Kydd. Andrew H. "When Can .Mediators Build Trust?". American Political Science Review 100.3 (August 2006): 4+9-462.

Lawrence. Bruce R. Defenders of God: The Fundamentalist Rerolt tgainst the Iodern Age. San Francisco. C.A: Harper \& Row. 1989.

Leonard. Bill J. God's Last and Only Hope: The Fragmentation of the Southern Baptist Convention. Grand Rapids. MI: William B. Eerdmans Publishing Company. 1990.

Levine. Lawrence IV. Defender of the Faith: Itilliam Jennings Brian. the Last Decade. 1915-1925. New York: Oxford Lniversity Press. 1965.

Linder. Doug. "William Jennings Bryan (1860-1925)."

http: w7w. law.umkc.edu facults projects ftrials scopes brvanw.htm (accessed October 18. 2006).

Lipset. Seymour Martin. The First Yew Yation: The Lnited States in Historical and Comparative Perspective. Garden City. NY: Anchor Books. 1967.

Lipset. Sermour Martin. Continental Divide: The I alues and Institutions of the Lited States and Canada. New York: Routledge. 1990.

Lipset. Seymour Martin. American Exceptionalism: A Double-Edged Sword. New York: H.W. Norton \& Company. 1996.

Lipset. Seymour Martin. and Earl Raab. Jews and the Yew American Scene. Cambridge. MA: Harvard Lniversity Press. 1995. 
Livingston, James C. Anatomy of the Sacred: An Introduction to Religion. $4^{\text {th }}$ Edition. Upper Saddle River, NJ: Prentice-Hall, 2001.

Lonnstrom, Douglas A., and Thomas O. Kelly II. "Rating the Presidents: A Tracking Study." Presidential Studies Quarterly 33.3 (September 2003): 625-634.

Lowi, Theodore J. The Personal President: Power Invested, Promise Unfulfilled. Ithaca, NY: Cornell University Press, 1985.

MacMillan, Margaret. Paris 1919: Six Months that Changed the World. American Edition; New York: Random House, 2003.

Mahmood, Zahid. "Sadat and Camp David Reappraised." Journal of Palestine Studies 15.1 (Autumn 1985): 62-87

Mansfield, Stephen. The Faith of George W. Bush. New York: Tarcher/Penguin, 2003.

Marsden, George M. Fundamentalism and American Culture: The Shaping of Twentieth-Century Evangelicalism, 1870-1925. New York: Oxford University Press, 1980.

Marsden, George M. "The Evangelical Denomination." In Piety and Politics: Evangelicals and Fundamentalists Confront the World, pp. 55-68.

Marsden, George M. "Contemporary American Evangelicalism." In Southern Baptists and American Evangelicals: The Conversation Continues, edited by David S. Dockery, pp. 27-39. Nashville, TN: Broadman \& Holman Publishers, 1993.

Mathiopoulos, Margarita. "The American President Seen Through German EyesContinuity and Change from the Adenauer to the Kohl Era." Presidential Studies Quarterly 15.4 (Fall 1985): 673-706.

Marty, Martin E., and R. Scott Appleby. The Glory and the Power: The Fundamentalist Challenge to the Modern World. Boston, MA: Beacon Press, 1992.

Mayer, Kenneth R., and Kevin Price. "Unilateral Presidential Powers: Significant Executive Orders, 1949-1999." Presidential Studies Quarterly 32.2 (June 2002): 367-386.

Mayer, William G. The Divided Democrats: Ideological Unity, Party Reform, and Presidential Elections. Boulder, CO: Westview Press, 1996.

Mayhew, David R. Congress: The Electoral Connection. New Haven, CT: Yale University Press, 1974. 
Marhew. David R. Divided We Govern: Party Control. Lawmaking. and Imestigations. 1946-1990. New Haven. CT: Yale Lniversity Press. 1991.

McClay. Wilfred M. "Two Concepts of Secularism." The Irilson Quarterly 24.3 (Summer 2000).

McDonald. Forrest. The American Presidency: An Intellectual History. Lawrence. KS: University of Kansas Press. 1994.

McGrath. Alister. Evangelicalism and the Future of Christianity. Downers Grove. IL: InterVarsity Press. 1995

McLoughlin. William G. The American Evangelicals. 1800-1900. New York: Harper \& Row Publishers. 1968.

McLoughlin. William G. Revivals Awakenings and Reform. An Essar on Religion and Social Change in America. $160^{-}-19^{--}$. Chicago. IL: Lniversity of Chicago Press. 1978.

Mead. Sidney. E. The Yation with the Soul of a Church. Macon. GA: Mercer Lniversity Press. 1985.

Meagher. Michael. "Fear and Malaise: The Impact of Words in Presidential Leadership." White House Studies (Winter 2006).

Menefee-Libey. David. The Triumph of Campaign-Centered Politics. New York: Chatham House Publishers. 2000.

Menendez. Albert J. Evangelicals at the Ballot Box. Amherst. NY: Prometheus Books. 1996.

Merkley. Paul Charles. American Presidents. Religion and Israel: The Heirs of Cyrus. Westport. CT: Praeger Publishers. 2004.

Milkis. Sidney M. The President and the Parties: The Transformation of the American Party Sistem Since the Vew Deal. New York: Oxford Lniversity Press. 1993.

Milkis. Sidney. M.. and Michael Yelson. The American Presidency: Origins and Development. 1--6-2002. Washington. DC: Congressional Quarterly Press. 2003.

Moen. Matthew C. The Transformation of the Christian Right. Tuscaloosa. AL: Lniversity of Alabama Press. 1992. 
Moore, R. Laurence. Touchdown Jesus: The Mixing of Sacred and Secular in American History. Louisville, KY: Westminster John Knox Press, 2003.

Morone, James A. Hellfire Nation: The Politics of Sin in American History. New Haven, CT: Yale University Press, 2003.

Muller, Steven. "Time to Kill-Employment in Europe." National Interest (Summer 1997).

Nash, Ronald H. Evangelicals in America: Who They Are, What They Believe. Nashville, TN: Abingdon Press, 1987.

Nelson, Michael. "Evaluating the Presidency." In The Presidency and the Political System, ed. Michael Nelson, pp. 1-26. Washington, DC: CQ Press, 2003.

Neustadt, Richard E. Presidential Power and the Modern Presidents: The Politics of Leadership from Roosevelt to Reagan. New York: The Free Press, 1990.

Niebuhr, H. Richard. The Kingdom of God in America. Middletown, CT: Wesleyan University Press, 1988. Originally Published in 1937.

Niebuhr, H. Richard Christ and Culture. New York: Harper and Row Publishers, 1951.

Noll, Mark A. "Foreword." In Southern Baptists and American Evangelicals: The Conversation Continues, pp. x-xiv.

Noll, Mark A. "Understanding American Evangelicals." Lecture delivered at the Ethics and Public Policy Center, Washington, DC, December 8, 2003, transcript available at the Ethics and Public Policy Center website, http://www.eppc.org/publications/pubID.1943/pub_detail.asp.

Noll, Mark A. "Interview with Judy Valente." Religious \& Ethics Newsweekly, April 16, 2004, Episode no. 733, http://www.pbs.org/wnet/religionandethics/week733/interview.html.

Norris, Pippa, and Ronald Inglehart. Sacred and Secular: Religion and Politics Worldwide. New York: Cambridge University Press, 2004.

Olasky, Marvin. The American Leadership Tradition: The Invevitable Impact of a Leader's Faith on a Nation's Destiny. Wheaton, IL: Crossway Books, 1999.

Olson, Laura R., and John C. Green. "The Religion Gap." PS: Political Science and Politics 39.3 (July 2006): 455-459. 
Paden. William E. Interpreting the Sacred: Ways of liewing Religion. Boston. MA: Beacon Press. 1992.

PBS Frontline: The Jesus Factor. Narrated by Will Lyman. Written. produced. and directed by Raney Aronson. WGBH Educational Foundation. 2004. http: WwW pbs.org wghh pages frontline shows jesus etc script.html. (accessed May 25.2004).

Ptiffner. James P. The Strategic Presidency: Hitting the Ground Running. Chicago. IL: Dorsey Press. 1988.

Pfiffner. James P. The Modern Presidency. New York: St. Martin`s Press. 1994.

Pfiffner. James P. The Character Factor: How We Judge America's Presidents. College Station. TX: Texas A\&M Lniversity Press. 2004.

Pierard. Richard V. "Evangelicals and the Bicentennial." The Reformed Journal (October 1976).

Pika. Joseph A.. John Anthony Maltese. and Norman C. Thomas. The Politics of the Presidencr: $5^{\text {th }}$ edition. Washington. DC: Congressional Quarterly Press. 2002.

Posner. Richard A. "Morality. Private and Public." Chap. in .An Affair of State: The Investigation. Impeachment. and Trial of President Clinton. Cambridge. MA: Harvard Lniversity Press. 1999. pp. 133-169.

Putnam. Robert D. Bowling .Alone: The Collapse and Reviral of American Community. New York: Simon and Schuster. 2000.

Rae. Nicol C. Southern Democrats. New York: Oxford University Press. 1994.

Ragsdale. Lyn. I'ital Statistics on the Presidency: Hashington to Clinton. Washington. DC: Congressional Quarterly Press. 1998.

Reichler. A. James. "Religion and the Future of American Politics." Political Science Quarterly 101.1 (I986): 23-47.

Reichley. A. James. The Life of the Parties: A History of American Political Parties. Lanham. MD: Rowman \& Littlefield Publishers. 2000.

Reichley. A. James. Faith in Politics. Washington. DC: Brookings Institution Press. 2002.

Rhodes. Terrel L. Republicans in the South: I'oting for the State House. I'oting for the Ithite House. Westport. CT: Praeger Publishers. 2000. 
Roberts, John B., II. Rating the First Ladies: The Women Who Influenced the Presidency. New York: Citadel Press Books, 2003.

Rohde, David W. Parties and Leaders in the Postreform House. Chicago, 1L: University of Chicago Press, 1991.

Rose, Richard. The Postmodern President: George Bush Meets the World. Chatham, NJ: Chatham House Publishers, 1991.

Rosenberg, Ellen M. The Southern Baptists: A Subculture in Transition. Knoxville, TN: The University of Tennessee Press, 1989.

Rothenberg, Stuart. "Evangelicals Are Politically Diverse." In Piety and Politics: Evangelicals and Fundamentalists Confront the World, pp.321-326.

Rubenzer, Steven J., and Thomas R. Faschingbauer. Personality, Character, and Leadership in the White House: Psychologists Assess the Presidents. Washington, DC: Brassey's Inc., 2004.

Sabato, Larry J., and Bruce Larson. The Party's Just Begun: Shaping Political Parties for America's Future. New York: Longman, 2002.

Said, Edward W. The Question of Palestine. New York: Vintage Books, 1979.

Schlesinger, Arthur, Jr. "Human Rights and the American Tradition." Foreign Affairs 57.3 (1979): 503-526.

Schlesinger, Arthur M., Jr., "Rating the Presidents: Washington to Clinton." In Jeffrey Cohen and David Nice, eds., The Presidency: Classic and Contemporary Readings, pp.89-100. New York: McGraw-Hill, 2003.

Schultz, Jeffrey D., John G. West, and Ian Maclean, eds. Encyclopedia of Religion in American Politics. Phoenix, AZ: Oryx Press, 1999.

Schultze, Quentin J. "Introduction." In American Evangelicals and the Mass Media, edited by Quentin J. Schultze, pp. 13-20. Grand Rapids, MI: Academie Books, 1990.

Shafer, Byron E. "The Notion of an Electoral Order." In The End of Realignment?: Interpreting American Electoral Eras, ed. Byron E. Shafer, pp. 37-84. Madison, WI: The University of Wisconsin Press, 1991.

Shields-West, Eileen. The World Almanac of Presidential Campaigns. New York: World Almanac, 1992. 
Shogan. Colleen J. The . Yoral Rhetoric of American Presidents. College Station. TX: Texas A\&.11 L'niversity Press. 2006.

Simes. Dimitri K. "End the Crusade." Vational Interest 87 (January February 2007): t-11.

Sinclair. Barbara. Legislators. Leaders. and Lawmaking: The L:S. House of Representatives in the Postreform Era. Baltimore. MD: The Johns Hopkins Lniversity Press. 1995.

Sinclair. Barbara. Lnorthodox Lawmaking: lew Legislative Processes in the L'.S. Congress. Washington. DC: Congressional Quarterly Press. 2000.

Skowronek. Stephen. The Politics Presidents Make: Leadership from John Adams to Bill Clinton. Cambridge. M.A: Harrard Lniversity Press. 1997.

Skowronek. Stephen. "Presidential Leadership in Political Time." In The Presidenc. and the Political Sistem. ed. Michael Nelson. pp. 111-157. Washington. DC: CQ Press. 2003.

Smart. Ninian. Horldriews: Crosscultural Explorations of Human Beliets. New York: Charles Scribner`s Sons. 1983.

Smith. Huston. The Itorld's Religions: Our Great Iisdom Traditions. Revised Edition. New York: HarperCollins Publishers. 1991.

Smith. Pamela Ann. "European Leaders Lnhappy with Sadat-Begin Treaty. " IERIP Reports 80 (September 1979): 19-21.

Spalding. Elizabeth Edwards. "True Believers." The II ilson Quarterly 30.2 (Spring 2006): $40-48$.

Spiegel. Steven L. "Israel and Berond: American Jews and L.S. Foreign Policy." In Jews in American Politics. pp. 251-269.

Stone. Walter I.. and Alan I. Abramowitz. "Winning May Not Be Everything. But It's More Than We Thought: Presidential Party Activists in 1980." Americun Political Science Review 77.+ (December 1983): 9+5-956.

Sundquist. James L. Dynamics of the Party System. Alignment and Realignment of Political Parties in the Linited States. Rerised Edition. Washington. DC: The Brookings Institution. 1983. 
Taranto, James, and Leonard Leo, eds. Presidential Leadership: Rating the Best and the Worst in the White House. New York: Wall Street Journal Book/Free Press, 2004.

Telhami, Shibley. "Evaluating Bargaining Performance: The Case of Camp David." Political Science Quarterly 107.4 (Winter 1992-1993): 629-653.

Tillich, Paul. Biblical Religion and the Search for Ultimate Reality. Chicago, IL: University of Chicago Press, 1955.

Tuck, William Powell. Our Baptist Tradition. Macon, GA: Smyth and Helwys Publishing, Inc., 1993.

Tulis, Jeffrey K. "The Two Constitutional Presidencies." In The Presidency and the Political System, ed. Michael Nelson, pp. 79-110. Washington, DC: CQ Press, 2003.

Uslaner, Eric M. "Religion and Civic Engagement in Canada and the United States." Journal for the Scientific Study of Religion 41.2 (2002): 239-254.

"U.S. Military Deployments/Engagements, 1975-2001." Center for Defense, http://www.cdi.org/issues/USForces/deployments.html (accessed November 1, 2004).

"Views from Abroad: Who Won at Camp David?" Journal of Palestine Studies 8.2 (Winter 1979): 168-173.

Voigt, Karsten D. "Religion is the wild card in transatlantic relations." EU Observer, June 16, 2006, http://euobserver.com/7/21839.

Wald, Kenneth D. Religion and Politics in the United States. New York: St. Martin's Press, 1987.

Wald, Kenneth D., Dennis E. Owen, and Samuel S. Hill, Jr., "Churches as Political Communities." American Political Science Review 82.2 (June 1988): 53 I-548.

Wald, Kenneth D., Dennis E. Owen, and Samuel S. Hill, Jr. "Political Cohesion in Churches." Journal of Politics 52.1 (February 1990): 197-215.

Wald, Kenneth D., and Clyde Wilcox. "Getting Religion: Has Political Science Rediscovered the Faith Factor?" American Political Science Review 100.4 (November 2006): 523-529. 
Wallace. Chris. "Mission from God: Woodrow Wilson and the League of Xations." Chapter in Character: Profiles in Presidential Courage. New York: Rugged Land. 2004. pp. 16t-189.

Wallis. Jim. God's Politics: Why the Right Gets It Wrong and the Left Doesn t Get It. New York: HarperCollins Publishers. 2005.

Walz. Jeff. "Religion and the American Presidency." In In God the Trust? Religion and . American Political Life. pp. 191-212.

Warren. Rick. The Purpose-Driven Life: What on Earth tm I Here For?. Grand Rapids. MI: Zonder an Publishing House. 2002.

Wattenberg. Martin P. The Decline of American Political Parties. 1952-1996. Cambridge. MA: Harvard Lniversity Press. 1998.

Wayne. Stephen I. "Great Expectations: What People Want From Presidents." In Rethinking the Presidency. ed. Thomas E. Cronin. pp. 18इ-199. Boston. MA: Little. Brown and Company. 1982.

Weber. Max. "Politics as a Vocation." In From Max Weber: Essals in Sociolog: Edited by H.H. Gerth and C. Wright Mills. New York: Oxford L niversity Press. 1946. pp. 77-128.

Weber. Max. The Protestant Ethic and the Spirit of Capitalism. New York: Charles Scribner"s Sons. 1958.

Wells. Darid. "On Being Erangelical: Some Theological Differences and Similarities." In Evangelicalism: Comparative Studies of Popular Protestantism in . Vorth America. the British Isles. and Belond. 1-og-199r). edited by Mark A. Voll. Darid W. Bebbington. and George A. Rawlyk. pp. 389-410. Vew York: Oxford Lniversity Press. 1994.

Wichham. Dellayne. Bill Clinton and Black America. New York: Ballantine Books. 2002

Wills. Garry. Linder God: Religion and tmericun Politics. New York: Simon and Schuster. 1990.

Witcover. Jules. Marathon: The Pursuit of the Presidency: 19-2-19-6. Хew York: Viking Press. 1977.

II itcover. Jules. Party of the People: A History of the Democrats. New York: Random House. 2003. 
Wolfe, Alan. "What Scholarship Reveals About Politics and Religion." The Chronicle of Higher Education, September 8, 2000, p. B7.

Wolfe, James S. "Exclusion, Fusion, or Dialogue: How Should Religion and Politics Relate?" Journal of Church and State 22 (1980): 89-105.

Woods, Randall B. LBJ: Architect of American Ambition. New York: Free Press, 2006.

Woodward, Bob. Shadow: Five Presidents and the Legacy of Watergate. New York: Simon and Schuster, 1999.

Zoba, Wendy Murray. The Beliefnet Guide to Evangelical Christianity. New York: Three Leaves Press, 2005.

\section{Polling Data}

Allen, Jodie T., and Alec Tyson. "The U.S. Public's Pro-Israel History." Pew Research Center Commentary, July 19, 2006. Available at http://pewresearch.org/pubs/39/the-us-publics-pro-israel-history.

Carroll, Joseph. "George W. Bush Is Most Admired Man in 2004." Gallup Poll News Service, December 29, 2004.

Carroll, Joseph. "Little Impact of Jimmy Carter's Book on the Middle East." Gallup Poll News Service, February 14, 2007.

"Carter Praised for Personal Qualities." The Gallup Opinion Index (December 1980), pp. 56-57.

"The Christianity Today-Gallup Poll: An Overview." Christianity Today, December 21, 1979, I2-15.

"C-SPAN Historian Survey of Presidential Leadership: Relations with Congress, 19992000," http://www.americanpresidents.org/survey/historians/congress.asp.

"GOP, the Religion-Friendly Party." Pew Research Center Report, August 24, 2004, http://people-press.org/reports/.

Jones, Jeffrey M. "Roosevelt, Kennedy Most Positively Rated Recent Presidents." Gallup Poll News Service, June 11, 2004.

Jones, Jeffrey M. "War Through Partisan Lenses." Gallup Poll News Service, November 15, 2005. 
Jones, Jeffrey M. "Bush. Hillary Most Admired. Again." Gallup Poll Verrs Service. December 28. 2005.

Jones. Jeffrey M. "Six in 10 Americans Think L.S. Ready for a Female President: Vast majority think country would not accept atheist or gay president. "Gallup Poll Verrs Service. October 3. 2006.

Jones. Jeffrey .M. "George W. Bush. Hillary Clinton Most Admired Again." Gallup Poll lews Service. December 29. 2006.

"Kosovo." Wrashington Post. June 16. 1999. www.washingtonpost.com. accessed April 16. 2003.

Lyons. Linda. "Religiosity Compass Points South." Gallup Poll Vews Service. Januar! 14. 2003.

"Many Americans Lneasy with Mix of Religion and Politics." Pew Research Center Report. August 24. 2006. http: people-press.org reports.

Yewport. Frank. "Democrats View Religious Groups Less Positively Than Republicans." Gallup Poll Vews Service. September 7. 2006.

Newport. Frank. and Joseph Carroll. "Republicans and Religious Americans Most Sympathetic to Israel." Gallup Poll Vews Service. March 27. 2006.

"Poll Topics At to Z: Religion." Gallup Poll lews Service. Data available at http иาтт.galluppoll.com topics (accessed February 21. 2007).

"Religion a Strength and Weakness for Both Parties." Pew Research Center Report. August 30. 2005. http: people-press.org reports.

"Religion and Politics: Contention and Consensus." Pew Research Center Report. July 24. 2003. http: people-press org reports.

Saad. Lydia. "Holy Land, or Just Ancient?" Gallup Poll Vews Service. July 29. 2003.

Saad. Lydia. "Americans Stand Apart in Support for Israel." Gallup Poll Vews Service. May 31.2005.

Saad. Lydia. "Majority Predicts History Will Judge Bush Harshly." Gallup Poll Vews Service. December 13. 2006.

Saad. Lydia. "Lincoln Resumes Position as Americans" Top-Rated President." Gallup Poll Vews Service. February 19. 2007. 
Saad, Lydia. "Palestinian-Israeli Dispute Engenders American Sympathy for lsraelis." Gallup Poll News Service, March 5, 2007.

Sarkar, Simon. "British Public Divided Over Middle East Conflict." Gallup Poll News Service, May 14, 2002.

Taranto, James. "How's He Doing? Bush is 'average,' but far from ordinary." Wall Street Journal, September 12, 2005.

"U.S. Stands Alone in Its Embrace of Religion." The Pew Global Attitudes Project, December 2002.

Winseman, Albert L. "Bringing Faith into the Voting Booth: Part I." Gallup Poll New's Service, December 9, 2003. 


\title{
APPENDIX I
}

\section{Carter's Writings on Faith, Values, and Peacemaking}

\author{
Books Audio Series on Spiritual Living ( 4$)$
}

Living Faith (1996)

Sources of Strength Meditations on Siripture for a Living Faith (1997)

Leading a Worth Life: Sundor. Mornings in Plains: Bible Stud with Jimm Carter (2007)

Measuring Ou Success: Sundan Mornings in Plains: Bible Study with Jimm Carter (2007)

Books with Religious Themes or Subjects (2)

Christmas in Plains (2001)

Our Endangered ralues: America's. Moral Crisis (2005)

(Entitled British version: Faith and Freedom: The Christian Challenge to the Horld. 2006)

\section{Books on Peacemaking Middle East (5)}

Vegotiation: The Alternative to Hostiliti 11984 )

The Blood of Abrahum: Insights into the . Hiddle East (1985. 1993)

Talking Peace: A l'ision for the lext Generation (1993)

The Vobel Peace Prize Lecture (2002)

Palestine. Peace not tpartheid (2006)

Additional Books that Include Religious. Moral Language in the Title (3)

A Gurernment as Good as Its People (19-7)

Keeping Faith: . Memories of a President (1982)

The lirtues of flging (1998)

Additional Book Chapters on Faith and Values (2)

"Learning About Sin" in An Hour Betrore Danlight 2001 ,

"Sharing My. Faith" in Sharing Good Times 12004)

Contributions to Books on Religion Religion and Politics (3)

"Foreword." God and Caesar on the Potomac. by Father Robert F. Drinan (1985)

"Forew ord." Religion: The . Missing Dimension of Statecraft. edited by Douglas Johnston and C!nthia Sampson (1994)

"Tribute." Bill, Graham \& Tribute From Friends. edited by Vernon McLellan (2002) 
"Rushdie's Book Is an Insult," New York Times (1989)

"First Steps Toward Peace," Newsweek (1990)

"Don't Reject a Cease-Fire," Time (1991)

"Sustained Aid Can Prevent Somalias," Wall Street Journal (1992)

"Time to Lay Down the Trade Weapon," Los Angeles Times (1994)

"Peace Is Everybody's Job," New York Times (1995)

"Don't Prolong the Bloodshed in Bosnia," USA Today (1995)

"The Crisis in Rwanda and Burundi," New York Times (1995)

"A Role for the United Nations in the Next 50 Years," New York Times (1995)

"It's Time to Forgive Pete Rose," USA Today (1995)

"Judge Not," Atlanta Journal-Constitution (1996)

"Offering a Healing Hand; Religious Groups Can Bolster the Health of Their Surrounding Communities,"

Time (1996)

"Prayer and Civic Religion," New York Times (1996)

"Realigning Religious Health Missions," Fort Worth Star-Telegram (1997)

"U.S. Must Take Lead to Ban Land Mines," Christian Science Monitor (1997)

"It's Wrong to Demonize China," New York Times (1997)

"Corporate Giving Is Part of the Solutions Equation," Los Angeles Times (1998)

"Kid Soldiers a War's Most Tragic Victims," USA Today (1998)

"A Time to Heal Our Nation," with Gerald Ford, New York Times (1998)

"Have We Forgotten the Path to Peace?" New York Times (1999)

"A Nuclear Crisis," Washington Post (2000)

"Openings to Cuba: We Must Find a Common Ground," Washington Post (2002)

"The Troubling New Face of America," Washington Post (2002)

"Engaging North Korea," New York Times (2002)

"North Korea: Back to the Framework," Washington Post (2003)

"Just War-or a Just War?" New York Times (2003)

"U.S.-North Korea War Seems 'Strong Possibility'," USA Today (2003)

"Surprisingly Fair Elections in Indonesia," International Herald Tribune (2004)

"Foreword," to Where We Stand: Voices of Southern Dissent, edited by Anthony Dunbar (2004)

"Saving Nonproliferation," Washington Post (2005)

"A Dangerous Deal with India" Washington Post (2006)

"Introduction," to A Moment of Crisis, by Martin Creekmore, Jr. (2006)

"Solving the Korean Stalemate, One Step at a Time," New York Times (2006)

\section{Some Other Writings on Human Rights (9)}

"U.S. Finally Ratifies Human Rights Document," Christian Science Monitor (1992)

"U.S. Can't Point Finger at Others on Human Rights," with Dominique de Menil, USA Todar (1992)

"Get Tough on Rights," New York Times (1993)

"U.S. Should Support World Criminal Court," Los Angeles Times (1996)

"Sadly, People Die as Human Rights Ignored," USA Today (1998)

"The Seeds of a Rights Scandal in Iraq," Washington Post (2004)

"U.S. Should Join the World in Halting Juvenile Executions," USA Today (2004)

"Human Rights Commission Must Change," San Francisco Chronicle (2006)

"Principles Defeat Politics at the U.N.," with Oscar Arias, Kim Dae Jung, Shirin Ebadi, and Desmond

Tutu, New York Times (2006) 


\section{Alleviation of Suffering and Disease. Aid to the Poor (14)}

". Lniversities Can Be of Greatest Benefit by Concentrating on the Third World." Chronicle of Higher. Education (1989)

"The Modern Horror of an Ancient Scourge." Washington Post (1990)

"Children Wait on World's Promises." Christian Suizuce Monitor (1991)

"Put Children First." Christian Sulence. Monitur 11992,

"Fragmented Aid Leaves Africa Hungry." LS.t Todon (1993)

"Making Global Development Aid Effective." Brown Journal of Horld Affairs (1994)

"Food. Health Programs Lead to Peace in Sudan." Vew York Times (1995)

"T.AP: The Power of a Project." Atlanta Journal-Constitution (1995)

"Vew Farm Techniques Spur Ethiopia"s Rebirth." LS.A Todar (1997)

"A Former President"s Plea to Curb AIDS in Africa." International Herald Tribune (2000)

"A Tale of Two Worlds." Foreword to Impact: From the Frontines to Glohal Health 2003 ,

"Inequitable Resources. Benefits Put World at Rish." LS.t Todan (2004)

"Longstanding Disaster Threats Can't Be Ignored." (S.t Todan (2005)

"Food for Thought." with Xorman Borlaug. Wall Street Journal (2005)

\section{Writings on Middle East Peace (21)}

"Foreword: A Personal Tribute to Anwar Sadat." to Anwar Sadat. Those I Have Known (1984)

"Middle East: Time for Yegotiations." Time (198-)

.Middle East Peace: New Opportunities." Hashington Quarterly (1987)

"Veeded: Middle East Peace Talks." Veu York Times (1991)

"Can Peace Still Come to Israel?". Atlanta Joumal-Constitution (1995)

"A Jerusalem Settlement Every one Can Live With." Vew Fork Times 12000)

"For Israel. Land or Peace." Hashington Post 12000$)$

"Precedents for Mideast Peace." Vew Kork Times 2001 )

"America Can Persuade Israel to Make a Just Peace." Yeu York Times (2002)

"Mideast Veeds Vew Mediator." (S.t Todin (2002)

"The Choice for Israelis." Washington Post 20031

"Middle East Accord Offers 'Best" Chance for Peace." (S.t Todan (2003)

"Casting a Vote for Peace." lew York Times (2004)

"Don't Punish the Palestinians." Hashington Post (2006)

"Colonization of Palestine Precludes Peace." Ha aretz (2006)

"Punishing Innocent Palestinians Is a Crime." International Herald Tribune (2006)

"Israel"s New Plan: A Land Grab." LSA Todon (2006)

"Stop the Band-Aid Treatment: We Yeed Policies for a Real. Lasting Middle East Peace." Hashington Pest (2006)

"How I See Palestine." Los Angeles Times (2006)

"A Vew Chance for Peace?". Washington Post (2007)

"A Viable Mideast Peace Plan." International Herald-Tritune 1200")

Source: The full list of President Carter's book's may be found at the Jimm! Carter Library and Museum website. http: wisw jimms carterlibrary gov librars carterbi html. and the full text for his articles and opeds may be found at the Carter Center website. http: 11 w 1 cartercenter.ory. 


\section{APPENDIX II}

\section{The Weekly Church Attendance of President Jimmy Carter, 1977-1981}

(Unless otherwise noted, President Carter attended both an adult Sunday school class and the worship service. Dates on which the President did not attend church were normally travel days.)

Source: "The Jimmy Carter Presidential Daily Diary Online," Jimmy Carter Library and Museum website, http://www.jimmycarterlibrary.gov/documents/diary/index.phtml.

\section{$\underline{\text { First Year }}$}

$01 / 23 / 77$

$01 / 30 / 77$

$02 / 06 / 77$

$02 / 13 / 77$

$02 / 20 / 77$

$02 / 27 / 77$

$03 / 06 / 77$

$03 / 13 / 77$

$03 / 20 / 77$

$03 / 27 / 77$

$04 / 03 / 77$

$04 / 10 / 77$

$04 / 17 / 77$

$04 / 24 / 77$

$05 / 01 / 77$

$05 / 08 / 77$

$05 / 15 / 77$

$05 / 22 / 77$

$05 / 29 / 77$

$06 / 05 / 77$

$06 / 12 / 77$

$06 / 19 / 77$

$06 / 26 / 77$

$07 / 03 / 77$

$07 / 10 / 77$

$07 / 17 / 77$

$07 / 24 / 77$

$07 / 31 / 77$

08/07/77

$08 / 14 / 77$

$08 / 21 / 77$

$08 / 28 / 77$

$09 / 04 / 77$

$09 / 11 / 77$

$09 / 18 / 77$

$09 / 25 / 77$
First Baptist Church, Washington DC

No Attendance Recorded; Travel Day to Pennsylvania

First Baptist Church, Washington DC

Plains Baptist Church, Plains, GA

First Baptist Church, Washington DC (President Carter taught Sunday school class) Harriet Chapel Episcopal Church, Catoctin Furnace, MD

First Baptist Church, Washington DC

First Baptist Church, Washington DC

First Baptist Church, Washington DC

First Baptist Church, Hagerstown, MD

First Baptist Church, Washington DC

First Baptist Church, Calhoun, GA (Easter)

First Baptist Church, Washington DC

First Baptist Church, Washington DC (President Carter taught Sunday school class)

First Baptist Church, Washington DC

Westminster Abbey, London, UK

Weller's United Methodist Church, Thurmont, MD

First Baptist Church, Washington DC

No Attendance Recorded; Vacationing St. Simons Island, GA

First Baptist Church, Washington DC

First Baptist Church, Washington DC (President Carter taught Sunday school class)

Worship Service at Camp David, MD

First Baptist Church, Washington DC

Worship Service at Camp David, MD

First Baptist Church, Washington DC

Worship Service at Camp David, MD

First Baptist Church, Washington DC

First Baptist Church, Washington DC (President Carter taught Sunday school class)

Plains Baptist Church (Sunday school); Maranatha Baptist Church, Plains, GA (worship Service)

First Baptist Church, Washington DC

Worship Service at Camp David, MD

First Baptist Church, Washington DC

Worship Service at Camp David, MD

First Baptist Church, Washington DC

Protestant Chapel Attendance, Fort Ritchie, MD

First Baptist Church, Washington DC (President Carter taught Sunday school class); 
Zion Baptist Church. Washington. DC w worship Service: President Carter spoke from pulpit,

\begin{tabular}{|c|c|}
\hline $1002^{--}$ & Worship Service at Camp David. MD \\
\hline $1009^{--}$ & Worship Service at Camp David. MD \\
\hline $1016^{--}$ & First Baptist Church. Washington DC \\
\hline $1023--$ & No Attendance Recorded: Travel Das. Returning to Washington. DC \\
\hline $1030^{--}$ & Worship Service at Camp David. MD \\
\hline $1106^{--}$ & First Baptist Church. Washington DC \\
\hline $13-2$ & First Baptist Church. Washinḡton DC \\
\hline $20^{--}$ & $\begin{array}{l}\text { First Baptist Church. Washington DC: Special Prayer for Peace in the Middle East } \\
\text { Service: President Carter offered a prayer for peace from pulpit }\end{array}$ \\
\hline $12-\cdots$ & Worship Service at Camp David. MD \\
\hline & First Baptist Church. Washington DC \\
\hline & Worship Service at Camp David. MD \\
\hline & First Baptist Church. Washington DC (President Carter taught Sunday school class) \\
\hline & $\begin{array}{l}\text { Plains Baptist Church. (Sunday school): Maranatha Baptist Church. Plains. G.A } \\
\text { (worship Service) }\end{array}$ \\
\hline & Vo Attendance Recorded: State Visit in Iran and India \\
\hline & First Baptist Church. Washington DC \\
\hline & L.S. Capitol Building: Memorial Service for Hubert H. Humphre! \\
\hline
\end{tabular}

\title{
Second Year
}

\author{
$0122-8$ \\ Vo Attendance Recorded: Vacationing St. Simons Island. G.A \\ $0129-8$ \\ First Baptist Church. Washington DC \\ $0=05-8$ \\ Worship Service at Camp David. MD \\ 0. $12-8$ \\ Worship Service at Camp David. ID \\ a $219-8$ \\ First Baptist Church. Washington DC \\ 1.2 $26-8$ \\ First Baptist Church. Washington DC \\ $0305-8$ \\ Worship Service at Camp David. WD \\ $0312-8$ \\ First Baptist Church. Washington DC ISunday schooly: St. John's Episcopal Church \\ (worship service) \\ $0319-8$ \\ $0326-8$ \\ Christ Episcopal Church. St. Simons lsland. G.A \\ Worship Service at Camp David. MD (Easter service) \\ $0+02-8$ \\ $0409-8$ \\ $0+16^{-9}$ \\ $0+23-8$ \\ $0.430-8$ \\ $050--8$ \\ $021+-8$ \\ $0 \leq 21-8$ \\ $0528-8$ \\ $0604-8$ \\ $0611-8$ \\ 06 I8 -8 \\ $0625-8$ \\ $0-0=-8$ \\ $0-0,0-8$ \\ i) $16^{-9}$ \\ $0-53-8$ \\ $0)^{-30}-8$ \\ $0806^{-8}$ \\ First Baptist Church. Lagos. Nigeria (Ambassador Young accompanied the President) \\ Protestant Chapel Attendance. Fort Ritchie. .1D \\ Worship Service at Camp David. MD \\ First Baptist Church. Washington DC \\ Worship Service at Camp David. MD \\ First Baptist Church. Washington DC \\ Worship Service at Camp Dasid. MD \\ No Attendance Recorded: Travel Das to Georgia \\ First Baptist Church. Washington DC \\ Worship Service at Camp David. MD \\ Worship Service at Camp David. MD \\ First Baptist Church. Washington DC \\ First Baptist Church. Washington DC (President Carter taught Sunday school class, \\ Worship Service at Camp David. MD \\ Worship Service at Camp David. MD \\ Stemson Memorial Chapel. American Protestant Church. Bonn. West German: \\ Worship Service at Camp David. MD \\ Worship Service at Fort Ritchie. MID \\ First Baptist Church. Washington DC
}


$01 / 14 / 79$

First Baptist Church, Washington DC

Americus Fellowship Church, Americus, GA (worship service); Maranatha Baptist Church, Sylvester, GA (worship service)

Chapel of the Transfiguration, Moose. WY (Worship and Communion Services)

First Baptist Church, Washington DC: also special prayer service for world peace

Worship Service at Camp David, MD; Sadat and Begin also at Camp David

Worship Service at Camp David, MD; Sadat and Begin at Camp David; signing of Camp David Accords

First Baptist Church, Washington DC

First Baptist Church, Washington DC (Sunday school)

Worship Service at Camp David, MD

Worship Service at Camp David, MD

Worship Service at Camp David, MD

Worship Service at Camp David, MD

Worship Service at Camp David, MD

First Baptist Church, Washington DC; Cedar Point Farm, Royal Oak, MD (Prayer and Discussion group)

Worship Service at Camp David, MD

Worship Service at Camp David, MD

First Baptist Church, Washington DC

First Baptist Church, Washington DC (President Carter taught Sunday school class)

Worship Service at Camp David, MD

Plains Baptist Church, (Sunday school); Maranatha Baptist Church, Plains, GA

(worship Service)

Worship Service at Camp David, MD

No Attendance Recorded; Vacationing in Guadeloupe; later attended reception with British Prime Minister James Callaghan

Ebenezer Baptist Church, Atlanta, GA; President Carter received $7^{\text {th }}$ Annual Non-

Violent Peace Prize Award from Coretta Scott King; Carter addressed the assembly; Ambassador Young accompanied the President

\section{Third Year}

$01 / 21 / 79$

$01 / 28 / 79$

$02 / 04 / 79$

$02 / 11 / 79$

$02 / 18 / 79$

$02 / 25 / 79$

$03 / 04 / 79$

$03 / 11 / 79$

$03 / 18 / 79$

$03 / 25 / 79$

$04 / 01 / 79$

$04 / 08 / 79$

$04 / 15 / 79$

$04 / 22 / 79$

$04 / 29 / 79$

$05 / 06 / 79$

$05 / 13 / 79$

$05 / 20 / 79$
No Attendance Recorded; Camp David, MD

Worship Service at Camp David, MD

Worship Service at Camp David, MD

Worship Service at Camp David, MD

Worship Service at Camp David, MD

First Baptist Church, Washington DC

First Baptist Church, Washington DC (President Carter taught Sunday school class)

St. Andrew's Scots Memorial Church, Jerusalem, Israel (worship service)

Worship Service at Camp David, MD

First Baptist Church, Elk City, OK

First Baptist Church, Washington DC; In the church fellowship hall, President Carter also viewed an exhibit, "Meeting of the Peacemakers"

Worship Service at Camp David, MD

First African Baptist Church, Sapelo Island, GA (worship service)

First Baptist Church, Calhoun, GA

First Baptist Church, Washington DC (President Carter taught Sunday school class): met with Pastor Georgi Vins, Baptist minister and Soviet dissident

First Baptist Church. Washington DC

No Attendance Recorded; Visiting Camp Hoover, Shenandoah National Park, VA

No Attendance Recorded; Travel Day to Pennsylvania 
061079

$061^{-79}$

$0624^{-9}$

$0^{-} 0179$

0- 0879

$0^{-} 1579$

072279

$0^{7} 2979$

$080=-9$

os 1279

os 1979

OS 2679

090279

090979

09 I 679

092379

093079

100779

$101+79$

$1021-9$

102879

$110+79$

111179

111879

$1125-9$

120279

I 20979

121679

122379

123079

010680

011380
Worship Service at Camp David. MD

First Baptist Church. Washington DC: President Carter received "Good Shepard Award": Metropolitan African Methodist Episcopal Church. Washington. DC

(Memorial service for A. Philip Randolph: President spoke from pulpit)

Worship Service at Camp David. MD

Hotburg Chapel. Vienna. Austria (Catholic Mass service)

No Attendance Recorded: Travel Day to Japan

Yoido Korean Baptist Church. Seoul. South Korea (worship service): also met with

Korean religious leaders in L'S. Embass:

No Attendance Recorded: Camp David Energy Discussion

First Baptist Church. Washington DC

First Baptist Church. Washington DC

Worship Service at Camp David. MD

First Baptist Church. Washington DC (President Carter taught Sunda! school class)

Worship Service at Camp David. MD

Delta Queen steamboat. La Cresent. MN (worship service)

Worship Service at Camp David. MD

Maranatha Baptist Church (Sunday school): Plains Baptist Church. Plains. GA (worship service): Plains Methodist Church. Plains. GA (Sunday luncheon)

First Baptist Church. Washington DC: President hosted Gospel Music Event at the

White House

Worship Service at Camp David. MD

First Baptist Church. Washington DC

Worship Service at Camp David. MD

First Baptist Church. Washington DC

First Baptist Church. Washington DC

Worship Service at Camp David. MD

Worship Service at Camp David. MD

Worship Service at Camp David. MD

First Baptist Church. Washington DC

Worship Service at Camp David. MD

Worship Service at Camp David. MD

Worship Service at Camp David. MD

First Baptist Church. Washington DC

Worship Service at Camp David. MD

Worship Service at Camp David. MD

First Baptist Church. Washington DC

Worship Service at Camp David. MD

First Baptist Church. Washington DC

\section{Fourth Year}

012080

$012-80$

020380

$0=1080$

$021-80$

$022+80$

030280

030980

031680

032380

033080
No Attendance Recorded: Appeared on NBC's. Heet the Press

Worship Service at Camp David. MD

Worship Service at Camp David. ID

Worship Service at Camp David. ID

First Baptist Church. Washington DC

Worship Service at Camp David. .1D

Worship Service at Camp David. MD

First Baptist Church. Washington DC

Worship Service at Camp David. MD

Worship Service at Camp David. MD

First Baptist Church. Washington DC (President Carter taught Sundas school class) 
$07 / 13 / 80$

07/20/80

$07 / 27 / 80$

$08 / 03 / 80$

$08 / 10 / 80$

$08 / 17 / 80$

$08 / 24 / 80$

$08 / 31 / 80$

$09 / 07 / 80$

$09 / 14 / 80$

$09 / 21 / 80$

$09 / 28 / 80$

$10 / 05 / 80$

$10 / 12 / 80$

$10 / 19 / 80$

$10 / 26 / 80$

$11 / 02 / 80$

$11 / 09 / 80$

$11 / 16 / 80$

$11 / 23 / 80$

$11 / 30 / 80$

$12 / 07 / 80$

$12 / 14 / 80$

$12 / 21 / 80$

$12 / 28 / 80$

$01 / 04 / 81$

$01 / 11 / 81$

$01 / 18 / 81$
Worship Service at Camp David, MD (including Easter Sunrise service)

First Baptist Church, Washington DC

First Baptist Church, Washington DC

First Baptist Church, Washington DC

Worship Service at Camp David, MD

Worship Service at Camp David, MD

Worship Service at Camp David, MD

Data for this date unavailable from website

Worship Service at Camp David, MD

Worship Service at Camp David, MD

Worship Service at Camp David, MD

Church of St. Eufenia, Venice, Italy (worship service)

Worship Service at Camp David, MD

Maranatha Baptist Church, Plains, GA (Sunday school); Plains Baptist Church (worship service); Attended Baptismal service at Maranatha Baptist Church in the evening

St. Lukes Baptist Church. Sapelo Island, GA (worship service)

First Baptist Church, Washington DC (President Carter taught Sunday school class)

Worship Service at Camp David, MD

Worship Service at Camp David, MD

Worship Service at Camp David, MD

No Attendance Recorded; Vacationing at Spruce Creek, PA

First Baptist Church, Washington DC

Worship Service at Camp David, MD

Worship Service at Camp David, MD

First Baptist Church, Washington DC

Worship Service at Camp David, MD

Worship Service at Camp David, MD

Upper Spruce Creek Presbyterian Church, Spruce Creek, PA (worship service)

First Baptist Church, Washington DC (Sunday school)

Worship Service at Camp David, MD

Worship Service at Camp David, MD

No Attendance Recorded; at the White House

Worship Service at Camp David, MD

First Baptist Church, Washington DC

Worship Service at Camp David, MD

No Attendance Recorded; Camp David, MD

First Baptist Church, Washington DC (Sunday school); Georgetown Baptist Church,

Washington DC (worship service)

Worship Service at Camp David, MD

Worship Service at Camp David, MD

No Attendance Recorded; Camp David, MD

First Baptist Church, Washington DC

No Entry Logged for this Date

No Entry Logged for this Date 


\section{APPENDIX III}

\section{Jimmy Carter's Prayer for Middle East Peace During Sadat's Visit to Israel}

\section{Special Service for Peace, First Baptist Church, Washington, D.C., November 20, 1977}

O Father in hearen. the people of Thy world want peace. Your Son. our Saviour. Jesus Christ. was the Prince of Peace. There rarely has been an opportunity in the history of mankind when the hearts and minds of people of all nations could be attuned to common hope in a simultaneous moment of thanksgiving. and concern. and praver.

We are especially concerned and hopeful about the Middle East of the people of Lebanon. and Syria. and Jordan. Egypt and Israel. who have been constantly torn. and killed each other in a continuing stream of conflicts. both large and small-four wars in the last thirty years - while the people have suffered torment and frustration. all desiring to live in peace. all suffering from the ravages of war.

This morning. God our Father in heaven. we have perhaps a more vivid realization that. in spite of the yearnings of the people for peace in the . Middle East. chosen leaders have not responded adequately to this constant yearning. Yesterday the Prime Minister of Israel worshiped you in a Jewish temple and. later. the President of Egypt worshiped you in a Moslem mosque and then. today. we worship you in a Christian holy place. We remember our Saviour was crucified and buried. and people all over the world are worshiping you today in the genuine hope that the meaning of these historic interviews might bring a new realization of the common commitment which binds us all together. in spite of the national boundaries and in spite of the fear. We pray for peace in Your Name.

To one can predict the outcome of this historic meeting taking place this weekend. but we know it is in Your Name. I know Prime Minister Begin to be an honorable and deeply religious man. He prays for me that we might truly lead our people in Your desire. in Your Yame. toward peace. I know President Sadat to be an honorable and courageous man. He has pledged to pray for me and I have pledged to pray for him. As we open our hearts may they provide an arenue to bind us all together. Be with us leaders and all other leaders that Thy people may be nurtured by these common dreams and strengthened by our organization. With Your guidance it is possible that peace might come to Your Glory. 


\section{JASON BERGGREN}

January 1, 1971

1991-1993

1993

1993-1995

1995

1995-1997

1997-2002

2002-2006

2005-2006

2006-2007
Born, St. Petersburg, Florida

Ford Foundation Scholar

Eckerd College

St. Petersburg, Florida

B.A., Religious Studies

Eckerd College

Teaching Assistant

Florida State University

Tallahassee, Florida

M.A., Religion

Florida State University

Social Studies Teacher

New Horizon Academy High School

Boca Raton, Florida

Adjunct Religion Professor

Broward Community College

Pembroke Pines and Davie, Florida

Political Science Instructor

Florida International University

Miami, Florida

Teaching Assistant Excellence in Teaching Award Academy for the Art of Teaching

Florida International University

Dissertation Fellow

Florida International University 


\section{PLBLIC.ATIONS}

Berggren. D. Jason (2007). Yorthern Strategr and Anti-South Polemics: A Review Essar of Thomas Schaller 's II histling Past Dixie. The Forum: A Journal of Applied Research in Contemporary Politics. 5 (2).

Berggren. D. Jason. and Rae. Nicol C. (2007). George It. Bush. Religion and Europeun Anti-Americanism. In Anti-Americanism: History. Causes. and Themes. Vol. I. edited by Brendon $\mathrm{O}^{\circ}$ Connor. Oxford. LK: Greenwood World Publishing. 85-114.

Berggren. D. Jason (2007). Two Parties. Two Types of . Yominees. Two Paths to Irinning a Presidential . Yomination. 19-2-2004. Presidential Studies Quarterly. 37 (2): 203-227.

Berggren. D. Jason (2007). Yore than the Limmah: A Study of Religious and Yutional Identity in the Islamic World. American Journal of Istamic Social Sciences. 24 (2): 71 93.

Berggren. D. Jason. and Rae. Nicol C. (2006). Jimmy Carter and George II: Bush. Faith. Foreign Policy: and an Evangelical Presidential Style. Presidential Studies Quarterly. $36(4)$ : 606-632.

Salokar. Rebecca Mae. Berggren. D. Jason. and DePalo. Kathryn A. (2006). Merit Selection Redefined: The New Politics of Judicial Selection in Florida. Iustice System Journal. 27 (2): 123-1+2.

Berggren. D. Jason. (2005). Jefferson Davis. Religion. and the Politics of Recognition. White House Studies. 5 (2): 231-241.

Berggren. D. Jason (2005). Ralph Vader and the Green Party: The Double-Edged Sword of a Candidate. Campaign-Centered Strategy: The Forum. 3 (1). Article 4.

Berggren. D. Jason (2005). "I Had a Different ITal of Governing": The Living Faith of President Carter. Journal of Church and State. 47 (1): 43-61.

Berggren. D. Jason (2004). Obstacles to an .Alliance: Muslims and the (hristiun Right in the LS.A. Contemporary Studies. No. 18. Translated into Arabic by Sadig Malki. Published by the King Faisal Center for Research and lslamic Studies. Riyadh. Saudi Arabia.

Berggren. D. Jason (2003). Obstacles to an Alliance: Muslims and the (hristiun Right. Middle East Affairs Journal. 9(1-2): 87-122.

Berggren. D. Jason (2001). The Vew Kid on the Bloc: Muslims Responsible for Bush II in in 2000. Middle East Affairs Journal. 7 (3-4): 155-182. 